\title{
GRIZZLY BEAR COMPENDIUM
}

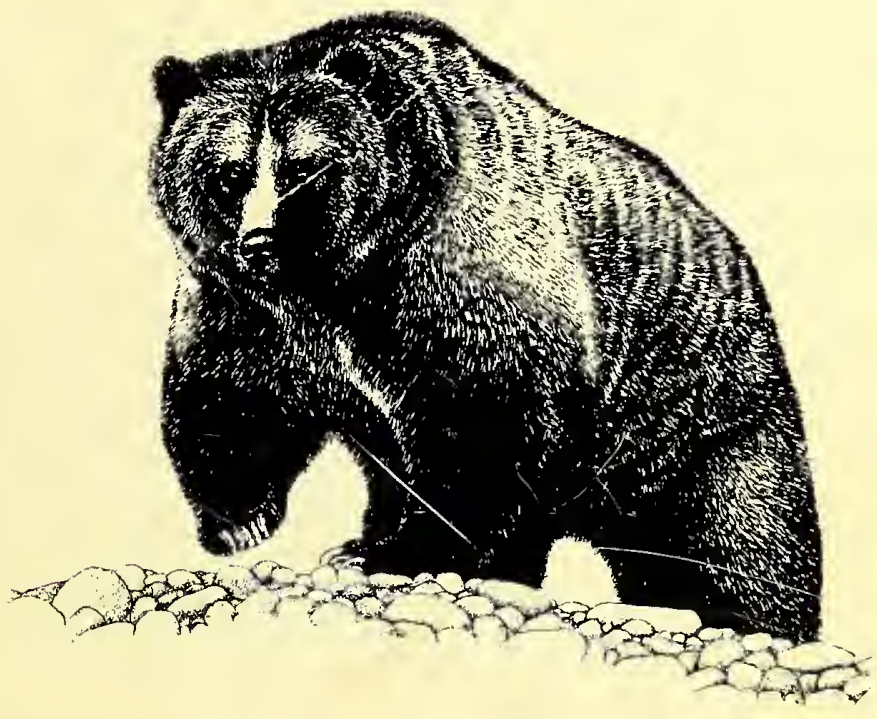

Sponsored by The Interagency Grizzly Bear Committee 1987
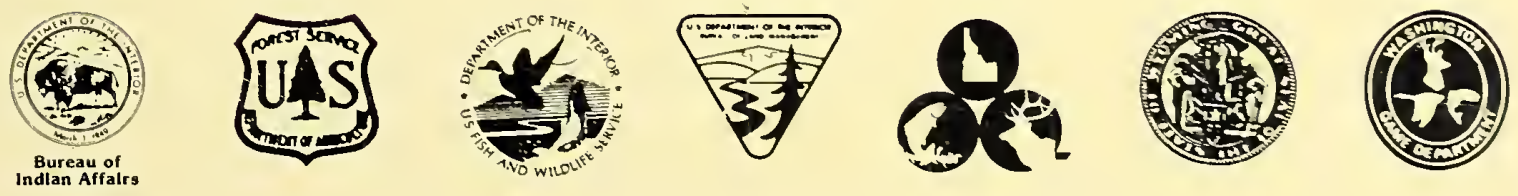


\section{DOV 151999 \\ JUL 1 \% 19991}

\section{FOREWORD}

The Interagency Grizzly Bear Committee (IGBC), established in 1983, plays a major role in the conservation and management of the grizzly. The IGBC is composed of Regional Directors of the Fish and Wildlife Service and National Park Service, three Forest Service Regional Foresters, Montana State Director of the Bureau of Land Management, and State wildlife agency directors or representatives from the States of Idaho, Montana, Washington, and Wyoming. The primary objective of the IGBC is to serve as the coordinating mechanism for research and management related to the grizzly bear recovery program in the contiguous 48 United States.

The Grizzly Bear Compendium was developed in order to assemble all available information on the biology and management of the grizzly bear in North America. The Compendium was designed to be a source document for grizzly bear managers, researchers, and students. The Compendium has a format designed to facilitate review of all available information on any subject area of interest regarding grizzly bears. It contains both published and unpublished information from all North American sources. It also includes a complete reference list along with a detailed narrative summary by topic, which covers all aspects of grizzly bear biology and management. It is hoped that the Compendium will be used to enhance the management of the grizzly bear and thereby to assure its continued existence as a wild species. 


\section{GRIZZLY BEAR COMPENDIUM}

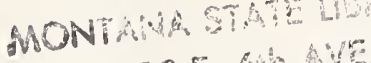

$1515 \mathrm{E} .6 \mathrm{~h}$ A

HELEA, MONHABS 29020

COMPENDIUM SPONSORED BY:

Interagency Grizzly Bear Committee

COMPENDIUM PRODUCED UNDER CONTRACT BY:

The National Wildlife Federation

Washington, D.C.

FUNDING FOR PRODUCTION OF THE COMPENDIUM:

U.S. Fish and Wildlife Service

U.S. Department of the Interior

FUNDING FOR PRINTING OF THE COMPENDIUM:

U.S. Fish and Wildlife Service

U.S. Forest Service

U.S. National Park Service

U.S. Bureau of Land Management

CONTRACTING OFFICER'S TECHNICAL REPRESENTATIVE AND PROJECT SUPERVISOR:

Christopher Servheen

Grizzly Bear Recovery Coordinator

U.S. Fish and Wildlife Service

1987
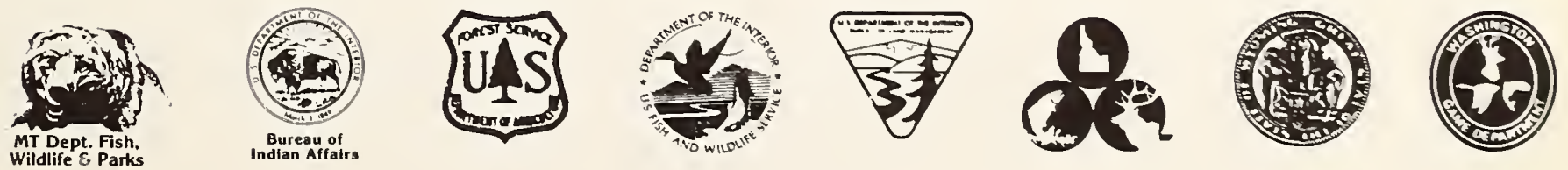
Harting, Albert L., Institute for Wildlife Research

Size

Growth Rates and Patterns

Pelage and Molt

Hematology

Digestive System

Genetic Considerations

Nutritional Requirements

Activity Patterns

Intraspecific Behavior

Courtship and Copulation

Age/Sex

Population Densities

Population Regulation

Impacts From Livestock and Other Agricultural Impacts

Industrial Impacts

Road and Highway Impacts

Aircraft Impacts

Garbage Impacts

Recreational Impacts

Grizzly Bear-Black Bear Relationships

Grizzly Bear-Wolf Relationships

Grizzly Bears and Other Mammals

Biogeographic Considerations

Human Attitudes

Aversive Conditioning, Deterrents and Attractants

Population Augmentation

Relocation of Nuisance Bears

Reintroduction of Grizzlies into Former Range

Methods for Estimating Population Size and Trends

Canfield, Jodie (Consultant) and A.L. Harting

Home Range and Movements

Reproductive Rates

Mace, Richard D., Consultant

Food Habits Summary

Cover

Approaches to Habitat Classification and Mapping

Grizzly Bear Ecosystems
Patnode, Kathleen A., Institute for Wildlife Research

Sensory Systems

Parasites, Diseases and Other Natural Mortality Factors

Denning

Patnode, Kathleen A. and M.N. LeFranc, Jr.

Distribution

Sugg, William C., III, Institute for Wildlife Research

Skull and Dentition

Body Temperature, Respiration and Heart Rate

Moss, Mary Beth, Institute for Wildlife Research

Recreation

Garbage

LeFranc, Maurice N., Jr., Institute for Wildlife Research

Introduction

Harvest Strategies

Moss, Mary Beth and M.N. LeFranc, Jr.

Administrative Management Guidelines

Timber

Roads

Grazing

Subdivision

Fire

Mining, Oil and Gas Development

Aircraft

Cumulative Effects Analysis

Outfitters

\section{Editors}

Maurice N. LeFranc, Jr.

Mary Beth Moss

Kathleen A. Patnode

William C. Sugg, III 


\section{TABLE OF CONTENTS}

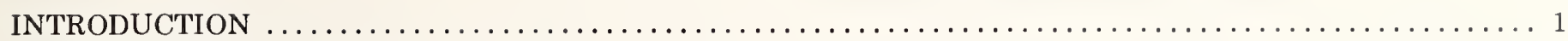

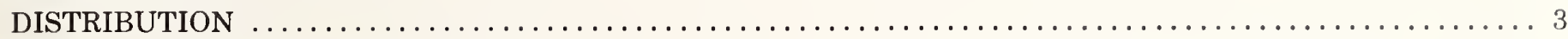

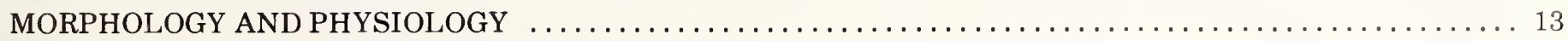

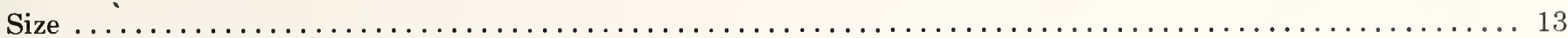

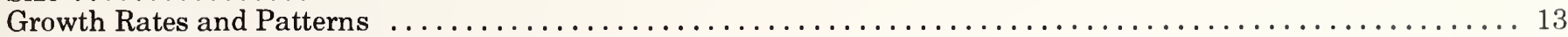

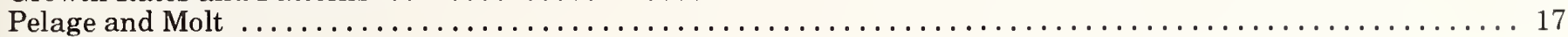

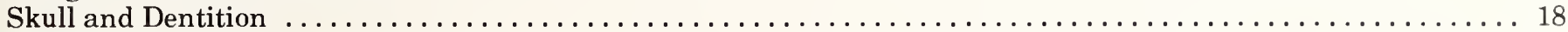

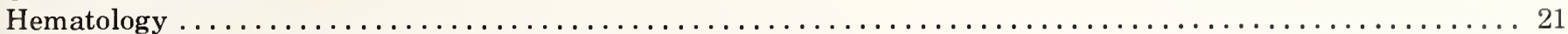

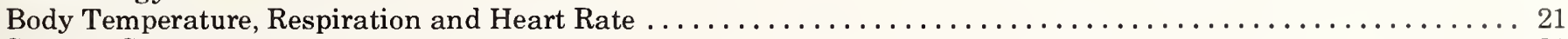

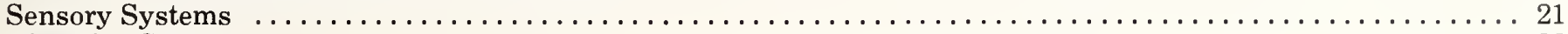

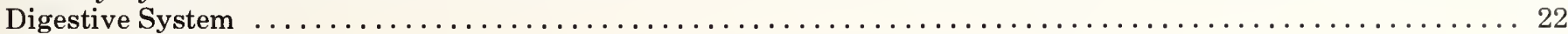

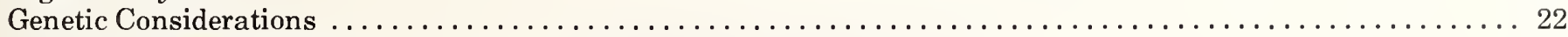

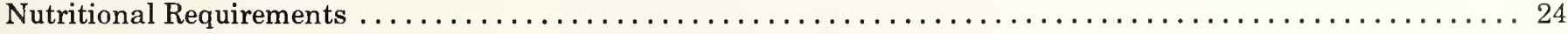

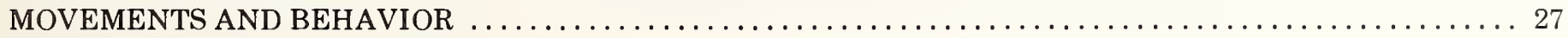

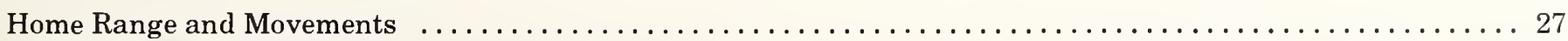

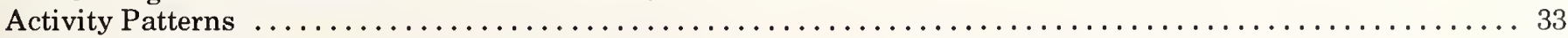

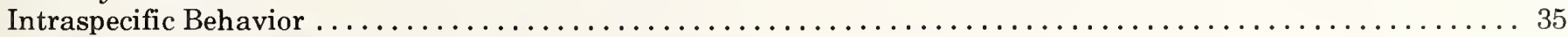

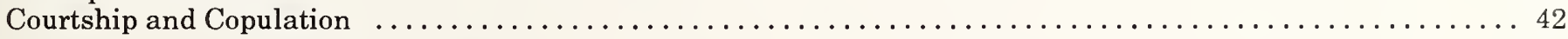

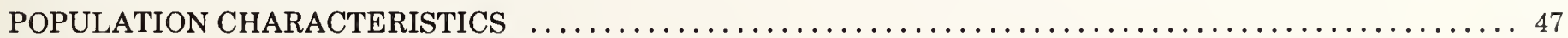

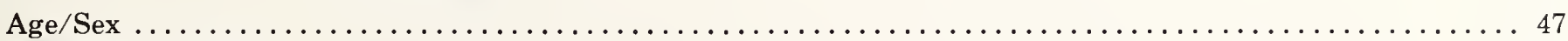

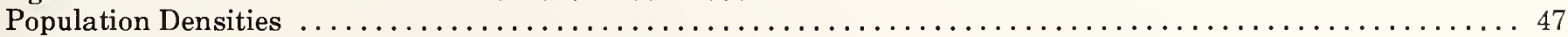

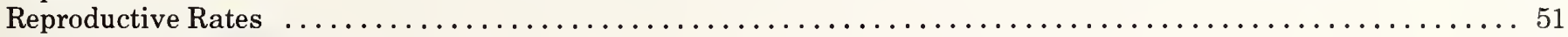

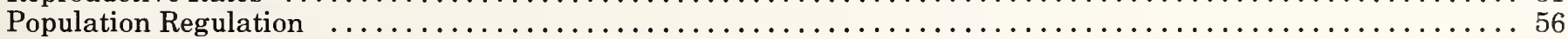

PARASITES, DISEASES AND OTHER NATURAL MORTALITY FACTORS $\ldots \ldots \ldots \ldots \ldots \ldots \ldots \ldots \ldots \ldots$

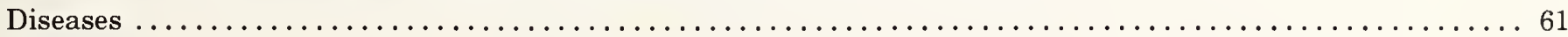

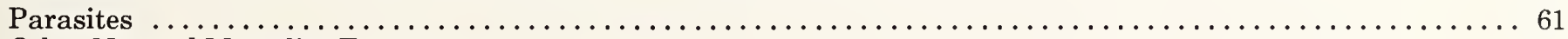

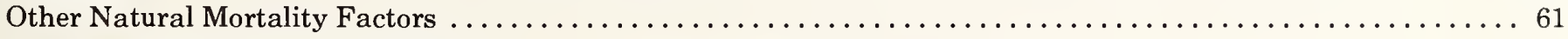

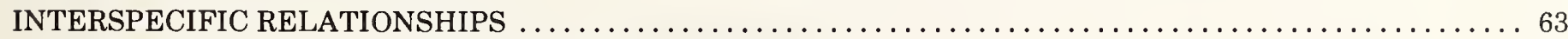

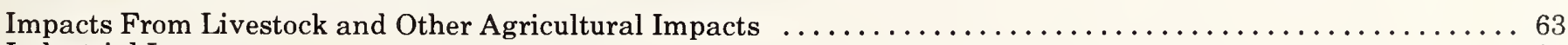

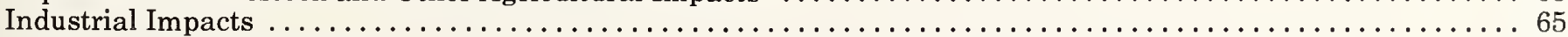

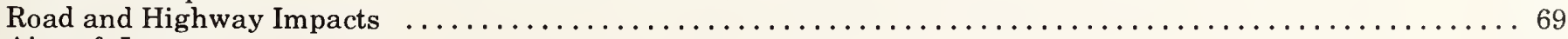

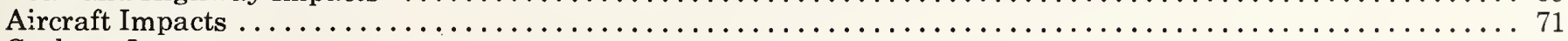

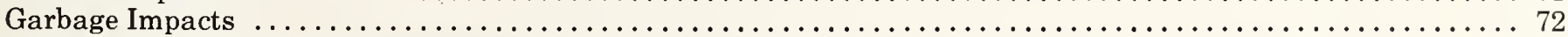

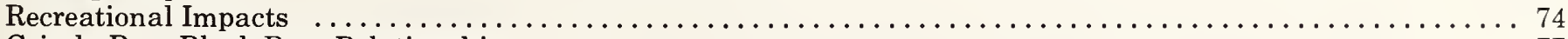

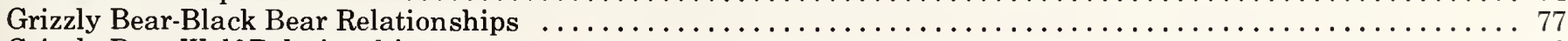

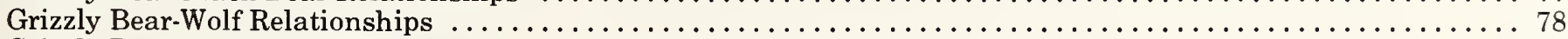

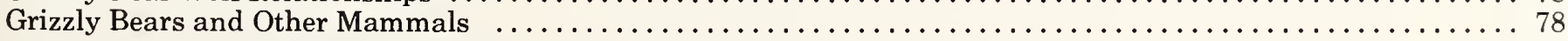

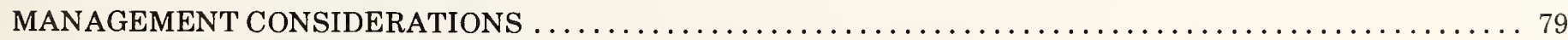

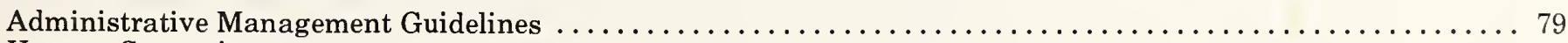

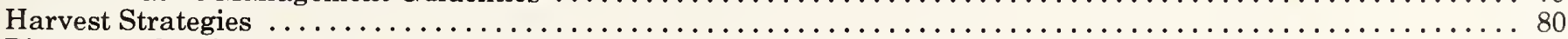

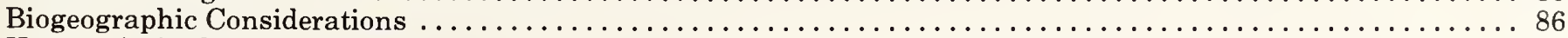

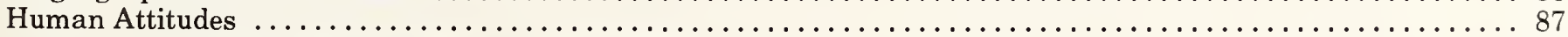

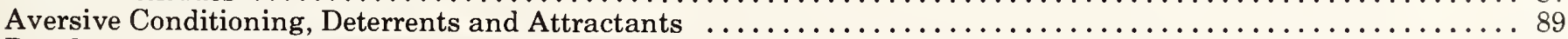

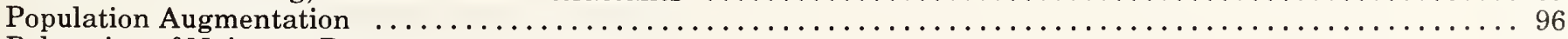

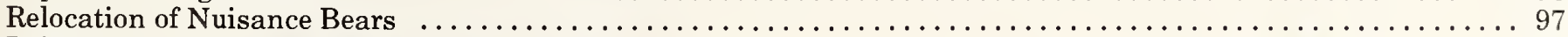

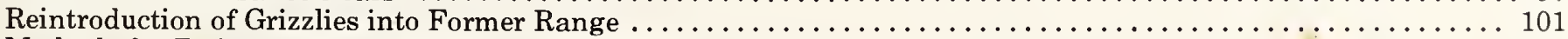

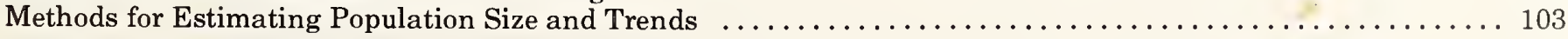

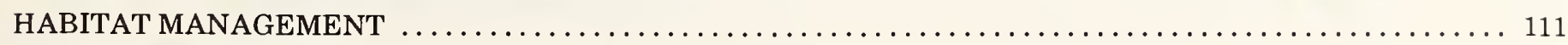

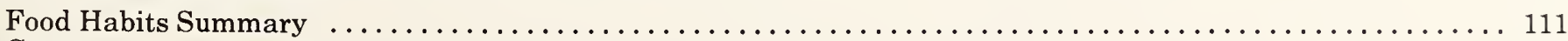

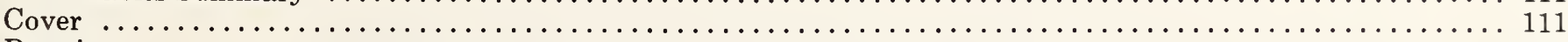

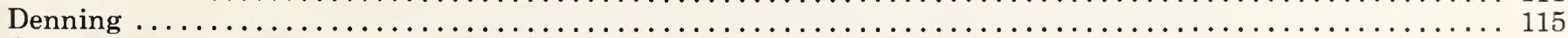

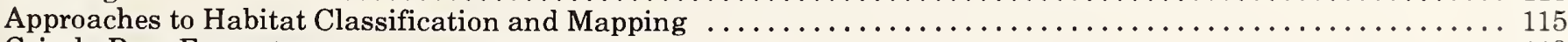

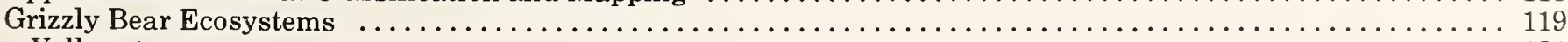

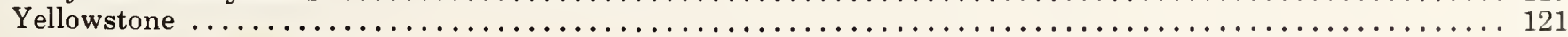

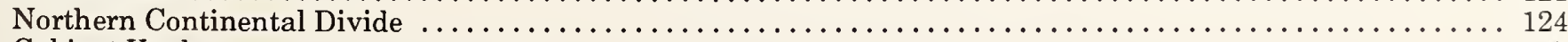

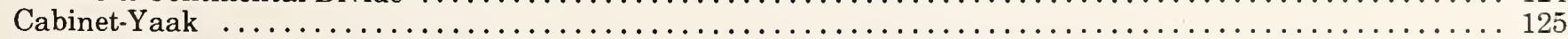

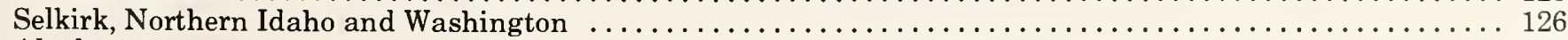

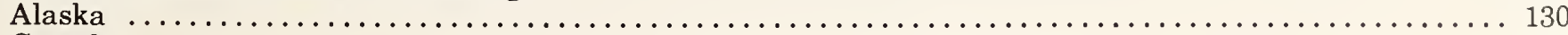

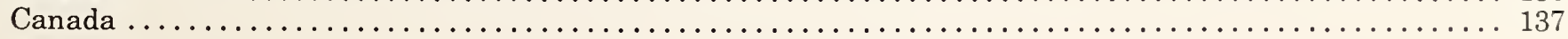




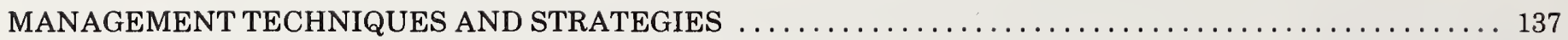

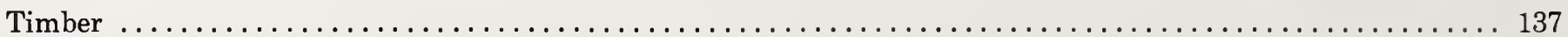

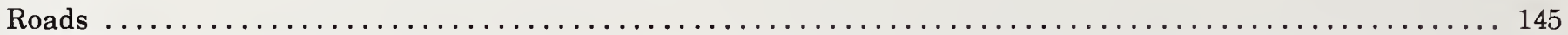

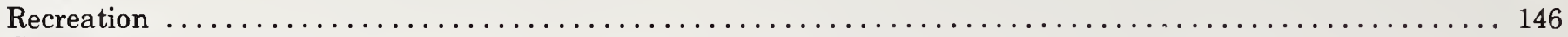

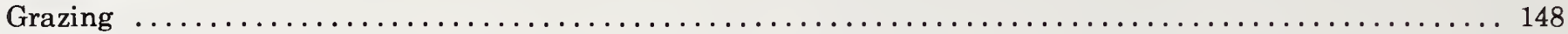

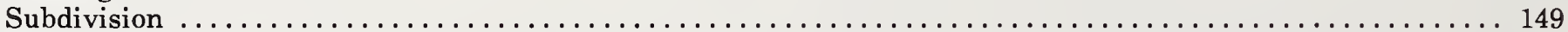

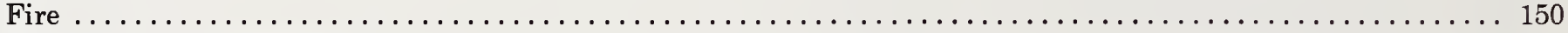

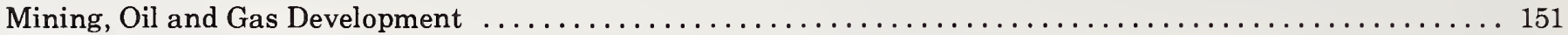

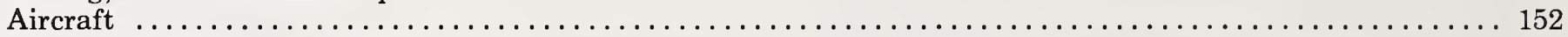

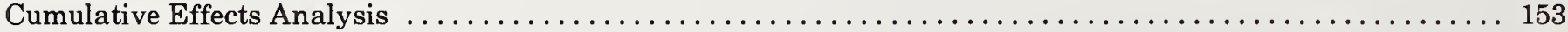

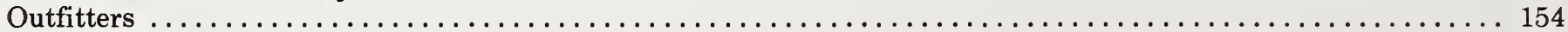

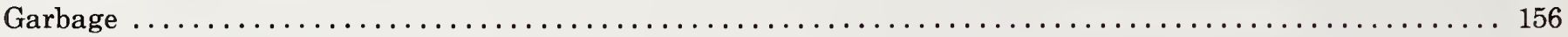

\section{LIST OF TABLES}

Table 1. Weight data (in pounds) recorded from grizzly bear capture records $\ldots \ldots \ldots \ldots \ldots \ldots \ldots$

Table 2. Summary of numerical data on 26 skull samples from various regions of North America $\ldots \ldots \ldots \ldots$

Table 3. Affects of various drugs on grizzly/black bear heart rate and respiration $\ldots \ldots \ldots \ldots \ldots \ldots \ldots 22$

Table 4. Nutrient content and digestible energy of major grizzly bear food items $\ldots \ldots \ldots \ldots \ldots \ldots \ldots \ldots \ldots$

Table 5. Mean minimum home range sizes (sq. $\mathrm{km}$ ) of grizzly bears in major study areas $\ldots \ldots \ldots \ldots$

Table 6. Mean annual home range size $(\mathrm{sq} . \mathrm{km})$ for adult females of different reproductive status $\ldots \ldots \ldots \ldots 32$

Table 7. Dates of breeding season (courtship associations) for North American grizzly bear populations ..... 43

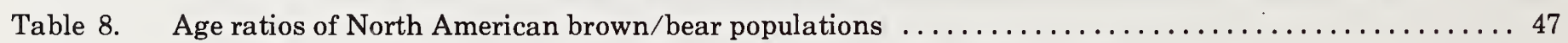

Table 9. Sex ratios reported for North American brown/grizzly bear populations $\ldots \ldots \ldots \ldots \ldots \ldots \ldots$

Table 10. Oldest brown/grizzly bears recorded for various North American populations $\ldots \ldots \ldots \ldots \ldots \ldots \ldots$

Table 11. Reported densities for North American brown/grizzly bear populations $\ldots \ldots \ldots \ldots \ldots \ldots \ldots \ldots$

Table 12. Reproductive characteristics of North American grizzly bear populations $\ldots \ldots \ldots \ldots \ldots \ldots \ldots$

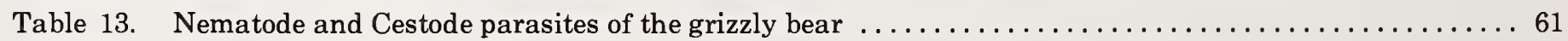

Table 14. References which documented agriculturally-related depredation and control actions ..........64

Table 15. Area summary of the Northern Continental Divide and the Greater Yellowstone Grizzly Bear

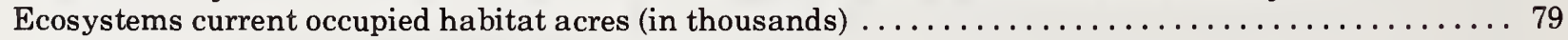

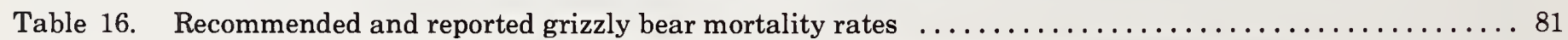

Table 17. Summary of major food items used by grizzly bears in Canada, by geographic location . . . . . . . 112

Table 18. Summary of major food items used by grizzly bears in the United States by geographic location $\ldots . . .113$

Table 19. Characteristics of grizzly bear dens and corresponding environment $\ldots \ldots \ldots \ldots \ldots \ldots \ldots \ldots$

Table 20. Seasonal use and availability of 23 cover types in the Yellowstone Ecosystem from 9 analysis

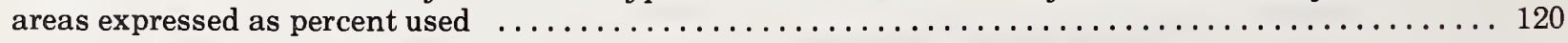

Table 21. Grizzly bear habitat use and availability, Northern Continental Divide Ecosystem $\ldots \ldots \ldots \ldots \ldots 122$

Table 22. Availability and use of 20 habitat components by one instrumented grizzly bear in the

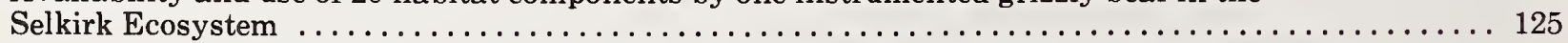

Table 23. Number of radio-instrumented brown bear observations in different habitat types in Susitna

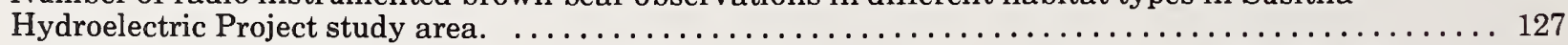

Table 24. Brown bear use of habitat types on the west Copper River, May -June, $1984 \ldots \ldots \ldots \ldots \ldots \ldots \ldots$

Table 25. Brown bear habitat use on Admiralty and Chichagof Islands, Alaska during $1984 \ldots \ldots \ldots \ldots$

Table 26. Index of grizzly bear vegetation type use (level II) in the Arctic National Wildlife Refuge, 1982-1983 .. 129

Table 27. Seasonal observations of 10 grizzly bears in 2 habitat types, $1984 \ldots \ldots \ldots \ldots \ldots \ldots \ldots \ldots \ldots$

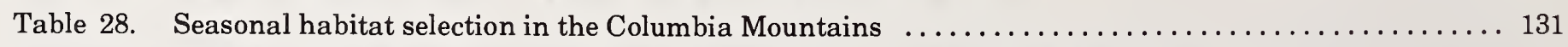

Table 29. Vegetation types associated with feeding activity for 11 major foods, Banff National Park $\ldots \ldots \ldots 132$ 
Table 30. Habitat component availability and use for 10 grizzly bears in southern British Columbia ....... 133

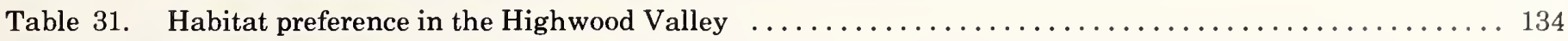

Table 32a. Habitat and grizzly bear considerations in forested grizzly habitat components in northwestern

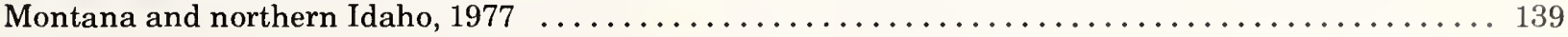

Table $32 \mathrm{~b}$. Habitat and grizzly bear considerations in nonforested grizzly habitat components in northwestern

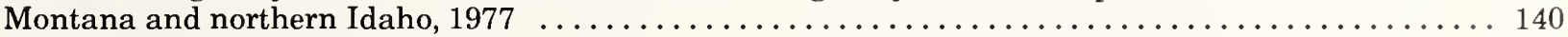

Table 33. Shrub revegetation response to 3 kinds of disturbance in 4 habitat types used by grizzly bears in northwestern Montana ................................................. 144

Table 34. Management actions and monitoring levels following bear sightings and/or incidents in the Targhee

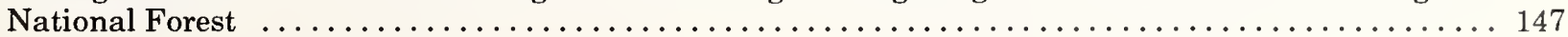

\section{LIST OF FIGURES}

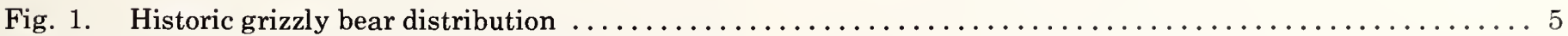

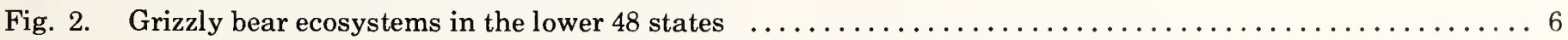

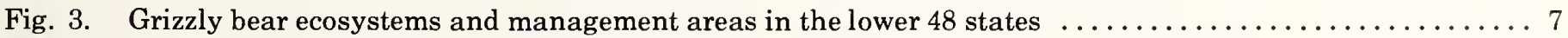

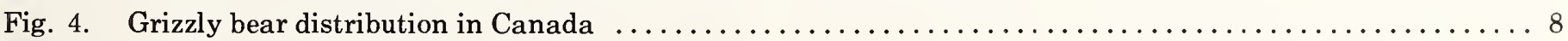

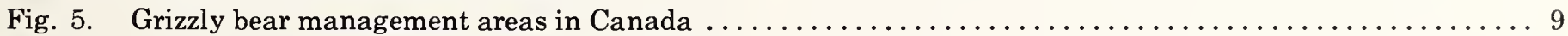

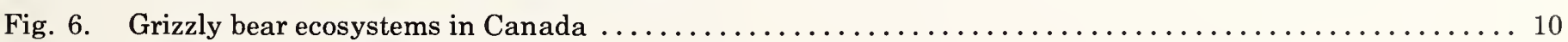

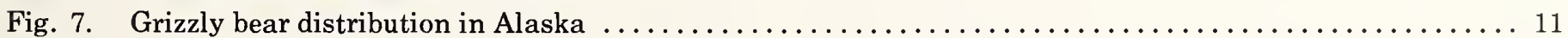

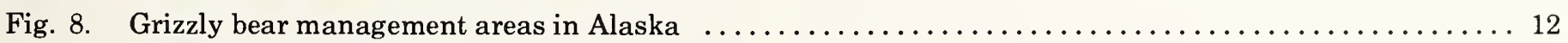

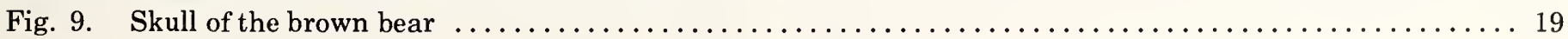

\section{APPENDIX LIST}

Appendix A. Common and scientific names of plants discussed in the narratives.

Appendix B. Subject keywords, abbreviations and definitions.

Appendix C. Geographic descriptors and abbreviations.

Appendix D. Citation index (with subject and geographic keywords).

Appendix E. Subject keyword index.

Appendix F. Geographic index (sorted by individual geographic keyword).

Appendix G. Geographic index (sorted by geographic location grouping). 



\section{INTRODUCTION}

On 1 September 1975, the grizzly bear was classified as a threatened species south of the Canadian border under provisions of the Endangered Species Act. The grizzly bear met the criteria for threatened status for the following reasons: 1) there exists both present and threatened future destruction and/or modification of its habitat; 2 ) there is at present a loss or potential loss of bears by illegal killing and by control actions involving grizzly bears threatening humans or killing livestock; 3) critical data are lacking on grizzly habitat conditions, carrying capacity, population estimations, annual reproduction, mortality and population trends; and, 4) some existing populations appear to be isolated from each other and cannot be reinforced by movements from other areas (Servheen 1982).

The grizzly bear in the lower 48 states presently numbers from 600-800 individuals (U.S. Fish and Wildlife Service 1982); a pproximately $75 \%$ of this population occurs in Montana. Historically, grizzly bears were distributed from the Pacific Ocean to the Mississippi River and from Mexico to the Arctic Circle. In the last century, grizzly bears disappeared from Texas, Kansas, Arizona, New Mexico, Oregon, Utah, California, North Dakota, South Dakota and perhaps Colorado and Washington (Craighead et al. 1974). At present, management is based on six recognized grizzly bear ecosystems, distributed over wilderness and park areas, and large national forests in the mountainous regions of Idaho, Montana and Wyoming (U.S. Fish and Wildlife Service 1982). Specific recovery plans have been approved for three of these areas: Yellowstone Grizzly Bear Ecosystem, Northern Continental Divide Grizzly Bear Ecosystem and the Cabinet-Yaak Grizzly Bear Ecosystem.

The grizzly bear in the conterminous 48 states is vulnerable to many threats, the greatest of which are habitat modification or loss, and human-caused direct mortality. Resource management activities, which include logging; geothermal, mineral and energy development; water impoundments; and livestock grazing, all lead to the destruction or modification of grizzly habitat (Knight 1977, U.S. Fish and Wildlife Service 1982). Man's activities not only lead to habitat loss, but activities such as subdivision development, commercial recreational development, livestock grazing, sport hunting and recreation increase the likelihood of bear/human conflicts and may lead to ultimate destruction of the bear (Knight 1977, Craighead et al. 1982, U.S. Fish and Wildlife Service 1982).

Craighead (1977) discussed management of grizzly bear populations, by stating; "To perpetuate the species and to expand the population where possible, as directed by the Endangered Species Act of 1973, federal and state agencies must develop guidelines and management programs that will alleviate direct competition between bears and man for the same geographic space and habitat." Agencies and the scientific community working with this species and its habitat must cooperate in developing this management plan.

In 1982, a Grizzly Bear Recovery Plan was prepared and approved. The specific objectives of the Plan (U.S. Fish and Wildlife Service 1982) are to:

1. Identify grizzly bear population goals that represent species recovery in measurable and quantifia- ble terms for the several regions that were determined to have suitable habitat for such populations, and to provide a data base that will allow informed decisions.

2. Identify population and habitat limiting factors that account for current populations existing at levels requiring threatened status under ESA.

3. Identify specific management measures needed to remove population limiting factors that will allow the populations to increase or sustain themselves at levels identified in the recovery goals.

4. Establish recovery of at least three populations in three distinct grizzly bear ecosystems in order to delist the species in the conterminous 48 states.

Management must be based on the biology and life history of the grizzly bear, incorporate all available scientific information and take into account the social, political and economic context in which the species functions. To achieve the stated management goals for the grizzly bear, $a$ thorough review of research, management and policy information was identified as a priority need. This information must be produced and published in a form readily available to researchers, managers and decision makers. Without this information, sound management decisions will be impossible. Production of the Compendium on Grizzly Bears in North America will hopefully accomplish this.

Completion of this project required a thorough review of all information available on the grizzly bear (both published and unpublished) in North America. Identification of previously compiled bibliographies (e.g., Tracy et al. 1982) on grizzly bears aided in assuring thoroughness of the Compendium. Information collection involved acquisition of literature from, but not limited to, the following sources:

1. computerized literature search services

2. library research

3. requests for information to grizzly researchers

4. state and provincial agencies; particularly Alaska, Wyoming, Washington, Idaho, Alberta, British Columbia, Northwest Territories, Yukon (reports, memorandums, etc.)

5. federal agencies; particularly U.S. Fish and Wildlife Service, U.S. Forest Service, National Park Service, Bureau of Land Mangement (reports, memorandums, etc.)

6. private conservation organizations.

Concurrent with identification and collection of the literature was reviewing and keywording each reference. An initial list of subject keywords was developed (Appendix B) and revised after review by the COTR. This list was used to assign subject keywords to describe each article.

The second task necessary for the completion of this project was the development of software for organizing and compiling references. Software was produced to achieve the following objectives: 
1. information storage and retrieval

2. edit capabilities

3. sorting by author, source, keyword and geographicindicator

4. produce a master list of citations alphabetized by author and assigned a master number

5. produce a list of keywords referenced by master number

6. produce a chapter of geographic indicators referenced by master number

7. produce a dictionary of keywords

8. print the above information in a format suitable for distribution.

Following literature collection and subsequent keywording, detailed narrataive summaries were prepared. Summaries were compiled from a review of the collected keyworded references and include:

1. introduction to the topic

2. review of past research

3. summary of biological statistics

4. regional variation relative to the topic

5. age/sex variation relative to the topic

6. management implications.

\section{Acknowledgements}

As in any project of this scope, numerous individuals contributed to its success. Principally we would like to acknowledge the assistance of Dr. Chris Servheen, Grizzly Bear Recovery Coordinator, U.S.F.\&W.S., Technical Representative on this project, who provided direction and advice. Dr. Fred Dean who laid much of the groundwork with his previous bibliographic efforts, provided additional assistance and much appreciated cooperation.

Several other individuals took an active part in the com. pletion of this project by providing access to their literature collections and advice and assistance on the project. They are G. Contreras, R. Harris, J. Hechtel, S. Herrero, C. Hunt,
C. Jonkel, K. Kendall, R. Knight, C. Martinka, S. Stringham, J. Weaver and P. Zager.

Numerous other individuals assisted by sending in references on grizzly bears. They include: W.R. Archibald, R.D. Brannon, T. Buxton (C.W.S. Library), B.H. Campbell, R. Case, K.N. Child, J. Dalle-Molle, A. Dood, G.E. Folk, Jr., E.H. Follman, R.D. Forbes, B. Gilbert, D. Griffel, B. Holder, B.L. Horejsi, K.L. Jope, W. Kasworm, D. Larsen, A.L. LeCount, S. Miller, J.A. Nagy, R.A. Nelson, R.L. Ruff, C.M. Shaver, M. Taylor, S. Tixier, L. Van Daele, B. van Drimmelen and B. Whitman, R. Engle (Yellowstone Library and Museum Association).

Several individuals provided direct assistance on the project including J. Canfield, A. Gaski, L. Harting and J. Hechtel. Their contributions are much appreciated.

In addition to staff of the National Wildlife Federation's Institute for Wildlife Research the following Federation personnel contributed to the completion of this project; S.D. Miller, Vice President, Research, Education and Development; M. Kiser, A. Thomas and J. Trussell, Data Processing; and, S. Levy, Librarian. Dr. J.D. Hair, Executive Vice President and W.W. Howard, Senior Vice President, Conservation Programs provided the support necessary to complete this project.

L.G. Muse, Administrative Assistant, Institute for Wildlife Research, provided the necessary support in keying citations, typing drafts and producing the final document.

Final acknowledgement goes to the narrative authors, primarily Albert Harting. His persistance in locatng documents, coding and keywording references, and writing narratives is central to this effort. Rick Mace authored several narratives on grizzly habitat and provided advice on others. Jodie Canfield assisted in the compilation of several tables and narratives.

Mary Beth Moss, Kathy Patnode and Will Sugg, Institute for Wildlife Research authored several narratives and provided essential asistance in editing and compiling the Compendium.

We appreciate the efforts of all involved, and apologize to anyone we may have neglected to mention. 


\section{DISTRIBUTION}

\section{HISTORIC RANGE}

Fossil evidence and historic accounts indicate that the grizzly bear originally occurred throughout most of central and western North America with concentrations in the Rocky Mountains and major river valleys (Fig. 1) (Craighead and Craighead 1967, Dood et al. 1986). Opinions differ as to the exact location of the eastern boundary. Most of the evidence supports a north-south edge between Manitoba and Ontario proceeding south through Minnesota, Nebraska, Kansas, Oklahoma and Texas and continuing down into the Mexican highlands (Bjorklund 1978, U.S. Fish and Wildlife Service 1982a). However, scattered records exist east of this boundary in Ontario, Quebec, Newfoundland, Ohio and Kentucky suggesting a broader prehistoric distribution (Elton 1954, Guilday 1968).

With man's westward expansion, the grizzly's range continued to recede. Extirpation from border states occurred in the following sequence: Texas (1890), North Dakota (1897), California (1922), Utah (1923), Oregon (1931), New Mexico (1933), Arizona (1935) and Colorado (1979) (U.S. Fish and Wildlife Service 1982, Dood et al. 1986a).

\section{CURRENT DISTRIBUTION: LOWER 48}

Today, remnant populations are managed in 6 ecosystems comprised of federal, state and private wilderness in Wyoming, Idaho, Montana and Washington. In addition, transient or relict populations were thought to possibly exist into the late 1970 s in California and Colorado, (Craighead and Craighead 1967) and more recently in northern Mexico (Jonkel et al. 1977). Population densities vary greatly between ecosystems, as well as seasonally with 4 of the 6 experiencing exchange with contiguous Canadian populations. The grizzly bear ecosystems currently exist as described below (Fig $2 \& 3$ ) (U.S. Fish and Wildlife Service 1982a, Dood et al. 1986).

Yellowstone

Includes Yellowstone and Grand Teton National Parks, John D. Rockefeller Memorial Parkway, portions of Bridger-Teton, Custer, Gallatin, Shoshone and Targhee National Forests andparcels of Bureau of Land Management (BLM), state and private lands in Montana, Wyoming and Idaho.

Northern Continental Divide

Includes Glacier National Park, portions of Flathead and Blackfeet Indian Reservations; portions of Flathead, Helena, Kootenai, Lewis and Clark and Lolo National Forests and parcels of BLM, state and private lands in Montana. Contiguous with Canadian Rockies ecosystem.

Cabinet/Yaak

Includes portions of Panhandle, Kootenai and Lolo National Forests; Cabinet Wilderness Area and state and private lands in Montana and Idaho. Contiguous with Canadian Rockies ecosystem.
Selkirk Mountains

Includes portions of Panhandle and Colville National Forests and private and state lands in Idaho and Washington. Contiguous with Canadian Rockies ecosystem.

North Cascades

Includes portions of North Cascades National Park, Ross Lake National Recreation Area, Mount Baker and Okanogaan National Forests. Contiguous with Interior B.C. ecosystem.

Selway/Bitterroot Includes portions of Clearwater, Bitterroot and $\mathrm{Nez}$ Perce National Forests and is centered in the SelwayBitterroot Wilderness Area.

\section{CANADA}

Currently, self-perpetuating populations occur in the wilderness areas of Alberta, British Columbia, Northwest Territories and Yukon Territory (Fig. 4). In addition, some evidence indicates relict populations may exist in Saskatchewan and possibly Manitoba (Pearson 1977, Cumbaa and Sciscenti 1978).

With Alaska, the Yukon Territory and British Columbia share the largest proportion of the remaining grizzly bear populations in North America. Relatively dense populations occur in the parks and wilderness areas of the northwest coastal, northern interior and Rocky Mountain ranges (Fig. 5) (British Columbia Fish and Wildlife Branch 1979a, Alberta Fish and Wildlife 1984). Grizzly bears are managed within 10 ecosystems, 4 of which are contiguous with U.S. populations (Fig. 6) (Pearson 1977. S. Herrero pers. commun).

Coastal B.C.

Covers the coastal mountains of British Columbia from Vancouver to southeastern Alaska including the coastal islands with the exception of Vancouver Island.

Interior B.C.

Covers central British Columbia from the U.S. border north to Williston Lake and includes portions of the North Cascades, Columbia, Omineca and Skeena Mountain ranges, as well as numerous lakes, drainages and provincial parks. Contiguous with North Cascades ecosystem of U.S.

Canadian Rockies

Covers the Rocky Mountains in both Alberta and British Columbia from the U.S. border northwest and includes portions of Waterton Lakes, Kootenay, Yoho, Banff, Glacier and Jasper National Parks; Willmore Wilderness Park; Rocky Mountain Forest Reserve and numerous provincial parks. Contiguous with three U.S. ecosystems: Northern Continental Divide, Cabinet/Yaak and Selkirk Mountains.

Boreal Forest

Covers the northwestern quarter of Alberta and the northeastern corner of British Columbia and includes the Caribou Mountains, and Buffalo Head Hills and the Peace River drainage. 


\section{Barren Ground}

Encompasses a broad band across the Northwest Territories from the Hudson Bay to the Mackenzie River and includes Great Bear Lake, Dubawnt Lake and a myriad of smaller lakes and drainages.

Canadian Arctic

Covers both the Yukon and Northwest Territories within the Arctic Circle from the Alaskan border east to Coronation Gulf and includes Richardson Mountains, Melville Hills, Tuktoyaktuk and Parry Peninsulas and Richards Island. Contiguous with Arctic Alaska ecosystem.

Northern Interior

Encompasses the Casia and Stikine Mountains in northcentral British Columbia, the Mackenzie Mountains of the Northwest Territories and all of the Yukon Territory up to the Arctic Circle with the exception of the extreme southwest corner of province. Contiguous with Interior Alaska ecosystem.

\section{ALASKA}

Alaskan grizzly bear distribution has undergone little alteration from its historic range. Only in areas surrounding human population centers has development encroached upon original habitat (Fig. 7) (Alaska Dept. of Fish and Game 1976).

The bears occur throughout the state with the following exceptions. No populations exist on some islands in southeastern Alaska, on the Aleutians beyond Unimak Island or on the islands of Prince William Sound, as well as in the Yukon-Kuskokwin Delta region (Anonymous 1980). Densities vary considerably with southeastern Alaska, the Kodiak Archipelago and the Alaska Peninsula having the highest concentrations and the Arctic the lowest (Fig. 8) (Anonymous 1980). 
Figure 2. Grizzly Bear Ecosystems in the Lower 48 States.

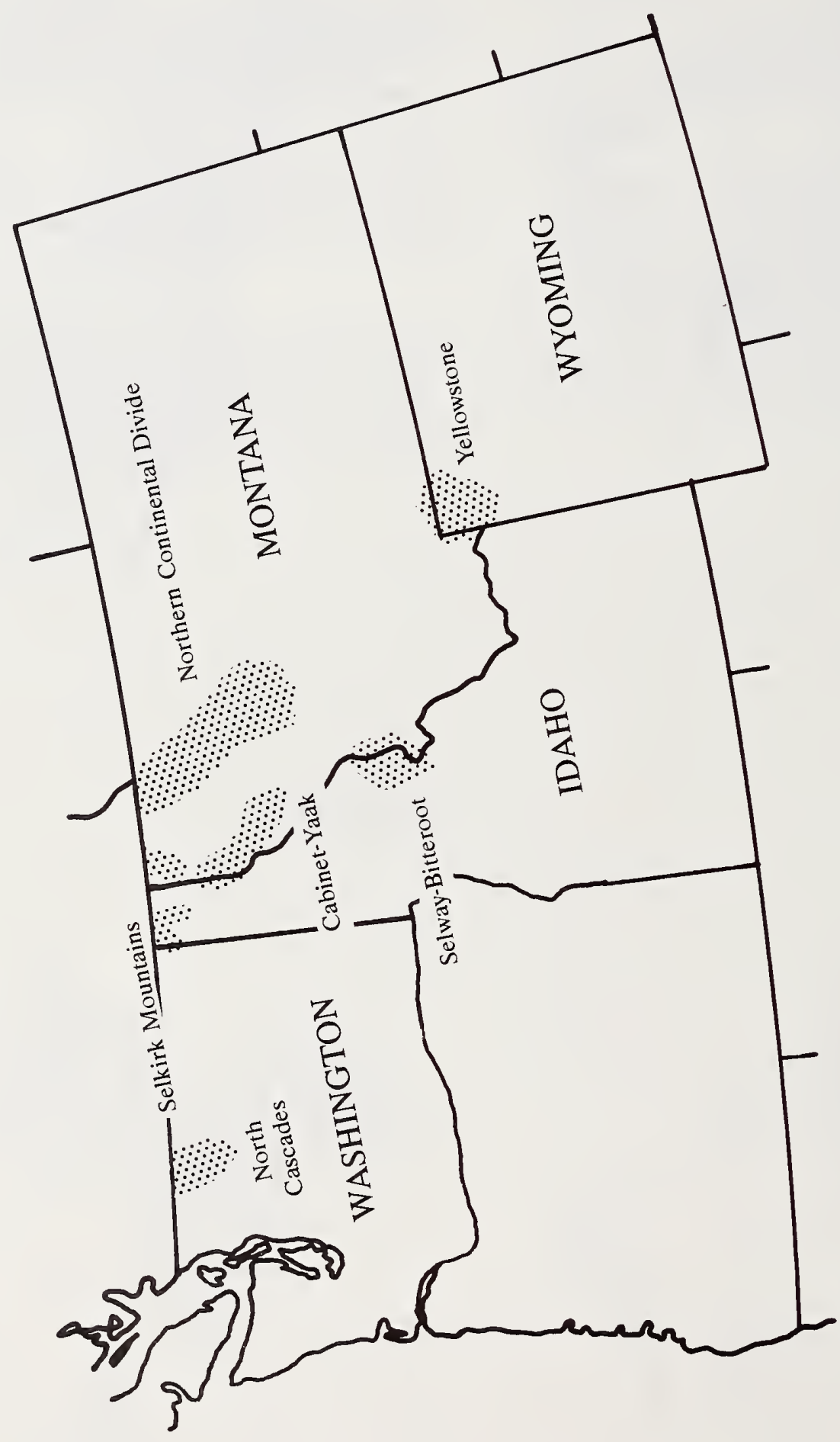


Figure 3. Grizzly Bear Ecosystems and Management Areas in the Lower 48 States.

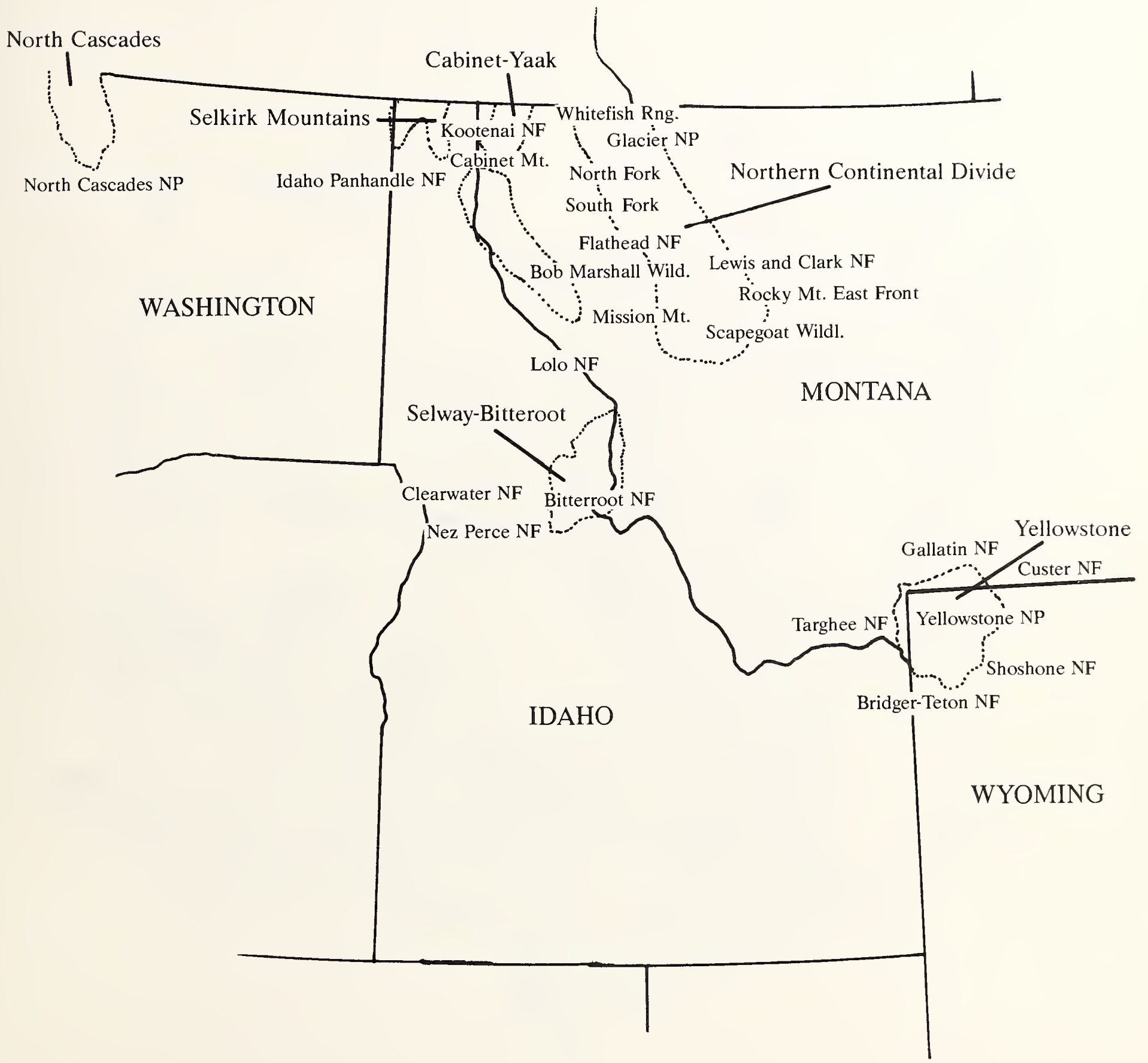


Figure 4. Grizzly Bear Distribution in Canada.

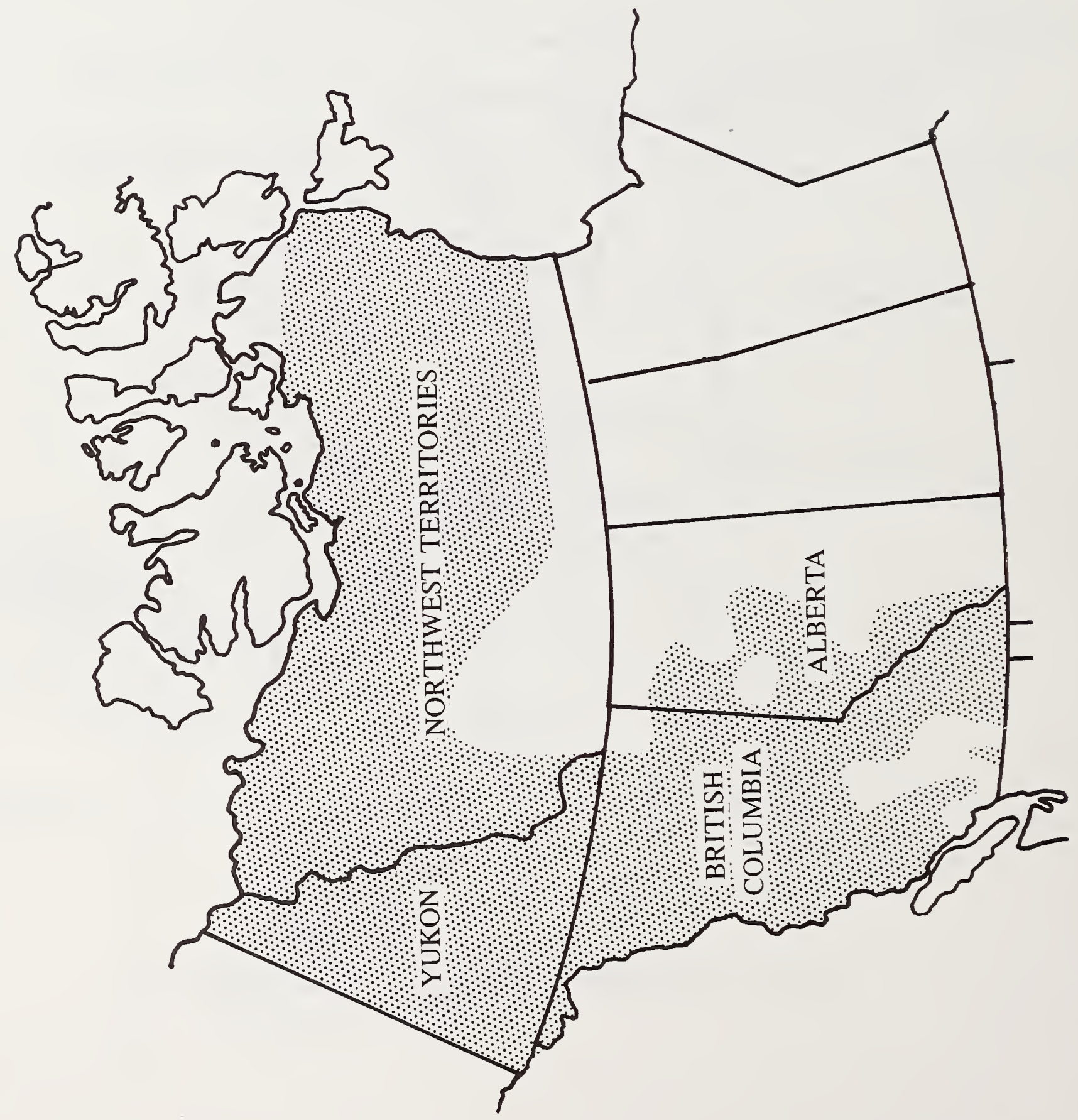


Figure 5. Grizzly Bear Management Areas in Canada.

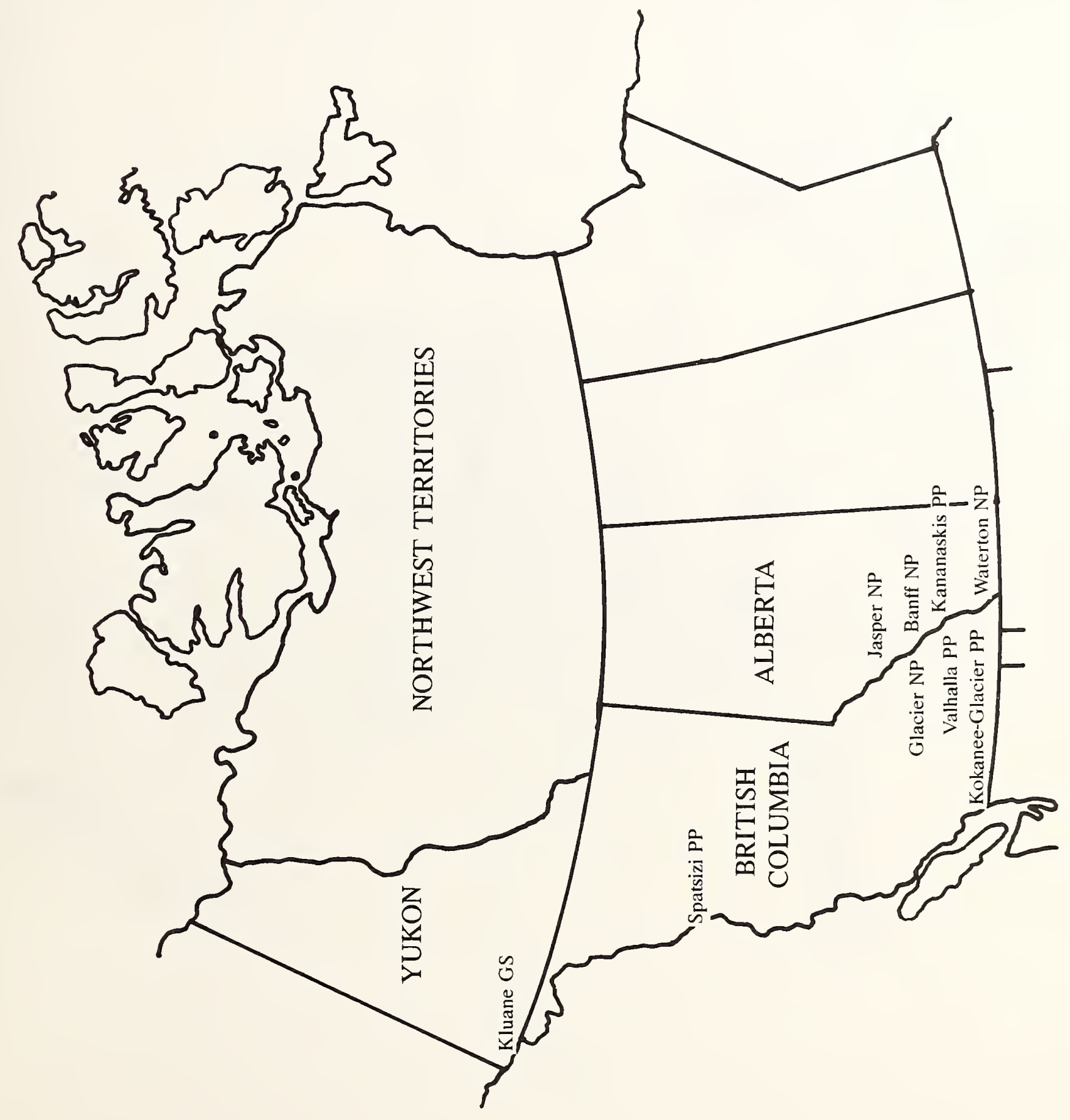


Figure 6. Grizzly Bear Ecosystems in Canada.

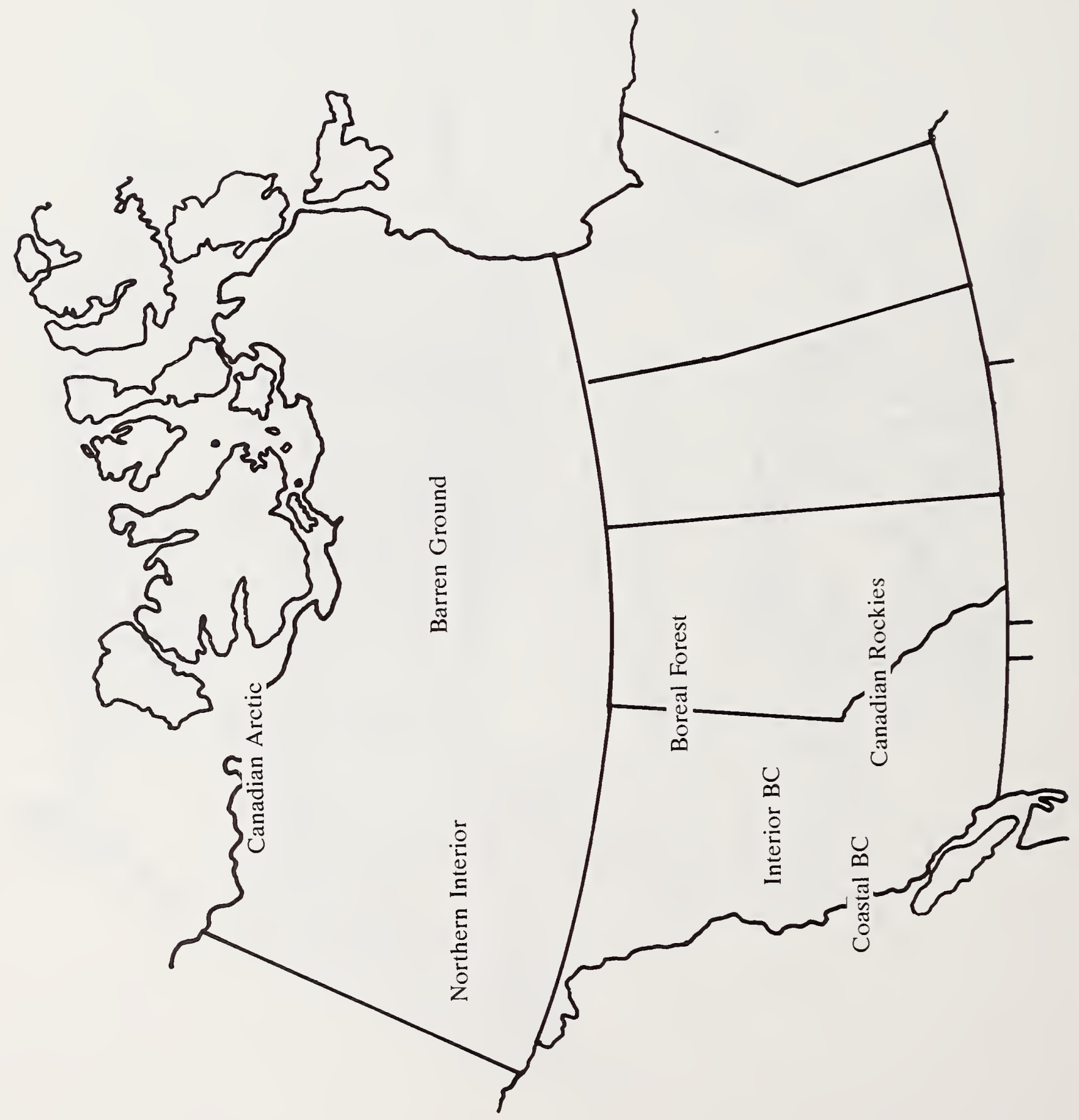


Figure 7. Grizzly Bear Distribution in Alaska.

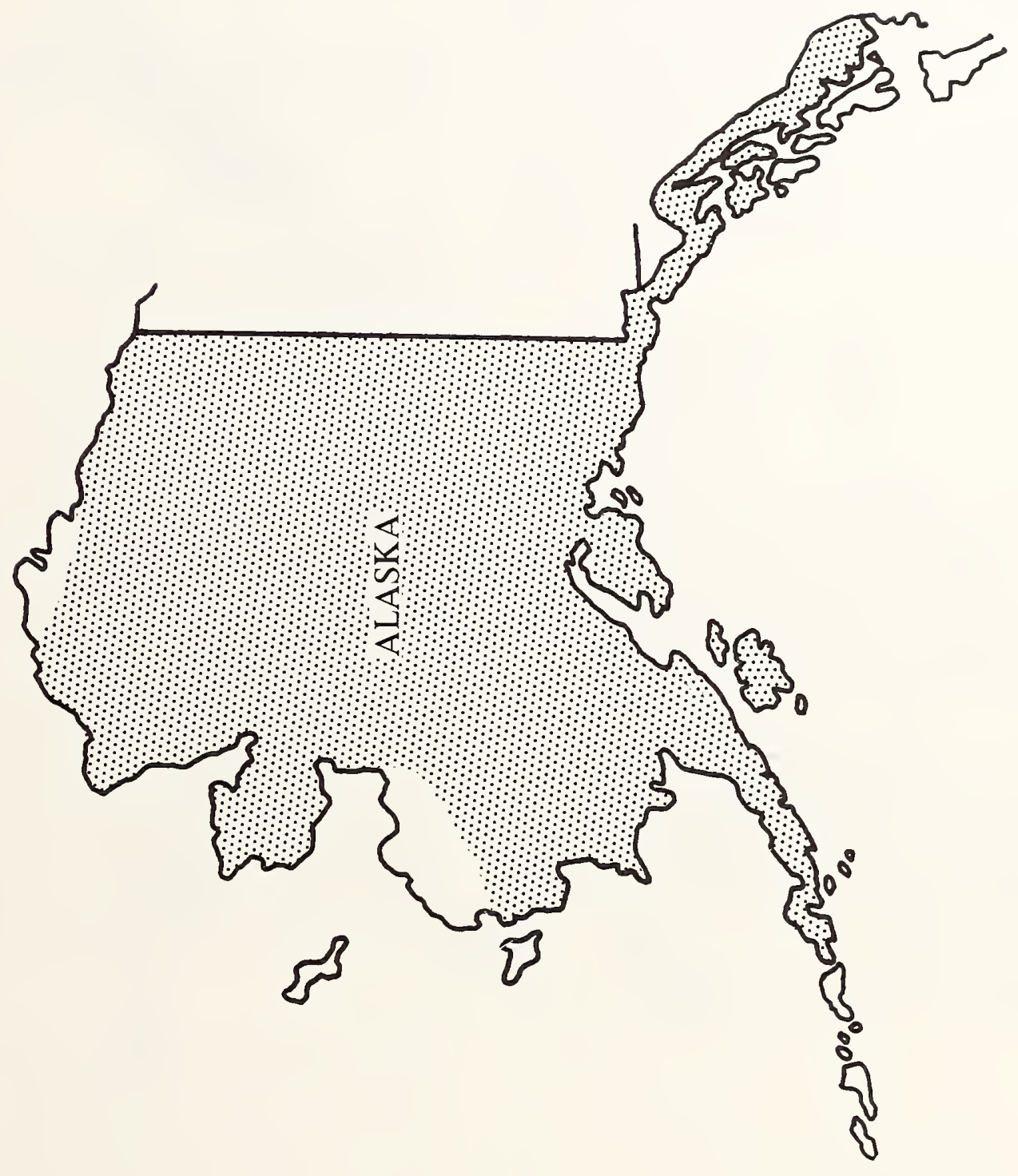


Figure 8. Grizzly Bear Management Areas in Alaska.

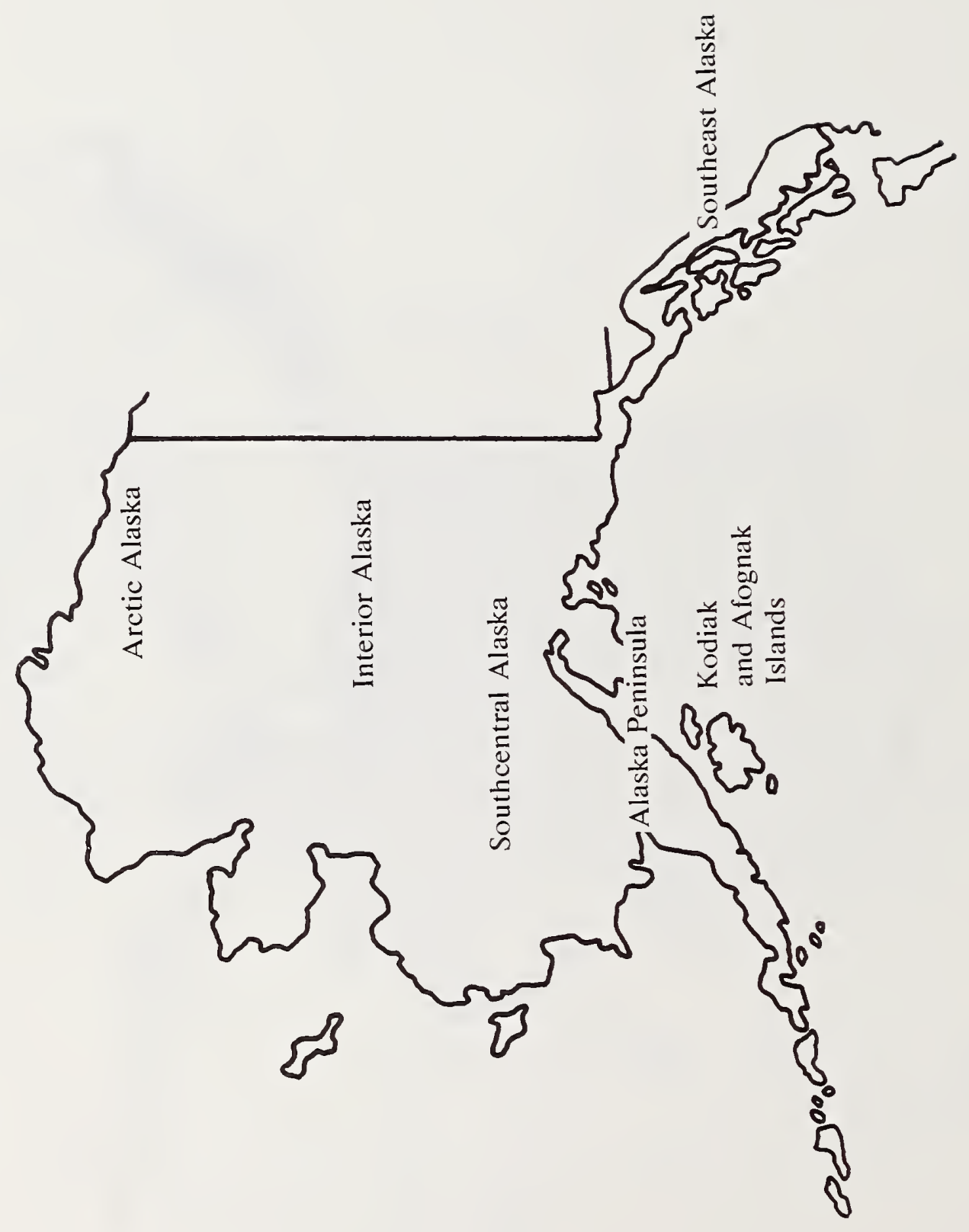




\section{MORPHOLOGY AND PHYSIOLOGY}

\section{SIZE}

A large number of reports reviewed included weight and measurement data along with capture records. Means and variance by age/sex class and season were usually not presented and this compilation of information does not attempt to analyze all of the new data from those reports lacking statistical compilations.

Weight data from most of the major capture studies are summarized in Table 1 . Weights presented in the table are not directly comparable due to differences in season of capture and sample size; the original data must be reviewed for this information.

Other quantitative measurements (e.g., length, height, girth, skull size) were also available in the literature, but were inadequate for between-area comparisons. Nagy et al. (1984) discussed the relationship of weight to chest girth for 3 Canadian grizzly bear populations. Strong correlations between weight and girth have also been reported for grizzly bears in other areas (Russell et al. 1979, Glenn 1980, Blanchard in press). Bunnell and Tait (1981) noted that bears from coastal populations tended to weigh less than those from interior populations, evident trend in Table 1. The extremes were represented by the brown bears of the Alaskan Peninsula and the grizzlies of the southwestern Yukon. Males and females from the Peninsula were 2.8 times and 2.2 times heavier, respectively, than bears from the interior population. The actual difference may have been even greater since the Peninsula data were spring weights and the interior data were collected for all seasons.

Rausch (1963) compared the size of brown/grizzly bears from various North American populations based on condylobasal length of 357 skulls from 26 regions. He found that geographic variation was clinal with 1 well-defined gradient from coastal British Columbia to the end of the Alaskan Peninsula with mean condylobasal length increasing from south to northwest. This pattern was also evident from the limited weight data available. Mean weights of adult females were: southern British Columbia coast, $122 \mathrm{~kg}$; southeast Alaska (Admiralty Island), $159 \mathrm{~kg}$; Kodiak Island, $202 \mathrm{~kg}$ and Alaska Peninsula, $207 \mathrm{~kg}$ (Table 1).

Another gradient existed along the Arctic coast with skull size increasing from Coronation Gulf, N.W.T., west to the Noatak River region of northwestern Alaska. The trends for interior populations were less apparent; the smallest mean condylobasal length occurred in the southern Yukon with mean sizes increasing both toward the southeast and the northwest. Mean weights of male and female adult grizzlies from the southern Yukon (Pearson 1975) were also less than the mean weights from any other region (Table 1). In Alaska and possibly northwestern Canada, mean condylobasal lengths decreased from south to north and from west to east.

Rausch (1963) noted that the larger size attained by bears in coastal zones appeared to be correlated with the distribution of salmon and the "luxuriance" of coastal vegetation. He concluded that maximum size was genetically determined and was not affected by either the rate of growth or quality of the diet. Glenn (1980) observed that growth rates of captive brown bears suggested that adult size was gen. erally fixed.

Blanchard (in press) reported that availability of garbage as a supplemental food source had a significant influence on grizzly bear weights in Yellowstone National Park. Both adult males and adult females with young that fed on garbage were significantly heavier than bears that did not. Mean weights of adult grizzlies in Yellowstone were heavier when open pit garbage dumps were available than after the dumps were closed. The mean annual weights of adult females which did not feed in dumps were highly correlated with annual habitat quality indices. Blanchard (in press) also examined weight data from 9 other North American bear populations. She found that, in general, females with reliable, high value foods (meats and berries) during summer and fall attained greater size, matured earlier and had larger litters than females with relatively low value foods (roots).

\section{GROWTH RATES AND PATTERNS}

Glenn (1980) in a short study of the morphometric characteristics of brown bears on the Alaskan Peninsula reported that both sexes experienced a period of rapid, continuous; growth in total body size (for several body and skull measurements) between the ages of 6 months and 2.5 years. Cranial dimensions showed a similar growth trend from 6 months to 3.5 years. There were no sex-related differences in body size at age 6 months, but yearling and 2-year-old males were larger than females for several morphometric measurements.

This period of rapid growth was followed by a period of more moderate growth during which males increased at a faster rate than females. From age 3 and older, males were significantly larger than females in all dimensions (including weight, body and skull measurements). Females attained at least $95 \%$ of their ultimate size (except in zygomatic width) by age 4-5, 2 years before that of males (ages 6-8). As indicated by cranial measurements, male rates of growth were approximately twice that of females between the ages of 6.5 and $15.5+$ years. By age 9 , there was no overlap between male and female bears in total skull size (sum of length and width).

Blanchard (in press) found that in Yellowstone National Park, male grizzlies were consistently heavier than females for all age classes except cubs and yearlings. Sexual dimorphism beginning at age 2 was also apparent in other study areas (Troyer and Hensel 1969, Pearson 1975). Males in Yellowstone steadily gained weight until at least 15 years, but the mean annual rate of weight increase for males aged 4-15 (5.6\%) was much less than the rate for cubs through 3 years $(42.1 \%)$. The mean weight of adult males was $29 \%$ greater than for females and body measurements were $8-17 \%$ greater. Males attained full size in 7 of 11 body measurements by age 6 and in all 11 by age 9 .

The growth pattern for female bears in Yellowstone was less clear (Blanchard in press). Only $48 \%$ of the variation in female weight could be explained by age, compared to $62 \%$ 
Table 1. Weight data (in pounds) recorded from grizzly bear capture records. Spring = emergence through June; Fall = August until den-up.

\begin{tabular}{|c|c|c|c|c|c|c|c|c|c|c|}
\hline \multirow[b]{2}{*}{ Ecosystem, Area and Citation } & \multicolumn{3}{|c|}{$\begin{array}{l}\text { Adults } \\
\text { (n) }\end{array}$} & \multicolumn{2}{|c|}{ Max } & \multicolumn{2}{|c|}{$\begin{array}{l}\text { Yearlings } \\
\text { (n) }\end{array}$} & \multicolumn{2}{|c|}{$\begin{array}{c}\text { Cubs } \\
(\mathbf{n})\end{array}$} & \multirow[b]{2}{*}{ Comments } \\
\hline & $\mathbf{M}$ & $\mathbf{F}$ & M:F & $\mathbf{M}$ & $\mathbf{F}$ & $\mathbf{M}$ & $\mathbf{F}$ & $\mathbf{M}$ & $\mathbf{F}$ & \\
\hline $\begin{array}{l}\text { Yellowstone } \\
\text { (Craighead and Mitchell 1982) }\end{array}$ & $\begin{array}{l}245 \\
(33)\end{array}$ & $\begin{array}{l}152 \\
(72)\end{array}$ & 1.61 & 500 & 204 & $\begin{array}{r}68 \\
(39)\end{array}$ & $\begin{array}{r}58 \\
(19)\end{array}$ & $\begin{array}{r}32 \\
(34)\end{array}$ & $\begin{array}{r}27 \\
(17)\end{array}$ & $\begin{array}{l}1959-1970 \text { data; } \\
\text { adult }=5+\text { years }\end{array}$ \\
\hline \multirow[t]{3}{*}{ (Blanchard in press) } & $\begin{array}{l}192 \\
(64)\end{array}$ & $\begin{array}{l}135 \\
(63)\end{array}$ & 1.42 & 325 & 194 & $\begin{array}{r}63 \\
(18)\end{array}$ & $\begin{array}{r}58 \\
(13)\end{array}$ & $\begin{array}{r}24 \\
(16)\end{array}$ & $\begin{array}{l}22 \\
(8)\end{array}$ & $\begin{array}{l}1975-1985 \text { data; } \\
\text { adult }=5+\text { years } \\
\text { (all seasons) }\end{array}$ \\
\hline & $\begin{array}{r}222 \\
(14)\end{array}$ & $\begin{array}{r}142 \\
(14)\end{array}$ & 1.56 & 325 & 194 & - & - & - & - & dump feeders \\
\hline & $\begin{array}{l}193 \\
(49)\end{array}$ & $\begin{array}{l}134 \\
(48)\end{array}$ & 1.44 & & & - & - & - & - & non-dump feeders \\
\hline
\end{tabular}

Northern Continental Divide

North and South Fork Flathead

Valley (Jonkel 1982)a

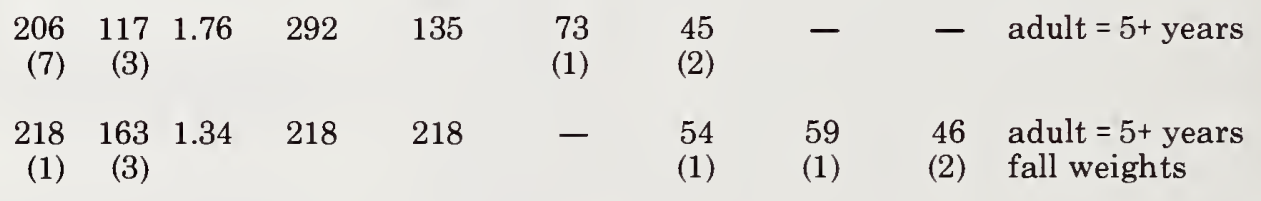

Mission Mountains

(1) (3)

(1)

(2) fall weights

Rocky Mountain East Front

(Aune 1985, Aune and Stivers

218 1982,1983, Aune et al. 1984)a

(1) (2)

- $\quad$ adult $=5+$ years spring weights

Canadian Rockies

Jasper National Park (Russell et al. 1979)

\begin{tabular}{|c|c|c|c|c|c|c|c|c|}
\hline $\begin{array}{ll}198 & 90 \\
(13) & (3)\end{array}$ & 2.20 & 345 & 96 & - & - & - & - & $\begin{array}{l}\text { adult }=6+\text { years } \\
\text { spring weights }\end{array}$ \\
\hline $\begin{array}{rr}299 & 167 \\
(4) & (4)\end{array}$ & 1.79 & 356 & 213 & $\begin{array}{r}73 \\
(1)\end{array}$ & - & - & - & fall weights \\
\hline $\begin{array}{rr}306 & 213 \\
(3) & (1)\end{array}$ & 1.44 & 356 & 213 & - & - & - & - & $\begin{array}{l}\text { dump feeders (all } \\
\text { seasons) }\end{array}$ \\
\hline $\begin{array}{rr}203 & 121 \\
(14) & (6)\end{array}$ & 1.68 & 311 & 159 & - & - & - & - & $\begin{array}{l}\text { non-dump feeders } \\
\text { (all seasons) }\end{array}$ \\
\hline $\begin{array}{rr}257 & 128 \\
(4) & (1)\end{array}$ & 1.85 & 354 & 131 & $\begin{array}{l}32 \\
(4)\end{array}$ & - & - & - & $\begin{array}{l}\text { Aug.-Sept. } \\
\text { weights (Mundy } \\
\text { and Flook 1973) }\end{array}$ \\
\hline $\begin{array}{rr}218 & 178 \\
(2) & (3)\end{array}$ & 1.22 & 218 & 206 & $\begin{array}{l}57 \\
(3)\end{array}$ & $\begin{array}{l}41 \\
(3)\end{array}$ & - & $\begin{array}{l}23 \\
(1)\end{array}$ & $\begin{array}{l}\text { adult }=6+\text { years } \\
\text { (all seasons) }\end{array}$ \\
\hline $\begin{array}{rr}139 & 95 \\
(40) & (21)\end{array}$ & 1.46 & 240 & 125 & $\begin{array}{l}40 \\
(6)\end{array}$ & $\begin{array}{l}28 \\
(1)\end{array}$ & $\begin{array}{l}12 \\
(1)\end{array}$ & - & $\begin{array}{l}\text { adult = "mature" } \\
\text { (all seasons) }\end{array}$ \\
\hline $\begin{array}{ll}148 & 110 \\
(20) & (28)\end{array}$ & 1.34 & 214 & 147 & $\begin{array}{l}63 \\
(3)\end{array}$ & - & $\begin{array}{l}30 \\
(2)\end{array}$ & - & $\begin{array}{l}\text { adult }=5+\text { years } \\
\text { (all seasons) }\end{array}$ \\
\hline $\begin{array}{ll}178 & 116 \\
(37) & (40)\end{array}$ & 1.53 & 272 & 186 & - & - & - & - & $\begin{array}{l}\text { adult males }=8+ \\
\text { years; adult } \\
\text { females }=6+\text { yrs. } \\
\text { (all seasons) }\end{array}$ \\
\hline
\end{tabular}

Interior British Columbia

Glacier National Park

$\begin{array}{lllll}257 & 128 & 1.85 & 354 & 131\end{array}$

weights (Mundy and Flook 1973)

Boreal Forest

Swan Hills, Alberta (Nagy and

Russell 1978)

$\begin{array}{rr}218 & 178 \\ (2) & (3)\end{array}$

Northern Interior

Southwest Yukon (Pearson 1975)

Mackenzie Mountains, NWT (Miller, Barichello and Tait 1982)

$\begin{array}{lllll}139 & 95 & 1.46 & 240 & 125\end{array}$

Canadian Arctic

Northern Yukon (Nagy et. al. 1983a) 


\begin{tabular}{|c|c|c|c|c|c|c|c|c|c|c|}
\hline \multirow[b]{2}{*}{ Ecosystem, Area and Citation } & \multicolumn{3}{|c|}{$\begin{array}{l}\text { Adults } \\
\text { (n) }\end{array}$} & \multicolumn{2}{|c|}{ Max } & \multicolumn{2}{|c|}{$\begin{array}{l}\text { Yearlings } \\
\text { (n) }\end{array}$} & \multicolumn{2}{|c|}{$\begin{array}{c}\text { Cubs } \\
(\mathbf{n})\end{array}$} & \multirow[b]{2}{*}{ Comments } \\
\hline & $\mathbf{M}$ & $\mathbf{F}$ & M:F & $\mathbf{M}$ & $\mathbf{F}$ & $\mathbf{M}$ & $\mathbf{F}$ & $\mathbf{M}$ & $\mathbf{F}$ & \\
\hline $\begin{array}{l}\text { Northwest Territory (Nagy } \\
\text { et. al. 1983b) }\end{array}$ & $\begin{array}{l}189 \\
(18)\end{array}$ & $\begin{array}{l}122 \\
(46)\end{array}$ & 1.55 & 283 & 230 & $\begin{array}{r}43 \\
(12)\end{array}$ & $\begin{array}{l}36 \\
(7)\end{array}$ & $\begin{array}{r}10 \\
(2)\end{array}$ & $\begin{array}{l}10 \\
(4)\end{array}$ & $\begin{array}{l}\text { adult males }=7+ \\
\text { years; adult } \\
\text { females }=5^{+} \text {yrs. } \\
\text { (all seasons) }\end{array}$ \\
\hline \multirow[t]{2}{*}{$\begin{array}{l}\text { Arctic Alaska } \\
\text { Western Brooks Range } \\
\text { (Reynolds and Hechtel 1982) }\end{array}$} & $\begin{array}{l}145 \\
(24)\end{array}$ & $\begin{array}{l}104 \\
(24)\end{array}$ & 1.39 & 218 & 134 & $\begin{array}{l}34 \\
(1)\end{array}$ & $\begin{array}{l}24 \\
(3)\end{array}$ & $\begin{array}{l}12 \\
(3)\end{array}$ & $\begin{array}{r}9 \\
(4)\end{array}$ & $\begin{array}{l}\text { adult }=5+\text { years } \\
\text { May - June } \\
\text { weights }\end{array}$ \\
\hline & $\begin{array}{r}210 \\
(4)\end{array}$ & $\begin{array}{r}130 \\
(9)\end{array}$ & 1.61 & 236 & 181 & - & - & - & $\begin{array}{l}18 \\
(3)\end{array}$ & Aug-Oct weights \\
\hline $\begin{array}{l}\text { Eastern Brooks Range } \\
\text { (Reynolds 1976) }\end{array}$ & $\begin{array}{r}205 \\
(9)\end{array}$ & $\begin{array}{l}116 \\
(14)\end{array}$ & 1.77 & 272 & 141 & $\begin{array}{l}50 \\
(2)\end{array}$ & $\begin{array}{l}43 \\
(2)\end{array}$ & - & - & $\begin{array}{l}\text { (Aug-Oct } \\
\text { weights) } 1974\end{array}$ \\
\hline North Slope (Crook 1972) & $\begin{array}{r}254 \\
(3)\end{array}$ & $\begin{array}{r}155 \\
(5)\end{array}$ & 1.64 & 313 & 209 & - & - & - & - & $\begin{array}{l}\text { adult }=5+\text { years } \\
\text { (summer } / \text { fall } \\
\text { wts) }\end{array}$ \\
\hline $\begin{array}{l}\text { Arctic Natl. Wildlife Refuge } \\
\text { (Garner et. al. 1984) }\end{array}$ & $\begin{array}{l}135 \\
(22)\end{array}$ & $\begin{array}{r}93 \\
(32)\end{array}$ & 1.45 & 184 & 116 & $\begin{array}{l}20 \\
(4)\end{array}$ & - & $\begin{array}{r}9 \\
(2)\end{array}$ & $\begin{array}{r}6 \\
(2)\end{array}$ & $\begin{array}{l}\text { May - July } \\
\text { weights }\end{array}$ \\
\hline $\begin{array}{l}\text { Interior Alaska } \\
\text { Alaska Range (Reynolds and } \\
\text { Hechtel 1983a) }\end{array}$ & $\begin{array}{r}176 \\
(5)\end{array}$ & $\begin{array}{c}114 \\
(12)\end{array}$ & 1.54 & 172 & 141 & $\begin{array}{l}48 \\
(2)\end{array}$ & $\begin{array}{l}40 \\
(2)\end{array}$ & $\begin{array}{l}12 \\
(2)\end{array}$ & $\begin{array}{l}12 \\
(3)\end{array}$ & $\begin{array}{l}\text { adult }=5+\text { years } \\
\text { (May } 15-\text { July } 15 \text { ) }\end{array}$ \\
\hline $\begin{array}{l}\text { Southcentral Alaska } \\
\text { Nelchina Basin (Miller and } \\
\text { Ballard 1980) }\end{array}$ & $\begin{array}{l}243 \\
(18)\end{array}$ & $\begin{array}{l}119 \\
(21)\end{array}$ & 2.04 & 289 & 170 & $\begin{array}{r}40 \\
(8)\end{array}$ & $\begin{array}{l}38 \\
(6)\end{array}$ & $\begin{array}{r}5 \\
(3)\end{array}$ & $\begin{array}{r}5 \\
(1)\end{array}$ & $\begin{array}{l}\text { adult }=5+\text { years } \\
\text { (spring weights) } \\
1978-1979\end{array}$ \\
\hline $\begin{array}{l}\text { Nelchina Basin (S.D. Miller } \\
\text { 1984) }\end{array}$ & $\begin{array}{l}221 \\
(16)\end{array}$ & $\begin{array}{l}128 \\
(28)\end{array}$ & 1.72 & 317 & 204 & $\begin{array}{l}30 \\
(3)\end{array}$ & $\begin{array}{r}4 \\
(1)\end{array}$ & $\begin{array}{l}5.4 \\
(5)\end{array}$ & $\begin{array}{l}4.7 \\
(3)\end{array}$ & $\begin{array}{l}\text { adult }=5+\text { years } \\
\text { (spring weights } \\
1980-1983 \text { ) }\end{array}$ \\
\hline $\begin{array}{l}\text { Alaskan Peninsula } \\
\text { Peninsula (Glenn et al. 1976, } \\
\text { Glenn 1971,1973a,1980) }\end{array}$ & 389 & 207 & 1.88 & 442 & 275 & 82 & 51 & - & - & $\begin{array}{l}\text { adult }=9+\text { years } \\
\text { (spring weights) }\end{array}$ \\
\hline $\begin{array}{l}\text { Kodiak/Afognak } \\
\text { Kodiak Island (Troyer and } \\
\text { Hensel 1969) }\end{array}$ & $\begin{array}{l}312 \\
(10)\end{array}$ & $\begin{array}{l}202 \\
(16)\end{array}$ & 1.55 & ${ }^{411}$ fall) & 299 & $\begin{array}{r}67 \\
(20)\end{array}$ & $\begin{array}{r}63 \\
(22)\end{array}$ & $\begin{array}{r}23 \\
(17)\end{array}$ & $\begin{array}{r}22 \\
(15)\end{array}$ & $\begin{array}{l}\text { adult }=6+\text { years } \\
\text { (midsummer } \\
\text { weight unless } \\
\text { indicated) }\end{array}$ \\
\hline $\begin{array}{l}\text { Southeast Alaska } \\
\text { Admiralty Island (Woody 1976) }\end{array}$ & - & 159 & - & - & 227 & 84 & - & 31 & 36 & $\begin{array}{l}\text { adult }=9+\text { years } \\
\text { (Sept } 1972 \text { and } \\
1973)\end{array}$ \\
\hline
\end{tabular}

aWeights estimated from body measurements 
for male bears. The mean annual rate of increase for females aged 4-13 (5.2\%) was much less than the rate for cubs through 3 years (36\%). An observed decrease in weight at age 6 may have been related to the nutritional costs of first cub production. Females reached mean adult size in 5 of 11 body measurements by age 4 and in the remaining 6 by age 7 .

Troyer and Hensel (1969) reported that growth rates of male and female bears began to diverge at age 4 . Limited data indicated that females approached their maximum size by their sixth summer while males continued to grow at a near constant rate until approximately age 9. Cessation of growth in females appeared to correspond with attainment of sexual maturity.

Kingsley et al. (1983) studied the growth patterns of 2 populations of grizzly bears in northern Canada. They found that the ultimate spring weight for males was nearly twice that for females, but males took 14 years to reach $95 \%$ of this weight while females took only 9 years. In another study, Kingsley et al. (in press) used "zoological length" (length along the spine from nose to tip of the tail) to study grizzly bear growth patterns. Their analysis showed that, unlike the weight-age patterns discussed above, the lengthage curves for the 2 sexes differed very little. The male asymptote was $21 \mathrm{~cm}$ larger than the female but both curves leveled off quickly. Females reached $90 \%$ of the asymptotic length at only 4.02 years and males reached this length at 4.69 years. Thus, for male bears, skeletal growth appeared to be completed rapidly while weight tended to increase throughout the normal life span. These results contrasted with Glenn's (1980) finding that males showed protracted growth in both length and weight (age for $95 \%$ total length was 4 years and 6 years for females and males, respectively).

The growth patterns of a grizzly bear population in the western Brooks Range, Alaska, differed significantly from the patterns observed for the 2 northern Canadian populations (northern Yukon and Tuktoyaktuk Peninsula). The initial growth rate (based on zoological length) for the Alaskan population was about $75 \%$ of the Canadian rate; Alaskan grizzlies reached $90 \%$ of their asymptotic length 1.4-1.9 years after the Canadian bears; however, Alaskan bears were $5 \mathrm{~cm}$ longer than the Canadian bears. In both regions, the age of first reproduction (6 years for northern Canada and 8 years for northwestern Alaska) corresponded to the age when females attained $95 \%$ of their asymptotic length. Kingsley et al. (in press) suggested that, as indicated by mean home range size, the Alaskan population might have been on a lower nutritional plane.

Kingsley et al. (in press) also studied the ecological aspects of sexual dimorphism in bears. They felt that competition for range and mates resulted in a selective advan. tage to large size for adult males. The selective advantage to females should be to complete growth early in life and, after attaining some minimum size, divert energy from growth to reproduction.

Bunnell and Tait (1981) noted that sexual dimorphism does not generally serve to partition food resources in large omnivores. They suggested that the larger body size of male bears favored the establishment of larger home ranges and, thus, access to a greater number of potential mates. Large size also conferred a selective advantage in intraspecific conflicts during the breeding season. The smaller body size of females enables them to establish smaller, more exclusive home ranges - a benefit while rearing young.

\section{Seasonal Patterns of Weight Gain and Loss}

Kingsley et al. (1983) studied seasonal weight changes in two northern Canadian grizzly bear populations. The fall asymptotic (final) weight for males was $28 \%$ greater than the spring asymptotic weight. During the first summer, male weight tripled and, thereafter, the relative weight gain (percent increase over spring weight) declined each year. The relative weight loss in winter remained fairly constant (slightly greater than a $20 \%$ decrease of the fall weight) throughout the lifespan. In contrast, female bears cycled more weight than males, both absolutely and relatively. The greater relative weight fluctuation in females was apparent from the age of first reproduction on. The gain and loss increased with age until the oldest females were cycling $70 \%$ of their spring weight.

In the Yellowstone ecosystem, adult grizzly bears lost weight from the time of den emergence through July and generally regained their emergence weight by August (Blanchard in press). Limited data suggested that subadults did not regain their emergence weight until September. Two-year-old grizzlies showed the lowest spring to fall weight gain, probably as a consequence of stress from weaning and dispersal; weaned yearlings steadily lost weight from July to September. Females showed the greatest spring to fall weight gain as 3 - and 4-year-olds (30 and $29 \%$, respectively), while males showed the greatest gain as 4- and 5-year-olds (39 and 34\%, respectively). The greatest daily weight gain was for 23 -year-old males which gained $1.3 \mathrm{~kg}$ /day over 17 and 22 days, respectively. Adult bears exhibited increases of $6-10 \%$ and $15 \%$ for females and males, respectively. Over winter, adult males lost a greater percent of body weight than adult females (18\% as compared to $8 \%$ ). These findings contrast with those of Kings ley et al. (1983) discussed above in that they reported that adult females lost higher percentages of their fall weight in the den.

Craighead and Mitchell (1982) discussed the seasonal patterns of weight gain and loss for Yellowstone grizzlies during the 1959-1970 period. Observation of feeding behavior and weight records suggested that losses in body weight during April and May exceeded gains. By June, grizzlies were on a normal feeding regime but still exhibited little or no gain in body weight until late July or August; however, from mid-July through September, weight gains were substantial. Observed weight gains for individual bears were $1.65 \mathrm{~kg}$ /day for a 2-year old female from mid-July to midAugust, $0.97 \mathrm{~kg} /$ day for a yearling male over a similar period and $1.13 \mathrm{~kg} /$ day for an adult female over a 26-day period. Observed weight gains for longer periods of time were $0.41,0.24$ and $0.46 \mathrm{~kg} /$ day over 111,114 and 118 days, respectively.

Troyer and Hensel (1969) inferred from the available data that brown bears on Kodiak Island lost about $30 \%$ of their acquired fall weight while denning. Male bears continued to lose weight rapidly after emergence; however, spring weight losses for mature females and immature bears were less pronounced as they remained in the den longer. The weight lost in spring was usually regained by 
midsummer. Summer-to-fall weight gains ranged from $110 \%$ for cubs to $42 \%$ for 5 -year-olds. One 3-year-old male gained $20 \mathrm{~kg}$ per day and another 3-year-old male gained $1.05 \mathrm{~kg} /$ day. Troyer and Hensel (1969) also provided an excellent discussion of fat deposition patterns based on inspection of carcasses.

Nagy et al. (1983b) reported that in the Northwest Territories, 3 adult males gained an average of $0.29 \mathrm{~kg} /$ day from spring to late summer or fall (mean of 111 days). Three subadult males had a verage daily increases of $0.35 \mathrm{~kg} /$ day over a mean of 102 days. Maximum rates of gain were 0.49 $\mathrm{kg} /$ day for an adult male over 117 days and $0.51 \mathrm{~kg} /$ day over 81 days for a subadult male. Average weight gains for 4 adult and 2 subadult females were 0.42 and $0.38 \mathrm{~kg} / \mathrm{day}$, respectively, from mid-August to mid-September while feeding mostly on ground squirrels. The results suggested that rates of gain were dependent on season, availability of various food items, feeding habits of individual bears and the reproductive status of females.

Weight losses during winter were highly variable for grizzly bears in the northern Northwest Territories (Nagy et al.1983b). Total weight losses during the denning period averaged $0.19 \mathrm{~kg}$ /day over 255 days for 2 adult males $(24 \%$ weight loss), $0.02 \mathrm{~kg} /$ day over 256 days for 1 subadult male (5\% loss), $0.18 \mathrm{~kg} /$ day over 249 days for 5 adult females $(30 \%$ loss) and $0.10 \mathrm{~kg} /$ day over 249 days for 2 subadult females (34\% loss).

Nagy et. al. (1983a) reported that in the northern Yukon, the average weight gain for 3 adult males was $0.57 \mathrm{~kg} / \mathrm{day}$ over 116 days from May to September (50\% weight gain). The greatest weight gain for an adult male was $0.74 \mathrm{~kg} / \mathrm{day}$ over 112 days. Two adult females with yearlings gained 0.14 and $0.58 \mathrm{~kg} /$ day over 28 and 62 days, respectively. Over-winter weight losses averaged $0.22 \mathrm{~kg} /$ day for 5 adult males and 4 adult females over 238 days. This loss corresponded to average reductions in body weight of $25 \%$ and $36 \%$ of males and females, respectively.

Pearson (1975) reported that in the southern Yukon the average over-winter weight loss for 4 grizzly bears (2 adult males and 2 subadult females) was $0.2 \mathrm{~kg} /$ day for an average of 220 days. These animals lost $28-43 \%$ of their fall weight in the den.

Weight increases in the fall were rapid. An adult male gained $0.41 \mathrm{~kg} /$ day for 126 days and an immature female gained $0.64 \mathrm{~kg} /$ day for 16 days in August. Nagy and Russell (1978) reported gains of $330 \%$ over 148 days $(0.39$ $\mathrm{kg} /$ day) for a 2-year-old male and $91 \%$ over 90 days $(0.36$ $\mathrm{kg} /$ day) for an immature female in the Swan Hills region of Alberta. Russell et al. (1979) reported that 2 subadult grizzlies in Jasper National Park gained an average of 0.22 $\mathrm{kg} /$ day from spring to autumn. The average rate of loss for 3 grizzly bears from denning to emergence was $0.22 \mathrm{~g} /$ day.

Several studies presented data on weight gains of captive grizzlies or brown bears. Bunnell and Tait (1983) fed 2 captive yearlings various experimental diets including horse meat, dog food, blueberries, salmon and beet pulp. During a 190-day trial period, the male yearling gained 0.63 $\mathrm{kg} /$ day ( $133 \%$ increase) and the female gained $0.51 \mathrm{~kg} /$ day ( $129 \%$ increase). Captive male and female brown bear cubs at the Houston Zoo gained 6.0 and $4.4 \mathrm{~kg} / \mathrm{month}$, respectively, from birth to 4 months. A female brown bear cub reared at the Copenhagen zoo gained $7.1 \mathrm{~kg} / \mathrm{mon}$ th during its first 7 months (Ben Shaul 1962). Jonkel et al. (1980) reported that a captive grizzly cub, fed a diet to encourage maximum weight gain, increased its weight by $12.7 \mathrm{~kg}$ in 31 days $(0.41 \mathrm{~kg} /$ day).

\section{PELAGE AND MOLT}

Great variation in color and color patterns exists throughout the range of the grizzly bear and is discussed briefly, by ecosystem, below.

\section{Yellowstone Grizzly Bear Ecosystem}

Knight et al. (1981) reported great variation in the pelage characteristics of Yellowstone grizzly bears. The distribution of lighter tipped guard hairs resulted in various patterns affected by light conditions. They found 5 major color patterns in the following frequencies: girth band $(n=28$, $44 \%)$; medium ( $n=14,22 \%)$; gold/silver $(n=9,14 \%)$; multicolored $(n=8,12 \%)$ and black $(n=5,8 \%)$.

The most common color pattern found in the Yellowstone ecosystem was "medium to dark brown underfur; brown legs, hump and underparts; light to medium grizzling on the head and part of the back and a light colored girth band or patch behind the forelegs" (Knight et al. 1981). Other common color patterns included overall gold or silver appearance with brown underparts and occasionally a dark back stripe; bears lacking silver-tipped guard hairs and appearing black or brown; and bears appearing mostly dark brown with grizzled forequarters and face. Subadults were often multicolored with a light-colored yoke. These distinctive color patterns often faded with maturity.

\section{Montana (statewide)}

Greer and Craig (1971) reported that the pelage of individual grizzlies varied annually. About $50 \%$ of the pelts examined by taxidermists were grizzled, 30\% were dark and $20 \%$ were lighter than the usual base black. Young animals were often lighter than adults.

\section{Northern Continental Divide Ecosystem}

Peacock (1978) found that in Glacier National Park the high degree of variation by season and illumination condition precluded the use of color marking and size for individual recognition. He discussed 3 cases in which striking color patterns faded markedly over time.

\section{Canada}

\section{Boreal Forest}

Nagy and Russell (1980) reported that most northern Alberta bears were brown. Others had brown underfur with blonde to white guard hairs over the head, shoulder and back with darker legs.

\section{Canadian Rockies}

Russell et al. (1978) found that about half of the grizzly bears in Jasper National Park were brown, some with a yellowish tinge on the sides and back. The rest had prominent blonde, yellow or silver-tipped guard hairs on the 
sides, back and neck. Heads were brown to yellow, the humps were darker than the torso and the legs were still darker.

\section{Yukon}

Pearson (1975) found that $72 \%$ of the grizzly bears he examined were brown (most commonly chocolate-brown underfur with silver-yellow guard hairs over neck and shoulders). The rest were blonde or yellow usually with a dark dorsal stripe and dark brown legs. Bears which were blonde or light yellow all over were least common. Pearson attributed very light coloration to bleaching which was, at least in part genetically regulated.

Chronology of the molt varied by age and sex class with mature males molting first (beginning in early July) followed by younger males and mature females (beginning in mid-July). The molt was completed by late July or August. In an earlier report, Pearson (1965a) noted that grizzlies appeared to lighten in August and gradually darken until October when most were again brown.

Similarly, Nagy et al. (1983a) found that in the northern Yukon, grizzly bears ranged from basic "chocolate" or lightly grizzled brown to blond animals with dark leggings. The affects of bleaching were described for 24 animals which were handled more than once during the study. Ten bears changed color patterns between handling including $60 \%$ of the males and $11 \%$ of the females. Pre-molt bears captured in the spring gradually faded or bleached to a straw blond color. After the molt these bears appeared as sleek brown once again.

\section{Northwest Territories}

As observed in the Yukon, grizzlies in the far northern, Northwest Territories ranged from a basic chocolate, light grizzled or rufous brown to blond with dark brown or black leggings. The affects of bleaching were described for 38 bears. Thirty-seven percent of these changed color, including $52 \%$ of the females and $13 \%$ of the males. (This sexspecific trend was opposite to that observed in the Yukon by Nagy et al. 1983a.)

\section{Alaska}

Rausch (1953) reported that for the Brooks Range, the general pattern was a light colored head and shoulders; dark back, sides and belly and still darker legs and feet. Overall, coloration varied from pale-yellow to black. $\mathrm{He}$ noted that bears in the Alaskan Peninsula and KodiakAfognak area may be more uniformly colored but exceptions were common. Erikson (1965) presented pelage data from 995 brown/grizzly bear pelts from 5 different harvest areas in Alaska. As in Rausch (1953), he found that coastal bears were more uniformly colored than interior bears, the latter being more mottled and often having light-tipped guard hairs over a dark underfur. Fewer bears were light blonde and creamy-white. The legs of all forms were dark. Most cubs had a white "collar" throughout their first summer and failed to shed during that period. Thirty-three percent of the spring kills had "rubbed" hides indicating shedding while only $5 \%$ of the fall hides were rubbed.

Quimby and Snarski (1974) reported that grizzly bears in Arctic Alaska were generally lighter than bears in other parts of the state. More than $50 \%$ of the adults observed by Crook (1971) in 1970-1971, were light brown or blond.
Quimby and Snarski (1974) found that dark colored bears predominated in the population during May, September and October, while lighter-colored bears predominated during June - August. They attributed these trends to differences in timing of emergence, sex-specific differences (darker colored males emerged before the lighter colored females), bleaching and general observability by sex.

Troyer and Hensel (1969) described the pelage characteristics of Kodiak Island brown bears. Cubs, hairless at birth, could have hair up to 4 in length by fall. Young bears frequently had white "collars" which faded by the time the bears emerged as 2-year olds. Cubs and immatures were otherwise more uniformly colored and had less inter-bear variation than adults. Adult males tended to be darker, have shorter, less dense, hair than females (except along their dorsal midline). Shedding occurred through the midseason and may have begun before den emergence. Twenty-nine percent of the spring hides examined were "rubbed" (in post-shedding condition) as opposed to only $8 \%$ of the fall hides.

\section{General}

Moen and Rodgers (1985) measured the radiant temperatures on 4 main body zones of the black bear and discussed the variation due to hair depth, exposure (body position) and other factors. Although he did not discuss bears specifically, Walsberg (1983) studied the thermal aspects of coat color and concluded that there was not a simple relation between pelage and solar heat gain as is commonly presumed. Rogers $(1976,1980)$ discussed the genetic basis for pelage color in black bears. He found that certain reproductive parameters were associated with coat color. Lighter colored females produced significantly larger litters than darker sows, but the cubs of the former group weighed less and experienced higher mortality in poor food years. He also speculated that mimicry of grizzly bears may provide, along with thermal regulation and camouflage, one basis for light coloration in black bears. The converse may be true, although it has not been studied.

\section{SKULL AND DENTITION}

\section{Skull}

Skull size, relative proportions and details of dentition are important in determining age, sex and subspeciation in grizzly bears (Fig. 9) (Merriam 1918, Rausch 1953, Mundy and Fuller 1964, Zavatsky 1976). The skull of Ursus arctos grows and changes in structure over the entire life of the animal. Bear cubs possess a circular shaped skull which lengthens during growth and at the time of sexual maturity (3-4 yrs. in females; 4-5 yrs. in males), the skull has the characteristic form for the species (Zavatsky 1976). Condylobasal length and zygogamatic width are frequently measured skull charcteristics; however, the latter dimension continues to increase after maximum skull length has been attained (Rausch 1963). Zavatsky (1976) recognized 11 distinct age classes using external characteristics of the skull, teeth and live weight of the bear. He claims that "with this method, accuracy of age determination to the 4 th year is within 1-2 months and from the 4 th to the 18 th year is to within 2-3 years." 
Figure 9. Skull of the Brown Bear.
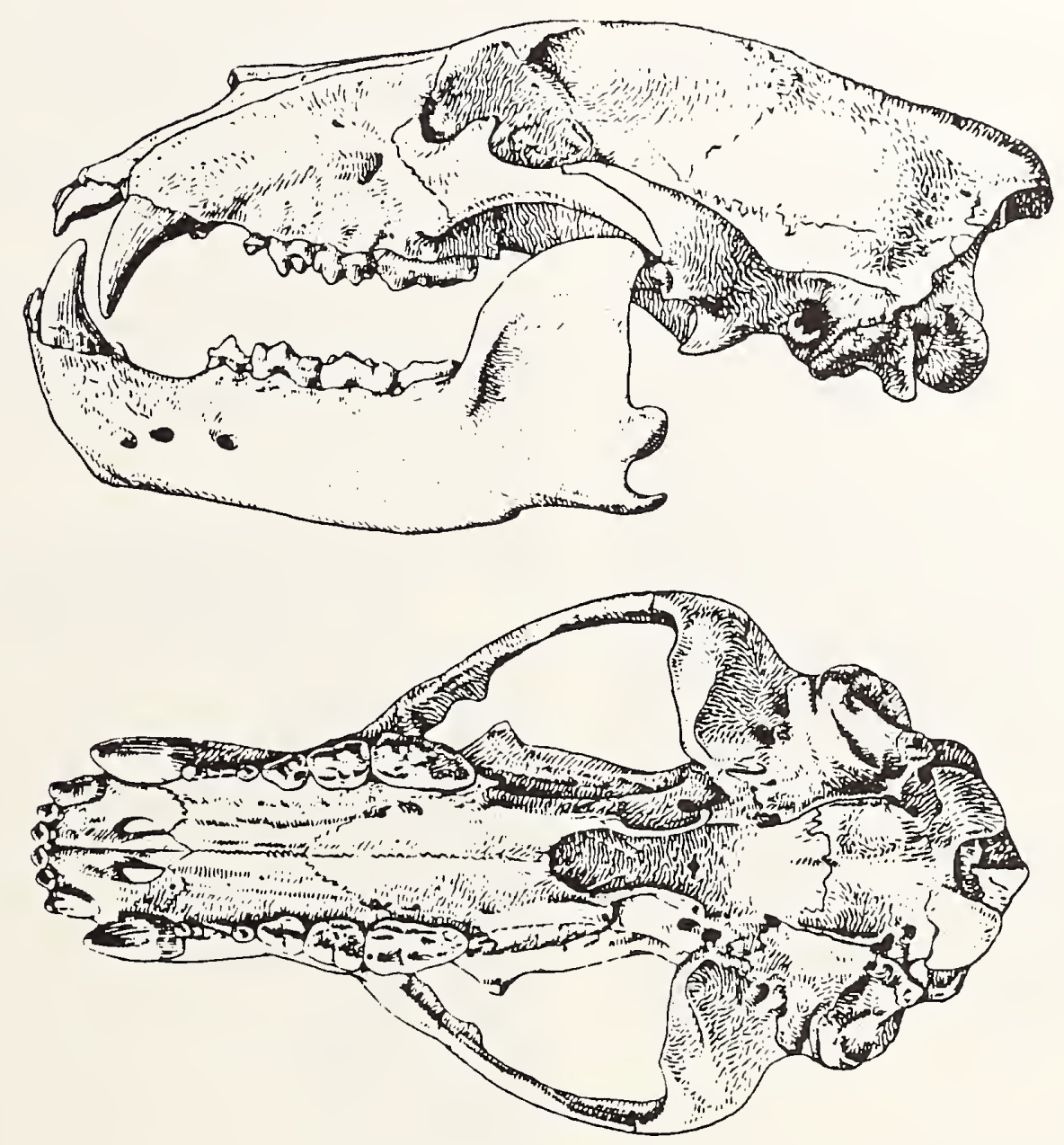
The largest grizzlies of most age categories are usually males, although some females may exceed small males in size. Glenn (1980) found that sex-related size differences were not apparent until about 6 months of age. Yearling males, however, were significantly larger than yearling females. Males at age 2 were larger in skull length and body weight, while at age 3 years and greater, all dimensions of males were significantly greater than those of females. In the same study, $95 \%$ of the female's ultimate dimensions (e.g., shoulder height, body length, skull length) were attained by 4 years, weight and skull size by 6 years and zygomatic width by 8 years. Similar ultimate size dimensions were not attained in males until ages 6, 8 and 10 years, respectively.

It is important to realize how variable skull dimensions can be within the species. Rausch (1953:102) emphasized this by stating:

"There is apparently so much individual variation in bear skulls that generalizations regarding the animals of a given locality can rarely be made. A great range in skull size is to be expected. There may be considerable variation in the length/width ratio of the skull (condylobasal length/zygomatic width) from a single locality. Skull profile is subject to much variation: in some cases the frontal region is gradually sloping and concave, while in others it is inflated and slopes abruptly. Rostral length is variable, and the nasals may show considerable range in length. The sagital crest may show much variation in degree of development, height and anterior-posterior extent. Variation is to be expected in the length and width of the palate. The ramus of the mandible varies greatly in form and relative length. The angle formed by the long axis of the skull with the horizontal, when the skull is at rest on the flat surface, differs from one individual to the other largely on the basis of mandible shape."

Variability within the species led Merriam (1918) to distinguish approximately 90 species of North American bears. He "failed to take into consideration any possibility of individual variation. Some 'species' were named on the basis of a single skull, and in some cases not even the sex of the animal was known" (Rausch 1953:86). Hall (1984) measured 2476 adult, subadult and juvenile grizzly skulls and from this information concluded that 9 subspecies existed in recent time.

\section{Dentition}

Bears have the general dental formula: $\mathrm{I} 3 / 3, \mathrm{C} 1 / 1, \mathrm{P} 4 / 4$, $\mathrm{M} 2 / 3$ for a total of 42 teeth. However, bears often have some, or all, of their first 3 upper and lower premolars missing (Glass 1973). The formidable dentition of Ursus is a valuable tool when aging an individual animal. The length of the teeth and their relative position in the skull are indicators of the approximate age of the animal. The permanent teeth of bears are useful for tracing age-related changes because they are large and develop relatively slowly (Rausch 1969). For a more detailed description of the development of the dentition in Ursus arctos, the reader is referred to Rausch (1969) "Morphogenisis and Age Related Structure of Permanent Canine Teeth in the Brown Bear in Arctic Alaska." Zavatsky (1976), uses dental development as an indicator of age in his designation of the 11 age classes of the grizzly.
The chronological age of many mammals can be accurately determined from the annual layers of dentin or cementum. Layers of cementum are produced when odontogenesis (tooth development) is interrupted during the annual period of denning. The age in years is determined by adding 1 to the number of annuli counted in the cementum of the third molar. Mundy and Fuller(1964) found that the number of annuli present is also correlated with the magnitude of the zygomatic width. It is important to note that bears that do not hibernate (i.e., captive bears) do not show the charcteristic annual deposition of dentin (Rausch 1967).

Molar measurements are also useful as a taxonomic tool in Ursus (Gordon 1977). Skulls of $U$. arctos $L$. and of $U$. americanus are quite similar; the inability to separate the 2 species is particularly acute when comparing female skulls of $U$. arctos with male skulls of $U$. americanus. Gordon (1977) a cheived $100 \%$ accuracy in the separation of these 2 species in a sample of 128 previously identified specimens using length and width measurements of the first mandibular molar.

Much can be learned from examining skulls, particularly when it comes to aging the animal. However, clinal and geographic differences in cranial and dental dimensions within the species must be recognized (Table 2). The reader is referred to Rausch (1963) for a more detailed discussion.

Table 2. Summary of numerical data on 26 skull samples from various regions of North America (from Rausch 1963).

\begin{tabular}{lrrr}
\hline \multicolumn{1}{c}{ Region } & N & Mean & Range \\
\hline Lower Alaska Peninsula & 25 & 404 & $372-429$ \\
Port Heiden - Becharof Lake & 10 & 402 & $379-432$ \\
Kamishak Bay - Iliamna Lake & 26 & 377 & $351-405$ \\
Kodiak - Afognak Islands & 37 & 397 & $372-433$ \\
Kenai Peninsula & 18 & 385 & $368-409$ \\
Skwentna Region & 10 & 366 & $353-382$ \\
Mt. McKinley Region & 7 & 349 & $320-374$ \\
Talkeetna Mountains Region & 16 & 366 & $343-394$ \\
Nabesna Region & 7 & 343 & $326-353$ \\
Lower Copper River & 5 & 386 & $374-400$ \\
Yakutat Bay Region & 11 & 376 & $367-391$ \\
Chichagof Island & 19 & 370 & $345-385$ \\
Admirality Island & 33 & 361 & $330-385$ \\
Baranof Island & 14 & 363 & $342-400$ \\
Bella Coola Region & 12 & 361 & $342-386$ \\
Norton Sound & 9 & 353 & $321-374$ \\
Upper Noatak River & 4 & 352 & $341-363$ \\
Anaktuvuk Pass Region & 11 & 334 & $307-357$ \\
Mackenzie Delta & 9 & 335 & $320-346$ \\
Coronation Gulf & 8 & 324 & $306-344$ \\
Western Yukon Region & 11 & 330 & $299-358$ \\
Southern Yukon Region & 12 & 330 & $318-344$ \\
Southeastern Yukon Region & 8 & 334 & $303-361$ \\
Cassiar Mountains Region & 15 & 346 & $311-371$ \\
Southeastern British Columbia & 10 & 337 & $318-356$ \\
Montana-Wyoming & 10 & 347 & $323-368$ \\
\hline
\end{tabular}




\section{HEMATOLOGY}

Most of the literature on bear hematology primarily concerns black bears. Only papers which specifically discussed grizzlies are included below.

1. Seal et al. (1967) analyzed serum from 7 captive brown/grizzly bears for major blood parameters. Interspecific differences within the Ursidae were discussed.

2. Craighead et al. (1962) presented hematological data for 3 grizzlies. Craighead and Craighead (1970) found low circulating thyroid levels in Yellowstone grizzlies suggesting a hy pothyroid state.

3. Jonkel and Greer (1975) discussed methods for collecting and analyzing blood data.

4. Halloran and Pearson (1972) and Pearson and Halloran (1972) reported statistically significant seasonal changes in the major blood parameters of 22 brown bears from southwestern Yukon Territory. Minor sex-related differences were also noted.

5. Miller and Ballard (1980) reported on blood data from 45 brown bear samples collected in southcentral Alaska. Their data included age and sex of the bear, serum levels of glucose, electrolytes, major proteins and other compounds of interest. They also presented protein electrophoresis data from their samples. Sparker and Ballard (1979) and Sparker et al. (1981) analyzed blood data for 31 bears from the same area (some overlapping data with Miller and Ballard 1980).

6. Franzmann et al. (1981) measured beta-endorphin levels from the blood of 3 Alaskan brown bears. Based on black bear data, they speculated that beta-endorphin may play a role in winter lethargy.

7. Brannon (1983ab, 1985) analyzed hematological data from 85 grizzly bears captured in the Alaska Range and in the Arctic National Wildlife Refuge. Samples were examined for erythrocyte count and leukocyte count, as well as hemoglobin, hematocrit and erythrocyte indices. He related the differences in some parameters to physiological response to capture stress. Regional variation in blood parameters may also have been stressrelated. Differences in urea nitrogen, ureatinine and uric acid varied by capture date suggesting regained renal function and dietary adjustments after den emergence. The effects of Serynlan on blood parameters were also discussed.

8. Nelson et al. (1983a) reviewed the annual behavioral and biochemical patterns of grizzlies and other ursids. Variation in blood parameters according to physiological stage was discussed for black and polar bears. Elsewhere (Nelson 1973, $1978,1980,1984$; Nelson et al. 1973, 1975, 1984), the relationships between hibernation physiology, protein metabolism and associated blood parameters were discussed. Changes in serum urea and serum creatinine before and during hibernation was analyzed.

\section{BODY TEMPERATURE, RESPIRATION, AND HEART RATE}

In general, grizzly bears exhibit the basic systemic physiology common to most mammals (Craighead 1982). The major notable exception to this is the period of hibernation, or winter sleep, during which the bear may not eat, drink, defecate, or urinate for a period of 3-5 months. Respiration, heart rate and core temperature are significantly reduced during this period.

During the normal active season, internal body temperatures of grizzly bears range from about 36.5-38.5 $\mathrm{C}$ and are reduced by $4-5 \mathrm{C}$ during the period of winter sleep, (Irving 1954, Hock 1958, Folk 1967, Folk et al. 1968b, Nelson 1973, Folk 1976, Follman 1978). As bears enter into winter sleep their heart rate decreases from summer sleeping rates of 40-50 beats/min to a low of $8-12$ beats/min (Folk et al. 1978). This bradycardia and reduction in oxygen consumption by as much as $50 \%$ is apparently associated with the shunting of most of the blood to the heart, lungs and brain (Folk et al. 1976). Temperature and heart rate sensitive radio transmitters surgically implan ted in bears have been important in giving insight into these physiological changes (Folk 1964, Craighead 1971, Philo et al. 1981, Follman et al. 1982).

A variety of drugs have been used to immobilize grizzly bears for research or relocation with varying effects on respiration, heart rate, and body temperature (Table 3 ). The drug is usually administered by a projectile syringe. Therefore, only those narcotics with a small effective dosage level are acceptable due to the limited capacity of the darts. It is important to be aware of dosage levels, side effects, antidotes, administration technique, toxicity to humans and legal status of a particular drug before beginning field studies.

\section{SENSORY SYSTEMS}

Knowledge of sensory systems is very limited. However, combined with research conducted on similar species within the family Ursidae, it provides basic information on grizzly bear audition, vision and olfaction.

Kuchak (1937, in Pruitt and Burghardt 1977) found the auditory system of brown bears to be well developed, observing responses to signals at distances of $150 \mathrm{~m}$.

Regarding vision, Kuchak (1937, in Pruitt and Burghardt 1977) estimated that recognition occurred at distances up to $15 \mathrm{~m}$. However, Craighead and Craighead (1964) expanded this figure to $60 \mathrm{~m}$ based on behavioral observations. In addition, Bacon and Burghardt (in press, in Pruitt and Burghardt 1977) demonstrated the ability of black bears to discriminate hues and patterns.

As their most developed sense, smell was determined to be the major factor in locating hidden food items (Kuchuk 1937, in Pruitt and Burghardt 1977). However, foraging, feeding and predatory behaviors are thought to be facilitated by an integration of all three systems (Pruitt and Burghardt 1977). 
Table 3. Affects of various drugs on grizzly/black bear heartrate and respiration.

\begin{tabular}{|c|c|c|c|c|c|c|c|c|c|c|}
\hline Species & Drug & $\mathbf{n}$ & $\begin{array}{c}x \\
\text { Dosage }\end{array}$ & $\stackrel{x}{\operatorname{Temp}(t)}$ & $\begin{array}{l}\mathrm{x} \\
\text { Heartrate } \\
\text { Beats/min }\end{array}$ & $\begin{array}{l}\text { Respira- } \\
\text { tion/min }\end{array}$ & $\begin{array}{l}\text { Time to } \\
\text { Take } \\
\text { Affect }\end{array}$ & $\underset{\text { Duration/ }}{\mathbf{m}}$ & Comments & Citation \\
\hline Grizzly & \multirow{2}{*}{ Succinylcholine chloride } & 20 & $.18 \mathrm{mg} / \mathrm{lb}$ & - & - & - & 4.0 & 9.4 & \multirow{2}{*}{ can cause respiratory failure } & Pearson 1968 \\
\hline Black & & 20 & $.19 \mathrm{mg} / \mathrm{lb}$ & - & - & - & 3.3 & 9.4 & & Pearson 1968 \\
\hline Grizzly & \multirow{2}{*}{$\begin{array}{l}\text { Phencyclidine } \\
\text { hydrochloride }\end{array}$} & 22 & $.68 \mathrm{mg} / \mathrm{lb}$ & - & - & - & 10.6 & 140 & & \\
\hline Black & & 11 & $.63 \mathrm{mg} / \mathrm{lb}$ & - & - & - & 15.2 & 179 & & \\
\hline Grizzly & Sernylan + Sparine 1:1 & 18 & $.76 \mathrm{mg} / \mathrm{lb}$ & - & - & - & 14.0 & - & $\begin{array}{l}2 \text { bears convulsed but } \\
\text { recovered }\end{array}$ & $\begin{array}{l}\text { Skonjsbergt an } \\
\text { Westhover } 1979\end{array}$ \\
\hline Polar & \multirow{2}{*}{$\begin{array}{l}\text { Tiletamine hydrochloride }+ \\
\text { Zolazepam hydrochloride } \\
\text { 1:1 }\end{array}$} & 11 & $4.9 \mathrm{mg} / \mathrm{kg}$ & 36 & 89.0 & 12.9 & 4.91 & 125.5 & darted at dump or in cage & Haigh 1985 \\
\hline Polar & & 13 & $5.3 \mathrm{mg} / \mathrm{kg}$ & 37.1 & 103.8 & 16.2 & 6.9 & 126.5 & $\begin{array}{l}\text { darted from helicopter, ran for } \\
\text { up to } 20 \mathrm{~min} \text {. }\end{array}$ & Haigh 1985 \\
\hline \multirow[t]{2}{*}{ Black } & \multirow{3}{*}{ Alpha-chloralose } & 8 & $2.5 \mathrm{gm}$ & - & 53.8 & 9.8 & 47.5 & 714.0 & \multirow{3}{*}{$\begin{array}{l}1 \text { caged bear, } 8 \text { trials with } \\
\text { drug placed in food. Field test, } \\
\text { culvert trapped males, drug } \\
\text { placed in food. }\end{array}$} & LeCount 1983 \\
\hline & & & & & & & & & & \\
\hline Black & & 7 & $2.9 \mathrm{gm}$ & - & 77.5 & 11.3 & 63.1 & 805.7 & & LeCount 1983 \\
\hline Grizzly & $\begin{array}{l}\text { Etorphine } \\
\text { hydrochloride (m99) }\end{array}$ & 27 & $.06 \mathrm{mg} / \mathrm{kg}$ & - & 46.0 & 2.0 & 5.6 & 38.9 & $\begin{array}{l}\text { severely depresses respiration, } \\
\text { can cause hypothermia, toxic } \\
\text { to humans }\end{array}$ & Hebert 1980 \\
\hline Grizzly & Etorphine + Xylazine & 6 & $1.4 \mathrm{mg}$ & - & - & 2.5 & 7 & - & $\begin{array}{l}\text { Diprenorphine given as } \\
\text { reversal agent }\end{array}$ & Gatesman 1982 \\
\hline
\end{tabular}

\section{DIGESTIVE SYSTEM}

Davis (1964) reported that in carnivores the ratio of intestine to head and body length was broadly correlated with diet. Those families such as Canidae, which exclusively ate meat, tended to have smaller intestine to body length ratios than more omnivorous families such as Ursidae. However, in no carnivore was this ratio as great as in mammalian groups which were primarily, rather than secondarily, herbivorous (e.g., the artiodactyls, with ratios up to $25: 1$ ). Davis (1964) reported ratios of $4.5: 1$ for the wolf, 5-6:1 for the domestic dog and 7.9:1 for the brown bear. The total intestinal length for the brown bear was $10.7 \mathrm{~m}$. Mealey (1975) gave ratios of 7.4 and 4.3 for 2 grizzly bears from Yellowstone, with total intestinal lengths of 9.8 and $8.6 \mathrm{~m}$, respectively.

Bielanska - Osuchowska and Szankowska (1970) reported an average intestinal length in adult brown bears of $7.10 \mathrm{~m}$, but accurate measurements were made on only 2 bears $(8$ and $10 \mathrm{~m})$. This study also detailed histological examinations of the alimentary tracts of 18 brown bears. The researchers found that the general histological structure of the esophagus, stomach and intestines was not, in principle, different from other carnivorous mammals (chiefly dogs and cats).

Jaczewski et al. (1960) studied the capacity of the different parts of the digestive tract in the brown bear. The absolute length of intestines from 3 male bears were 9.3, 11.2 and $17.4 \mathrm{~m}$, with ratios of intestine length to body length of $5.1: 1,6.1: 1$ and 7.7:1 respectively. Other characteristics of the digestive system also indicated adaptations principally to a meat diet. The capacity of the stomach was nearly $50 \%$ of the total digestive tract capacity. The strong, well-developed muscular coat of the digestive tract and the lack of difference between the large and small intestine were also typical of carnivorous species.

A general preponderance of the foregut and a reduction of the caecum and hindgut exists in Carnivora (Ewer 1973).
Since, unlike ungulates, bacterial fermentation is of minor importance to the digestive physiology of carnivores, the size of the caecum in the different families does not a strong relationship to the importance of vegetation in the diet. Mealey (1975) found no caecum in 2 grizzly bear carcasses he examined. Ewer (1973) reported that the caecum was absent in bears. This suggested that the considerable reliance on vegetable foods by most members of Ursidae (along with Mustelidae and Procyonidae) was a secondary habit arising after the caecum was already lost in ancestral forms. Jaczewski et al. (1960) found a small caecum (about $5 \times 1 \mathrm{~cm}$ ) in 1 older brown bear.

Bunnell and Hamilton (1983) studied the apparent digestibilities of dry matter, crude protein and gross energy for 2 captive grizzly bears. They reported that the grizzly's ability to digest dry matter and crude protein was similar to that recorded for obligate carnivores. The digestive system was essentially that of a carnivore with herbivorous adaptations of modified dentition and lengthened claws. These adaptations do not enable the grizzly bear to digest coarse forage efficiently. An increase in dietary fiber dramatically decreased the apparent digestibilities of fiber, dry matter, gross energy and, to a moderate extent, crude protein.

\section{GENETIC CONSIDERATIONS}

The loss of genetic variation associated with small population size is an important concern in conservation biology. A detailed discussion of the genetic principles involved is beyond the scope of this narrative. Several recent books have treated this topic extensively (e.g., Soule and Wilcox 1980, Frankel and Soule 1981, Schonewals-Cox et al. 1983). Shaffer (1986) reviewed these works and summarized the basic conclusions regarding genetic aspects of population viability.

Small populations can experience reduced genetic variation in 3 ways (Frankel and Soule 1981, Schonewald-Cox et al. 1983, Shaffer 1986): 
1. The Founder effect - populations founded by only a few individuals have limited genetic "raw material."

2. Genetic drift - loss of genetic variation due to random sampling of gametes each generation; more pronounced in small populations due to low representation of rare alleles.

3. Inbreeding - continued mating of closely related individuals.

A genetic bottleneck occurs when a population is reduced to a few individuals as a result of a major environmental change, a natural colonization or an artificial founder effect. Populations passing through a bottleneck reflect both qualitative and quantitative losses of genetic variability. Qualitatively, certain alleles are lost or retained and quantitatively, the amount of variability for specific characteristics can be reduced. At low numbers, a population essentially goes through a serious bottleneck each generation with the deleterious effects being cumulative (Frankel and Soule 1981).

The deleterious effects of reduced genetic variation have long been recognized from studies of domestic animals (Allendorf and Leary in press). In natural animal populations, the loss of heterozygosity due to inbreeding depression has been associated with decreases in survival, disease resistance, growth rate and developmental stability. The antithesis of inbreeding depression is heterosis - the enhancement of fitness (e.g., viability, vigour, fecundity, fertility) due to increased heterozygosity (Frankel and Soule 1981). The genetic mechanisms underlying inbreeding depression and heterosis have not been fully revealed (Allendorf and Leary in press).

\section{Genetic Variation in the Grizzly Bear}

Preliminary information on genetic variation in the grizzly bear was recently reported by Knudsen and Allendorf (1985). Tissue samples for genetic analysis were collected from 4 ecosystems in the United States and from 2 captive brown bears. Starch gel electrophoresis (with 4 electrophoretic buffer systems) was used to screen 48 enzymes for use in electrophoretic investigation of grizzly bear genetic variation. Seventy loci encoding 36 enzymes that could be screened for genetic variation were detected. Nineteen and 45 loci could be examined from blood and skeletal muscle samples, respectively.

While sample sizes were inadequate to estimate the amount of genetic variation either within or between populations, preliminary information was encouraging. One loci, Me, was genetically variable in samples from the Northern Continental Divide and Yellowstone ecosystems. The 1 bear sampled from the Cabinet-Yaak ecosystem was homzygous for an allele that was uncommon in the other 2 areas. This suggested that either this locus was also variable in the Cabinet-Yaak Ecosystem, or there were large genetic differences between this ecosystem and the other 2 . Variation at another locus, Pgd, suggested substantial genetic divergence between Montana grizzly bears and grizzly bears from Alaska. Two captive Alaskan brown bears were homozygous for an allele not seen in any other wild bears.

\section{Effective Population Size}

The deleterious effects of inbreeding depression and genetic drift depend in part on the population's mating structure and distribution of offspring (Samson 1983, Schonewald-Cox et al. 1983). Geneticists developed the concept of a genetically effective population size, $\mathrm{Ne}$, to assess the species-specific or population-specific effects of genetic drift and inbreeding. This can be defined as the size of an ideal population (numbers are constant, sex ratio is equal and all members make an equal contribution to each subsequent generation) in which the loss of genetic variability takes place at the same rate as in the actual population (Schonewald-Cox et al. 1983, Harris 1986c).

The principal factors used to assess the risk of extinction due to genetic changes are effective population size and time (Salwasser et al. 1983). Inbreeding depression is considered the most serious threat to short-term and genetic drift the most serious to long-term survival (Shaffer 1986). Based on breeding experiments, researchers have concluded that an $\mathrm{Ne}$ of approximately 50 is required to avoid deleterious inbreeding effects. Effective populations of about 500 are necessary for natural mutation rates to balance the loss of genetic variation due to genetic drift (Shaffer 1986). Following this reasoning, minimum viable population sizes equivalent to effective population sizes of 50 and 500 animals must be maintained to assure shortterm survival and continuing adaptation, respectively (Shaffer 1986). Long-term evolutionary potential, or adaptability, may require substantially larger populations. The genetic variation of a large, well distributed population allows for continual adjustment to environmental change (Soule 1980).

Samson et al. (1985) developed a computer simulation model for grizzly bears that incorporated the effects of inbreeding depression, $F$, as a function of effective population size, $\mathrm{Ne}$. The model was similar to Shaffer's (1978, $1981,1983)$ in that population structure, age/sex specific reproductive and mortality rates and stochastic factors were considered. The simulation model was used to determine the change in Ne over a 100-year period for a hypothetical Yellowstone grizzly bear population with an initial $\mathrm{Ne}$ of 50 . The stochastic model showed a continual decline in $\mathrm{Ne}$ until it equalled 0 at year 50. A deterministic version of the model showed $\mathrm{Ne}$ increasing for the first 25 years and then decreasing to 0 by year 75 . The effects of migration on the inbreeding depression coefficient and effective population size were also examined. One individual entering the population every 5 years reduced the $\mathrm{Ne}$ needed to maintain a population (based on genetic considerations) to a negligible level.

The effective population size, $\mathrm{Ne}$, of a grizzly bear population is always less than the number of animals in the population, $N$, because: 1) not all animals are of breeding age, 2) a few males dominate the breeding and 3) some adults have more offspring than others. Preliminary analyses suggest that $\mathrm{Ne}$ 's of grizzly bear populations may be in the range of $0.2 \mathrm{~N}-0.4 \mathrm{~N}$ (Harris 1986c).

The Grizzly Bear Recovery Plan (U.S. Fish and Wildlife Service 1982a) sets a threshold recovery level for the Cabinet-Yaak ecosystem of 70 bears. This corresponds to an $\mathrm{Ne}$ of 14-28 bears and an expected loss of genetic variation of $2-4 \%$ per generation or $9-17 \%$ of the total genetic 
variation in 5 generations. These preliminary investigations suggest that loss of genetic variation may be a potentially serious problem for populations maintained at threshold recovery levels over a long time period (Harris 1986c).

Data concerning the effects of inbreeding depression on grizzly bear populations are insufficient to either validate or invalidate the general $50 / 500$ rule of effective population sizes. Although the importance of genetic considerations for both short- and long-term viability of grizzly bear populations is recognized, demographic considerations may constitute the most direct threat to survival of these populations. The summary statements from the 1985 Workshop on grizzly bear population genetics stated that "... if there is a conflict in management between genetic and demographic considerations, demographic considerations should be paramount in the short-term (Harris 1986c)."

\section{NUTRITIONAL REQUIREMENTS}

Bears are the youngest family within the Order Carnivora (Colbert 1969). Over the course of evolutionary history, the Ursus line has followed a broad trend towards increased body size, longer claws, reduction of cheek teeth and replacement of carnassial shearing teeth with blunt bunodont molars (Colbert 1969). Bears also have the unspecialized digestive system of a carnivore, although somewhat lengthened (Davis 1964). The Ursidae have a cecum, not a rumen, that passes food through the digestive system relatively quickly. Few nutrients are extracted but bears compensate for this by a higher rate of passage (Hamer and Herrero in press a). These physical characteristics are clearly an adaptation to an herbivorous diet without sacrificing the ability to digest animal matter (Mealey 1977, Bunnell and Hamilton 1983). This flexibility has allowed Ursidae to exploit a wide variety of foods in numerous habitats.

Food habits studies in North America document the omnivorous diet of the grizzly bear. In all areas, vegetal matter comprises a dominant portion of the seasonal, if not annual, diet (Servheen and Wojciechowski 1978). Animal matter (e.g., fish, mammal, insect) is also consumed throughout the North American range in varying amounts. Although predatory behavior and efficiency varies within North America, digging of underground plant parts is a universal foraging trait suggesting that selection pressures are operating within $U$. arctos to enhance energy uptake (Bunnell and Hamilton 1983).

The quality and digestability of grizzly bear foods has received considerable attention in recent years. Foraging stategies in relation to food and habitat selection have been particularly prominent (Mealey 1977, Graham 1978, Sizemore 1980, Hamer and Herrero in press a). Craighead et al. (1982) and Knight et al. (1984b) have incorporated the nutritive quality of foods into models of habitat quality and prediction of habitat use.

\section{Forage}

During the early portion of their active season, grizzly bears tend to forage primarily on immature green vegeta- tion or animal matter. Food plants at this time are in an early phenological stage of development and are high in soluble nutrients (Table 4) and low in lignin and cellulose (Hamer and Herrero in press a). Specific patterns of habitat use throughout North America are tied closely to the distribution of immature plant foods. Bears select habitats of specific elevation, aspect and moisture gradients to obtain these emergent succulent foods (Mealey 1977, Atwell 1980, Sizemore 1980, Stelmock 1981, Craighead et al. 1982, Hamer and Herrero 1983b, Hechtel 1985, Mace and Jonkel in press). Plants that generally appear early in the growing season, such as grasses, sedges, horestails and clover tend to be important foods until more nutritous foods become available (Craighead et al. 1982).

Green vegetation has also been documented as important during late seasons. Selection of vegetation at this time coincides with the use of mesic habitats such as stream bottoms and receding snowbed communities (Atwell et al. 1980, Mealey 1980, Hamer and Herrero in press a). Succulent vegetation in these mesic habitats have higher protein content than similar plant species in exposed areas (Graham 1978). The underground roots, corms and bulbs of foods such as Herdysarum spp., Claytonia spp. or Erythronium spp. are also selected at a specific time or in a specific habitat when nutrient quality is high and fiber content is low. Fiber in the diet may be of some benefit as ingestion of fiber may reduce the rate of food passage providing more opportunity for protein utilization (Stelmock 1981).

\section{Insects}

Insects such as ants are important diet items. Because of the monogastric nature of the digestive system, bears require certain amino acids and insect material may help meet this requirement (Eagle and Pelton 1983). Amino acids not used for synthetic purposes can be converted to metabolizable energy to help maintain homeostasis (Bumgarner 1979).

\section{Fruit}

Fruit is an important diet item in all areas as it provides bears with a superabundant source of sugar prior to denning (Hamer and Herrero in press a). During the period of fruit availabilty, bears must not only gain sufficient weight to survive denning, but must also store energy for the following spring. This is especially true for adult males that tend to forsake spring foraging opportunities to seek, find and mate with females (Sizemore 1980). During this period of fruit foraging, bears may consume nearly 20,000 $\mathrm{kcal} /$ day (Nelson 1980). Over-wintering berries are also consumed during the spring in some areas (Hamer et al. 1977, Hechtel 1985, Mace and Jonkel in press) and may have a higher sugar content than during the previous autumn (Hamer et al. 1977).

Several black bear studies have indicated that berry crop failures may be responsible for reproductive inhibition (Jonkel and Cowan 1971, Rogers 1977). Conversely, Mealey (1980) believed that periodic failures of berries or nut crops probably has no major impact in Yellowstone National Park because bears are "anchored to the more stable energy supply available from grasslands, herblands and associated forest edges." 


\section{Animal Matter}

Because it is highly digestible and high in protein (Table 4) meat is often preferred over vegetal foods when available. Grizzly bear productivity and density in northern Alaska appears to be greatest in areas frequented by large numbers of caribou; this restricted availability of animal protein may limit grizzly populations (Phillips 1985). Small prey such as ground squirrels may be either a dietary supplement (Hamer et al. 1978, Stelmock 1981, Mace and Jonkel in press) or may constitute a major protein source prior to denning (Nagy et al. 1983, Hechtel 1985ab).

Table 4. Nutrient content and digestible energy of major grizzly bear food items (adapted from Knight et al. 1982).

\begin{tabular}{|c|c|c|c|c|c|c|c|}
\hline \multirow[b]{3}{*}{ Food Item } & \multicolumn{5}{|c|}{ Nutrient Component } & \multicolumn{2}{|c|}{ Digestible Energy } \\
\hline & \multirow[b]{2}{*}{ Protein } & \multirow[b]{2}{*}{ Fat } & \multicolumn{3}{|c|}{ Nitrogen-free extract } & \multirow{2}{*}{$\begin{array}{c}\text { Gross } \\
\text { Energy } \\
\text { (kcal/g) }\end{array}$} & \multirow{2}{*}{$\begin{array}{c}\text { Digested } \\
\text { Energy } \\
\text { (kcal/g) }\end{array}$} \\
\hline & & & Sugar & Starch & Total & & \\
\hline \multicolumn{8}{|l|}{ Foliage: } \\
\hline $\begin{array}{l}\text { Trifolium spp. } \\
\text { Taraxacum spp. } \\
\text { Epilobium spp. } \\
\text { Graminae spp. } \\
\text { Equisetum spp. } \\
\text { Claytonia spp. } \\
\text { Circium spp. } \\
\text { Heracleum lanatum } \\
\text { Angelica arguta }\end{array}$ & $\begin{array}{l}19.7^{\mathrm{abdg}} \\
16.2^{\mathrm{cd}} \\
22.3^{\mathrm{be}} \\
13.1^{\text {abce }} \\
14.8^{\text {abcd }} \\
29.0^{\mathrm{ac}} \\
7.9^{\mathrm{abg}} \\
26.3^{\mathrm{j}} \\
13.8^{\mathrm{j}}\end{array}$ & $\begin{array}{l}3.6 \\
6.2^{\mathrm{cd}} \\
2.6^{\mathrm{f}} \\
3.0^{\mathrm{abc}} \\
3.9^{\mathrm{abcd}} \\
3.8^{\mathrm{ac}} \\
1.0^{\mathrm{ab}} \\
6.6^{\mathrm{j}} \\
5.3^{\mathrm{j}}\end{array}$ & & & $\begin{array}{l}52.6 \\
57.0 \\
50.3 \\
54.5 \\
49.6 \\
45.2 \\
58.8\end{array}$ & $\begin{array}{l}3.2^{\mathrm{ab}} \\
3.0^{\mathrm{k}} \\
3.0^{\mathrm{k}} \\
2.9^{\mathrm{ab}} \\
2.8^{\mathrm{ab}} \\
4.0^{\mathrm{a}} \\
2.9^{\mathrm{a}}\end{array}$ & $\begin{array}{l}0.5 \\
0.5 \\
0.5 \\
0.5 \\
0.4 \\
1.2 \\
0.4\end{array}$ \\
\hline \multicolumn{8}{|l|}{ Roots: } \\
\hline $\begin{array}{l}\text { Lomatium spp. } \\
\text { Polygonum spp. } \\
\text { Perideridia gairdneri }\end{array}$ & $\begin{array}{l}8.3^{\mathrm{abd}} \\
9.0^{\mathrm{ab}} \\
4.1^{\mathrm{ab}}\end{array}$ & $\begin{array}{l}3.3^{\mathrm{abd}} \\
3.3^{\mathrm{ab}} \\
0.6^{\mathrm{ab}}\end{array}$ & & $\begin{array}{l}34.3^{\mathrm{a}} \\
43.3^{\mathrm{k}} \\
40.1^{\mathrm{a}}\end{array}$ & $\begin{array}{l}73.4 \\
73.4 \\
88.2\end{array}$ & $\begin{array}{l}3.2^{\mathrm{ab}} \\
3.2^{\mathrm{ab}} \\
3.8^{\mathrm{ab}}\end{array}$ & $\begin{array}{l}1.3 \\
1.0 \\
3.8\end{array}$ \\
\hline \multicolumn{8}{|l|}{ Fruits: } \\
\hline $\begin{array}{l}\text { Pinus albicaulis } \\
\text { Vaccinium scoparium } \\
\text { V. globulare } \\
\text { Shepherdia canadensis } \\
\text { Fragaria spp. } \\
\text { Sorbus sitchensis }\end{array}$ & $\begin{array}{r}13.0^{\mathrm{ab}} \\
8.3^{\mathrm{ab}} \\
5.4^{\mathrm{bd}} \\
11.2^{\mathrm{bc}} \\
9.4^{\mathrm{ab}} \\
12.9^{\mathrm{j}}\end{array}$ & $\begin{array}{l}26.1^{\mathrm{ab}} \\
5.4^{\mathrm{ab}} \\
4.9^{\mathrm{bd}} \\
2.0^{\mathrm{bc}} \\
5.6^{\mathrm{ac}} \\
3.2^{\mathrm{j}}\end{array}$ & $\begin{array}{l}40.0^{\mathrm{b}} \\
38.0^{\mathrm{b}} \\
34.0^{\mathrm{b}} \\
25.0^{\mathrm{b}}\end{array}$ & & $\begin{array}{l}21.8 \\
69.9 \\
73.5 \\
76.7 \\
65.9\end{array}$ & $\begin{array}{l}4.0^{\mathrm{ab}} \\
3.8^{\mathrm{ab}} \\
3.2^{\mathrm{b}} \\
3.3^{\mathrm{b}} \\
3.5^{\mathrm{ab}}\end{array}$ & $\begin{array}{l}1.9 \\
3.4 \\
2.8 \\
2.9 \\
3.1\end{array}$ \\
\hline \multicolumn{8}{|l|}{ Animal: } \\
\hline $\begin{array}{l}\text { Ungulates } \\
\text { Rodents } \\
\text { Cutthroat trout } \\
\text { Coho salmon } \\
\text { Ants }\end{array}$ & $\begin{array}{l}88.2^{\mathrm{a}} \\
69.8^{\mathrm{a}} \\
72.3^{\mathrm{a}} \\
73.2^{\mathrm{i}} \\
43.8^{\mathrm{d}}\end{array}$ & $\begin{array}{r}6.7^{\mathrm{a}} \\
8.7^{\mathrm{a}} \\
15.3^{\mathrm{a}} \\
5.6^{\mathrm{i}} \\
15.4^{\mathrm{d}}\end{array}$ & & & $\begin{array}{r}0.1 \\
3.7 \\
4.3 \\
\\
27.0\end{array}$ & $\begin{array}{l}5.6^{\mathrm{a}} \\
4.9^{\mathrm{a}} \\
5.7^{\mathrm{a}} \\
4.8^{\mathrm{d}}\end{array}$ & $\begin{array}{l}4.6 \\
3.8 \\
4.1 \\
\\
2.7\end{array}$ \\
\hline
\end{tabular}

a Mealey 1975

b Craighead et al. 1982

c Sizemore and Jonkel 1980

d Reinecke and Owen 1980 e Hamer et al. 1977

${ }^{\mathrm{f}}$ Hamer et al. 1979

g Graham 1978

h Bunnell and Hamilton 1983

\section{i Lloyd 1979}

j Sizemore 1980

$\mathrm{k}$ estimated by relationship to other foods 



\section{HOME RANGE AND MOVEMENTS}

\section{Home Range}

\section{Methods of Home Range Analysis}

The minimum area polygon (Mohr 1947) is the most commonly used method of home range analysis in grizzly bear research. For purposes of comparison, only results using this method have been tabularized (Tables 5 and 6 ).

Because the minimum area polygon method assumes uniform distribution of habitat use (Samuel and Garton 1985), an assumption not satisfied by most bear home range data, some researchers have employed other methods of home range analysis. Harestad (1979) modified the minimum home range method of Mohr (1947) to allow stepwise deletions of the outermost relocation points for a given data set. Using this method, sub-areas which included $90 \%$ or $50 \%$ of the observed relocations for each bear could be determined (McLellan 1981, Hamilton 1982, Hamilton and Archibald 1984). Harvey and Barbour(1965) developed the "modified minimum area method" which used concave angles in connecting peripheral relocation points (Servheen and Lee 1979b, Kasworm 1984, Aune 1985). The exclusive boundary method, a grid method based on animal movement patterns (Stickel 1954), was modified for use with bears by Berns and Hensel (1972) and Reynolds (1976). The method of Jennrich and Turner (1969), which calculates home range area based on the determinant of the recapture point covariance matrix, was used by Sizemore (1980) and Harting (1985).

Geometric centers of activity can be determined from bear relocation data using the method of Hayne (1949). A standard diameter can be calculated for each relocation data set to delineate a circular area around the geometric center which incorporates $68 \%$ of all relocation points (Harrison 1958). Variations on this method of analyzing relocation data were used by Joslin et al. (1977) and Knight et al. (1979).

\section{Home Range Size Comparison Between Ecosystems}

It is difficult to directly compare grizzly bear home range data from different ecosystems and study areas since the methods used to calculate areas, sample sizes, duration of observations and intensity of relocations vary greatly among studies. The accuracy of home range determination is further complicated by the logistical difficulties in keeping functional radio transmitters on grizzly bears and other problems encountered in radiotracking (Nagy and Russell 1978). Substantial variation in individual foraging strategies, habitat use and, consequently, home range patterns (Simpson and Hebert 1982, Hamer et al. 1983, Harting 1985) can obscure between-population distinctions, especially when sample sizes are small.

Nonetheless, it is obvious that home range sizes vary widely both within, and between, ecosystems (Table 5). In general, though, the home range sizes of female grizzly bears are less variable than those of males. Home range sizes for both sexes (adults) are smallest in Southeast
Alaska and on Kodiak Island. Home range size increases for bears from the Alaskan Peninsula, Interior British Columbia, the Northern Interior of Canada and the Coast of British Columbia, and is largest for bears from the Rocky Mountains of Canada and Montana, Yellowstone, the Alaskan and Canadian Arctic, South Central Alaska, the Boreal Forest in Alberta and the Cabinet/Yaak ecosys-tem of Montana.

\section{Seasonal Home Ranges and Habitat Relationships}

The lifetime home range of a grizzly bear contains all the components necessary for its survival, although seasonal and annual home ranges may not (McLellan 1981). Use of areas within the lifetime home range depends on seasonal food availability, breeding activity and status and denning sites (Russell et al. 1979).

Craighead and Mitchell (1982) hypothesized that 2 types of populations exist: those in ecosystems having concentrated food sources (ecocenters), and those in ecosystems without food concentrations. Home ranges where ecocenters exist, often consist of 2 or more seasonal activity centers connected by a travel corridor (Craighead and Craighead $1972 \mathrm{~b}$ ). This pattern of discrete seasonal ranges was also evident in some populations lacking distinct ecocenters (e.g., Servheen and Lee 1979b). Reynolds (1976) and Murie (1981) noted that some bears remained in the same general area throughout the active seasons, whereas others shifted ranges with the "food season." Many authors recognized the importance of seasonal and annual food availability and distribution, and the presence of concentrated food sources (Glenn 1976, Nagy and Russell 1978, Bernes et al. 1980, Judd and Knight 1980, Mace and Jonkel 1980b, Spencer and Hensel 1980, Reynolds 1980, Servheen et al. 1981, Craighead and Mitchell 1982, Miller and McAllister 1982, Archibald 1983, Hamer et al. 1983, Knight et al. 1984b, Miller 1984, Aune 1985). Some examples of seasonal food sources that influenced grizzly movements and home range relationships included garbage dumps (Mundy and Flook 1970, Craighead and Mitchell 1982, Knight et al. 1984b), salmon spawning streams (e.g., Russell 1974, Atwell et al. 1980, Glenn and Miller 1980, Troyer 1980ab), berry concentrations (Mundy and Flook 1973, Pearson 1975, Wielgus 1986), pine nuts (Knight et al. 1984b), ungulate winter range (carrion) and calving areas (Quimby and Snarski 1974, Craighead and Mitchell 1982, Knight et al. 1984b), and lush sedge/forb meadows (Quimby and Snarski 1974, Atwell et al. 1980).

There is some evidence that home range size varies according to climate and annual food production. Mace and Jonkel (1980c), Sizemore (1980) and Picton et al. (1986) felt that climate or snow depth influenced home range size and shape. Knight et al. (1984b) found that home ranges, especially those of females, were smallest in optimal food years. Miller (1984) found an inverse correlation between home range size and berry crop success.

Mean annual home range sizes in the Yellowstone Grizzly Bear ecosystem increased rather dramatically between the studies of the Craigheads (1959-1970) and the Interagency Grizzly Bear Team (1974-1984) (Table 5). These increases were partially attributable to the closing of 
Table 5. Mean minimum home range sizes (sq. $\mathrm{km}$ ) of grizzly bears in major study areas. Minimum and maximum ranges are given in parentheses. Sample size, $n$, equals the Most ranges calculated by minimum area (convex polygon) method (Mohr 1947). number of "bear-years" (annual home ranges) used to calculate means: some bears may be represented more than once.

\begin{tabular}{|c|c|c|c|c|c|}
\hline \multirow[b]{2}{*}{$\begin{array}{c}\text { Ecosystem, Area and } \\
\text { Citation }\end{array}$} & \multicolumn{4}{|c|}{ Home Range (sq. km) } & \multirow[b]{2}{*}{ Comments } \\
\hline & \multicolumn{2}{|c|}{ Adult } & \multicolumn{2}{|c|}{ Subadult } & \\
\hline \multicolumn{6}{|l|}{ Yellowstone Ecosystem } \\
\hline $\begin{array}{l}\text { Whole Ecosystem } \\
\text { (F. Craighead 1976) }\end{array}$ & $\begin{array}{c}233 \\
(31,435) \\
\mathrm{n}=2\end{array}$ & $\begin{array}{c}73 \\
(18-275) \\
\mathrm{n}=4\end{array}$ & $\begin{array}{c}126 \\
(52-324) \\
\mathrm{n}=4\end{array}$ & - & $\begin{array}{l}\text { pre-dump closure }(1959-70) ; \text { annual } \\
\text { ranges; adult }=5+\text { years }\end{array}$ \\
\hline $\begin{array}{l}\text { Whole Ecosystem } \\
\text { (Knight et al. 1984b) }\end{array}$ & $\begin{array}{c}828 \\
(189-2743)\end{array}$ & $\begin{array}{c}384^{\mathrm{a}} \\
(28-1259)\end{array}$ & $\begin{array}{c}468 \\
(50-2185)\end{array}$ & $\begin{array}{c}323 \\
(70-580)\end{array}$ & $\begin{array}{l}\text { post-dump closure (1974-1984); } \\
\text { annual ranges ( }>14 \text { relocations); } \\
\text { total sample size = 118; individual } \\
\text { sample sizes not available; adult = } \\
5+\text { years }\end{array}$ \\
\hline $\begin{array}{l}\text { Whole Ecosystem } \\
\text { (Knight et al. 1984b) }\end{array}$ & $\begin{array}{c}1970 \\
(754-3238)\end{array}$ & $\begin{array}{c}874 \\
(368-1463)\end{array}$ & - & - & $\begin{array}{l}\text { post-dump closure }(1974-84) ; \\
\text { lifetime range }(>60 \text { relocations } \\
\text { over } 3 \text { years); adult }=5+\text { years }\end{array}$ \\
\hline \multicolumn{6}{|l|}{$\begin{array}{l}\text { Northern Continental } \\
\text { Divide Ecosystem }\end{array}$} \\
\hline $\begin{array}{l}\text { Mission Mountains } \\
\text { (Servheen and Lee 1979b) }\end{array}$ & $\begin{array}{c}1398 \\
(293-3029) \\
\mathrm{n}=3\end{array}$ & $\begin{array}{c}133 \\
(20,205) \\
\mathrm{n}=2\end{array}$ & $\overline{-}$ & 56 & annual ranges; adult $=5+$ years \\
\hline $\begin{array}{l}\text { South Fork of Flathead } \\
\text { River } \\
\text { (Mace and Jonkel 1979b, } \\
\text { Mace and Jonkel 1980c) }\end{array}$ & $\begin{array}{c}286 \\
(166-559) \\
n=5\end{array}$ & $\begin{array}{c}99 \\
(94-104) \\
\mathrm{n}=2\end{array}$ & $\begin{array}{c}261 \\
(143-432) \\
n=4\end{array}$ & & $\begin{array}{l}\text { annual ranges; female with range = } \\
104 \text { sq. km. accompanied by } 3 \text { cubs; } \\
\text { adult }=5+\text { years }\end{array}$ \\
\hline $\begin{array}{l}\text { South Fork of Flathead } \\
\text { River } \\
\text { (Sizemore 1980) }\end{array}$ & $\underset{\mathrm{n}=1}{511}$ & $\underset{\mathrm{n}=1}{158}$ & $\underset{\mathrm{n}=1}{295}$ & $\underset{\mathrm{n}=1}{155}$ & $\begin{array}{l}\text { annual ranges; adult = } 6+\text { years; } \\
\text { female accompanied by } 3 \text { cubs; } \\
\text { used method of Jennrich and } \\
\text { Turner (1969) }\end{array}$ \\
\hline $\begin{array}{l}\text { North Fork of Flathead } \\
\text { River } \\
\text { (Rockwell et al. 1978) }\end{array}$ & $\begin{array}{c}463 \\
(221-705) \\
\mathrm{n}=2\end{array}$ & $\underset{\mathrm{n}=1}{104}$ & $\frac{618}{\mathrm{n}=1}$ & - & annual ranges; adult $=5^{+}$years \\
\hline $\begin{array}{l}\text { Rocky Mountain East } \\
\text { Front } \\
\text { (Schallenberger and } \\
\text { Jonkel 1980) }\end{array}$ & $\begin{array}{c}747 \\
(280-1400) \\
\mathrm{n}=5\end{array}$ & $\begin{array}{c}226 \\
(171-305) \\
\mathrm{n}=3\end{array}$ & $\begin{array}{c}566 \\
(505-627) \\
\mathrm{n}=2\end{array}$ & $\begin{array}{c}56 \\
(39-73) \\
\mathrm{n}=2\end{array}$ & annual ranges; adult $=5+$ years \\
\hline $\begin{array}{l}\text { Rocky Mountain East } \\
\text { Front } \\
\text { (Aune 1985, Aune and } \\
\text { Stivers 1982,1983,1985; } \\
\text { Aune et al. 1984) }\end{array}$ & $\begin{array}{c}828 \\
(388-1804) \\
n=4\end{array}$ & $\begin{array}{c}413 \\
(175-735) \\
\mathrm{n}=17\end{array}$ & $\begin{array}{c}1252 \\
(235-2056) \\
n=5\end{array}$ & $\begin{array}{c}308 \\
(196-374) \\
n=5\end{array}$ & annual ranges; adult $=5+$ years \\
\hline \multicolumn{6}{|l|}{ Cabinet/Yaak Ecosystem } \\
\hline $\begin{array}{l}\text { Cabinet Mountains } \\
\text { (Kasworm } 1984,1985 \text { ) }\end{array}$ & $\begin{array}{c}1290 \\
\mathrm{n}=1\end{array}$ & $\frac{430}{n=1}$ & - & - & annual ranges; adult $=5+$ years \\
\hline $\begin{array}{l}\text { Selkirk Mountains Ecosyster } \\
\quad \text { (Almack 1985) }\end{array}$ & - & $\begin{array}{c}402 \\
(195-609) \\
n=2\end{array}$ & - & - & $\begin{array}{l}\text { annual range of same bear from } 2 \\
\text { consecutive years }\end{array}$ \\
\hline
\end{tabular}


Table 5. (Continued)

\begin{tabular}{|c|c|c|c|c|c|}
\hline \multirow[b]{2}{*}{$\begin{array}{c}\text { Ecosystem, Area and } \\
\text { Citation }\end{array}$} & \multicolumn{4}{|c|}{ Home Range (sq. km) } & \multirow[b]{2}{*}{ Comments } \\
\hline & Male ${ }^{\mathbf{A}}$ & $\begin{array}{l}\text { Adult } \\
\text { Female }\end{array}$ & \multicolumn{2}{|c|}{ Subadult } & \\
\hline \multicolumn{6}{|l|}{ Canadian Rockies } \\
\hline $\begin{array}{l}\text { Akamina-Kishinena/ } \\
\text { North Fork Flathead } \\
\text { (McLellan 1981) }\end{array}$ & $\begin{array}{c}446 \\
(215-679) \\
n=5\end{array}$ & $\begin{array}{c}200 \\
(65-391) \\
n=5\end{array}$ & $\begin{array}{c}156 \\
(153-159) \\
n=2\end{array}$ & $\frac{48}{n=1}$ & annual range; adult $=5+$ years \\
\hline $\begin{array}{l}\text { Jasper National Park } \\
\text { (Pearson and Nolan 1977) }\end{array}$ & $\begin{array}{c}535 \\
(482-588) \\
n=2\end{array}$ & $\begin{array}{c}201 \\
(189-212) \\
n=2\end{array}$ & - & - & annual range; adult $=5+$ years \\
\hline $\begin{array}{l}\text { Jasper National Park } \\
\text { (Russel et al. 1979) }\end{array}$ & $\begin{array}{c}916 \\
(189-1628) \\
n=11\end{array}$ & $\begin{array}{c}224 \\
(89-358) \\
n=2\end{array}$ & $\begin{array}{c}633 \\
(33-1233) \\
n=2\end{array}$ & $\begin{array}{c}109 \\
(33-185) \\
n=2\end{array}$ & $\begin{array}{l}\text { annual range; adult }=6+\text { years; } \\
\text { subadults with range }=33 \mathrm{sq} . \mathrm{km} . \\
\text { were orphaned siblings }\end{array}$ \\
\hline $\begin{array}{l}\text { Kananaskis Country } \\
\text { (Wielgus 1986) }\end{array}$ & $\begin{array}{c}92 \\
(104-2110) \\
\mathrm{n}=8\end{array}$ & $\begin{array}{c}133 \\
(36-345) \\
n=10\end{array}$ & $\begin{array}{c}575 \\
(444-683) \\
\mathrm{n}=3 \\
\end{array}$ & $\begin{array}{c}82 \\
(46-128) \\
n=4 \\
\end{array}$ & $\begin{array}{l}\text { male ranges are multiannual; } \\
\text { female ranges are mean annual } \\
\text { range; adult }=5+\text { years }\end{array}$ \\
\hline \multicolumn{6}{|l|}{ Interior British Columbia } \\
\hline $\begin{array}{l}\text { Revelstoke Area } \\
\text { (Simpson et al. in prep) }\end{array}$ & $\begin{array}{c}297 \\
(130-512) \\
\mathrm{n}=7\end{array}$ & $\begin{array}{c}79 \\
(42-2098) \\
n=3 \\
\end{array}$ & $\begin{array}{c}125 \\
\mathrm{n}=1\end{array}$ & - & annual ranges; adult $=6+$ years \\
\hline $\begin{array}{l}\text { Northern Interior } \\
\text { SW Yukon: Kluane } \\
\text { National Park } \\
\text { (Pearson 1975) } \\
\end{array}$ & $\begin{array}{c}287 \\
\mathrm{n}=5 \\
\end{array}$ & $\begin{array}{c}86 \\
\mathrm{n}=8\end{array}$ & $\begin{array}{c}70 \\
\mathrm{n}=3 \\
\end{array}$ & $\underset{n=4}{88}$ & annual ranges; adult = "mature" \\
\hline $\begin{array}{l}\text { Boreal Forest } \\
\text { Swan Hills, Alberta } \\
\text { (Nagy and Russell 1978) }\end{array}$ & $\begin{array}{c}1022 \\
\mathrm{n}=1 \\
\end{array}$ & $\underset{\mathrm{n}=1}{425}$ & $\frac{82}{n=1}$ & $\begin{array}{c}140 \\
n=3 \\
\end{array}$ & annual ranges; adult $=6+$ years \\
\hline $\begin{array}{l}\text { Canadian Arctic } \\
\text { Northern Yukon } \\
\text { (Nagy et al. 1983a) }\end{array}$ & $\begin{array}{c}286 \\
(8-1352) \\
n=17\end{array}$ & $\begin{array}{c}121 \\
(7-701) \\
n=24\end{array}$ & $\begin{array}{c}841 \\
(10-1898) \\
n=4\end{array}$ & $\begin{array}{c}36 \\
(2 \cdot 78) \\
n=5\end{array}$ & $\begin{array}{l}\text { annual ranges; adult male }=8+ \\
\text { years, adult female }=6+\text { years }\end{array}$ \\
\hline $\begin{array}{l}\text { Northwest Territories: } \\
\text { Tuktoyaktuk Peninsula/ } \\
\text { Richards Island } \\
\text { (Nagy et al. 1983b) }\end{array}$ & $\begin{array}{c}875 \\
(81-1943) \\
n=10\end{array}$ & $\begin{array}{c}514 \\
(42-2098) \\
n=4\end{array}$ & $\begin{array}{c}1516 \\
(156-2631) \\
n=4\end{array}$ & $\begin{array}{c}20 \\
(9-40) \\
n=3\end{array}$ & $\begin{array}{l}\text { annual ranges; adult male }=7+ \\
\text { years, adult female }=6+\text { years }\end{array}$ \\
\hline \multicolumn{6}{|l|}{ Arctic Alaska } \\
\hline $\begin{array}{l}\text { Eastern Brooks Range } \\
\text { (Reynolds 1976) }\end{array}$ & 702 & 382 & $\underset{n=5}{-}$ & $\frac{-}{n=3}$ & annual ranges; adult $=8+$ years \\
\hline $\begin{array}{l}\text { Western Brooks Range } \\
\text { (Reynolds 1978; Reynolds } \\
\text { and Hechtel 1980) }\end{array}$ & $\begin{array}{c}776 \\
(746-1927) \\
\mathrm{n}=4 \\
\end{array}$ & $\begin{array}{c}220 \\
(80-873) \\
\mathrm{n}=37 \\
\end{array}$ & $\begin{array}{l}142 \\
\mathrm{n}=1\end{array}$ & $\begin{array}{c}113 \\
(104-122) \\
n=2 \\
\end{array}$ & $\begin{array}{l}\text { annual ranges; subadult } \leq 4 \\
\text { years }\end{array}$ \\
\hline \multicolumn{6}{|l|}{ Interior Alaska } \\
\hline $\begin{array}{l}\text { Alaska Range } \\
\text { (Reynolds and Hechtel } \\
\text { 1983a) }\end{array}$ & $\begin{array}{c}710 \\
(202-1476) \\
n=6\end{array}$ & $\begin{array}{c}132 \\
(26-556) \\
n=6\end{array}$ & $\begin{array}{c}23 \\
(21-26) \\
\mathrm{n}=2\end{array}$ & $\begin{array}{c}65 \\
(16-184) \\
n=6\end{array}$ & annual ranges; adult $=6+$ years \\
\hline
\end{tabular}




\begin{tabular}{|c|c|c|c|c|c|}
\hline \multirow{3}{*}{$\begin{array}{c}\text { Ecosystem, Area and } \\
\text { Citation }\end{array}$} & \multicolumn{4}{|c|}{ Home Range (sq. km) } & \multirow[b]{3}{*}{ Comments } \\
\hline & \multicolumn{2}{|c|}{ Adult } & \multicolumn{2}{|c|}{ Subadult } & \\
\hline & Male & Female & Male & Female & \\
\hline \multicolumn{6}{|l|}{ Southcentral Alaska } \\
\hline $\begin{array}{l}\text { Cooper River Delta } \\
\text { (Campbell 1985) }\end{array}$ & $\begin{array}{c}295 \\
(240-349) \\
n=2\end{array}$ & $\begin{array}{c}174 \\
(97-261) \\
n=4\end{array}$ & $\underset{n=1}{316}$ & $\begin{array}{c}203 \\
(144,262) \\
n=2\end{array}$ & $\begin{array}{l}\text { annual ranges; female with } \\
\text { home range }=97 \mathrm{sq} . \mathrm{km} \\
\text { accompanied by yearling; adult } \\
=5+\text { years }\end{array}$ \\
\hline $\begin{array}{l}\text { Nelchina/Upper Susitna } \\
\text { basins } \\
\text { (Miller and Ballard 1980) }\end{array}$ & $\begin{array}{c}850 \\
(496-1252) \\
n=6\end{array}$ & $\begin{array}{c}415 \\
(222-734) \\
n=4\end{array}$ & $\begin{array}{c}848 \\
(282-1038) \\
n=4\end{array}$ & $\begin{array}{c}118 \\
\mathrm{n}=1\end{array}$ & annual ranges; adult $=5+$ years \\
\hline $\begin{array}{l}\text { Susitna Hydro Project } \\
\text { (Miller and McAllister } \\
\text { 1982; Miller 1984) }\end{array}$ & $\begin{array}{c}1014 \\
(100-2135) \\
n=10\end{array}$ & $\begin{array}{c}294 \\
(110-536) \\
n=15\end{array}$ & $\begin{array}{c}1218 \\
(88-2655) \\
n=14\end{array}$ & $\begin{array}{c}320 \\
(131-712) \\
n=17\end{array}$ & annual ranges; adult $=5+$ years \\
\hline $\begin{array}{l}\text { Alaska Peninsula } \\
\qquad(\text { Glenn and Miller 1980) }\end{array}$ & $\begin{array}{l}262 \\
(62-749) \\
n=4\end{array}$ & $\begin{array}{c}293 \\
(26-1098) \\
n=30\end{array}$ & $\begin{array}{c}749 \\
(111-2109) \\
n=5\end{array}$ & $\begin{array}{c}244 \\
(104-420) \\
n=6\end{array}$ & $\begin{array}{l}\text { annual ranges; adult }=9+\text { years, } \\
\text { subadult }=2-4 \text { years }\end{array}$ \\
\hline \multicolumn{6}{|l|}{ Kodiak/Afognak } \\
\hline $\begin{array}{l}\text { Karluk Lake } \\
\text { (Berns et al. 1980) }\end{array}$ & $\begin{array}{c}24 \\
(3-49) \\
n=7\end{array}$ & $\begin{array}{c}14 \\
(9-20) \\
n=6\end{array}$ & - & - & annual ranges \\
\hline $\begin{array}{l}\text { Terror Lake Hydro Project: } \\
1982 \\
\text { (Smith and Van Daele } \\
\text { 1984) }\end{array}$ & $\begin{array}{c}230 \\
(82-465) \\
n=8\end{array}$ & $\begin{array}{c}26 \\
(6-94) \\
n=16\end{array}$ & $\begin{array}{c}51 \\
(30-77) \\
n=4\end{array}$ & - & $\begin{array}{l}\text { annual ranges for bears with } \geq 5 \\
\text { relocations; adult and subadult } \\
\text { females combined; minimal } \\
\text { construction activity }\end{array}$ \\
\hline $\begin{array}{l}\text { Terror Lake Hydro Project: } \\
1983 \\
\text { (Smith et al. 1981) }\end{array}$ & $\begin{array}{c}119 \\
(33-327) \\
n=10\end{array}$ & $\begin{array}{c}31 \\
(7-157) \\
n=26\end{array}$ & $\begin{array}{c}99 \\
(12-68) \\
n=6\end{array}$ & - & $\begin{array}{l}\text { annual ranges for bears with } \geq 5 \\
\text { relocations; adult and subadult } \\
\text { females combined; expanded } \\
\text { construction activity }\end{array}$ \\
\hline
\end{tabular}

garbage dumps, which once served as "ecocenters" in Yellowstone National Park (Judd and Knight 1980). Knight et al. (1984b) noted that home range sizes for 3 grizzly bears were inversely proportional to the intensity with which they foraged at a garbage dump in Cooke City, Montana (on the northeast park border).

The influence of topographic structure and diversity on home range size and shape was noted for several areas (Curatolo and Moore 1975, Pearson 1977, Schallenberger and Jonkel 1978b, Lloyd 1979, Judd and Knight 1980). Pearson (1977) reported that in the southwestern Yukon, the greatest bear densities and smallest home ranges were found in areas with the most rugged terrain and the highest habitat diversity. He hypothesized that social intolerance regulated grizzly bear numbers and in diverse, rugged areas there was less chance for 2 bears to confront one another. Lloyd (1979) found that home range shape and size in coastal British Columbia was determined by topography. Judd and Knight (1980) suggested that the large home ranges in Yellowstone relative to the high mountain ecosystems may be due to its plateau topography.

\section{Home Range Overlap and Territorial Defense}

Craighead and Mitchell (1982) hypothesized that in Yellowstone National Park the lack of territorial defense and the great degree of home range overlap among sex and age classes of grizzly bears related to a social linear hierarchy that permitted freedom of travel and, therefore, the ability to maximize exploitation of rich food sources. Extensive home range overlap among all sex and age classes was also noted by Lloyd (1979), Ballard et al. (1982b), Nagy et al. (1983b) and Servheen (1983). Others noted that there was overlap, but not of core areas: that is, that geometric activity centers were well spaced (Martinka 1970 [adults of same sex], Russell et al. 1979, McLellan 1981 [females only], Aune et al. 1984 [females]). Mace and Jonkel (1980c) found that the degree of overlap between male and female home ranges was $41 \%$, but only $14 \%$ overlap between different males. Murie (1981) noted varying degrees of home range overlap, but also observed that bears avoided close contact with more dominant bears. Archibald (1983) reported that home ranges tended to be exclusive "where food sources are evenly distributed and predictable." There is some evidence that subdominant bears (females and subadults) were relegated to high elevation, suboptimal habitat, whereas mature males frequented the most productive lower elevation areas (Nagy and Russell 1978, Russell et al. 1979, Wielgus 1986). 


\section{Movement}

\section{Grizzly Bear Movement Patterns}

Mobility is an important aspect of grizzly bear feeding ecology (Hamer et al. 1983). Quimby and Snarski (1974) documented four kinds of movements by grizzly bears: (1) movement to an abundant or preferred food source, (2) localized movement, (3) intensive feeding prior to denning and (4) movement to a den site.

Rates of movement, as reported in the literature, are moderate when averaged per day (e.g., for adult males, 1.34 $\mathrm{km} /$ day and $4 \mathrm{~km} /$ day as reported by Knight et al. [1984b] and Reynolds [1980], respectively). However, there are reports of grizzlies making extensive movements in relatively short time periods (e.g., $26 \mathrm{~km}$ in 10 hours, [Linderman 1974] and $54 \mathrm{~km}$ in 62 hours, [Craighead 1976]).

Grizzly bear movements may be abrupt, rapid or direct. Craighead and Mitchell (1982) found that movements to fall foraging sites and the final movements to den sites were often abrupt and rapid. Ruttan (1974) found that bears in Northern Canada moved directly to the Arctic Coastal Plain after den emergence and made the reverse movement back in September. Almack (1985) observed long, direct, treks to specific food sources and to den sites.

Grizzly bear movement may also involve indirect travelling as bears forage for widely dispersed food items. Knight et al. (1984b) found that summer movements consisted largely of a wandering search pattern because food sources were scattered at that time. Hechtel (1978) and Archibald (1983) hypothesized that grizzly bear movements reflected a random search pattern in order to increase the probability of encountering high energy animal food sources. Several authors reported that spring movements were greatest relative to other seasons due to the dispersed, patchy nature of food sources at this time (Glenn 1975, Lloyd and Fleck 1977, McLellan 1982, Aune et al. 1984). Wielgus (1986) found that spring movements of females were closely tied to vegetative food items, whereas males were seeking carrion and elk calves.

Grizzly bears often exhibit discrete altitudinal movements from spring to fall, following seasonal food availability (Mundy and Flook 1973, Russell 1974, Pearson 1975, Valkenburg 1976, Servheen and Lee 1979b, Spencer and Hensel 1980, Zager 1980b, B.I.A. 1981, Martinka 1981, Smith and Van Daele 1984). For example, Valkenburg (1976), Mundy and Flook (1973) and Martinka (1971) described the following pattern; after den emergence, grizzly bears moved down in elevation to feed on the first green vegetation and winter-killed ungulates, later moved up in elevation to forage on fresh vegetation in avalanche chutes and alpine zones, and in late summer and fall, moved down to feed on spawning salmon or berries.

\section{Differences in Movement Patterns and Home Range Size According to Age, Sex and Reproductive Status}

Most studies of grizzly bear movement patterns have shown that males have larger home ranges and move greater distances than do females (Table 5). Generally, the large home range and movements of males is thought to result from spring breeding behavior; it is advantageous for a mature male's home range to encompass several home ranges of estrous females, and wide-ranging movements increase the probability of encountering receptive females (Bunnell and Tait 1981, Russell et al. 1983, Knight et al. $1984 \mathrm{~b}$, Smith and Van Daele 1984). Another explanation is that males, having the larger body size, and hence greater energy needs, require a larger area for sustenance than do females (Harestad and Bunnell 1979). For example, Schoen and Beier (1983) found that male grizzly bears tended to forage along more than 1 salmon stream, whereas females tended to remain in 1 drainage during salmon spawning.

Reasons given for small female home ranges include: (1) that it is advantageous for a female to lessen her chances of encountering an aggressive male (Curatolo and Moore 1975 ) and, (2) that young females tend to remain on maternal home ranges and maintain an attachment to an area of familiarity (Pearson 1975). This may be supported by the observation that females in some areas showed more yearto-year fidelity to a specific geographic area (Murie 1981, Nagy et al. 1983ab, Knight et al. 1984b, Smith and Van Daele 1984). Furthermore, habitat selection by females with young may be constrained by the need for security. Patterns of habitat use segregation observed in several areas suggested that isolation from other adults was a factor in habitat selection by family groups (e.g., Pearson 1975, Gebhard 1982, Nagy et al. 1983, Stelmock, Knight et al. 1986).

Table 6 compares the home range sizes of females of different reproductive status. Many authors reported that home ranges of females accompanied by cubs of the year were smaller than those females accompanied by yearlings (Pearson 1974, Atwell et al. 1980, Berns et al. 1980, Glenn and Miller 1980, McLellan and Jonkel 1980, Miller and McAllister 1982, Smith and Van Daele 1982, Knight et al. 1984, Miller 1984, Aune 1985, Barnes 1985, Wielgus 1986). The enlarged home ranges of females accompanied by yearlings or 2-year olds (relative to solitary females and females with cubs of the year) may be due to increased nutritional demands, greater mobility and "training" of the young bears (Hamer et al. 1978, Knight et al 1984b).

Conversely, Servheen (1983), Hamer et al. (1983) and Reynolds (1978) reported that home ranges for females were largest when they were accompanied by cubs of the year. McLellan (1981b), Ballard et al. (1982b), Miller et al. (1982), and Curatolo and Moore (1975) reported no significant difference in the size of the home range for females of different reproductive status.

\section{Dispersal of Subadults}

Generally, subadult males disperse out of the maternal range (Glenn 1980, Nagy et al. 1983a, Knight et al. 1984b, Miller 1984), and establish a separate home range coincident with the onset of breeding activity (Servheen and Lee 1979b, Knight et al. 1984b). Home range size gradually increases with reproductive success and new food experiences (Craighead 1980), and may become twice the size of the maternal range (Knight et al. 1984b).

Reynolds and Hechtel (1983) observed 1 subadult (of 3), and Miller (1984) observed 1 (of 5) subadult males which remained in the maternal home range. However, most research showed that subadult males dispersed long distances (Glenn 1980, Craighead and Mitchell 1982, Reynolds and Hechtel 1983ab), as reflected in the relatively large home range sizes for this age/sex class (Table 5). Establishment of a separate home range is related to the availability of suitable habitat (Martinka 1970, Nagy and 
Table 6. Mean annual home range size (sq. $\mathrm{km}$ ) for adult females of different reproductive status. Most ranges calculated from minimum area (convex polygon) method (Mohr 1947).

\begin{tabular}{|c|c|c|c|}
\hline Ecosystem, Area and Citation & $\begin{array}{c}\text { Reproductive } \\
\text { Status } \\
\end{array}$ & $\begin{array}{c}\text { Home Range Size } \\
(\mathbf{s q} . \mathbf{k m})\end{array}$ & Sample Size a \\
\hline $\begin{array}{r}\text { Yellowstone Ecosystem } \\
\text { (Knight et al. 1984b) }\end{array}$ & $\begin{array}{l}\text { single } \\
\text { cubs } \\
\text { yearlings }\end{array}$ & $\begin{array}{l}424 \\
225 \\
546\end{array}$ & $\begin{array}{l}8 \\
9 \\
7\end{array}$ \\
\hline $\begin{array}{l}\text { Canadian Rockies } \\
\text { Banff Natl. Park } \\
\text { (Hamer et al. 1983) }\end{array}$ & $\begin{array}{l}\text { single } \\
\text { cubs } \\
\text { yearlings } \\
\text { 2-yr olds }\end{array}$ & $\begin{array}{l}149 \\
193 \\
195 \\
206\end{array}$ & $\mathrm{~b}$ \\
\hline $\begin{array}{l}\text { Kananskis country } \\
\text { (Wielgus 1986) }\end{array}$ & $\begin{array}{l}\text { single } \\
\text { cubs } \\
\text { yearlings } \\
\end{array}$ & $\begin{array}{l}147 \\
122 \\
126 \\
\end{array}$ & $\begin{array}{l}4 \\
4 \\
2 \\
\end{array}$ \\
\hline $\begin{array}{l}\text { Canadian Arctic } \\
\text { Northwest Territories } \\
\text { (Nagy et al. 1983b) }\end{array}$ & $\begin{array}{l}\text { single } \\
\text { cubs } \\
\text { yearlings } \\
2 \text {-yr olds }\end{array}$ & $\begin{array}{l}513 \\
239 \\
507 \\
726\end{array}$ & $\begin{array}{r}14 \\
5 \\
10 \\
2\end{array}$ \\
\hline $\begin{array}{l}\text { Arctic Alaska } \\
\text { Western Brooks Range } \\
\text { (Reynolds and Hechtel 1980) }\end{array}$ & $\begin{array}{l}\text { single (breeding) } \\
\text { single (non-breeding) } \\
\text { cubs } \\
\text { yearlings } \\
2-4 \text { yr olds }\end{array}$ & $\begin{array}{l}194 \\
290 \\
220 \\
133 \\
197\end{array}$ & $\begin{array}{r}4 \\
14 \\
5 \\
7 \\
5\end{array}$ \\
\hline $\begin{array}{l}\text { Eastern Brooks Range } \\
\text { (Reynolds 1976) }\end{array}$ & $\begin{array}{l}\text { single } \\
\text { with young }\end{array}$ & $\begin{array}{l}382 \\
280 \\
\end{array}$ & $\begin{array}{l}3 \\
5 \\
\end{array}$ \\
\hline $\begin{array}{l}\text { Interior Alaska } \\
\quad \text { Alaska Range } \\
\text { (Reynolds and Hechtel 1983a) } \\
\end{array}$ & $\begin{array}{l}\text { single } \\
\text { with young }\end{array}$ & $\begin{array}{r}167 \\
51 \\
\end{array}$ & $\begin{array}{l}4 \\
7 \\
\end{array}$ \\
\hline $\begin{array}{l}\text { Southcentral Alaska } \\
\text { Susitna Hydro Project } \\
\text { Phase I: minimal construction } \\
\text { (Miller and McAllister 1982) }\end{array}$ & $\begin{array}{l}\text { cubs } \\
\text { yearlings }\end{array}$ & $\begin{array}{l}230 \\
168\end{array}$ & $\begin{array}{l}4 \\
2\end{array}$ \\
\hline $\begin{array}{l}\text { Phase II: increased construction } \\
\text { (Miller 1984) }\end{array}$ & $\begin{array}{l}\text { cubs } \\
\text { yearlings }\end{array}$ & $\begin{array}{l}642 \\
625\end{array}$ & $\begin{array}{r}11 \\
4\end{array}$ \\
\hline $\begin{array}{l}\text { Nelchina/Upper Susitna } \\
\text { (Miller and Ballard 1980) }\end{array}$ & $\begin{array}{l}\text { single } \\
\text { with young }\end{array}$ & $\begin{array}{l}364 \\
568 \\
\end{array}$ & $\begin{array}{l}7 \\
4 \\
\end{array}$ \\
\hline \multicolumn{4}{|l|}{ Kodiak/Afognak } \\
\hline $\begin{array}{l}\text { Karluk Lake } \\
\text { (Berns et al. 1980) }\end{array}$ & $\begin{array}{l}\text { single } \\
\text { with young }\end{array}$ & $\begin{array}{l}14 \\
11\end{array}$ & $\begin{array}{r}6 \\
17\end{array}$ \\
\hline $\begin{array}{l}\text { Kodial Natl. Wildl. Refuge } \\
\text { (Barnes 1985) }\end{array}$ & $\begin{array}{l}\text { single } \\
\text { cub } \\
\text { yearlings }\end{array}$ & $\begin{array}{l}21 \\
32 \\
57\end{array}$ & 22 \\
\hline $\begin{array}{l}\text { Terror Lake Hydro. Project } \\
\text { (Smith and Van Daele 1984) }\end{array}$ & $\begin{array}{l}\text { cubs } \\
\text { yearlings }\end{array}$ & $\begin{array}{l}17 \\
46\end{array}$ & $\begin{array}{l}4 \\
7\end{array}$ \\
\hline (Smith et al. 1984) & $\begin{array}{l}\text { cubs } \\
\text { yearlings or other }\end{array}$ & $\begin{array}{r}8.5 \\
31\end{array}$ & $\begin{array}{l}1 \\
7\end{array}$ \\
\hline
\end{tabular}

aNumber of home ranges, not number of bears.

bSame bear; 4 years data. 
Russell 1978, Miller and McAllister 1982), or the attainment of social status necessary to occupy the home range of an adult that dies (Martinka 1970, Russell et al. 1979).

Subadult females often establish a home range encompassing some portion of the maternal range (Pearson 1975, 1977, Glenn 1980, Nagy et al. 1983b, Reynolds and Hechtel 1983ab, Knight et. al. 1984b, Miller 1984, Wielgus 1986). Movement and home range size of subadult females is often smaller than all other sex and age groups (B.I.A. 1981, Craighead and Mitchell 1982). Knight et al. (1984b) documented that home range increases between weaning to reproductive age when it contracts, then increases and contracts cyclically according to annual food availability and reproductive status.

Few authors speculated as to why there is a tendency for young males to disperse and young females to stay within the maternal home range. Wielgus (1986) and Craighead and Mitchell (1982) noted that adult sows and dominant males directed more aggression toward young males than toward young females. There is also some theoretical basis for adult male aggression being directed primarily at other males (Bunnell and Tait 1981). Thus, interference by resident adult males could disproportionately affect movements and home range use of other males, especially juveniles. Craighead et al. (1964) hypothesized that male dispersal was partially a function of population density.

Waser and Jones (1983) suggested that dispersal may be selected for if it increased an individual's chances of encountering members of the opposite sex, produced more heterozygous offspring (avoided inbreeding) or gave access to empty but suitable habitats. In most of the vertebrate species they reviewed, females were least likely to leave the parental area. For bears, a female can promote reproductive success of her female offspring by enhancing growth and the attainment of sexual maturity. This is less true for male offspring which need a large area to find and inseminate several females in order to maximize their reproductive success. Other factors which may be important in favoring subadult females' continued residence on the natal home range are the potential opportunity for inheriting the parental home range, habitat saturation (i.e., no empty suitable habitat exists), and the advantage of being familiar with an area in terms of foraging efficiency (Waser and Jones 1983).

\section{ACTIVITY PATTERNS}

Activity patterns refer to the diel rhythms of activity and inactivity displayed by grizzly bears. These patterns can be discerned by direct observation (e.g., Stelmock 1981, Gebhard 1982), radio-telemetry (e.g., Sizemore 1980), or motion-sensing radio collars (e.g., Schleyer 1983, Harting 1985). Several researchers included discussions of the attendant behaviors (e.g., travelling, foraging, resting) with their analysis of temporal activity patterns.

Activity patterns of a species are of interest for several reasons (Roth 1983). Once the activity patterns have been quantitatively described for various environmental conditions, the pattern observed for a given population could possibly help to interpret the level of stress experienced by that population. Insight into the activity regimes for a given population might also help to reduce the potential for undesirable bear-man encounters and to promote better research schedules for censuses, etc.

\section{Yellowstone Ecosystem}

Schleyer (1983) used motion-sensing telemetry collars to study grizzly bear activity patterns in the Yellowstone ecosystem. He found that the bear activity level (number of minutes active per half-hour time block) varied greatly with time of year (month and season), time of day, food source and individual bear.

Four weather factors had significant effects on the activity level. Temperature explained a significant portion of the variation but the relationship varied seasonally. Annually, the by temperature response curve was roughly bell-shaped with highest activity from 5.6-11 C and above $22 \mathrm{C}$. Changes in relative humidity were significantly related to activity level. Activity increased with relative humidity until it reached $95 \%$ at which point activity diminished slightly. The type of precipitation, or lack of it, was significantly related to activity level. Hail impeded activity while fog appeared to enhance activity. Bears were less active than average when there was no precipitation and slightly more active than average during rain. Lunar phase also explained a significant portion of the variance in activity level, grizzlies were most active under intermediate light levels.

Harting (1985) also studied the activity patterns of grizzly bears in Yellowstone. Like Schleyer (1983), he found that temperature had a significant effect on bear activity levels. Peak activity was in the $10-15 \mathrm{C}$ range with lower activity at both temperature extremes. Unlike Schleyer's (1983) results, Harting (1985) reported that bears were most active when there was no precipitation. The effects of wind speed and cloud cover were inconclusive. The probable effects of these environmental variables on foraging efficiency were also discussed.

Schleyer (1983) reported that grizzlies were least active (about 2.4 - 4.8 hours/day) during the 2 months prior to denning (September and October) and immediately following den emergence. Activity during the summer months was high and fairly constant at 8-12 hours of activity during any 24-hour period. Harting (1985) also found high activity during the summer months and lower activity in the fall. The low fall activity level was attributed to predation and feeding on carcasses by the monitored bears. Schleyer (1983) also reported that grizzly bears were significantly less active while using a carcass than at other times, however, Harting (1985) reported that grizzly activity levels were lowest during May while Schleyer (1983) found that grizzly activity was highest in May.

Schleyer (1983) reported that annually, Yellowstone grizzly bears were somewhat nocturnal with crepuscular activity peaks at 0630 and 2400 and very little activity from 1030 - 1830. Grizzlies were basically crepuscular in all 3 seasons with increased diurnal activity evident in spring. The fall activity pattern was fairly erratic as grizzlies fed primarily on ungulate carcasses.

Harting (1985) also found that Yellowstone grizzly bears were most active during the crepuscular periods and significantly less active during the day than during any other period. Primary activity peaks occurred at 0500 and 2200 with lower activity from early to mid-afternoon. Seasonal 
differences in activity patterns were discussed but data were limited.

Gunther and Renkin (1985) presented data on grizzly bear activity patterns in the Pelican Valley of Yellowstone National Park. Activity levels were determined from direct observation of bears during the summer season. Major peaks in activity occurred at 0630,1000 and 2030 . Activity quickly declined after 1000 with very low activity from 1230 1500, gradually increasing until the peak at 2030. This crepuscular pattern basically follows that discussed above.

Both Schleyer (1983) and Harting (1985) reported that grizzly bear activity patterns varied significantly by individual bear. One of the 5 grizzlies monitored by Schleyer (1983) appeared to be diurnal to crepuscular with very little nocturnal activity except during the summer. Harting (1985) discussed the correlations between the observed differences in diel activity patterns, foraging behavior and habitat use for individual grizzlies. His preliminary data suggested a substantial interdependence among these variables.

Schleyer et al. (1984) studied the effects of nonmotorized recreation on grizzly bear activity patterns and habitat use in the Yellowstone ecosystem. Activity patterns were determined during pre- and post-disturbance periods with the aid of motion-sensing radiocollars. Non-disturbed grizzlies were basically crepuscular with an early morning activity peak (1 bear was somewhat diurnal). Disturbed bears displayed a similar pattern but the activity level during 4 of 6 periods was elevated.

\section{Northern Continental Divide Ecosystem}

Sizemore (1980) found that the diel rhythms of 4 grizzly bears in the North Fork of the Flathead River Valley varied by season. All bears were more active at night than during the day for the spring-summer period but in the summerfall period there was no difference between nocturnal and diurnal activity levels and the spring-summer activity level was significantly less than the summer-fall activity level. Monitored bears were active during all hours of the day during the latter period. A 5-year-old male was significantly more active during the day for the spring-summer period than either a 4-year-old female or an adult female with cubs. There were ro significant differences by age/sex class for the summer-fall period.

Aune and Stivers (1985) and Aune et al. (1984) discussed the activity patterns of 4 bears along the Rocky Mountain East Front of Montana. Observations were collected during July and August as grizzlies fed primarily on berries. They reported that grizzlies became fully active between 2100-2400 hours after an awakening period of "stationary activity" in the twilight and evening hours. Bears remained active (feeding and travelling) until 0600-0900 hours. The researchers noted that the same bears behaved differently in different locales. Grizzlies were more crepuscular in mountainous or isolated terrain than in populated foothills or plains.

Shaffer (1971) discussed the activity patterns of grizzly bears feeding on huckleberries in Glacier National Park. Based upon direct observations and fresh field sign, he concluded that grizzly activity was concentrated in 2 periods of 0400-1100 and from 1530 until after dark.

\section{Selkirk Mountains Ecosystem}

Almack (1985) collected activity data from a collared adult female in the Selkirk Mountains of northern Idaho. In spring, the bear was mostly crespuscular. In summer, she was slightly crespuscular but often remained active for 24-hour periods. During the fall, she was often active for several hours during the day and inactive for most of the night.

\section{Arctic Alaska Ecosystem}

Gebhard (1982) studied the activity patterns of a grizzly bear family (sow and 2 yearlings) in the Brooks Range of Alaska. He reported that the family's activity level increased from about 14 hours/day in spring and summer to 20 hours/day by late fall. In spring, activity peaks occurred in early morning, mid-day and evening. Most of the active time was devoted to foraging for roots. The family alternated between periods of rest and activity which were quite variable in duration. By late summer, the active and inactive periods were longer and more continuous. The family was most active in the early morning and evening with little or no activity in mid-to late afternoon. About $80 \%$ of the sow's active time was spent feeding, with grazing being the dominant feeding activity. By early to late fall, the afternoon slump in activity diminished and the overall activity level increased. Foraging activities included digging for ground squirrels, digging for roots and grazing. Nocturnal observations were limited but the researcher felt that the family was probably active for much of the night.

Hechtel (1985) collected activity data from 5 female grizzly bears ( 4 with cubs) in the same general area of the western Brooks Range. As in most other studies of bear activity patterns (Stelmock 1981, Roth 1983, Schleyer 1983, Harting 1985, Phillips 1985), he found considerable variation among bears. Direct observation showed that 3 females with cubs were active for $20-40 \%$ (4.8 - 9.6 hours) of the 24-hour periods just after den emergence. The level of activity of 1 female after leaving the den area was in the $46-58 \%$ range. The author noted that this pattern of activity was consistent with the 4 physiological stages described for bears by Nelson et al. (1983a).

Hechtel (1985) also described the activity pattern of a female before and after initiation of breeding activity. During the pre-breeding period the sow (accompanied by 2 3 -year-olds) was active an average of $56-74 \%$ of the monitored 24-hour time blocks. After expelling the cubs and pairing with a large male, she was active only $21 \%$ of the time. Murie (1981) and Phillips (1985) also reported that mated pairs spent less time foraging during the breeding season but some studies reported that activity patterns of breeding pairs were similar to other groups (Pearson 1975, Stelmock 1981).

Phillips (1985) studied the behavior patterns of grizzly bears in the Arctic National Wildlife Refuge of northeastern Alaska. As observed in most other studies of grizzly bear activity patterns, grizzlies in this study were most frequently active from early evening to early morning with crepuscular activity peaks. Phillips concluded that bear activity patterns were a response to the differential distribution (temporally and spatially) and size of important food items and fall hyperphagia. In spring, grizzlies fed on roots, ground squirrels and overwintered berries. These 
food items were small and widely dispersed and required prolonged foraging for satiation. Grizzlies also spent more time travelling in spring than during other seasons. The observed grizzlies were active $100 \%$ of the time. In summer, grizzlies were active for $71 \%$ of the observation time as they fed primarily on herbaceous vegetation which could be ingested in large quantities over a short period of time. In fall, grizzlies were active for $79 \%$ of the observation time. During this time, the small, widely dispersed arctic ground squirrels were the major diet item. Spring and fall sample sizes were very small, and therefore, not conclusive.

Lindermann (1974) monitored the activity patterns of an adult male grizzly during spring in the eastern Brooks Range of Alaska. For all days combined, the bear spent $31 \%$ of his time feeding, $59 \%$ resting and $10 \%$ travelling. He tended to feed most often in the morning and rest more in the evening and night than in the morning. This result is in contrast to most of the studies discussed previously which also documented an evening activity peak. Magoun (1976) observed grizzlies as they fed on carcasses in the eastern Brooks Range. He reported that grizzlies fed more than expected from 0500-0600 and 1805-2400, less than expected from 0605-1200 and about as expected from 1205-1800.

\section{Interior and Central Alaska Ecosystem}

Stelmock (1981) studied the activity patterns of grizzly bears in Denali National Park by direct observation. Like Gebhard (1982), he found that activity peaks were generally crepuscular. Diurnal inactivity peaked around midday during spring and summer with shorter rest periods in mid-morning and early evening. The time spent resting diurnally decreased during late summer. Feeding activity during spring and summer consisted primarily of grazing, excavating roots and feeding on over wintered berries. As day length decreased in the fall, diurnal activity increased. Grizzlies foraged almost continuously as they fed on ground squirrels and berries.

Several studies documented bear activity along Alaskan salmon streams. These studies indicated that peak activity generally occurred in the evening with some fishing in the early morning and late afternoon periods (Erickson 1963, Troyer and Hensel 1969, Stokes et al. 1981). Nocturnal observations were limited but Troyer and Hensel (1969) felt that feeding activity continued for several hours into the night and then diminished before dawn. Stokes et al. (1981) found some evidence of social regulation of activity patterns. Dominant bears were active at the most productive fishing times and other bears were relegated to less productive periods.

\section{Northern Interior (Yukon) Ecosystem}

Unlike most of the other studies discussed above, Pearson (1975) found that there were no seasonal changes in the daily rhythms of grizzly bears in the southwestern Yukon. Moderately high, early morning activity was followed by low activity from 1100-1500. Activity increased in the late afternoon, reached a peak at dusk and, as evidenced by trap disturbance, continued in to the night. Some age, sex and reproductive class distinctions were noted. Older males appeared to feed more purposefully and rest more often than other bears. Sows with young had activity pat- terns similar to other bears but moved more during daylight when feeding in areas of high grizzly concentration.

\section{INTRASPECIFIC BEHAVIOR}

\section{Dominance Hierarchies at Dumps and Spawning Streams}

Grizzly bears generally show a low degree of social organization but may form loose social aggregations at sites of plentiful food. At these sites, grizzly bear behavior assumes the characteristics of more gregarious species. This social organization enables adaptation to fluctuating environmental conditions and permits efficient use of the available resources (Hornocker 1962, Egbert and Stokes 1976, McArthur 1979c, Herrero 1978b, Bunnell and Tait 1981).

Detailed studies of grizzly bear dominance hierarchies have been conducted at Yellowstone garbage dumps (Hornocker 1962) and at Alaskan salmon spawning streams (Stonorov and Stokes 1972, Egbert and Stokes 1976, Luque and Stokes 1976, Egbert 1978, Luque 1978, Stokes et al. 1981).

Hornocker (1962) identified 5 classes of adult male grizzlies at the Trout Creek dump in Yellowstone National Park. These are:

Dominant male - One male held the dominant position at the dump during all 3 years of the study. Dominance was gained by actively seeking and defeating "aggressive" males (see below). Approach of this male elicited a strong avoidance reaction by all bears except the aggressive males and females.

Subdominant male - This class was recognized for only 1 year of the study and describes 1 adult male which was persistently aggressive toward the dominant male and other adult males. When the dominant male was absent, this male assumed the dominant position.

Aggressive males - This class, comprised of 2 to 4 adult males, referred to the third tier in the "ruling class" of adult males. Overt aggressiveness, rather than size or age was the primary factor determining relative rank. A definite peck order existed within this class and these males were intolerant of all other bears below their rank except for "aggressive females."

Defensive males - These males avoided the aggressive males, but would fight when surprised or cornered. These males appeared to be younger than the aggressive and dominant males but often equaled them in size. Fighting within this class was rare and these bears were more tolerant of lesser individuals than were the aggressive males.

Cautious males - These males, smaller and generally younger than males of the above classes, were aggressive only toward inferior classes.

Female position in the social hierarchy varied according to aggressiveness, reproductive condition, age and size. Hornocker (1962) identified 3 classes of adult females. These are: 
Aggressive females - Some females with cubs of the year were subordinate only to the Dominant Male and those males immediately below him. These females demonstrated extreme hostility toward all dominant adult males and did not hesitate to attack even the adult male. This hostility was apparently related to protection of their offspring.

Defensive females - Females with cubs of the year and females with yearlings that avoided contact with superiors were included in this group. These females, generally younger than the aggressive females, protected their young by warning them away from males and through bluff rushes rather than actual physical contact.

Cautious adult females - This class included all adult females without young. These females avoided aggressive males at all times but ignored smaller males. Aggressiveness, size and age determined the social rank of these females.

The behavior of younger bears was sufficiently different from that of adults to warrant their placement in a separate dominance class - the subordinate class. Three subclasses of younger bears were identified (Hornocker 1962). These were:

Young adults - Age ( 3 and 4 years) was responsible for these bears' inferior status relative to other bears, while size determined the individuals' status within the class. Individuals within this class displayed a much wider range of aggressive-submissive behavior than any other class.

Two-year-olds - These bears exhibited behavior similar to the young adults. Those still with litter mates held a somewhat higher position than lone individuals since litter mates often joined forces in attempted bluffs against superior bears.

Weaned yearlings and orphans - These bears, the lowest members in the dominance structure, were physically inferior relative to other bears. They were very secretive and ran at the approach of other bears.

The social hierarchy observed by Egbert (1978) and Egbert and Stokes (1976) on the McNeil River, Alaska, was similar in many respects to the system described by Hornocker (1962), however, they found that status relationships were somewhat variable and were often interpretable only in a relative sense. The status ranking of classes varied by year; i.e., tallies of the number of encounters "won" or "lost" by each age/sex class showed marked, betweenyear, differences.

As in Yellowstone, adult males were the most dominant and aggressive age/sex class. A single "alpha" bear was dominant over all other bears. Unlike Yellowstone, the alpha male was firmly entrenched and was never seriously challenged by other males. Other adult males were next in the hierarchy and had priority over the best fishing locations during the most productive times of day.

Again, as was found in Yellowstone, females with young were particularly aggressive and were the only bears to consistently challenge adult males. During the second year of the study, the salmon run was higher than in the first year and more salmon were available to bears in areas other than at McNeil Falls. Fewer females with young were present at the falls this year, suggesting that when fish were plentiful, these females preferred more secure habitat away from the bear concentrations. In an earlier study at McNeil Falls, Stonorov and Stokes (1972) noted that 3 females with cubs also avoided the falls. Erickson (1965) reported that in peak fish years fewer bears congregated at the Falls and these were mostly large males and single females. Single adult females (equivalent to Hornocker's "cautious adult females") were more tolerant of other bears than were females with young, however, there was much variation within this class.

Adolescent males (4.5 - 8.5 years) were the least aggressive of any group and were never observed initiating an aggressive encounter. Adolescent females (4.5 - 5.5 years) behaved much like single adult females. Adolescents of both sexes engaged in a greater number of non-agonistic encounters (amicable or playful contact) than did other groups. Subadult $(2.5-3.5)$ bears occupied the lowest position in the social hierarchy, typically avoiding contact with other bears and forced to patrol for salmon scraps along the periphery of the main fishing areas. Stonorov and Stokes (1972) reported that some subadults were so intimidated that they would lay by a good fishing spot but not fish.

At both Yellowstone and McNeil River, the primary benefits of high social status related to food and breeding activity. Hornocker (1962) reported that dominant individuals were more successful at obtaining food both at the dump and in backcountry areas, therefore, in years of food scarcity, these individuals would be at an advantage. At McNeil River, the main advantage of social status was determining the place and time to fish without conflict (Egbert and Stokes 1976). The link between food access and aggressive behavior was most evident late in the summer when agonistic encounters increased as fishing success declined. Aggressive encounters declined by $50 \%$ and nonagonistic encounters increased during the second year of the study when salmon were more plentiful. Stonorov and Stokes (1972) reported that competition for a choice fishing spot was 1 of 4 situations that released aggression. Violation of individual distance, redirected aggression following loss of an encounter and meetings of unfamiliar bears also caused aggression.

Evidence linking dominance to reproductive success was inconclusive. Hornocker (1962) found that the dominant male mated and defended only 1 female in all 3 years of his study. Although aggressive males were more successful in the competition for breeding females, males near the top of the dominance hierarchy did not dominate the breeding activity. Some cautious males were more active in the reproductive effort than were their superiors. Aggressive males sometimes lost possession of female consorts while engaged in fights to defend her. At McNeil River, the alpha male was observed to attack and dislodge a copulating subordinate male (Egbert and Stokes 1976). However, estrous females displayed an apparent preference for mature, but relatively small, adolescent males as opposed to the larger, more threatening adults.

In both study areas, aggression increased during the breeding season. Egbert and Stokes (1976) found that all males, regardless of social status, were highly aggressive when associating with adult females. Hornocker (1962) reported that in all 3 years of his study, aggressive behavior by the dominant male toward all bears except adult 
males, dropped dramatically on the day following the last observed breeding activity.

\section{Social Relationships in Dispersed Populations}

Social relationships observed in backcountry and low density areas differred somewhat from the patterns described above for high densities. Many researchers reported that mutual spacing or detection followed by avoidance, was the norm for backcountry populations (e.g., Martinka 1974a, 1974c, 1976, Pearson 1975, Stelmock 1981, Murie 1981, Gebhard 1982, Hechtel 1985, Phillips 1985).

The frequent contact required for formation and maintenance of a dominance hierarchy is not typically found in widely dispersed backcountry populations (Pearson 1975). However, some of the age/sex class relationships, expressed at the high density areas (McNeil Falls and Yellowstone dumps) were also observed in the context of chance encounters or moderate seasonal aggregations of normally dispersed populations.

Grizzly bear concentrations at early spring foraging areas, fall berry crops or other seasonal attractants were documented in a number of areas. For example, Atwell et al. (1980) reported that grizzlies congregated (up to 2.6 bears per $\mathrm{km}^{2}$ at midsummer alpine foraging areas on Kodiak Island. Singer (1978) studied the spring and fall grizzly bear concentrations along the North Fork of the Flathead River, along the western border of Glacier National Park. Martinka (1974a, 1974c) reported that in Glacier National Park, grizzlies concentrated in lowland meadows and snowslides in spring, subalpine areas in summer and spawning streams in fall. He observed distinct spacing among individuals and social units at these concentrations. Pearson (1975) reported that all bears except family groups congregated along valley floors as berries ripened in the fall. He felt that avoidance reactions tended to minimize confrontations. Murie (1981) reported that grizzly bears in Denali National Park sometimes concentrated at choice feeding areas. He found that most chance encounters between grizzly bears were followed by a quick appraisal and possibly a brief chase.

As at salmon streams and garbage dumps, observation of encounters in backcountry populations suggested that adult males occupied a dominant position and young bears held a low position in the social hierarchy. A few representative encounters are described below. Incidents involving intraspecific killing by adult males and the influence of adult male density on reproduction and recruitment rates are discussed in subsequent sections.

Peacock (1978) noted that in the Apgar Mountains, large solitary adults influenced the distribution and dispersal of the fall berry-feeding congregation. Family groups and smaller adults avoided the particular drainages where lone adults foraged. Murie (1981) described several cases where adult males intimidated family groups or young bears in Denali National Park. Younger bears appeared very apprehensive and almost always retreated when near other bears. Mattson et al. (in pressb) reported that relocation data from the Yellowstone ecosystem suggested that subadult grizzlies were displaced away from secure backcountry areas and toward human emplacements (roads and developments) by more dominant bears. Mundy and
Flook (1973) reported that in Glacier National Park 2 subadult bears consistently retreated when a certain large adult approached. Phillips (1986) observed a mature male pursuing a 5-year-old male which walked and ran from the larger bear for 1 hour.

Magoun (1976) reported that a female and cub abandoned a caribou carcass when an adult male approached. Similarly, Craighead and Craighead (1971) reported that a male elicited submissive behavior from a female and yearling at a backcountry bison carcass. Conversely, Barnes and Bray (1967) reported that a sow with 2 yearlings observed at a backcountry bait station was often tolerant of other bears but was consistently dominant in aggressive interactions.

Several studies revealed spatial segregation by age and sex class. Family groups appeared to seek isolation from other bears, particularly adult males. Peacock (1978) noted that in the Apgar Mountains, large, solitary, adults influenced the distribution and dispersal of the fall berryfeeding congregation. Family groups and smaller adults avoided the particular drainages where lone adults foraged. Similarly, Pearson (1975) reported that in the Yukon, females with young of the year avoided the fall berryfeeding concentrations along the valley bottoms. Gebhard (1982) and Stelmock (1981) found that during the breeding season, family groups avoided contact with other bears. In Yellowstone, females with cubs of the year appeared to select secure but less productive habitat during the spring to provide security for the cubs (Knight et al. 1986). In the northern Yukon, adult females with, and without, young were found most often at elevations less frequented by adult males (Nagy et al. 1983a). On the Alaskan Peninsula, females with newborn cubs were captured infrequently in the spring because they tended to remain in mountainous terrain in protective cover (Glenn and Miller 1980). Russell et al. (1979) found that in Jasper National Park, females with young and independent subadults actively avoided adult males. Adult males tended to frequent valley bottoms or lower slopes while females and subadults spent a disproportionately greater time on upper slopes and side basins with readily available escape routes. Movement patterns of family groups and weaned subadults also suggested avoidance of other bears.

Wielgus (1986) reported that in the Kananakis country of southern Alberta, grizzly bear habitat use segregation suggested a dominance hierarchy similar to the 1 described at McNeil Falls (Egbert and Stokes 1976). Adult males were dominant and excluded other bears from the most productive foraging areas (ungulate prey and rich berry-feeding areas). Females with cubs were subordinate only to adult males which they actively avoided. Lone females and subadults had lower social standings.

\section{Threat Behavior}

Social species have evolved complex communication repertoires to minimize aggression by the substitution of ritualized behavior for actual fighting. Bears, being solitary carnivores, lack the wide assortment of visual signals found in some social species (Egbert and Stokes 1976). The short ears, short tail and long fur of bears prevent the grizzly from using these parts for signals as effectively as some other mammals. Instead, body orientation and movements are the primary means of conveying information to rivals (Stonorov and Stokes 1972). 
Certain behavior patterns are characteristically associated with dominance or submission. Mouth, head, ear and body positions have important signal value. Lateral body orientation, looking away and retreating generally connote submission while frontal body orientation, a direct gaze and forward locomotion connote aggression or dominance (Stonorov and Stokes 1972, Egbert and Stokes 1976, Egbert 1978, Colmenares and Rivero 1983b).

Stonorov and Stokes (1972) recorded individual behavioral components seen during encounters at McNeil Falls to determine how threat or appeasement signals were used to reduce physical contact. Individual behaviors were placed into 6 broad groupings: locomotion, body orientation, head orientation, mouth position, ear position and contact. Each behavior was analyzed according to the number of times it was associated with dominant or subordinate interactions. Components which were associated largely with dominance were frontal orientation, approach, showing of canines, muzzle twist and neck stretch. Components which were shown largely by subordinates were lateral orientation, turning away and dropping of the head and sitting or lying down. Laid-back ears were associated equally with dominant and subordinate interactions. The nature of agonistic encounters changed during the course of the fishing season. Dominant animals shifted to less intensive threat; the frequency of charges fell sharply as the number of deferrals rose correspondingly. The work of Egbert and Stokes (1976) corroborated those findings; the frequency of fleeing and chasing declined rapidly during the first 10 days of the fishing season while tolerances to the proximity of other bears and number of reciprocal threats increased.

A later study at McNeil Falls (Egbert and Stokes 1976) identified generalized forms of brown bear interactions: head-low threat (low intensity), head-high threat (high intensity), charges, contact or fighting, approach - avoidance, amicable (non-agonistic) behavior and play. The head-low threat (head held below horizontal line of the body) involved various body orientations and typically occurred when bears were separated by less than $4 \mathrm{~m}$. Stonorov and Stokes (1972) described a similar low intensity threat, "jawing," which typically occurred between bears of comparable status, especially females. The headhigh threat (head held diagonally upward) occurred at close range and was usually associated with a frontal body orientation. As in Stonorov and Stokes' (1972) study, ear position was variable. Ears were usually laid-back during the head-low threat and final stages of a direct charge but were erect during the initial stages of a direct charge and during some stages of avoidance reactions.

Egbert (1978) described the nuances of bear facial expressions and vocalizations associated with agonistic encounters. He found that vocalizations were the least ambiguous signals in the brown bear's communication repertoire. The 5 major types of vocalizations and the context within which they most frequently occurred were: huffing (tension), woofing (startled), growling (intolerance), roaring (conflict) and bawling (seeking contact).

Colmenares and Rivero (1983a, 1983b) performed a temporal analysis of brown bear behavior patterns to determine what behaviors or groups of behaviors were most closely associated with aggression. Of particular interest was the appearance of certain "maintenance activities" (rubbing, clawing, biting and scratching) in the context of aggressive encounters. Individual behaviors were grouped into 9 "clusters" according to temporal association and function. One such cluster consisted of various behaviors, such as clawing or biting of objects, rubbing and urination, which occurred in conflict situations and resulted in the deposition of scent marks on particular objects. Behaviors indicative of avoidance or fear included huffing, looking away, fearful growl, sitting, teeth clacking and retreat. Detailed descriptions of these beh aviors were not provided.

J. Craighead (panel discussion, Int. Conf. Bear Res. and Manage. 2:245) described the aggressive behavior of grizzly bears at the Yellowstone dumps. Threatening males generally approached other males with a stiff legged walk. The second bear turned its head to one side and backed up if it wished to avoid an encounter. A stiff-legged gait was associated with dominant behavior in other studies also (Stonorov and Stokes 1972, Pearson 1975). Facing away and backing up were always associated with submission at McNeil Falis (Stonorov and Stokes 1972). Erickson (1965) reported that when a sow with cubs threatened a large male, the male typically turned its shoulder toward the female. Stonorov and Stokes (1972) also found that a "lateral orientation" was generally associated with submission.

Several types of charges were described in the literature (Egbert and Stokes 1976, Egbert 1978). "Direct" charges were hard, fast rushes at the opponent with head held slightly below normal, gaze fixed on the opponent, and ears erect initially but laid back as it closed or when the receiving bear fled. A direct charge was usually accompanied by a growl which developed into a roar. "Short" charges were similar to direct charges but ended after a few strides and sometimes bluffing. These rushes ended when the receiving bear either fled or stood its ground (Egbert and Stokes 1976, Egbert 1978)

A third type of charge, described at McNeil Falls, seemed to involve a combination of threat and avoidance and was seen only during the early days of the fishing season. It was characterized by a stiff, exaggerated rocking gait with the head held erect and the ears cocked forward. Jope (1982, 1985) observed a similar charge, the "hop-charge" directed toward hikers in Glacier National Park. In the hop-charge, the grizzly advanced with a rapid, stiff-legged, hopping gait moving both legs together and holding the head erect. These charges were terminated after only a few paces.

\section{Breeding Season Conflict and Scarring}

Several studies have shown an increase in intraspecific conflict during the breeding season (e.g., Hornocker 1962, Mundy and Flook 1973, Pearson 1975, Egbert and Stokes 1976). J. Craighead (panel discussion, Int. Conf. Bear Res. and Manage. 2:245) reported that breeding season conflicts resulted in severe injuries but no mortalities. Schleyer (1983) found evidence of a violent confrontation between 2 adult males during the breeding season in Yellowstone. Since no carcass or other food source was found in the area, he attributed the fight to a breakdown of the usual avoidance reaction during the breeding season. Mundy and Flook (1973) described 2 cases in which adult males fought during the breeding season while females were nearby. Magoun (1976) observed a mated pair appropriate a caribou carcass from a younger male. The male of the mated pair confronted and expelled the smaller male from the 
area before feeding on the carcass. Russell(1967) described 2 incidences of breeding season combat, 1 in Jasper National Park and the other in Denali National Park. Egbert and Stokes (1976) reported that males were particularly "irascible," especially toward other males, when consorting with, or trailing, an estrous female. Pearson (1975) reported that in the southern Yukon, most large males captured during the breeding season had fresh wounds. He felt that competition for sows in estrous resulted in the breakdown of the avoidance reaction and an increase in physical contact. He also observed that the presence of an estrous female increased a male's "zone of intolerance" and the violation of this zone by another male provoked aggression.

Several researchers reported that adult male grizzlies often bore scars or wounds. Hornocker (1962) reported that in Yellowstone, some adult males had massive wounds and scars on the head and neck when captured. Ears were often mutilated or torn off on older males and many had torn and scarred lips and jaws. Egbert and Stokes (1976) reported that at McNeil River Falls, most adult males bore scars and battered ears. Wielgus (1986) found that in the Highwood Valley of southern Canada all adult males had many combat scars on the head, neck and shoulders. Some subadults also bore scars but no females had scarring. In the central Brooks Range, only 2 of 23 captured grizzlies had evident wounds or scars. One of these was thoroughly mauled and the other was missing the pinna and front of the lower lip (Crook 1971).

\section{Intraspecific Aggression, Mortality and Cannibalism}

\section{Cases of Predation on Cubs, Young Bears and Families by Adult Males or Unknown Adults}

Most cases of intraspecific mortality described in the literature involved cubs or young bears killed, or presumed to be killed, by adult males. Instances of overt aggression, without actual killing, by adult males towards young bears or family groups are also discussed herein.

Troyer and Hensel (1962) described 3 cases in which cubs were apparently killed by adult bears during May and June on Kodiak Island. In 2 of these cases, adult males consumed at least part of the carcass. On Admiralty Island, Schoen and Beier (1986) reported that 1 litter with 2 cubs of the year was presumed killed by a male in early summer. On the Alaskan Peninsula, Rausch (1958) found the remains of a cub which was apparently eaten by an adult and, on another occasion, witnessed a large bear pursuing a cub of the year. Both incidents occurred in August. Also on the Alaska Peninsula, Miller (panel discussion, Int. Conf. Bear Res. and Manage. 2:254) observed a large bear eating a cub; an agitated female with another cub was nearby. This case was also described by Glenn (1971:7).

At McNeil River Falls, researchers found the fresh, partially consumed remains of a $2 \frac{1}{2}$-year-old subadult which had been killed by another bear. At the time, 4 large males and 5 estrous females were present at the falls (Egbert and Stokes 1976). However, Egbert (1978) reported that only 1 adult male at McNeil River Falls ever demonstrated an interest in a cub and, in that case, the male apparently only wanted to smell it. Glenn et al. (1976) reported finding 1 dead cub at McNeil River Falls with a large neck wound apparently inflicted by another bear (possibly the same bear that killed the 21/2-year-old noted above). They also described 2 cases in which single cubs out of triplet litters became separated from their mother and were not seen again.

Ballard et al. (1982b) observed a female with a single surviving cub from a litter of 3 fleeing from a lone adult bear. They believed that predation by adult males may have been responsible for a marked difference in litter size between cub and yearling litters. Miller and Ballard (1982b) suggested that the offspring of translocated females suffered high mortality rates due to increased vulnerability to predation by resident adult males.

Several researchers reported cases of intraspecific aggression or mortality in Denali National Park, Alaska. Russell (1967) described an incident in Denali in which a 3-year-old male approached a mating pair and was subsequently killed by the mature male. Stelmock (1981) observed what may have been a lone male pursuing a female with 2 2-year-old young. The chase, which lasted about 1 hour, was apparently directed toward the female rather than her offspring. Dean et al. (1985) described 2 cases of adult males pursuing family groups in late May and early June. In the first case, a female was killed and her yearling was critically injured. In the second, the male killed a yearling and fed on its carcass. Murie (1981) reported that a 4-year-old grizzly (sex undetermined) was killed and partially eaten by a larger bear in late July near the Denali garbage dump. On another occasion, also in July, a large male grizzly was observed pursuing a sow and yearling. The chase was suspended after the male was apparently alarmed by nearby hikers (Murie 1981).

In the eastern Brooks Range, a large bear was observed feeding on a sow and yearling at the mouth of a den. It was not evident if the 2 bears had died in the winter or were killed by the larger bear (Reynolds 1976). Reynolds and Hechtel (1980) reported that in the western Brooks Range, a single large adult male killed at least 2 young grizzlies (a 2-year-old male and a cub) and may have also killed an adult female and her 2 2-year-old offspring. In the latter case, the female was found dead about 1 mile from her den with wounds inflicted by a much larger, presumably male, grizzly. The young bears were not observed again and were suspected mortalities. On another occasion, a large male was observed stalking and confronting a female with 3 young. A later report from the same study area (Reynolds and Hechtel 1984b) documented another case of an adult male killing a cub. A large adult male was observed feeding on a cub and presumably also killed its missing littermate. The family group had been observed intact the previous day. Also in the Western Brooks Range, Gebhard (1982) observed a large male chasing a sow with 2 cubs for over 4 $\mathrm{km}$.

Nagy et al. (1983b) documented 3 cases in the Tuktoyaktuk Peninsula/Richards Island region of northern Canada in which entire litters were lost in the spring. These losses were tentatively attributed to predation by adult males. Nagy and Russell (1978) reported that in the Swan Hills region of Alberta a yearling male "succumbed to natural predation" in late July. Specifics of the case were not provided although "natural predation" would seemingly refer to predation by another grizzly. In Jasper National Park, 1 of 3 orphaned grizzly bears which survived a winter and spring on their own disappeared in late July. Evidence 
suggested that an adult male probably killed the yearling orphan (Russell et al. 1978). Herrero (1985) reported that a large grizzly bear severely mauled and killed a smaller (68 $\mathrm{kg}$ ) male during the end of the breeding season in Jasper. In the southwestern Yukon, a young (4.5-year-old) male was killed after a violent struggle with another bear (Pearson 1975). This encounter occurred during the period when bears congregated in the alluvial floodplains to feed on berries and roots. Pearson noted that this aggregation was accompanied by a recurrence in agonistic encounters but most skirmishes were usually of short duration and ended when 1 bear retreated. The outcome of this encounter may have been influenced by the recent capture and drugging of the young male.

Craighead et al. (1976a) documented 8 records of infanticide in Yellowstone National Park. Details of these mortalities were not provided. Craighead (panel discussion, Int. Conf. Bear Res. and Manage. 2:245) reported that he had found some yearlings killed or severely mauled in Yellowstone. He also noted that cubs were usually killed by large males in the spring and these mortalities were not restricted to the dump areas. McCullough (1981) reported that National Park Service personnel found 3 cubs killed in one night at the Rabbit Creek dump. Knight et al. (1986) reported that grizzly cub remains were sometimes found in scats in Yellowstone. Roop (1980a) reported that a yearling female which sustained an ankle injury in a snare east of Yellowstone National Park was killed a few days after release (in May) by a large bear.

\section{Cases of Predation on Older Bears by Adult Males}

Pearson (1972) reported that in the southwestern Yukon, an old male (20+ years) was killed by other bears. Pearson (1975) described a case in which an adult male apparently dug a mature female out of an exposed den and killed her. He interpreted this as possible evidence of intense competition for den sites on a preferred slope. Nagy et al. (1983a) reported that in late September, a 6-year-old, $152 \mathrm{~kg}$ male, was killed by a 9-year-old $273 \mathrm{~kg}$ male in their northern Yukon study area. Much of the carcass was consumed (also described by Pearson 1976b).

Reynolds (1974) reported that in the eastern Brooks Range, an adult male killed an adult female in late September. The female died as a result of a broken neck and massive wounds along the top of the hump. The carcass was not consumed but the male had bitten the genitalia several times. Tracks in the snow suggested that the male had deliberately shifted his direction of travel to approach the female when he was about $23 \mathrm{~m}$ away.

Murie (1981) reported that an old female (mother of 3 cubs) was killed in late August near the Denali National Park garbage dump. Murie speculated that she may have been attacked by a large male while she was trying to protect her cubs.

\section{Intraspecific Aggression and Killing by Adult Females}

Intraspecific killing by adult female grizzlies has been documented in the literature less frequently than predation by males. Some of the cases described in the preceding section in which the identity of the aggressor was undetermined may actually have involved adult females.
Murie (1981) described an encounter in Denali National Park in which a female (with 2 cubs) pursued another family group and killed 2 cubs. The 2 family groups had occupied the same summer range in relative harmony but on this occasion, 1 cub apparently strayed too near the other family group and provoked a charge.

In southcentral Alaska, Miller (1985b) observed a lone female chasing another female with 3 yearlings. The pursuing female was accompanied by an adult male. On Kodiak Island, Troyer and Hensel (1962) reported that a female with at least 1 yearling killed and fed upon a female bear which was caught in a snare. At Pack Creek, in southeastern Alaska, a young female grizzly (with 1 cub) attacked and killed an adult male which ventured too near. In this case, the female also suffered mortal wounds (Herrero 1985).

Schoen and Beier (1986) described 1 instance of maternal cannibalism on Admiralty Island. Two cubs apparently died during the winter and were consumed by their mother. Although this was not a confirmed case of maternal infanticide, other researchers (Knight et al. 1986) reasoned that infanticide could allow a sow to terminate an energy deficit state (from lactation) and also recycle energy already invested in cub production.

\section{Theoretical Considerations of Intraspecific Killing}

Adult bears can increase their fitness through "prudent cannibalism" (Rogers 1978, Bunnell and Tait 1981, McCullough 1981). Bunnell and Tait (1981) noted that an adult male's reproductive fitness was critically dependent upon changes in the relative density of adult males to adult females. Consequently, anything an adult male did to reduce the number of competing adult males could enhance his own fitness. This is manifested by aggression toward younger males (killing and forced dispersal).

Reynolds and Hechtel (1984b) discussed the sociobiological implications of infanticide. They noted that females which lost their cubs from early May to late June were often available for breeding soon thereafter. Nagy et al. (1983b) reported that 2 females bred soon after losing their cubs. Thus, dominant males can increase their individual reproductive fitness by killing cubs of females they have not copulated with and thereby induce a female to come into estrous sooner than if the cubs were reared $(\mathrm{McCullough}$ 1981).

Other benefits derived from killing genetically unrelated bears as related to food value of the carcass and reduced competition for food, mates and space. Costs, including energy expenditure and potential injury, are minimized by killing small or vulnerable bears (Rogers 1978).

\section{Non-Agonistic Encounters and Unusual Groupings}

Egbert and Stokes (1976) observed 2 types of nonagonistic encounters at McNeil River Falls. "Amicable" encounters referred to brief encounters in which bears lightly contacted each other in the head and neck regions. More prolonged interactions involving mock fighting or sexual mounting were defined as "play." Almost all of the observed non-agonistic encounters involved adolescent or subadult bears. The frequency of these encounters varied according to the within-year and between-year abundance 
of salmon with the greatest number of encounters when salmon were most plentiful.

Reports of unusual groupings of grizzlies or seemingly amicable encounters are also available for other study areas. Most un usual associations appeared to result from breeding or maternal behavior. A few of these cases are mentioned below.

Peacock (1978) observed a female with 2 yearlings accompanied by a medium-sized adult and, on another occasion, a female and 1 yearling accompanied by an adult (at $50-150 \mathrm{~m}$ ). Both groupings were observed during the late summer berry-feeding concentrations in the Apgar Mountains of Glacier National Park. Martinka (1974) reported 4 unusual associations among grizzly bears. In one case, an adult male was observed with a family group shortly before dissolution of the maternal bond and breeding took place. In the other 3 cases, females with young tolerated the presence of subadults or young adults for brief periods. Murie (1981), Stelmock (1981) and Gebhard (1982) also found that females with young sometimes tolerated the presence of nearby young bears for brief periods.

Colmenares and Rivero (1983b) documented an exceptional case of group cohesion among 6 captive brown bears. They found that a social hierarchy was present, however, unlike the situation in wild populations (Hornocker 1962, Egbert and Stokes 1976), the main factor in attaining a high social rank was each male's ability to achieve an alliance against other bears. Young bears played together and developed cohesive social bonds with companions. These affiliations were apparent in cooperative attacks on rival bears. Hornocker (1962) mentioned 1 incident in which 2 "aggressive females" simultaneously attacked the dominant male at the Trout Creek dump. Craighead and Craighead (1972c) reported that 2 or more grizzlies sometimes pursued and killed elk in well-coordinated attacks. They did not state if these observations referred to family groups.

Certainly the most common form of non-agonistic or amicable behavior described in the grizzly bear literature was sibling play behavior. Good descriptions of sibling play are provided in Troyer and Hensel (1969), Murie (1981) and Gebhard (1982).

\section{Territoriality}

A territory, by strict definition, refers to a "specific area from which an animal excludes all others of its species except mates and its own offspring (usually of that year)... (Craighead 1979:142)."

Bears are socially flexible in their use of space (Herrero 1978b, Cowan: panel discussion, Int. Conf. Bear Res. and Manage. 2:250). The system of spacing varies according to the relative evenness or concentration of food and the defendable nature of the food source (Herrero 1978b). Bunnell and Tait (1981) noted that, in theory, where resources were plentiful and evenly distributed or accessible and predictable, territoriality would be the optimal spacing mechanism. Conversely, territorial defense of ranges with patchy or unpredictable food resources would not be advantageous.

Grizzly bear home ranges are often so large and disjunct that territorial defense is infeasible (Jope 1982). Many studies of grizzly bear home ranges and movement patterns have found substantial home range overlap (e.g., Lloyd 1979, Ballard et al. 1982b, Craighead and Mitchell 1982, Nagy et al. 1983b, Servheen 1983). In Yellowstone (19591970 ), grizzlies did not defend the peripheries of seasonal or home ranges (Craighead 1976, 1979). Grizzly bears also did not defend den sites. Craighead and Craighead (1973) reported that 2 sows with cubs which travelled together throughout the summer and fall were together at 1 sow's freshly dug den with no indication of aggressive behavior by either grizzly. Feeding sites were sometimes temporarily defended. On 1 occasion, a male grizzly was observed to defend a bison carcass from a sow and yearling. The incident could be interpreted as either territorial defense of an extensive area surrounding a temporary food source or as submissive behavior by the sow (Craighead and Craighead 1971, Craighead 1979). Hierarchical behavior and territorial defense merge and may be difficult to distinguish in certain aggressive interactions (Craighead 1979).

In the southeastern Yukon, adult females maintained home ranges with minimal overlap, however, Pearson (1975) felt that intraspecific aggression in defense of a home range was not the mechanism that maintained this spacing. Rather, the distinct ranges related to attachment to, or preference of, a familiar area. Although intraspecific aggression in defense of a home range was not apparent, Pearson felt that an intraspecific intolerance zone did exist around each individual. The size of this zone varied with season and situation. For example, the zone was enlarged when males consorted with estrous females.

"Violation of individual distance" was 1 of 4 situations which precipitated aggression at McNeil River Falls (Stonorov and Stokes 1972). The establishment and maintenance of dominance hierarchies at feeding aggregations results in the temporary breakdown of the usual avoidance reaction (Pearson 1975) and enables maximum exploitation of rich food sources with a minimum of conflict (Bunnell and Tait 1981, Craighead and Mitchell 1982). Where a social hierarchy is formed, it may serve as a substitute for territorial behavior and territorial defense (Craighead 1979; panel discussion, Int. Conf. Bear Res. and Manage. $2: 250)$.

\section{Marking Behavior}

Two major kinds of marking behavior by brown/grizzly bears were discussed in the literature: marking trees (e.g., Shaffer 1971, Valkenburg 1976, Smith 1978, Lloyd 1979, Hamer et al. 1980, Murie 1981, Hamilton and Archibald 1984) and ground (step or trail) marking (e.g., Valkenburg 1976, Smith 1978, Lloyd 1979, Murie 1981, Hamilton and Archibald 1984).

\section{Marking Trees}

Bear trees are generally located adjacent to bear travel routes. Physical evidence of bear use may include stripped or smoothed bark, tooth marks, broken or bent branches (up to a height of 3-5 m), and hairs lodged in cracks or pitch (Shaffer 1971, Lloyd, et al. 1977, Smith 1978, Lloyd 1979, Hamer et al. 1980, Murie 1981). Lloyd (1979) noted that physical evidence might not always be apparent for those bear trees used exclusively for rubbing.

Lloyd (1979) found that bear trees were widespread and common in his coastal British Columbia study area. The density of bear trees was 3.4/linear $\mathrm{km}$ of major watercourse or 20 per sq $\mathrm{km}$. During the salmon run, trees were 
marked as often as once every 5 days. Lloyd (1979) concluded that the high incidence of marking behavior served to reduce intra- and interspecific strife by warning other bears of the presence of nearby fishing or resting bears. $\mathrm{He}$ felt that the unpredictable wind currents and high level of background noise along watercourses interferred with the usual olfactory clues. A later study in coastal British Columbia also documented a relatively high incidence of marking trees and trails (Hamilton and Archibald 1984). Two types of trees were identified: "scratch" trees with claw marks or, sometimes, tooth marks, and "rub" trees with little or no scratching of the bark.

Various hypotheses have been proferred to explain the function of bear trees. It has been suggested that they serve as information signposts, territorial markings, declaration of ownership, sexual advertisement (during the breeding season) or for grooming and comfort purposes (Hamer et al. 1980, Murie 1981, Hickman 1984). Murie (1981) concluded that although bear trees might serve to communicate the passage of an estrous female during the breeding season, their primary function was for massaging. Craighead (panel discussion, Int. Conf. Bear Res. and Manage. 2:248) also felt that tree rubbing was most common soon after emergence and probably served for grooming or comfort.

Studies with captive brown bears have suggested that the massaging function may be intergrated with the scentmarking function. Colmenares and Rivero (1983a) found that "rubbing against objects" was one of 5 behaviors which appeared in conflict situations and whose performance resulted in the deposition of scent marks on particular objects. Tschanz et al. (1970) studied the rubbing behavior of captive brown bears and concluded that scents emanating from rubbing places, urine and feces did have a social communication function. In males, maximum rubbing occurred during May (breeding season) while in females it occurred in July (end of the molt). Males demonstrated the strongest response to rubbing places and were able, by sniffing, to determine the sex of the previous individual to rub at that site. Young bears withdrew from a frequently used male rubbing tree when first introduced to the enclosure.

Reiger (1972) discussed the origins, types and significance of scent-rubbing behavior in various carnivore groups. "Scent-rubbing" referred to rubbing or rolling on an environmental object, usually an odorous scent-source, to transfer scent from the environment on to the animal's body. He reported (based primarily on earlier studies of European brown bears) that brown bears were induced to rub by urine, previous scent marks and certain chemicals. Some bears rolled in fresh urine before tree-rubbing. Possible functions of scent-rubbing included vestigal behavior of scent-gland rubbing (for glands lost during evolution), comfort behavior, camouflage of odors for predation and increased social attractiveness.

\section{Ground Marking}

Grizzly bear ground marking was also described in the literature. Murie (1981) reported that in Denali National Park, he sometimes found short stretches of trail where grizzly bears stepped in the same tracks over a period of years eventually creating a series of depressions. The depressions were about $2.5 \mathrm{~cm}$ deep, $25 \mathrm{~cm}$ wide and $30 \mathrm{~cm}$ long and were separated by a distance of $58-76 \mathrm{~cm}$ where the front and hindfeet stepped in the same spot. Murie also observed grizzly bears crossing snowbanks in a similar fashion, precisely placing their feet in previous imprints.

Lloyd (1979) found very similar impressions in his coastal British Columbia study area. Five to 16 elliptical depressions (about $18-25 \mathrm{~cm}$ by $15 \mathrm{~cm}$ ) were generally found in a single series. The surface vegetation was removed and no sign of a track or claw marks was visible. Lloyd (1979) concluded that these ground marks were deliberately formed and functioned as visual and possibly tactile com. munication. Smith (1978), also in coastal British Columbia, found 6 instances of ground marks in sandy substrate. The marks were in a typical stride sequence but, in at least 1 case, were 4 times deeper than the usual foot imprint. Some ground marks were near marking trees. Hamer et al. (1980) reported that they sometimes found a series of stepping places several centimeters deep leading to bear trees in Banff National Park.

\section{COURTSHIP AND COPULATION}

\section{Breeding Season Chronology}

The breeding season may be defined as either the period when copulations are observed or as the more inclusive period when males and females are observed consorting together or displaying pre-and post-copulatory behavior (in addition to actual mating). Most studies expressed breeding season dates according to the latter criteria. Representative breeding season dates from major grizzly/ brown bear studies are given in Table 7.

The most extensive data on grizzly bear reproductive behavior comes from the Craighead study in Yellowstone National Park (Craighead et al. 1969, Craighead and Mitchell 1982). They found that although the start of the breeding season (copulatory period) varied from 26 May to 12 June during a 6-year period, the length of the season proved remarkably similar, averaging 26 days per season. Over all years, $80 \%$ of the observed copulations were in June (particularly during the first 2 weeks), $12 \%$ were in late May and $8 \%$ were in July.

\section{Estrous Duration and Reproductive Physiology}

In Yellowstone, the maximum duration of estrous for an individual female was 27 days, with a range for other females of 25 to 16 days and less. Females in estrous were identified by their attraction and receptivity to adult males and by marked enlargement of the vulva. Conspicuous vulva swelling on estrous females was also noted by other researchers (Troyer et al. 1969, Pearson 1975, Glenn et al. $\mathrm{mm}$ in diameter before the breeding season in comparison to 6 , Nagy et al. 1983a, 1983b). Estrous generally ended abruptly and pre- and post-estrous females did not attract any males (Craighead et al. 1969, Craighead and Mitchell 1982).

Observations in Yellowstone also suggested that female grizzlies had 2 estrous cycles or "mating periods" of 10 6-12 mm during the breeding season. Three females harvested while aximum (identified by attraction of mates, paired 
Table 7. Dates of breeding season (courtship associations) for North American grizzly bear populations.

\begin{tabular}{|c|c|c|}
\hline Ecosystem, Area and Citation & Breeding Season & Comments \\
\hline \multicolumn{3}{|l|}{ Yellowstone Ecosystem } \\
\hline \multirow[t]{2}{*}{$\begin{array}{l}\text { (J. Craighead et al. 1969, J. Craighead } \\
\text { and Mitchell 1982) }\end{array}$} & May 14-Jul 15 & $\begin{array}{l}\text { period of estrous behavior (including pre and } \\
\text { post-copulatory behavior) }\end{array}$ \\
\hline & May 26-Jul 9 & $\begin{array}{l}\text { copulations observed ( } 80 \% \text { in June, especially } \\
\text { first } 2 \text { weeks) }\end{array}$ \\
\hline $\begin{array}{l}\text { Trout Creek dump } \\
\text { (Hornocker 1962) }\end{array}$ & Jun 10-Jul 10 & copulations observed; peak in late June \\
\hline \multicolumn{3}{|l|}{ Northern Continental Divide Ecosystem } \\
\hline $\begin{array}{l}\text { Rocky Mountain East Front } \\
\text { (Aune 1985, Aune and Stivers 1983,1985, } \\
\text { Aune et al. 1984, 1986) }\end{array}$ & Apr 21-Jun 28 & earliest and latest courtship associations \\
\hline \multicolumn{3}{|l|}{ Canadian Rockies } \\
\hline $\begin{array}{l}\text { Jasper Natl. Park } \\
\text { (Russell et al. 1979) }\end{array}$ & mid-May-early July & $\begin{array}{l}\text { probably courtship dates for Banff/Jasper } \\
\text { area }\end{array}$ \\
\hline $\begin{array}{l}\text { Banff Natl. Park } \\
\text { (Hamer et al. 1978,1979,1980, Herrero } \\
\text { and Hamer 1977) }\end{array}$ & May 13-Jun 21 & courtship associations observed \\
\hline \multicolumn{3}{|l|}{ Interior British Columbia } \\
\hline $\begin{array}{l}\text { Glacier Natl. Park } \\
\text { (Mundy and Flook 1973) }\end{array}$ & Apr 30-Jun 25 & observations of 21 adult pairs \\
\hline \multicolumn{3}{|l|}{ Coastal British Columbia } \\
\hline $\begin{array}{l}\text { Kimsquit River Valley } \\
\text { (Hamilton and Archibald 1984) }\end{array}$ & May 19-Jun 21 & breeding activity \\
\hline \multicolumn{3}{|l|}{ Northern Interior } \\
\hline $\begin{array}{l}\text { S.W. Yukon: Kluane Natl. Park } \\
\text { (Pearson 1975) }\end{array}$ & May 21-Jul 16 & $\begin{array}{l}\text { courtship associations; peak in June and } \\
\text { early July }\end{array}$ \\
\hline \multicolumn{3}{|l|}{ Canadian Arctic } \\
\hline $\begin{array}{l}\text { Northern Yukon } \\
\text { (Nagy et al. 1983a) }\end{array}$ & May 5-Jul 15 & courtship associations \\
\hline $\begin{array}{l}\text { NWT: Tuktoyaktuk Peninsula/ } \\
\text { Richards Island } \\
\text { (Nagy et al. 1983b) }\end{array}$ & May 21-Jul 23 & courtship associations \\
\hline \multicolumn{3}{|l|}{ Arctic Alaska } \\
\hline $\begin{array}{l}\text { Eastern Brooks Range } \\
\text { (Reynolds 1974) }\end{array}$ & May 26-Jul 9 & breeding pairs \\
\hline $\begin{array}{l}\text { Canning River } \\
\text { (Quimby and Snarski 1974) }\end{array}$ & June 2-30 & paired adults observed \\
\hline $\begin{array}{l}\text { Arctic Natl. Wildlife Refuge } \\
\text { (Phillips 1986) }\end{array}$ & Jun 13-Jul 8 & observed 5 breeding units \\
\hline \multicolumn{3}{|l|}{ Interior Alaska } \\
\hline $\begin{array}{l}\text { Denali Natl. Park } \\
\text { (Dean 1976) }\end{array}$ & May 30-Jul 17 & observations of mated pairs \\
\hline (Stelmock 1981) & May 14-Jul 4 & $\begin{array}{l}\text { consorting bears; also documents one Aug } 12 \\
\text { date from previous year }\end{array}$ \\
\hline (Murie 1981) & May 14-Jul 10 & $\begin{array}{l}\text { breeding pairs; peak in last week of May and } \\
\text { in June }\end{array}$ \\
\hline \multicolumn{3}{|l|}{ Southcentral Alaska } \\
\hline $\begin{array}{l}\text { Upper Susitna } \\
\text { (Ballard et al. 1982) }\end{array}$ & $\begin{array}{l}\text { late May (in progress)- } \\
\text { end of June }\end{array}$ & breeding pairs \\
\hline $\begin{array}{l}\text { Copper River Delta } \\
\text { (Campbell 1985) }\end{array}$ & May 14-Jun 18 & observed pairs \\
\hline
\end{tabular}


Table 7. (Continued)

\begin{tabular}{lcc}
\hline Ecosystem, Area and Citation & Breeding Season & Comments \\
\hline $\begin{array}{l}\text { Alaska Peninsula } \\
\begin{array}{l}\text { Black Lake area } \\
\text { (Modafferi 1984) }\end{array}\end{array}$ & early May-early August & breeding pairs and copulation \\
\hline $\begin{array}{l}\text { Kodiak/Afognak } \\
\begin{array}{l}\text { Kodiak Island and Alaskan Peninsula } \\
\text { (Hensel et al. 1969) }\end{array}\end{array}$ & May through mid-July & $\begin{array}{l}\text { as evidenced by studies of reproductive tracts } \\
\text { and observations of matings }\end{array}$ \\
\hline
\end{tabular}

with tivity and copulation) separated by a 4-18 day period of non-estrous behavior. The intervening period may have corresponded to the time required for follicular males during ment which followed the first ovulation (Craighead et al. 1969, Craighead and Mitchell 1982). Nagy et al. the last half ptured 3 mated or estrous females in May which of May subsequently observed consorting with males in late June or early July. Observations suggested that these had ovaries may have cycled more than once in a single mating season or remained in constant estrous between observations.

Hensel et al. (1969) studied the reproductive physiology of female brown bears from examination of 96 reproductive tracts. They found that follicular development apparently began during torpor. Mature females had follicles from 1-5 with follicles $10-12 \mathrm{~mm}$ in diameter. Counts of corpora lutea in 10 pairs of ovaries indicated a mean of 2.1 ovulations. Ovaries from prepubertal bears weighed half as much as those from mature animals and showed no gross morphological differences during the breeding season. Pearson (1975) reported that 3 females killed during the breeding season had either large developing follicles on the ovarian surface or recently formed corpora lutea. Mature females harvested from August 14 through October 21 which showed reproductive activity during that period all had corpora lutea and unimplanted blastocysts in the uteri.

Erickson et al. (1968) examined the testes, epididymides and vasa deferentia of 127 brown bears collected in Alaska. Their histological studies indicated that the male bear's reproductive period extended prior to and beyond the female's breeding season. Some individual males were sexually capable well before the peak breeding season while others were still able to breed until near denning in November. Thus, the male bear had a potential breeding season slightly exceeding half of the year and encompassing most of the den-free period. Practically all mature males produced sperm during the period of normal female breeding activity (late May to early July).

Pearson (1975) also examined the reproductive tracts of male grizzlies. Presence or absence of spermatozoa and condition of the seminiferous tubules indicated the male's reproductive status. An animal collected on May 22 was the first to show spermatozoa in the epididymis. Testes collected on 3 September showed characteristics of a postbreeding state and those from 22 September were in a resting state. Mundy and Flook (1973) reported that a testicular section from a bear captured on June 1 showed maturing seminiferous tubules with a few spermia present.

\section{Courtship Behavior, Activities and Habitat Use}

Descriptions of courtship behavior in the literature varies greatly. General characteristics of courtship activity are described below.

Several researchers noted that sexually aroused males could be recognized by their walk or by other behaviors. Murie (1981) reported that some males deliberately searched for females during the breeding season. These males travelled steadily and appeared to be trying to locate the scent trail of estrous females. Hornocker (1962) reported that aroused males were characterized by their stiff-legged, swaggering walk with bowed neck and head held low. These males also salivated profusely and urinated on their belly and legs. Schleyer (1983) noted that a mated male assumed a similar walk and head position without the urination or salivation. Lindermann (1974) observed a strange, swinging gait in a male approaching an estrous female. Egbert (1978) reported that males approached estrous females with a slow, deliberate walk with their ears cocked and with the head held higher than normal.

Murie (1981) reported that in Denali, males of mated pairs frequently behaved as though "herding" females by directing their movements and intercepting their attempted departures. Herrero and Hamer (1977) observed a prolonged incidence of herding behavior in Banff National Park. In this case, a male kept a female confined within a 2-3 ha "mating area" for 13 days. Mounting and copulation occurred only during the final stages of the confinement and the herding behavior subsided immediately thereafter. Additional observations of herding behavior were described by Hamer et al. $(1978,1979)$ for Banff National Park and by Stelmock (1981) for Denali National Park.

Mated pairs often engage in various forms of nonaggressive physical contact including playful behavior, nuzzling, licking and genital inspection (Hornocker 1962, Lindermann 1974, Herrero and Hamer 1977, Egbert 1978, Murie 1981, Stelmock 1981, Schleyer 1983, Phillips 1986). Several observers noted that females controlled the occurrence of this nonaggressive physical contact and the course of the courtship activity (e.g., Herrero and Hamer 1977, Egbert 1978, Murie 1981).

As Herrero and Hamer (1977) observed, pairing during courtship is a fragile bond which could easily revert to aggression. The mating bond is a tenuous, short-term arrangement for the convenience of breeding or sometimes a partnership that persists throughout the estrous period 
(Craighead et al. 1966, Craighead and Mitchell 1982). Several observers noted that brief episodes of aggression sometimes occurred between mated pairs (e.g., Herrero and Hamer 1977, Murie 1981, Schleyer 1983). Egbert (1978) noted that female bears at McNeil River never appeared to fully shed their fear of adult males and frequently walked or ran from adult males. Hornocker (1962) reported that although estrous females were receptive to all males, they invariably cowered and assumed a submissive attitude at the approach of an aroused male.

Phillips (1986) recorded the activity patterns of 5 breeding bear units ( 2 groups included 3 bears) in the Arctic National Wildlife Refuge. He found that breeding units spent $67 \%$ of the observation time resting; rest periods were longer and more frequent than for lone bears. Similarly, Hechtel (1985) found that a female, accompanied by 23 year-olds prior to pairing with a male during the breeding season, was significantly less active during the breeding period ( $21 \%$ of the observation time) than while still with her young (56-74\%). Stelmock (1981) reported that during the spring, mated pairs were somewhat less active during the day than other bear units.

Hechtel (1985) reported that the percent of time spent feeding dropped dramatically (from $60 \%$ to less than 10\%) during the breeding period. Phillips (1986) reported that only $6.7 \%$ of the observation time of breeding units was devoted to foraging. Herrero and Hamer (1977) noted that in Banff National Park, both members of a mated pair reduced their food intake for several weeks during the breeding season despite the fact that their energy reserves were probably depleted from the recent denning period. Hornocker (1962) reported that the dominant male at the Trout Creek dump in Yellowstone rarely fed while defending his mate from other suitors. However, Pearson (1975) felt that feeding continued to govern the activities and movements of mated grizzlies even during the breeding season. Females continued to search for food and males followed, although the males did not always forage.

Limited observations are available on habitat use by mated pairs. Murie (1981) reported that the movements and habitat use of mated bears in Denali National Park varied a great deal depending on the timing of the union. Pairs which mated during a food transition period might relocate from, for example, a favorite rooting area to an area providing green forage. Similarly, Stelmock (1981) reported that grizzly pairs which he observed in Denali were found in the areas where spring foraging items were most abundant. $\mathrm{He}$ speculated that this pattern of habitat use enhanced the probability of encounter between potential mates. Phillips (1986) found that in the Arctic National Wildlife Refuge, breeding units were most often seen in areas frequented by large numbers of caribou. On the Rocky Mountain East Front, some courtship associations remained in low elevation spring habitat while others moved to secluded, mountain ridges and foothills at, or above, snowline (Aune and Stivers 1983, Aune et al. 1986). Herrero and Hamer (1977) noted that the ability of a male grizzly to herd and confine a female to a particular summit ridge during the breeding period was partially a function of the topography and habitat in the mating area.

\section{Duration of Pair Bonds}

Murie (1981) reported that in Denali, the duration of pair bonds ranged from about 1 week to a maximum of 23 days. Dean (1976) documented 1 male: female association in Denali National Park that lasted for 42 days. In contrast to these relatively long pairings, copulation is sometimes preceded by little or no prior association. Hornocker (1962) reported that only the dominant and subdominant males were observed defending particular females at the Trout Creek dump in Yellowstone National Park. Other males were either "opportunity breeders" or associated with estrous females for brief periods (several days) only. However, Craighead (1972) reported that some subdominant males in Yellowstone travelled with individual females for periods of up to 2 weeks. Research at the Black Lake study area on the Alaskan Peninsula suggested that males spent very little time with females during the breeding season. There were no resightings of the same male: female pair within a season (Modafferi 1984). Egbert (1978) reported that at McNeil River Falls, mating could occur "within seconds" of a male's approach to an estrous female.

\section{Breeding Structure and Reproductive Strategies}

The nature of the breeding structure (i.e., monogamous vs. polygamous) and duration of the pair bond may depend in part on the density and distribution characteristics of the bear population. In most areas, both male and female grizzly bears will associate with more than 1 mate during a single breeding season. Observations of males consorting or mating with more than 1 female are provided by Hornocker (1962), Dean (1976), Murie (1981), Stelmock (1981), Modafferi (1984), Aune (1985), Aune et al. (1986) and Phillips (1986). Observations of females mating with more than 1 male are provided in Hornocker (1962), Sparrowe (1968), Craighead et al. (1969), Lindermann (1974), Egbert and Stokes (1976), Murie (1981), Craighead and Mitchell (1982) and Modafferi (1984). Murie (1981) and Modafferi (1984) observed adult females consorting with 2 adult males at the same time. Craighead and Mitchell (1982) noted that grizzly bears were definitely polygamous in Yellowstone National Park and were probably polygamous wherever they congregated or were abundant enough to allow estrous females to meet more than 1 male. Individual females observed at the Yellowstone dumps often mated with 2 males in 1 day and 2 females were observed to mate with 4 males in one day. Estrous females were attracted and receptive to almost all males (Hornocker 1962).

Herrero and Hamer (1977) noted that bears adapted their mating strategies according to the prevailing social structure. Where bears are highly concentrated and suitable mates are easily located, pair bonds may be of short duration. Conversely where bears are more widely dispersed, potential mates may be more difficult to locate. Once a "good" mate is found it may be beneficial for both sexes to remain together until copulation and insemination are achieved.

Furthermore, males may derive additional benefits from a protracted association. The probability of a male siring a mate's cub is inversely related to the number of males which copulate with that mate (litter mates need not have a common father). Consequently, by remaining with the female and thwarting the advances of other males, a male may increase his own fitness. In so doing, however, he forfeits other reproductive opportunities and risks losing a contest to a superior male (Bunnell and Tait 1981). 
Tending of 1 female by a male may not necessarily prevent that male from mating with other females (Stelmock 1981, Murie 1981). Stelmock (1981) documented "postcopulatory" guarding by a male grizzly in Denali National Park which would be consistent with Bunnell and Tait's (1981) hypothesis. Conversely, in some other cases described in the literature, a male's attraction to a female waned soon after copulation (Hornocker 1962, Sparrowe 1968, Herrero and Hamer 1977, Murie 1981).

The sex ratio of a population may also influence courtship behavior. In populations with a shortage of reproductively available females, the best reproductive strategy for males may be to remain with a single female and defend her from the surplus of far-ranging males (Herrero and Hamer 1977, Modafferi 1984). However, the ratio of adult females to adult males at the Trout Creek dump in Yellowstone was 1: 1.59 , yet brief, opportunistic relationships were the norm. As Herrero (1978) observed, the fact that even the dominant male at Trout Creek was unable to successfully guard his mate from reproductive advances by other males suggests that isolation and defense of a single female was not a viable reproductive strategy at such high densities. In populations with a surfeit of available females, a polygymous arrangement may be favored (Modafferi 1984).

Stringham (1984) suggested that grizzly bear females might also benefit from breeding with multiple males. Since adult males should theoretically refrain from aggression directed at their own progeny, a female can protect her offspring from intraspecific aggression by copulating with several males and confusing them as to their actual paternity.

Physiological considerations may also favor a protracted courtship. Herrero and Hamer (1977) noted that since evidence suggests that grizzly bears, like black bears, are induced ovulators (Wimsatt 1963), a period of interaction prior to copulation might be required to initiate ovulation. This interaction need not necessarily be by the male that eventually copulates with the female. Murie (1981) suggested that the increased tolerance by a female grizzly to a male's advances late in the breeding season might correspond to the onset of sexual receptivity during estrous.

\section{Copulation and Implantation}

Craighead and Mitchell (1982) characterized grizzly bear copulation as "vigorous and prolonged." The copulatory act and associated behavior varied considerably with the female's age, receptivity and number of males attempting to associate with her.

Duration of copulations reported in the literature varied greatly. Hornocker (1962) reported that the length of 41 copulations observed in Yellowstone National Park ranged from 5-41 minutes and averaged 16-20 minutes. Craighead et al. (1969) found that 49 copulations averaged 23 minutes in length and ranged from 10-60 minutes. Stelmock (1981) reported that in Denali National Park, the length of 15 copulations varied from $2.4-27.0$ minutes and averaged 7.0 minutes. Other durations reported in the literature were 43 minutes (Herrero and Hamer 1977), 17 minutes (Lindermann 1974), 25 minutes (Sparrowe 1968), 5-8 minutes (mean=6 minutes) (Schleyer 1983), and 26 minutes (Mundy and Flook 1965).

The typical copulatory position was for the male to clasp the standing female with his forelegs anterior to her hind legs (Hornocker 1962, Mundy and Flook 1965, Schleyer 1983). Roop (1980a) described an exceptional variation in which the female lay on her back with the male above her. Several researchers reported that during copulation, periods of pelvic thrusting were alternated with periods of quiescence (Mundy and Flook 1965, Hamer and Herrero 1977). Brief (2-15 second) periods of accelerated movement or "quivering" thrusts may occur singularly or intermittently (Sparrowe 1968, Herrero and Hamer 1977, Stelmock 1981, Phillips 1986). Some descriptions noted that the female moved from side-to-side or in a circular motion during copulation (Herrero and Hamer 1977, Hamer et al. 1980, Schleyer 1983). Multiple mounting, with or without confirmed copulation, was frequently observed (e.g., Hornocker 1962, Lindermann 1974, Herrero and Hamer 1977 , Hamer et al. 1980, Schleyer 1983). Hornocker (1962) reported that some males copulated with a single female up to 6 times in 1 evening.

Wimsatt (1963) provided conclusive proof that, in black bears, implantation of the blastocyst is delayed for up to 5 months after ovulation. Several studies have shown that discontinuous embryonic development also occurs in the grizzly bear. Unimplanted blastocysts were recovered from the uterine horns of 2 Yellowstone females 50 days and at least 30 days, respectively, after mating (Craighead et al. 1969, Craighead and Mitchell 1982). Hensel et al. (1969) reported that reproductive tracts taken from mature females in November contained corpora lutea of pregnancy but no evidence of implantation. This suggested that embryonic development began after November, presumably near the start of winter denning. Pearson (1975) recovered unimplanted blastocysts from the uterus of a female on October 21 after she had already entered the winter den. 


\section{POPULATION CHARACTERISTICS}

\section{AGE/SEX}

Age and sex data for North American grizzly bear populations are presented in Tables 8 and 9, respectively. Unless otherwise indicated, ratios in the tables were calculated from capture records or visual observations. Populations without a designated legal hunting season (in the primary study area) are so indicated in the table.

Capture records rather than harvest data were used in Tables 8 and 9 to avoid some of the inherent biases of harvest age/sex ratios (see Caughley 1974, Bunnell and Tait 1980,1985, Paloheimo and Fraser 1981, Fraser et al. 1982, Harris 1986). However, capture records may also be biased due largely to unequal catchability of certain segments of the population. For example, Miller and Ballard $(1980,1982)$ found that females and cubs through 2-years old, were underrepresented in capture records. Some of the difficulties in intrepreting harvest ratios are discussed in a subsequent section.

Sample sizes upon which the age and sex ratios in Tables 8 and 9 were based varied enormously between studies (from 12 bears for the Mission Mountains to over 400 bears for the Black Lake study area on the Alaskan Peninsula): in some cases, particular age/sex classes were represented by a single individual. Population characteristics based on such small samples should be considered as tentative.

Table 10 gives the age of the oldest grizzly bear recorded for several North American populations. The oldest bear reported was a 28.5 year old female in the western Brooks Range of Alaska (Reynolds and Hechtel 1984B), accompanied by a 3-year old offspring.

\section{POPULATION DENSITIES}

Table 11 presents data on densities of North American grizzly bear populations. The technique used to derive the density estimate for each study is given in the table. A discussion of the common methods used to estimate population size, density and trend is provided in a subsequent section.

Estimated densities as reported in the literature were lowest in the Arctic study areas of the Tuktoyaktuk Peninsula (211-262 sq. km per bear). Highest densities were reported for Kodiak Island (1.52-4.0 sq. km per bear) and Admiralty Island (3.2-4.2 sq. $\mathrm{km}$ per bear). Discussions of the major habitat characteristics for each ecosystem are provided in a subsequent section.

Stringham (1984) considered the relationship between habitat (coastal vs. inland), latitude and density of grizzly bear populations. He found that for 5 inland populations, latitude accounted for $96 \%$ of the variation in density. However, densities for 2 coastal Alaskan populations were considerably greater than predicted from the regression of density on latitude for inland populations. Latitude and habitat type together accounted for only $48 \%$ of the variance in density when all 7 populations (including inland and coastal) were considered. As Stringham (1984) observed, the exceptionally high densities given for Kodiak Island by Troyer and Hensel $(1964,1969)$ resulted from surveys of high seasonal bear concentrations within their 248 sq. km Karluk Lake study area. These densities may not be representative of the year-round distribution. Stringham (1984) also noted that inter-area comparisons might be improved by expressing density in terms of biomass (calculated from mean weight of bears in each agesex class) and by incorporating habitat suitability considerations in the analysis.

Table 8. Age ratios of North American brown/grizzly bear populations. All ratios compiled from capture records unless otherwise specified.

\begin{tabular}{|c|c|c|c|c|c|}
\hline Ecosystem, Area and Citation & $\begin{array}{c}\text { \% Adults } \\
\text { (n;age) }\end{array}$ & $\begin{array}{c}\text { \% Subadult } \\
\text { (n;ages) }\end{array}$ & $\begin{array}{c}\% \text { Yearling } \\
(\mathbf{n})\end{array}$ & $\begin{array}{c}\% \text { Cubs } \\
(\mathbf{n})\end{array}$ & Comments \\
\hline \multicolumn{6}{|l|}{ Yellowstone Ecosystem } \\
\hline (Craighead and Mitchell 1982) & $\begin{array}{c}43.6 \\
(77 ; 5+)\end{array}$ & $\begin{array}{c}24.9 \\
(44 ; 2-4)\end{array}$ & $\begin{array}{c}13 \\
(23)\end{array}$ & $\begin{array}{l}18.5 \\
(33)\end{array}$ & $\begin{array}{l}\text { pre-dump closure; 1959-1967 } \\
\text { data }\end{array}$ \\
\hline$(\text { Knight et al. 1985) })^{a}$ & $\begin{array}{c}57 \\
(55 ; 5+)\end{array}$ & $\begin{array}{c}25.5 \\
(25 ; 2-4)\end{array}$ & $\begin{array}{l}14.5 \\
(14)\end{array}$ & $\begin{array}{c}3 \\
(3)\end{array}$ & $\begin{array}{l}\text { post-dump closure; ratios } \\
\text { constructed from captured } \\
\text { bears known or believed to } \\
\text { be alive in } 1984\end{array}$ \\
\hline
\end{tabular}

Northern Continental Divide

Ecosystem

Glacier Natl. Parka

(Martinka 1974)

68\%: adults and subadults

15 combined

(48)

Rocky Mountain Front

(Aune et al. 1986)

Mission Mountains

(Servheen 1981)

$31.6 \quad 24.7$

$(55 ; 5+)$

$(43 ; 2-4)$

50

$(6 ; 5+)$
16.7

$(2 ; 2-4)$
23.6

8.3

(1) sample sizes represent mean number sampled over 5 survey years (1967-71)

1980-85 data

1976-79 data 
Table 8. (Continued)

\begin{tabular}{|c|c|c|c|c|c|}
\hline Ecosystem, Area and Citation & $\begin{array}{l}\text { \% Adults } \\
\text { (n;age) }\end{array}$ & $\begin{array}{c}\text { \% Subadult } \\
\text { (n;ages) }\end{array}$ & $\begin{array}{c}\% \text { Yearling } \\
(\mathbf{n})\end{array}$ & $\begin{array}{l}\% \text { Cubs } \\
(\mathrm{n})\end{array}$ & Comments \\
\hline $\begin{array}{l}\text { North and South Forks of } \\
\text { Flathead } \\
\text { (Jonkel 1982) }\end{array}$ & 50 & 25 & 25 & 0 & 1976-79 data \\
\hline \multicolumn{6}{|l|}{ Canadian Rockies } \\
\hline $\begin{array}{l}\text { Akamina-Fishinena/N. Fork of } \\
\text { Flathead } \\
\text { (McLellan 1984) }\end{array}$ & $\begin{array}{c}43.4 \\
(46 ; 4+)\end{array}$ & $\begin{array}{c}23.6 \\
(25 ; 2-3)\end{array}$ & $\begin{array}{l}17.9 \\
(19)\end{array}$ & $\begin{array}{l}15.1 \\
(16)\end{array}$ & $1980-83$ data \\
\hline $\begin{array}{l}\text { Jasper Natl. Parka } \\
\text { (Russell et al 1979) }\end{array}$ & $\begin{array}{c}67 \\
(16 ; 6+)\end{array}$ & $\begin{array}{c}29 \\
(8 ; 2-5)\end{array}$ & $\begin{array}{c}0 \\
(1)\end{array}$ & 4 & 1975-78 data \\
\hline \multicolumn{6}{|l|}{ Coastal British Columbia } \\
\hline $\begin{array}{l}\text { Kimsquit River Valley } \\
\text { (Hamilton and Archibald 1984) }\end{array}$ & $\begin{array}{c}46.7 \\
(7 ; 6+) \\
\end{array}$ & $\begin{array}{c}53.3 \\
(8 ; 2-5) \\
\end{array}$ & 0 & 0 & $1982-83$ data \\
\hline \multicolumn{6}{|l|}{ Northern Interior } \\
\hline $\begin{array}{l}\text { Mackenzie Mtns. NWT } \\
\text { (Miller et al. 1982) }\end{array}$ & $\begin{array}{c}51.1 \\
(43 ; 7+)\end{array}$ & $\begin{array}{c}24.2 \\
(16 ; 2-6)\end{array}$ & $\begin{array}{c}10.4 \\
(8)\end{array}$ & $\begin{array}{l}14.3 \\
(11)\end{array}$ & $\begin{array}{l}\text { based on aerial observations } \\
\text { ("random encounters"), } \\
1971-77\end{array}$ \\
\hline $\begin{array}{l}\text { SW Yukon: Kluane Natl. Parka } \\
\text { (Pearson 1975) }\end{array}$ & $\begin{array}{c}43.7 \\
(18 ; 7+)\end{array}$ & $\begin{array}{c}31.7 \\
(13 ; 2-6)\end{array}$ & $\begin{array}{c}17.1 \\
(7)\end{array}$ & $\begin{array}{l}7.3 \\
(3)\end{array}$ & $\begin{array}{l}\text { 1965-67 captures: age } \\
\text { structure constructed for } \\
1969\end{array}$ \\
\hline \multicolumn{6}{|l|}{ Boreal Forest } \\
\hline $\begin{array}{l}\text { Swan Hills, Alberta } \\
\text { (Nagy and Russell 1978) }\end{array}$ & $\begin{array}{c}20.8 \\
(5 ; 6+) \\
\end{array}$ & $\begin{array}{c}58.4 \\
(14 ; 2-5) \\
\end{array}$ & $\begin{array}{l}8.3 \\
(2) \\
\end{array}$ & $\begin{array}{c}12.5 \\
(3)\end{array}$ & 1975-77 data \\
\hline \multicolumn{6}{|l|}{ Canadian Artic } \\
\hline $\begin{array}{l}\text { Northern Yukon } \\
\text { (Nagy et al. 1983a) }\end{array}$ & $\begin{array}{c}55.6 \\
(103 ; 7+)\end{array}$ & $\begin{array}{c}23.8 \\
(44 ; 2-6)\end{array}$ & $\begin{array}{l}9.2 \\
(17)\end{array}$ & $\begin{array}{l}11.4 \\
(21)\end{array}$ & $\begin{array}{l}1973-74 \text { data; light harvest } \\
\text { rate }\end{array}$ \\
\hline $\begin{array}{l}\text { NWT: Tuktoyoktuka/Peninsula } \\
\text { Richards Island } \\
\text { (Nagy et al. 1983b) }\end{array}$ & $\begin{array}{c}36.5 \\
(115 ; 7+)\end{array}$ & $\begin{array}{c}34.6 \\
(109 ; 2-6)\end{array}$ & $\begin{array}{l}13.3 \\
(42)\end{array}$ & $\begin{array}{l}15.6 \\
(49)\end{array}$ & 1974-77 data \\
\hline \multicolumn{6}{|l|}{ Arctic Alaska } \\
\hline $\begin{array}{l}\text { Eastern Brooks Range } \\
\text { (Reynolds 1976) }\end{array}$ & $\begin{array}{c}51.4 \\
(56 ; 7+)\end{array}$ & $\begin{array}{c}21.1 \\
(23 ; 2-6)\end{array}$ & $\begin{array}{l}18.3 \\
(20)\end{array}$ & $\begin{array}{c}9.2 \\
(10)\end{array}$ & 1973-74 data \\
\hline $\begin{array}{l}\text { Western Brooks Range } \\
\text { (Reynolds 1984) }\end{array}$ & $\begin{array}{c}47.3 \\
\left(53 ; 5^{+}\right)\end{array}$ & $\begin{array}{c}24.1 \\
(27 ; 2-4)\end{array}$ & $\begin{array}{l}11.6 \\
(13)\end{array}$ & $\begin{array}{c}17 \\
(19)\end{array}$ & $\begin{array}{l}\text { 1977-78 captures: age } \\
\text { structure constructed for } \\
1987\end{array}$ \\
\hline \multicolumn{6}{|l|}{ Interior Alaska } \\
\hline $\begin{array}{l}\text { Alaska Range } \\
\text { (Reynolds and Hechtel 1984a) }\end{array}$ & $\begin{array}{c}44.9 \\
(31 ; 6+)\end{array}$ & $\begin{array}{c}24.6 \\
(17 ; 2-5)\end{array}$ & $\begin{array}{l}14.6 \\
(10)\end{array}$ & $\begin{array}{l}15.9 \\
(11)\end{array}$ & $\begin{array}{l}\text { constructed for } 1982 \text { based } \\
\text { on capture and hunter kill } \\
\text { data }\end{array}$ \\
\hline \multicolumn{6}{|l|}{ South Central Alaska } \\
\hline $\begin{array}{l}\text { Upper Susitna } \\
\text { (Miller and Ballard 1980) }\end{array}$ & $\begin{array}{c}45.3 \\
(24 ; 5+)\end{array}$ & $\begin{array}{c}28.3 \\
(15 ; 2-4)\end{array}$ & $\begin{array}{l}22.6 \\
(12)\end{array}$ & $\begin{array}{l}3.8 \\
(2)\end{array}$ & 1979 data \\
\hline $\begin{array}{l}\text { Susitna Hydro Project } \\
\text { (Miller 1985a) }\end{array}$ & $\begin{array}{c}42.6 \\
\left(40 ; 5^{+}\right) \\
\end{array}$ & $\begin{array}{c}34.0 \\
(32 ; 2-4) \\
\end{array}$ & $\begin{array}{l}6.4 \\
(6) \\
\end{array}$ & $\begin{array}{l}17.0 \\
(16)\end{array}$ & $1980-85$ data \\
\hline \multicolumn{6}{|l|}{ Alaskan Peninsula } \\
\hline $\begin{array}{l}\text { Black Lake } \\
\text { (Glenn 1975) }\end{array}$ & $\begin{array}{c}25.6 \\
(143 ; 5+)\end{array}$ & $\begin{array}{c}34.3 \\
(192 ; 2-4)\end{array}$ & $\begin{array}{l}15.0 \\
(84)\end{array}$ & $\begin{array}{l}25.0 \\
(43)\end{array}$ & $\begin{array}{l}\text { 1970-74 data; cub ratio } \\
\text { calculated from aerial } \\
\text { survey data; others from } \\
\text { capture records }\end{array}$ \\
\hline
\end{tabular}


Table 8. (Continued)

\begin{tabular}{|c|c|c|c|c|c|}
\hline Ecosystem, Area and Citation & $\begin{array}{c}\text { \% Adults } \\
\text { (n;age) }\end{array}$ & $\begin{array}{c}\begin{array}{c}\text { \% Subadult } \\
\text { (n;ages) }\end{array} \\
\end{array}$ & $\begin{array}{c}\% \text { Yearling } \\
(\mathbf{n})\end{array}$ & $\begin{array}{c}\% \text { Cubs } \\
(n)\end{array}$ & Comments \\
\hline \multicolumn{6}{|l|}{ Kodiak/Afognak } \\
\hline $\begin{array}{l}\text { Terror Lake Hydro Project } \\
\text { (Smith et al. 1984) }\end{array}$ & $\begin{array}{c}46.8 \\
(45 ; 5+)\end{array}$ & $\begin{array}{c}29.2 \\
(28 ; 2-4)\end{array}$ & $\begin{array}{l}16.7 \\
(16)\end{array}$ & $\begin{array}{l}7.3 \\
(7)\end{array}$ & 1982-83 data \\
\hline $\begin{array}{l}\text { Karluk Lake } \\
\text { (Troyer and Hensel 1969) }\end{array}$ & $\begin{array}{c}24.5 \\
(43 ; 4+) \\
\end{array}$ & $\begin{array}{c}29.5 \\
(52 ; 2-3) \\
\end{array}$ & $\begin{array}{l}21.6 \\
(38) \\
\end{array}$ & $\begin{array}{l}24.4 \\
(43) \\
\end{array}$ & 1959-64 data \\
\hline \multicolumn{6}{|l|}{ Southwest Alaska } \\
\hline $\begin{array}{l}\text { Admirality Island } \\
\text { (Schoen and Beier 1986) }\end{array}$ & $\begin{array}{c}78.5 \\
(33 ; 5+)\end{array}$ & $\begin{array}{c}16.7 \\
(7 ; 2-4)\end{array}$ & $\begin{array}{l}4.8 \\
(2)\end{array}$ & 0 & 1981-84 data \\
\hline $\begin{array}{l}\text { Admirality and Chichagof } \\
\text { Island } \\
\text { (Schoen and Beier 1986) }\end{array}$ & $\begin{array}{c}69.8 \\
(44 ; 5+)\end{array}$ & $\begin{array}{c}27 \\
(17 ; 2-4)\end{array}$ & $\begin{array}{l}3.2 \\
(2)\end{array}$ & 0 & 1983-85 data \\
\hline $\begin{array}{l}\text { Hood Bay, Admirality Island } \\
\text { (Wood 1976) }\end{array}$ & $\begin{array}{c}52.2 \\
(24 ; 5+) \\
\end{array}$ & $\begin{array}{c}28.3 \\
(13 ; 2-4) \\
\end{array}$ & $\begin{array}{l}6.5 \\
(3) \\
\end{array}$ & $\begin{array}{c}13.0 \\
(6)\end{array}$ & 1971-74 data \\
\hline
\end{tabular}

aNo formal hunting season in main study area.

Table 9. Sex ratios reported for North American brown/grizzly bear populations.

\begin{tabular}{|c|c|c|c|c|c|c|c|c|}
\hline \multirow[b]{2}{*}{ Ecosystem, Area and Citation } & \multicolumn{2}{|c|}{ Adults } & \multicolumn{2}{|c|}{ Subadults } & \multicolumn{2}{|c|}{ Yearling } & \multicolumn{2}{|c|}{ Cubs } \\
\hline & $\mathbf{M}: \mathbf{F}$ & (n) & M:F & (n:ages) & $M: F$ & $(\mathbf{n})$ & $\mathrm{M}: \mathrm{F}$ & $(\mathbf{n})$ \\
\hline \multicolumn{9}{|l|}{ Yellowstone Ecosystem } \\
\hline $\begin{array}{l}\text { Craighead and Mitchell } 1982(1959 \\
\text { data) }\end{array}$ & 46.3:53.7 & $(577)$ & $57.7: 42.3$ & $(44: 2-4)$ & $63: 37$ & $(44)$ & $59: 41$ & $(78)$ \\
\hline $\begin{array}{c}\text { Knight et al. } 1986 a \\
\text { 1975-85 data: } \\
\text { 1975-79 data: } \\
\text { 1980-84 data: }\end{array}$ & $50: 50$ & $(205)$ & $60: 40$ & $(174: 2-4)$ & - & - & $\begin{array}{l}55: 45 \\
71: 29 \\
43: 57\end{array}$ & $(78)$ \\
\hline \multicolumn{9}{|l|}{ Northern Continental Divide Ecosystem } \\
\hline $\begin{array}{l}\text { North and South Forks of Flathead } \\
\text { River } \\
\text { (Jonkel 1982) }\end{array}$ & 66.7:33.3 & $(12)$ & $12.5: 12.5$ & $(6: 2-4)$ & 33.3:66.7 & (6) & - & - \\
\hline $\begin{array}{l}\text { Mission Mountains } \\
\text { (Servheen 1981) }\end{array}$ & $50: 50$ & (6) & $0: 100$ & $(2: 2-4)$ & $0: 100$ & (1) & 33.3:66.7 & (3) \\
\hline $\begin{array}{l}\text { Rocky Mountain Front } \\
\text { (Aune 1985, Aune et al. 1986) }\end{array}$ & 28.9:71.1 & $(45)$ & $62.5: 37.5$ & $(24: 2-4)$ & 66.7:33.3 & (9) & - & - \\
\hline \multicolumn{9}{|l|}{ Canadian Rockies } \\
\hline $\begin{array}{l}\text { Akamina-Kishinena/Flathead } \\
\text { (McLellan 1984) }\end{array}$ & $46: 54$ & $(46)$ & $52: 48$ & $(25: 2-3)$ & $50: 50$ & (19) & - & - \\
\hline $\begin{array}{l}\text { Jasper Natl. Parka } \\
\text { (Russell et al. 1979) }\end{array}$ & $72: 28$ & $(18)$ & $50: 50$ & $(2: 2-5)$ & - & - & - & - \\
\hline \multicolumn{9}{|l|}{ Coastal British Columbia } \\
\hline $\begin{array}{l}\text { Kimsquit River Valley } \\
\text { (Hamilton and Archibald 1984) }\end{array}$ & $43: 57$ & (7) & $75: 25$ & $(8: 2-5)$ & - & - & - & - \\
\hline \multicolumn{9}{|l|}{ Northern Interior } \\
\hline $\begin{array}{l}\text { Mackinzie Mountains } \\
\text { (Miller et al. 1982) }\end{array}$ & $41.2: 58.8$ & $(34)$ & $53.6: 46.4$ & $(28: 2-6)$ & 100: & $(3)$ & 100: & $(2)$ \\
\hline
\end{tabular}


Table 9. (Continued)

\begin{tabular}{|c|c|c|c|c|c|c|c|c|}
\hline \multirow[b]{2}{*}{ Ecosystem, Area and Citation } & \multicolumn{2}{|c|}{ Adults } & \multicolumn{2}{|c|}{ Subadults } & \multicolumn{2}{|c|}{ Yearling } & \multicolumn{2}{|c|}{ Cubs } \\
\hline & M:F & (n) & M:F & (n:ages) & M:F & (n) & M:F & (n) \\
\hline \multicolumn{9}{|l|}{ Boreal Forest } \\
\hline $\begin{array}{l}\text { Swan Hills, Alberta } \\
\text { (Nagy and Russell 1978) }\end{array}$ & 100:0 & (1) & 61.5:38.5 & $(13: 2-5)$ & $0: 100$ & $(2)$ & - & - \\
\hline \multicolumn{9}{|l|}{ Canadian Artic } \\
\hline $\begin{array}{l}\text { Northern Yukon } \\
\text { (Nagy et al. 1983A) }\end{array}$ & $51.5: 48.5$ & (103) & $42.5: 57.5$ & $(40: 2-6)$ & $30: 70$ & $(10)$ & - & - \\
\hline $\begin{array}{l}\text { NWT: Tukloyatuk/Richards Island } \\
\text { (Nagy et. al 1983B) }\end{array}$ & $31.3: 68.7$ & (115) & $53.4: 46.6$ & $(88: 2-6)^{\circ}$ & $69: 31$ & $(29)$ & $66.7: 33.3$ & $(24)$ \\
\hline \multicolumn{9}{|l|}{ Arctic Alaska } \\
\hline $\begin{array}{l}\text { Eastern Brooks Range } \\
\text { (Reynolds 1976) }\end{array}$ & $48.2: 51.8$ & $(56)$ & $38.8: 61.2$ & $(18: 2-6)$ & $50: 50$ & $(4)$ & - & - \\
\hline $\begin{array}{l}\text { Western Brooks Range } \\
\text { (Reynolds 1984) }\end{array}$ & $43.4: 56.6$ & $(53)$ & $45: 55$ & $(20: 2-4)$ & 28.6:71.4 & (7) & $75: 25$ & $(4)$ \\
\hline \multicolumn{9}{|l|}{ Interior Alaska } \\
\hline $\begin{array}{l}\text { Alaska Range } \\
\text { (Reynolds and Hechtel 1984a) }\end{array}$ & 41.9:58.1 & $(31)$ & $41.2: 58.8$ & $(17: 2-5)$ & $66.7: 33.3$ & (9) & $42.9: 57.1$ & $(7)$ \\
\hline \multicolumn{9}{|l|}{ South Central Alaska } \\
\hline $\begin{array}{l}\text { Nelchina/Upper Susitna } \\
\text { (Miller and Ballard 1980) }\end{array}$ & $58.3: 41.7$ & $(24)$ & $66.7: 33.3$ & $(15: 2-4)$ & $66.7: 33.3$ & (12) & $100: 0$ & $(2)$ \\
\hline $\begin{array}{l}\text { Susitna Hydro Project } \\
\text { (Miller 1985a) }\end{array}$ & $40: 60$ & $(40)$ & $50: 50$ & $(32: 2-4)$ & 66.7:33.3 & (6) & $50: 50$ & (16) \\
\hline \multicolumn{9}{|l|}{ Alaskan Peninsula } \\
\hline $\begin{array}{l}\text { Black Lake } \\
\text { (Glenn 1975) }\end{array}$ & $15.4: 84.6$ & (143) & 46.9:53.1 & $(192: 2-4)$ & $47.6: 52.4$ & $(84)$ & $50: 50$ & $(24)$ \\
\hline \multicolumn{9}{|l|}{ Kodiak/Afognak } \\
\hline $\begin{array}{l}\text { Karluk Lake } \\
\text { (Troyer and Hensel 1969) }\end{array}$ & 23.3:76.7 & $(43)$ & $51.9: 48.1$ & $(52: 2-3)$ & $47.4: 52.6$ & $(38)$ & $51.2: 48.8$ & (43) \\
\hline $\begin{array}{l}\text { Terror Lake Hydro Project } \\
\text { (Smith et al. 1984) }\end{array}$ & $31.1: 68.9$ & $(45)$ & $53.6: 46.4$ & $(28: 2-4)$ & $25: 75$ & (16) & 42.9:57.1 & (7) \\
\hline \multicolumn{9}{|l|}{ Southwest Alaska } \\
\hline $\begin{array}{l}\text { Admiralty Island } \\
\text { (Schoen and Beier 1986) }\end{array}$ & $24.2: 75.8$ & (33) & $85.7: 14.3$ & $(7: 2-4)$ & $50: 50$ & $(2)$ & - & - \\
\hline $\begin{array}{l}\text { Hood Bay, Admiralty Island } \\
\text { (Wood 1976) }\end{array}$ & $16.7: 98.3$ & $(24)$ & $30.8: 69.2$ & $(13: 2-4)$ & $100: 0$ & (3) & $50: 50$ & (6) \\
\hline
\end{tabular}

aNo formal hunting season in main study area. 
Table 10. Oldest brown/grizzly bears recorded for various North American populations.

\section{Ecosystem, Area, Citation}

Yellowstone Ecosystem

(Craighead and Mitchell 1982)

(Knight et al. 1985)

Northern Continental Divide Ecosystem

North Fork of the Flathead River

(Jonkel 1982)

South Fork of the Flathead River

(Jonkel 1982)

Rocky Mountain Front

(Aune et al. 1986)

Mission Mountains

(Servheen 1981)

Canadian Rockies

Jasper Natl. Park

(Russell et al. 1979)

Interior British Columbia

Revelstoke Area

(Simpson et al. (in prep))

Glacier Natl. Park, BC

(Mundy and Flook 1973)

Coastal British Columbia

Kimsquit River Valley

(Hamilton and Archibald 1984)

Northern Interior

SW Yukon: Kluane National Park

(Pearson 1975)

Mackenzie Mountains, NWT

(S.J. Miller et al. 1982)

Boreal Forest

Swan Hills, Alberta

(Nagy and Russell 1978)

Canadian Arctic

Northern Yukon

(Nagy et al. 1983a)

Arctic Alaska

Eastern Brooks Range

(Reynolds 1976)

Western Brooks Range

(Reynolds and Hechtel 1984b)

Interior Alaska

Alaska Range

(Reynolds and Hechtel 1984a)

Southcentral Alaska

Susitna Hydor Project

(Miller 1985)

Copper River Delta

(Campbell 1985)

Alaska Peninsula

Black Lake Area

(Modafferi 1984)

Kodiak/Afognak

Terror Lake Hydro Project

(Smith et al. 1984)

Southeast Alaska

Admirality Island

(Schoen and Beier 1986)

\section{REPRODUCTIVE RATES}

The factors contributing to the reproductive rate of a population include mean litter size, mean age at initial reproduction, mean interval between litters and mean maximum age of reproduction (Craighead et al. 1974). Table 12 summarizes reproductive data for North American grizzly bear populations as reported in the literature (data were generally lacking for maximum age of reproduction and are therefore not included in the table). Comparisons of these reproductive parameters among populations should be done with caution. Sample sizes and duration of sampling periods vary widely (Table 12), data on successive litters of individual females are lacking (Stringham 1980) and different methods have been employed in estimating age at first reproduction and breeding interval. (For further discussion on the limitations of comparing available data, see Stringham 1980, 1984).

\section{Factors Influencing Reproductive Rate}

General relationships between habitat features, food availability and reproductive potential are described herein. The effects of annual climatic variation and food availability are discussed in the section on population regulation.

As Stringham (1984) observed, most analyses of the relationships between reproduction/recruitment vs. food supply and nutrient-energy balance have been constructed using surrogate indices of food supply such as latitude or bear weight rather than actual data for the controlling factors. Hence, conclusions drawn from these studies are tentative.

Body weights may be used as a "surrogate index" of food supply and nutrient energy of populations. Blanchard (in press) found a high correlation bet ween mean adult female weight and mean cub litter size for 8 North American grizzly populations. She also found a moderately high negative correlation between mean adult female weight and age at first cub production. In general, females in those populations with reliable, high value foods (meats and berries) during summer and fall attained greater size, matured earlier and had larger litters than females with relatively low value foods (roots).

Similarly, Stringham (in press b) found that body size was a good predictor of the mean rate of reproduction and, probably, juvenile survival. For 10 grizzly bear populations, variations in body weight corresponded strongly with variations in productivity (number of cubs per adult female per year).

Bunnell and Tait (1981) compared the reproductive rates of coastal and interior grizzly populations and found that coastal populations (which had access to spawning salmon) had larger litter sizes, earlier maturation and heavier female weights. They also found a correlation between litter sizes and latitude of den sites. They at tributed the lower northern latitude litter sizes to reduced primary productivity.

Stringham (1984) reached similar conclusions. He found that litter size, productivity, reproductive vigor (net effects of reproductive rate on population growth rate) and indices of maturation rate to weaning and to puberty, were all negatively correlated with latitude. Like Bunnell and Tait 
Table 11. Reported densities for North American brown/grizzly bear populations.

\begin{tabular}{ccc}
\hline Ecosystem, Area and Citation & $\begin{array}{c}\text { Pop. Density } \\
\text { (sq. km/bear) }\end{array}$ & Comments/methods \\
\hline $\begin{array}{l}\text { Yellowstone Ecosystem } \\
\text { (Craighead and Mitchell 1982) }\end{array}$ & 80.3 & $\begin{array}{l}\text { pre-dump closure (1959-1970); direct count of individually } \\
\text { recognizable animals; projection from mathematical } \\
\text { computer model } \\
\text { post-dump closure; based on number of unduplicated bears } \\
\text { sighted; an optimistic estimate of 350 bears in 20,000 sq } \\
\text { km. }\end{array}$ \\
\hline
\end{tabular}

Northern Continental Divide Ecosystem

Glacier National Park

(Martinka 1974)

Mission Mountains

(Servheen 1981)

Mission Mountains

(Dood et al. 1986)

South Fork of Flathead River

(Dood et al. 1986)

Rocky Mountain East Front

(Aune et al. 1986)

Rocky Mountain East Front

(Dood et al. 1986)

Cabinet-Yaak Ecosystem

Cabinet Mountains

(Kasworm 1985)

Canadian Rockies

Jasper Natl. Park

(Russell et al. 1979)

Banff National Park

(Vroom 1974)

Akamina-Kishinena/North Forks of

Flathead

(McLellan 1984)

Interior British Columbia

Revelstoke Area

(Simpson et al. in prep.)

Glacier National Park, B.C.

(Mundy and Flook 1973)

Boreal Forest

Swan Hills, Alberta

(Nagy and Russell 1978)

Northern Interior

SW Yukon: Kluane National Park

(Pearson 1975)

Mackenzie Mountains, NWT

(Miller et al. 1982)
21.2 direct count; unduplicated sightings of identifiable bears and family groups

49 direct count of radio-collared bears and young plus observations of unmarked bears

137 recalculated from data of Servheen (1981) using only marked and identifiable animals and their composite home range with a boundary strip added (See Dood et al. 1986, p. 48-49)

49 recalculated from above data; see comments for Mission Mountains, Dood et al. 1986

71.6-74.2 marked bears only

51.1 marked and observed bears included (area for both estimates determined from $98 \%$ of adult relocations excluding non-habitat.)

158 recalculated from above data; see comments for Mission Mountains, Dood et al. (1986)

44 determined from number of identified grizzlies within polygon encluding all captures and sign

85.5-101.6 direct count (captured and accompanying bears plus other identifiable bears)

79-120.5 unverified, cited in McLellan (1984)

10-15.6 direct count of captures and observed bears; range of counts over 4 years; "rough estimate"

32 direct counts, captures and sightings

28 direct count (captured and observed)

18 Schnabel method

139 direct count (captured and observed)

104 based on number of known females and young on study area and estimate of males using 50:50 sex ratio

22.8-27.2 aerial surveys (identifiable animals with most of home range in study area)

86 based on captures, aerial surveys (random encounters) and projection from observed sex ratio and age ratio (see pp. 67.71 in Miller et al. 1982) 
Table 11. (Continued)

\begin{tabular}{lll}
\hline & Pop. Density & Comments/methods \\
\hline
\end{tabular}

Canadian Arctic

NWT: Tuktoyaktuk Peninsula/Richards

Island

211-237 spring density

255-262 fall density

(Nagy et al. 1983b)

both estimates from marked bears and direct counts

Northern Yukon

48 from number of marked and identifiable females and

(Pearson 1976)

young and estimate of malesusing assumed 50:50 sex ratio

Northern Yukon

(Nagy et al. 1983a)

33-39 ratio of marked to unmarked (bears with home ranges in study area)

Arctic Alaska

Eastern Brooks Range

(Quimby and Snarshi 1974)

173 direct counts: aerial transects along valleys within 4 river

(Quimby 1974)

120 Lincoln/Peterson index for mountainous portion of

(Curatolo and Moore 1975)

148 minimum density from marked bears and young in 9234

(Canning, Ivishak and Echooka drainages)

(Reynolds 1976)

148 intensive study area only (high quality habitat)

260 region wide

both estimates from direct counts of marked and identifiable bears

Western Brooks Range

42-44 intensive study area only: observed minimum population

(Reynolds 1984; Reynolds and Hechtel

1980)

Interior Alaska

Alaska Range

(Reynolds and Hechtel 1984a)

35.0-52.9 "probable density" based on captures, observations, hunter kills and inference for additional, unrecorded bears

Denali National Park (minimum density $=54 \mathrm{~km} 2$ per bear)

(Dean 1976)

24-38 direct count: unduplicated sightings of individual bears and family groups; 4 counts $(1957-1959,1973)$

Southcentral Alaska

Susitna River Hydro Project

34.4 Lincoln/Peterson Index (aerial counts) for predefined

(Miller 1985a) search area, adjusted for unequal capture probabilities

Nelchina/Upper Susitna

(Miller and Ballard 1982)

41 Peterson index, corrected for biases

Copper River Delta

(Campbell 1985)

14-16.3 marked and harvested bears

Alaska Peninsula

(Glenn: pers. commun. as cited in Miller

16 method not specified: presumably from marked:unmarked and Ballard 1982) ratios as per Glenn (1975)

Kodiak/Afognak

Karluk lake Area ( 248 sq. km)

Entire Kodiak Island

1.52 Schnabel method; optimal habitat

$-3.75$

rough estimate/extrapolation

3.40 rough estimate/extrapolation

(Troyer and Hensel 1969)

Terror Lake Hydro project

4

(Smith and Van Daele 1984)

Direct count: cumulative total of captures and

unduplicated sightings over 10 -month period $(2.8 \mathrm{~km}$ 2 /bear) in $900 \mathrm{~km} 2$ high-density area)

Southeast Alaska

Northern Admiralty Island

(Schoen and Beier 1986)

3.2-4.2 marked:unmarked ratios; early summer aerial surveys of alpine areas 
Table 12. Reproductive characteristics of North American grizzly bear populations.

\begin{tabular}{|c|c|c|c|c|}
\hline Ecosystem, Area and Citation & $\begin{array}{c}\text { Mean litter } \\
\text { Size } \\
(\mathbf{n})\end{array}$ & $\begin{array}{l}\text { Mean age of } \\
\text { first } \\
\text { parturition } \\
\text { (n) }\end{array}$ & $\begin{array}{l}\text { Breeding } \\
\text { Interval } \\
\text { (n) }\end{array}$ & Comments \\
\hline \multicolumn{5}{|l|}{ Yellowstone Ecosystem } \\
\hline (Craighead amd Mitchell 1982) & $\begin{array}{l}2.24 \\
(68)^{\mathrm{a}}\end{array}$ & $\begin{array}{c}5.6 \\
(16)^{\mathrm{b}}\end{array}$ & $\begin{array}{c}4.3 \\
(68)^{\mathrm{c}}\end{array}$ & pre-dump closure (1959-1970) \\
\hline (Knight et al. 1985) & $\begin{array}{c}1.90 \\
(104)\end{array}$ & $\begin{array}{c}6.2 \\
(12)\end{array}$ & $\begin{array}{c}3.0 \\
(33)\end{array}$ & post-dump closure (1974-1982) \\
\hline \multicolumn{4}{|c|}{ Northern Continental Divide Ecosystem } & - \\
\hline $\begin{array}{l}\text { Rocky Mountain Front } \\
\text { (Aune 1985, Aune et al. 1986) }\end{array}$ & $\begin{array}{l}2.23 \\
(30)\end{array}$ & $\begin{array}{l}5.5 \\
(2)\end{array}$ & $\begin{array}{l}2.0 \\
\text { (est.) }\end{array}$ & \\
\hline $\begin{array}{l}\text { Mission Mountains } \\
\text { (B.I.A. files; from Dood et al. } \\
\text { 1986) }\end{array}$ & 2.12 & 5.5 & 3.3 & \\
\hline $\begin{array}{l}\text { North Fork of Flathead } \\
\text { (Jonkel pers. commun: in Dood } \\
\text { et al. 1986) }\end{array}$ & 2.66 & 5.0 & - & \\
\hline $\begin{array}{l}\text { Glacier Natl. Park } \\
\text { (Martinka 1974) }\end{array}$ & 1.70 & - & - & \\
\hline \multicolumn{5}{|l|}{ Canadian Rockies } \\
\hline $\begin{array}{l}\text { Akamina-Kishinena/N. Fork of } \\
\text { Flathead } \\
\text { (McLellan 1984) }\end{array}$ & $\begin{array}{l}2.5 \\
(8)\end{array}$ & $\begin{array}{c}6 \\
\text { (est.) }\end{array}$ & $\begin{array}{l}3.4 \\
(5)\end{array}$ & \\
\hline $\begin{array}{l}\text { Jasper Natl. Park } \\
\text { (Russell et al. 1979) }\end{array}$ & $\begin{array}{l}2.0 \\
(3)\end{array}$ & $\begin{array}{c}5-7 \\
\text { (est.) } \\
\end{array}$ & - & \\
\hline \multicolumn{5}{|l|}{ Interior British Columbia } \\
\hline $\begin{array}{l}\text { Glacier Natl. Park, B.C. } \\
\text { (Mundy and Flook 1970, 1973) }\end{array}$ & $\begin{array}{c}2.0 \\
(143)\end{array}$ & - & $\begin{array}{c}2-3 \\
\text { (some } 4)\end{array}$ & \\
\hline $\begin{array}{l}\text { Revelstoke Area } \\
\text { (Simpson et al. in prep.) }\end{array}$ & $\begin{array}{l}2.33 \\
(3) \\
\end{array}$ & - & - & \\
\hline \multicolumn{5}{|l|}{ Northern Interior } \\
\hline $\begin{array}{l}\text { SW Yukon: Kluane Natl. Park } \\
\text { (Pearson 1975) }\end{array}$ & $\begin{array}{l}1.70 \\
(11)\end{array}$ & $\begin{array}{l}7.8 \\
(6)\end{array}$ & $3+$ & \\
\hline $\begin{array}{l}\text { Mackenzie Mtns. NWT } \\
\text { (Miller et al. 1982) }\end{array}$ & $\begin{array}{c}1.83 \\
(6)\end{array}$ & $\begin{array}{l}8.0^{\mathrm{d}} \\
(32) \\
\end{array}$ & $\begin{array}{c}3.8 \\
(11) \\
\end{array}$ & \\
\hline \multicolumn{5}{|l|}{ Canadian Arctic } \\
\hline $\begin{array}{l}\text { Northern Yukon } \\
\text { (Nagy et al. 1983a) }\end{array}$ & $\begin{array}{l}2.0 \\
(6)\end{array}$ & $\begin{array}{c}6.6-7.5 \\
(15)\end{array}$ & $\begin{array}{l}3-4 \\
(4)\end{array}$ & \\
\hline $\begin{array}{l}\text { NWT: Tuktoyoktuk } \\
\text { Peninsula/Richards Island } \\
\text { (Nagy et al. 1983b) }\end{array}$ & $\begin{array}{c}2.3 \\
(28) \\
\end{array}$ & $\begin{array}{c}6.4 \\
(20) \\
\end{array}$ & $\begin{array}{l}3.3 \\
(8) \\
\end{array}$ & \\
\hline \multicolumn{5}{|l|}{ Arctic Alaska } \\
\hline $\begin{array}{l}\text { Eastern Brooks Range } \\
\text { (Reynolds 1976, Reynolds and } \\
\text { Hetchel 1980) }\end{array}$ & $\begin{array}{l}1.78 \\
(13)\end{array}$ & $\begin{array}{c}9.6 \\
(19)\end{array}$ & 4.24 & \\
\hline $\begin{array}{l}\text { Eastern Brooks } \\
\text { Range: Canning River } \\
\text { (Quimby 1974) }\end{array}$ & $\begin{array}{c}1.6 \\
(69)\end{array}$ & - & - & \\
\hline $\begin{array}{l}\text { Western Brooks Range } \\
\text { (Reynolds and Hetchel 1980) }\end{array}$ & $\begin{array}{l}2.03 \\
(23)\end{array}$ & $\begin{array}{c}8.4 \\
(11)\end{array}$ & $\begin{array}{l}4.03 \\
\text { (est.) }\end{array}$ & \\
\hline $\begin{array}{l}\text { Central Brooks Range } \\
\text { (Crook 1971) }\end{array}$ & 2.0 & - & - & \\
\hline
\end{tabular}


Table 12. (Continued)

\begin{tabular}{|c|c|c|c|c|}
\hline Ecosystem, Area and Citation & $\begin{array}{c}\text { Mean litter } \\
\text { Size } \\
(n)\end{array}$ & $\begin{array}{c}\begin{array}{c}\text { Mean age of } \\
\text { first }\end{array} \\
\text { parturition } \\
(n)\end{array}$ & $\begin{array}{l}\text { Breeding } \\
\text { Interval } \\
\text { (n) }\end{array}$ & Comments \\
\hline \multicolumn{5}{|l|}{ Interior Alaska } \\
\hline $\begin{array}{l}\text { Alaska Range } \\
\text { (Reynolds and Hechtel 1984a) }\end{array}$ & $\begin{array}{l}2.03 \\
(23)\end{array}$ & $\begin{array}{l}8.4 \\
(11)\end{array}$ & $\begin{array}{l}4.03 \\
\text { (est.) }\end{array}$ & \\
\hline $\begin{array}{l}\text { Denali Natl. Park } \\
\text { (Murie 1981) }\end{array}$ & $\begin{array}{l}1.85 \\
(68) \\
\end{array}$ & - & - & \\
\hline \multicolumn{5}{|l|}{ South Central Alaska } \\
\hline $\begin{array}{l}\text { Susitna Hydro Project } \\
\text { (Miller 1984) }\end{array}$ & $\begin{array}{l}2.1 \\
(19)\end{array}$ & - & - & \\
\hline $\begin{array}{l}\text { Nelchina/upper Susitna } \\
\text { (Spraker et al. 1981) }\end{array}$ & $\begin{array}{l}2.8 \\
(4)\end{array}$ & $\begin{array}{l}4.7 \\
(6)\end{array}$ & - & \\
\hline \multicolumn{5}{|l|}{$\overline{\text { Alaskan Peninsula }}$} \\
\hline $\begin{array}{l}\text { McNeil River } \\
\text { (Glenn et al. 1976) }\end{array}$ & $\begin{array}{l}2.5 \\
(41)\end{array}$ & $\begin{array}{c}6 \\
(8)\end{array}$ & $\begin{array}{l}3.6 \\
(12)\end{array}$ & \\
\hline $\begin{array}{l}\text { NcNeil River } \\
\text { (Lentfer 1966) }\end{array}$ & $\begin{array}{l}2.13 \\
(24)\end{array}$ & - & - & \\
\hline $\begin{array}{l}\text { Black Lake } \\
\text { (Glenn 1973) }\end{array}$ & $\begin{array}{c}2.3 \\
(200)\end{array}$ & 5.2 & $\begin{array}{c}\sim 3 \\
\text { (est.) }\end{array}$ & \\
\hline (Klein 1985) & 2.2 & - & - & \\
\hline \multicolumn{5}{|l|}{ Kodiak/Afognak } \\
\hline $\begin{array}{l}\text { Terror Lake Hydro Project } \\
\text { (Smith and Van Daele 1984) }\end{array}$ & $\begin{array}{l}2.30 \\
(4)\end{array}$ & - & - & \\
\hline $\begin{array}{l}\text { Kodiak Natl. Wildl. Refuge } \\
\text { (Barnes 1985) }\end{array}$ & $\begin{array}{l}2.21 \\
(14)\end{array}$ & - & - & \\
\hline (Troyer and Hensel 1969) & $\begin{array}{l}2.23 \\
(98) \\
\end{array}$ & $4-5$ & $\begin{array}{c}3 \\
\text { (est.) } \\
\end{array}$ & \\
\hline \multicolumn{5}{|l|}{ Southwest Alaska } \\
\hline $\begin{array}{l}\text { Admiralty Island } \\
\text { (Schoen and Beier 1986) }\end{array}$ & $\begin{array}{l}1.84 \\
(19)\end{array}$ & $\begin{array}{c}8 \\
(4)\end{array}$ & - & \\
\hline $\begin{array}{l}\text { Admiralty, Baranof and } \\
\text { Chichagof } \\
\text { (Klein 1958) }\end{array}$ & $\begin{array}{l}2.2 \\
(79)\end{array}$ & - & - & \\
\hline
\end{tabular}

anumber of litters in sample

${ }^{b}$ number of females in sample

cnumber of cycles in sample

dyoungest observed age, not mean age of first reproductive

(1981), he attributed this to the decline in primary productivity and longer, harsher winters at higher latitudes. The same reproductive indices tended to be higher on Alaskan coasts than in inland habitats in Alaska and northern Canada. However, since the coastal populations he examined were also at a lower latitude than the inland populations, the differences in reproductive indices may have arisen from either lower latitude or availability of food (salmon and marine mammal carrion). Latitude and habitat type together accounted for at least $74 \%$ of the variance in body weights in grizzly bears 4 years of age or older and, as noted earlier, bear weight is highly correlated with reproductive parameters.
Other researchers found that some reproductive rate differences between interior populations were related to nutritional differences. Reynolds and Hechtel (1984) compared reproductive rates in the western and eastern Brooks Ranges. They concluded that the higher rate in the western Brooks Range resulted from access to traditional caribou calving grounds. Caribou calves and carrion provided bears in the western Brooks Range with a high protein food source in early spring when other foods were low in nutrition and energy demands were high. Aune (1985) noted that along the Rocky Mountain East Front, litter sizes sou th of the Sun River $(n=3)$ were smaller than those in the more productive habitat north of the Sun River $(n=16)$. 
Stringham (1980) suggested that bears in high quality habitats may undergo selection for genotypes promoting large litter sizes. There also may be selection for genetic poly morphism where carrying capacity and hence optimal litter size fluctuates year to year. Russell et al. (1979), Nagy et al. (1983a) and Dood et al. (1986) noted that low reproductive rates may be inherent in populations also having low mortality and recruitment rates.

Positive correlations between garbage availability and reproductive performance have been noted for several areas. Bears with access to garbage matured earlier (Nagy and Russell 1978, Knight et al. 1986), had larger litter sizes and bred more frequently than bears in similar habitat without access to garbage (Rogers 1978 [black bear data], Knight et al. 1986). Access to garbage has also been shown to positively influence bear weight (Rogers et al. 1976, Russell et al. 1979, Blanchard in press) which is, in turn, correlated with reproductive success (Rogers 1976, 1978, Blanchard in press). Correlations between dump closure and reproductive rate depression in the Yellowstone grizzly bear population are discussed in the section on Population Regulation.

\section{POPULATION REGULATION}

Because of the rich demographic database available for the Yellowstone population from the Craighead studies (1959-1971) and the Interagency Grizzly Bear Study Team research (1974-1986) and because of the vigorous controversy surrounding the impacts of dump closure on this population, much of the literature devoted to grizzly bear population regulation focuses on the Yellowstone bears. Stringham $(1980,1983,1984$, in press a) presented the results of an elaborate set of analyses (and an exhaustive literature review) concerning the effects of various environmental and biological factors on grizzly bear population dynamics. A number of his analyses dealt with the Yellowstone grizzlies and the factors responsible for the reproductive rate depression which followed closure of the open-pit garbage dumps. Stringham's work should be consulted for a more definitive treatment of these as pects of bear biology.

Population regulation generally pertains to maintenance of a stable mean (either density or density relative to habitat carrying capacity) with only brief deviation from that mean (Stringham 1984). Shaffer (1978) reviewed the major findings on population regulation in bears. He noted that there were 2 major views on how bear population's were regulated. One view held that bear populations were self-regulated by social (intrinsic) factors while the other view supported environmental (extrinsic) regulation primarily through effects of food supply. Shaffer (1978) felt that these mechanisams were generally related, and hence, were best regarded as a hierarchy of controls rather than as alternative means of population regulation. While extensive factors determine the resource base available to any bear population, intrinsic factors determine the extent to which the resource base could be subdivided. Shaffer (1978) noted that observations at McNeil River, Alaska, were of intraspecific behaviors. Egbert and Stokes (1976) found that aggression by brown bears depended on the abun. dance of spawning salmon which supported this view.

Bunnell and Tait (1981) reached similar conclusions. They suggested that a broad but consistent pattern of pop- ulation regulation was found in the genus Ursus. Nutritional conditions dominated the reproductive rate, and social mechanisms regulated access to sources of nutrition. Thus, both density-independent (nutritional regulation) and density-dependent (social) mechanisms appear to be implicated in bear population regulation. These mechanisms are discussed in greater detail in subsequent sections.

\section{Extrinsic (Nutritional and Climatic) Regulation}

Evidence for nutritional regulation of reproductive rates has been found in both black and grizzly bear populations. Rogers $(1976,1978)$ studied black bears in northern Minnesota and reported that well-fed captive bears and garbagefed wild bears matured earlier than wild bears with little or no access to garbage. Within the latter group, only 1 of 9 females produced her first litter following a year of food scarcity. Furthermore, some multiparous females which were expected to produce cubs failed to do so following poor food years.

Reproductive performance was correlated with predenning weight for females 3.5 years of age or older. Females weighing less than $67 \mathrm{~kg}$ in October all failed to produce cubs while 28 of 30 females weighing more than 80 kg produced cubs. Females of intermediate weights had varied reproductive performance. Stringham (in press a) reported that, based on weight data for 10 grizzly bear populations, comparable body weights for grizzly bear females were $95 \mathrm{~kg}$ for the mean body weight below which reproduction did not occur and $180 \mathrm{~kg}$ for maximum reproductive output.

Spring weights of black bear cubs were also positively correlated with female pre-denning weight. Rogers (1976) suggested that bears physiologically assessed their supply of stored nutrients in the fall and prevented embryo implantation when stores were insufficient to support themselves and their young through the denning period.

Jonkel and Cowan (1971) and Beecham (1980) also found that black bears with nutritionally superior diets matured earlier, had larger litters and shorter breeding intervals than bears with poorer diets. Beecham (1980) concluded that climate, and its influence on habitat, was the primary extrinsic factor governing long-term population size. Social and reproductive systems were governed by the quality and quantity of available food and its spatial and temporal distribution.

Picton (1978) found a strong correlation between an index of climate (plus carrion availability) and litter size of Yellowstone grizzly bears. His analysis indicated that the depression in reproductive rate which followed closure of the park dumps (from 2.2 cubs per litter during 1959-69 down to 1.8 cubs per litter during 1972-76) was largely due to unfavorable climatic conditions. A subsequent analysis (Picton and Knight in press) demonstrated the predictive capability of the climate-carrion regression and provided an updated index to incorporate 1977-81 litter size data. Picton et al. (1986) developed seasonal climate scores which, along with season-specific habitat quality indices, were used to explain between year differences in food habits, movements, mortality and weight gain. Nutritional regulation of reproductive rates was not specifically discussed. 
Stringham (in prep.) reevaluated Picton's climatecarrion index (CCI) and disputed his conclusions. He disagreed with Picton (1978) on 5 points:

1. climatic change accounted for only about half of the observed litter size decline

2. the years selected to represent the pre-closure period included 2 cohorts affected by dump closure

3. the carrion index actually contributed very little to the correlation with litter size

4. additional evidence and inference which substantiated the impacts of dump closure on the nutritional status and reproductive parameters of the population

5. the statistical method upon which Picton (1985) based his conclusions failed to adequately separate the effects of climatic variation from dump closure. Stringham (in prep.) using multiple regression, determined that only about $31 \%$ of the observed 0.37 cubs/litter decline (1959-68 vs. 1972 81) was accounted for by climate while $70 \%$ of that decline could be attributed to dump closure. J. Craighead et al. (1976a) also concluded that the drop in reproductive rate after closure resulted from loss of the stable, reliable food source at the dumps.

Stringham (in press a) developed an alternative index to integrate the effects of climate and garbage availablity on nutrient supply and energy balance for Yellowstone grizzlies from 1959-81. Graphical presentation showed a strong relationship between his food/nutrient balance index for the postnatal period (infancy) and recruitment of cubs-ofthe-year. Furthermore, postnatal balance continued to influence each cohort until adulthood. Stringham (in press a) extended his analysis to consider the effects of food supply per unit bear mass (i.e., $\mathrm{kg}$ food/kg grizzly) and found an even stronger relationship between this index and reproduction and recruitment. When mean individual nutrient-energy balance was high for Yellowstone grizzlies, many cubs were produced. These cohorts had high rates of recruitment to adulthood and were predominantly male. Conversely, when energy balance was low, few cubs were produced and these predominantly female cohorts had low recruitment to adulthood. In either case, later changes in nutritional conditions did not modify the recruitment rate.

McCullough (1981) presented a different interpretation on regulation of sex ratios for Yellowstone grizzlies sug. gesting that size of the adult population was the controlling factor. Overall, a disproportionate number of males were present at conception. When adult populations were low, cub production and survivorship to adulthood were high leading to an increase in the proportion of males as the number of adults increased. At higher adulthood population age structures, cub production was low, male survivorship declined drastically and the proportion of males in the population decreased as the total adult population declined.

\section{Intrinsic (Social) Regulation}

Impetus for research into the role of density dependent compensatory mechanisms affecting grizzly bear repro- ductive rates stemmed from disagreement about the status of the Yellowstone grizzly bear population following closure of the garbage dumps (Cowan et al. 1974, Craighead et al 1974). The computer model developed by the Craighead team to describe the population dynamics of the Yellowstone population assumed that no compensatory processes were operative (Craighead et al. 1973, 1974, McCullough 1981). They contended that for a long-lived species with delayed maturity, compensatory processes (e.g., increased litter size, shorter reproductive cycle or higher subadult survival) would act slowly. Furthermore, population regulatory mechanisms (infanticide and hormonal regulation of estrus intervals) could offset compensatory processes (Craighead et al. 1976, Craighead and Mitchell 1982).

Cole (1974) argued that the decrease in litter size after dump closure resulted from increased breeding by younger aged females. These females, formerly prevented from breeding by older, more dominant females, produced smaller litters, thereby lowering the average litter size. Knight et al. $(1985,1986)$ reported that smaller litters did typify the first reproductive cycles of young female grizzly bears in the Yellowstone ecosystem.

Cowan et al. (1974) reviewed the available demographic data for Yellowstone grizzlies and concluded that failure to incorporate compensatory mechanisms into the Craighead model rendered their population predictions suspect. They noted that the grizzly bear was characterized by attributes of a strongly K-selected species - long life span, delayed maturity, extended parental care, nonreproductive intervals and high adult survivorship. Although grizzly bears were limited in the range of compensatory response that was possible, Cowan et al. (1974) felt that increased adult mortality (as occurred following dump closure) would be offset by compensatory increases in juvenile recruitment.

Avrin (1976) and McCullough (1981) reanalyzed the data from Craighead et al. (1974) and found that the number of juveniles recruited was strongly compensatory, with high populations of adults (postnatally) recruiting few juveniles and low numbers of adults recruiting high numbers of juveniles. McCullough's (1981) analysis revealed that both litter size and proportion of reproducing females contributed to the variation in juvenile recruitment. The delay of sexual maturity until age 5 resulted in an oscillatory tendency with a periodicity of about 10 years in the relationship between the adult and juvenile segments of the population. Regression of recruitment rate on number of adult males resulted in a highly significant correlation, suggesting that adult males were responsible for most of the suppression of cub recruitment.

Similarly, Shaffer $(1978,1983)$ found that the percent of females which reproduced and the average litter size were significantly correlated with adult population size. However, unlike McCullough (1981), the strongest correlation was with the number of adults prenatally (at the time of breeding).

Stringham (1980, 1983, 1984, in press a) also examined the role of adult males in grizzly bear population regulation. Stringham (1980) found that the differences in reproductive potential among 6 North American bear populations were directly related to differences in food supply and density, but negatively correlated with differences in proportions of adult males. As did McCullough (1981), he found that, in Yellowstone National Park, there was a 
strong negative correlation between numbers of adult males during a given year and number of offspring. Stringham $(1983,1984$, in press a) expanded on this latter finding. The years when adult males were most abundant were years with the smallest litter sizes and fewest number of litters. Cohorts born during years of peak adult male abundance also showed the highest attrition rates to at least 2.5 years of age (Stringham 1983). However, Stringham (in press a) noted that it was difficult to distinguish between the nutritional impacts caused by dump closure and the coincidental increase in male abundance. Considering only the period preceding dump closure, the addition of a male abundance factor to a regression model already containing a climate index did not appreciably improve the correlation with litter size. Stringham (in press a) postulated that as dump closure reduced the amount of food available to the population, the contemporaneous increase in adult male abundance lowered the proportion of the reduced food supply available to adult females and younger bears. The proportion and number of females reproducing each year was apparently less sensitive than litter size to variation in food supply and number of males.

There are several alternative explanations to account for the apparent inverse relationship between cub production and recruitment vs. density of adult males at Yellowstone dumps. Stringham (1983) noted that the correlation could actually be an artifact of conducting censuses at dumps. Adult male abundance appeared highest when the natural food supply was lowest because that was the period when more males regularly fed at the dumps. Another possibility is that females with cubs avoided the dumps when and where adult males were most abundant. Stringham (1984) found that other aspects of the census procedure corrected for dump avoidance by females with cubs. Furthermore, cohort size and litter size were correlated with prenatal as well as postnatal density of adult males.

Additional evidence for regulation of bear populations by adult males comes from black bear studies near Cold Lake in northeastern Alberta. Kemp (1976) postulated that aggression toward subadults by adult males had a strong regulatory effect. The experimental removal of 26 large adult males was followed by a major increase in the bear population (from 80 in the pre-manipulation period to 175 in the post-manipulation period). The recapture rate, and presumably, ingress and survivorship of subadults also increased. A followup study conducted 3 years after the removal experiment (Young and Ruff 1982) indicated that the population declined to 137 bears as the adult male segment was partially restored. The fact that there was no decrease in the average weights of bears during the postremoval period suggested that food was not in short supply at the higher densities. In another often cited black bear study, Jonkel and Cowan (1971) found evidence that a northwestern Montana bear population was regulated by a combination of nutritional factors which affected reproductive success, and intrinsic factors (adult male aggression) which influenced subadult dispersal.

Mechanisms by which adults could regulate, or at least limit to some degree, grizzly bear population densities include killing conspecifics; enforced eviction of subadults, females with cubs or other conspecifics from the more productive foraging habitats; and, repelling potential immigrants (Bunnell and Tait 1981, McCullough 1981, Stringham 1984). Reports of intraspecific mortality and theoretical advantages to adult bears from "prudent cannibalism" (Rogers 1978) were discussed in a previous section: also see discussions on hierarchies, territorial behavior and subadult dispersal. Stokes (1970) noted that the rise in cumulative stress levels associated with increased density and social intolerance can upset hormonal balances in the adrenal pituitary-gonad system. This can lead to reduced breeding and maternal care.

Population regulation by adult females has also been proposed in the literature. Examples of intraspecific mortality by adult females and maternal infanticide were previously discussed. Knight et al. (1985, 1986) suggested that maternally-induced infanticide could liberate a female from an energy deficit state under unfavorable conditions. They theorized that sex-specific infanticide could be expected under stressful conditions accompanying a population near carrying capacity. Because females are generally the key to determining population growth, killing female cubs would tend to reduce existing population pressures.

Tait's (1980) discussion of cub abandonment as a reproductive tactic in grizzly bears may have some theoretical bearing on the Knight et al. (1985, 1986) hypothesis. Tait (1980) found that under certain circumstances, females with a single cub might best enhance their individual fitness by abandoning the cub and entering a new reproductive cycle. As noted previously, Reynolds and Hechtel (1984) reported that 3 females which lost their cubs in early spring were available for reproduction soon thereafter. Both of the above reproductive tactics, maternal infanticide and abandoment, might provide mechanisms for females to tailor their reproductive investment according to prevailing nutritional and social context.

\section{Carrying Capacity}

Carrying capacity, K, may be defined as the density of organisms at which the net reproductive rate (average number of offspring produced by an organism during its entire lifetime) equals 1 and the intrinsic rate of increase of a population equals 0 . At densities below $\mathrm{K}$, the population grows and at densities greater than $\mathrm{K}$ declines (Pianka 1978). Grizzly bears show characteristics typical of strongly K-selected species (Cowan et al. 1974).

In the conterminous United States, recovery goals for the grizzly bear have been established to maintain at least a minimum viable population, MVP, within each ecosystem. However, estimates of the carrying capacity for these ecosystems are needed to determine if the area within each delineated recovery zone is sufficiently large to sustain an MVP (Edge 1985, Servheen 1986).

Edge (1985) discussed the concept of carring capacity as it pertained to grizzly bears and suggested approaches for determining $\mathrm{K}$. He noted that habitat quality was the ultimate factor determining grizzly bear carrying capacity. Habitat quality depends, in turn, on the quality, quantity and distribution of foods; the juxtaposition of cover; and, human-related disturbance factors. Edge (1985) considered 3 potential approaches for estimating qrizzly bear carrying capacity. He felt that the present knowledge of grizzly bear nutrition was insufficient for constructing a nutritionbased carrying capacity model as has been done with ungulates. An estimate based on the rate of subadult male 
dispersal was also rejected due to uncertainty of how dispersal related to carrying capacity. Edge (1985) concluded that an index based on the mean home range size and degree of overlap for adult females was the most promising approach. Potential problems with this method included obtaining adequately large samples representative of an entire ecosystem and selection of an appropriate home range model. This technique is discussed in greater detail in Edge (1985). 


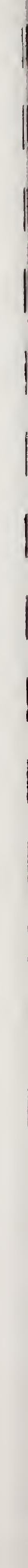




\section{PARASITES, DISEASES AND OTHER NATURAL MORTALITY FACTORS}

\section{DISEASES}

Researchers have substantiated the susceptibility of grizzly bears to Brucellosis in both field studies and experimental investigations. Neiland (1975) and Zarnke (1983) found serologic signs of ex posure to rangiferine brucellosis in bears preying or scavenging on caribou herds in Alaska. Experimentally, grizzlies have been contaminated with Brucella suis (type 4) via food rations (Neiland 1979). Whether or not rangiferine brucellosis adversely affects bears is unknown, but it is suspected to impact reproduction as in other species (Neiland and Miller 1979).

Also bacterial in nature, Leptospirosis is less well understood. In Alaskan grizzlies, Zarnke's (1983) research indicated a prevalence in older animals suggesting that the probability of previous exposure is directly related to age. The kidney and reproductive tract infections, known to result in moose and caribou, could also pertain to bears, however, additional research is needed to substantiate this effect.

Several other infectious diseases are reported to occur in grizzly bears: Clostridium (Williamson et al. 1965), Toxoplasmosis, canine distemper, and rabies (Fowler and Theobald 1978). In addition, researchers have reported incidences of noninfectious diseases such as neoplasms (Moulton 1960, Wallach 1978) and hypothyroidism (Russell 1970). While some research has been conducted on these illnesses, further information is needed on their prevalence and impacts, if any, on natural populations.

\section{PARASITES}

\section{Endoparasites}

Of public health and bear management concern is the occurrence of Trichinella in grizzly populations. In most studies, researchers have recorded infestations in over $50 \%$ of bear populations (Pearson 1968b, Choquette et al. 1969, Greer 1969-1972b, 1974, 1975, 1976a-1980, 1982-1983, Ott 1984, Greer 1985). Maintained through ingestion of infected meat via cannibalism and scavenging (Worley et al. 1974), encysted $T$. spiralis have been found in consistently high concentrations in the tongue, masseter, diaphragm and femoral muscles of grizzlies (Ott 1984). With larval densities surpassing those considered lethal to humans, Ott (1984) suggests that infestations could be sufficient to affect the nervous system and possibly cause abnormal behavior in bears.

Baylisascaris spp. have been established as the grizzlies' most common intestinal parasites (Browne 1962, Pearson 1968b, Choquette et al. 1969, Greer 1969-71, 1974, 1975, 1978, Wallach 1978). The apparent loss of these intestinal parasites each year before denning and the reinfestation upon emergence in spring is believed to be due to dietary changes (Mundy 1963, Choquette et al. 1969, Mundy and Flook 1973).

Although not as frequently, grizzly bears are susceptible to several other nematode genera, as well as 2 cestode genera (Table 13). In addition, Wallach (1968) and Greer (1972) cite occurrences of intestinal flukes, but these trematodes are considered rare parasites of grizzlies.

\section{Ectoparasites}

Grizzly bears are relatively free of ectoparasites being host to only 2 genera of fleas: Chaetopsylla (Holland 1949, Pearson 1968b, Worley 1976) and Arctopsylla (Browne 1962, Greer 1969), as well as 1 tick species: Dermacenter andersoni (Rogers and Rogers 1976).

Table 13. Nematode and Cestode parasites of the grizzly bear.

\begin{tabular}{|c|c|c|}
\hline Class & Genus & Citation (s) \\
\hline \multirow[t]{4}{*}{ Nematoda } & Ancylostoma & Wallach 1978 \\
\hline & Dochmoides & $\begin{array}{l}\text { Pearson } 1968 \\
\text { Choquette et al. } 1969\end{array}$ \\
\hline & Dirofilaria & $\begin{array}{l}\text { Pearson } 1968 \\
\text { Choquette et al. } 1969 \\
\text { Greer } 1974 \\
\text { Craighead and Mitchell } 1982\end{array}$ \\
\hline & Urcinari & $\begin{array}{l}\text { Browne } 1962 \\
\text { Greer } 1970,1971,1974 \\
\text { Craighead and Mitchell } 1982\end{array}$ \\
\hline \multirow[t]{2}{*}{ Cestoda } & Taenia & $\begin{array}{l}\text { Mundy } 1963 \\
\text { Pearson } 1968 \\
\text { Greer } 1971,1972,1974,1975 \\
\text { Wallach } 1978 \\
\text { Craighead and Mitchell } 1982 \\
\end{array}$ \\
\hline & Diphyllobothrium & $\begin{array}{l}\text { Mundy } 1963 \\
\text { Pearson } 1968 \\
\text { Choquette et al. } 1969 \\
\text { Greer 1970,1971,1972 } \\
\end{array}$ \\
\hline
\end{tabular}

\section{OTHER NATURAL MORTALITY FACTORS}

\section{Predation/Cannibalism}

According to Archibald (1983), mortality of grizzly bears through predation is attributable almost exclusively to conspecifics. While large male predation upon smaller individuals is most frequently observed (Reynolds 1978, Reynolds and Hechtel 1982, Nagy et al. 1983a, 1983b), Knight et al. (1978) documented cannibalism within a litter of cubs that had been abandoned. Mundy and Flook (1973) proposed that the frequency of this behavior may be a function of population density. Consequently, decreasing habitat could cause cannibalism to become even more prevalent. 


\section{Malnutrition}

As Reynolds and Hechtel (1982) point out, cubs of the year sustain the highest mortality rate with the loss of entire litters being common. In fact, Nagy et al. (1983b) reported cub mortality to be as high as $75 \%$ in parts of Canada. Because the majority of these deaths occur during denning or within 1 to 4 weeks of emergence, researchers believe the primary agent to be malnutrition (Roop 1980a, Nagy et al. 1983b, Roop 1983, Knight et al. 1985). Once past the second year, mortality drops to $25 \%$ (Nagy et al. 1983b). In adults, nutritionally-related deaths become almost neg- ligible (Martinka 1970, Herrero 1982) with the exception of reproducing females in areas, or periods, of low habitat productivity (Knight et al. 1986).

\section{Accidental Deaths}

In addition to disease, diet and predation factors, occasional accounts of accidental deaths for all age classes have been recorded (Kolz et al. 1978, Nagy et al. 1983b). However, the rarity of these observations indicates their minor role in population dynamics. 


\section{INTERSPECIFIC RELATIONSHIPS}

\section{IMPACTS FROM LIVESTOCK AND OTHER AGRICULTURAL IMPACTS}

\section{Types of Impacts/Relationships}

Impacts to grizzly bears from agriculture and livestock could be categorized into 5 classes:

1. Direct loss: mortality or loss of grizzly bears through control actions, relocations and illegal kills associated with livestock allotments, ranching or farming operations.

2. Indirect loss: habituation of grizzly bears to human activity following attraction to livestock, livestock carrion, crops, etc., predisposing them to nuisance behavior elsewhere.

3. Habitat loss or modification due to grazing or other agricultural activity.

4. Displacement (temporally or spatially) away from agricultural activity.

5. Direct competition with livestock for preferred forage species.

\section{General}

Storer and Tevis (1955) and Brown (1985) discussed the "undeclared war" between early stockmen and the grizzly in California and the southwestern U.S. Intensive campaigns of hunting, trapping and poisoning culminated in the bear's eventual extinction from those regions. Conflicts with livestock were also a major factor in the decimation on the grizzly population in Mexico (Koford 1968, 1969, Leopold 1967).

Table 14 lists some of the reports which documented control actions as a direct result of conflicts with livestock or other agricultural activity. The "control kill" column includes losses from both authorized personnel and private individuals. Mortality data in the literature often lumped all "control losses" without specifying the number lost to each type of offense. In these cases, a "check" in Table 14 was used to indicate that some mortality was due to agricultural conflict but the number of bears involved could not be determined. No attempt was made to identify instances of mortality cited in that report, thus the data in Table 14 can not be used to calculate the cumulative mortality due to agricultural conflict. These data are presented merely to give a rough idea of the magnitude of agricultural impacts on the grizzly bear.

\section{Livestock-Related Impacts}

Thier and Sizemore (1981) analyzed grizzly bear relocation data from the NCDE from 1975-80. They found that livestock depredation was significantly the most common offense for which a bear was relocated. Furthermore, these relocations were significantly less "successful" (i.e., success being no return and no further conflict) than relocations after other offenses. Mace et al. (in prep) also analyzed grizzly bear relocations in the Northern Continental
Divide Ecosystem and found that $44 \%$ of the relocations resulted directly from livestock depredations. Knight and Judd (1983) calculated that, dependent on which mortality and population estimates they employed, from $1.5 \%$ to $20 \%$ of the entire YGBE grizzly bear population may have been lost due to livestock conflicts in 1976-77. Lee and Weaver (1981) estimated that $10 \%$ of the YGBE population may have been lost due to livestock related conflict on the Targhee National Forest alone during 1960-1979. However, Burns (1986) noted that the pre-1980 livestock related grizzly mortality statistics were based largely grazing reports filed annually by grazing permittees and may not have accurately portrayed the actual losses. He reported only 1 grizzly bear mortality on a Targhee National Forest grazing allotment for the 1980-84 period.

Knight et al. (1985) reported that depredations (livestock and property) were the leading cause of nonhunting mortality in the NCDE from 1975 to 1984 . Eighty-nine percent of these mortalities specifically involved sheep depredations. Aune and Stivers (1983) reported that from 1977 1982, 5 grizzly bears on their Rocky Mountain East Front study area were known to prey on sheep; all 5 were subsequently killed.

Unreported grizzly bear mortality related to livestock operations may be a significant part of the overall mortality. Jorgensen (1979) reported that only $41 \%$ and $17 \%$ of known bear kills in 1976 and 1977, respectively, were ever reported. Griffel (1978) likewise found that some herders were either incommunicative or provided erroneous information concerning depredations. Knight and Judd (1983) noted that the grizzly's threatened status under the Endangered Species Act may have contributed to this problem. Stockmen, cognizant of the stiff penalties for poaching a grizzly and dissatisfied with the preferred policy to relocate rather than dispatch a depredating bear (Anonymous 1979, USFS 1985e), may be more reluctant to report depredation conflicts than before listing. Other stockmen may be inclined to inflate the extent of their depredation loss although losses due to other factors, such as poor herding practices, may greatly exceed predator loss (Griffel 1982).

One critical question is whether or not some bears can peacefully coexist with livestock without serious depredation conflicts. Traditionally, many stockmen felt that all bears were livestock-killers and should be eliminated from grazing allotments and ranches (Griffel 1978, Schallenberger and Jonkel 1980). Knight and Judd (1983) reported that all instrumented bears (except 1 orphaned cub) that came into contact with sheep killed them. However, Claar et. al. (in press) found that only 2 of 20 marked grizzly bears in the Mission Mountains (NCDE) were involved in sheep depredations although almost all were in proximity to livestock during spring and fall. Several investigations observed that depredation behavior was apparently a learned process (Johnson and Griffel 1982, Jorgensen 1983, Knight and Judd 1983). This may account for some of the regional differences in depredation as might the previous level of control (Johnson and Griffel 1982).

Hunter and Gunson (1980) and Gunson et al. (1985) documented livestock-related grizzly bear mortalities in Alberta. Nielson (1975) and McCrory and Herrero (1982) discussed the historical conflict between agricultural activ- 
Table 14. References which documented agriculturally-related depredation and control actions. Numbers in control columns indicate number of grizzly bears involved in that category of control action.

\begin{tabular}{|c|c|c|c|c|c|c|c|c|}
\hline \multirow[b]{2}{*}{ Ecosystem, Area and Citation } & \multicolumn{3}{|c|}{ Livestock } & \multirow[b]{2}{*}{$\begin{array}{l}\text { Property } \\
\text { Depred. }\end{array}$} & \multicolumn{3}{|c|}{ Control } & \multirow[b]{2}{*}{ Comments } \\
\hline & sheep & cattle & $\begin{array}{c}\text { other or } \\
\text { unspecified }\end{array}$ & & Kill & Reloc. & $\begin{array}{l}\text { Capture, } \\
\text { Release } \\
\text { or other }\end{array}$ & \\
\hline \multicolumn{9}{|l|}{ Yellowstone } \\
\hline Knight and Judd (1985) & $\mathbf{x}$ & $\mathbf{x}$ & horse & & 22 & & & data for $1970-75$ \\
\hline \multicolumn{9}{|l|}{ Targhee Natl. Forest } \\
\hline $\begin{array}{l}\text { Griffel (1976) } \\
\text { Griffel (1977) } \\
\text { Griffel (1978) } \\
\text { Jorgensen (1979) } \\
\text { Lee and Weaver (1981) } \\
\text { Griffel (1982) } \\
\text { Johnson and Griffel (1982) } \\
\text { Franklin and Matejko (1983) } \\
\text { (Island Park) } \\
\text { Jorgensen (1983) } \\
\text { Matejko and Franklin (1983) } \\
\text { Matejko (1985) }\end{array}$ & $\begin{array}{l}\mathbf{x} \\
\mathbf{x} \\
\mathbf{x} \\
\mathrm{x} \\
\mathrm{x} \\
\mathrm{x} \\
\mathrm{x} \\
\mathrm{x} \\
\mathrm{x} \\
\mathrm{x} \\
\mathrm{x}\end{array}$ & $\mathbf{x}$ & $\mathbf{x}$ & $\mathbf{x}$ & $\begin{array}{c}\mathbf{x} \\
19 \\
7\end{array}$ & $\begin{array}{l}3 \\
\\
3 \\
6 \\
\end{array}$ & $\begin{array}{l}4 \\
\mathrm{x} \\
\mathrm{x} \\
3 \\
\end{array}$ & data for $1976-77$ \\
\hline \multicolumn{9}{|l|}{ Northern Continental Divide } \\
\hline $\begin{array}{l}\text { Flathead Indian Reservation } \\
\text { Frost (1985) } \\
\text { Claar et al. (in press) }\end{array}$ & & & $\begin{array}{l}\mathbf{x} \\
\mathbf{x}\end{array}$ & $\mathbf{x}$ & $\mathbf{x}$ & 2 & & \\
\hline \multicolumn{9}{|l|}{ Rocky Mountain East Front } \\
\hline $\begin{array}{l}\text { General (location not specified) } \\
\text { Anon. }(1942) \\
\text { Brown }(1959) \\
\text { Brown }(1960) \\
\text { Brown }(1960) \\
\text { Greer }(1970,1971,1976,1979 \\
\quad 1980,1981,1982,1983) \\
\end{array}$ & $\begin{array}{l}\mathbf{x} \\
\mathbf{x} \\
\mathbf{x}\end{array}$ & $\begin{array}{l}\mathbf{x} \\
\mathbf{x} \\
\mathbf{x}\end{array}$ & $\begin{array}{l}\text { goat } \\
\mathbf{x} \\
\text { swine } \\
\mathrm{x}\end{array}$ & $\mathbf{x}$ & $\begin{array}{l}\mathbf{x} \\
\mathbf{x} \\
\mathbf{x}\end{array}$ & $\mathbf{x}$ & & $\begin{array}{l}\text { control not specified } \\
\text { control not specified }\end{array}$ \\
\hline $\begin{array}{l}\text { Alberta } \\
\text { Hunter and Gunson (1980) } \\
\text { Gunson et al. (1985) }\end{array}$ & $\begin{array}{l}\mathbf{x} \\
\mathbf{x} \\
\end{array}$ & $\mathbf{x}$ & & $\mathrm{x}$ & $\begin{array}{c}x \\
25 \\
\end{array}$ & $\mathbf{x}$ & & $\begin{array}{l}\text { data for } 1970-79 \\
\text { data for } 1972\end{array}$ \\
\hline $\begin{array}{l}\text { Alaska } \\
\text { Kodiak/Admirlty Islands } \\
\text { Eide (1965) }\end{array}$ & & $\mathbf{x}$ & & & 19 & & & \\
\hline $\begin{array}{l}\text { General } \\
\text { Lentfer (1965) } \\
\text { Lentfer (1966) } \\
\text { Lentfer (1967) } \\
\text { Lentfer (1968) }\end{array}$ & & $\begin{array}{l}\mathbf{x} \\
\mathbf{x} \\
\mathbf{x} \\
\mathbf{x}\end{array}$ & & & $\begin{array}{c}8 \\
8+ \\
5 \\
10\end{array}$ & & & \\
\hline
\end{tabular}

ity and grizzly bears in Alberta. Horejsi (1986) noted that the expansion of agricultural activity in prime grizzly bear habitat in Alberta posed a serious threat to these bear populations. This threat was multi-faceted, involving land clearing, permanent inhabitations and demand for stock protection from predators.

Griffel and Basile (1981) and Murie (1948) discussed means to identify livestock kills by bears. Jorgensen (1979) reviewed the literature on grizzly predatory techniques. Unfortunately, even when a confirmed grizzly predation has occurred, the culprit bear may still be difficult to identify. Since bears are fairly easy to capture around sheep carcasses, many control kills and relocations may handle innocent bears (Griffel 1978, Jorgensen 1983). Thus, even though some individual grizzlies may be capable of coexisting with livestock, it is evident that few bears can coexist with the livestock/human complex.

Most livestock depredation incidents in the contiguous United States involve sheep, although some grizzlies will prey on cattle (Lee and Weaver 1981, Knight and Judd 1983). Cattle depredation was traditionally a major problem on Kodiak Island, Alaska (Eide 1965). The larger size of the Kodiak brown bears undoubtedly accounts for much of the difference. Knight and Judd (1983) noted that all 4 grizzlies which killed adult cattle in their study were adult males, although 2 sows did prey on calves. Cattle depredation may also be less detectable than sheep depredation because cattle are not generally herded as closely as sheep nor are they checked as frequently (Knight and Judd 1983). 
Grizzlies also feed on livestock carcasses either scattered on rangeland or dropped in "boneyards" by ranchers (Servheen et al. 1981, Aune and Stivers 1983). Claar et. al. (in press) suggested that historically the grizzly/human relationship was partially symbiotic as bears ate livestock carrion and ranchers benefitted from carcass removal. In the NCDE, bear use of boneyards is greatest in spring and many provide a valuable food resource when other foods are scarce prior to spring green-up (Schallenberger and Jonkel 1980, Servheen 1981). There is disagreement in the literature concerning whether or not grizzly use of livestock carrion may lead to active depredation of live animals. It is generally accepted, however, that improperly situated boneyards may function much like garbage dumps and attract grizzlies to areas near human habitation where they are increasingly vulnerable (Schallenberger and Jonkel 1980, Servheen et al. 1981, Aune and Stivers 1983).

Direct competition for forage between grizzlies and livestock was discussed in a number of reports. Jorgensen (1979, 1983) developed a "competition index" to identify food plants for which bears and sheep might compete. Twenty-four of the 31 plant groups she examined had a "potential" for competition (i.e., both bears and sheep consumed the plant). Competiton was likely to be greatest in the spring when succulent, palatable vegetation was least available and concentrated in particular areas. Most of Jorgensen's data pertained to black bears, however, and she noted that sheep competition with grizzlies would probably be less than sheep competition with black bears (Jorgensen 1979).

Schallenberger (1976) noted that cattle appeared to compete directly with grizzly bears for forage on more mesic sites. Competiton with sheep for certain forb and shrub species was also possible, particularly if the sheep were loosely herded and allowed to concentrate on moist areas. Based on U.S. Forest Service ratings of desirable range plants, he listed forage species for which grizzlies and livestock might compete. He did not provide quantitative data on livestock forage items.

Summerfield (1978) felt that there was little competition for food between grizzly bears and cattle in part of the Idaho Panhandle National Forest. He attributed this to spatial and temporal segregation and the grizzlies broad food base. He also reported that competiton for cover was unlikely. Davis (1986) reported that most herbaceous grizzly bear foods were also listed as forage plants for domestic livestock (taken from U.S. Forest Service data).

Perhaps the most extensive analysis of grizzly bearlivestock forage competition was undertaken by Aune for the Rocky Mountain East Front area in northern Montana (Aune and Stivers 1983,1985, Aune et. al. 1984). Aune et. al (1984) found that over $50 \%$ of 1379 grizzly bear radio locations occurred on areas where the predominant land use was livestock grazing. Aune (1985) compared the food habits and habitat use of grizzly bears and cattle along the Rocky Mountain East Front. He found that 2 species commonly shared 6 habitat components with the riparian component being used most commonly by both. A food habits comparison (using fecal analysis) showed some degree of overlap in the diets of cattle and grizzly bears. A use:availability analysis of 3 preferred habitat components of grizzly bears showed no significant difference in the use of grazed versus ungrazed components. However, Aune noted that numerous years trampling and overgraz- ing in riparian areas actually reduced the diversity of plant species and increased the abundance of low-palatibility species. Cattle browsing on aspen suckers potentially threatened the aspen community on his study area and caused a subsequent loss of the palatible forb understory.

Lee and Jonkel (1980) reported that intensive livestock grazing, primarily cattle, had induced significant modification of the riparian vegetation within portions of the Pine and Antelope Butte wetlands (NCDE). Soil compaction by livestock had resulted in predestaling and puddling in some areas. They also noted that major shifts in species composition of trampled areas (fewer succulent forbs and perennial graminoids) could render the wetlands less desirable as bear habitat. Other researchers have also commented on the effects of livestock trampling (Schallenberger 1976, Aune and Stivers 1983, Jorgensen 1983).

\section{Other (Non-Livestock) Agricultural Impacts}

Most of the data in the literature concerning nonlivestock agricultural impacts pertains to control kills of nuisance or depredating grizzlies. Reports which specifically mentioned agriculturally related control actions are indicated in Table 14. The particular attractant which lead to complaints of confrontation was not usually specified.

Hunter and Gunson (1980) reported that 24 of 137 grizzly bear complaints in Alberta (1970-1979) were from farms. A recent survey of residents in the Mission Valley (NCDE) indicated that of 30 respondents who had experienced some "problem" with grizzly bears, 5 reported damage to fruit and orchards and another 4 reported damage to fences, buildings, etc.

The most common non-livestock attractants leading to control actions were apparently apiaries and fruit orchards. Schallenberger and Jonkel (1980) reported that many of the a piaries along the Rocky Mountain East Front were situated in riparian habitats where the potential for grizzly encounters was greatest. Few apiaries were equipped with deterrent devices. Agricultural depredations may increase dramatically in years when there is a shortage of natural foods. Knight et. al. (1982) reported that 6 grizzly bears were relocated from a single fruit orchard following a year with low winterkill, poor pine-nut crop and low rainfall.

Lee and Jonkel (1980) discussed the impact on grizzly habitat greatly from the development of water resources in the Pine Butte wetlands. They found that old irrigation systems had a marked effect on adjacent plant communities and on the occurrence of hydrophillic plants in drained areas.

\section{INDUSTRIAL IMPACTS}

The 2 industrial activities (excluding timber extraction) of foremost concern to grizzly bear management are hydrocarbon exploration and development, as well as hydroelectric development. Mining activities and geothermal development are important in certain areas but there is little literature on impacts of these activities.

Potential impacts common to these types of industrial activities include: 
1. Construction or upgrading of roads providing increased access into grizzly bear habitat and consequent escalation of human activities (e.g., hunting, recreation) in both frontcountry and backcountry areas. (The impacts associated with road construction were covered in another section. It is assumed that the general conclusions regarding road impacts apply regardless of the purpose for which a road was constructed).

2. Increased human activity related directly to project construction or maintenance.

3. Increased availability of artificial attractants (especially garbage) and possibly increased legal and illegal grizzly bear mortality due to both of the above.

4. Possible displacement or disruption of normal behavior patterns (including denning, movements and habitat use) due to increased human activity, construction, operation of industrial equipment or habitat modification.

5. Direct habitat loss due to road construction, buildings, etc. or, with regards to hydroelectric development, more extensive habitat loss from impoundments.

6. Increased aircraft disturbance. (Aircraft impacts are discussed in a seperate section although grizzly bear reactions to aircraft, especially to seismic helicopters, were frequently mentioned in the industrial-related literature.)

7. Physiological disturbance/arousal not accompanied by overt behavioral response.

\section{Hydrocarbon Exploration and Development}

\section{Overview of Impacts and Magnitude of the Problem}

M. Bromley (1985) discussed the general sequence of operations and types of activities related to oil and gas exploration and development. These may be divided into 5 main phases;

1. preliminary exploration - including seismic testing

2. exploratory drilling - including construction of temporary access roads, preparation of well-site, provisions for water and drilling

3. development - including drilling facilities, wellhead and pumping equipment, storage facilities, treatment facilities, disposal facilities, construction of adequate road network and electric transmission lines communication

4. production

5. reclamation or abandonment - restoration of impacted area to pre-disturbance or improved status.

The impacts to wildlife vary by each phase and may be largely site-specific (M. Bromley 1985).
Nielson (1975) reviewed the status of the plains and boreal forest grizzly bear in Alberta. She concluded that development of oil fields in the Swan Hills region was largely responsible for the $50 \%$ reduction in the grizzly bear population from the early 1950 s to the mid 1970 s. The rapid influx of seismic and construction crews, the establishment of over 100 "bush camps" and the building of an extensive road network into previously inaccessible areas were the primary factors. Improperly handled garbage attracted grizzlies to the camps where they were easy targets for camp workers.

Nagy and Russell (1978) also noted that petrochemical exploration and development was one of the most important economic factors affecting the Swan Hills area. The "labyrinth" of oil field roads related to this development provided nearly complete access into Swan Hills grizzly bear habitat. Hunter and Gunson (1980) reported that $20 \%$ of the grizzly bear complaints in Alberta from 1970-79 were industry-related (including complaints from oil rig sites, construction units and logging camps).

Oil and gas development during the last $15-20$ years has had a significant impact on certain populations of the barren-ground grizzly bear in Arctic Canada. The combined impacts of seismographic testing, temporary and permanent construction camps, airstrips, communication towers, drilling rigs, extensive road networks, generating plants and related construction activities have influenced grizzly bear distribution around the Tuktoyoktuk Peninsula and Richards Island, Northwest Territories (Nagy et al. 1983b). Hunting was considered to be the most severe impact in both of these areas.

Spurned by highly productive oil and gas fields in similar geologic formations in Alberta, Utah and Wyoming hydrocarbon exploration activity in the overthrust belt of Montana has escalated significantly. As of 1977, lease applications for oil and gas development had been filed for greater than 404,858 ha of federal and other land with federal subsurface rights. Some of these leases have been filed within occupied grizzly bear habitat (Schallenberger 1980). Oil and gas exploration and development combined with the effects of associated roads, recreational use and construction activity constitute a major disturbance factor for grizzly bears along portions of the Rocky Mountain East Front (Lee and Jonkel 1980, Schallenberger 1980). A recent environmental assessment for a proposed drilling site in the area included the following observation:

"Common to all concerns about the effect of oil and gas activities on wildlife behavior, is our limited capability to predict effects before activity begins. Oil and gas activities in ecosystems like those in the study area are a fairly recent development." (U.S. Forest Service and Bureau of Land Management 1985).

\section{Impacts of Seismic Testing and Drilling}

McLellan and Mace (1985) studied the reaction of 11 different grizzly bears of various age and 6 classes to several types of seismic disturbances including crews stringing cable, helicopters stringing cable, tracked vehicles drilling shot holes and seismic blasting. Reactions to 3 instances of on-ground activity varied greatly. Several bears moved nearer to the activity site (including 1 male which moved within $100 \mathrm{~m}$ of ongoing blasting) while others ventured nearer and then left the area. Based on 7 
observations of 5 bears, the authors concluded that there was no indication of avoidance of seismic activity.

In another case, the reactions of 4 bears to drilling and blasting and heavy helicopter traffic near preferred foraging habitat were studied (1985) Mclellan and Mace. All 4 bears used the area within $500 \mathrm{~m}$ of the seismic line less than when there was no disturbance. A female with 2 cubs avoided the $500 \mathrm{~m}$ zone during the disturbance but seemed to be relatively undisturbed by the helicopter traffic 1000 $2000 \mathrm{~m}$ distant. Although the investigators concluded that disturbance from seismic activity was evident within the $500 \mathrm{~m}$ zone, they noted that 3 difficulties arose in in terpreting these data. These are:

1. distinguishing between "natural" movements (e.g., to better foraging areas) and seismicinfluenced movements was not easy,

2. it was difficult to determine the distance at which bears could see or hear the stimuli and

3. those bears with the strongest escape reaction might be overlooked because they fled from initial disturbances before monitoring began.

Aune (1984) and Aune et. al. (1984) studied the responses of grizzly bears along the Rocky Mountain East Front to seismic testing. They concluded that grizzlies did appear to distribute themselves temporally and spatially to avoid seismic activity. Mean distances of bear relocations to the nearest active seismic line was 9.7 and $8.1 \mathrm{~km}$ in 1983 and 1984, respectively. Similar to the grizzlies studied by McLellan and Mace (1985), individual bears differed significantly in their tolerance to seismic activity. Some bears showed minimal reaction to seismic activity or support helicopters; others vacated particular drainages while seismic blasting was taking palce. One subadult male tolerated seismic activity less than $3 / 4$ mile distant while he was involved in a series of sheep depredations (Aune et. al. 1984). An adult female demonstrated decreasing reactions to seismic blasting during the course of 4 exposures over $11 \frac{1}{2}$ months. After initially showing displacement reactions, by the third exposure she failed to abandon a choice foraging area while blasting was underway in the same drainage (Aune 1984). The use of motion sensing "activity collars" indicated that although some bears were not displaced by seismic testing they were temporarily agitated (Aune et. al. 1984).

Reynolds et. al. (1984) studied the physiological and behavioral responses of denning grizzly bears in the National Petroleum Reserve to seismic testing and related disturbances. Reactions were evaluated with the aid of collar-mounted temperature sensors and internal heartrate transmitters.

They found that although none of the radioed bears abandoned their dens due to seismic explosions or other activity, all showed some degree of agitation or movement within the den. Heart-rate monitors indicated that when seismic vehicles passed within $1 \mathrm{~km}$ of the den, the bear's heart-rate periodically reached $40 \mathrm{bpm}$ or greater (normal $12-32 \mathrm{bpm}$ ) much more often than when undisturbed. Reynolds and Hechtel (1980), referring to the same series of experiments, noted that agitation within the den could have serious consequences for females with newborn cubs. Geist (1978) discussed the bioenergetics of disturbance and noted that when an animal is excited, the en ergetic costs of increased metabolism and heart-rate can be significant. These costs must be added to the costs of locomotion, forfeited food intake and possible suboptimal habitat selection due to the disturbance.

Harding and Nagy (1980) found that grizzlies on Richards Island, Northwest Territories, often denned successfully within the general area of hydrocarbon activity. Of 35 dens which they located, 28 were within the potential impact area, including several within $1.6-6.4 \mathrm{~km}$ of active areas. Two dens were apparently disturbed and abandoned, 1 by a seismic vehicle and the other by a gravel mining operation.

\section{Impacts of Drill Sites and Other Site-Specific Activities}

Aune (1984) and Aune et al. (1982, 1983, 1984) studied the effects of drilling operations on the movements, home range and habitat use of grizzlies along the Rocky Mountain East Front. They compared the geometric activity centers (GAC's) of bears in consecutive pre- and postdisturbance years and found that grizzlies were not displaced from their seasonal ranges by drilling operations (Aune et al. 1983, 1984). Although seasonal GAC's did shift from 1 year to the next, these shifts were attributed to food availability, reproductive status and age/sex class. Grizzlies did appear to be temporarily displaced from areas immediately around active drill sites. For most bears, a minimum impact zone of about $0.8 \mathrm{~km}$ existed around active wells. This distance varied depending on the degree of habituation of individual bears and the cover and topography of the area. Grizzlies began to reuse the area around a drill site once human activity at the site tapered off (Aune et al.1984). Increased road construction was considered the most serious impact of oil and gas development in the area (Aune and Stivers 1983, Aune et al. 1984).

Harding and Nagy (1980) had similar results. They concluded that although grizzlies did not avoid the general area of industrial activity, they did avoid the area within 1 $\mathrm{km}$ of drill sites, camps, etc. Of 13-24 grizzlies in the area, only 6 ever entered the immediate area of industrial activity. They concluded that the grizzly population had apparently adapted to existing facilities. However, as new industrial activities were introduced to the island, the population might be jeopardized. Of greatest concern was the construction of new all-weather roads, disturbance of denning bears, marginal habitat loss and relocation of problem bears from construction camps.

\section{Hydroelectric Project Impacts}

Large scale hydroelectric projects involve a wide array of associated activities each of which have potential impact to grizzly populations. These activities include road and dam construction, water diversion projects, transmission line construction, vehicle and aircraft activity and in undation of suitable habitat. The impacts of hydroelectric projects are probably comparable to the impacts anticipated from other major construction activities.

\section{Impacts on Movements, Home Range and Habitat Use}

Miller and McAllister (1982) felt that 1 of the primary impacts of the proposed Susitna River hydroelectric projects on the brown bear was the interference with seasonal 
migrations which would result from lakes, access roads, borrow pits and other construction activities. Disruption of traditional movement corridors was also a suspected impact from 2 existing hydroelectric projects in northwestern Montana (Casey et al. 1984, Wood and Olsen 1984ab). Smith and Van Daele (1984) found no major disruption of interdrainage travel due to construction activities of the Terror Lake hydroelectric project (dams were still under construction at time of study).

As with hydrocarbon exploration and development, the impacts of hydroelectric construction activity varied by individual tolerance to disturbance. Overall, bear densities near major construction sites appeared fairly high during both years of the Terror Lake construction work (Smith and Van Daele 1984). During the 1982 field season, the home ranges of 16 (10 males and 6 females) bears intersected major construction activities. Bears were observed frequently by construction workers both years and certain bears appeared to be highly habituated to construction activity. Bears in 1 area appeared to show increased nocturnal activity patterns to avoid construction activity near a favored salmon fishing site (Smith and Van Daele 1984). There was some indication that grizzlies vacated particular drainages where construction was intense, but the impacts of comparable construction in different areas was largely site-specific and dependent on the mitigating influences of cover and topography. An impact zone of $3.5 \mathrm{~km}$ may have existed around the primary construction site at the Terror Lake dam. Overall, shifts in home range were subtle and there was no obvious correlation between home range size and construction intensity (Smith et. al 1984).

Transmission lines constructed during 1983 at the Terror Lake site may have exerted a stronger influence on bear distribution than more localized construction. At least 1 female was displaced from her traditional home range by construction of the line (Smith et al. 1984). Potential impact zones of $3.5 \mathrm{~km}$ and $1.5-2 \mathrm{~km}$ were postulated for 2 different transmission lines. Some bears may have been attracted to the cleared right-of-way beneath the lines for use as a travel corridor.

Miller and McAllister (1982) felt that disturbance of denning bears was another major impact to be expected from the proposed Susitna hydroelectric projects. Grizzlies near the Terror Lake project site denned at progressively higher elevations as construction escalated (Spencer and Hensel 1980, Smith and Van Daele 1984, Smith et al. 1984). However, the increased elevation was attributed to greater accuracy in identifying den locations rather than to displacement away from construction activity. No major den disturbances were reported for 1982-83; but in 1983-84, 1 female was definitely routed from her den and another male may have been disturbed.

The inundation of extensive areas of suitable riparian and lowland habitat is another significant impact of hydroelectric development. Specser and Hensel (1980) predicted that flooding of the 200 ha (500 acre) foraging area on the floor of the Terror River Valley and possible inundation of adjacent subalpine habitat and cover areas would be a major impact on resident brown bears. In the Susitna Valley, proposed flooding of important lowland habitats which provide early spring forage and over-wintering berries was potentially a major impact of hydroelectric development (Miller and McAllister 1982). Loss of key riparian and shrub habitats was regarded as the primary impact of
4 hydroelectric projects in northwestern Montana (Casey et al. 1984, Wood and Olsen 1984,1984ab, Yde and Olsen 1984).

Additional impacts associated with hydroelectric development include disruption of salmon spawning and brown bear feeding due to water diversions, obstruction or siltation (Miller and McAllister 1982, Miller 1983, Smith and Van Daele 1984, Smith et al. 1984); possible disruption of social mechanisms as bear distribution changes (Spencer and Hensel 1980, Casey et al. 1984); localized climatic effects from major impoundments (Miller and McAllister 1982) and reduction of ungulate prey base (Miller and McAllister 1982).

\section{Impacts of Industrial Camps}

When large temporary or permanent maintenence or construction camps are established, another factor is added to the issue of industrial impacts. Follman et. al. (1980) described the problems between grizzly bears and humans during construction of the Trans-Alaskan Pipeline System (TAPS). Grizzly bears were involved in 69 of 245 animal problems reported from 1971-79. Most concerned grizzlies lured to dumps or camps by available garbage or handouts. Contributing factors included placement of some camps in prime bear habitat and early habituation of some freeloading grizzlies. Thirteen grizzlies were killed and another 12 translocated during TAPS construction.

Miller and McAllister (1982) noted that the increase in human activity at the proposed Susitna hydroelectric project could lead to greater disturbance of brown bears and a rise in bear mortality due to hunter kills, defense kills and control actions. At the Terror Lake hydroelectric project, peek occupancy of construction camps was 480 people in 1983 (Smith et al. 1984). Although the authors found that garbage was improperly stored at some sites during both years of construction no direct mortality due to control actions was reported (Smith and Van Daele 1984, Smith et. al. 1984).

\section{Geothermal Leasing}

Geothermal development is a relatively recent and localized phenomenon and consequently the literature base is weak. A U.S. Fish and Wildlife Service biological opinion on geothermal leasing (Duncan 1978) made the following conclusions:

1. impacts on the grizzly bear from geothermal activity would increase with each successive phase of development (e.g., exploration, shallow test holes, deep well)

2. impacts during the "casual use" phase would have minimal adverse impact on the grizzly bear

3. deep well drilling would require 3-5 miles of new or upgraded road for each drill site. Numbers of employees and facilities would also increase.

Although the resource being exploited differs, many of the impacts associated with hydrocarbon drilling could apply to geothermal activity. 


\section{ROAD AND HIGHWAY IMPACTS}

Problems associated with roads and increased road densities have had a major influence on grizzly bear populations and habitat use patterns in numerous, widespread areas (Tracy 1977, Elgmark 1978a, Schallenberger and Jonkel 1980, Jonkel et al. 1981, Brannon 1985). Lyon and Basile (1980) and Lyon (1984) discussed the general nature of road impacts on wildlife with particular reference to grizzly bears and ungulates. These impacts include lethal encounters, habitat modification and various stressrelated behavioral adaptations. Listed below are several types of impacts:

1. Increased access for humans into grizzly bear habitat. Consequences may include increased use of adjacent backcountry areas, settlement, introduction of artificial foods and attractants and additional mortality factors.

2. Use of roads, especially secondary roads, as grizzly bear travel corridors into developed areas.

3. Direct mortality from roadkills, legal and illegal harvest and other factors resulting from increased human-bear encounters.

4. Avoidance/displacement of grizzly bears away from roads and road activity.

5. Changes in grizzly bear behavior, especially habituation, due to ongoing contact with roads and road activity.

6. Habitat loss or modification due to roads and road construction, including vegetative and topographic disturbances.

\section{Mortality From Roads}

The most direct form of road-related mortality involves grizzly bears killed by vehicles (Knight et al 1981, 1986, Greer 1985, Palmiscano 1986, Burns 1986). However, most researchers have concluded that the effects of increased human access into bear habitat, particularly increased vulnerability to legal and illegal harvest, constitute the most critical impacts of road activity on the grizzly bear (Nagy and Russell 1978, Ruediger and Mealy 1978, Smith 1978, Schallenberger 1980, Zager 1980ab, McLellan and Mace 1985). McLellan and Mace (1985) found in their southeastern British Columbia study area, that a disproportionate number of grizzly bear mortalities occurred near roads. Of 11 known mortalities, 7 bears were definitely shot and 2 others may have been poached from roads. Dood et al. (1985) analyzed all Montana grizzly bear mortality data with known locations and found that $32 \%$ of all hunting mortality and $48 \%$ of all non-hunting mortality occurred within 1.0 mile of a road ( $n=170$ and 258 , respectively).

\section{Avoidance/Displacement by Roads}

$\checkmark$ Much of the literature on road impacts concerns avoidance/displacement of grizzlies from roads. Lloyd and Flect (1977) found that in southeastern British Columbia, grizzly bears avoided areas within 0.5 miles of roads. Along the Rocky Mountain East Front, grizzly bear observations near heavily travelled roads, including those which paralleled riparian areas, were markedly absent (Schallenberger and Jonkel 1980). Analysis of 408 radio relocations and 973 other grizzly observations showed that the mean distance to automobile roads and 4-wheel drive roads was 3.4 and $6.2 \mathrm{~km}$, respectively.' In a poor food year, these distances decreased suggesting that grizzlies compromised security factors when stressed by food shortages.

Aune et al. (1984) also studied the influence of roads on grizzly bear distribution in the Rocky Mountain East Front. They partitioned their relocation data ( $\mathrm{n}=1379$ relocations) into $500 \mathrm{~m}$ distance zones from the nearest road (e.g., 0-499 m, 500-999 m). The analysis indicated that in all 3 seasons, the zone nearest a road accounted for more relocations than any outlying zone. These results were potentially biased by the easy researcher access along the roads (leading to a disproportionate number of relocations collected from the roads), the high density of roads throughout the study area and the presence of habituated bears. The researchers observed that grizzlies whose home range included large tracts of wilderness were found within $1 \mathrm{~km}$ of roads only $29.3 \%$ of the time, whereas, bears whose home range lay in more heavily roaded areas were relocated within $1 \mathrm{~km}$ of a road $64 \%$ of the time.

Zager (1980ab) and Zager et al. (1983) evaluated grizzy use of habitat in logged and roaded areas in northeastern Montana. No overall avoidance of roads was evident in their analyses but this may have been a result of the high density of roads throughout their study area. They observed that logged areas were more likely to be used when located along secondary and closed roads than when located along primary roads. Females and females with cubs avoided habitat within 200 m of roads, whereas, males appeared to prefer habitat adjacent to roads. Zager (1980ab) attributed the latter result to extensive travelling by males.

Another study conducted in the Cabinet Mountains of northeastern Montana (Kasworm 1985) showed that the mean distance of grizzly bear relocations from open roads ( $2467 \mathrm{~m}$ ) was significantly greater than the mean distance to closed roads $(740 \mathrm{~m} ; \mathrm{p}<.001)$.

Three studies included use/availability analysis to evaluate the impacts of roads on grizzly bears. In southeastern British Columbia, grizzly bears used the area within $100 \mathrm{~m}$ of a road an average of $40 \%$ of the expected value in spring and $50 \%$ of the expected value in summer/fall (McLellan and Mace 1985). Beyond $100 \mathrm{~m}$ the displacement effect was minimal or absent. No differences were detected between the effects of primary, secondary and tertiary roads. Based on the total proportion of the study area which lay within $100 \mathrm{~m}$ of a road, the researchers calculated that $8.5 \%$ of the total area was "lost" to bears as a consequence of road avoidance.

Aune and Stivers (1985) performed a similar use/availability analysis for 385 grizzly bear relocations from the Pine Butte Preserve (NCDE). Bears were relocated within $500 \mathrm{~m}$ of an open road far less than expected. The number of relocations from $500-1000 \mathrm{~m}$ was about equal to the expected value and the number of relocations beyond 1000 $m$ exceeded the expected value. The apparent avoidance of roads within $0-500 \mathrm{~m}$ was especially noteworthy because $59.9 \%$ of the total area of the 3 most preferred habitat components occurred within this zone and most of the reloca- 
tion data were from road-habituated bears. The type of road was also important. Grizzly bear observations on jeep and field roads were common while use of primary roads was rare except when artificial attractants were available.

Brannon (1984) found that in Yellowstone National Park, grizzly bears avoided areas within $50 \mathrm{~m}$ of a road and used the area between 3.0 and $4.5 \mathrm{~km}$ more than expected. Computer-generated random points were compared to the distribution of bear relocations. ANOVA tests indicated that bear observations occurred at significantly greater distances than random grid points from most "zones of influence" (distance zones from roads).

Mattson et al. (in press) also analyzed the effects of roads on grizzly bear distribution and habitat use in Yellowstone National Park. They found that primary roads and developments were situated in the most productive grizzly bear habitat in the Park. On a "micro" analysis scale (0-1500 m), primary roads depressed bear use up to $600 \mathrm{~m}$ in the spring. The effect was somewhat less in the summer and absent in the fall. On a "macro" scale (0-15 km) deviation of observed from expected levels of bear use in zones paralleling roads was significant for all seasons, however, the pattern of this deviation varied markedly by season. Individual classes of bears were impacted differently by road presence. Subadult bears were disproportionately represented adjacent to roads, apparently displaced out of more secure zones by dominant bears. Habitat use patterns were also affected. Whereas grizzlies tended to occupy the most productive habitat in areas beyond the conceivable influence of roads, productivity of habitat occupied by grizzlies in zones proximal to roads was depressed below the average for the zones. Grizzly bear foraging strategies were disrupted out to approximately $2-5 \mathrm{~km}$ in spring and summer and out to 4 $\mathrm{km}$ during fall.

Bears in Denali National Park also seemed to prefer areas away from roads. A comparison of paired road and off-road study plots showed consistently higher bear densities in the off-road plots. Eighty-three percent of the bears which displayed a strong reaction to road activity were within $200 \mathrm{~m}$ of the road; $96 \%$ were within $400 \mathrm{~m}$ (Tracy 1977).

In addition to general avoidance, roads may sometimes influence normal movement patterns. Miller and Ballard (1982b) found that following translocation, the return movements of 3 sows with young in southcentral Alaska were delayed or deflected by a highway. A similar case was described for 2 translocated bears in the Yukon (Spredbury 1984). Jonkel et al. (1981) noted that interference with natural movements, especially along bear travel corridors, was a major impact of roads and highways in northern Montana. Some bears may utilize secondary roads as travel routes especially when off-road travel is impeded by slash of thick vegetation (Smith 1978). Movements along secondary or closed roads can potentially lead grizzlies into developed areas and increase the chances of undesirable bear-human encounters (Ruediger and Mealey 1978).

- Displacement of grizzly bears by road activity can be temporal as well as spatial. McLellan and Mace (1985) found that although there was no significant difference between day and night distances of bear relocations from roads, bears were found directly on roads more frequently at night $(9.8 \%$ of 41 relocations) than during the day $(0.6 \%$ of 1050 relocations). Zager (1980ab) in northwestern Mon- tana and Aune and Stivers (1985) in the Rocky Mountain East Front also found increased use of secondary roads at night.

\section{Factors Affecting Grizzly Bear Responses to Roads}

$\checkmark$ A number of factors may influence an individual bear's reaction to roads and road activity. These factors include age/sex class of the bear, type of area (remote vs. accessible), individual habituation to road-related stimuli, nature of the stimuli and character of the habitat adjacent to the road.

Some segments of the population may be influenced by the presence of roads more than others. Zager (1980ab) felt that avoidance of roads by females with cubs was a major concern. As noted previously, Miller and Ballard (1982b) found that in southcentral Alaska, roads interferred with the movements of sows with cubs. Smith (1978) observed that no family groups were seen along roads in his coastal British Columbia study area. In Denali National Park, some family groups appeared to be thoroughly habituated to tour bus travel along the major park roads while single bears seemed to be underrepresented in areas adjacent to roads (Tracy 1977). Another study in Denali indicated that males reacted to vehicles more frequently than did other groups. Some single bears and family groups fled from vehicles and others were habituated to raod activity (Stelmock 1981). Aune et al. (1984) found that subadult bears were displaced further away from roads than adults.

Bear populations in different areas show pronounced differences in their reactions and degree of habituation to road stimuli. Smith (1978) found that all grizzly bears in his remote study area displayed a strong escape reaction. McLellan and Mace (1985) noted that "local" bears (those customarily near human activity) reacted less strongly to road activity than "remote" bears. However, local bears in remote settings reacted more strongly than remote bears in remote settings. Some grizzlies in Denali National Park demonstrated a high level of habituation to road activity. In $1973 \cdot 74,78 \%$ of all grizzly bears observed from tour buses showed no reaction to the stimuli. This included $58 \%$ of the bears sighted within $200 \mathrm{~m}$ of the highway (Tracy 1977). By $1982-83$, the number of vehicles per day on the main Denali road had increased by $50 \%$ from the 1973-74 level while grizzly bear sightings declined $32 \%$ (Singer and Beattie in press). The researchers concluded that this decline reflected either displacement away from the road due to the increased activity or a major change in the grizzly bear population. Those bears which were seen in 1982-83 were seen closer to the road than in 1973-74 suggesting increased habituation by the remaining bears. Stelmock (1981) reported that the inten sity of grizzly bear reactions to vehicles along the Denali road generally decreased during the summer. This would seem to indicate that road habituation was partially a seasonal phenomenon.

Not all road-related disturbances result in the same response by grizzly bears. Those grizzlies in Denali which fled from vehicles showed increased flight distances after vehicle restrictions prohibiting passenger cars (as opposed to tour buses only) were lifted in the fall $(50.5 \mathrm{~m} \mathrm{vs} .95 .5 \mathrm{~m})$. The percent age of bears showing a flight response also increased slightly. Increasing numbers of vehicles present near a group of grizzlies also increased bear responses 
(Singer and Beattie in press). In the earlier Denali study, grizzlies demonstrated the same reaction to tour buses regardless of whether sightseers were on or off the bus (Tracy 1977). Loud noises were found to increase the degree of response (Tracy 1977, Stemlock 1981).

The character of the habitat adjacent to roads may influence grizzly bear reactions to road stimuli. McLellan and Mace (1985) observed that bears in direct view of vehicles generally fled but bears close to roads but yet in some $\checkmark$ protective cover were not affected. In northwestern Montana, grizzly bear use of logged areas adjacent to roads was largely dependent on the availability of cover including a well-developed shrub strata, leave trees and an undulating boundary for the logged area (Zager 1980ab). Conversely, grizzly bears in Denali National Park appeared to feel less secure when their view of the road was obscured by vegetation (Singer and Beattie in press).

\section{Habitat Modification Effects of Roads}

$\checkmark$ Vegetative disturbances associated with road construction have received less attention in the literature than the avoidance issue. Zager (1980ab) and Jonkel et. al. (1981) noted that road building could disrupt ground and surface water hydrology. Reseeding to present erosion may result in a substantial increase in forage (Nagy and Russell 1978, Ruediger and Mealey 1978) In Denali National Park, snow removal, road dust and modified drainage patterns along roads cause roadside vegetation to green-up somewhat before other areas. Hastened phenology of several favored forage species attracts grizzlies to road areas in late spring (Tracy 1977). Unfortunately, any advantages accrued from the additional foraging opportunities along roads are likely to be outweighed by the undesirable increase in bearhuman encounters.

\section{AIRCRAFT IMPACTS}

Numerous studies have documented the reactions of grizzly bears to aircraft disturbance. Quimby (1974) found that $67 \%$ of the grizzly bears in the Canning River drainage of northern Alaska reacted strongly to both fixed-wing aircraft and helicopters. Thirty-two were already fleeing when first spotted from the aircraft including 1 at 1.0 mile away and several at 0.5 miles. Eighteen percent of these bears ran a short distance and stopped. Klein (1974) found that grizzly bears reacted more severely to all types of aircraft than did ungulate species. Generally, there are 2 types of impacts. These are:

1. Possible displacement and/or disruption of normal behavior patterns (including denning, movements and habitat use) due to aircraft disturbance.

2. Physiological arousal without overt behavioral response.

\section{Helicopter Disturbance}

Grizzlies may be more sensitive to helicopter disturbance than to fixed-wing aircraft. In the Canning River study (Quimby 1974), 90\% of the grizzlies reacted moderately or strongly to helicopters while only $21 \%$ reacted strongly to fixed-wing aircraft. All of the most severe reactions were to helicopters. Grizzly bears on Richards Island, Northwest Territories, also reacted more strongly to helicopters than to fixed-wing aircraft (Harding and Nagy 1980). Bears showed a strong response (fled to cover) 61 and $88 \%$ of the time to fixed wing aircraft and helicopters, respectively.

Helicopters had been used in both of the above study areas to pursue and tranquilize grizzlies. Researchers in several areas found that grizzlies which had previously been captured or relocated using helicopters were particularly sensitive to helicopter disturbance (Harding and Nagy 1980, Eebhart 1983, Spreadbury 1984, Harding and Nagy 1980). However, grizzlies in some areas where helicopters had not been employed for this purpose also showed strong reactions (Hamer et al. 1979, Kendall 1985). In the Apgar area of Glacier National Park, $81 \%$ of the grizzlies displayed a strong reaction to an approaching helicopter despite the fact that scenic helicopter tour flights had been conducted in the area for several years (Kendall 1984b,1985). Individual bears in several areas demonstrated significantly different tolerances to helicopter disturbance (Lindermann 1974, Aune et al. 1984, McLellan and Mace 1984).

\section{Fixed-Wing Aircraft Disturbances}

Some grizzlies also showed strong escape reactions to fixed-wing aircraft. In Yellowstone National Park, both Graham (1978) and Peacock (1978) observed grizzlies which fled into timber as research tracking planes approached. Conversely, Schleyer (1980) reported that grizzlies which he radiotracked in Yellowstone were not disturbed by the research plane while they were in daybeds. Smith and Van Daele (1984) felt that use of small aircraft to spot schools of fish for commercial herring fisheries may have disrupted bear feeding in intertidal areas of Terror Bay, Alaska. McCourt et al. (1984) reported that grizzlies were more sensitive to disturbance by small fixed-wing aircraft than either caribou or moose. However, Campbell (1985) observed that $54.5 \%$ of the grizzlies seen from a small plane showed no response while only $29 \%$ showed a severe response. McLellan and Mace (1985) similarly found that 15 of 20 grizzlies observed from the air showed no reaction to the aircraft; the remaining 5 ran to cover.

\section{Factors Influencing Grizzly Bear Reactions to Aircraft}

Many researchers emphasized the wide variability in grizzly bear reactions to aircraft. Factors which may be important include the degree of habituation to aircraft (Harding and Nagy 1980, Gebhart 1982, Reynolds et al. 1984, Kendall 1985); availability of cover (Klein 1974, Lindermann 1974, Aune et al. 1984, Spreadbury 1984) and altitude, noise level and behavior of the aircraft (Lindermann 1974, McLellan and Mace 1980, Gebhart 1982, Reynolds et al. 1984). McCourt et al. (1974) found that there was no consistent trend in grizzly bear reaction to fixed-wing aircraft at different altitudes.

Grizzly bear relocation data in the Copper River Delta of southern Alaska indicated a relationship between age/sex class of grizzlies and their reaction to fixed-wing aircraft (Campbell 1985). Lone or paired adults seldom reacted 
severely while females with cubs were more susceptible to disturbance. However, some females with cubs in other areas appeared to be somewhat habituated to aircraft disturbance (Gebhart 1982, McLellan and Mace 1985).

A bear's pre-disturbance activity may also influence its reaction to aircraft disturbance. Grizzlies may be reluctant to flee from aircraft when feeding on carcasses (Quimby 1974, Rutton 1974) or while at feeding sites (McLellan and Mace 1985).

Reynolds et al. (1984) monitored the heart rates of denning and active grizzlies during aircraft over-flights. Midwinter flights caused no significant increase in heartrate of denning bears. However, during the period just after emergence, the heartrates of 2 different sows increased up to 10 bpm or became erratic when planes flew overhead. Later in the summer, this reaction tapered off. The researchers found that the maximum increase of $22 \mathrm{bpm}$ was not associated with any overt behavioral changes. Although no dens were abandoned due to aircraft overflights in their study area, however, Quimby (1974) reported that 5 bears abandoned den construction due to helicopter disturbance.

\section{GARBAGE IMPACTS}

\section{Use of Garbage}

Management philosophies regarding the grizzly bear in the national parks of the U.S. and Canada underwent a renaissance in the late 1960 s and early 1970 s. Prior to that time, grizzlies were often closely associated with garbage in many of these preserves.

Schullery (1980) chronicled the history of the grizzly bear/garbage situation in Yellowstone National Park. Both grizzly and black bears were feeding at hotel dumps as early as the 1890 s and "nuisance bears" had emerged by the early $1900 \mathrm{~s}$. The number of grizzlies feeding at dumps rose drastically during the early part of this century. Censuses conducted at the dumps indicated 40 grizzlies in 1920 and 260 in 1930 (Schullery 1980). The consequences of the bear-garbage association were recognized long before the issue generated intense public controversy in the early 1970s. In 1913, a representative of the U.S. Geological Survey studying sanitation procedures in Yellowstone recommended that all dumps be fenced to exclude bears. In 1932, a report prepared by the Branch of Research and Education suggested that the dumps were unhealthy for the bears and no longer necessary in Yellowstone. Two "feeding grounds" at Old Faithful and Canyon Village, were maintained for public viewing of the bears until 1935 and 1942 , respectively. Prior to closure, up to 70 grizzly bears could be observed at the Canyon Village public feeding area on a single night (Schullery 1980). Murie (1944) conducted the first legitimate scientific study of the grizzly bears in Yellowstone. Following his first field season, he concluded that:

"Some such contrivance for keeping bears out of garbage cans is the most important recommendation I can make as a result of my observations last summer."

The high attraction of garbage dumps to grizzly bears was evident from the movement patterns of Yellowstone grizzlies as documented by the Craighead study from 19591970. Individual bears moved up to $86 \mathrm{~km}$ from marking sites at the dumps to subsequent relocations or death in national forests adjacent to the park (Craighead 1980, Craighead and Mitchell 1982). Ratios of marked to unmarked grizzlies in various areas yielded estimates of from 56 to $77 \%$ as the proportion of the total Yellowstone population which congregated at the dumps (Cowan et al. 1974, Craighead et al. 1974 McCullough 1981). These concentrations of grizzly bears were likened to the "natural" concentrations of grizzlies at other dependable sources of high-calorie foods such as salmon spawning runs (Craighead and Mitchell 1982). Hornocker (1962) discussed the complex social dynamics which developed at these dump aggregations.

The last of the open pit garbage dumps inside Yellowstone National Park was closed in 1970. The controversy surrounding closure of the Yellowstone dumps is beyond the scope of this report. Detailed accounts are available elsewhere (Cole 1973, Craighead 1979, Schullery 1980, Meagher and Phillips 1983). Garbage was still available to grizzlies in municipal dumps near the park until the late 1970s (Greer 1976b, 1979; Schullery 1980, Knight et al. 1981).

Yellowstone was not the only North American park to experience problems with garbage and bears. Martinka (1971) felt that declining injury rates in Glacier National Park, Montana, during the 1960s were related to decreased availability of unnatural foods along with greater emphasis on preventative control policies. Open-pit garbage dumps and poorly designed incinerators enabled grizzly bears to obtain garbage in several Canadian national parks throughout the 1960s (Mundy and Flook 1973, Kaye 1982). The landfills in Banff and Jasper National Parks were fenced in 1970 but habitual "garbage bears" still managed to obtain garbage by digging under, or breaking through, the enclosures (Kaye 1982). The Banff landfill was closed in 1980 and an electric fence was placed around the Jasper landfill in 1981 to discourage bear activity. Kootenay and Yoho National Parks have hauled all refuse to nearby communities since 1973 and 1974 , respectively (Kaye 1982).

Dean (1978) documented problems with grizzly bears and garbage in Katmai National Monument, Alaska. In some cases, garbage cans were used to bait bears for photographs. Downing (1975) observed 17 different grizzly bears feeding in the Denali National Park landfill in 1974. This dump was fenced and an electric line was installed in 1976 77 (Singer 1982, Van Horn and Dalle-Molle 1984). Prior to being fenced, 10-25 grizzlies fed in the dump each year (Singer 1982). Beginning in 1980, all refuse from Denali was hauled to the public landfill in Nenana. Singer (1982) felt that closure of the park dump, bear-proofing of most garbage cans and increased visitor awareness were the primary factors in minimizing grizzly bear incidents in Denali. However, poor garbage handling practices by the park concessionaire enabled bears to acquire garbage at least until 1984 and some garbage-related bear incidents persisted (Van Horn and Dalle Molle 1984).

Although progressive management programs to isolate bears from garbage have been implemented in most Canadian and American national parks, garbage handling practices have caused persistent problems in towns bordering Yellowstone National Park (Knight et al. 1982). Hunt (1982) observed grizzlies using the West Glacier dumpster site by Glacier National Park, Montana. Hoak and Clark 
(1979) found that garbage handling was inadequate in 14 of 36 outfitter camps which they examined in the BridgerTeton National Forest (YGBE). Improper handling of garbage was a "constant" problem during construction of the Northwest Alaskan Pipeline Project (Follmann et al. 1980). In brief, any activity which brings humans into bear country, whether recreational, industrial or residential, can potentially allow grizzlies access to garbage if proper sanitation procedures are not followed. Impacts from garbage generally fall into 4 categories:

1. Attraction of bears to human developments or activity.

2. Effects on bear behavior toward humans, in particular habituation to human scent or association of human stimuli with a food reward.

3. Effects on intraspecific behavior due to congregations at garbage dumps.

4. Effects on nutritional status and, secondarily, on reproductive parameters of a grizzly bear population.

\section{Impacts of Garbage Feeding}

The foregoing discussion merely establishes that grizzlies have had, and in many instances continue to have, access to garbage. That this association was undesirable for both bears and humans has long been appreciated (Murie 1944), but only recently has a systematic study of the topic been undertaken.

Herrero $(1970,1976,1978 a, 1982,1985)$ and others analyzed the circumstances behind grizzly bear inflicted injuries to humans. He concluded that bears which habitually fed on human food and garbage often lost their natural wariness of people. Such "food conditioned" bears were more likely to show aggressive tendencies than non-foodconditioned bears (Herrero 1970, 1976, 1985). Herrero (1970) postulated that although grizzlies which fed on garbage in dumps did not necessarily become conditioned to human scent, these bears might be more readily drawn to food in developed areas where a firm association of humans with food would be established. J.J. Craighead and F.C. Craighead, Jr. (1972) found that the greater tolerance to man which grizzlies showed while feeding at the dumps was not observed when these same bears were encountered in the backcountry 0.5 miles or more from the dump sites.

Although there is some uncertainty as to the degree of habituation/conditioning related solely to feeding at remote garbage dumps, there is general agreement that acquisition of garbage or other human foods in campgrounds or developed areas can have serious consequences (Herrero 1970, J.J. Craighead and F.C. Craighead, Jr. 1972). McCullough (1982) applied the principles of behavioral learning theory to the bear-garbage issue. He observed that once a bear had been positively conditioned by food rewards from human sources, it might seek food in response to any of the broad stimuli (i.e., human scent, human presence, human structures and equipment) associated with prior successful procurement of food even when no food was detected.

Regardless of the exact scenario leading to an encounter, the evidence linking food conditioned grizzly bears to human injury is persuasive. Within the North American national parks, habituated, food-conditioned grizzlies accounted for a pproximately two thirds of all bear-inflicted human injuries up to 1970 (Herrero 1976, 1985). Ninety percent of these injuries occurred in developed campgrounds in Yellowstone National Park where grizzlies had a long history of feeding on human refuse. Since 1970 (when many national parks initiated new programs for garbage management), improperly stored food and garbage was the second most common circumstance, following surprise encounters, associated with grizzly bear inflicted injuries (Herrero 1982). The peak human injury rate in Yellowstone National Park occurred in the 1960s when an average of 3.6 and 0.3 injuries occurred each year in developed and backcountry areas, respectively (Cole 1973). This was also the period of greatest use of garbage dumps by grizzly bears. The Craighead study team documented up to 137 individuals feeding at dumps in a single evening (Craighead and Mitchell 1982).

Seven of 9 deaths inflicted by grizzlies in Yellowstone and Glacier National parks between 1967 and 1984 were by garbage habituated bears. One of the other 2 deaths (Lawrence Gordon, Glacier National Park, September 1980) was due to a human-habituated grizzly without a known history of garbage feeding. The bear responsible for the most recent death (Brigitta Frendenhagen, Yellowstone National Park, July 1984) was not identified although circumstantial evidence suggested that the grizzly was a subadult having some prior experience with human activities. Likewise, the grizzly bear which killed 1 man and mauled 3 others in Banff National Park in 1980 had been previously feeding on garbage on the edge of Banff townsite (Herrero 1985).

Only a very small fraction of the grizzly bears which have a history of garbage feeding are ever involved in human injuries (Herrero 1982). However, garbage-feeding bears may be predisposed to other infractions requiring control actions and potential loss to the population. The number of grizzly bear control actions in Yellowstone National Park escalated dramatically following closure of the last open pit dump in 1970. Thirty grizzlies were translocated and 12 were destroyed during that year (Meagher and Phillips 1983). An earlier peak in control actions occurred in 1942 when closure of the Canyon Village dump combined with a poor food year resulted in 28 grizzlies being killed for control (Schullery 1980). Comparisons of control actions from one period to another must be viewed cautiously as management philosophies are subject to change (e.g., Cole 1976). A shortage of natural foods in 1981 also created grizzly bear problems in the Yellowstone ecosystem. During that year, 23 grizzly bears were trapped and relocated 33 times by management agencies. Nearly all grizzly bear complaints during 1981 were related to the availability of human food and garbage (Knight et al. 1982).

During construction of the Northwest Alaskan pipeline from 1971-1979, 12 grizzly bears were translocated and 13 were killed for control actions. Sixty-seven of 85 reported grizzly bear incidents involved bears in camp dumps or bears feeding on garbage or handouts (Follmann et al. 1980). 


\section{Effects of Garbage Feeding on Grizzly Bear Weight and Reproduction}

The nutritional value of garbage and its influence on grizzly population biology has been examined in several studies. Rogers (1976) reported that black bear females that lived near large garbage dumps tended to produce larger litters or have higher cub survival than females which did not feed on garbage. In Yellowstone National Park, the average size of grizzly bear litters before closure of the dumps (1959-70) was 2.1 cubs whereas the average litter size after dump closure (1974-82) was 1.9 cubs. Age of first reproduction also declined between the 2 periods. From $1959-70,70 \%$ of the females first reproduced at age 5 while from 1974-82, 60\% produced their first litters at age 6 (Knight and Eberhardt 1984, 1985). Whether this variation in reproductive rate was actually due to dump closure has been debated in the literature. Picton (1978, in press) found a high correlation between climatic variation and grizzly bear litter size in Yellowstone. Other researchers found that cub recruitment was highly correlated with the number of adult males in the population (McCollough 1981, Stringham 1983, in press a).

Knight et al. (1981) found that 3 adult males which frequented the Cook City dumps weighed less when recaptured in 1980 after the dump was closed than when initially captured in 1975-79. The mean weight of male bears 5 years and older was significantly less after dump closure (Knight et al. 1981). Russell et al. (1979) observed that the only monitored grizzly in Jasper National Park which used a major landfill was exceptionally large for his age. Their observations, though limited, suggest that bears which used garbage to supplement their natural diet did attain greater weights than bears without this subsidy.

\section{RECREATIONAL IMPACTS}

A number of recent studies have addressed the impacts of recreational activities on grizzly bear behavior, habitat use and survival. The effects of motorized recreation on grizzlies were discussed in the previous section on road impacts and will not be reported here.

Recreational developments are often situated within, or adjacent to, high quality bear habitat and recreational activity often concentrates people in areas of high grizzly bear use (B.I.A. 1981, Servheen 1981). High elevation areas provide both panoramic vistas and grizzly bear foods while lower elevation streambottoms or sparsely timbered ridges serve as easy travel corridors for both bears and people (Tirmenstein 1983).

Correlations between increased visitor use of designated recreational areas and grizzly bear problems have been noted in several areas (e.g., Noble 1972, Faro and Eide 1974, Mundy and Flook 1973, Martinka 1982a). In Denali National Park, Alaska, bear incidents were very uncommon prior to the opening of the park highway in 1972 and the resultant influx of visitors. Both frontcountry and backcountry incidents increased greatly during the 197678 period. Bear incidents were significantly correlated to the total visitation in backcountry units, with $58 \%$ of the backcountry incidents relating to a food incentive (Sizemore 1982). Similarly, Martinka (1982a) reported that in
Glacier National Park, Montana, the number of bear confrontations appeared to be closely correlated with park visitation for the 1951-80 period.

Researchers in Denali noted that bear encounters could be expected to occur each year because campgrounds were located near prime bear habitat or along travel routes (Van Horn and Dalle-Molle 1984). Bear managers in other major park units have made similar observations. In Katmai National Monument, man-made facilities at Brooks River Camp interfere with the normal movements of bears fishing along the Brooks River and bring bears and humans into close proximity (Dean 1968, Troyer 1980a, Beattie 1983). A comparable situation exists at the Fishing Bridge development in Yellowstone National Park; primary roads and developments were situated within the most productive spring bear habitat. Concern about the impact on grizzly bears from expanding recreational use of productive bear habitat has been expressed for numerous other areas (e.g., Noble 1972, B.I.A. 1981, Post 1982, McCory and Herrero 1983b, McCrory et al. 1986).

\section{Mortality Relating to Recreational Activity}

The consequences of superimposing high recreational activity on productive grizzly bear habitat include both direct mortality and reduced habitat effectiveness. Miller and Chihuly (in press) recently analyzed the causes of non-sport grizzly bear deaths in Alaska. They found that $31.3 \%$ of these mortalities were caused by hunters, most $(87 \%)$ of whom perceived the bear as an immediate or potential threat to their life or property. Another $8.1 \%$ of the non-sport mortalities involved individuals who were sport fishing or hiking. Gunson (1985) evaluated grizzly bear mortalities in Alberta for the 1972-84 period and found 12 cases of mistaken identity deaths (grizzlies mistaken for black bears), 24 cases of self-defense killings by hunters and 4 cases of problem bears killed in recreational or tourist camps. Problems involving grizzly bears attracted to hunter camps or causing other hunter related problems are also common in the conterminous states (e.g., Greer 1982, Roop 1982,1983). The special consideration of grizzly bears being mistaken for black bears by hunters of the latter species is discussed in a subsequent section.

Mattson et al. (in press b) studied the impacts of developments and primary roads on grizzly bears in Yellowstone National Park. They found that adult bears which were relocated most often within a $0-3 \mathrm{~km}$ zone around developments had twice the risk of mortality as adults in more remote areas. The mortality risk was nearly 5 times greater for females in the inner zone but only marginally greater for adult males. Conversely, subadults suffered their greatest mortality risk in zones furthest from developments. These results suggested that the subadults were either displaced by adult bears into the less secure zones adjacent to developments (as indicated by a model representation of subadults in the $0-3$ and $3-9 \mathrm{~km}$ zones around developments) or stood an increased mortality risk by cooccupying the more remote zones with adult bears.

High adult female mortality risk close to developments was believed to be a consequence of habituation to predictable high density human presence. Subadults and adult males occupying the inner zone were presumably "neutral" (i.e., indifferent to human presence or developments but not 
actively seeking human foods) rather than habituated (seeking out human-related foods). Thus, these classes of bears were less predisposed toward conflict situations than were the habituated adult bears.

\section{Displacement and/or Reduced Habitat Effectiveness for Nonmotorized Recreational Activity}

Several recent studies have specifically addressed impacts of recreational activity on grizzly bear habitat use and activity patterns. The most intensive work has been conducted in Yellowstone National Park.

Schleyer et al. (1984) studied the effects of nonmotorized recreational activity on grizzly bear behavior and habitat use in Yellowstone. Bears were monitored for 24 hours before a simulated disturbance (an approach on foot or erection of a campsite) was initiated. They found that human activity in wilderness habitat did affect the habitat use, activity patterns and behavior of grizzly bears. Six of 7 planned disturbances, and 3 incidential disturbances, caused immediate and rapid displacement of the studied bears. During the predisturbance phase, the bears' probability of activity a veraged $56 \%$, while during the immediate (0-2 hour) post-disturbance phase, the probability of activity rose to $78 \%$. During the 224 -hour post-disturbance period, the disturbed bears' average range length, average total daily movement and average net daily movement exceeded that of undisturbed bears.

Disturbances also resulted in bears using less suitable habitat. Tested bears spent more time in dense timber further from natural openings and perennial water. They also used higher elevation, less gentle terrain and locations remote from human travel more often than did nondisturbed bears. Two of the tested bears were less sensitive to disturbance than the others. Their diminished reaction was attributed to 2 different factors; habituation for 1 and residence within a preferred foraging area (elk calving ground) by the other.

Haroldson and Mattson (1985) reported results from the second year of the Yellowstone recreation study. They noted that the earlier study (Schleyer et al. 1984, discussed above) tested bears' responses to recreational activity in improbable settings, collected no long duration postdisturbance data and failed to give adequate consideration to the study bears' individual character and the unique episode conditions. In this study, Haroldson and Mattson (1985) tested the response of 3 radioed bears to simulated recreationsl activity by monitoring their response for 36 hours before and after they were approached at 100-400 m. Four episodes were executed as planned. Responses varied greatly by individual bear and only 1 of the 3 adult females tested exhibited a long duration response to the study's most flagrant impingement.

The researchers constructed a conceptual model to describe the factors contributing to a bears' immediate and long duration response to recreational activity. Four factors (cultural background, status, physiological state and foraging strategy) conditioned bears for a repertoire or "syndrome" which elicited a specific response according to the particular setting and level of human presence. The spatial-temporal predictability and level of human use were probably significant factors determining the level of a bears' response to "accumulated" backcountry use. The researchers concluded that Yellowstone grizzly bears were likely to experience longer duration disturbance effects than were indicated by their results since much of the Yellowstone backcountry received greater sustained, predictable recreational use than was simulated by their tests. Responses were likely to be greater for the least habituated or neutral bears and in open or productive habitats.

Gunther (1984a) and Gunther and Renkin (1985) studied the effects of backcountry recreational activity on grizzly bear use of Pelican Valley adjacent to the Fishing Bridge development in Yellowstone National Park. Of special interest was the response of grizzlies to seasonal closures of the valley to human use. The researchers found a significant difference in the number of bear sightings during the closed and open periods with a significant inverse relationship between the number of bears per day and the number of people per day (versus the average number of parties per day). The number of bear sightings within $0.4-0.8 \mathrm{~km}(0.25$ -0.50 miles) of backcountry campsites was dependent upon site occupancy. Fewer bears were observed near campsites when they were occupied by people. Some effects on bear habitat use was also noted. Bears were observed significantly closer to cover during the open periods than during the closed periods. (The relationship between plant phenological changes and numbers of grizzlies using the Pelican Valley was not addressed in this study.)

These findings correlated well with the results of an earlier study on the relationships between angler and bear use in the Clear Creek and Cub Creek drainages east of Yellowstone Lake (Gunther 1984b). That study indicated that in years with the highest spawning run, the number of anglers peaked but the bear fishing activity was lowest. After an area closure was initiated in 1983, the angler use reached its lowest and the bear use its highest level in 7 years.

Few other systematic studies of the impacts of nonmotorized recreation on grizzly bears have been conducted. McLellan and Mace (1984) reported that people travelling on foot in areas more than $500 \mathrm{~m}$ from a primary or secondary road resulted in strong flight responses from their study bears. People walking on primary or secondary roads or at a residence elicited a more moderate response. Schallenberger and Jonkel (1979a, 1980) measured the distance of grizzly bear relocations in the Rocky Mountain East Front to hiking trails of various use levels. They found that bears tended to be closer to low and moderately used trails than to trails receiving high or extremely high use. They noted that this result could be due to either disturbance factors or to the relative densities of the different trail types. Kasworm (1985) reported that in the Cabinet Mountains of northwestern Montana, the annual mean distances of grizzly bear relocations to roads and trails were 2467 $\mathrm{m}$ and $821 \mathrm{~m}$, respectively.

\section{Impacts of Recreational Developments}

Mattson et al. (in press b) evaluated the impacts of primary roads and developments on grizzly bears in Yellowstone. They found that in zones beyond the conceivable influence of human emplacements, grizzly bears occupied habitat which was more productive than the average for that zone. However, in zones proximal to roads and developments, grizzlies occupied habitat which was close to, or 
below, the average for that zone. Thus, it appeared that grizzly bear foraging strategies directed towards habitat optimization were disrupted by human emplacements. Around developments, this disruption was evident out to $3.5 \mathrm{~km}$ in spring and summer (less in fall). Around roads, habitat use was influenced out to $2.5 \mathrm{~km}$ in spring and summer and $4.0 \mathrm{~km}$ in fall.

Mattson et al. (in press b) also evaluated the displacement effects of human developments. They found that adult bears showed a bimodal distribution with neutral/ habituated bears occupying the $0-3 \mathrm{~km}$ zone around developments and a group of more wary adults occupying the $9-15 \mathrm{~km}$ zone. All of the young adults in the study occupied the $9-15 \mathrm{~km}$ zone, while subadults were more often occupants of the $0-3$ and $3-9 \mathrm{~km}$ zones. Possible explanations for the observed subadult distribution were discussed previously.

Overall, roads tended to reduce grizzly bear use to a "micro" scale (0-1500 m) while developments did not. However, the concentrated human activity at developments had a much greater "micro" scale (0-15 km) effect on grizzly bear occupancy and use of habitat than did roads. This was attributed to the greater human density and persistently high levels of human activity into the nocturnal hours around developments. The researchers calculated that up to $15.7 \%$ of the available habitat production in Yellowstone was not used by adult females during summer because of primary road and development effects.

The impact on grizzly bears by recreational activity and development in the Fishing Bridge/Pelican Valley area of Yellowstone National Park has received considerable attention in recent years. Controversy has arisen surrounding the proposed removal of all recreational facilities and increased regulation of backcountry human use around the Fishing Bridge area (Knight et al. 1984a, NPS 1984d).

The Fishing Bridge area has been used by tourists since the early days of the park. As of 1984, it continued to receive intensive human use in the form of day use, overnight backcountry hiking, angling, camping ( 2 established frontcountry campgrounds) and horse use (NPS 1984d) (Note: Some of the activities have been, or are scheduled, to be discontinued). Visitor cabins were retired from use in 1975.

Habitat analysis of the development area indicated that it was better-than-average grizzly bear habitat relative to the rest of Yellowstone National Park. It ranked high for vegetative diversity and was ecologically more diverse than any other developed area in the park. The development also lies adjacent to 2 of the most critical spawning areas for Yellowstone cutthroat trout, an important food source for grizzly bears (Knight et al. 1984a, NPS 1985d).

The unique status of Fishing Bridge as the only major development to lie within superior grizzly bear habitat was reflected in the number of injuries, control actions and bear mortalities that have occurred in the area. Fishing Bridge accounted for more than $50 \%$ of all grizzly bear injuries in Yellowstone National Park from 1968-83. Injury rates declined after 1977, but this decline may have been due to displacement of bears by increasing numbers of visitors. The annual number of bear observations at Fishing Bridge dropped abruptly after 1977 suggesting that bears had reached a threshold of tolerance for visitor numbers in the area (Knight et al. 1984, NPS 1984d). The Fishing Bridge area also led the park in number of bear removals (control kills, accidential kills and removal from the ecosystem) for the 1968-83 period. Although management actions declined parkwide from 1968-83, the proportion of control actions occurring at Fishing Bridge increased dramatically (NPS 1984d).

\section{Impacts of Recreational Activity on Bear Behavior: Habituation}

Habituation may be defined as a long-term decrease in the frequency or magnitude of a response as a result of a repeated stimulation (Jope 1982). Indications of grizzly bear habituation to human stimuli have been noted for several areas (e.g., Jope 1982, 1983a, 1985, Haroldson and Mattson 1985, Mattson et al. in press b).

The effect of recreational activity on grizzly bear habi. tuation was originally discussed by Jope (1982, 1983a, 1985) with reference to grizzly bear behavior in Glacier National Park, Montana. Factors which contributed to bear habituation were a consistent context for encounters with hikers (such as along trails); frequent, irregularly spaced, encounters; easily recognized stimuli (such as hikers with bear bells); and, innocuous behavior by the hikers (Jope 1985). Jope theorized that by reducing the occurrence of "full" charges, habituation of grizzly bears' fear response actually reduced the rate of injury to hikers from surprise encounters with adult and subadult grizzlies. She noted (Jope 1982) that no recorded hiker injuries had involved a bear that appeared to be habituated.

Keating (1983) further examined the trends in grizzly bear numbers and behavior (1910-1980) relative to sightings and confrontation rates in Glacier National Park. His analysis supported Jope's (1982) observation that habituated behavior resulted in fewer confrontations per encounter. Data showed that the number of confrontations per encounter (visual contact with 1 or more grizzlies) declined exponentially at about $9 \%$ annually. However, confrontation rates continued to increase exponentially (about 5\% annually) despite that trend. Thus, the total number of encounters (a function in increases in both visitation and grizzly population size) was greater than the habituation. related decline in the number of confrontations per encounter.

Kendall (in press) also studied the trends in encounter and confrontation rates in Glacier National Park. Several trends appeared to be related to the habituation behavior described by Jope (1982, 1983a, 1985). Kendall found that "approach" encounters had increased during the last 7 years and were most prevalent in areas of high visitor use. This was due either to increased visitation which brought more people into contact with habituated bears or an increase in the number of habituated bears. Kendall also found that the number of grizzly bear incidents occurring around high visitor use areas was lower than expected from the amount of visitor use these areas received. There was also a lower frequency of camper incidents in high use areas than predicted by camper distribution. Both of these findings suggested that the increased exposure to humans by grizzly bears in these areas resulted in more habituated bears or, alternatively, that management practices may have mitigated some of the expected bear problems. Kendall noted that habituation might also have deleterious 
consequences in that loss of the usual avoidance response could lead to more grizzly bear/camper encounters.

Warner (in press) observed what appeared to be habituated behavior by some bears at the Pack Creek brown bear reserve on Admiralty Island. She found that brown bears using the reserve area were more diurnal than those in the nearby control area. She attributed this to possible habituation of the less wary bears.

Haroldson and Mattson (1985) reported that most grizzly bears in Yellowstone could logically be placed into 1 of 3 categories according to their reaction to human presence and developments. "Wary" bears were those which characteristically fled from human encounters and avoided development areas. "Neutral" bears were those indifferent to human presence or developments but not actively seeking human foods. "Habituated" bears were those which tended to actively search out human-related foods. The findings of Mattson et al. (in press b) relating to habituated grizzlies in development areas were discussed previously. It should be noted that the definition of habituation applied in these 2 studies differs somewhat from the definition employed by Jope (1982, 1983a, 1985).

\section{Impacts of Winter Recreation Activities and Developments}

Literature pertaining to the impacts of winter recreation sites and snowmobile activity on grizzly bears was very limited. Madel (1983) evaluated the potential impacts of a proposed ski development in northwestern Montana. He concluded that the development could potentially influence bear use of the area by reducing the amount of secure, undisturbed habitat to a level below that necessary for normal nutritional and behavioral needs, displacing bears from important seasonal habitat components during critical use areas, causing permanent loss of seasonal habitat and increasing the possibility of undesirable grizzly bear/ human interactions. Hadden and Jonkel (1983) reported that the most deleterious effects of another proposed northern Montana ski development would result from the habitat alterations and increased potential for human activity in the non-ski seasons. McCrory and Herrero (1983b) noted that the increased recreational use around Mt. Allan (site of the 1988 Olympic downhill skiing events) would result in increased possiblilites of bear/human encounters.

Mealey (1976) evaluated the habitat characteristics and potential impacts on grizzly bears from the proposed Ski Yellowstone development west of Yellowstone Park. His analysis of late spring/early summer food and cover values indicated that the area was generally low-quality grizzly habitat. He therefore concluded that negative impacts from the ski facilities and adjoining resort community would be minimal.

A subsequent review of the Ski Yellowstone development by Knight and Blanchard (1984) reached different conclusions about the probable impacts of the project. Their analysis was based primarily on data collected by the Interagency Grizzly Bear Study Team and an intensive study of the development area by Blanchard (1978). They concluded that the Ski Yellowstone development had the potential of becoming a major population sink for the Yellowstone ecosystem grizzly population. From 1973-83, home ranges of 7 collared grizzlies encompassed the project area. Final dispositon of the Ski Yellowstone proposal by the U.S. Forest Service is currently pending as the agency completes a cummulative effects analysis of the project as per Weaver et al. (1986).

Impacts on grizzly bears from snowmobile activity are largely unknown. Jonkel (1980b) reported that 1 grizzly bear den was abandoned after snowmobile disturbance and another after foot disturbance. Reid et al. (1983) evaluated the effects of the proposed Clark Fork snowmobile corridor on grizzly bears. As with the ski area developments noted above, they felt that the most serious consequences of the corridor development were off-season uses. The potential for displacement and stress caused by 2 wheeled vehicular traffic was of greatest concern, especially in the late fall and early spring.

\section{GRIZZLY BEAR-BLACK BEAR RELATIONSHIPS}

Herrero (1978b, 1979) compared the evolutionary adaptations of grizzlies with black bears. He noted that while the 2 species are capable of coexisting in some forest ecosystems, the grizzly is better adapted for exploiting more open habitats. The grizzly's larger body size (1.5:1 to 2.0:1 for same sex and age class) and more aggressive nature generally give it an advantage in open areas. Several studies in northern and northwestern Montana likewise found that grizzlies predominated in open shrub and burn areas (Jonkel and Cowan 1971, Shaffer 1971, Martinka 1972, Kasworm 1983). The grizzly is better adapted than the black bear for extracting food from the soil (Herrero 1979) and small mammals comprise a greater portion of the grizzly's diet than the black's (Jonkel and Cowan 1971, Shaffer 1971, Martinka 1972). Comprehensive food habit comparisons for the 2 species were not available.

Where grizzly bears and black bears occur sympatrically, temporal isolation may help prevent direct competition. In the Apgar Mountains of Glacier National Park, grizzlies appeared to displace black bears from preferred huckleberry foraging sites during peak availability. Later in the season, grizzlies abandoned these patches and black bears moved in (Kendall 1984b, 1985, Peacock 1978). In an earlier study in the same area, Shaffer (1971) observed that when both species were foraging in medium and low elevation huckleberry stands, grizzlies had priority during twilight and night while blacks foraged more often during the day. Jorgensen (1979) reviewed the literature on activity patterns of black bears and grizzly bears and concluded that in the Targhee National Forest (YGBE) limited overlap in peak activity patterns probably prevented most aggressive encounters between the 2 species. Trapping data reinforced the temporal segregation hypothesis for blacks and grizzlies in the Yellowstone region (Schleyer 1983).

\section{Grizzly Bear-Black Bear Encounters}

Barnes and Bray (1967) analyzed 49 encounters between grizzly and black bears at Yellowstone National Park garbage dumps. Black bears were submissive in $40.8 \%$ of the encounters and dominant in $28.6 \%$. The 2 species were mutually tolerant in $15 \%$ of the enounters. Mortality of 
black bears from grizzly attacks has been documented in several areas (Arnold 1930, Hornocker 1962, Jonkel and Cowan 1971, Murie 1981). Some of the aggressive encounters involved adult grizzlies killing, or attempting to kill, black bear cubs (Miller 1985b). Murie (1981) witnessed 1 exceptional case in which a lone grizzly happened upon a black bear sow with 2 cubs. After quickly killing both cubs the grizzly moved a short distance and continued grazing. In other cases, black bear sows with cubs have mounted successful defenses against adult grizzlies (Mundy and Flook 1970, Miller 1985b).

\section{Grizzly Bear-Black Bear Population Relationships}

Some interesting relationships between black and grizzly bear population densities have been detected in several areas. Jonkel and Miller (1970) noted that as local grizzly populations declined west of Hudon Bay, black bears extended their range into barren-ground habitats. Similarly, as human encroachment and habitat disturbances increased in the Swan Hills region of Alberta, black bear densities increased while grizzly bear densities declined (Nagy and Russell 1978).

In the North Fork of the Flathead Valley, grizzlies were predominant toward the northern end while black bears were predominant toward the southern end (Jonkel 1984b). Comparing densities for 2 consecutive years, Jonkel (1984b) noted that a drought in 1 year may have forced grizzlies into bottomland areas where black bears were common the previous year, resulting in a much reduced black bear density due to displacement or killing by grizzlies. The overall disparity from north to south may have been due to a habitat gradient (more open, burned, areas in the north), human pressure on the grizzly population or the competitive advantage of an established high density population of black bears in the south and grizzlies in the north.

The above studies indicate that although interspecific conflict may prevent the black bear from making significant inroads into habitats and areas with flourishing grizzly populations, black bear dendties may rise if the grizzly population is suppressed by some other factor (especially human activity). The higher reproductive rate, smaller home range and greater adaptibility to human presence give the black bear some selective advantage under certain circumstances (Herrero 1978b, Nagy and Russell 1978). In areas with existing high densities of black bears, expansion of grizzly populations may be partially due to competitive exclusion of subadult grizzlies (Jonkel 1984b).

\section{Mistaking Black and Grizzly Bears}

One aspect of the grizzly-black bear relationship which has received increased attention recently is the "lookalike" hunting problem. Black bear hunters sometimes mistakenly harvest a grizzly bear. In Montana, 10 grizzly bear mortalities fell into this category from 1975-1984, 4 in 1983 alone (Dood et al. 1985). In Wyoming, 9 mistaken identity mortalities occurred from 1982-1984 (Roop pers. commun. in Dood et al. 1985).

\section{GRIZZLY BEAR-WOLF RELATIONSHIPS}

Most of the literature on grizzly bear-wolf relationships deals with behavior at carcasses. In most of the described encounters, grizzlies either successfully defended a carcass or were able to appropriate carcasses from wolves (Murie 1981, Ballard 1982). Magoun (1976) analyzed 173 observations of grizzly bears and wolves interacting at carcasses in northeastern Alaska. He observed 39 aggressive acts by bears toward wolves and only 1 aggressive act by a wolf. Ballard (1980) described 1 instance in southcentral Alaska when a brown bear apparently displaced a wolf pack from a moose carcass and killed an adult male wolf in the process.

Wolves were not always the losers, however. Ballard (1982) found that wolves managed to tree 3 yearling cubs and in another case a yearling brown bear was apparently killed by wolves. Ballard (1982) found evidence for competitive predation/scavenging by wolves and bears. Encounters between the 2 species were most frequent when prey density was lowest. Carcasses were contested for more often after mid-June when other prey was less available.

\section{GRIZZLY BEARS AND OTHER MAMMALS}

Kendall $(1981,1983 b)$ investigated bear use of pine nuts in Yellowstone National Park. She found that grizzly bears compete with red squirrels (and possibley black bears) for whitebark pine nuts by raiding squirrel nut caches in fall and spring. The dynamics of this relationship were of interest because pine nuts are high in food value and provide a nutritious food source when alternate foods are scarce.

Murie (1981) briefly described encounters between grizzly bears and wolverine, fox, golden eagles and corvids. Grah am (1978) stated that bison and elk appeared to compete heavily with grizzlies for succulent grasses and forbs. No quantitative data were provided. 


\section{ADMINISTRATIVE MANAGEMENT GUIDELINES}

Standardized grizzly management guidelines have been developed for all National Forest, National Park and Bureau of Land Management lands (Mealey 1986). Each management situation classifies a type of land area where unique grizzly populations and habitat conditions exist, and where the management direction applies. Managers are required to identify the different management situations in their areas of responsibility and apply the management directives. The management situation guidelines are presented below (Mealey 1986). A summary of the acreage classified under Management Situations 1-3 are presented in Table 15.

\section{Management Situation 1}

\section{Population and Habitat Conditions}

The area contains grizzly population centers (areas key to the survival of grizzlies where seasonal or year-long grizzly activity under natural, free-ranging conditions is common) and habitat components needed for the survival and recovery of the species or a segment of its population. The probability is very great that major federal activities or programs may affect (have direct or indirect relationships to the conservation and recovery of) the grizzly.

\section{Management Direction}

Grizzly habitat maintenance and improvement and grizzly/human conflict minimization will receive the highest management priority. Management decisions will favor the needs of the grizzly bear when grizzly habitat and other land use values compete. Land uses which can affect grizzlies or their habitat will be made compatible with grizzly needs or such uses will be disallowed or eliminated. Grizzly/human conflicts will be resolved in favor of grizzlies unless the bear involved is determined to be a nuisance. Nuisance bears may be controlled through either relocation or removal, but only if such control would result in a more natural, free-ranging grizzly population and all reason able measures have been taken to protect the bear or its habitat (including area closures or activity curtailments).

\section{Management Situation 2}

\section{Population and Habitat Conditions}

The area lacks distinct grizzly population centers; highly suitable habitat does not generally occur, although some grizzly habitat components exist and grizzlies may be present occasionally. Management Situation 2 areas may be necessary for survival and recovery of the species, although the status of such areas is subject to review and change according to demonstrated grizzly population and habitat needs. Major activities or programs may affect the conservation and recovery of the grizzly bear primarily as they may contribute toward human-caused mortalities.

Table 15. Area summary of the Northern Continental Divide and the Greater Yellowstone Grizzly Bear Ecosystems current occupied habitat acres (in thousands).

\begin{tabular}{|c|c|c|c|c|c|}
\hline Administrative Unit & $\begin{array}{c}\text { Management } \\
\text { Situation } 1 \\
\end{array}$ & $\begin{array}{c}\text { Management } \\
\text { Situation } 2 \\
\end{array}$ & $\begin{array}{c}\text { Management } \\
\text { Situation } 3 \\
\end{array}$ & Unstratified & Total \\
\hline \multicolumn{6}{|l|}{ National Park Service } \\
\hline Yellowstone NP & 2219 & 33 & 0.2 & - & 2222.2 \\
\hline Grand Teton and Parkway & 95 & - & 2.4 & - & 97.8 \\
\hline Glacier NP & 1007 & - & 7 & - & 1014 \\
\hline Bureau of Land Management & - & 3 & - & 24 & 27 \\
\hline Indian Reservations & 116 & 107 & 0 & - & 392 \\
\hline Private/State & - & - & - & 697 & 697 \\
\hline \multicolumn{6}{|l|}{ Forest Service } \\
\hline Bridger-Teton & 666 & 62 & 7 & - & 734 \\
\hline Custer & 6 & 105 & - & - & 111 \\
\hline Flathead & 1694 & 355 & 7 & - & 2056 \\
\hline Gallatin & 413 & 340 & 1 & - & 754 \\
\hline Helena & 96 & 84 & - & - & 180 \\
\hline Kootenai & 116 & 90 & 0.4 & - & 207 \\
\hline Lewis and Clark & 764 & 5 & 7 & - & 776 \\
\hline Lolo & 213 & " 58 & - & - & 271 \\
\hline Shoshone & 412 & 820 & 17 & 9 & 1249 \\
\hline Targhee & 171 & 217 & 1 & - & 389 \\
\hline
\end{tabular}




\section{Management Direction}

The grizzly bear is an important, but not the primary use on the area. Habitat maintenance and improvement and grizzly/human conflict minimization may be, in some cases, important, but not the most important, management consideration. Management will at least maintain those habitat conditions which resulted in the area being stratified as Management Sitation 2. Minimization of grizzly/ human conflict potential that could lead to human-caused mortality of grizzlies is a high management priority. Demonstrated grizzly populations or grizzly habitat use will be accomodated in other land use activities if feasible, but not to the extent or exclusion of other use needs. A feasible accomodation is one which is compatible with (does not make unobtainable) the major goals or objectives of other uses. When grizzly population or grizzly habitat use and other land use needs are mutually exclusive, the other land use needs may prevail in management considerations. If grizzly population or habitat use represents demonstrated needs that are so great (necessary to the normal needs or survival of the species or a segment of its population) that they should prevail in management considerations, then the area should be reclassified under Management Situation 1 . Nuisance grizzlies will be controlled.

\section{Management Situation 3}

\section{Population and Habitat Conditions}

Grizzly presence is possible but infrequent. Developments, such as campgrounds, resorts or other high human use facilities and human presence result in conditions which make grizzly presence untenable for humans.

\section{Management Direction}

Grizzly habitat maintenance and improvement are not management considerations. Grizzly/human conflict minimization is a high priority management consideration. Grizzly bear presence and factors contributing to their presence will be actively discouraged. Any grizzly involved in a grizzly/human or frequenting an area will be controlled.

\section{Management Situation 4}

\section{Population and Habitat Conditions}

Grizzly bears do not occur in the area but habitat and human conditions make the area potentially suitable, and the area is necessary for the recovery and survival of the species.

\section{Management Direction}

The grizzly bear is an important potential use on the area. Habitat maintenance and improvement are important management considerations. Human and habitat conditions will not be degraded by decisions regarding grizzlies.

\section{Management Situation 5}

\section{Population and Habitat Characteristics}

Grizzly bears do not, or only rarely, occur in the area. Habitat may be unsuitable, unavailable or unoccupied. The area lacks survival and recovery values for the species or said values are unknown. Activities and programs will not affect the species.

\section{Management Direction}

Consideration for grizzly bears and their habitat in other resource related decisions is not directed. Maintenance of grizzly habitat is optional. Any grizzly involved in a grizzly-human conflict will be controlled.

\section{HARVEST STRATEGIES}

Montana is the only state among the conterminous 48 authorized to allow sport hunting of grizzly bears under the Endangered Species Act, granted by Chapter 1, Title 50 of the Code of Federal Reg., Part 17, Paragraph 17.4 (50 CFR 17.40), made effective August 1, 1975. This authorization to hunt established a mortality quota of 25 grizzlies for northwestern Montana, based on an annual mortality of 28 bears for the years 1967-1974. In 1985, an Emergency Federal Regulation reduced the quota to 15 grizzlies with a female subquota of 6 (Dood et al. 1986).

From 1975-1985, the average annual hunting mortality for this segment of the grizzly population was 10.2 bears/ year (range 5-17) of which 3.8 /year were females (38\% of harvest). Adult females comprised $54 \%$ of the female harvest with a median age of 5 ; adult males comprised $47 \%$ of the male harvest, with a median age of 4 (a more detailed discussion of the harvest is presented in Dood et al. 1986). The combined adult to subadult ratio in the population is 51:49.

Indications are that the population in the NCDE has been stable or increasing since the early 1970s (Dood et al. 1986). If the current minimum population estimate were applied in 1974 (356 grizzlies exclusive of Glacier National Park), the quota of 25 individuals would result in a total mortality rate of $7 \%$, a rate within that reported in the literature. Analysis of hunter harvest for 1975-85 shows a sex ratio of $63 \%$ males to $37 \%$ females, also similar to that in the literature (Table 16). Additionally, population data suggest that the reduction in the number of adults in the population from hunting increases survival and recruitment rates.

Age structure data from the Rocky Mountain East Front also indicate that this segment of the population is healthy and productive. Mean litter size, sex ratio of the harvest and hunter success are further indications of a stable or increasing population (Dood et al. 1986).

In the past several years, the grizzly bear hunting policy in Montana has come under close scrutiny. Because of this, a detailed Environmental Impact Statement was prepared in 1986. In addition to the conclusions stated above, several other points were presented as justification for the grizzly harvest. These are summarized briefly below (Dood et al. 1986);

1. there is indirect evidence that other remnant hunted populations survive, through genetic selection and learned behavior, by avoiding human confrontation and withdrawing from human contact

2. the average of 10 grizzly bears killed per year in the NCDE does not appear to be detrimental to the population 
Table 1.6. Recommended and reported grizzly bear mortality rates (from Dood et al. 1986).

\begin{tabular}{|c|c|c|c|c|c|}
\hline \multirow[b]{2}{*}{ Reference } & \multicolumn{2}{|c|}{ Hunter Harvesta } & \multicolumn{3}{|c|}{ Total Mortalityb } \\
\hline & Total & Male/Female & Female & Adult & Total \\
\hline Reynolds (1975) & $3 \%$ & & & & \\
\hline B.C. Fish and Wildl. Branch (1979) & & $60: 40$ & & & $5 \%$ \\
\hline Tompa (1984) & & & $2 \%$ & & $3-5 \%$ \\
\hline van Drimmelen (1984) & & $65: 35$ & $2 \%$ & & $3 \%$ \\
\hline Sidororowicz and Gilbert (1981) & $2-3 \%$ & & & $4.5 \%$ & $10.5 \%$ \\
\hline Lortie and McDonald 1977, Lortie 1978 & $3 \%$ & $61: 39$ & & & \\
\hline $\begin{array}{l}\text { B. Smith (pers. commun. Yukon } \\
\text { Wildl. Branch) }\end{array}$ & $4 \%$ & & & & \\
\hline Martinka (1974) & & & & & $17 \%$ \\
\hline $\begin{array}{l}\text { Craighead et al. } \\
(1974)\end{array}$ & & & & & $\begin{array}{r}8.2 \% \\
14.4 \%\end{array}$ \\
\hline McCullough (1981) & & & & & $13.2 \%$ \\
\hline Cowan (1972) & $5-7 \%$ & & & & \\
\hline Bunnell and Tait (1980) & & & & & $10.7 \%$ \\
\hline Harris (Unpublished) & & & & & $\begin{array}{l}6.4 \% \\
6.6 \% \\
\end{array}$ \\
\hline $\begin{array}{l}\text { Average annual mortality in the } \\
\text { NCDE, } 1967-1984\end{array}$ & $3 \%$ & $59: 41$ & $4.5 \%$ & $6 \%$ & $6 \%$ \\
\hline
\end{tabular}

aRate includes only man caused mortality.

bRate includes all known causes of mortality.

3. hunters might legally harvest problem bears and, therefore, bear/human conflicts may be reduced

4. hunting may reduce the need for agency control of nuisance bears

5. Hunting may cause bears to become wary of humans as is shown in studies of other species in hunted $v s$. unhunted populations

6. hunting may increase cub survival and recruitment, resulting in a population increase.

\section{Differential Vulnerability}

Males are more vulnerable to hunting than are females. This is consistently demonstrated by the number of males harvested, higher apparent mortality rate of males in the capture data and higher actual mortality (Nagy et al. $1983 \mathrm{~b}$, Dood et al. 1986, Bunnell and Tait in press). There is also a differential vulnerability by age class as evidenced in the Montana data (Dood et al. 1986).

Several factors contribute to the differential vulnerability of age and sex classes in the harvest, between and within populations (Bunnell and Tait in press). These include;

1. hunter selectivity (e.g., avoidance of females with cubs; selection of large (male), grizzlies)
2. behavioral differences (e.g., hunting practices such as bear baiting, or shooting over gut piles that attract dominant males)

3. movement patterns of both hunters and bears (Bunnell and Tait in press)

4. vulnerability as affected by earlier emergence from dens and greater mobility (larger spring ranges) of males (Nagy et al. 1983b)

5. season dates influence the sex ratio of the harvest - early fall and late spring seasons result in a higher percentage of females in the harvest (Troyer 1961, Dood et al. 1986).

Troyer (1961) stated that because fall hunting produced a higher female harvest (i.e., earliest part of fall season is the most productive for females), seasonal restrictions would have the most significant result. Stirling et al. (1976), following this line of thought, stated that the fall seasons might be detrimental to the population as a whole because of the high female vulnerability. Additionally, because a decreasing proportion of females are reported in the fall kill as the season progresses, Pearson (1975) proposed postponing the early fall season until after females have denned.

\section{Harvest Data}

Several researchers have investigated the application of grizzly harvest data to population modelling in general 
(Stringham 1980, Tait 1983, Harris 1984b, 1985ab, 1985b, 1986a, Bunnell and Tait in press).

Tait (1983) in his analysis of hunter kill data, stated that the description of the number of animals in the population over time will reveal both population trends and harvest impacts on the population. However, harvest data do not represent an unbiased sample of the overall hunted population; the age and sex distribution in the harvest does not necessarily reflect the age and sex distribution of the population (Tait 1983, Bunnell and Tait in press). This disparity suggests cautious use of these data as indicators of population size and trends. Harvest rates should be governed by more reliable evidence of how close a population is to the carrying capacity of its habitat (Stringham 1980).
Harris (1984b, 1985ab, 1985b, 1986a) developed several grizzly bear population models to determine the affects of various population characteristics and harvest strategies on the populations. Data required for these analyses include age specific natality rates (litter size, breeding interval, age of first reproduction), age specific survival in the absence of hunting, relative vulnerability to hunting by age and sex class, initial population age structure and responses of the above to lowered density caused by hunting (Harris 1985b). Details of the models are described in the papers discussed and are beyond the scope of this narrative.

Specific harvest regulations are presented by state/province in the following section.

\section{Montana}

(from Montana Dept. of Fish, Wildlife and Parks, 1986b Grizzly Bear Hunting Regulations)

Fees: $\quad$ Conservation license (prerequisite): $\quad \$ 2.00$

resident: $\$ 50.00$

non-resident: $\$ 300.00$

trophy fee: $\$ 25.00$

Season: Legally described grizzly bear management areas (Rocky Mountain East Front, Scapegoat and Flathead) within the NCDE are open October 1, 1986 and will continue until 48 hour notice in appropriate bear management area if "total mortality quota or female subquotas are reached" but will close no later than Nov. $30,1986$.

Bag limits: One grizzly bear of either sex per license year.

Female bears with young and individual young may not be taken; young are defined as 2 years old or younger. To reduce the likelihood of taking a female grizzly, the regulations request that hunters, if possible, refrain from shooting grizzlies in groups of 2 or more. The grizzly license and tag must be attached to the hide immediately upon harvest. Evidence of the sex of the animal must remain intact on the carcass.

The Northern Continental Divide Grizzly Bear Ecosystem is divided into 3 bear management areas (see below). Montana is the only state/province that uses a quota system (Dood et al. 1986). In 1986, the quota for the ecosystem was set at a total of 14 grizzly bears (subquota of 6 females) killed by hunting or other human activity. Included in this total is the relocation of a grizzly or any other human action that leads to the loss of a bear from the ecosystem. Each of the 3 bear management areas has its own subquota at which the specific season will close on 48 hours notice when achieved. These areas and subquotas are:

Flathead Bear Management Area: The season will close when 2 females have been killed.
Rocky Mountain East Front Bear Management Area: The season will close when 3 females have been killed.

Scapegoat Bear Management Area: The season will close when 1 female grizzly has been killed.

Prior to the start of the 1986 season (Sept. 19) a total of 9 grizzly bears remained in the overall quota; only 2 females remained within the female subquota - only 1 of which could be taken from the Rocky Mountain East Front. The season eventually closed on October 11, after the Dept. of Fish, Wildlife and Parks was notified that a sixth female grizzly had been taken by a hunter along the Middle Fork, Flathead River (Montana Dept. Fish, Wildlife and Parks 1986a).

Hunters accounted for 3 male and 2 female grizzlies killed of the total 10 removed from the ecosystem this year. One grizzly was relocated to a zoo; 4 died due to nonhunting, human causes (Montana Dept. of Fish, Wildlife and Parks 1986a). 


\section{Alberta}

(from Alberta Fish and Wildlife Division, 1986 Summary of Big Game Regulations)

Fees:

all hunters: $\quad \$ 11.00$ wildlife certificate and resource development stamp

resident: $\quad \$ 20.00$ license

non-resident: $\$ 125.00$ license

non-resident alien: $\$ 250.00$ license

Seasons: Seasons vary by zones, but in general are: 1) fall season, Sept. 10 - Nov. 29, northwest 2) spring authorizations, April 1 - May 15, Kananaskis Range area 3) general spring season, April 1 - June 2, northwest fourth of the province and 4) April 1 - June 13, zone along border of Banff and Jasper National parks.

Bag Limits: Resident, 1 per license (if successful in 1985, ineligible to purchase license in 1986). Non-residents and non-resident aliens, 1 per license (if successful in 1982,1983,1984 or 1985 ineligible to purchase license in 1986). Authorizations and special licenses (residents only) from a drawing can be applied once.

It is illegal to hunt or possess a grizzly under the age of 2 years, or a female grizzly accompanied by a cub under the age of 2 years. Grizzlies killed must be tagged through the hide and the hide and skull must be submitted.

\section{British Columbia}

(from British Columbia Ministry of the Environment, B.C. Hunting Regulations. Synopsis 1985-1986)

Fees: $\quad$ resident: $\quad \$ 70.00$ plus hunting license fee non-resident: $\$ 320.00$ plus hunting license fee

Seasons: fall: Oct. 1 - Nov. 19 spring: April 1 - May 31

Bag limits: Regional bag limits are set, with limited entry and non-resident quotas established for some regions. Some regions have a limit of 1 grizzly bear taken per 5 year period.

In British Columbia, as in other regions, grizzly bears cannot be taken when part of a family group. The taking of a grizzly must be reported immediately and the entire skull turned into the authorities.

During possession and transport, the hunter must leave attached to a portion of the carcass either: 1) a readily identifiable portion of the hide, not less than $6 \mathrm{sq} \mathrm{cm}$ in size or 2) either a testicle or part of the penis, or a portion of the udder or teats to identify the sex.

The first priority of grizzly bear management in British Columbia is sport hunting at a level which is not detrimen. tal to the population (British Columbia Ministry of Environment 1979a, Van Drimmelen 1985). Management for hunting emphasizes the production and continued availability of large, mature, animals (British Columbia Ministry of Environment 1979c).

Proposed harvest levels should be based on biological considerations such as reproductive capability, movements and differential vulnerability of specific age and sex classes (Van Drimmelen 1985). Tompa (1984) stated that a $3 \%$ harvest level (or $2 \%$ of the female segment of the population) is a normally sustainable level of annual harvest. According to the management plan described for British Columbia (British Columbia Ministry of Environment $1979 \mathrm{ab}$ ), the harvest should be directed toward males and held at less than $5 \%$ of local populations. When discussing these levels, consideration must be given to crippling loss, removal of problem bears and illegal loss (Woods and Hebert 1983, Van Drimmelen 1985).

Three sub-objectives of grizzly bear management were stated for British Columbia (British Columbia Ministry of Environment 1979ab). These are:

1. maintain the population at not less than 5000 animals distributed in the wilderness

2. provide an opportunity for people to view grizzly bears in their natural habitat

3. provide 6000 hunter days and an annual sustained harvest of 200 grizzlies (based on productivity of the population, allowable harvests, some area closures, habitat alterations and past hunting statistics).

Based on hunter sample returns for the period 1965-74, a harvest of 250 grizzly bears (27.7 bears/year) was estimated for 2 game management units. From 1975-81, a total of 87 bears were harvested from 3 units (13.4 bears/year) (Woods and Hebert 1983). From 1965-73 inclusive, nonresidents harvested an average of 218 grizzlies; residents harvested 177, for a total of 396 grizzlies/year for that period (British Columbia Ministry of Environment 1979b).

In Woods and Hebert's (1983) study, females comprised $43 \%$ of the total non-resident harvest. Ideally the male/ female harvest ratio should be close to $3 / 2$, with $60 \%$ of the 
harvest comprised of subadults (British Columbia Ministry of Environment 1979a). Age of grizzly bears harvested ranged from a high of 9.1 to a low of 4.3 years. The average female age was 6.3 years; average male age was 6.8 years. The fall season accounted for $69 \%$ of the harvest (Woods and Hebert 1983).

Trends in hunter harvest must be maintained and harvest levels reduced if overharvest is indicated. Such indicators are: 1) decreased hunter success, 2) decreased average age of harvest, and 3) increased female component of the harvest (Van Drimmelen 1985). Intrepretation of the historic and current harvest suggests that: 1 ) the average age of harvested bears must increase, 2) the number of females in the harvest must decrease, and 3) harvest between coastal management units must be redistributed (Woods and Hebert 1983).

As a result of this trend information, the following remedial measures may be required to assure a sustainable population (Woods and Herbert 1983, Van Drimmelen 1985);
1. regulations should change from protecting females with 1-year-old cubs to females with 2year-old cubs (current regulations protect "family groups")

2. harvest limits will be imposed for non-residents (or formal quotas)

3. reduction in length of fall and spring seasons

4. limited entry restrictions should be imposed

5. total closure if needed

6. elimination of fall season as needed.

Future harvest levels should be based on a combination of harvest data analysis and relative population indices (Woods and Hebert 1983). Ideally harvest should be constantly maintained and checked against known population data (Tompa 1984).

\section{Northwest Territories}

(from Northwest Territories Renewable Resources, Summary of Hunting Regulations, 1986)

Fees: $\quad$ Mountain Grizzly -

$$
\text { resident: } \quad \$ 5.00 \text { license }
$$

non-resident: closed

non-resident alien: closed

$$
\begin{array}{rrl}
\text { Barren Ground Grizzly - } & & \\
\text { resident: } & \$ 5.00 & \text { license } \\
\text { non-resident: } & \$ 10.00 & \text { license } \\
& \$ 500.00 & \text { trophy fee } \\
& \$ 25.00 & \text { license } \\
\text { non-resident alien: } & \$ 500.00 & \text { trophy fee }
\end{array}
$$

Seasons: Mountain Grizzly - Aug 15 - Oct 31, Zone E/1, northwest along Yukon border.

Barren Ground Grizzly - Aug. 15 - Oct. 31, Zones C/1-1, 1-2, 1-3, F/1-1, northcentral above Yellowknife, Fort Good Hope.

Bag limits: Mountain Grizzly - (residents only) - 1, any adult not accompanied by a cub; only one per lifetime. Barren Ground Grizzly - (all hunters) - 1 or more, any adult not accompanied by cubs, in accordance with the number of tags held.

From 1965-1978, 397 bears, an average of 28/year, were taken in 2 game management zones (12 and 19) by nonresident hunters, declining at a rate of 2 /year. No strict conclusions were made from the age structure of the harv. est (Miller et al. 1982).

Based on the available harvest data, Miller et al. (1982) concluded that the harvesi rates for this period were exces- sive, resulting in an overexploitation of the population. This resulted in a net immigration into the harvested area, which possibly resulted in a gradual, overall population decline for the entire area. The above stated hypothesis suggested that the ability of the population to sustain a harvest is limited. Some of the regulations have been changed to address these points. 


\section{Yukon}

(from Yukon Renewable Resources, 1986/87 Yukon Hunting Regulations Synopsis)

Fees:

$$
\begin{array}{rrl}
\text { resident: } & \$ 10.00 & \text { license } \\
& \$ 25.00 & \text { seal } \\
\text { non-resident: } & \$ 75.00 & \text { license } \\
& \$ 25.00 & \text { seal } \\
& \$ 500.00 & \text { trophy fee, male grizzly } \\
& \$ 750.00 & \text { trophy fee, female grizzly } \\
\text { non-resident alien: } & \$ 150.00 & \text { license } \\
& \$ 25.00 & \text { seal } \\
& \$ 500.00 & \text { trophy fee, male grizzly } \\
& \$ 750.00 & \text { trophy fee, female grizzly }
\end{array}
$$

Seasons: Both spring and fall seasons vary by management zones. Briefly they are: 1) April 15 - June 21, Aug. 1 - Nov. 15 , south west corner, northeast of Kluane Natl. Park 2) April 15 - June 15, Aug. 1 - Oct. 1, extreme northwest and northcentral region 3) Aug. 1 - Oct. 31, southwest corner and 5) April 15 - May 30, Sept. 7 - Oct. 31, southwest corner, along British Columbia border (see regulations for more details).

Bag limits: Harvest limits vary by Game Management Zone for resident hunters from 1 grizzly per license year to 1 grizzly/3 license years.

A system of annual quotas to regulate non-resident harvest of grizzly bears has been replaced by a system of harvest points for the period April 1, 1985 to March 31, 1987. Points will be deducted for each male grizzly (1 pt.) and female grizzly ( 3 pts.) harvested by non-residents ( $1 \mathrm{pt}$. is also taken for each goat). This new system provides an incentive to harvest male bears and opportunity and flexibility for outfitters to operate their businesses.

Each successful hunter must present evidence of the sex of a harvested grizzly by submitting the skull of any female or skull and baculum attached to the hide of any male grizzly not more than 10 days later than season closure. Species seals must be affixed to the hide upon killing a grizzly and to the skull when prepared. Hunters who kill a female bear are requested to deliver the reproductive tract to the Dept. of Renewable Resources. Marked grizzly bears cannot be taken by hunters.

Harvest data in the Yukon over the past 20 years show that the number of bears harvested annually varies little and averages about 100 (Sidorowicz and Gilbert 1981). In central Yukon, females comprised $52 \%$ of the 1973-1976 reported kill. Harvest data revealed significant differences in the distribution of bears killed by time of day and sex: females most numerous in mid-morning and early afternoon and males in late afternoon (Smith in prep.).
Sidorowicz and Gilbert (1981), upon reviewing the harvest and population data, made the following recommendations;

1. total adult mortality must be restricted to $5 \%$ or less and sport harvest to 2-3\% (100 or less bears/ year)

2. if fewer females than males are taken, a higher total number can be harvested

3. obtain age and sex data from every kill so that harvest may be maintained and regulations for subsequent years adjusted

4. management strategies should avoid the use of quotas that may lead to a biologically detrimental harvest

5. the reestablishment of effective management zones based on ecophysical criteria should be considered.

Smith (in prep. c) recommended an active management strategy for sex-selective hunting to maximize harvest and protect the reproductive segment of the population. This has been addressed by initiation of the point system described above. 


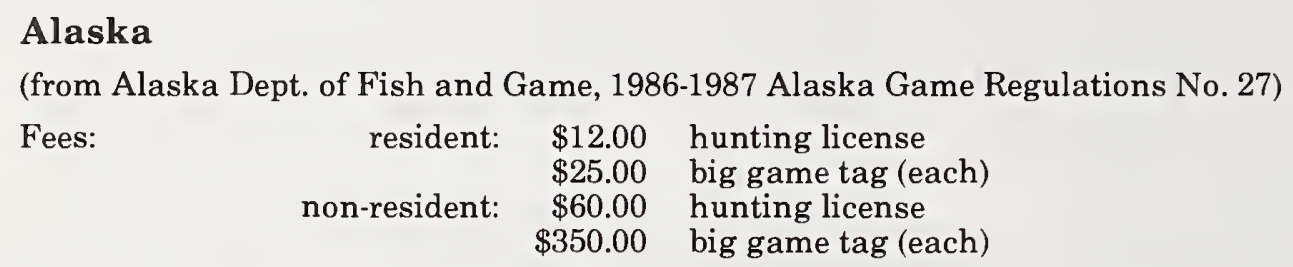

Seasons: Seasons vary by Game Management Unit but generally fall between Sept. 1 - Oct. 31 (fall season) and May June (spring season). Seasons range from Sept. - May, mid-August - October, Sept. - December, and into July. See regulations for specific dates.

Bag limits: Limits also vary by Game Management Unit and are different for residents, non-residents and subsistence hunters. In general, the limit is 1 bear every 4 years, but varies to 1 bear per year. Some units have limits on the number of permits issued.

Neither a bear cub nor a female accompanied by a cub can be legally taken. Bear tags must be affixed to the hide, which must be salvaged along with the skull. Non-resident hunters must be acompanied by a guide or a resident over 19 years of age. The regulations differentiate between brown and grizzly bears.

In areas of intensive hunter use, brown bears will be managed for an optimum sustained yield of animals (Anon. 1980). Regulations in the past have been based on the fluctuation of trophy size bears, total take, chronology of the kill and the sex differential in the harvest (Troyer 1961). Seasonal restrictions have been imposed to control these factors.

In Alaska, the necessity for subsistence hunting must be a management goal within the limitations of a sustained yield. Additionally, certain areas of the state are managed to provide hunting opportunities with high aesthetic quality (Anon. 1980).

Troyer (1961), in examining the harvest, came to several conclusions. They are;

1. fall hunting success is lower than spring

2. the estimated illegal kill comprises $20-25 \%$ of the total kill

3. in fall, the earliest portion of the season is the most productive, gradually diminishing as bears approach denning

4. the spring kill is lowest in early April, gradually increasing until it reaches a peak in the latter part of May.

5. males comprise $65 \%$ of the harvest, attributed to selective hunting for size; males more in spring than in fall ( $68 \%$ and $59 \%$, respectively).

Based on these factors Troyer (1961) recommended reducing or eliminating the early fall season to reduce the take of females in the harvest.

\section{BIOGEOGRAPHIC CONSIDERATIONS}

Shaffer (1986), motivated largely by recent work on the equilibrium theories of island biogeography (MacArthur and Wilson 1967), noted that traditional theories of extinction have been dramatically expanded. The traditional view held that species viability was constrained only by its ability to adapt to gradually changing environmental conditions or to survive rare global catastrophes. In recent decades, biologists have recognized that extinction may occur fairly often on a local scale, especially with small populations, due to various stochastic factors. Types of stochastic perturbations which can influence population viability include demographic stochasticity, environmental stochasticity, natural catastrophes and genetic stochasticity (Shaffer 1978, 1981, 1986). Habitat fragmentation and isolation exposes remnant populations (such as the Yellowstone grizzly bear population) to higher extinction rates due to the increasing importance of these stochastic forces (Shaffer 1983). Species preservation tactics which address only the sustained, systematic pressures confronting a population may prove inadequate for handling stochastic perturbations in the long-term.

\section{Minimum Viable Population Size}

Of fundamental concern is the population size threshold below which susceptibility to stochastic perturbations is so great that the probability of chance extinction approaches an unacceptable level. Shaffer $(1978,1981,1983)$ termed this the minimum viable population (MVP) size and defined it for any given species as the population size below which the population had less than a $93 \%$ chance of surviving for 100 years. The MVP is a population that, within its particular biogeographic context, is able to not only maintain itself under average conditions but is also of sufficient size to withstand the various stochastic perturbations (Shaffer 1981). There are 5 approaches for determining MVP sizes (Shaffer 1981, Samson 1983, Samson et al. 1985): experimental, analysis of biogeographical patterns (observed distribution and extinction/colonization rates), analysis of genetic considerations, theoretical models and simulation models. Simulation models have several advantages over the other approaches including the ability to incorporate population-specific data on vital parameters 
(mortality and fecundity rates) and to test the effects of changes in these parameters (Shaffer 1981).

Shaffer $(1978,1981,1983)$ and Shaffer and Samson (1985) developed a stochastic computer simulation model to determine the relationship of population size to extinction probabilities for grizzly bears. The model used data for the Yellowstone grizzly bear population collected by the Craighead research team from 1959-1970. Density dependent relationships were determined from analysis of these data. Various versions of the simulations tested the effects of demographic or environmental stochasticity on population survival. Fifty replicates were run for each initial population size to determine the smallest isolated population having a $95 \%$ chance of surviving for at least 100 years. As first reported (Shaffer 1978, 1983), the MVP for the Yellowstone population was 35 to 70 bears; subsequent analysis detected 2 systematic errors in the original simulation leading to a new MVP estimate of $50-90$ bears (revision in Shaffer 1983, Shaffer and Samson 1985). This corresponds to a minimum area requirement of $1000-13,500 \mathrm{sq} \mathrm{km}$. A sensitivity analysis indicated that a slight increase in the specified mortality rate had a substantial impact on the estimated MVP.

Shaffer and Samson (1985) extended the simulation up to 300 years. Their modification enabled a more complete analysis of the variance in extinction times for different initial population sizes. This work showed that although a grizzly bear population of 50 had a .06 probability of survival for 300 years, $56 \%$ of these populations were extinct by 114 years (range of 24 to $300+$ years). Another significant finding was the long survival times for populations having a low probability of ultimate survival. For example, no populations of 20 bears survived the 100 -year test period, yet the average time to extinction was 44 years. Servheen (in press) noted that these findings had important implications for grizzly bear management.

Comparisons of the estimated times to extinction from the simulation model with the predictions of analytical extinction models revealed some striking differences (Sampson et al. 1985, Shaffer and Samson 1985, Shaffer 1986). The MacArthur and Wilson (1967) equilibrium island biogeography model produced an expected time to extinction of 8336 years for an initial population of 50 grizzlies. The more sophisticated structure of the Shaffer simulation model accounted for the great difference in estimated extinction times (8336 years vs. 114 years) between the analytical and simulation results. The simulation model also incorporated the effects of environmental stochasticity and population age/sex structure in its analysis, neither of which was included in the MacArthur and Wilson analytical model.

Several weaknesses of the simulation model were dis. cussed. Lack of generality was one difficulty. The model required detailed, population-specific data on basic lifehistory parameters. These data were available only through intensive, long-term studies of individual populations (Shaffer 1981, 1983). Another weakness was the inability to incorporate genetic considerations in the simulations. Shaffer and Samson (1985) felt that inclusion of genetic factors could increase the simulated extinction probabilities substantially.

Suchy et al. (1985) modified Shaffer's model to reflect more recent (1975-1982) Yellowstone grizzly bear data. As with Shaffer's earlier work, this model simulated the effects of both demographic and environmental variation. Simulations were run using 2 different mortality estimates. The lower mortality rate was based on confirmed mortalities only; the higher mortality rate included 7 additional suspected mortalities. The lower mortality estimate yielded an MVP of 40 bears while the higher mortality estimate yielded an MVP of 125 bears. Thus, as noted previously regarding Shaffer's sensitivity analysis, the addition of a few mortalities drastically changed the prognosis for a given bear population.

\section{Management Applications of MVP Concepts}

Minimum viable population analyses provide the grizzly bear manager with knowledge about the susceptibility of various sized populations to stochastic perturbations. Although MVP analysis can determine the probabilities of persistence for a given population size, the actual outcome is stochastic and therefore can not be predicted beforehand. A population of 50 grizzly bears will survive an average of 114 years, but over half of such size populations become extinct in less than 114 years. Grizzly bear managers are not indifferent to that outcome (Samson et. al. 1985).

Attempts to transfer the simulation results to other grizzly bear populations must recognize the great variability in vital parameters between populations (Shaffer $1978,1983,1986)$. The nature of the ecosystem, or reserve, in terms of habitat security and management intensity, is also critical to the application of MVP concepts (U.S. Fish and Wildlife Service 1982a, Shaffer and Samson 1985).

Based on the findings of Shaffer (1978), the Grizzly Bear Recovery Plan (U.S. Fish and Wildlife Service 1982a) established a recovery goal for the Cabinet-Yaak grizzly bear ecosystem of 70 bears within $1,818 \mathrm{sq}$ miles of occupied habitat. The plan notes that management according to MVP objectives alone could mean maintaining grizzly bears at threshold numbers at which unpredictable catastrophes could plunge the population toward extinction.

The evolving views on the dynamics of extinction have led to an increased appreciation by management agencies that viable population problems must play an integral role in endangered species management (Shaffer 1986). Salwasser et al. (1983) discussed the legal and ethical mandates to manage National Forest land to maintain viable populations of vertebrate species. As Shaffer (1986) observed:

The grizzly bear MVP analysis has been useful primarily in elucidating the problem of species conservation where habitat area and population size are key issues; providing a conceptual framework for defining population viability; and demonstrating what can be done with available information to better assess the possible long-term consequences of short-term management decisions.

\section{HUMAN ATTITUDES}

A number of surveys have been conducted to evaluate public attitudes toward the grizzly bear and grizzly bear 
management, and general public knowledge about bears. Some of these studies also attempted to identify factors which influenced these attitudes. While an attempt was made herein to compare results from these studies, it must be emphasized that considerable variation existed in the instruments employed (questionnaire or survey), the sample size and the population sampled. Additionally, there was a 15 year time span between the earliest (March 1970) and most recent studies (Frost 1985, Sundstrom 1985, Maw in progress). Such factors must be considered when reviewing findings of these studies and apparent contrasts must be approached cautiously. A brief overview of the most important surveys is provided below:

Marsh. 1970, 1972.

Personal interviews of visitors to Banff and Glacier National parks (B.C.) $(n=114)$ concerning general knowledge and attitudes toward bears and bear management programs.

Bryan and Jansson. 1973.

A questionnaire survey of 393 persons in 3 Alberta communities included a cross-section of geographic areas (representing different levels of opportunity for exposure to grizzly bears and other wildlife) and a breakdown by: park visitors vs. non-park visitors and hunters vs. non-hunters. Designed to evaluate perceptions of hazard and general attitude toward wildlife.

Freeman-Haet. 1973.

Questionnaire administered to visitors (all use categories) to Glacier National Park $(n=312)$. Designed to analyze the perception of the grizzly bear image of the general public.

Hodgson. 1974.

Analyzed the effects of different types of grizzly bear warning messages on perceptions and behavior of wilderness survival students $(\mathrm{n}=78)$.

Mihalic. 1974.

Questionnaire survey of visitors to Glacier National Park, Montana $(n=150)$ to evaluate attitudes, knowledge, information sources and experience regarding grizzly bears. Included a complex, detailed analysis of "intervening factors" (e.g., place of residence, age) which influenced attitudes toward bears.

McAllister. 1977.

Random sample questionnaire of Vancouver area residents $(n=42)$ and Sierra Club members in Vancouver area $(n=70)$ to assess overall attitudes, knowledge and information sources regarding grizzly bears.

Perry. 1977.

Informal interview of visitors and residents to the North Fork of the Flathead Valley (NCDE) regarding attitudes toward grizzly bear management and behav. ior in bear country (sample size not available).

Post. 1982.

Questionnaire survey of visitors $(n=79)$ to the Pack Creek brown bear reserve on Admiralty Island National Monument. Evaluated attitudes toward bears, bear encounters and visitor activities.

Fortier. 1983.

Questionnaire survey of visitors to Yellowstone National Park ( $n=274$, including 137 inbound and 137 outbound visitors). Designed to evaluate effectiveness of bear information dissemination in the park. Included cross section of all user categories.

Frost. 1985.

Questionnaire survey from households in Mission Valley, Montana ( $n=154)$ to evaluate residents' knowledge, attitudes and experience with grizzly bears (note that $71 \%$ of the residents sampled had seen a grizzly bear in the wild.)

Sundstrom. 1985.

Questionnaire survey of visitors, employees and professionals at Denali National Park, Alaska. Evaluated attitudes, and knowledge regarding bears and effectiveness of visitor education efforts. $(n=2384)$.

Maw. In progress.

\section{General Attitude Toward Grizzly Bears}

Several studies conducted in Canadian and American national parks showed predominantly favorable attitudes toward the grizzly bear. Sixty-five percent of the Glacier National Park visitors surveyed had positive sentiments about the grizzly bear (20\% neutral, $15 \%$ negative; Mihalic 1974). An associated study indicated that the aesthetic qualities of the grizzly were the strongest components of the positive image (Freeman-Haet 1973). In Waterton National Park, grizzly bears were valued for their ecological role ( $32 \%$ of respondents), their aesthetic attributes (25\%) and for moral considerations (12\%). Only $5 \%$ of the respondents had negative attitudes about the grizzly (Maw in progress). In the Pack Creek reserve for brown bears in Admirality Island National Monument, $60 \%$ of the visitors who had seen one or more bears felt that the experience had added to enjoyment of their trip. Sixty-seven percent of those who had seen "lots of bears" said that the experience had "extremely added" to their trip (Post 1982).

Studies conducted outside of the parks and reserves also showed generally favorable attitudes toward the grizzly. In the Mission Valley, $61 \%$ of the residents said they liked grizzly bears, $27 \%$ disliked grizzlies and $12 \%$ were uncertain or neutral. Fifty-five percent of these residents felt that having grizzly bears in the Mission Valley contributed to their quality of life. Thirteen percent felt that the grizzly bear did not add to their quality of life. Sixteen percent and $11 \%$ favored reducing (or eliminating) grizzly bears in the Mission Valley and the United states, respectively (Frost 1985). An informal survey in the North Fork of the Flathead Valley revealed that $84 \%$ of the users wanted to have grizzly bears in the area, $11 \%$ were neutral and $5 \%$ preferred to have no grizzlies (Perry 1977). Only $20 \%$ of the Vancouver Island residents surveyed by McAllister (1977) had positive attitudes toward the grizzly, $20 \%$ were "concerned," $41 \%$ were "cautious" and $14 \%$ were negative (definitions of these terms were not provided).

\section{Perception of Danger and Effect on Human Activities}

Several surveys attempted to assess the visitor's perception of danger from grizzlies and the effect this perception had on their activities in bear country. Bryan and Jansson (1973) surveyed Alberta residents from 3 different areas of the province. Overall, $57 \%$ of the respondents felt that 
grizzly bears were dangerous and $12 \%$ felt "personally endangered" by grizzly bears. In Banff and Glacier National parks, $20 \%$ of the visitors were discouraged from hiking because of the presence of bears and $10 \%$ were discouraged from camping because of the presence of bears (Marsh 1970). Perry (1977), found that $89 \%$ of the visitors encountered in the Flathead Valley would not avoid an area specifically because of grizzly bear presence. In Yellowstone National Park, 40\% of the outgoing visitors claimed that they would be willing to assume some risks for the opportunity to see bears. Twenty-eight percent of these visitors felt that the danger from bears was overrated and $42 \%$ favored the establishment of some sort of controlled viewing area (Fortier 1983).

\section{Knowledge About Grizzly Bears}

Several studies evaluated the knowledge level of the general public and park visitors concerning bear biology and management. Higher knowledge levels were generally associated with increased exposure to bears and participation in outdoor activities (Bryan and Jansson 1973, Mihalic 1974, McAllister 1977, Fortier 1983, Frost 1985, Sundstrom 1985). The relationship between knowledge level and attitude toward grizzly bears was less conclusive. Frost (1985) reported that Mission Valley residents with favorable attitudes toward grizzlies tended to have more knowledge about bears and more experience with bears in the wild. Residents who opposed reducing or eliminating the Mission Valley grizzly population were likely to have more knowledge about grizzly habitat needs and behavior than those with the opposing viewpoint. Similarily, there was a significant relationship between knowledge and positive attitude for visitors to Yellowstone National Park (Fortier 1983).

Conversely, Mihalic (1974) reported that for visitors to Glacier National Park, knowledge of bear biology was not a valid indicator of attitude. Past behavior (i.e., outdoor experience) was also not significantly related to attitude unless the interviewing factors of visitor origin and, to a lesser extent, age were incorporated into the analysis. Those visitors who had previously seen bears were equally divided between positive, negative and neutral attitudes.

\section{Attitudes Toward Bear Management}

Attitudes toward bear management goals and activities were discussed in several reports. Marsh (1970) found that $70 \%$ of the Canadian park visitors surveyed felt that removal and relocation, rather than killing, were the best control methods for first-offense nuisance bears. Nineteen percent said that troublesome bears should be shot when first detected and $10 \%$ felt that bears should be left alone regardless of their offense. Bryan and Jansson (1973) reported that a significant majority of Alberta residents believed that animals causing property damage should be removed and those causing human injury should be destroyed. In the North Fork of the Flathead Valley, 63\% of those surveyed felt that relocation was appropriate for nuisance bears; $26 \%$ favored killing nuisance bears; and $11 \%$ felt no action should be taken (Perry 1977). Residents of the Mission Valley overwhelmingly agreed $(98 \%)$ that they would kill a grizzly for protection of self and family (Frost 1985). Fifty-one percent would kill a grizzly for livestock depredation. Increased willingness to kill a grizzly was associated with lower knowledge about grizzly habitat needs and behavior (other factors were also discussed).

Visitors to Waterton National Park showed some surprisingly encouraging attitudes concerning bear management (Maw in progress). All of those surveyed felt that bear injuries were human caused. When asked whether bears or people should have priority in management of a certain valley, $56 \%$ gave priority to bears in all circumstances and $4 \%$ gave full priority to bears only when in prime bear habitat. Only $6 \%$ gave full priority to people. If bear problems arose, $20 \%$ of the visitors favored people management, $75 \%$ favored relocation and only $3 \%$ favored killing nuisance bears. In the case of repeat offenders, $8 \%$ favored people management and $11 \%$ favored killing the incorrigible bear.

\section{Effectiveness of Information Programs}

Three studies evaluated the effectiveness of park bear information programs. Fortier (1983) reported that exposure to Yellowstone National Park bear information had no significant effect on visitor knowledge concerning bears. Conversely, Sundstrom (1985) found that visitors departing from Denali National Park showed a highly significant increase in knowledge compared to arriving visitors. This finding did not apply to those classes of visitors with the least chance of encountering bears (e.g., day users, hotel guests and tour bus passangers). However, some attitude changes after exposure to park information sources were counter to bear management goals. Compared to inbound visitors, outgoing visitors were more willing to take risks to see bears and more likely to feel that park bears were unusually tame. Written information was the most effective method for disseminating knowledge.

Hodgson (1974) analyzed the effectiveness of different types of warning messages on subjects' perceptions of the grizzly bear. He found that although grizzlies were not rated as more dangerous by subjects exposed to strong threats, the subjects' anxiety level and predilection toward aggressive behavior increased with increased exposure to inhibition threats (i.e., threats which emphasized gruesome consequences of attack).

\section{AVERSIVE CONDITIONING, DETERRENTS AND ATTRACTANTS}

The research and development of non-lethal techniques for controlling problem bears is a relatively new field. To date, most of the work concerning deterrents, repellents and aversive conditioning has focused on canids, deer, birds or laboratory animals (Hunt 1983).

Hunt (1983) recently prepared a comprehensive, annotated bibliography on topics concerning aversive condi. tioning and deterrents. Over 400 citations, cross-referenced by species and subject, are included. Follmann et al. (1980) also reviewed the literature on carnivore deterrent methodologies and made recommendations for a carnivore control program for the North west Alaskan Pipeline Project. Both of these reports incorporated information from research 
studies on non-ursid species. The following discussions will adhere primarily to techniques which have been tested with bears. Readers interested in a more exhaustive treatment of deterrent/repellent research are urged to consult the above-mentioned reports.

Hunt $(1983,1984,1985)$ noted that these was a general lack of distinction in the literature between the terms repellents, deterrents and aversive conditioning and suggested the following definitions:

1. Repellents are activated by humans and should immediately turn a bear away during a close approach or attack.

2. Deterrents should prevent undesirable behaviors by turning bears away before a conflict occurs and need not be monitored or manually activated by humans.

3. Aversive conditioning should modify previously established undesirable behavior through the use of repellents or deterrents. This conditioning must be repeated until avoidance of people or their property has been firmly established.

The use of deterrents and repellents should be considered as a second line of defense against bear nuisance behavior. These systems should aid but not substitute for other preventative measures that reduce the possibility for bearhuman encounters such as excluding bears from the resource or decreasing its attractiveness (NPS 1984, Hunt 1985).

\section{Aversive Conditioning}

Aversive conditioning is a specialized form of learning that involves pairing a normally desirable food, space, object or event with a negative reinforcement. This process leads to an avoidance of the former attractive stimulus (Dorrance and Gilbert 1977, Follmann et al. 1980).

The effect of an aversive conditioning program depends on individual and species behavior, the character of the resource and the selection of the appropriate aversion stimuli and substrates (Dorrance and Gilbert 1977). The type of resource being damaged (i.e., live prey versus other types of food or attractants) is of particular importance. Predation may be more difficult to suppress than, for example, scavenging because predation involves a more complex array of motivational systems (searching, chasing, killing and eating) than does scavenging (searching and feeding) (Dorrance and Gilbert 1977).

Aversive conditioning of bears involved in nuisance behavior can provide an alternative to relocation or destruction of problem bears (Hunt 1984). However, these methods are generally expensive, time consuming and often ineffective as long-term solutions.

\section{Emetics}

Several researchers experimented with the use of emetics and noxious chemicals to condition bears to avoid certain attractants or conflict situations. Emetics are nauseaproducing agents which require ingestion to be effective whereas noxious substances are any chemical compounds which are distasteful or discomforting when inhaled or contacted (Follmann et al. 1980). Unlike emetics, noxious substances are theoretically effective upon first exposure and do not require a "conditioned" response. Hence, these chemicals will be discussed in the subsequent section on bear deterrents and repellents.

Impetus for research into aversive conditioning of bears through the use of emetics arose from their successful application with canids. Reviews of the use of emetics for aversive conditioning in canids and other mammals are provided in Follmann et al. (1980) and Wooldridge (1980). Among the most common emetics used as aversion control agents are lithium chloride, sodium salicylate, syrup of Ipecac, apomorphine (a narcotic with limited availability), peruvoside and ovabain (Follmann et al. 1980). Of these, lithium chloride ( $\mathrm{LiCl}$ ) has shown the most promise and has been most frequently used with bears.

Gilbert and Roy (1977) found that $\mathrm{LiCl}$ showed good potential for reducing the amount of black bear damage to Alberta beeyards. The best results were achieved by using both $\mathrm{LiCl}$ baits ( $\mathrm{LiCl}$ capsules wrapped in honey or brood comb) in combination with electric fencing. However, subsequent testing of $\mathrm{LiCl}$ and cupric sulfate ( $\mathrm{CuSO} 4)$ in honey baits failed to reduce black bear damage in beeyards; the researchers concluded that $\mathrm{LiCl}$ was not an effective emetic for this purpose (Dorrance and Roy 1978). Hastings et al. (1981) attempted to avert bears to a particular food by feeding them $\mathrm{LiCl}$ pellets placed in hot dogs. No definite results were documented due to problems in identifying treated bears and other difficulties.

Wooldridge (1980) experimented with the use of three emetic compounds [ $\mathrm{LiCl}$, emetine hydrochloride $(\mathrm{EHCl})$ and alpha-naphthyl-thiourea (ANTU)] for aversive conditioning of captive and free-ranging black and polar bears. Two captive black bears fed baits containing $\mathrm{LiCl}$ and $\mathrm{EHCl}$ avoided untreated bait for 3.8 days after exposure. The bears' pre-exposure diet (starvation level) influenced their reluctance to subsequently accept the untreated bait. Wooldridge also found that when livestock carcasses were treated with ANTU and $\mathrm{LiCl}$, the time required for freeranging black bears to consume the carcasses rose by 44 $55 \%$. All 3 emetic compounds reduced the consumption of baits by free-ranging black and polar bears at dumps. The effective dosages and relative merits of each compound were discussed.

A number of problems with the use of emetics have been noted. Foremost among these is the over-specificity of the resulting aversions; bears may be conditioned to avoid only the particular food(s) used as bait (Revusky and Bedarf 1967, Dorrance and Gilbert 1977, Follmann et al. 1980). While some success may be possible in instilling aversions to specific items, much bear nuisance behavior is oriented toward several or many attractants as at dumps. Achieving aversive conditioning to the wide variety of human attractants encountered by bears may not be possible (McCullough 1981). The best success with the use of emetics is achieved when the bait substrate closely approximates the item being damaged (Dorrance and Gilbert 1977, McCullough 1981).

Wooldridge (1980) acknowledged the problem of baitspecific aversions induced by emetics. He maintained, however, that continued noxious experiences at a particular bait site (e.g., a dump) should lead to a "location avoidance" response - a general reduction in visits to that site. Dorrance and Gilbert (1977) felt that barriers and repellents would be more effective than aversive conditioning in 
the protection of a particular area, unless an animal was motivated to approach that area by a specific hunger.

Studies with coyotes have shown limited success with inducing aversions to prey killing through the use of emetics in dead prey (Gustavson et al. 1975, as reported in Miller 1983; Gustavson et al. 1976 as reported in Follmann et al. 1980). However, other studies suggested that although some test animals learned to avoid LiCl-treated baits, killing of live prey was not diminished (Conover et al. 1977; Shumake et al., unpublished data as reported in Wooldridge 1980).

Another major problem with the use of emetics is that animals can "learn" the taste of the emetic and avoid only the baited foods (Follmann et al. 1980). Dorrance and Gilbert (1977) felt that the emetic must not alter the acceptability of the bait either by repellency or contrasting flavor characteristics. Several authors noted that the large volume required and salty taste of $\mathrm{LiCl}$ made it difficult to administer a full dose (Gilbert and Roy 1977, Wooldridge 1980). Wooldridge (1980) also reported that the hygroscopic nature of $\mathrm{LiCl}$ may have altered the surrounding tissues and affected their palatability.

Another problem encountered in the field application of emetics is determining the proper dosage for effective treatment of free-ranging bears of varying size, health and motivational state (Wooldridge 1980; Hastings et al. 1981). Some emetics, such as ANTU, are potentially lethal in large doses (Wooldridge 1980).

The uncertain duration of the aversive response induced by emetics is also a problem (Follmann et al. 1980). Wooldridge's (1980) data showed that 2 black bears which were given emetic-laced bait reluctantly sampled untreated meat after several days of starvation. The availability of alternate sources of food will affect the success of any aversive conditioning program (Dorrance and Gilbert 1977).

In conclusion, it appears that although some tests have been encouraging, the use of emetics as a bear control method is presently limited by the lack of a colorless, tasteless and non-lethal chemical, by the specificity of the created food aversion and by problems with dosages and field applications (Gilbert and Roy 1977, Follmann et al. 1980, Wooldridge 1980, Hunt 1985).

\section{Aversive Conditioning with Captive Bears}

Programs designed to apply aversive conditioning to captive bears have been very limited to date. Brady and Maehr (1982) reported that the trauma of capture and release was itself sufficient to deter further damage to beeyards in Florida. Greene (1982) applied the principles of classical conditioning and behavioral technology to a nuisance black bear. The bear was trained to associate a neutral, ultrasonic tone with the aversive sound of a loud boat horn. One post-release test was conducted in which the bear was successfully repelled from a well-baited campsite by the ultrasonic tone alone.

Researchers with the Border Grizzly Project in Missoula, Montana, have developed methodologies for aversively conditioning nuisance grizzly bears in captivity. Suggested procedures included repellent and deterrent tests in captivity and intensive post-release monitoring accompanied by various aversive conditioning tactics should the bears enter any conflict situations (Jonkel 1982b, Anon. $1983 \mathrm{~b})$.

Hunt (1984) delivered repellents to 1 black bear yearling and 2 grizzly bear cubs (held in captivity in the Border Grizzly Project facilities in Missoula, Montana) and a black bear adult temporarily restrained by an Aldrich leg snare. The objective was to aversively condition these nuisance bears to avoid humans and human proximity. The repellents used included an air horn, Bear Skunker and Halt (capsaicin product). The fate of the bears after release was not determined, but none of the 4 bears was known to have caused additional trouble or was reported in the hunter harvest.

Jonkel (pers. commun.) reported that over 50 black bears and 6 grizzly bears have been aversively conditioned by Border Grizzly Project researchers in British Columbia and Montana. Of these, only 2 black bears and 1 grizzly bear were reported to have encountered further conflict; the grizzly bear was involved in a different sort of conflict than that for which it had been aversively conditioned. Jonkel noted that the primary aim of the conditioning program was to train bears to avoid people and recent human scent; attempting to negatively condition bears to avoid all of the vast array of potential attractants was not a realistic objective. Reports on the Border Grizzly Project's aversive conditioning program are forthcoming (Jonkel in prep., Klassen in prep., M. Smith in prep.).

\section{Other Aversive Conditioning Research}

Researchers in Yosemite National Park developed a conditioning program to break the positive link between backcountry camper food and the item which nuisance bears most often oriented toward - the foodsack (Hastings et al. 1981, Hastings and Gilbert 1981). Their tests involved hanging "aversion sacks" containing ammonium hydroxide-filled balloons in the camp. Bears seeking food in these sacks ruptured the balloons containing the noxious chemical. Favorable changes in bear behavior were documented in the limited area where the conditioning took place.

Researchers in Denali National Park have used aversive conditioning techniques to deal with black and grizzly bears which showed signs of learning to aggressively seek human foods (Jope 1983b, Dalle-Molle 1984, NPS 1984a). Their technique involved setting up a test camp near the site of a recent bear depredation. A food cache is placed $15-20 \mathrm{~m}$ from the tent. If a bear approaches the cache, it is drugged and radioed. Another test camp is set up near the bear the following day and if it approaches this camp, it is hit with a plastic bullet (discussed later). This procedure is repeated until the bear no longer approaches the camps or shows any aggressive behavior. Resource managers in Denali feel that aversive conditioning may be successful in the park because bears there do not have a long history of intensive use of human foods, human foods do not constitute a major portion of the diet and bears in Denali do not exhibit the strong aggressive behavior found in other areas (NPS 1984a).

Follmann et al. (1980) suggested another technique for aversive conditioning of problem bears which has been successfully applied to dogs and laboratory animals. Offending bears could be trapped and fitted with electroshock collars which could be remotely triggered to deliver a 
painful shock to the bear whenever an undesirable behavior was repeated. Drawbacks of this approach included the expense of the collars and the time required to trap each bear twice (to fit and later remove the collar) and to monitor their activities.

\section{Electric Fencing}

\section{General}

Bear-proofing or complete physical containment of an attractant is the optimal means to avoid bear problems. Where this is not possible, electric forces provide the next most effective option (Hunt 1985).

Electric fences have been widely and successfully used to isolate attractants from black and grizzly bears (Follmann et al. 1980, Herrero 1982, Hunt 1985). However, success with polar bears has been minimal (Stenhouse 1982, Anon. 1983b, M. Bromley 1985).

Much of the relevant literature on electric fences relates to the prevention of black bear damage to beeyards or apiaries. Follmann et al. (1980) provided an excellent review of the available literature on the use of electric fences. As they observed, much of the reason for the large number of reports on fences is the ever-increasing sophistication of electrical fence equipment and design.

Electric fences were used to deter brown bears at salmon spawning streams on Kodiak Island as early as 1951 (Clark 1960, Gard 1971). These early systems, although relatively simple structures by later standards, were fairly effective when installed prior to initiation of the spawning run. Gard (1971) noted that the primary effect of fencing streams was to displace bear predation to other non-fenced streams.

Electric fences were used to exclude grizzly bears from garbage dumps in and around Yellowstone National Park beginning in the early 1970 s. Hepburn (1974) reported that a high voltage $(12000 \mathrm{v})$, low amperage $(22 \mathrm{ma})$ electric fence, $2.7 \mathrm{~m}$ high and $0.9 \mathrm{~m}$ buried, was $100 \%$ effective in preventing bear penetration. A mat of wire netting was laid on the substrate around and connected to the fence to improve the ground. The same design was later used successfully in Denali National Park (Herrero 1982).

Greer (1972b, 1976b) reported that a $3.3 \mathrm{~m}$ high chain link fence with $0.9 \mathrm{~m}$ buried and surrounded by an electrified 3 wire stock fence failed to prevent grizzlies from entering the West Yellowstone dump. Grizzlies gained access to the dump by going both under and over the fence. Later modifications improved the system and alleviated many of the problems at the dump (Whitman pers. commun., in Follmann et al. 1980).

At Banff and Jasper National Parks, traditional, unburied, chain link fences did not deter grizzly bears from using park dump sites (Follmann et al. 1980). Later electrification of the fence at Jasper (with a grounded wire mat surrounding the fence) prevented bear access (Herrero 1982).

Electrical and physical barriers were highly effective in preventing bears from entering 2 large work camps during preliminary testing for the proposed Northwest Gas Pipeline in Alaska. These camps, which had experienced major bear problems during an earlier project, were active for 2 full summers with virtually no bear problems (Herrero
1982). The barriers were designed according to the recommendations of Follmann et al. (1980).

\section{Fence Design and Specifications}

Reviews of successful fence designs are provided by Follmann et al. (1980), Herrero (1982), Wooldridge (1983) and Hunt (1985). More detailed specifications, including diagrams, are available in those reports. The following conclusions were drawn primarily from their recommendations.

1. Fence designs adequate to deter black bears may not be effective for grizzly bears (Follmann et al. 1980).

2. Various charges have been used, but, in general, high voltage ( $10000 \mathrm{~V}$ or more) and low amperage (1 amp or less) will ensure that a sufficiently painful jolt is administered if contact is made (Herrero 1982). Wooldridge (1983) recommended voltages high enough to cause muscle tetany ( $60 \mathrm{sq} \mathrm{kv}$ wave DC pulse at a frequency of $40 \mathrm{hz}$ ) for use with polar bears. He found that a nominal $200 \mathrm{kv}$ charge was required to reliably arc through a $6 \mathrm{~cm}$ patch of dry polar bear fur. Pulse frequency is also an important electrical consideration (Follman et al. 1980, Wooldridge 1983).

3. Barbed wire will ensure better contact than smooth wire (Follmann et al. 1980, Herrero 1982, Wooldridge 1983).

4. Achieving an effective ground can be difficult on dry or frozen substrate (Follmann et al. 1980, Herrero 1982, Wooldridge 1983). This problem can be corrected by laying a grounded, wire-mesh mat around the fence (Hepburn 1974), using a grounded upright chain link fence in combination with positively charged overhanging wires (Herrero 1982) or by placing charged wires an appropriate distance outward from the grounded fence so that an intruding bear will contact both wires (Follmann et al. 1980).

5. Some authors suggested that baits be attached to the charged wires so that a bear would contact the wire with the non-insulated nose or mouth and receive a more effective shock (Ridley 1976, Wooldridge 1983, Hunt 1985). However, Follmann et al. (1980) cautioned against the use of baits before bear problems developed as they could act as an unnecessary attractant.

6. Bears must be prevented from digging beneath a fence by a wire mat, buried fence, concrete pads or other physical obstructions (Follmann et al. 1980, Herrero 1982).

7. Fences must receive regular, proper maintenance to operate effectively (Ridley 1976, Follmann et al. 1980, Herrero 1982, Hunt 1985).

8. Gates represent an unavoidable weak point with any electric or physical barrier. Follmann et al. (1980) suggested 2 types of gates for use at construction camps which, with proper attendance, should prevent bear entrance.

For some purposes, as when bears must be excluded from the area around a temporary attractant, a portable electric 
fence may be preferable to the elaborate permanent structures described in the preceding section. Wynnk and Gunson (1977) described a portable electric fence which effectively deterred black bear depredation at Alberta beehives. Hunt (1985) reported that a portable, high-visibility electric fence was effective in preventing depredation in $95 \%$ of 500 black bear incidents. The fence also prevented 11 of 14 grizzly bears which contacted the fence from engaging in further depredation. The principle component of the fence is an electrified, highly visible, yellow webbed ribbon (VGS). The ribbon is pre-baited with a food odor so that bears will be attracted to the ribbon and receive a shock.

\section{Noxious Chemicals}

\section{General}

While a variety of chemical compounds have been assumed to have deterrent properties, formal research into the use of noxious chemicals as bear repellents and deterrents is relatively recent. (Miller 1980, 1983, in press, M. Smith 1983, Hunt 1984, Rogers 1984). Since some chemicals have been found to have both repellent (actively sprayed) and deterrent (poured on a passive attractant) capabilities, both groups are discussed herein.

\section{Capsaicin Products}

One of the most promising repellents yet found for grizzly and black bears is capsaicin, an ingredient of cayenne peppers. Capsaicin is widely used as a dog repellent and is commercially available (Halt, Dog Shield and Animal Repel) in spray cannisters of various sizes (Hunt 1984, 1985). The compound is a powerful local irritant of sensory nerve endings which appears to cause no long term damage to skin or eyes of people or test animals (Rogers 1984, Hunt 1985).

Capsaicin products have been tested on captive and free ranging bears (Miller 1980, 1983, 1985a, in press, M. Smith 1983, Hunt 1984, Rogers 1984). Miller $(1980,1983)$ found that Halt effectively repelled polar bears in laboratory tests. After being sprayed, charging bears immediately retreated and rubbed their eyes. This product, like other chemicals Miller $(1980,1983)$ tested, did not deter polar bears from approaching baits treated with the chemical. However, bears did spend significantly less time at chemically contaminated bait sites than at untreated bait sites (Miller 1980,in press). Hunt (1984) also reported that capsaicin products did not appear to be effective deterrents when placed on or around baits.

Hunt $(1984,1985)$ tested capsaicin spray on captive black and grizzly bears and on free-ranging black bears. Capsaicin and a Capsaicin/Bear Skunker (synthetic skunk odor) combination elicited the strongest repellent response of any chemicals tested on captive bears. These chemicals also reduced the number of subsequent charges by treated bears. Smith (1983) reported comparable results with 3 captive grizzly bears and 1 captive black bear. In both Hunt's (1984, 1985) and Miller's (1980, 1983, in press) studies, the bears were provoked to charge before being sprayed.

Rogers (1984) sprayed 5 free-ranging adult black bears in the eyes with capsaicin. All 5 retreated although 1 large male returned and was sprayed 3 more times before leaving the area. M. Smith (in prep., in Hunt 1985) conducted a similar test with comparable results; 3 bears were imme- diately repelled while 1 male responded more slowly to the spray.

Hunt (1984) and M. Smith (1983, in prep. in Hunt 1985) sprayed free-ranging black bears with capsaicin using remote-controlled devices to release the chemical. Bears were repelled during $63(88 \%)$ of the tests and no aggressive reponses were observed. Responses (immediate vs. slow retreat) appeared to depend on the individual bear, the activities of other bears and the availability of other, natural foods (Hunt 1984). Failure of capsaicin to repel some bears may have been due to the spray missing the eyes, poor quality of commercial product or higher tolerance of some bears for the chemical (Hunt 1984, M. Smith pers. commun., in Hunt 1985). Bears repelled by the remote controlled devices often returned to feed at the site in less than a half-hour (Hunt 1984, 1985, M. Smith in prep.). Capsaicin has been used once to repel an attacking, free-ranging grizzly bear in Yellowstone Park with favorable results (Hunt 1985).

The usual behavior pattern for bears sprayed with capsaicin was immediate and vigorous retreat, stop, head shake, paw at face, re-orient and move away (Miller 1980, Hunt 1984, 1985, Rogers 1984, M. Smith in prep.). No aggressive responses have been noted in lab or field tests (Hunt 1985).

Limitations in the use of capsaicin products are that the chemical must be sprayed in the eye to be effective and dispensers presently available have a limited range, accuracy and volume (Hunt 1984, 1985, Rogers 1984). However, improved dispensers are presently being developed (Hunt 1985).

\section{Other Noxious Chemicals}

Miller (1980, 1983) tested the deterrent effects of several common household chemicals (e.g., onion juice, ammonia, mustard) and commercial repellents on captive polar bears. He found that the household chemicals were generally effective in repelling the bears, but the capsaicin product (see preceding discussion) elicited the most dramatic response. Miller (1980,in press) tested various household chemicals poured on sardine baits as passive deterrents for free-ranging polar bears. Bears were repelled from treated baits only 5 times out of 294 visits, each time by Pine-Sol. However, as noted previously, bears did spend significantly less time at treated baits.

M. Smith (1983) tested the effects of 5 chemicals as repellents and deterrents for black and grizzly bears. Two capsaicin products (Phaser and Halt) had the strongest repellent effect on captive bears (see previous discussion), but Bear Skunker (an artificual skunk mercaptin) also caused slow, controlled retreats and inhibited subsequent charges. Bear Skunker also had the greatest deterrent effect with wild black bears at a dump site; only 1 bear of 11 returned to the bait station where he was sprayed with Bear Skunker. M. Smith (1983) noted that wild skunks might provide some reinforcement for the use of this compound. Two other chemicals, Child's 5-B (test product containing ammonia) and Child's Shark repellent, appeared to have some potential as deterrents when poured directly on baits.

Hunt (1984) also found that Bear Skunker and a Skunker/Halt combination were effective repellents when sprayed on captive bears. However, in tests with wild black bears, Skunker spray repelled bears only $54 \%$ of the time 
and many of the repelled bears resumed feeding shortly thereafter. Bear Skunker did not appear to have deterrent potential as a passive stimuli (i.e., when poured on or around baits).

Hunt (1984) tested several other chemicals as passive deterrents for free ranging black bears. Male human urine and full strength ammonia were the most effective stimuli. Urine deterred bears $78 \%$ and $38 \%$ of the time when placed on and near the bait, respectively. Comparable figures for the ammonia were $67 \%$ and $56 \%$. Miller (1980) reported that full-strength ammonia did not deter most polar bears from eating when placed around baits; however, when sprayed in the face of captive polar bears, ammonia elicited a strong response. Aversive conditioning experiments in Yosemite National Park which used ammonium hydroxide as a repellent were described previously.

Passive stimuli which did not appear to have deterrent potential (in addition to Bear Skunker and capsaicin, as noted previously) were Boundry (commercial dog deterrent), mothballs, Technichem (potential commercial bear deterrent) and ammonia with a detergent additive (Hunt 1984).

Follmann et al. (1980) briefly reviewed the literature concerning the physiological effects of lacrimating agents (tear gas). He noted that if the dose levels used in some laboratory experiments were achieved in the field, tear gases could injure animals or cause pain. In such a case, the animal could become enraged and more dangerous. Hunt (1984) sprayed a black bear with commercial tear gas (Shield) as it was restrained by a snare. The bear immediately recharged and continued to act aggressively until the tester left the area.

\section{Acoustic Repellents}

Considerable literature has been written on the biological effects of sound (see review in Follmann et al. 1980). Much of this material relates to the health effects of manmade sounds or to the use of sound as a deterrent for avian pests. However, several studies of acoustic deterrents and repellents for bears have recently been conducted. Potential advantages of acoustic repellents are that they are nondestructive, require no direct contact between the target bears and the equipment, are effective for moderately long ranges and can be easily interfaced with devices designed to detect intrusion (Wooldridge and Belton 1980).

Two main approaches to using sound as a deterrent exist (Follmann et al. 1980). The first utilizes a sound of the proper frequency $(\mathrm{HZ})$ and pressure level (intensity in $\mathrm{dB}$ ) to cause pain or discomfort in the target animal (Miller 1980, 1983, in press, Compuheat 1986). The second approach is biosonics, or the use of biologically significant sounds (alarm or aggressive vocalizations), to cause distress in an animal (Miller 1980, 1983, in press, Wooldridge and Belton 1980, Wooldridge 1983).

Wooldridge and Belton (1980) recorded the aggressive sounds of captive polar bears. These sounds were analyzed for their characteristic frequencies and then electronically simulated to test their effect on captive and free-ranging bears. All captive polar $(n=5)$ and brown bears $(n=2)$ except the 2 original sources for the sounds were intensely frightened by the recordings. A heart-rate transmitter implanted in 1 of the polar bears showed increases of $54-180 \%$ over normal when various sounds were presented to the bear. In tests with wild black bears $(n=13)$ all responded significantly to at least 1 of the sounds and most reacted strongly to 3 or more of the sounds. All but 1 free-ranging polar bear retreated upon exposure to an effective sound. Wooldridge and Belton (1986) concluded that biologically significant sounds could be effective in repelling nuisance bears. Recommendations for the most effective frequency, amplitude and pattern were provided.

In a later study (Wooldridge 1983), 74 free-ranging polar bears were tested with the same acoustic repellents as described above. Fifty-one were strongly repelled, 8 showed no response and 15 investigated the sound. Wooldridge (1983) felt that the combined effects of a high-amplitude sound (i.e., at the pain or discomfort threshold) plus a biologically significant message could reduce the possibility of habituation to acoustic repellents. Another recent study conducted at Cape Churchill (Compuheat 1986) revealed that polar bears were most sensitive to sounds in the 0.1 $9.0 \mathrm{kHZ}$ range and were effectively deterred by loud, pulsed sounds in the $1.0-4.0 \mathrm{kHZ}$ range.

Miller (1980, 1983, in press) tested the repellent effects of recorded, aggressive polar and grizzly bear vocalizations on captive and free-ranging bears. In lab tests, these recorded sounds were either attractive or induced caution instead of fear (Miller 1980, 1983). However, in $50 \%$ of the field tests, polar bears were repelled by the recorded vocalizations. Hunt (1984) reported that taped sounds of a male grizzly bear caused a male black bear to charge and remain aggressive.

The most promising acoustic repellent tested by Miller (1980, 1983, in press) was a hand-held, freon-powered boat horn. Captive grizzly and polar bears were repelled by this device in $81 \%$ of 31 lab tests; however, bears were also repelled during $50 \%$ of the control (no auditory stimulus) tests. Free-ranging polar bears were repelled by the horn in $81 \%$ of 31 field tests but, again, $50 \%$ of the control tests elicited an escape response. Hunt (1984) tested the air horn on captive and restrained black bears and concluded that it was not a promising repellent. Tested bears responded to the horn blast with increased aggression. Stenhouse (1983) reported that a loud $(115 \mathrm{~dB}$ at $1 \mathrm{~m})$ siren was not effective as a polar bear deterrent.

A number of other acoustic repellents have been tested and shown to have marginal or no value as repellents. Miller (1980,in press) found that bells, whistles and shouting humans were not effective repellents (bears repelled in less than $33 \%$ of the trials). A loud radio repelled wild polar bears in both of 2 tests. Hunt (1984) reported that a captive male black bear showed a mixed reaction to taped rockand-roll music.

Stenhouse $(1982,1983)$ tested the effect of recordings of barking dogs on polar bears at Cape Churchill, Manitoba. In the first field season, $87 \%$ of the approaching bears $(n=26)$ were not deterred and in 4 cases, became aggressive. In the second field season, no bears were deterred by the recordings $(n=131)$. However, other researchers reported that the most successful and practical deterrents for protecting work camps from bears were noisy, aggressive welltrained bush dogs (Hamilton and Smith 1981, Yukon Dep. Renew. Res. 1983). 


\section{Visual and Explosive Repellents}

Several types of visual repellents have been used or tested with bears. Miller $(1980,1983)$ tested a "loom" stimulus on captive polar and grizzly bears. This stimulus consisted of a $1 \times 1.5 \mathrm{~m}$ piece of plywood which was rapidly flashed before an approaching bear. The loom consistently repelled or deflected charging bears but the effect was short-lived (about 30 seconds) and bears habituated to it rapidly. Hunt (1984) tested a similar stimulus, a quickly opened umbrella, on captive black bears. Bears responded by becoming aggressive or charging during $63 \%$ of the tests.

Flares, thunderflashes and various other pyrotechnic devices have been used as bear repellents. Hunt (1984) reported that captive black bears responded aggressively to flares during $65 \%$ of the tests. However, tests of "flare/ scare cartridges" at Cape Churchill, Manitoba, showed that these devices did have potential as repellents on freeranging polar bears (Stenhouse 1983, Stenhouse and Cattet 1984). These flares, designed to scare avian pests from civil and military airfields, emitted a yellow flare trace before exploding to produce a bright white flash. The flares successfully deterred bears from approaching field crews in $77 \%$ of the tests $(n=58)$ during the first field season (Stenhouse 1983). In the second (1983) field season, 64\% of the bears tested $(n=25)$ were deterred, or viewed in another way, $36 \%$ of the bears continued their approach despite the flares. Two marked bears which had been previously deterred using rubber batons (see below) displayed a faster reaction than untested bears when the flare/scare cartridges exploded. These bears may have associated the auditory stimuli (explosion) with the impact of the rubber baton (Stenhouse and Cattet 1984). The researchers concluded that although the flares were not totally effective in deterring polar bears, they were useful because they were reliable, had a long range $(120 \mathrm{~m})$ and could illuminate bears in darkness.

Miller (1983) reported that the explosive sounds of a Thunderflash (very loud firecracker) and a Cap-Chur gun (firing a .22 caliber blank) caused captive bears to scramble away from the tester. A propane cannon noisemaker used to frighten a marauding grizzly bear away from a sheep allotment near Yellowstone National Park was only temporarily effective (Matejko and Franklin 1983).

Various types of fireworks (cracker shells) have been routinely used to frighten bears in some areas (Henderson 1982, NPS 1984, Anon. 1984). These types of bear scaring devices may lose their effect after repeated exposure (Yukon Dep. Renew. Res. 1983, B. Bromley 1985).

\section{Projectiles as Repellents}

\section{Rubber Batons - 38 mm}

Small gauge birdshot and rock salt have been used to repel bears in some areas (Henderson 1982, Jope 1983b, Anon. 1984a), but research to analyze the effectiveness of these repellent methods has not been conducted. However, extensive research has been done, primarily with polar bears, on the use of $38 \mathrm{~mm}$ anti-riot rubber batons and 12-gauge slugs as bear deterrents. The Government of the Northwest Territories has been testing these devices at Cape Churchill, Manitoba, since 1981 (Stenhouse 1982,
1983, Stenhouse and Cattet 1984, Derocher and Miller 1986).

Two different models of $38 \mathrm{~mm}$ anti-riot batons were tested. Both are cylindrical rubber projectiles wholly or partially sealed in a waterproof aluminum cartridge case. Stenhouse (1982) gives the dimensions and ballistics data for the batons. The batons are fired from a riot gun with a conventional break-open design similar to that of a shotgun.

During 3 years of deterrent research at Cape Churchill, 405 polar bears were tested with the rubber batons (Stenhouse and Cattet 1984). Four hundred and four of these bears were successfully deterred. Testing was discontinued on 1 large, emaciated male after it was hit 5 times without leaving the bait site. A yearling male was killed after being struck behind the left shoulder from a distance of $30-35 \mathrm{~m}$. A necropsy showed that the baton had broken a rib. The cause of death was diagnosed as cardiac tamponade subsequent to filling of the pericardial sac with blood from a rupture in the ventricular wall (Stenhouse and Cattet 1984, Haigh and Stenhouse 1985).

The rubber batons were also used in 22 actual control operations, including 9 cases involving grizzly bears. The field officers firing the batons reported that the effectiveness of the deterrent was "good to very good" although range (about $40 \mathrm{~m}$ ) and accuracy needed improvement (Stenhouse and Cattet 1984).

Bears struck with the batons responded by flinching, snapping at the impact area, spinning around and leaving the area (Stenhouse and Cattet 1984). None of the animals subjected to deterrent tests displayed any overt agression toward the person firing the batons. Of 42 marked bears tested, $12(28.6 \%)$ were observed to return to the bait site 1 or more times, but these bears displayed much more caution in returning to the bait site than did untested bears.

Stenhouse (1982) recommended that all batons be directed at the chest or hind quarters. Intensive training is required to effectively use the $38 \mathrm{~mm}$ anti-riot gun before a fair degree of accuracy is achieved (Stenhouse 1983). Accuracy rates for highly experienced users ranged from $80-89 \%$ (Stenhouse 1983, Stenhouse and Cattet 1984). Other drawbacks of the $38 \mathrm{~mm}$ batons are short range, single shot capability, cost and the need for a special $(38 \mathrm{~mm})$ gun to fire the batons (Stenhouse and Cattet 1984).

\section{Plastic Slugs - 12-Gauge}

Several types of plastic projectiles which can be fired from standard 12-gauge shotguns have been tested on black, grizzly and polar bears (Stenhouse 1983, Stenhouse and Cattet 1984, Dalle-Molle 1984B, Derocher and Miller 1986).

Preliminary tests of 12-gauge slugs were conducted at Churchill, Manitoba (Stenhouse 1983, Stenhouse and Cattet 1984). The projectile (SS 200) was a $5 \mathrm{~cm}, 90 \mathrm{gm}$, solid, plastic, tapering projectile with 4 tail-fins. These tests showed that the slugs were not highly effective in deterring polar bears from baited sites. Nevetheless, use of the slugs had 3 major advantages over the $38 \mathrm{~mm}$ rubber batons: high degree of accuracy, low cost and use of a standard 12-gauge shotgun (Stenhouse 1983).

Wooldridge (1984) and Dalle-Molle (1984) also conducted tests using the SS-200 plastic slug. Wooldridge reported 
that the slugs could be accurately placed from a distance of $10 \mathrm{~m}$ although accuracy was reduced considerably with moderate cross-winds. When fired at a plywood target, the slugs penetrated to depths of $9 \mathrm{~mm}$ and $0 \mathrm{~mm}$ when fired from distances of $3 \mathrm{~m}$ and $8 \mathrm{~m}$, respectively. Wooldridge concluded that the "range of choice" for the SS-200 slugs was $5 \mathrm{~m}$. Dalle-Molle (1984) found that when fired at carcasses from $20 \mathrm{~m}$, the slugs sometimes penetrated hide, fat and flesh to a depth of several millimeters.

Wooldridge (1984) tested the SS-200 slugs on 23 identifiable black bears as they fed on garbage at a dump site. All of the bears were repelled by the slugs; $91 \%$ immediately ran into adjacent woods. However, $38 \%$ returned to feed at the dump including 4 within 24 hours and the others within 7 to 9 days. Dalle-Molle (1984) tested the SS-200s on 2 grizzly bears and 1 black bear for a total of 6 trials. These bears, which had succeeded in obtaining food from a camp, were shot at from an average distance of $24 \mathrm{~m}$ as they approached test camps. All the bears immediately ran 15 $100 \mathrm{~m}$ after being shot, but reapproached test camps from 2-59 days later.

Following the initial tests at Churchill, a number of prototype slugs were produced (using heavier projectiles and a variety of powder charges) to provide similar impact velocities to the $38 \mathrm{~mm}$ batons at distances of $35-40 \mathrm{~m}$. These prototypes were tested on bear carcasses to evaluate their impact. Since these cartridges broke the hide and penetrated the flesh, they were deemed unacceptable for use on live bears (Stenhouse and Cattet 1984).

A subsequent study at Churchill evaluated the repellent capabilities of the heavier (125 gram) "Bear Deterrent Round" prototypes on polar bears. A total of 119 trials were completed, including 77 bears hit with the rounds and 42 control animals. Test bears were hit an average of 2.14 times per trial indicating that a single hit was not a sufficient deterrent. Eighty-seven percent of the marked bears returned to the bait site 1 or more times with an average return time of 17 hours. None of the bears hit showed any signs of injury. The overall accuracy of the shells was high: $89 \%$ from an average distance of $24 \mathrm{~m}$. The maximum effective range was $20-25 \mathrm{~m}$. Shell drifting of $0.5-1.5 \mathrm{~m}$ was common at distances of $25 \mathrm{~m}$ or greater in moderate wind.

The studies cited above indicated that the 12-gauge plastic slugs show some promise as a bear repellent. However, an effective 12-gauge shell with the necessary impact and accuracy has yet to be developed (Hunt 1985, Derocher and Miller 1986).

\section{Other Projectiles}

Jonkel and Klassen (1985) studied the tissue impacts of the "Bear Thumper" - a modification of the "stun gun" designed by Mountain Scent Research. The projectiles used were 20 cc plastic bottles filled with low tension latex or water. These projectiles were tested because the stun gun's standard rubber projectile was expensive, easy to lose and became very hard when cold. Two shots were fired at a captive bear from 1.8 and $3.5 \mathrm{~m}$ away, respectively. These shots were directed at each side of the rib cage to test the effects of the projectiles hitting a vulnerable (thoracic) area from closer than recommended range. Necropsy revealed that the projectile inflicted no serious organ damage although some cutaneous and sub-cutaneous bruising and minor muscle separation were noted.
Stenhouse (1983) tested the effectiveness of darting polar bears with tetracycline as a deterrent method. All bears darted were deterred. However, Stenhouse concluded that logistical difficulties in preparing and handling the powder charges, injection fluid and syringe darts rendered this method unsatisfactory as a deterrent technique.

\section{Bear Attractants}

Very little research has been done on identifying and studying particular bear attractants. The problem of garbage as an attractant is discussed in a subsequent section.

A link between human menstruation and bear attacks has been the subject of much speculation (Natl. Park Service 1967, Herrero 1985). Cushing (1983) studied the responses of polar bears to human menstrual odors. In laboratory experiments, used tampons elicited a "maximum behavioral response" similar to the stereotypic response to seal scents. Polar bears also responsed to the presence of a human female but the response was less strong than that to the seal or menstrual scents. In field tests, bears detected (usually by scent) and consumed food scent samples and used tampons,but ignored non-food scents (castoreum, musk, manure) and human blood. These findings suggested that some factor in menstrual fluid other than blood was responsible for the attraction. In his analysis of grizzly bear inflicted injuries, Herrero (1985) did not find a correlation between attacks on women and stage of menstrual cycle; however, he noted that the data for this analysis were very incomplete.

Miller (1980) found that bells of the type generally sold to hikers to warn bears of their approach sometimes attracted captive bears. One bear slept through 2 tests as the bear bells were sounded from $6 \mathrm{~m}$ away. Jope $(1982,1984,1985)$ evaluated the effectiveness of bear bells as part of her analysis of grizzly bear/hiker interactions in Glacier National Park, Montana. She found that hikers who wore bells did observe bears at closer distances than those without bells, but she attributed this to possible overconfidence of the bell-wearers and their tendency to be less observant than non-bear wearers. In addition, more bears which were not moving when initially observed moved away from hikers with bells than from hikers without bells ( $67 \%$ vs. $26 \%$ ). Other data also suggested that bear bells were an effective protection device and not a dangerous attractant.

\section{POPULATION AUGMENTATION}

The encroachment of human activities into areas formerly occupied by the grizzly bear have resulted in range fragmentation and insularization of certain subpopulations. Once the number of bears in these isolated populations become very low, the grizzly's low reproductive rate and various demographic aberrations may interfere with "natural" recovery. Such populations may also be extremely sensitive to any new mortality factors or major habitat disturbances. In these cases, population augmentation may be required to ensure the long-term survival of the grizzly bear in isolated areas (Servheen et al. in press, USFS 1985ag). Augumentation differs from reintroduction in that the former involves the transplanting of bears to 
bolster small extant populations while the latter involves attempts to reestablish grizzlies in areas from which they have been extirpated (Servheen et al. in press).

Population augmentation has both demographic and genetic advantages for the recipient population. Demographic advantages include the direct contribution from the addition of the transplanted bear to the ecosystem and the contribution to future reproduction and population growth in the augmented population (Maguire 1985). The genetic problems associated with population isolation were discussed in a previous section. The introduction of bears from outside the target ecosystem can help to avoid the deleterious effects of excessive inbreeding in small populations (Servheen et al. in press).

\section{Augmentation Methods}

Two methods of augmentation have received serious consideration (Servheen et al. in press). The first method involves transplanting grizzlies of a predetermined, optimal, age, sex and behavioral history from a high density (donor) to a low density (target) area. The second method involves the cross-fostering of captive-reared grizzly bear cubs to resident black bear females in the target area. The most promising cross-fostering method is placement of grizzly cubs inside black bear natal dens prior to emergence (Servheen et al. in press). Other augmentation methods, including placement of cubs with postemergence lactating females and the release of single cubs into the wild, have been successful with black bears and grizzly bears (Jonkel et al. 1980, Alt and Beecham 1984). However, since these methods involve older cubs and greater opportunity for habituation to humans, they are much less desirable than the natal den approach. Servheen et al. (in press) provided detailed scenarios of the 2 preferred augmentation methods.

Success of an augmentation effort can be interpreted from either a short- or long-term basis. Proximate success may be judged by retention in the target area for 2 years without conflicts (Mace and Haroldson 1984, Maguire 1985). For cross-fostering augmentation, successful weaning of the grizzly cub followed by retention in the foster mother's home range and successful denning defines shortterm success (Servheen et al. in press). Long-term success for either method requires that the transplanted bear enter the target population as a reproducing adult (Servheen et al. in press).

\section{Selecting Suitable Age/Sex Class and Area for Augmentation}

The probability of success for a particular augmentation effort may depend largely on the age/sex class of the transplanted bear. Maguire (1985) employed the principles of "decision making under uncertainty" to identify the optimal age/sex class(es) for a hypothetical augmentation effort in the Cabinet-Yaak ecosystem. Her analysis revealed that maximizing the benefit to the target population (through the reproductive value of the bear) while simultaneously minimizing the probability of conflict or "wasting" of transplanted bear (due to mortality or failure to remain in the target area) was a difficult exercise. The analysis incorporated both objective and subjective evaluations of reproductive value, conflict potential and reten- tion for 16 different augmentation categories. A computer simulation model was later employed to futher refine these values. The major conclusion of the study was that young (4-6 yr. old) female bears were the best candidates for successful augmentation. This agrees with Mace and Haroldson's (1984) earlier results. Female cubs were also preferred for cross-fostering augmentation (Servheen et al. in press). If "optimal" ages were not available, any of the female age classes would be acceptable. Male bears of any age class were poor prospects for translocation. August was considered the best time for augmentation since bears tended to be more sedentary in August than at other times of the year. Even under optimal conditions, the probable success rate of translocated bears was fairly low. Additional research was suggested to examine the costs and benefits of augmentation to the donor population, the mortality rates used in the analysis and the public relations and education aspects of augmentation. Osmundson (1983) encountered significant public opposition to the 1981 translocation of 2 bears into the Cabinet-Yaak ecosystem. It is noteworthy that in that attempt, the age/sex of the 2 bears (yearling males) and season of the transplant (Spring) were those deemed least desirable by Maguire's (1985) analysis.

Age/sex class and season are not the only factors to be considered prior to initiating an augmentation effort. Servheen et al. (in press) noted that the history of the bear in relation to man is of vital concern. Bears with a previous history of positive attraction to humans or human use areas are not suitable for augmentation. When information on the individual bear is lacking, inferences should be based on the type of human activities occurring in the donor area.

The donor area should be topographically and vegetatively similar to the target area to enhance retention and probability of successful adjustment of the transplanted bear to the target area. Mace and Haroldson (1984) outlined the habitat features which should be comparable in the 2 areas.

No legitimate tests of the augmentation strategy have been undertaken to date although serious consideration is being given to population augmentation for the CabinetYaak ecosystem (Maguire 1985, Servheen et al. in press). Seven different grizzly bears were added to the CabinetYaak ecosystem from 1980-1985 but none were known to remain in the target area by 1985 . All of these bears were nuisance relocations and none were selected according to the criteria previously outlined (USFS 1985ag). Although the biological questions concerning grizzly bear population augmentation are not fully resolved, the most formidable obstacles confronting augmentation efforts may be social and political.

\section{RELOCATION OF NUISANCE BEARS}

Translocation of nuisance bears has been a common management tool since the 1950's (Taylor 1984). Most North American park management plans include provisions for translocating grizzlies which have entered developed areas or demonstrated some form of undesirable behavior. The Bear Management Plan for Glacier National 
Park, Montana (NPS 1985a) calls for relocation of "habituated" bears (those accustomed to frequenting developed areas but not overly familiar with humans). "Conditioned" bears (those obtaining non-natural foods, destroying property or displaying unnatural aggressive behavior) are destroyed or relocated outside the park. A set of guidelines helps to standardize the decision making for different settings and conflict situations.

In Yellowstone National Park, bears which have obtained food in campgrounds or developed areas or which persistently frequent frontcountry areas are candidates for relocation. In the backcountry, bears are relocated only if they become unnaturally aggressive or if there are no other means to provide for human safety (NPS 1984a,1985b). From 1968-83, 272 grizzly bear relocations were performed in Yellowstone National Park (NPS 1985d). Greer (1968. 1985) and Roop (1975-1983) provided relocation data for portions of the YGBE in Montana and Wyoming, respectively.

Elsewhere in the contiguous United States, specific guidelines have been developed for determining grizzly bear nuisance status and prescribing appropriate control actions (Anon. 1979, Mealey 1979, Servheen et al. 1981, Dood et al. 1986). In general, these guidelines recommended either relocation or removal according to conflict severity (e.g., depredation, aggression, human injury), number of offenses, age/sex class and reproductive status of the grizzly.

Taylor (1984) reviewed the bear management plans in Canadian national parks. He found that beginning in the mid 1950s, when culvert traps first enabled the livetrapping of bears, translocation has been a preferred bear management procedure. Mundy and Flook (1973) reported that a minimum of 19 grizzly bears were relocated in the Canadian mountain parks from 1963-68. Beginning in the mid-1970s, park managers began to recognize that control of human activity must be the foundation of a successful bear management program and that destroying, capturing and translocating bears were undesirable management actions to be minimized (Taylor 1984). However, translocation of nuisance bears continues to play a major role in park management programs. In Jasper National Park, 56 and 48 bears (species not specified) were relocated in 1980 and 1981, respectively. In Banff National Park, 70 and 15 bears were relocated in the same years. The Waterton Lakes National Park Bear Management Plan allows for up to 3 relocations per bear unless the animal is particularly aggressive. No diseased or otherwise infirmed bears are to be relocated and females with cubs are given special consideration.

Leonard et. al. (1983) reviewed the bear management procedures in the prairie region national parks and historic sites of western Canada. In Kluane National Park, bear management emphasized preventative measures and grizzlies were to be relocated only once before being destroyed. Nahanni National Park planned to trap and relocate nuisance grizzlies once helicopter support became available.

The Alberta Provincial Parks Bear Conflict Prevention Programme (Alberta Recreation Parks and Wildlife 1978) states that persistent nuisance bears are to be live-trapped and translocated. Grizzly bears are to be translocated rather than destroyed except when dictated by considera- tion of immediate visitor safety or injury. The Alberta Fish and Wildlife Division translocated 24 grizzlies in the province during the 1970s (Gunson 1981).

In Denali National Park, grizzly bears are relocated only after all experimental aversive conditioning efforts have failed to alter the undesirable behavior. A bear may be destroyed after 2 unsuccessful relocation attempts or when involved in a non-defensive, unprovoked attack on humans (NPS 1984a). Twenty-seven grizzly bear relocations were preformed within the present boundaries of Denali National Park from 1946-82 (Buskirk and Johnson 1976). In Katmai National Park, nuisance bears are handled by eviction from the conflict area, "peppering," monitoring of activity and, if the nature of the offense warrants, by destruction. No provisions for relocation were included in the 1984-85 management plan (Anon 1984a).

\section{Homing}

Grizzly bears have demonstrated an impressive ability to home to familiar territory following relocation attempts. Haroldson and Mace (in prep.) provided a general discussion of the homing instinct in bears. A few of the more noteworthy examples of grizzly bear homing are discussed below.

Pearson (1975) reported that 1 young sow which was translocated twice returned $32 \mathrm{~km}$ in 22 days after the first release and $75 \mathrm{~km}$ in 5 days after the second. Another sow was translocated $113 \mathrm{~km}$ and returned to her captive site after only 3 days (Pearson 1972). In Yellowstone National Park, 1 grizzly sow returned $54 \mathrm{~km}$ in 62 hours after her first relocation and $85 \mathrm{~km}$ after a second relocation. One male returned $43 \mathrm{~km}$ in 1 week and another covered $50 \mathrm{~km}$ in 4 days (Craighead 1976). Judd and Knight (1980) reported that a 5-year-old male successfully denned near the release area after relocation but the following summer he covered at least $153 \mathrm{~km}$ to return to his earlier home range.

Perhaps the most remarkable case of homing was described by Miller and Ballard (1982b). A subadult male brown bear was transplanted $93 \mathrm{~km}$ by boat to an island in Prince William Sound, Alaska. The bear managed to return to its capture site 28 days later. Depending on which of 2 possible return routes the bear actually followed, he swam 15.1 or $10.5 \mathrm{~km}$ across strong tidal currents to reach his destination. Based on their observations of 29 translocated brown bears in Alaska, the authors concluded that homing was not the result of random movements until familiar terrain was encountered. Their observations on postrelease movement directions (discussed below) supported this finding.

\section{Criteria for Evaluating Relocation Success}

The criteria used to define "success" of relocation attempts have varied widely between studies. Aune and Stivers (1981) noted that unless a relocated bear partici. pates in another breeding season, no contribution has been made to population perpetuation and the management agency often absorbs considerable expense for aborted relocation attempts. Since most relocations are undertaken to achieve spatial separation between a nuisance bear and a conflict-attractant, many managers have considered relo- 
cations a success if there is no further nuisance behavior for the remainder of the season (Cole 1971, J.J. Craighead and F.C. Craighead, Jr. 1972, Meagher and Phillips 1983) or for longer periods (Thier and Sizemore 1981, Haroldson and Mace in prep.).

\section{Success Rates and Transplant Distance}

Sixty-eight percent of 145 translocation attempts in Yellowstone National Park from 1959-69 were unsuccessful in that the translocated grizzlies returned to the same or another development (J.J. Craighead and F.C. Craighead, Jr. 1972). The percentage of relocated bears which returned in each distance class were as follows: $0-16 \mathrm{~km}, 71 \%$; 16 $33 \mathrm{~km}, 70 \%$; 32-48km, 60\%; 48-64km, 25\%.

Cole (1971, 1972, 1976) and Meagher and Phillips (1983) also evaluated the success of relocation efforts in Yellowstone National Park. The percent of successful relocations (i.e., no further conflict in the same year) ranged from $33 \%$ in 1968-69 to $100 \%$ in 1979 (only a single grizzly was relocated that year). All other years had success rates of between $57-80 \%$. In 1968-69, when success rates were lowest, grizzly bears which returned from transplant sites were moved a maximum of $45 \mathrm{~km}$ (Cole 1972).

Thier and Sizemore (1981) reviewed the 1975-80 grizzly bear relocation data for the Northern Continental Divide ecosystem. A "successful" relocation was 1 for which the relocated bear did not return to the capture area or come into any further conflict during the 5-year analysis period. By this definition, $62 \%$ of 26 relocations were successful. The distance moved was the most important factor determining the success of relocations. Bears were moved from $19-272 \mathrm{~km}$. All relocations greater than $120 \mathrm{~km}$ were successful while $44 \%$ of those less than $120 \mathrm{~km}$ were successful.

Mace and Riley (in prep.) also analyzed relocation data for the Northern Continental Divide ecosystem. They found that $56 \%$ of 45 relocation attempts successfully deterred further conflict for at least 2 years. Bears were moved mean distances of $119 \mathrm{~km}$ and $90 \mathrm{~km}$ in successful and unsuccessful attempts, respectively. Martinka (1982a) reported that 9 out of $16(56 \%)$ of the grizzly bears relocated within Glacier National Park from 1966-81 successfully avoided further conflict. The distances of these relocations were not provided.

Miller and Ballard (1982b) studied the homing behavior of 29 brown bears transplanted in southcentral Alaska as part of a moose mortality study. A bear was treated as a "return" when it arrived within 1.2 average home range diameters $(32.4 \mathrm{~km})$ of its capture site. By this criterion, 12 of $20(60 \%)$ adults returned to familiar territory. The researchers noted that the success rate in their study would probably exceed that for most relocations since they were dealing with non-nuisance bears. Relocation distances for these bears averaged $198 \mathrm{~km}$ (range of 145-255 km) and average return time was 58 days (range of 13-133 days). Non-returning bears were transplanted further than returning bears. Eight non-returning adults were moved an average of $233 \mathrm{~km}$ (range of $168-286 \mathrm{~km}$ ).

The movement rates and directions of transplanted bears were also examined. Returning bears had greater movement rates $(x=3.6 \mathrm{~km} /$ day) while in route than follow- ing their return $(\mathrm{x}=0.6 \mathrm{~km} /$ day) or than non-returning bears $(\mathrm{x}=1.4 \mathrm{~km} /$ day). Returning bears moved in a homing direction for $87 \%$ of the distance between sighting, whereas, non-returning bears moved in a homing direction for only $39 \%$ of the distance between sightings. Spreadbury (1984) also found increased movement rates for 2 translocated grizzlies for 10 days following release.

\section{Relocation Factors}

\section{Age/Sex Factors}

A number of studies documented age or sex class differences in success of relocations. Pearson (1975) felt that for successful relocations, native male grizzlies should be moved at least $161 \mathrm{~km}$ while mature females should be moved $81 \mathrm{~km}$. Thier and Sizemore (1981) reported that from $1975-80,80 \%$ of the female relocations in the Northern Continental Divide ecosystem were successful as compared to $36 \%$ of the male relocations. However, females were relocated at significantly greater distances than males and, as noted earlier, distance was the most important factor in relocation success. Relocations of subadult males were significantly more successful than those of adult males. There was no apparent difference in relocation success between female age groups. Younger age classes (both sexes combined) had high probabilities of success; 7 relocations of bears less than 2.5 years of age were all successful. Martinka (1982a) reported that 7 of 9 successful relocations inside Glacier National Park from 1966-81 were subadults or cubs. Mace and Riley (in prep.) examined Northern Continental Divide relocation data for 1975-84. As in the above study, female relocations were more successful than male relocations ( $65 \%$ and $43 \%$, respectively) but this difference was not significant. Age class differences in success rates were minor: $57 \%$ for adults, $59 \%$ for subadults and $54 \%$ for cubs.

In Miller and Ballard's (1982b) Alaskan brown bear study, there was no significant difference in the incidence of return between the sexes. However, female bears took longer than male bears to return to the capture site ( $72 \mathrm{vs}$. 24 days). The mean age of returning males ( 10.0 years) was significantly greater than that of nonreturning males (4.8 years) when hunter killed bears were excluded from the analysis. There was also a significant difference in the mean of returning (8.8 years) and non-returning bears (5.3 years) when data for both sexes were combined. There was no threshold age below which bears would not return.

\section{Reproductive Status}

Miller and Ballard (1982b) stated that reproductive status was not a factor in determining whether or not a female brown bear returned. Females in estrus and females with offspring were included in both returning and nonreturning groups. However, only 3 of 9 young transplanted with 5 radio-collared females were still with their mothers when last observed. The missing young were suspected mortalities. The homing movements of females with young appeared to be more influenced by natural or man-made barriers than was observed for other bears. Two of 5 adult bears deflected by a major river and all 3 of the bears deflected by a highway were sows with young. There was also some indication of reduced productivity by transplanted females in the year following transplant. 


\section{Topography}

Miller and Ballard (1982b) found that 5 bears which appeared to be returning to their capture area reversed directions after intersecting the Copper River. Two of these bears eventually crossed the river. As noted previously, 3 females with young were temporarily deflected by a major highway. Spreadbury (1984) also reported that the travel routes of a grizzly sow and yearling were deflected by a highway. In both of these studies, the grizzlies later overcame the aversion and crossed highways.

\section{Bear History and Type of Offense}

Cole $(1971,1972)$ stated that the excessive number of control actions in Yellowstone National Park from 1968-70 was due in part to inadequate control in previous years. He concluded that repeated transplants of bears which habitually frequented developed areas was ineffective and placed bear control on a "sustained yield" basis. Improved success by 1971 was attributed in part to selective removal, rather than relocation, of bears which had prior experience in returning from transplants (Cole 1971). Examination of the Yellowstone relocation data for 1970-79 (Meagher and Phillips 1983) indicated that $31 \%$ of 147 grizzly bear relocations were repeat transplants.

While the literature was replete with instances of bears repeating their nuisance behavior following relocation, only 1 study examined this issue in depth. Thier and Sizemore (1981) analyzed relocation success by type of offense leading to the relocation attempt. Bears involved in livestock depredations and cabin break-ins were negatively correlated with success while relocations of bears captured after coming into proximity with campgrounds or residences were significantly more successful. Surprisingly, association with garbage was not a significant factor in relocation success. The researchers postulated that the aggressive nature of the depredation and break-in offenses contributed to the poor success rate. Sample sizes for all offense types was small $(n=3-10)$.

\section{Season of Transplant}

Thier and Sizemore (1981) found that summer relocations were significantly less successful than relocations in the other seasons. However, the non-successful summer relocations all involved depredation and property damage, offenses which were negatively correlated with success. A regression analysis indicated that individual seasons did not significantly contribute to relocation outcome. Maguire (1985) concluded that grizzly bears transplanted for population augmentation would be less likely to vacate the target area in August than in spring when bears ranged more widely in search of patchily distributed forage items.

\section{Stress from Relocation}

Several studies found evidence of increased stress or vulnerability to mortality factors following relocation. Russell et al. (1979) recorded a $43 \mathrm{~kg}$ weight loss for a transplanted male grizzly which was recaptured 23 days after the transplant. Miller and Ballard (1982b) found evidence suggesting reduced reproductive performance by transplanted female brown bears. Greer (1976a) reported that in 1971, when 17 bears were translocated in the Yellowstone ecosystem (excluding Yellowstone Park), 9 were legally killed by hunters in that same year.
Spreadbury (1984) postulated that increased post-release movements (as were also documented by Miller and Ballard 1982) through unfamiliar terrain increased the stress level of transplanted bears. A dart-induced wound on a grizzly yearling which he monitored had failed to heal 4 months after its capture and relocation. He interpreted this as possible physiological evidence for elevated stress although he notes elsewhere that both bears appeared to be in excellent physical condition when killed.

Spreadbury (1984) also observed that the movement patterns of recently translocated bears could increase the likelihood of human conflict. This could arise from either chance encounter with attractants or physiological stress. He noted that the 2 translocated grizzlies in his study had probably experienced minimal human contact prior to release since the area of the Yukon where they were trapped was remote and lacked much recreational activity. However, both grizzlies were killed after breaking into a meat cache less than 4 months after their release.

Conflicts with resident bears could cause increased stress or abandonment of the release area by the translocated bears. Pearson (1975) recommended that bears be released where there were no resident grizzly bears since intraspecific encounters might cause translocated bears to seek their original home range. Stokes (1970) observed that relocations were less likely to succeed if release areas already included high numbers of bears. Because introduced "newcomers" would be disadvantaged relative to resident bears, he suggested that transplanted bears might be best used to reestablish grizzlies in remote areas without resident bears. However, other researchers concluded that nuisance bears would be ill-suited for this purpose (Haroldson and Mace in prep.)

\section{Habitat and Food Availability}

Haroldson and Mace (in prep.) suggested that grizzly bear augmentations had a higher possibility of success if habitat variables were similar between the capture and release areas. Presumably, a bear should be better able to exploit the habitat at the release area during the critical post-release period if this habitat is somewhat comparable to the bear's familiar home range. They noted that the abundance and diversity of natural foods at the release site could be a major factor in determining the success of a relocation.

Spreadbury (1984) experimented with the use of feeding supplements to induce a bear to remain in the release area. One whole and 2 halves of black bear carcasses were air dropped within $100 \mathrm{~m}$ of a translocated grizzly sow and yearling but the bears failed to use the carcasses. The researcher speculated that placement of carcasses in the release area prior to release might be more effective. Pearson (1975) also suggested that some type of habitat manip. ulation might entice relocated bears to remain at release areas.

Thier and Sizemore (1981) recommended that prior to release, the area within a 20 mile radius of the release area should be surveyed for potential conflict sites. Conflicts of the same type as the 1 for which the bear was captured were of primary concern as their data suggested that grizzlies tended to specialize at a single kind of offense. Haroldson and Mace (in prep.) similarly recommended that a conflict- 
free buffer zone should surround release areas. Most national park bear management programs stipulated that release areas be remote from potential conflict areas (NPS 1984a, 1985b, Parks Canada 1984).

\section{Aversive Conditioning Prior to Release}

In an attempt to improve the probability of success for relocations of nuisance grizzlies, some researchers have experimented with pre-release aversive conditioning (Servheen 1977ab, Jonkel 1982b, 1983). Aversive conditioning techniques were discussed in a previous section.

\section{Conclusions}

Research has indicated that relocation can be a moderately effective management tool when properly applied. As Taylor (1984:292) noted "one might consider capture attempts, relocations or destructions as a reactive style of management that usually reflects a failure in one or more of the other program elements." Pearson (1975) observed that translocation could be most useful in temporarily relieving pressure and conflict until human activities leading to the problem could be remedied.

The preceding discussion further indicates that the following factors contributing to the probability of relocation success should be considered in management actions:

1. Suitable relocation distance as determined by: a. age/sex class of the bear

b. usual home range sizes in the release area

c. habitat characteristics, topography

2. Type of offense and history (number of previous relocations or offenses) of the bear

3. Characteristics of the release area including:

a. habitat similarity to capture area

b. food availability and diversity

c. potential conflict zones within release area and surrounding buffer zone

d. number of resident bears already present

4. Experimental manipulations which may improve relocation success but need further research including:

a. pre-release aversive conditioning

b. food supplements in release area

\section{REINTRODUCTION OF GRIZZLIES INTO FORMER RANGE}

Very little information was available in the literature concerning the reintroduction of grizzly bears into areas from which they have been extirpated. For purposes of discussion, reintroduction is distinguished from population augmentation in that the former involves transplanting of bears into ecosystems where there are either no grizzlies or occasional unverified transient grizzlies only (no resident breeding bears). Reintroduction has been considered for several areas but, judging from the literature, there are no plans to reintroduce grizzlies to any portion of their former range in the foreseeable future.

\section{Alaska}

The Alaskan "species management policies" (Anon. 1980) states that transplanting of brown/grizzly bears for restocking of former ranges is usually not feasible, but could be a useful management tool under certain conditions. Transplants of this type would be considered only when substantial resource or public benefit could be shown and the following qualifications were met: 1) sufficient habitat was available to support a viable population; 2) no adverse effects on resident species or conflicts with humans would occurr; 3 ) incompatible land uses would not occurr and 4) future public use of the resource would be guaranteed.

\section{American Southwest}

In 1973, the New Mexico-Arizona section of the Wildlife Society passed a resolution encouraging the U.S. Forest Service to prepare management and contingency plans for the reintroduction of the grizzly bear into the southwest (Brown 1985). A study to evaluate the suitability of the Gila Wilderness as grizzly habitat was initiated soon thereafter by Erickson (1974) under contract to the U. S. Forest Service. He concluded that the area was sufficiently large to satisfy the spatial, food, cover and denning requirements of a small population. He felt that overall, the Gila Wilderness was equivalent in habitat attractiveness to areas in the Northern Rockies with extant grizzly populations. Although the core of the wilderness area appeared adequate for reintroduction, Erickson noted that conflicts with other uses, especially livestock grazing, was a "near certainty." The availability of garbage from recreational or other sources was also of concern. The researcher reasoned that with appropriate management such as reduction of grazing in bear high-use zones and control of nuisance bears, these conflicts could be suppressed. If reintroduction was given further consideration, Erickson suggested that the introduced grizzlies should be taken from southwestern or Mexican stock. If no bears of this descent were available, other stocks could be used but bears from populations subjected to some prior harassment or control were preferrable.

The prospect of reestablishing a small grizzly population in the Gila Wilderness was opposed by the cattle industry (Brown 1985). Apparently the social and political climate remains nonconducive to reestablishment of the grizzly in the Southwest. When asked if they would be willing to accept relocated grizzly bears from Montana, the directors of the state game departments in New Mexico and Arizona both responded that they did not anticipate any reintroductions in their state in the foreseeable future (Dood et. al. 1986). The Arizona director added that he perceived no interest by either the game commission or the public favoring reintroduction of the grizzly.

\section{Colorado}

The last confirmed grizzly bear in Colorado was killed near the Navajo River in the San Juan Mountains in 1979. Prior to that time, there had been no confirmed grizzly kills 
or sightings in Colorado for 25 years (Brown 1985). Surveys and trapping efforts conducted in the south San Juan Mountains in 1981-1982 failed to provide conclusive evidence of grizzly bears in Colorado (Mace 1982, Seitz 1983). In 1982, the Colorado Wildlife Commission unanimously adopted a resolution declaring its opposition to reintroduction of the grizzly into Colorado (Anon. 1982). The resolution cited management problems and conflicts with huntable species, livestock and humans as the basis for the opposition.

\section{North Cascades Ecosystem}

The status of the grizzly bear in the North Cascades ecosystem of Washington is uncertain. The last confirmed grizzly bear in the area was killed in 1967. There have been unverified reports of grizzlies in the Cascades each year since then (Bjorklund 1980, Sullivan 1983). Bjorklund $(1978,1980 \mathrm{ab})$ investigated the feasibility of reestablishing a grizzly population in the North Cascades National Park complex. His conclusions were similar to those of Erickson (1974) for New Mexico. Spatial and habitat attributes of the area were probably adequate to support a grizzly population, however, the 5 secure (low visitation) zones identified by Bjorklund (1978) were segmented by areas of high human use. Only one of the 5 zones was sufficiently large to provide satisfactory isolation from conflict.

The North Cascades ecosystem is contiguous with a small, low-density grizzly bear population in southern British Columbia (B.C. Ministry of Environment 1979ab). Failure of grizzlies from that area to disperse and establish a resident breeding population in the North Cascades could be construed as evidence of unfavorable conditions for the grizzly in Washington. However, the British Columbia population has only been given total protection since about 1975 and this may have been insufficient time for recovery and dispersal into Washington (Bjorklund 1980a).

A preliminary meeting in 1979 among federal, state and provincial biologists and managers indicated that reintroduction of the grizzly into the North Cascades was worthy of further consideration (Bjorklund 1980a), however, there are currently no plans to reintroduce grizzly bears into Washington. The Washington Dept. of Game is currently planning and developing an assessment of the North Cascades as grizzly bear habitat. A recovery plan for the North Cascades Ecosystem is also being developed. Augmentation will be considered as a management tool depending on Ecosystem needs and the political climate of the area (Hickman pers. commun.).

\section{Selway-Bitteroot Ecosystem}

The Selway-Bitterroot ecosystem (SBGBE) of Idaho and Montana is another area where a once abundant grizzly bear population has been severely depleted or eliminated. Factors contributing to the disappearance of grizzlies from the Selway-Bitterroot ecosystem by the 1950 s included fire suppression, loss of the anadromous salmon fishery and conflicts with livestock (Davis et. al. 1979). Changes in fire and range management policies in recent years have substantially improved the habitat capability and security of the Selway-Bitteroot ecosystem (Davis et al. 1986). Habitat surveys in the Selway-Bitterroot Wilderness Area indicated that superior habitat was available in this ecosystem
(Scaggs 1979, Butterfield and Almack 1985). Davis et. al. (1986) concluded that, of the 6 ecosystems identified in the Grizzly Bear Recovery Plan (USFWS 1982a) "central Idaho may offer the largest contiguous area of land in which to recover a viable population of grizzlies without escalating major conflicts." The Recovery Plan states that, due to the paucity of baseline data available for the Selkirk Mountain, Selway-Bitterroot and North Cascades grizzly bear ecosystems, and the high cost of collecting data in these areas, recovery efforts should be focused on the other identified ecosystems.

Melquist (1985) reviewed the history and current status of the grizzly bear in the Clearwater National Forest of Idaho. Based on an analysis of 88 grizzly bear observations from 1900-1984, he concluded that a few grizzly bears probably occupy, at least temporarily, portions of the Clearwater National Forest and adjacent areas. Melquist also noted that suitable travel corridors existed which could conceivably enable grizzlies to disperse from the CabinetYaak ecosystem south into the Bitterroot Range. This scenario is comparable to that previously discussed for the North Cascades ecosystem in that the seed population is itself "unrecovered" (USFWS 1982a). Given that a few grizzlies may occasionally occupy both the North Cascades and Selway-Bitterroot ecosystems, it becomes a question of semantics as to whether transplanting of grizzlies into these ecosystems constitutes augmentation or reintroduction

The Idaho Department of Fish and Game has adopted the position that grizzlies may be relocated inside Idaho as necessary (including possible between-ecosystem transplants) but no grizzlies will be accepted from other states (correspondence in Dood et al. 1986, J. Beecham pers. commun.). There are no plans pending to reintroduce grizzlies into Idaho.

\section{Mexico}

Grizzlies were once common in the breaks and chaparral of northwestern Mexico. The last known grizzly in the Sierra Madre range was killed in 1932 (Leopold 1967). In 1957-1961, field parties from the Museum of Vertebrate Zoology (University of California) found abundant evidence of grizzlies in the Sierra del Nido mountain range of central Chihuahua. After a series of cattle depredations in 1961 , this small grizzly population (up to 30 bears) was subjected to a vigorous poisoning campaign. Two surveys to determine the status of the Mexican grizzly bear in 1968 and 1979 failed to verify the presence of grizzlies in the Sierra del Nido (Koford 1969, Lee and Thier 1979). However, unconfirmed reports suggest that some grizzlies may still roam this range (Lee and Thier 1979, Trevino 1981). There was no mention in the literature of plans to reintroduce the grizzly into any portion of Mexico.

\section{Reintroduction Techniques}

The techniques discussed previously for population augmentation would presumably apply to reintroduction as well. There are, however, several additional considerations.

Bjorklund (1978) notes that the age and sex of introduced bears must be selected to achieve a viable demographic 
structure. Demographic considerations would have to be balanced with the suitability criteria (likelihood of avoiding conflict and remaining in the transplant area) discussed by Maguire (1985). The history and genetic attributes of the seed population might also influence the success of a reintroduction attempt (Erickson 1974, Brown 1985).

Because proposed reintroduction actions are certain to generate controversy, a major public education program is essential for a successful reintroduction effort (Bjorklund 1980a). Brown (1985) noted that timing and proper planning would be essential to achieve public support for reintroduction of the grizzly into the American Southwest, as the opportunity would probably present itself only once. One vital phase of the planning process would be an indepth habitat analysis of the proposed reintroduction area. Although there are many unknowns concerning grizzly bear movements and distribution, detailed habitat data could be used to predict grizzly bear distribution and anticipate probable conflict zones.

Craighead (1982) perhaps best summarized the status of the reintroduction issue: "the requisite technology is available; the legal, social, political, economic and philosophical requirements are not."

\section{METHODS FOR ESTIMATING POPULATION SIZE AND TRENDS}

Harris (1986a) recently completed a comprehensive review of techniques for determining population size and trends. Much of the following discussion was derived from Harris' work and the reader is referred to his report for a more detailed treatment of these topics.

Certain characteristics of grizzly bears make population estimation difficult (Reynolds 1976, Hebert et al. 1983, Harris 1986a). These are:

1. Grizzly bear behavior, habitat use and foraging patterns make them difficult to observe.

2. Individual bears and different age/sex classes may have different probabilities of capture or observability. This violates the assumption of equal capture probability required by most estimation methods.

3. Because of low population densities, large home ranges, low harvest rates and inherent difficulties for capture or resighting, sample sizes available for population analyses are typically small.

4. Concentrations of grizzlies where food density is high (e.g., salmon spawning areas, huckleberry patches) may make bears easier to count but:

a. the attractiveness of these areas may vary annually according to productivity/availability of forage items

b. the timing of peak attractiveness may vary each year, thus, requiring that the bear survey coincide with the same phase of the aggregation each year c. some individuals or age/sex classes may be less likely to interested in these gatherings

5. Age/sex classes are difficult to determine without direct handling.

6. Black bears and black bear sign can be mistaken for grizzly sign where both species occur in close proximity.

Methods for estimating population size and trends were placed in to the following categories (based partially on the divisions used by Harris $1986 \mathrm{~b}$ ), and are presented in detail in the section below;

1. second-hand reports

2. harvest data indices

3. surveys using tracks and other bear sign

4. bait and scent stations

5. surveys without marked bears: direct counts and general censuses

6. mark-recapture studies

7. population modelling.

\section{Second Hand Reports}

Reports of grizzly bear sightings may be extracted from existing material (e.g., ranger logs, journals) or actively solicited (e.g., questionnaires). These can be used to assess general distribution, or, if the records span several years and represent a uniform sampling procedure, to determine population trends. The National Park Service has maintained a computerized storage and retrieval system for a number of years (NPS 1982, J. Smith 1983). Other systems have been developed (or suggested) to assemble information on bear occurrence and activity for several areas (e.g., Leonard 1983, Taylor 1984, Hickman 1985, Claar et al. in press). Keating (1983, 1986) derived a standardized sighting index based on the number of grizzly bears sighted per kilometer traveled as reported in Glacier National Park ranger station logs. Results from his study correlated well with other estimates of grizzly bear trends in the park.

Harris (1986a) noted that although secondhand reports are inexpensive compared to other methods of trend estimation, interpretation of secondhand data can be problematic. Sources of variation other than actual increases or decreases in bear populations may include observer bias, habitat alteration and fluctuating interest in filing reports. Such biases can be handled with appropriate models but quantifying these variables may be difficult.

\section{Harvest Data as an Index of Population Size and Trend}

The analysis of harvest rates and age/sex ratios to assess population size and trends has received considerable attention in the literature. Harris (1986a) identified 3 major categories of harvest data analyses;

1. those which use trends in the number of animals killed to identify population trends

2. those which treat the age and sex structure of the harvest as representative of the general popula- 
tion (unbiased sample) and construct a life table using these data

3. those which recognize inherent biases in harvest age/sex data and draw inferences about the population's status by interpreting the data in light of these biases.

The first method has not been commonly used for bear population studies (Harris 1986a). Carlock et al. (1983) found a weak correlation between legal harvest of black bears in Tennessee and population size (as estimated by the Jolly-Seber method). The harvest followed the same general trend as the population but a time lag occurred between the 2 . Pearson (1975) pointed out that grizzly bear harvest trends may only reflect the abundance of bears in preferred hunting areas rather than the region-wide trend. This problem may be most pronounced in areas such as the Yukon, where most grizzly hunting is done by guided outfitters who tend to hunt the same areas each year.

The second method, use of harvest age ratios as an unbiased sample, was used in several areas. Caughley (1974) noted that age ratios often provided ambiguous information on population trends. Similar age ratios can result from very different population trajectories and, without additional demographic data, age ratios alone are uninterpretable.

Pearson (1975) used age/sex data from 5 years of harvest to construct a life table and calculate mortality rates for grizzly bears from the Yukon and Northwest Territories. Age ratios have also been used as a crude index of population trend in some Alaskan hunting units to supplement information from other sources (Barnett 1984, Seward 1984).

The third method uses information on the differential vulnerabilities of specific age/sex classes to draw inferences on harvest intensity. Bunnell and Tait (1980, 1985) found that, due primarily to their larger home ranges, male bears were overrepresented in the harvest. The magnitude of the sex-specific difference varied according to the particular hunting method employed. They found that certain counterintuitive results could arise from these differential vulnerabilities. For example, although males of all age classes were more vulnerable to harvest than females, the ratio of males to females in the harvest declined in the older age classes because fewer older males were available for harvest. Thus, in heavily hunted bear populations where males were more vulnerable to harvest than females, the overall sex ratio of the kill could be close to 50:50 (Bunnell and Tait 1980).

Paloheimo and Fraser (1981) and Fraser et al. (1982) presented a statistical model to use the age-related changes in harvest sex ratio to estimate the rate of harvest and the population size. Several assumptions vital to the application of this model are not commonly met by bear harvest data. Harris (1986b) elaborated on the inherent difficulties with Fraser et al. (1982) and related methods.

Harris $(1984,1985 a)$ used a stochastic simulation model to investigate the age/sex structures of grizzly bear populations with increasing harvest pressure. His results generally agreed with the predictions of Bunnell and Tait (1980) and Gilbert et al. (1978) regarding the effects of increased male vulnerability. However, his simulations revealed an inherent low sensitivity of harvest data to short-term population trends. Pronounced time-lags in the response of age/sex ratios to changes in harvest level confounded interpretation of harvest data. For example, 2 harvest simulations, 1 at a sustainable harvest rate and the other at an extreme overharvest, resulted in similar mean female ages for 6 years after initiation of the new harvest regimes. The author concluded that even the most sensitive harvest indices were highly variable and the ability to detect trends in small grizzly bear populations based on harvest data was weak.

The models discussed above (Bunnell and Tait 1980, 1981, 1985, Paloheimo and Fraser 1981, Fraser et al. 1982, Tait 1983, Harris 1984, 1985a) have provided some insights into the behavior of age/sex ratios as a function of various levels of harvest and population trajectories. However, it appears that more research will be required before these indices can be used with confidence to evaluate population trends.

Dood et al. (1986) considered the use of harvest age data to assess population trends or harvest intensity in Montana. Due to the ambiguous interpretations of these data, they concluded that age data could only be appropriately applied in conjunction with other trend indicators. Tompa (1984) acknowledged the limitations of harvest data for lifetable calculations, but felt that differences in age/sex kill samples over time would reflect the actual population structure providing that differential vulnerabilities of specific classes were persistent during the period. He utilized data for 3000 grizzly bears harvested in British Columbia over an 8-year period (along with mortality and natality rates from the literature) to determine regional population trends.

\section{Surveys Using Tracks and Other Bear Sign}

Counts of tracks, scats, bear trees or other sign have 2 obvious advantages over other census methods; they are inexpensive and they do not require bears to be handled or otherwise disturbed. Unfortunately, sign counts do not generally yield the precision desired for rigorous population analyses.

Bear tracks have been used as a rough index of grizzly bear abundance in a number of areas. A series of surveys conducted in northern Montana used the number of tracks or scats observed per mile travelled to supplement data from direct observations of grizzlies (Cooney 1941, Stockstad 1954, Marshall 1955). Measurements of tracks helped to minimize duplication in these counts.

Klein (1959) and Edwards and Green (1959) evaluated the use of tracks for censusing grizzly bears on Admiralty Island and in British Columbia, respectively. Data from both studies indicated that track-counts were not an effective technique for population censuses, but the reasons differed. Klein (1959) found that track measurements did permit discrimination between individual bears except where bear densities were high. He felt that the main obstacle in using track-counts was determining the proportion of bears not feeding at the salmon streams where the track-counts were made.

Edwards and Green (1959) concluded that variation in track measurements due to stride and substrate condition 
precluded the use of track-counts for censuses. Valkenburg (1976) used a stepwise discriminant analysis to differentiate between 63 different sets of brown bear tracks measured in Mt. McKinley National Park, Alaska. Only 3 sets could be distinguished at the $95 \%$ probability level. Similarly, other researchers found that variability or overlap in track measurements prevented reliable separation of individuals (Pearson 1965a, Lloyd 1979). However, under some circumstances, track counts can be helpful for making rough comparisons of bear densities between areas (Klein 1959, Russell 1974).

The use of scat surveys to assess bear densities has several inherent problems. Grizzly bear defecation rates may vary by season, diet, age class and between individuals (Smith 1978, Roth 1980). Attem pts to estimate bear densities from scat occurrence must account for this variation. Furthermore, lack of a reliable method for differentiating between black and grizzly bear scats is a major problem where both species occur in close proximity. Separation of grizzly and black bear scats according to diameter and volume (e.g., Husby et al. 1977, Smith 1978) may discriminate against smaller grizzlies. Methods to distinguish species using fecal bile acids are being investigated (Goodwin and Miller 1982, Welsh and Picton 1984).

Smith (1978) recorded the number of scats deposited per day on a road in his coastal British Columbia study area. He used this index to gain a rough estimate of bear use of various areas and habitats adjacent to the road. Systematic scat surveys are conducted annually in some Alaskan Game Management Units (Townsend 1985). These surveys assess seasonal and annual bear occurrence according to the number of scats per mile of road.

Sign surveys have some of the same problems as counts at concentration areas. To establish annual trends, the survey must be conducted under comparable conditions (e.g., same phase of the salmon run) each year. If counts at concentration areas are to be extrapolated to a broader area, the researcher must have some prior knowledge about relative distribution and habitat use patterns within the area. Alternatively, the sign survey can be calibrated with another more rigorous population estimate (Harris 1986a). Carlock et al. (1983) found that black bear scat occurrence along index routes correlated poorly with population trends in 2 out of 5 years.

\section{Bait and Scent Stations}

Bait stations have been used with some success to census black bears and other carnivores (Lindzey et al. 1977, LeCount 1982, see review in Harris 1984, 1986a). Application of this technique for grizzly bears has been attempted in only a few studies. Winter (1969) used horse carcasses to attract grizzlies to 15 bait stations in the Yellowstone ecosystem. The low response rate was attributed to the bait being too fresh and to the short observation period.

A later study in the Yellowstone area used time-lapse cameras placed at bait stations to document grizzly bear use (Ball 1976, 1980, Roop 1977). Thirty-six stations were monitored for 551 camera days in 1975-76. Three categories of lures were used: scents (nonconsummable), horse carcasses (consumable) and combination lures (scent and carcass). Thirty-one bears, including 5 grizzlies, were identified at 15 stations. Carrion, and scents which mimicked carrion, were the most efficient baits although none were very successful, especially when natural foraging conditions were favorable. Nonconsummable baits had the advantage of attracting bears without enticing them to remain at the station and thereby inhibiting other bears from visiting the bait. Consumable baits could contribute to the association of human activity with food reward (Jonkel pers. commun.).

Smith (1978) also used cameras to document grizzly occurrence but, unlike the above study, he did not use baits to attract bears. Cameras were placed along natural movement corridors and a line was stretched across the corridor to trigger the shutter.

Sumner and Craighead (1973) used bait stations to census grizzly bears in the Scapegoat Wilderness Area. They placed 6 horse carcasses in a variety of habitats throughout their study area and maintained continuous observation of the carcasses from the time of placement until they were consumed. Grizzly bears visited $50 \%$ of the carcasses. Time elapsed from placement to first visit varied from 3-16 days. Grizzlies visiting the stations included all previously recorded bears plus 2 additional bears which had not been recorded. The researchers felt that the use of carcasses was superior to direct observation without baits as a means to count and classify grizzlies.

Harris (1984a) tested several scent station techniques for censusing grizzly bears in Montana. A variety of attractants were used including synthetic compounds and sardines. "Hair grabbers" (wool cards) or time-lapse cameras were installed at some stations to verify bear species. In the first set of experiments, the response rate was $1.3 \%$ (2 visits in 150 operational station-nights). In a second set of experiments, in which an attempt was made to place scent stations in proximity to radio-collared grizzlies, the response rate was only $0.82 \%$ ( 3 visits in 367 station-nights). Based on these results, Harris (1986a) reached the following conclusions:

1. Wool cards were effective for collecting hair samples only if the visiting animal made physical contact with them, however, even when hair was collected, species discrimination from hair micromorphology (e.g., Picton and Knight 1980) was not always certain.

2. Results from time-lapse photography were inconclusive. Infra-red, motion-detecting systems could be used, when funds permitted, for photographing nocturnal activity.

3. Sardines appeared to be the most efficient bait, although all attractants preformed poorly.

4. The relationship of a bait station index to population numbers was not determined. Some calibration with another population estimator was needed to at least ascertain the nature of this relationship (i.e., linear or non-linear).

5. The primary difficulty with using scent station indices was in obtaining adequate sample sizes for analysis. Sample sizes to detect true (statistically significant) differences between 2 bait station indices could be exceedingly large when response rates were low. 
6. Although bait stations may be unsuitable for detecting small changes in population abundance, they could be useful for detecting gross changes or as an indicator of presence/absence.

\section{Surveys Without Marked Bears: Direct Counts and Aerial Censuses}

\section{Direct ground counts}

Direct counts are often used to census grizzlies when marking programs or other techniques are infeasible or undesirable. Based largely on undisputed direct counts of grizzlies, Martinka $(1971,1974 \mathrm{ac})$ estimated the bear density within a $290 \mathrm{sq}$ mi sample area in Glacier National Park. He then derived a park-wide population estimate by extrapolation from the sample area density. Hoak and Clark (1980) and Hoak et al. (1983) used direct sightings by qualified observers as a method to determine the status and distribution of grizzly bears in the Bridger-Teton National Forest. Potential problems with direct ground counts include incomplete sampling, sampling biases and variability associated with small sample size or effects of uncontrollable variables (Harris 1986a).

\section{Known bears}

Some direct counts attempted to determine a minimum population estimate by identifying individual bears and groups of bears. Identification based on pelage or other unique characteristics can be used along with knowledge of marked or harvested bears to increase the number of "known" bears in an area (Craighead et al. 1973, 1974, Reynolds 1974, Pearson 1975, Nagy and Russell 1978, Russell et al. 1979, Miller and Ballard 1982a, Nagy et al. 1983ab, Reynolds and Hechtel 1983a, Aune et al 1984, McClellan 1984, Aune 1985, Aune and Stivers 1985). Difficulties with using known bears are similar to those with direct counts. Seasonal variation in pelage characteristics can pose a problem when recognition is based on pelage alone. Peacock (1978) and Knight et. al. (1975) attempted to overcome this problem by photographing grizzlies.

\section{Counts at concentration areas, aerial censuses}

Bear attendance at seasonal concentrations of preferred forage items has frequently been used to gauge trends in the population at large. These surveys may be conducted from the air (e.g., Glenn 1971, Kendall 1983a, 1984ab, 1985); from the ground (Peacock 1978, Singer 1978); or, in combination (Troyer 1962, Troyer and Hensel 1969, Barnes 1985).

Data from the Black Lake area of the Alaska Peninsula illustrates the usefulness of aerial survey data. Aerial surveys recorded brown bear usage of salmon streams in this area from 1962-1969. Several replicates were conducted annually. The peak number of bears observed each year were averaged to give a mean of 103 bears/survey or 38 bears/hour. Annual surveys in the Black Lake area were resumed in 1982 (several were conducted in the intervening years). Data from 10 surveys, 1982-84, showed a mean of 145 bears/survey, about $40 \%$ higher than the peak surveys during the 1960s. The researchers felt that, despite the unquantified biases associated with aerial censuses, these results suggested a large, stable, or increasing population (Sellers and McMay, in Townsend 1985).

Aerial surveys over broader areas have also been conducted. Crook (1971) used aerial survey transects along river valleys to census bears in an 84,000 sq mi study area in northern Alaska. The survey method was designed to minimize biases due to bear activity patterns, bear avoidance of aircraft, season, aircraft type and other sampling biases. However, bear densities calculated from replicate surveys over the same area were highly variable. The researcher concluded that relative abundance comparisons were not possible given the limited data.

Since 1974, a number of aerial census techniques have been used to monitor the Yellowstone grizzly bear population. Knight et al. $(1977,1978)$ attempted to determine the minimum number of grizzly bears by recording numbers of unduplicated individuals seen during aerial surveys. Location of the bear, obvious age, sex or coloration distinctions and photographs were used to distinguish individual bears and groups of bears. In 1983, an ad hoc committee for population analysis suggested a method to estimate population size and trends from the number of unduplicated females with cubs (the most readily identifiable segment of the population) observed over a 3 -year period (Knight 1983). Subsequently, an intensive aerial survey system involving 3 aircraft working simultaneously for 4 days was developed to standardize the system for monitoring females with cubs (Knight 1984). Weather problems and observer fatigue rendered this system impractical. However, a somewhat less intensive flight system was developed which would cover only areas where females with cubs had been sighted during the previous 10 years. Other prospective indices based on grizzlies seen per hour flying and grizzlies seen per flight were also considered (Knight and Eberhardt 1985).

Klaver and Claar (1982) attempted to develop a survey technique based on counting bears as they left dens. They selected females with young as the best class for monitoring. The censuses were conducted for 2 years but only 1 family group was seen during the 2 surveys. The researchers concluded that den surveys were expensive and had limited efficiency. They recommended that if the technique was to be applied in other areas the researchers should have some prior knowledge of denning habitat in the study area and radio-collared bears should be monitored to ensure proper timing of the survey.

\section{Difficulties and biases with aerial surveys}

The inherent biases in traditional aerial surveys are well recognized. Inconsistencies in survey data can arise from differences in observer skill and experience, time of day, season, weather, lighting condition, food availability and other considerations (Ericksen and Siniff 1963, Erickson 1965, Crook 1971, Knight and Eberhardt 1985). Even with the aid of telemetry equipment, grizzly bears are difficult to observe (Knight et al. 1977, 1980, Hamilton and Archibald 1984). Troyer and Hensel (1969) found that aerial observers located less than $25 \%$ of the bears known to be present in the Karluk River drainage. Erickson and Siniff (1963) conducted 10 simultaneous air and ground surveys along coastal Alaskan salmon streams. The air observers recorded an average of only $47 \%$ of the bears known to be present from the ground surveys.

Group identification and classification is also difficult from the air. Barnes $(1984,1985)$ reported that ground observers were able to identify a higher number of individual grizzly bears feeding along 2 Kodiak Island salmon streams than did aerial observers. In that study, numerous 
replicate surveys were conducted from both the air and ground. Ground crews were able to spend more time observing individual groups to obtain accurate age and sex classifications. Erickson (1965) found that although aerial observers did not differ significantly in their abilities to make total counts, their classification of bears did differ. Knight et al. (1975) felt that photos taken from the air could help to distinguish individual bears and groups.

As noted previously, many aerial censuses are conducted at concentration areas, such as salmon spawning streams, berry patches or garbage dumps. For these counts to yield reliable data on population composition, it must be assumed that the age and sex class composition at the concentration area is the same as the composition in the population at large (Harris 1986). Annual censuses of grizzlies on McDonald Peak appear to include a disproportionate number of adult females (Klaver in Harris 1986). Similarly, timing of an aerial survey can influence the results. At McNeil Falls, Alaska, adult brown bears fished for salmon most often in the afternoon and evening periods (Egbert and Stokes 1976). Thus, censuses conducted in the morning might underrepresent adult bears. Erickson and Siniff (1963) found large differences in the overall number of bears observed at different times of day during aerial surveys on the Alaska Peninsula.

Harris (1986a) evaluated the precision of aerial bear surveys by reviewing data in the literature for biologically unrealistic annual changes and variability between replicate surveys. Data from 3 Alaskan surveys suggested average annual increases of 42 to $158 \%$ - rates of increase deemed unrealistically high given the bears' low reproductive rate. Review of within-year replicate counts indicated coefficients of variation (standard deviation divided by the mean) ranging from 36 to $149 \%$.

\section{Means to Minimize or Correct for Biases in Aerial Surveys}

Harris (1986a) reviewed the literature on aerial survey biases and discussed quantitative procedures for handling these biases. The following discussion pertains only to techniques which have been applied to grizzly bears.

Erickson and Siniff (1963) evaluated the factors influencing aerial surveys of brown bears in coastal Alaska. Factors which had a significant effect on census results included time-of-day, weather factors and ability of different observers to distinguish between age classes. They determined that at least 15 replicate surveys would be required to derive a $95 \%$ confidence interval equal to $10 \%$ or less of the mean population estimate.

Caughley and Goddard (1972) developed a method to estimate the number of animals in an area from the mean and variance of several counts conducted at 2 levels of survey efficiency. Reynolds (1974, 1975) attempted to employ this "differential efficiency" method to estimate grizzly bear populations in the North Slope, Alaska area. This method yielded an estimate of -6.0 bears and the technique was rejected in favor of direct counts of marked and distinguishable bears.

One source of variability in surveys at concentration areas can be reduced by synchronizing the survey with the same phase of the aggregation each year. Kendall (1983a, $1984 \mathrm{ab}, 1985)$ conducted annual helicopter surveys of bears in a large huckleberry patch in the Apgar Mountains of
Glacier National Park. Each year, berry development was monitored so that the survey could be timed to coincide with maximum succulence of the berry crop. Erickson and Siniff (1963) noted that because of the great differences in timing of salmon migrations and, consequently, of bear concentrations on different stream systems, prior knowledge of the bear-salmon relationships in each area was necessary before initiating aerial surveys.

Erickson (1965) reported that stratified aerial sampling techniques for censusing bears was tested on Kodiak Island. However, since most brown bears sought shelter when alarmed by aircraft, the technique was unworkable except in relatively open terrain.

\section{Mark-Recapture Studies}

Mark-recapture studies have been used to evaluate the size and trends of grizzly bear populations in several areas. Lincoln-Petersen which requires only a single recapture, is the most common mark-recapture method. Hornocker (1962) used the Petersen Index method to estimate the number of grizzly bears using the Trout Creek dump in Yellowstone National Park in 1960 and 1961. In this study, "recaptures" were actual physical recaptures rather than visual observations used in most other mark-recapture studies. Estimates from this method were lower for both years than estimates from either the Schnabel method or direct counts; small sample sizes and selective capture methods were likely problems. Craighead et al. (1973) reported that the parkwide population estimates derived from both the Petersen and Schnabel methods were comparable to their direct count estimate.

Reynolds (1974) used the Lincoln Index to estimate the grizzly bear population for a segment of his Alaskan North Slope study area. Data from 18 aerial surveys were used to calculate the ratio of marked to unmarked bears for the analysis. The estimated population size from this method was comparable (slightly higher) to the estimate from direct counts of identifiable bears along the survey route. Thirty-six percent of the grizzlies sighted during the survey were marked animals. Wood $(1974,1975,1976)$ used the ratio of marked to unmarked brown bears observed at Hood Bay (Admiralty Island, Alaska) to derive a rough population estimate for his study area.

Miller and Ballard (1980, 1982a) used a modified Petersen Index to estimate the brown bear population size and density in their southcentral Alaska study area. Fortyeight bears were captured and removed in 1979 as part of a moose calf mortality study. Twelve brown bears marked in 1978 served as the basis for the Petersen Index, and separate mark-recapture calculations were performed for each sex. The "raw" estimates for females and newborn cubs were adjusted upwards to correct for the apparent low probability of capture for these groups. The researchers felt that their procedures provided a realistic and replicable method for estimating population size and density.

Miller (1985a) reported a further modification of the above procedure. A series of independent population estimates were determined from the ratio of marked (radiocollared) to unmarked bears observed during aerial censuses. Unmarked bears seen during these censuses were captured and marked so that the total mumber of marked animals in the population increased over time. To deter- 
mine the number of marked bears actually present within the defined search area, a correction was made for bears whose home ranges overlapped the search area boundaries. These bears were assigned fractional "presence" values based on the proportion of times they were relocated inside the boundaries. This procedure corrected for the demonstrated absence of closure for this brown bear population. A subsequent publication reported further reinforcement for this aerial census technique (S. Miller et al. in press).

The Schnabel method has been used less frequently than the Lincoln-Petersen Index for grizzly bear mark-recapture studies. Hornocker (1962) used data from 23 and 29 counts in 1960 and 1961, respectively, to estimate the Trout Creek grizzly population using the Schnabel estimator. Results from this estimate correlated closely with direct count estimates. Troyer and Hensel (1969) used the Schnabel method to determine the size of the brown bear population on their Kodiak Island study area. The data collection procedure described by Miller (1985a) and discussed above was similar to the Schnabel method in that all unmarked animals seen during the censuses were captured and marked, however, the standard Lincoln Index was used for data analysis.

Pelton and Marcum (1977) and Carlock et al. (1983) injected captured black bears with radioactive isotopes and then used the Schnabel method for estimating population size according to the ratios of tagged to untagged droppings collected on trails. Use of the radioactive fecestagging technique had several advantages over traditional mark-recapture methods including large sample size and minimization of animal handling. Tagging and scat collection in both studies were done on the same trail system, thus, 1 possible source of bias was disproportionate sampling of trail-habituated bears. The radioactive-tagging technique has not been applied to grizzly bear population estimates.

The Jolly-Seber method of population estimation (Jolly 1965, Seber 1965) allows for immigration, emigration, death and recruitment to the census area. This "open" model for mark recapture studies has been applied to bears less frequently than the "closed" models (Lincoln-Petersen and Schnabel methods) discussed above. Roop (1980b) described an attempt to apply the Jolly-Seber and ManleyParr estimates to Yellowstone grizzly bear data. Trapping data used in his analysis were collected opportunistically and violated the models' requirement that trapping effort be evenly distributed in space and time. Beecham (1980) and Carlock et al. (1983) used the Jolly-Seber method to estimate the size of black bear populations in Idaho and the southeastern United States, respectively. In the latter study, the Jolly-Seber estimate appeared to be the most appropriate estimation method.

Harris (1986a) discussed problems in the use of markrecapture studies for grizzly bear populations. Population closure is assumed by the Lincoln-Petersen and Schnabel estimators but this assumption is seldom met by grizzly bear studies. Miller and Ballard (1980, 1982a) found no evidence to indicate that the closure assumption was violated in their brown bear removal study. As discussed earlier, subsequent studies in the Susitna area adjusted for movement of marked bears into, and out of, the study area (Miller 1985a, Miller et al. in press). This was the only study in which specific corrections for lack of closure were incorporated into the analysis.

Most mark-recapture estimators also assume equal catchability of all members of the population throughout the survey period. Unequal catchability in bear population studies can arise from seasonal variation in trap vulnerability, individual variation in trap response, prior trap history, effects of trap distribution and age/sex class variation (Harris 1986a). Partitioning of the population into separate age/sex class groups for data analysis can alleviate some of the unequal catchability difficulties. Miller and Ballard (1980, 1982a) made separate calculations for each sex and only included animals older than 3 years. Estimates for the cub through 2-year-old age classes were inferred from other data. Beecham (1980) also chose to limit his estimates to adult age classes.

Small sample sizes, high variability and large confidence intervals are typical of most bear mark-recapture studies. Reynolds (1974) had a 95\% confidence interval width equal to $151 \%$ of his population estimate. Miller and Ballard $(1980,1982 a)$ had a $95 \%$ confidence interval width of $230 \%$ for their uncorrected Petersen estimate. Comparable figures from the Jolly-Seber estimates were $71 \%$ (Roop 1980 ) and 47\% (Beecham 1980). DeMaster et al. (1980) developed a modified Jolly-Seber method for use with polar bears that improved the precision with small samples but required a stable age distribution and equal catchability. Pollock (1982) suggested an a sampling regime for the Jolly-Seber method to allow for unequal catchability.

\section{Population Modelling}

Population projection models require reliable data on litter size, breeding age, breeding interval, survivorship and age/sex structure of the modelled population (Harris $1986 \mathrm{~b})$. Since these parameters often vary greatly between bear populations (Bunnell and Tait 1981, 1985) and many years of data collection are usually required to obtain reliable values, sufficient data for population modelling are available for few bear populations.

A number of models have been constructed using data for the Yellowstone grizzly bear ecosystem. Based primarily on their data collected from 1959-1970, Craighead et al. (1973) developed a simulation/projection model for Yellowstone grizzlies. Both stochastic and deterministic models were discussed therein. A subsequentreport(Craighead et al. 1974) reported further on the deterministic Leslie matrix type simulation model. A primary objective of their simulations was to evaluate the potential effects of the new management policies which began in 1968 .

The Craighead et al. $(1973,1974)$ model assumed a stable age distribution and constant rates of reproduction and mortality throughout the analysis period. The lack of compensatory processes in their model was criticized by Cowan et al. (1974) and McCullough (1981). Further analysis of the Yellowstone data suggested that certain compensatory relationships were operative. Avrin (1976) developed a partially compensatory model for the Yellowstone grizzly population. He used the fixed survival rates of adults as previously reported by Craighead et al. (1974) but included a compensatory relationship between the number of adults and juvenile recruitment. McCullough (1981) reviewed the previous modelling efforts and constructed a model which 
allowed for compensatory interactions between age structure, recruitment, sex ratio and adult mortality. Greer (1980) and Roop (1980b) also reported on population projection models for the Yellowstone bears.

Shaffer $(1978,1983)$ and Shaffer and Samson (1985) used a stochastic computer simulation model to study the relationship of population size to extinction probability for Yellowstone grizzlies. Density dependent mechanisms were built in to the model to determine the average litter size and proportion of reproducing females. Suchy et al. (1985) modified Shaffer's program to include the more recent (1975-1982) Yellowstone data. Their simulations also tested the influence of environmental and demographic stochasticity on the long-term (100 year) viability of the grizzly population.

Knight and Eberhardt (1984, 1985) built a stochastic simulation model to study the dynamics of the Yellowstone grizzly population. In their model, individual females were followed through life with their survival and reproductive performance determined annually by stochastic assignment using calculated age-specific rates. The authors felt if the Yellowstone population stabilized at a new level some sort of inherent regulatory mechanism would probably be operative. However, since the nature of that mechanism was unknown, no compensatory processes were incorporated into their model.
Population modelling efforts for other grizzly bear populations have been limited. McLellan (1984) used a basic Leslie matrix model with no density dependent or compensatory mechanisms to examine population trends for the grizzly population in the North Fork of the Flathead Valley. Sidorowicz and Gilbert (1981) used a com puter model to evaluate the effects of alternative management strategies and mortality patterns on the Yukon grizzly bear population. Taylor et al. (in press) recently developed an elaborate projection model (ANURSUS) for use with polar bear populations. As some peculiar aspects of reproductive biology (such as multiannual reproduction) are shared by all species in the genus Ursus (Bunnell and Tait 1981), the ANURSUS models may also prove valuable for grizzly bear population analyses.

Several models have been developed to investigate the effects of hunter harvest on grizzly bear population size and age structure. Bunnell and Tait $(1980,1981)$ discussed the general features of simulation models and described the effects of hunter harvest on hypothetical bear populations. A sim ple Leslie matrix type model with some density dependent features was used for their analyses. Harris (1984a) also investigated the effects of harvest intensity on grizzly bear age structure and population status. He used a stochastic, discrete-time, age structured projection model. Several different forms of density dependent mechanisms were tested. The reader is referred to each of these papers for more detailed discussions. 



\section{HABITAT MANAGEMENT}

\section{FOOD HABITS SUMMARY}

A review of the food habits of grizzly bears on the North American continent shows that a wide variety of plant and animal foods are utilized on a seasonal and annual basis. Vegetal matter (e.g., stems, leaves, roots/corms/bulbs, fruit) and animal matter are universally important and, as such constitute 4 major food categories. Although bears have obviously adapted to local availability of foods, several items appear to comprise a significant portion of their diet in all areas. In areas where these specific major items are absent, alternate foods within the same food category are selected.

Equisetum spp. is the only plant genera used in all regions within the North American range of the grizzly bear (Table 17 and 18) and is selected during all seasons. Equisetum spp. is typically found in mesic habitats in association with other preferred vegetal foods. A variety of grasses and sedges are also important throughout the bears' North American range although the species selected differs by location. These 3 food types represent true staple items in the grizzly bear diet.

Heracleum lanatum, Trifolium spp. and Taraxacum spp. are major early, and mid-season items in coastal and Continental Divide mountain habitats. This food item does not occur throughout much of the northern interior and Arctic habitats. Trifolium spp. and Taraxacum spp. tend to pioneer early successional habitats and their use as vegetal foods correlates well with bear use of seral or disclimax plant communities. The number of vegetal food items used appears to be less within the far-northern range of grizzlies in comparison to more southern areas.

The roots of Hedysarum spp. are dug in all mountainous and Arctic habitats of Canada and Alaska (Table 17 and 18 ), but are not a major diet item in the contiguous 48 states. $H$. sulpherescens, for example, only appears in grizzly bear scats collected from the extreme northern portion of Montana (Mace and Jonkel in press) and has very limited distribution further south in the state (Mace 1986). Where Hedysarum spp. is absent or of limited availability, Lomatium spp., Erythronium spp. or Perideridia spp. roots are dug. Kodiak, Admiralty and Chichagof Islands in Alaska are the only location where a primary seasonal food was not dug.

The fruit of 2 shrub taxa constitute a vital mid- and late-season food item in much of the Continental interior. The fruit of Vaccinium and Shepherdia spp. are the primary sources for energy and fat deposition whereever available. $V$. membranaceum, ovalifolim, myrtillus, scoparium, globulare, uliginosum, and vitis-idaea are particularly important species to local bear populations. The overwintering berries of Arctostaphylos spp. are an important early-season diet item throughout Canada and in the Northern Ecosystem of Montana. The fruit of this gen us is the single most important mid- and late-season energy source in Arctic habitats of Canada and Alaska (Table 17 and 18). Rubus spectabilis and Oplopanax horridus fruits are important to coastal bears.

The nuts of Pinus albicaulis are important only in the most southern portion of grizzly bear range. In the relatively xeric habitats of Yellowstone National Park and the
Rocky Mountain East Front (Montana), these nuts either intensively supplement or basically replace the fruit of shrubs.

The grizzly bear maintained the ability to either kill or consume as carrion, mammals and fish. Local concentrations of large ungulates constitute an important source of protein wherever available. In many locations, animal matter may not constitute a major annual diet item but may be vital to bears on a seasonal basis. Caribou, elk, moose or livestock are particularly important. Salmon constitute a confined and extremely vital seasonal food in coastal habitats. Small trout are locally important only in Yellowstone National Park. Rodents, primarily ground squirrels and microtines, supplement the annual diet of the grizzly bear throughout much of Continental North America. However, in the Arctic habitats ground squirrels constitute a primary, staple protein source. Marine mammal carcasses constitute an important spring food in several coastal Alaskan and Canadian locations.

\section{COVER}

Grizzly bear cover requirements and use have not been fully documented in the literature. In all areas studied, the home range of the grizzly bear is composed of a mosaic of several to many relatively dissimilar habitat units (e.g., cover types, components, vegetation types). Grizzly bear seasonal use of these units has most often been described in terms of the presence of preferred foods items and few measurements have been obtained in reference to thermal or escape cover. Measurements of cover requirements are futher complicated by individual behavior, behavior hierarchies within a given population may determine habitat use patterns and use of cover (Mattson 1983, Schleyer 1983, McLellan and Mace 1985). The intraspecific propensity for adult males to kill young bears, for example, has led female bears in the northcentral Alaska Range to use habitats close to escape cover (Reynolds and Hechtel 1982). As with other wildlife species, annual differences in gross weather conditions, and environmental factors such as elevation, slope, topography, precipitation, temperature and wind dictate the type and degree of cover use (Schleyer 1983).

$\checkmark$ Cover use also varies with female reproductive status. Females with young often select rugged, isolated habitats throughout the range of the species (Pearson 1975, Russell et al. 1979, Glenn and Miller 1980, Sizemore 1980, Stelmock 1981, Darling in press).

Grizzly bear behavior in relationship to cover use may also vary between hunted and unhunted populations. The lack of secretive behavior and associated use of open habitats has been documented in wildlife preserves (Hamer 1985). Conversely, it is theorized that individuals from hunted populations use habitats with relatively high cover values (Archibald 1983).

$\checkmark$ McLellan and Mace (1985) investigated the behavior and habitat use patterns of grizzly bears in response to road traffic, seismic activity and people on foot. Analyses showed that grizzly bear use of habitats within $100 \mathrm{~m}$ of an open road was less than expected for the habitat available. Because substantial clearcutting had occurred adjacent to 
Table 17. Summary of major food items used by grizzly bears in Canada, by geographic location.

\begin{tabular}{|c|c|c|c|c|c|c|}
\hline \multirow[b]{2}{*}{ Food } & \multicolumn{6}{|c|}{ ECOSYSTEMa } \\
\hline & Coastal & $\begin{array}{c}\text { Interior } \\
\text { Mtns. }\end{array}$ & $\begin{array}{c}\text { Rockies } \\
\text { Mtns. }\end{array}$ & $\begin{array}{l}\text { Boreal } \\
\text { Forest }\end{array}$ & $\begin{array}{l}\text { Northern } \\
\text { Interior }\end{array}$ & Arctic \\
\hline \multicolumn{7}{|l|}{ Vegetal Parts: } \\
\hline $\begin{array}{l}\text { Equisetum spp. } \\
\text { Graminae spp. } \\
\text { Carex/ Juncus spp. } \\
\text { Lysichitum americanum } \\
\text { Rubus spectabilis } \\
\text { Vaccinium spp. } \\
\text { Claytonia lanceolata } \\
\text { Oxyria digyna } \\
\text { Heracleum lanatum } \\
\text { Trifolium spp. } \\
\text { Athryium filix femina } \\
\text { Oplopanax horridus } \\
\text { Angelica spp. } \\
\text { Taraxacum spp. } \\
\text { Salix spp. (catkins) } \\
\text { Osmorhiza spp. } \\
\text { Ligusticum spp. } \\
\text { Mitella brewerii } \\
\text { Tiarella trifoliata } \\
\text { Luzula hitchcockii } \\
\text { Claytonia lanceolata } \\
\text { Circium scariosum } \\
\text { Boykinia richardsonii } \\
\text { Oxytropis spp. } \\
\text { Hordeum brachyantherum } \\
\text { Carex macrochaeta } \\
\text { Lupinus nootkatensis } \\
\text { Eriophorum vaginatum }\end{array}$ & $\begin{array}{c}\text { NS } \\
\text { NS } \\
1,2 \\
2 \\
2 \\
1,2 \\
\\
\text { NS } \\
1,2 \\
2\end{array}$ & $\begin{array}{c}1,2,3 \\
1,2,3 \\
1,2,3 \\
\\
2 \\
2 \\
1,2\end{array}$ & $\begin{array}{c}2 \\
2 \\
1,2,3 \\
\\
\\
2 \\
1,3\end{array}$ & $\begin{array}{c}1,2 \\
1,2,3 \\
1,2,3\end{array}$ & $\begin{array}{l}1,2,3 \\
1,2,3\end{array}$ & $\begin{array}{l}2,3 \\
2,3\end{array}$ \\
\hline
\end{tabular}

Roots/Corms/Bulbs:

Hedysarum spp.

H. alpinum

NS $\quad 1,2,3$

1,3

1,3

$1,2,3$

1

H. sulphurescens

Claytonia lanceolata

Osmorhiza chilensis

Angelica genuflexa

Oplopanax horridus

Erythronium grandiflorum

Lomatium spp.

Polygonum spp.

Perideridia gairdneri

Eriophorum vaginatum

Fruit:

Chimpaphila umbellata

Oplopanax horridus

Shepherdia spp.

Empetrum nigrum

Vaccinium spp.

Ribes spp.

Arctostaphylos spp.

Cornus sericea

NS

NS

1

Lonicera spp.

Rubus spectabilis

Viburnum edule

Sorbus spp.

Sambucus spp.

3

3

NS

2,3

2,3

1

NS

NS

2

NS

2,3

2,3

1
2,3

2

1
1

2

2

2

2,3 
Table 17. (Continued)

\begin{tabular}{|c|c|c|c|c|c|c|}
\hline \multirow[b]{2}{*}{ Food } & \multicolumn{6}{|c|}{ ECOSYSTEMa } \\
\hline & Coastal & $\begin{array}{l}\text { Interior } \\
\text { Mtns. }\end{array}$ & $\begin{array}{l}\text { Rockies } \\
\text { Mtns. }\end{array}$ & $\begin{array}{l}\text { Boreal } \\
\text { Forest }\end{array}$ & $\begin{array}{l}\text { Northern } \\
\text { Interior }\end{array}$ & Arctic \\
\hline $\begin{array}{l}\text { Crataegus spp. } \\
\text { Rhamnus alnifolia } \\
\text { Prunus virginiana } \\
\text { Amelanchier alnifolia } \\
\text { Domestic apples, plums, cherries } \\
\text { Rosa acicularis } \\
\text { Pinus albicaulis (nuts) }\end{array}$ & & & $\begin{array}{l}2,3 \\
2,3\end{array}$ & & & \\
\hline \multicolumn{7}{|l|}{ Mammal/Avian Fish/Insect: } \\
\hline $\begin{array}{l}\text { Caribou } \\
\text { Salmon or trout } \\
\text { Moose }\end{array}$ & 2,3 & & & & & 1 \\
\hline $\begin{array}{l}\text { Wild ungulate carrion/predation } \\
\text { Domestic livestock (Carrion/predation) }\end{array}$ & 1 & 1,3 & & $1,2,3$ & & \\
\hline $\begin{array}{l}\text { Rodent } \\
\text { Bird } \\
\text { Colonial nesting bird eggs }\end{array}$ & & $\begin{array}{c}1,2,3 \\
2\end{array}$ & & 1,2 & 3 & 2,3 \\
\hline $\begin{array}{l}\text { Insect } \\
\text { Earthworms }\end{array}$ & & $1,2,3$ & 2 & & 2 & \\
\hline Marine mammal carrion & & & & & 1 & \\
\hline
\end{tabular}

aNS = season not specified, 1 = early season, 2 = mid-season, 3 = late season (actual seasonal dates differ among study area).

Table 18. Summary of major food items used by grizzly bears in the United States by geographic location.

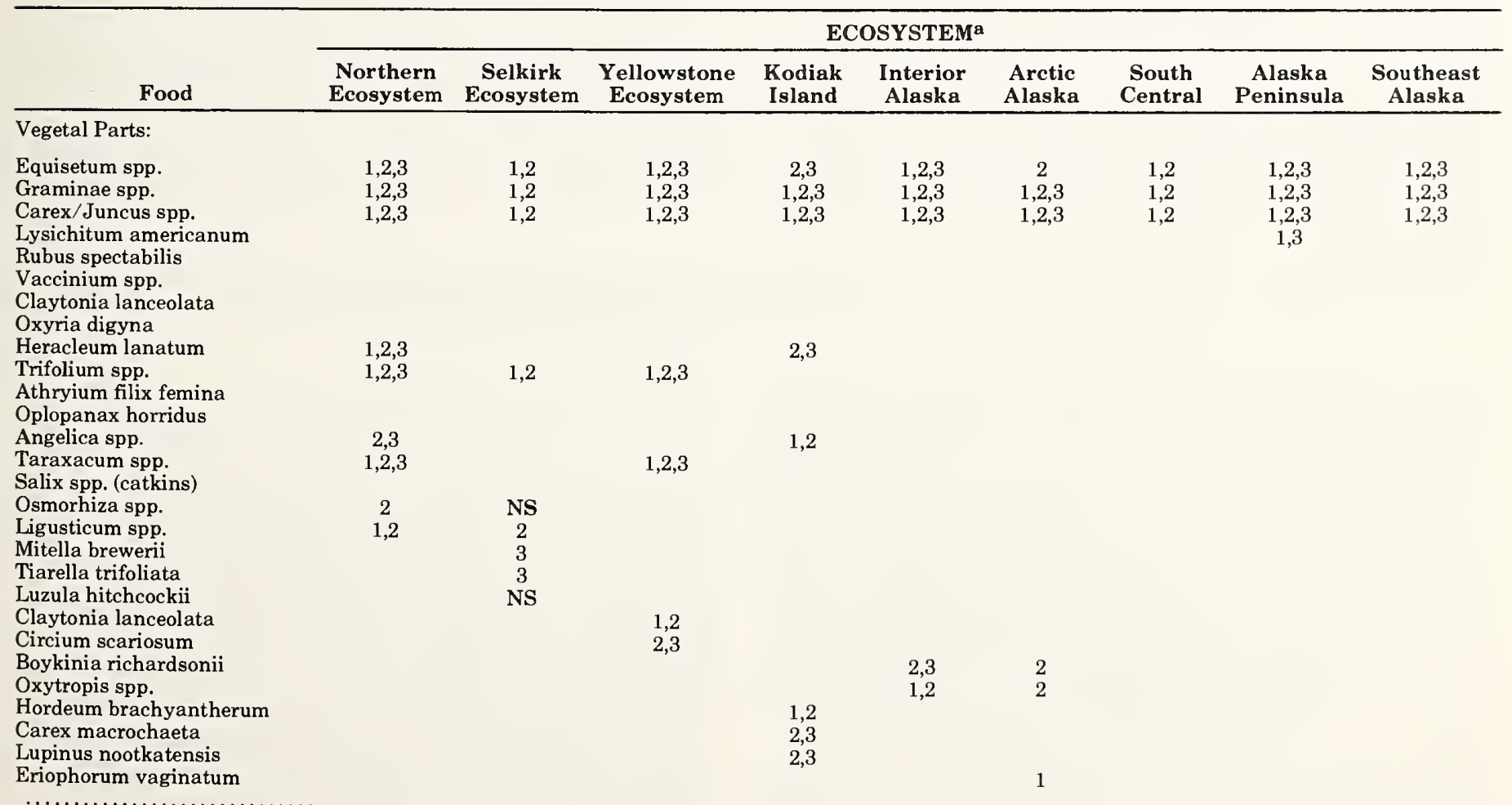


Table 18. (Continued)

\begin{tabular}{|c|c|c|c|c|c|c|c|c|c|}
\hline \multirow[b]{2}{*}{ Food } & \multicolumn{9}{|c|}{ ECOSYSTEM $^{a}$} \\
\hline & $\begin{array}{l}\text { Northern } \\
\text { Ecosystem }\end{array}$ & $\begin{array}{c}\text { Selkirk } \\
\text { Ecosystem }\end{array}$ & $\begin{array}{c}\text { Yellowstone } \\
\text { Ecosystem }\end{array}$ & $\begin{array}{c}\text { Kodiak } \\
\text { Island }\end{array}$ & $\begin{array}{c}\text { Interior } \\
\text { Alaska } \\
\end{array}$ & $\begin{array}{c}\text { Arctic } \\
\text { Alaska } \\
\end{array}$ & $\begin{array}{c}\text { South } \\
\text { Central }\end{array}$ & $\begin{array}{c}\text { Alaska } \\
\text { Peninsula }\end{array}$ & $\begin{array}{c}\text { Southeast } \\
\text { Alaska }\end{array}$ \\
\hline \multicolumn{10}{|l|}{ Roots/Corms/Bulbs: } \\
\hline $\begin{array}{l}\text { Hedysarum spp. } \\
\text { H. alpinum } \\
\text { H. sulphurescens } \\
\text { Claytonia lanceolata } \\
\text { Osmorhiza chilensis } \\
\text { Angelica genuflexa } \\
\text { Oplopanax horridus } \\
\text { Erythronium grandiflorum } \\
\text { Lomatium spp. } \\
\text { Polygonum spp. } \\
\text { Perideridia gairdneri } \\
\text { Eriophorum vaginatum }\end{array}$ & $\begin{array}{l}1,2 \\
1,2 \\
1,3\end{array}$ & $\begin{array}{l}1 \\
1\end{array}$ & $\begin{array}{c}1,2,3 \\
1,2,3 \\
2,3\end{array}$ & & $1,2,3$ & $1,2,3$ & & & \\
\hline \multicolumn{10}{|l|}{ Fruit: } \\
\hline $\begin{array}{l}\text { Chimpaphila umbellata } \\
\text { Oplopanax horridus } \\
\text { Shepherdia spp. } \\
\text { Empetrum nigrum } \\
\text { Vaccinium spp. } \\
\text { Ribes spp. } \\
\text { Arctostaphylos } \\
\text { Cornus sericea } \\
\text { Lonicera spp. } \\
\text { Rubus spectabilis } \\
\text { Viburnum edule } \\
\text { Sorbus spp. } \\
\text { Sambucus spp. } \\
\text { Crataegus spp. } \\
\text { Rhamnus alnifolia } \\
\text { Prunus virginiana } \\
\text { Amelanchier alnifolia } \\
\text { Domestic apples, plums, cherries } \\
\text { Rosa acicularis } \\
\text { Pinus albicaulis (nuts) }\end{array}$ & $\begin{array}{c}3 \\
\\
2,3 \\
2,3 \\
2,3 \\
2,3 \\
2,3 \\
3\end{array}$ & 2 & 1,3 & $\begin{array}{l}2,3 \\
2,3\end{array}$ & $\begin{array}{c}2,3 \\
1,2,3 \\
2,3\end{array}$ & 1,3 & $\begin{array}{l}2,3 \\
2,3 \\
2,3\end{array}$ & $\begin{array}{l}2,3 \\
\\
2,3 \\
2,3\end{array}$ & 2,3 \\
\hline \multicolumn{10}{|l|}{ Mammal/Avian/Fish/Insect: } \\
\hline $\begin{array}{l}\text { Caribou } \\
\text { Salmon or trout } \\
\text { Moose } \\
\text { Wild ungulate (carrion/predation } \\
\text { Domestic livestock } \\
\quad \text { (carrion/predation) } \\
\text { Rodent } \\
\text { Bird Colonial nesting bird eggs } \\
\text { Insect } \\
\text { Earthworms } \\
\text { Marine mammal carrion }\end{array}$ & $\begin{array}{c}1,2,3 \\
2,3 \\
1,2,3\end{array}$ & $\begin{array}{c}\text { NS } \\
\\
2 \\
3\end{array}$ & $\begin{array}{l}1,2,3 \\
1,2,3\end{array}$ & $\begin{array}{c}2,3 \\
2,3 \\
1,3 \\
1 \\
1\end{array}$ & $\begin{array}{c}1,2,3 \\
3 \\
1,2,3\end{array}$ & 1,2 & $\begin{array}{c}2,3 \\
1,2 \\
1\end{array}$ & $\begin{array}{c}1 \\
2,3 \\
\text { NS } \\
1\end{array}$ & $\begin{array}{l}2 \\
1\end{array}$ \\
\hline
\end{tabular}

aNS = season not specified, 1 = early season, 2 = mid-season, 3 = late season (seasonal dates differ among study area).

many of these open roads, McLellan and Mace (1985) hypothesized that the loss of cover was more responsible than the intensity of traffic. Visual cover was important in predicting a bear's response to human stimuli. Bears in direct view of vehicles usually fled to adjacent cover, whereas bears close to roads but in cover did not appear to be affected.' Limited data also suggested that the need for vegetative or topographic cover was less during night hours. The importance of security cover was indicated during seismic activity. No indication of displacement was observed by McLellan and Mace (1985) when bears were in cover, but displacement appeared to occur when several bears were in relatively high-elevation, open habitats. Helicopter traffic at $1500 \mathrm{~m}$ distance appeared to have little effect on bears, even when in open habitats with little cover.
Schleyer (1983) analyzed the daily activity patterns of instrumented grizzly bears in Yellowstone National Park, and found that some individuals were primarily nocturnal and others more diurnal. In general, nocturnal bears foraged in open and ecotonal areas but were quick to seek timbered cover before or soon after light. Bedding areas were often located in dense timber with downfall. Schleyer (1983) also observed that ungulate carcasses located in open areas were usually dragged to cover before being consumed. Thermal regulation and the need for seclusion are probable causes for bears to seek cover during daylight hours of summer (Jonkel 1980a).

Blanchard (1983) documented that instrumented grizzly bears in Yellowstone Naitonal Park were located in timbered habitats $90 \%$ of the time; $79 \%$ of these bears were 
located in cover over $3 \mathrm{~m}$ tall. Of the locations in the open, most were less than $100 \mathrm{~m}$ from forested cover. Ground examinations showed that areas with little cover and forested areas were both used for foraging. Blanchard (1983) did not know if forested areas were used more because of foraging/bedding preference or to avoid human contact. Graham (1978) analyzed grizzly bear observation sites (e.g., tracks, scats, digs) in the Pelican and Hayden valleys of Yellowstone National Park. Graham found that the forest/open edge effect was an important factor governing bear distribution. Seventy-five percent of all observation sites were within $50 \mathrm{~m}$ of timber (average $=12 \mathrm{~m}$ ). Bears that used openings greater than $100 \mathrm{~m}$ from timber were most often traveling (Graham 1978).

Smith (1978) measured the cover characteristics of logged areas of different ages in coastal British Columbia, and found that even recently logged areas afforded adequate visual cover. Documented use of logged areas with little vegetative cover has been minimal in the Northern Continental Divide Ecosystem. Zager (1980a) suggested that cutting unit design, size and shape affect habitat use patterns. Eighty-two percent of 34 grizzly relocations in cutting units were within $50 \mathrm{~m}$ of escape cover.

\section{DENNING}

Numerous studies have delineated the characteristics of grizzly bear dens and corresponding environmental parameters. The results of these investigations in the United States and Canada have been summarized and are presented in Table 19.

\section{Variability}

Within each ecosystem, den characteristics were relatively consistent with the exception of entry and emergence dates. These differences in denning chronology have been attributed to sex and age factors. In general, adult males remain active longer and emerge from dens earlier, while females with newborn cubs are usually the last to leave denning areas in the spring (Pearson 1975, Craighead and Mitchell 1982, Judd et al. in press).

For the most part, interecosystem variability can be explained by local biogeographic characteristics, learned behavior of individual bears and human environmental impacts (Hamer et al. 1977 and Craighead and Mitchell 1982).

\section{Site Fidelity}

Throughout the grizzly bear's range, researchers have observed that dens rarely occur singly, but are concentrated in areas which apparently possess appropriate environmental conditions (Craighead and Craighead 1972a, Hamer et al. 1977). These denning areas are thought to be the result of 2 factors: individual fidelity over several years and population distribution in any particular year. Regarding fidelity, Reynolds (1978) observed 8 of 13 bears denning within $5 \mathrm{~km}$ of their previous year's site and Valkenburg (1986) found 10 of 23 individuals within $.5 \mathrm{~km}$. In Banff National Park, Canada, 1 female denned within a 4.3 $\mathrm{km}$ diameter circle for 4 years (Hamer and Herrero 1983a).
As for the effect of distribution, Valkenburg (1986) determined that as many as $57 \%$ of the active dens near Mt. McKinley were clumped in the same area, and at Terror Lake, Alaska. Smith and Van Daele (1984) observed bears denning at a density of 2 bears $/ \mathrm{sq} \mathrm{km}$.

In light of these preferences for particular areas, biologists have investigated the frequency of den reuse. Although several instances of den reuse have been documented (Craighead and Craighead 1969, Harding 1976, Servheen 1981, Miller 1984, Schoen and Beir 1985, Aune et al. 1986, Judd et al. in press), it is uncommon even when dens have remained structurally sound (Hamer et al. 1977, Servheen and Lee 1979b, Servheen 1981, Schoen and Beir 1986).

\section{APPROACHES TO HABITAT CLASSIFICATION AND MAPPING}

Several approaches have been used for the classification, evaluation and mapping of grizzly bear habitat depending on the specific research or management objectives. Theoretically, habitat classification serves to provide a stratification of a large or diverse area into smaller meaningful, yet repeatable, classes that are of value to grizzly bears and manageable by the researcher.

Classification methods used to describe grizzly bear habitat generally fall into 1 of 2 types: formal classifications that are built from precise field and analysis methods, and informal classifications that tend to subjectively stratify habitat units on the basis of apparent dominant vegetation, vegetation structure or suspected patterns of bear use. Informal techniques are less precise than formal methods, but often fulfill the classification objectives.

Habitat classifications for grizzly bear management may also be hierarchical or nonhierarchical. Hierarchical systems evaluate and then arrange or rank habitat classes in a logical or meaningful order, such as food quality. No order is assumed in nonhierarchical classifications and each unit is assumed to be of equal value to the bear.

\section{Formal Classifications}

Several researchers have attempted to formally classify grizzly bear habitat using climax vegetation classes. Banner et al. (1986) refined an existing broad climax-based biogeoclimatic system into forest ecosystem associations and seral variations. This classification for coastal British Columbia was then used to describe grizzly bear habitat use patterns for the area (Hamilton and Archibald 1986). Habitat use investigations based on the climax vegetation system of Pfister et al. (1977) have been employed in the United States (Kasworm 1985, Aune et al. 1986). Habitat inventories and evaluations incorporating, in part, the "habitat types" of Pfister et al. (1977) have been conducted by Craighead et al.(1982). Zager et al. (1983), Tiermenstein (1983) and Mace (1986).

Formal habitat classification that describe climax, disclimax, topo-edaphic climax and seral classes have been developed for numerous areas. Atwell et al. (1980) used an 


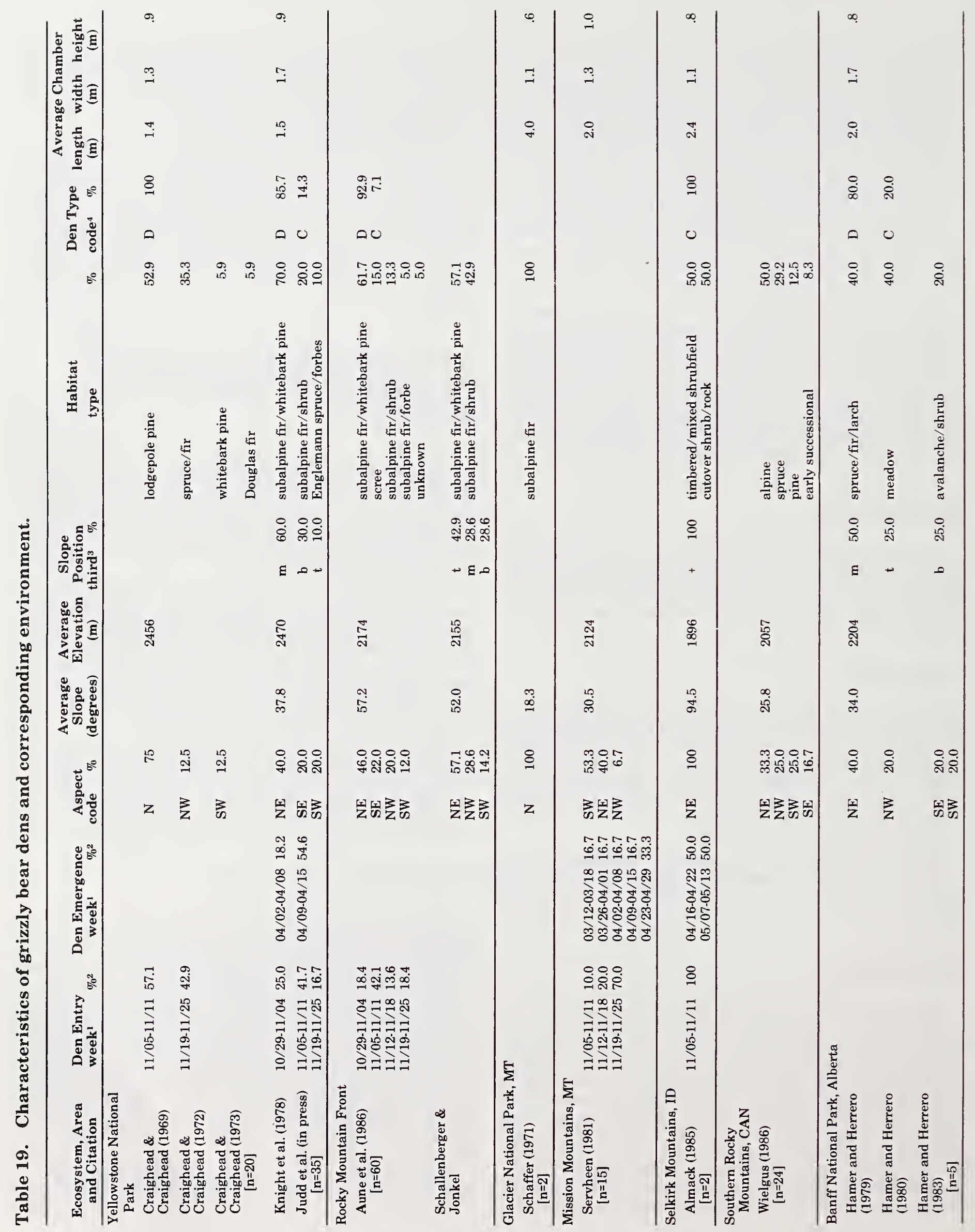




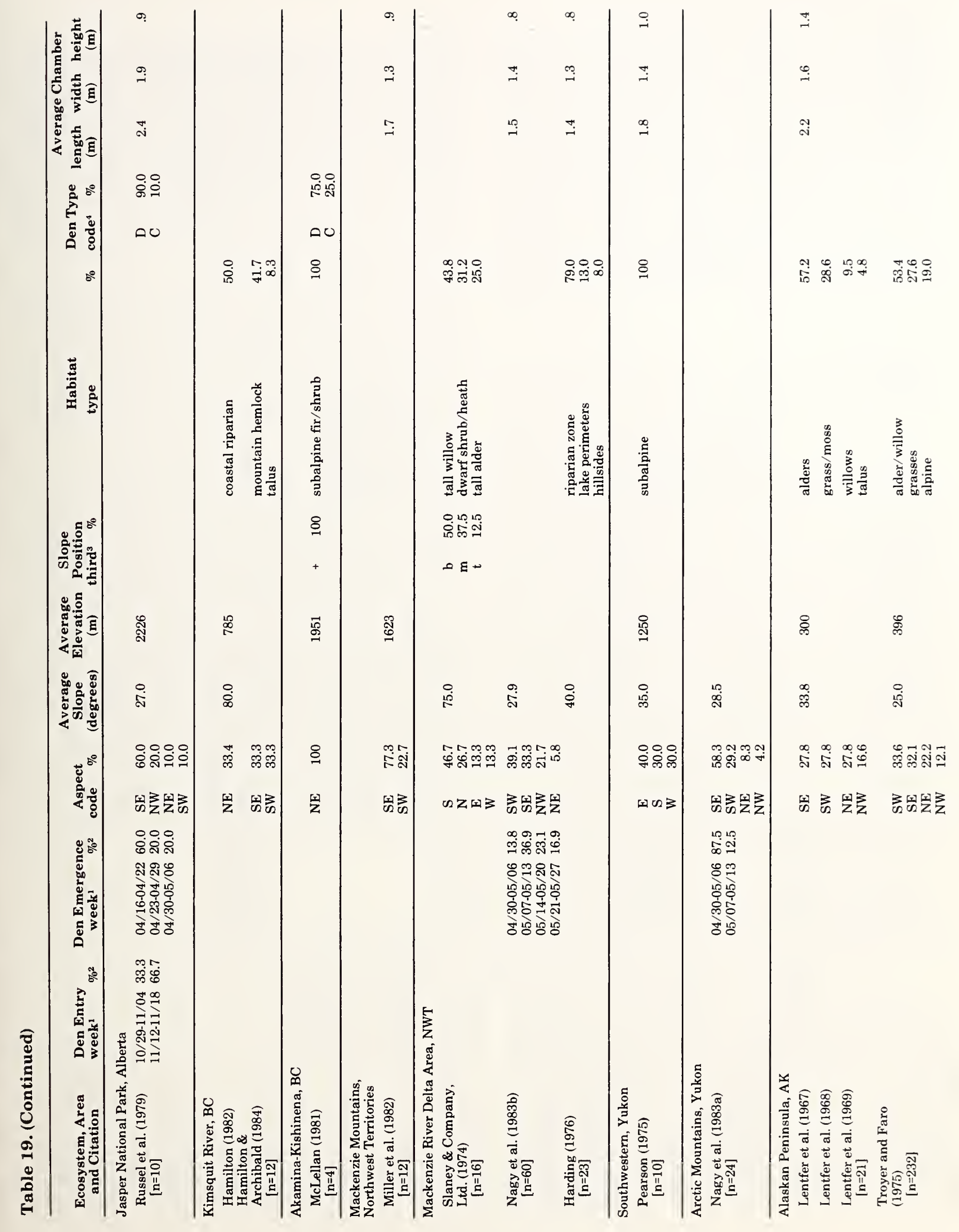




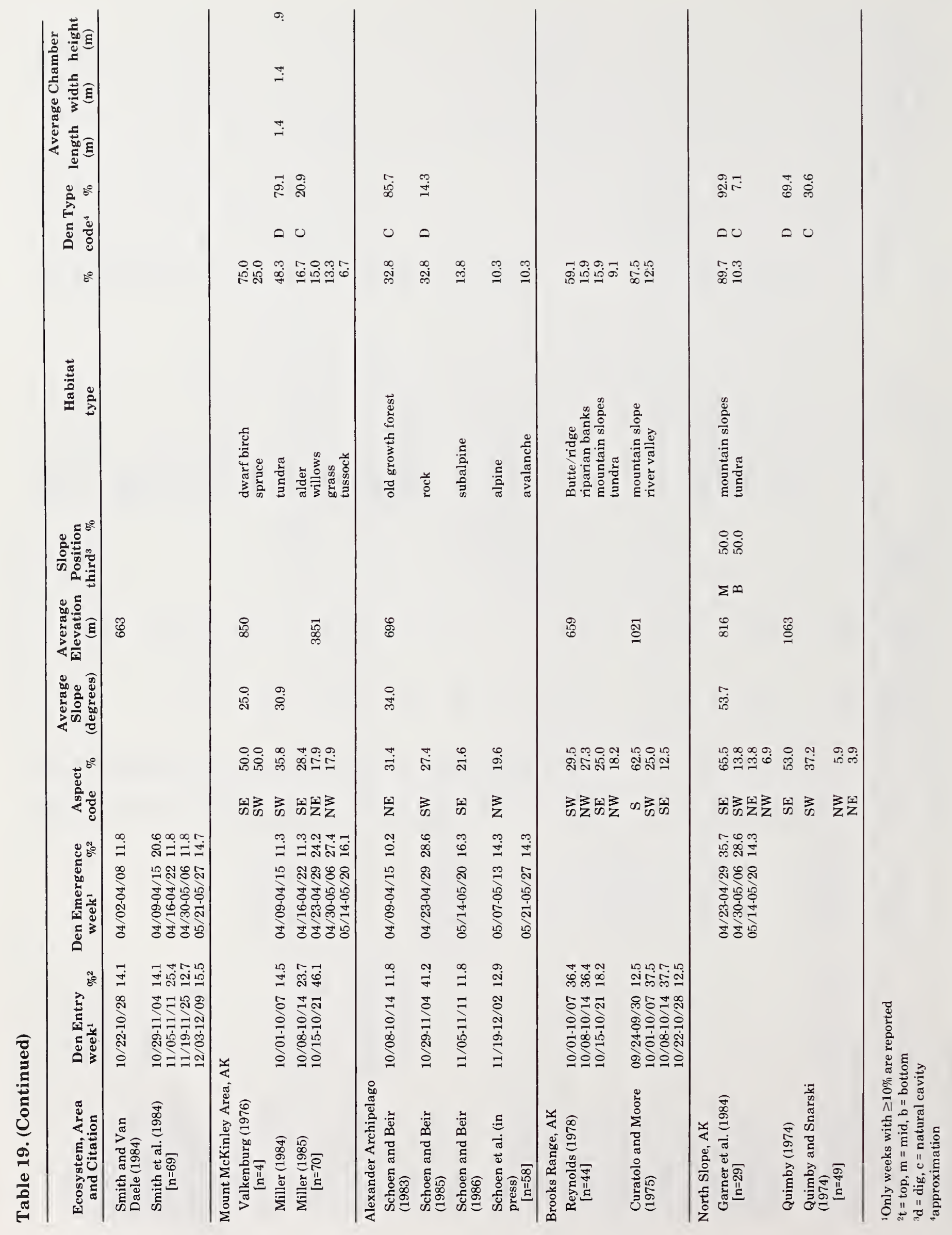


existing alpine vegetation classification for Kodiak Island. Alpine was grouped into communities based on species composition, structure and micro-habitat, and as such included seral to climax classes. Hamer and Herrero (1983b) provided information on bear use and habitat quality based on a precise classification of vegetation types, vegetation groups and special features. Mace (1986) developed a hierarchical classification of vegetation types present within habitat components for the Bob Marshall Wilderness, Montana. Vegetation types were based on the existing composition of the vegetation and were recorded as variable stages within the successional continuum.

Craighead et al. (1982) described "Ecological Land Units" for the Scapegoat Wilderness Area, Montana. The distinctive plant communities of repetitive land features and patterns in 3 elevation zones served as the framework for this hierarchical classification. A similar vegetation system was used by Scaggs (1979) and Butterfield and Almack (1985) in the Selway-Bitterroot Wilderness. Craighead et al. (1982) also established the foundation for remote sensing grizzly habitat using LANDSAT-1 multispectral imagery and computer analysis.

Knight et al. (1984b) used pre-established cover type maps in conjunction with vegetation data from random bear-use sites in the Yellowstone National Park area. These methods provided habitat use information for seral to climax classes. Knight et al. (1984b) also developed a prediction model of habitat quality using regression analysis. Important variables in this model were positively selected cover types, radio-telemetry densities per cover type and an index of mortality potential.

A 5-level classification system (Viereck 1982) was used by Stelmock (1981) and Darling (in press) to assess habitat use in Denali National Park, Alaska. Level 1 in this system is a general ordering (e.g., forest) and level 5 specifically denotes the dominant overstory and understory species.

Wielgus (1986) used Forest Service forest inventory maps to assess habitat use in the southern Rocky Mountains of Canada. Variables chosen for this discriminant analysis included forest cover type, percent canopy closure, stand age, mean stand height, elevation, aspect and slope. This classification system provided habitat use results that would be directly applicable to timber management.

\section{Informal Classification}

Informal habitat classification systems, less precise than previously discussed formal methods have been commonly used. Mundy (1963), for example, stratified bear observations from Glacier National Park, British Columbia into 1 of 3 units: forest, alpine or avalanche chutes. Curatolo and Moore (1975) classified observations as occurring in either river valleys or mountains. To assess the importance of timbered areas to grizzly bears, McLellan (1986) simply classified telemetry data by occurrence in either forested or nonforested areas. These 3 examples show that informal habitat classifications are adequate for certain management or research objectives.

Mealey et al. (1977) first presented the concept of delineating grizzly bear habitat components for north western Montana. Mace (1984) defined a habitat component as "a combination of vegetation types of a distinctive successional stage exhibiting a unique physiognomy." Habitat research by the Border Grizzly Project was tailored to the identification and evaluation of habitat components that would enhance land management decisions. The U.S. Forest Service has endorsed this component method for use in general management decisions and for cumulative effects analyses. However, because the system is informal, the implementation and mapping of components has caused much confusion when attempting to extrapolate or expand component definitions to areas with no valid habitat use information. Most components mapped to date have consisted of various types of forest openings such as meadows or shrubfields. Attempts to classify forested habitats have been hampered by the inability to photographically intrepret the understory composition of forested areas (Leach 1986).

\section{GRIZZLY BEAR ECOSYSTEMS}

\section{Yellowstone Ecosystem}

The Greater Yellowstone Ecosystem (GYE) includes Yellowstone National Park and the surrounding areas used by grizzly bears. The GYE is a large, high elevation basin surrounded by mountain ranges where elevation varies from $1620 \mathrm{~m}$ to $4197 \mathrm{~m}$ (Knight et al. 1984b). The area is widely underlain by sedimentary strata and has a history of volcanic, glacial and geothermal activity. The mountainous terrain results in relatively xeric conditions occurring in several rain shadows.

Most of the GYE is in the subalpine zone (Knight et al. 1984 b, Mattson et al. in press ab). A closed canopy forest constitutes approximately $75 \%$ of the area, with Pinus contorta the most prominent conifer. Picea engelmannii is the indicated major climax species in the subalpine zone with Pseudotsuga menziesii at lower elevations. Higher elevation forested areas are typified by Pinus albicaulis and Abies lasiocarpa. Large contiguous nonforested areas occur below $2125 \mathrm{~m}$ (Mattson et al. in press) characterized by Festuca idahoensis, Artemisia tridentata and Agropyron spicatum. Nonforested rock and tundra dominate the higher elevations with Deschampsia cespitosa and Carex spp. composing significant portions of the cover (Knight et al. 1984b).

Natural fire has greatly influenced the vegetation dynamics in the GYE and forest characteristics typical of fire surpression activities are in evidence today. Large populations of elk (Cervus elaphus), bison (Bison bison), mule deer (Odocoileus hemionus) and moose (Alces alces) occur within Yellowstone National Park.

Knight et al. (1984b) have published an intensive analysis of grizzly bear diet and habitat availability/use in the GYE. Digitized cover type maps, relocations of instrumented bears and analysis of feeding sites were integrated to assess grizzly bear-habitat relationships. The GYE data base was too large to analyze as a whole, thus the data were stratified into 10 smaller analysis areas. Knight et al. (1984b also presented information on grizzly bear diet, diet diversity, feeding behavior and plant succession as related to bear use of cover types, cover type diversity and habitat use. These aspects of grizzly bear ecology in the GYE are summarized below. 


\section{General Trends in Cover Type Use}

Twenty-three existing cover types were identified for the GYE, representing successional stages of apparent climax communities, nonforested types and krumholtz. The 23 cover types were distributed naturally among the 10 analysis areas. Grizzly bear use of cover types was not random. In all but 1 analysis area, cover type differed significantly from expected random occurrence, and substantial differences among analysis areas was evident (Table 20).

Bears generally preferred nonforested (NF) areas primarily during the summer. Low elevation Douglas-fir $(P$. menziesii) and $P$. menziesii/NF sites were markedly perferred in spring. Higher elevation whitebark pine (P. albicaulis) and $P$. albicoulis/NF sites were preferred during fall and to a lesser extent during summer. Grizzly bear use of the lodgepole pine ( $P$. contorta) types was ambiguous, with climax $P$. wntorta generally avoided except in 1 analysis area. Use of the spruce (Picea spp.)/Douglas fir type was typically neutral or perferred in some areas.

\section{Use of Successional Stages}

Grizzly bear use of successional stages varied by analysis area depending on the availability of the stage. Differences in use were most pronounced in low-elevation $P$. menziesii and high elevation $P$. albicaulis sucessional stages where preference towards late successional, or climax types, was apparent. Ambivalence for early successional WP cover types occurred because pine nuts (a major food) are not produced until the tree is at least 100 years old. Bear use of older $P$. menziesii types was tied to the distribution of elk, another food item of the grizzly bear. In the absence of $P$. menziesii types, over-mature $P$. contorta was used during spring. Late successional or climax lodgepole types were often associated with wet to moist conditions and contained succulent plants perferred by grizzly bears in the GYE. Therefore, late successional or climax cover types were more critical than early successional stages (Knight et al. 1984b).

\section{Diversity and Edge Density}

Grizzly bears in the GYE did not select cover type diversity during any season or in any analysis area. Bears did not maximize their use of diverse cover types during spring or fall. Lingering snow-pack in the spring and very directed foraging behavior in the fall were factors responsible for this lack of selection of cover-type diversity. During summer, diversity of types used by bears approximated random expectation. Bears generally favored areas with relatively high edge density, most notably forest-nonforest ecotones. Similar conclusions were reached in other GYE studies (Graham 1978, Blanchard 1983, Brannon 1984).

\section{Seasonal Habitat use and Food Habits}

\section{Spring}

Grizzly bear habitat use patterns during spring, although variable by geographic area, correlated with availability of ungulates, characteristics of ungulate

Table 20. Seasonal use and availability of 23 cover types in the Yellowstone ecosystem from 9 analysis areas (from Knight et al. 1984) expressed as percent used.

\begin{tabular}{|c|c|c|c|c|c|c|c|c|c|}
\hline \multirow[b]{3}{*}{ Cover Type } & \multicolumn{9}{|c|}{ Seasonal Useb } \\
\hline & \multicolumn{3}{|c|}{ Spring } & \multicolumn{3}{|c|}{ Summer } & \multicolumn{3}{|c|}{ Fall } \\
\hline & + & - & $\mathbf{0}$ & + & - & $\mathbf{0}$ & + & - & 0 \\
\hline Nonforested (NF) & 44 & & 56 & 44 & & 56 & 22 & 11 & 67 \\
\hline Aspen (ASP) & 11 & & 89 & 11 & 11 & 78 & 11 & 22 & 67 \\
\hline Douglas Fir pole stand (DF1) & & & 100 & & 11 & 89 & & 11 & 89 \\
\hline Late successional Doug. Fir/NF & 33 & & 67 & 11 & 11 & 78 & & 22 & 78 \\
\hline Late successional Doug. Fir (DF) & 44 & & 56 & 22 & 11 & 67 & & 11 & 89 \\
\hline Lodgepole pine (seed-sapling) (LP) & & 11 & 89 & & 11 & 89 & & 22 & 78 \\
\hline Lodgepole pine (pole stage) (LP1) & 11 & 33 & 56 & 11 & 44 & $44^{\mathrm{a}}$ & & 22 & 78 \\
\hline $\mathrm{LP} 1 / \mathrm{NF}$ & & 11 & 89 & & & 100 & & 11 & 89 \\
\hline Mature lodgepole pine (LP2) & 11 & 11 & 78 & 11 & 22 & $56^{\mathrm{a}}$ & 11 & 56 & 33 \\
\hline $\mathrm{LP} 2 / \mathrm{NF}$ & & & 100 & 11 & & 89 & & & 100 \\
\hline Late successional lodgepole pine (LP) & 22 & 33 & $44^{\mathrm{a}}$ & 11 & 44 & $44^{\mathrm{a}}$ & 11 & 33 & 56 \\
\hline Old lodgepole passing to spruce (LP3) & 33 & 33 & $33^{\mathrm{a}}$ & 11 & 56 & 33 & 11 & 44 & $44^{\mathrm{a}}$ \\
\hline $\mathrm{LP} 3 / \mathrm{NF}$ & & & 100 & & 22 & 78 & & 11 & 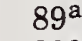 \\
\hline $\mathrm{LP} 1 / \mathrm{LP}$ & 11 & & 89 & 22 & & 78 & 11 & & $89^{\mathrm{a}}$ \\
\hline LP1/LP2 & & & 100 & 11 & & 89 & & & 100 \\
\hline LP2/LP & 11 & & 89 & 11 & 11 & 78 & 11 & & $89^{\mathrm{a}}$ \\
\hline LP2/LP3 & & 11 & 89 & & 11 & 89 & & 11 & $89^{\mathrm{a}}$ \\
\hline Climax spruce and subalpine fir (SF) & & 11 & 89 & & 22 & 78 & 11 & & $89^{\mathrm{a}}$ \\
\hline $\mathrm{SF} / \mathrm{NF}$ & & 11 & 89 & & 22 & 78 & 11 & & $89^{\mathrm{a}}$ \\
\hline Early successional whitebark pine (WB1) & & 11 & 89 & 11 & 11 & 78 & 11 & & $89^{\mathrm{a}}$ \\
\hline Whitebark pine (WB) & & 44 & 56 & 44 & 22 & $33^{a}$ & 67 & & 33 \\
\hline $\mathrm{WB} / \mathrm{NF}$ & 22 & 22 & 56 & 33 & 11 & 56 & 67 & & 33 \\
\hline Krumholtz (KH) & & & 100 & & & 100 & 11 & & 89 \\
\hline
\end{tabular}

a Data insufficient for 1 analysis area.

$\mathrm{b}_{+}=$use significantly greater than available, $-=$use less than available, $0=$ not used. 
winter/spring range and overall distribution and availability of cover types (Knight et al. 1984b). Areas in which ungulate concentrations occurred appeared to support most of Yellowstone National Park's grizzly population. Bears preferred forest cover on, or adjacent to, relatively open winter range sites, usually $P$. menziesii, Populus tremuloides or climax $P$. contorta stands. The tendency of grizzly bears to move carcasses to cover (Schleyer 1983) may be a factor in this observed pattern. Several large valleys and geothermally active areas attracted large numbers of elk and bison which greatly influenced habitat use and food habits of a segment of the bear population. In some areas of the Park, elk bands were smaller and occupied smaller pockets of habitat. Use of elk in these areas was less, relative to large concentration areas, and bears subsidized their diet with other items, principally Trifolium spp., Equisetum spp., and rodents. In all locations, however, interspersion, proximity of cover and ungulate restriction to specific sites characterized particularly suitable spring habitat.

Eleven diet items were of particular value to grizzly bears in the spring (Knight et al. 1984b, Mattson et al. 1986). Ungulates, rodents, and ants were animal diet items. The nuts of $P$. albicaulis were selected by some individuals. Grasses and Trifolium spp. foraging occurred in the nonforested and the $P$. contorta cover types. Aspen and climax Picea spp.-A. lasiocarpa types were important feeding sites for Equisetum.

\section{Summer}

Geographical differences in grizzly bear habitat selection in the GYE during summer were explained primarily by the distribution of either specific vegetal items or spawning cutthroat trout (Salmo clarki). Trout spawning in tributaries to the south and west of Yellowstone Lake appeared to draw bears from surrounding locales. The consumption of trout provided bears with a high-protein summer diet relative to other places in the GYE. Streams fished by grizzly bears were also close to nonforested cover types and provided other vegetal foods (Knight et al. 1984b).

Nonforested areas and successional $P$. contorta stages were important to bears in the plateau area of the GYE during summer. The foliage of Taraxacum spp., Circium scariosum, Trifolium spp. and the roots of Perideridia gairdneri and Lomatium spp. were major diet items. Opportunity for summer use of ungulate meat was also high in several locales and grizzly selection of cover types reflected ungulate summer range. Preferential use of $P$. albicaulis cover types during summer was also evident for those bears securing pine nuts or digging Lomatium spp. The fruits of Vaccinium scoparium and $V$. globulare were consumed primarily in the Picea spp.-A. lasiocarpa types. High elevation rock or tundra areas were not favored by bears in the GYE during summer months.

\section{Fall}

Fall cover type use in most of the GYE was explained by directed foraging on $P$. albicaulis nuts. These nuts were available generally from late August through October and were obtained from red squirrel caches within the $P$. albiculis cover types (Kendall 1981, Knight et al. 1984b). Where pine nuts were not available such as in the Gallatin Range, continued use of ungulates in lower elevation $P$. contorta and Populus tremuloides types was noted.

\section{Northern Continental Divide Ecosystem}

Telemetry studies have been conducted in 4 major areas within the Northern Continental Divide Ecosystem (NCDE). Statistical analyses of habitat availability and use have been reported for the South Fork (Zager et al. 1983), the Mission Mountains (Servheen 1981), and the Rocky Mountain East Front (Aune et al. 1986.) Vegetative habitat descriptions and measurements of habitat quality were assessed in the Scapegoat Wilderness (Craighead et al. 1982), the Bob Marshall Wilderness (Mace 1986, Mace and Bissell 1986), and the Rattlesnake Wilderness (Tirmenstein 1983). LANDSAT investigations in Glacier National Park were discussed by Martinka and Kendall (1986). Mealey et al. (1977) conducted a habitat survey at selected sites throughout the NCDE. Hadden et al. (1986) described a habitat classification method developed in the North Fork.

The North Fork and South Fork of the Flathead River and the Mission Mountains are situated west of the Continental Divide in western Montana. The East Front area straddles the Divide and includes the transition zone between the Rocky Mountain Cordillera and the Great Plains. Descriptions of these areas were given by Jonkel and Cowan (1971), Schallenberger (1977), Servheen (1981), and Mace and Jonkel (in press). Pfister et al. (1977) described the forested habitat types of western Montana. The rugged mountain terrain and complex climate of western Montana create an array of habitats and associated vegetation.

The North Fork, South Fork and Mission Mountains are distinctly influenced by maritime air masses moving east from the Pacific Ocean. Upon reaching the Continental Divide, much of the moisture in these air masses has been depleted. Continental climate, dramatic temperature fluctuations and severe chinook winds influence vegetation in the East Front (Daubenmire 1969). Here, where the Great Plains meet the Rocky Mountains, extensive stands of limber pine (Pinus flexilis) are interspersed with aspen groves (Populus tremuloides) and grasslands.

Human land use patterns affect the available grizzly bear habitat in the 4 study areas. In the North and South Fork areas, timber harvesting has created a diversity of stand ages. The bench lands adjacent to the North Fork contain seasonal and permanent homes, while much of the lower South Fork has been flooded for hydroelectric power (Hungry Horse Reservoir). Livestock ranching is the major land use practice along the East Front. Livestock are grazed less commonly in the Mission Valley, but other agricultural uses of this fertile valley have altered the natural vegetation and patterns of grizzly bear habitat use (Servheen 1981).

\section{South Fork Flathead River}

Zager et al. (1983) stratified the South Fork study area into 12 habitat components (Table 21). Although all components were used annually, several components were preferred while others were avoided. During the spring (den emergence to $31 \mathrm{July}$ ), snowchutes and ridgetops were significantly preferred by 4 monitored bears and timber and cutting units were avoided (Zager et al. 1983). The creekbottom component was preferred but not significantly. Mace and Jonkel (1980) suggested that ridgetop components were used primarily as travel corridors. During spring, the 
leaves and stems of Umbelliferae were eaten most frequently and in the greatest quantity, of which Heracleum lanatum and Osmorhiza spp. were most important. Monocots and Equisetum spp. were the second and third ranking foods at this time (Mace and Jonkel 1980). Snowchutes were by far the best producers of major forb food plants (Zager 1980). Mace and Jonkel (1980) reported that several bears dug the underground parts of Erythronium grandiflorum and Lomatium spp. in the snowchute and slabrock components at this time. Although not identified in South Fork scat samples, the cambium layer of several conifer species was also consumed in the spring (Bumgarner et al. 1980).
During the summer/fall season grizzly bears preferred shrubfields, burn shrubfields, slabrock, creekbottoms and ridgetops (Zager et al. 1983), snowshutes, timber and cutting units were avoided. The fruits of 8 plants were consumed during this season, of which Vaccinium globulare was predominant in scat samples (Mace and Jonkel 1980). Amelanchier alnifolia and Sorbus spp. were other important fruits. Zager et al. (1983) stressed the importance of wildfire created habitats to South Fork grizzly bears during the summer/fall season.

Table 21. Grizzly bear habitat use and availability, Northern Continental Divide Ecosystem.

\begin{tabular}{|c|c|c|c|c|}
\hline \multirow[b]{2}{*}{ Area/Habitat Component } & \multicolumn{4}{|c|}{ Seasonal Use ${ }^{\text {abc }}$} \\
\hline & Summer & $\begin{array}{c}\text { Summer/ } \\
\text { Fall }\end{array}$ & Fall & Annual \\
\hline
\end{tabular}

Mission Mountains (Servheen 1981):

Snowchute/sidehill park

Snowchute/shrubfield

Sidehill park

Shrubfield

Timber sidehill park

Wet meadow

Slabrock alpine

Slabrock (mid or low elevation)

Talus/scree/rock

Riparian zone

Riparian zone/cutting unit

Road

Cutting unit

Timbered shrubfield

Timber

Marsh

Agricultural lands

Seep areas

East Front (Aune et al. 1986):

Cutting units

Meadows

Roads

Sidehill park

Mountain grassland

Prairie grassland

Rock/talus/scree/rubble

Pinus flexilis savanna

Shrubfield

Snowchute

Populus spp. stands

Riparian shrub

Riparian complex

Closed timber

Open timber

Unclassified

Burns (all ages)

$\begin{array}{cc}\mathbf{x} & 0 \\ \mathbf{x} & 0 \\ 0 & 0 \\ 0 & 0 \\ 0 & 0 \\ 0 & \mathbf{x} \\ \mathbf{x} & + \\ \mathbf{x} & 0 \\ 0 & 0 \\ + & 0 \\ \mathbf{x} & 0 \\ 0 & \mathrm{x} \\ 0 & 0 \\ 0 & - \\ 0 & - \\ \mathbf{x} & \mathrm{x} \\ - & - \\ + & +\end{array}$

$\mathrm{x}$
$\mathrm{x}$
0
0
0
+
+
0
0
+
$\mathrm{x}$
0
0
-
-
$\mathrm{X}$
$\mathrm{X}$


Table 21. Continued.

\begin{tabular}{|c|c|c|c|c|c|}
\hline \multirow[b]{2}{*}{ Area/Habitat Component } & \multicolumn{5}{|c|}{ Seasonal Use ${ }^{a b c}$} \\
\hline & Spring & Summer & $\begin{array}{c}\text { Summer/ } \\
\text { Fall }\end{array}$ & Fall & Annual \\
\hline \multicolumn{6}{|l|}{ Habitat Series: } \\
\hline $\begin{array}{l}\text { Pinus flexilis } \\
\text { Pseudotsuga menziesii } \\
\text { Picea spp. } \\
\text { Abies lasiocarpa (lower elevation) } \\
\text { Abies lasiocarpa (upper-timberline) } \\
\text { Pinus contorta } \\
\text { Other }\end{array}$ & $\begin{array}{l}- \\
+ \\
0 \\
- \\
+ \\
0 \\
0\end{array}$ & $\begin{array}{l}- \\
+ \\
0 \\
- \\
0 \\
0 \\
+\end{array}$ & & $\begin{array}{l}- \\
- \\
- \\
0 \\
+ \\
- \\
-\end{array}$ & $\begin{array}{l}- \\
+ \\
0 \\
- \\
+ \\
- \\
0\end{array}$ \\
\hline \multicolumn{6}{|l|}{ South Fork Flathead River (Zager 1980): } \\
\hline $\begin{array}{l}\text { Snowchute } \\
\text { Sidehill park } \\
\text { Shrubfield } \\
\text { Meadow } \\
\text { Slabrock } \\
\text { Talus/scree } \\
\text { Creek bottom } \\
\text { Road } \\
\text { Cutting unit } \\
\text { Timber } \\
\text { Ridgetop } \\
\end{array}$ & $\begin{array}{l}+ \\
0 \\
0 \\
0 \\
0 \\
x \\
0 \\
x \\
0 \\
- \\
+\end{array}$ & & $\begin{array}{l}- \\
0 \\
0 \\
0 \\
+ \\
0 \\
+ \\
0 \\
0 \\
- \\
+\end{array}$ & & \\
\hline
\end{tabular}

aSignificance levels differ among areas.

bSeasonal dates differ among areas.

$c_{+}=$significantly used more than available, $-=$significantly used less than available, $o=$ use not significantly different than available, $\mathrm{x}=$ not used.

\section{Mission Mountains}

Servheen (1983) described 19 habitat components (Table 21 ) in the Mission Mountains of Montana and conducted habitat availability and use analyses from radioinstrumented grizzly bears. Relatively low-elevation riparian zones and seeps were used more than expected during spring (15 April-15 June). Of the 19 components, only agricultural lands were used less than expected in the spring, although limited nocturnal telemetry data showed that such areas were traversed. Food productivity ratings per component showed that seep areas near the valley floor provided the greatest diversity of foods throughout the year. These perennially moist areas, characterized by Picea spp., Lysichitum americanum and Athyrium felixfemina represented $2 \%$ of the study area (Servheen 1981). Perennial graminoids, Taraxacum spp., and Trifolium spp. were primary spring foods. Livestock carrion, birds, beaver (Castor canadensis) and insects from rotten logs were other spring foods.

Seeps and alpine slabrock were used more than expected during the summer (16 June-30 August) with $24 \%$ of the summer telemetry locations in low-elevation seeps (Servheen 1983). Agricultural lands, timber and timbered shrubfields were used less than expected during summer. Heracleum lanatum and other Apiaceae were consumed during the late spring and early summer period. As snowpack decreased at higher elevations, avalanche chutes and sidehill parks became important foraging sites for the underground parts of Hedysarum spp., Lomatium spp. and
Erythronium grandiflorum. Equisetum spp. was also consumed during the summer until the fruits of Vaccinium spp., Amelanchier alnifolia, Shepherdia canadensis and Crataegus spp. rippened. Army cut-worm moths (Chorizagrotis auxiliaris) were excavated from alpine talus slopes.

Autumn (1 September-den entry) habitat components important to Mission Mountain grizzly bears were riparian zones, wet meadows, seeps at low elevations and alpine slabrock. Domestic fruit orchards were also im portant during autumn. Domestic apples, plums and pears were the major autumn food resources (Servheen 1983).

\section{East Front}

Aune et al. (1986) reported on habitat availability and use information obtained from over 1000 radio locations collected along the East Front from 1977-1983. Grizzly bear seasonal use by elevation, aspect and slope was also reported. Several classification schemes were used to describe habitat use: forested habitat types (Pfister et al. 1977), grassland habitat types (Mueggler and Handl 1974), land types, photographic interpretive types (P-I) and habitat components. Grizzly bear seasonal habitat as described by these habitat types and components are briefly described below.

Following den emergence, bears used relatively low elevation habitats although much individual variation was noted (Aune et al. 1984, Aune et al. 1986). Three major taxonomic groups comprised important spring (AprilJune) foods: monocots, forbs and mammals. Important 
monocot genera during spring were Poa and Carex spp. while important forbs included Angelica spp., Lathyrus spp., and Taraxacum spp. Domestic livestock carrion provided the largest source of protein. Equisetum $\mathrm{spp}$. was also eaten during spring.

Grizzly bear use of the Populus spp. and riparian shrub components was significantly greater than random availability during spring (Table 21). P. tremuloides and $P$. trichocarpa stands were an important spring component and relatively mesic stands were used more extensively than those with relatively dry understories. Major spring grizzly bear activities in this component included grazing, carcass or carrion feeding and bedding (Aune et al. 1984). The riparian shrub component was often closely associated with Populus spp. stands, and included seeps, bogs, fens, glades and marshes. Such sites were often dominated by Salix spp. or Betula spp. with an understory of grasses and sedges. Grazing and bedding were major spring activites in the riparian shrub component.

Most spring bear activities within the closed and open timber components were bedding, traveling and denning. Relatively little grazing activity in closed timber was noted. The rock/talus/rubble/scree habitat component was also used during spring. Primary activities in this component included mating, bedding, traveling and root digging. Common underground food items included Claytonia megarhiza, Allium spp. and some Hedysarum alpinum. The prairie grassland habitat component was most extensively used in spring (Aune et al. 1984). The most common activity in prairie grasslands was traveling to preferred habitats although grazing and small mammal digging also occurred.

The summer diet of the grizzly bear in the East Front was more diverse than other seasons (Aune et al. 1984). Berries, graminoids, forbs, mammals and insects were major food categories at this time. Berry producing shrubs used by bears included Arctostaphylos uva-ursi, Ribes spp., Amelanchier alnifolia, Shepherdia argentia and S. canadensis, Cornus stolonifera and Prunus virginiana. Domestic oats (Avena sativa) were used heavily on occasion. Umbelliferae species were also important. The roots of Lomatium cous and corms of Claytonia megarrhiza were dug at higher elevations.

Five habitat components were major use areas during summer. The rock/talus/scree/rubble component was used for digging roots and small mammals. Timbered components (open and closed canopy) were selected by bears for feeding on berries and bedding (Aune et al. 1984). The Abies lasiocarpa habitat type series received $55 \%$ use during summer (Aune et al. 1984). The timber/burn component was also an important berry producing habitat. Populus spp. stands and riparian shrub components were important for general grazing, bedding and berry-feeding and were the only 2 components where use significantly exceeded availability (Aune et al. 1986).

Berries, the nuts of Pinus albicaulis and mammals were primary fall grizzly bear foods along the East Front. Once again bear use of Populus spp. stands and the riparian shrub component exceeded availibility. Use of open and closed timber components during fall also significantly exceeded availability (Aune et al. 1986). Typical activities in timbered components included securing pine nuts $(P$. albicaulis), bedding and denning. The Abies lasiocarpa-P.
albicaulis-Vaccinium scoparium habitat type was especially important. Use of open timbered areas at all elevations correlated with directed foraging on Shepherdia canadensis, Vaccinium spp., Prunus virginiana and Amelanchier alnifolia berries.

\section{North Fork}

A synthesis of grizzly bear habitat use and food habits is not available for the North Fork of the Flathead River, however, yearly summaries of habitat use patterns are given by Rockwell et al. (1977) and Mace et al. (1979). Interim results of feeding-site analyses are given by the above authors and by Mealey et al. (1977). The food habits of North Fork grizzly bears was reported by Mace and Jonkel (in press).

The results of 64 radio locations obtained in 1977 suggest that south-facing sidehill parks, avalanche chutes and shrubfields are important during spring and early summer (Rockwell et al. 1977). Primary foods eaten at this time included $H$. lanatum, Angelica spp., Osmorhiza spp., Equisetem spp., and graminoids (Mace and Jonkel 1979, in press). Trapping and direct observation of bear sign suggested the importance of floodplain habitats for grazing, digging for Hedysarum sulpherescens and carrion feeding (Singer 1978). Home range comparisons between the United States portion of the North Fork (Rockwell et al. 1977, Mace et al. 1979) and British Columbia (Jonkel and McLellan 1979) suggested that there are 2 distinct habitat-use strategies in this area: some bears rarely leave floodplain areas throughout the active season, while others restrict their activities to mid-elevational, mountainous, habitats.

Timber, timbered burns, open burns and shrubfields were selected during summer and fall (Rockwell et al. 1977). The $A$. lasiocarpa/Xerophyllum tenax- $V$. globulare habitat type was particularly important. The fruit of $V$. globulare and $S$. canadensis were principal foods.

\section{Cabinet-Yaak Ecosystem}

The Cabinet Mountains were shaped by alpine and continental glaciation, have an elevational gradient of $610 \mathrm{~m}$ to $2664 \mathrm{~m}$, and are under strong influence of Pacific airmasses. Valley bottoms to upper slopes are heavily forested (Kasworm 1985), with stands of Abies grandis and Thuga plicata at lower elevations, with extensive areas of Pinus contorta and Pseudotusga menziesii. Timberline habitats include Larix lyallii-Abies lasiocarpa, Pinus albicaulis type and the A. lasiocarpa series (Mace et al. 1978).

Detailed habitat-use studies of the small grizzly bear population in the Cabinet-Yaak Ecosystem were begun in 1983 (Kasworm 1984, 1985). Prior to this time, limited habitat data were collected and reported for several bears that were reintroduced into this Ecosystem (Mace et al. 1978). Kasworm (1985) provided interim habitat use data, from 105 radio locations, expressed as percent of locations occurring in 12 habitat components (Madel 1982). The Mixed Shrub Snowchute component was used most often during the spring, as was Closed Timber in over $10 \%$ of the samples. Other important spring components included Riparian Streams, open Timber and Graminoid Sidehill Parks (Kasworm 1986). Important habitat types in which these components occurred included Thuga heterphyllaClintonia uniflora and Abies grandis-C. uniflora. 
The Mixed Shrub Snowchute component was again most commonly used during summer, and the Mixed Shrub Burn and Closed Timber Components were also reported to be important. Over $40 \%$ of the summer components were within the Abies lasiocarpa-Xerophyllum tenax habitat type.

Major fall habitat use occurred in the Timbered Shrubfield and Closed Timber components. Fall habitat types used most frequently by bears were $T$. heterphylla-C. uniflora, A. lasiocarpa-Menziesia ferruginea and $A$. lasiocarpa-X. tenax.

Mace et al. (1978) described general habitat-use patterns of 2 reintroduced yearling bears in the Yaak portion of the Cabinet-Yaak Ecosystem. These yearlings spent the last 2 weeks of July in mesic portions of a subalpine basin within the Abies lasiocarpa-Calamagrostis canadensis habitat type. Field analysis of scats from this location showed that while the fruit of Vaccinium globulare was the dominant food, Senecio triangularis, Veratrum viride and Angelia spp. were also grazed upon. From July through August, radio locations indicated that these bears foraged extensively in Vaccinium globulare-Rododendron albiflorum dominated shrubfields. Mesic meadows dominated by sedges were also used (Mace et al. 1978).

\section{Selkirk Ecosystem, Northern Idaho and Washington}

Although grizzly bears occur in the Selkrirk Ecosystem in northern Idaho and Washington, population levels are believed to be low (U.S. Fish and Wildlife Service 1982). Almack (1986) investigated the movements, food habits and habitat use of 1 instrumented adult bear. The following discussion comes from that investigation.

The climate of the study area in northern Idaho is influenced by Pacific maritime weather patterns. Forest stands are dominated by amixture of Pseudotsuga menziesii, Picea engelmannii, Abies grandis, Pinus contorta, A. lasiocarpa, Tsuga heterophylla, Thuga plicata, Larix occidentalis and Pinus monticola. Almack (1986) deliniated 20 habitat components for the area (Table 22) from which availability and use measurements were obtained.

During spring, the instrumented bear fed on Carex spp., Equisetum spp., grasses, and the roots of Claytonia lanceotata, Erythronium grandiflorum, and Lomatium spp. Meadows, marshes and moist cirque basins were primary feeding sites (Table 22).

Vaccinium spp. and Lonicera spp. fruits were the dominant food items during the summer. Liguisticum spp. and Equisetum spp. were other common food items. These food items were secured in mixed shrubfields within a large burn.

Digging was the primary foraging activity in the autumn (Almack 1986). The underground parts of Mitella breweri, Tiarella trifoliata and Lonicera spp. were dug in old clearcuts and selection cuts. The instrumented bear also ate ants and earthworms (Class Oligochaeta). Almack (1986) documented the use of 8 food plants not found in previous food habits literature for North America.

Table 22. Availability and use of 20 habitat components by one instrumented grizzly bear in the Selkirk Ecosystem (Almack 1986).

Seasonal Use ${ }^{a}$

Alnus spp. shrubfield

Mixed shrubfield burn

Mixed shrubfield snowchute

Drainage forbfield

Timbered mixed shrubfield

Forbfield burn

Forbfield cutting unit

Open-timbered grass

Grass sidehill park

Mixed shrubfield

Rock

Marsh

New cutting unit

Riparian streambottom

Mixed shrubfield cutting unit

Vaccinium spp. shrubfield

Wet Meadow

Xerophyllum spp. sidehill park

Dry meadow
Closed timber

\section{Seasonal Use}

$a_{+}=$use significantly greater than available, $o=$ use equal to available, - = use less than available. 


\section{Alaska}

\section{Kodiak Island}

Kodiak Island is located southeast of the Alaska Peninsula in the Gulf of Alaska, and is characterized by fjord-like bays, interior mountainous terrain, cirques and alpine peaks (Atwell et al. 1980). The higest peaks retain snow thoughout the year and several small glaciers are found on the Island. The Island is under the influence of the Japanese Current and temperatures are mild. Fog, rain and drizzle are common maritime weather conditions.

The northeastern portion of Kodiak Island contains extensive stands of Picea sitchensis, not present elsewhere on the Island (Troyer and Hensel 1969, Atwell et al. 1980). River deltas often contain extensive stands of Elymus arenarius on relatively dry sites with adjacent intertidal vegetation dominated by sedges, most notably Carex lyngbyaei (Smith and Van Daele 1984). Atwell et al. (1980) stated that the most characteristic vegetation of the Island, from sea level to approximately $580 \mathrm{~m}$ was a complex of Alnus crispa sinuata and Salix spp. interspersed with lush grass and forb openings. Common herbs include Heracleum lanatum, Veratrum viride, Angelica spp., Lupinus nootkatensis and Equisetum spp. Patches of Rubus spectabilis, Sambucus spp., Echinopanax (Oplopanax) horridus are also present. Stands of Betula papyrifera var. kenaica and Populus balsamifera are common along river courses.

Alpine vegetation is most prominent on high peaks in the northwestern portion of the Island; 7 alpine plant communities have been recognized (Atwell et al. 1980). The Ericaceous Knolls and Hummocks, Alnus spp., and Willow FieldSubalpine Meadow communities were dominant in the area studied by Atwell et al. (1980). Carex macrochaeta, $H$. lanatum, Empetrum nigrum and R. spectabilis were characteristic species in these alpine communities.

The major rivers on the Island are important spawning areas for 5 species of salmon (Oncorhynchus spp.), steelhead (Salmo gairdnerii) and dolly varden trout (Salvelinus malma). The Sitka black-tailed deer (Odocoileus hemionus sitkensis) is the dominant ungulate.

Clark (1957) presented a detailed analysis of seasonal food habits of the Kodiak bear based on stomach and scat content. More recent studies using radio telemetry have indentified specific foraging habitats. Berns and Hensel's (1972) telemetry studies showed that Kodiak Island bears in the Karluk Lake area used lowland, midland and upland habitats. Further telemetry studies in this area by Berns et al. (1980) and Barnes (1985) have more intensively evaluated these 3 elevational categories of habitat. Differential use of habitats by age, sex and reproductive status was reported (Smith et al. 1983, Barnes 1985).

After den emergence in early spring, some bears move to beaches to feed on seaweed and carrion (Clark 1957). Other early foods documented by Clark (1957) included tree conks (Fomes applanatus and F. pinicola), and Boschniakia rossica. Troyer and Hensel (1969) stated that herring eggs (Clupea pallasii) may be locally important in spring as well. Barnes (1985) determined that some bears remained at high elevations, fed rarely and selected areas of high resting and escape cover. Grazing in tidal-flats was also observed in the Terror Lake region by Smith and Van Daele (1984).
As snow receded in May, bears began consuming green vegetation. Clark (1957), Troyer and Hensel (1969), and Smith and Van Daele (1984) stated that low-elevation exposed slopes and beaches were important feeding areas. Tall Shrub (Alnus spp.) and Moist Herbaceous Meadow habitat types were used (Barnes 1985). Specific foods consumed at this time included Calamagrostis canadensis, Hordeum brachyantherum, Elymus arenarius and Angelica lucida. H. lanatum (Clark 1957) and Populus spp. cambium (Troyer and Hensel 1969) were also consumed. Limited use of alpine habitats, where they occurred, was also reported (Atwell et al. 1980). Eide (1965) and Troyer and Hensel (1969) discussed the extent of brown bear predation on domestic cattle on Kodiak Island during spring and autumn.

During summer, numerous bears are attracted to vegetation available in midland and upland habitats (Clark 1957), and individual intensive use of alpine habitats where available. Two alpine communities were recognized by Atwell et al. (1980) as being particularly important: the Carex spp.-Forb Meadow and Willow Field-Subalpine Meadow. Primary alpine foods included Carex macrochaeta, A. lucida, Equisetum arvense and Lupinus nootkatensis.

As spawning salmon became available, most bears abruptly moved to lowland habitats (Clark 1957, Troyer and Hensel 1969, Bernes et al. 1980, Smith and Van Daele 1984, Barnes 1985), however, the duration and intensity of feeding on salmon varied considerably among individuals, and some bears, especially females, ignored salmon (Berns and Hensel 1972, Smith and Van Daele 1984). The impact of brown bear predation on salmon populations has been debated in the literature (e.g., Clark 1959, Gard 1971).

Although fish are are still available in mid-August, bears began eating fruit, primarily Sambucus spp. (Clark 1957, Smith et al. 1984). The fruit of O. horridus, Viburnum edule, $R$. spectabilis and $E$. nigrum were also consumed. Midland shrubfields were primary foraging areas (Berns et al. 1980, Barnes 1984). Autumn food habits are characterized by both alternate and simultaneous use of fish and berries (Troyer and Hensel 1969, Berns and Hensel 1972, Smith and Van Daele 1984).

\section{Interior Alaska}

The primary grizzly bear food habits and habitat use studies in Interior Alaska were conducted in Denali (Mount McKinley) National Park (Valkenburg 1976, Stelmock 1981, Darling in press), located in the central Alaska Range. The predominant vegetation is a gradation of Picea glauca-hardwood forests, to moist and alpine tundra types (Stelmock 1981). The topography is typified by high mountain peaks with broad, glacial river channels. P. glauca generally occurs in isolated patches at lower elevations, valleys and mountain slopes are dominated by dwarfSalix spp. and Betula nana. Rivers and streams are bordered by relatively taller Salix spp. and Alnus crispa shrubs (Darling in press). Other shrubs in the Park include Shepherdia canadensis, Vaccinium uliginosum, V. vitis-idaea, and Empetrum nigrum. Moist sedge-dominated tundra may be found on northern and east-facing slopes, while drier tundra typified by Dryas octapetala, Cassiope tetragona, and Salix reticulata are found on southern slopes and at relatively higher elevations. Ungulates present include Ovis dalli, Rangifer tarandus and Alces alces. 
Stelmock (1981) described grizzly bear habitat use patterns using a 5 level vegetation hierarchical system (Viereck et al. 1982). Bear habitat use was quantified using "bear-unit-hours" per hour of observation in 2 study sites: Toklat River and Sable Pass. Darling's (in press) research was developed to investigate habitat use differences between family units and lone individuals and to quantify the concept of "nursery habitats." Darling (in press) concluded that while some differences in habitat use among cub families, yearling families and single bears was evident, the ability to quantifiy selection was hampered by annual vagaries in habitat productivity.

The roots of $H$. alpinum and the over-wintering fruit of $E$. nigrum were important spring foods in Denali National Park although scat analysis and direct observations showed that use of these 2 items varied locally. These and other spring foods were obtained from mat and cushion tundra, tall and low shrublands and various forest types (Stelmock 1981). The D. octopetela-E. nigrum mat/cushion types were extensively selected for available over-wintered berries while the $S$. alaxensis- $H$. alpinum was typically seclected for roots (Table 18). Bears grazed on Calamagrostis canadensis near roads and along exposed streambanks within the Arctagrostis latifolia-E. arvense type.

During summer, bears confined their foraging activities to very specific vegetation types which provided an abundance of favored foods. To accomplish this, bears constantly shifted to habitats of variable elevation, aspect and moisture levels. Tall shrublands, low shrublands, herbaceous and sedge-grass tundra types were selected during summer. Bears grazed extensively on grasses, sedges, Equisetum spp., and Boykinia richardsonii during this period. These foods were secured near perennial snow accumulations ( $A$. latifolia- $B$. richardsonii type). Additionally, flowers of Oxytropis viscida were eaten when encountered. Arctic ground squirrels were actively dug from their chambers and fruits were consumed as they ripened.

$E$. nigrum and $S$. canadensis berries were the most important fall diet item and were both generally found in the same vegetation types within low shrublands and mat/ cushion tundra (Stelmock 1981). In areas were Shepherdia spp. shrubs were uncommon, Arctic ground squirrels constituted a major fall diet item.

Stelmock (1981) noted that bears often left a particular vegetation type before food resources were depleted and travelled sinuously during all seasons. He attributed this behavior to procuement of animal matter, seasonal changes in food availability and curiosity.

\section{South Central Alaska}

Brown bear studies in south central Alaksa have been conducted in both coastal (Campell 1985) and interior habitats (Miller and McAllister 1982). Interior studies have focused on the effects of the proposed Susitna hydroelectric facility and coastal investigations were designed to assess the impacts of brown bears on waterfowl nesting success. Limited food food habits data are available for this area. Interior habitat selection on an annual basis can be inferred from Table 23. Brown bear predation on moose calves has been investigated by Ballard et al. (1981). In this study, brown bears were responsible for $79 \%$ of the radioinstrumented calf mortality.
Table 23. Number of radio-instrumented brown bear observations in different habitat types in the Susitna Hydroelectric Project study area (from Miller and McAllister 1982).

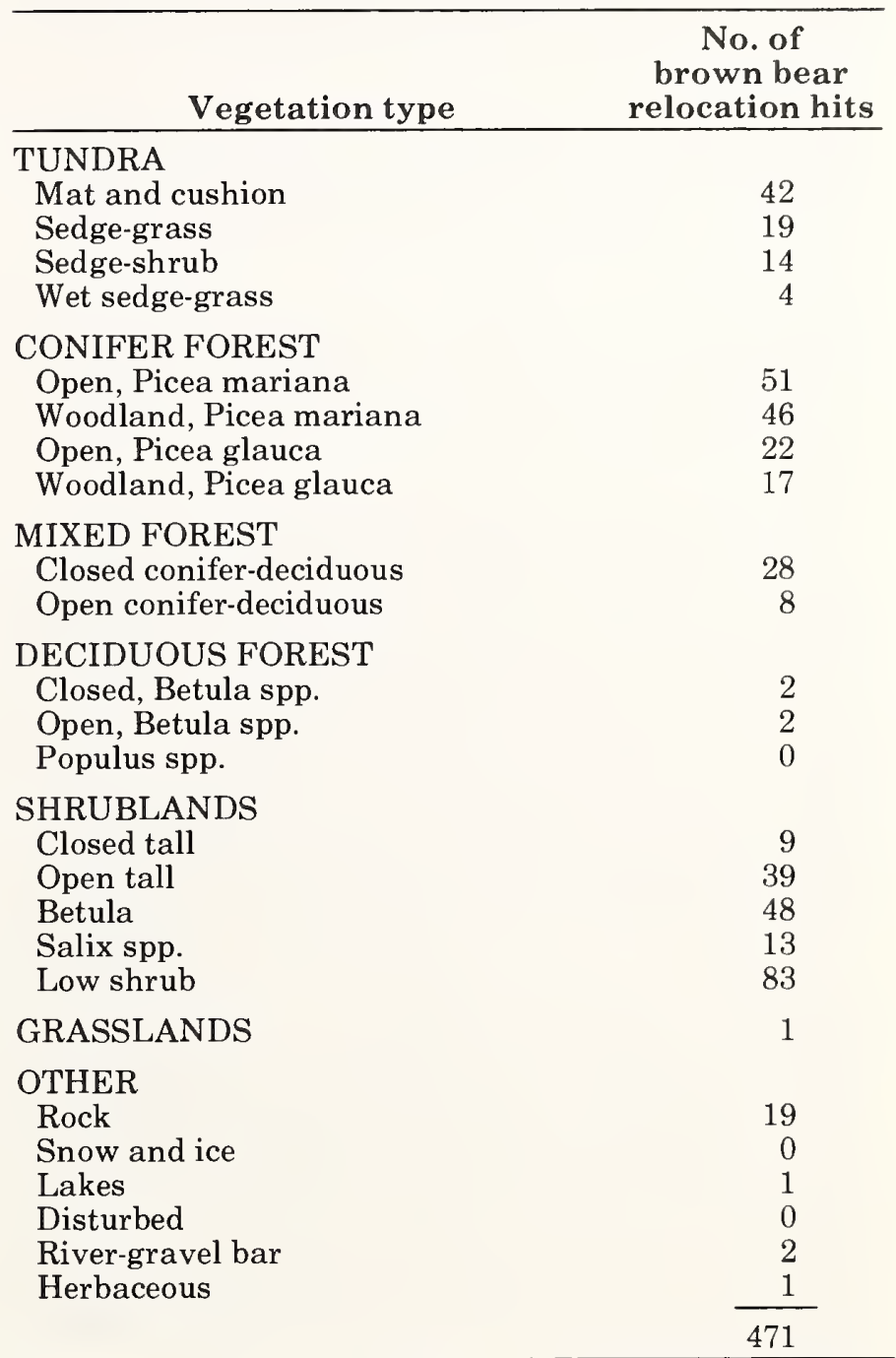

The brown bear investigations in coastal habitats of south central Alaska are on-going, and therefore results presented here are preliminary. Campbell's (1985) study area was situated on the Copper River between the Heney Range and the Chugach Mountains. This area contains approximately $190 \mathrm{sq}$. mile of deltic plain with braided streams fed by adjacent glaciers. Montane elevations of approximately $1000 \mathrm{~m}$ occur in the area. Vegetation types on the delta were disrupted by the 1964 earthquake. Coastal plant communities are dominated by freshwater Carex spp. meadows interspersed with Alnus crispa and Salix spp. shrubfields. Tall shrub and shrub-bog habitats (Myrica gale, Menyanthea trifolicata) are more prevelant on inland sites (Campbell 1985). Alnus-Picea spp. communities become dominant between 4 and 14 miles inland. Stands of Populus balsamifera interspersed with Alnus spp. and Oplopanax horridus are present in some locations. 
Brown bear habitat use and food item selection data are available only for the May-June period (Campell 1985). Food habits data for this period are based on 16 scats in which Equisetem spp. and grasses/sedges were most predominant. Miscellaneous vegetation and waterfowl egg fragments were also identified. These scats showed that bears in this coastal habitat consumed moose, beaver and microtines.

Differences in the distribution between 2 age classes was observed during the May-June period although habitat selectivity was similiar (Table 24). Immature bears were located more often in coastal habitats while adults occupied habitats further inland.

Although telemetry data are limited for the summer and fall period, bears continued to use the delta to some extent with a general movement inland during August and September. During this period bears moved to spawning salmon streams and took advantage of this food source.

\section{Alaska (Kenai) Peninsula}

No intensive brown bear habitat studies have been conducted in the Alaska Peninsula, however, general trends in food item and habitat selection are presented for several areas. Predation intensity on marine bird eggs is presented by Bailey and Faust (1984); salmon/bear relationships are reported by Gard (1971), Egbert (1975) and Luque and Stokes (1976) among others; and, evidence of predation on moose on the Peninsula is given by Franzmann et al. (1983). Bevin et al. (1984) provided an overview of major food items available on the Alaska Peninsula. Moose and salmon are important sources of protein. Equisetum spp. use is inferred from other areas as this food is widespread on the Peninsula. Important fruit species include Rubus spectabilis, Oplopanax horridus, Viburnum edule, Empetrum nigrum and Vaccinium spp.

Glenn and Miller (1980) described the seasonal movements of marked bears in the Black Lake area. After leaving their winter dens, bears generally moved from mountainous subalpine areas onto coastal plains. Bears of all age and sex classes were attracted to Bristol Bay to consume dead gray whales (Eschrichtius robustus), walruses (Obobenus rosmarus) and harbor seals (Phoca vitulina). Some predation on moose and caribou calves was reported (Glenn and Miller 1980).

During summer, bears in the Black Lake area moved to salmon spawning streams in the foothills of the Aleutian Range. Salmon feeding generally followed the spawning chronology of particular salmon species and began in early July and, at times, continued into late November.
Near the end of August, bears began to disperse from salmon streams and moved into the subalpine Alnus spp. zone and alpine areas (Glenn and Miller 1980) to feed on berries (species not specified). Seasonal differences in habitat use and use of cover by different age and sex classes was apparent from the data.

\section{Southeast Alaska}

Brown bear habitat studies in the northern Alexander Archipelago have been conducted by Schoen and Beier $(1983,1986)$ and by Schoen et al. (in press b). The objective of this investigation was to determine seasonal movements and habitat use of brown bears in relation to logging and mining activities on Admiralty and Chichagof islands. Vegetation in these study areas is dominated by 2 major habitat types; temperate rain forest and alpine tundra (Schoen et al. in press b). The forested zone is in terspersed with poorly drained and open muskeg habitats. Tsuga heterophylla, Picea sitchensis and Chamaecyparis nootkatensis are dominant confiers. Numerous small lakes and tidal flats are situated at low elevations, and numerous salmon spawing streams are present.

Schoen and Beier (1986) divided habitat use into 4 seasonal categories; spring (emergence-15 May), early summer (16 May-15 July), late summer (16 July-15 September) and fall (16 September-denning). Admiralty Island bears used higher elevation habitats than Chichagof bears during spring and early summer. Schoen and Beier (1986) believed that this difference reflected a greater availability of alpine and subalpine habitats on Admiralty. During summer, bears on both islands used low elevation habitats coinciding with the period of fishing for salmon on coastal streams (Table 25)

Habitat use and availability on Chichagof Island was reported by Schoen and Beier (1986). Upland old-growth was used in proportion to availability except during early and late summer when use was less than availability. Riparian oldgrowth use exceeded available habitat during late summer. In spring, avalanche slopes were preferred. Clear cut areas and alpine/subalpine habitats were avoided on Chichagof throughout the year (1\% of locations). Several other parameters of brown bear habitat use were also reported by Schoen and Beier (1986). These included: seasonal elevation, percent slope, aspect, topography, canopy cover, soil drainage and timber volume.

McCarthy (1986: Appendix B in Schoen and Beier 1986) has provided interim food habits results for the Admiralty Island study area (Hawk Inlet). Twenty-eight food items were found in scats collected in 1984. Carex spp. was the

Table 24. Brown bear use of habitat types on the west Copper River, May-June 1984 (from Campbell 1985).

Percent utilization

\begin{tabular}{|c|c|c|c|c|c|c|c|c|}
\hline \multirow[b]{3}{*}{ Age class } & \multirow[b]{3}{*}{$(\mathrm{n})$} & \\
\hline & & \multicolumn{4}{|c|}{ Lowland Delta } & \multicolumn{3}{|c|}{ Montane } \\
\hline & & $\begin{array}{c}\text { Forest } \\
(\%)\end{array}$ & $\begin{array}{c}\text { Tall Shrub } \\
(\%)\end{array}$ & $\begin{array}{c}\text { Meadow } \\
(\%)\end{array}$ & $\begin{array}{c}\text { Mudflat } \\
(\%)\end{array}$ & $\begin{array}{c}\text { Forest } \\
(\%)\end{array}$ & $\begin{array}{c}\text { Tall Shrub } \\
(\%)\end{array}$ & $\begin{array}{c}\text { Meadow } \\
(\%)\end{array}$ \\
\hline$\overline{\text { All }}$ & 295 & 14.6 & 58.6 & 15.3 & 0.7 & 3.7 & 5.8 & 1.4 \\
\hline Adult & 195 & 17.9 & 61.5 & 11.8 & 0 & 4.1 & 3.1 & 1.5 \\
\hline Immature & 100 & 8.0 & 53.0 & 22.0 & 2.0 & 3.0 & 11.0 & 1.0 \\
\hline
\end{tabular}


Table 25. Brown bear habitat use on Admiralty and Chichagof Islands, Alaska during 1984 (from Schoen and Beir 1986)

\begin{tabular}{|c|c|c|c|c|c|c|c|c|}
\hline \multirow[b]{3}{*}{ Habitat Type } & \multicolumn{8}{|c|}{ Percent utilization $^{a}$} \\
\hline & \multicolumn{2}{|c|}{ Spring } & \multicolumn{2}{|c|}{$\begin{array}{c}\text { Early } \\
\text { Summer }\end{array}$} & \multicolumn{2}{|c|}{$\begin{array}{c}\text { Late } \\
\text { Summer }\end{array}$} & \multicolumn{2}{|c|}{ Fall } \\
\hline & $\mathrm{A}$ & $\mathrm{C}$ & $\mathrm{A}$ & $\mathrm{C}$ & $\mathrm{A}$ & $\mathrm{C}$ & $\mathrm{A}$ & $\mathrm{C}$ \\
\hline $\begin{array}{l}\text { Old-growth } \\
\text { forest }\end{array}$ & 45 & 50 & 35 & 33 & 22 & 18 & 30 & 45 \\
\hline $\begin{array}{l}\text { Riparian } \\
\text { old-growth }\end{array}$ & 13 & 4 & 4 & 6 & 32 & 57 & 31 & 18 \\
\hline Subalpine & 2 & 0 & 12 & 6 & 16 & 1 & 4 & 0 \\
\hline Alpine & 9 & 0 & 18 & 0 & 17 & 1 & 9 & 0 \\
\hline $\begin{array}{l}\text { Avalanche } \\
\text { slope }\end{array}$ & 23 & 36 & 23 & 40 & 7 & 8 & 15 & 13 \\
\hline Rock & 6 & 0 & 5 & 2 & 0 & 0 & 5 & 5 \\
\hline Road & 0 & 4 & 0 & 0 & 0 & 0 & 0 & 0 \\
\hline $\begin{array}{l}\text { Beach/tidal } \\
\text { flat }\end{array}$ & 2 & 4 & 1 & 6 & 3 & 0 & 1 & 0 \\
\hline Second growth & 0 & 0 & 0 & 4 & 0 & 0 & 0 & 0 \\
\hline Garbage dump & 0 & 0 & 0 & 0 & 0 & 7 & 0 & 16 \\
\hline Stream & 0 & 0 & 1 & 0 & 4 & 8 & 4 & 3 \\
\hline Clear cut & 0 & 4 & 0 & 2 & 0 & 1 & 0 & 0 \\
\hline$(\mathrm{n})$ & 64 & 28 & 175 & 48 & 76 & 119 & 166 & 38 \\
\hline
\end{tabular}

a $=$ Admiralty, $\mathrm{C}=$ Chichagof

most important food to both high and low elevation bears during May and June. Low elevation bears consumed Lysichitum americanum and Equisetum spp. while grasses and sitka black-tailed deer (Odocoileus hemionus sitkensis) were important to bears using higher elevation sites.

Salmon and Carex spp. were heavily used during July and August (McCarthy 1986). The berries of Oplopanax horridus and $L$. americanum were consumed following feeding at salmon runs. Ribes spp., Carex spp., and $O$. horridus berries were eaten by high elevation bears on avalanche slopes.

\section{Arctic Alaska}

Habitat and food habits related investigations on the northern slope of the Brooks Range have been conducted by Gebhard (1982), Hechtel (1985) Phillips (1985), and
Curatolo and Moore (1975). Although specific vegetation descriptions differ somewhat among study areas, the overall habitat types availabile are similiar. The north slope area has been described in terms of 4 general physiographic zones: northern plateaus, Arctic mountains, Arctic foothills and Arctic coastal plains (Phillips 1985). The coastal plain is characterized by relatively flat and poorly drained wet meadows dominated by sedges and associated shrub species. Eriophorum vaginatum tussock communties are common in the foothill region on moderatelydrained slopes (Curatolo and Moore 1975). The Arctic mountain zone is characterized by wide river valleys and rugged (glaciated) mountains where vegetation is limited due to permafrost, frost action and rapid erosion of slopes. River valleys are typified by braided river channels, Salix spp. flats and large expanses of non-vegetated gravel bars.

The seasonal food habits and foraging behavior of north slope foothill bears was described by Hechtel (1985). During spring, the roots of Hedysarum alpinum and Oxytropus borealis were dug extensively by bears in mat/cushion types, Dryas spp. tundra and riparian areas (Hechtel 1985). Other major spring foods included $E$. vaginatum floral parts, over-wintering Arctostaphylos rubra berries, grasses/sedges, mictotines and Arctic ground squirrels (Spermophilus parryii). Caribou were consumed to a lesser degree at this time. Tussuck tundra, and tall and low shrublands were used by bears in the Arctic National Wildlife Refuge for Hedysarum spp. digging (Table 26) (Phillips 1985). In the eastern Brooks Range, river valley habitats were used more often than mountainous areas during spring (Table 27) although home range location in relation to these types differed among bears (Curatolo and Moore 1975).

Major summer vegetal foods of the barren-ground grizzly included Boykinia richardsonii, Equisetum arvense, and grasses/sedges. Ground squirrels and roots continued to be eaten although the incidence of root digging decreased (Hechtel 1985). Favored foraging areas for these items in Hechtel's study were moist herbaceous meadows, ground squirrel mounds and snowbank communities. Early summer use of tussock tundra, mat/cushion tundra, and shrublands was observed by Phillips (1985) for those bears digging roots. Herbaceous tundra was used in later summer (Table 26) in the Arctic National Wildlife Refuge by bears feeding on Equisetum spp., grasses and Boykinia spp. Preference for more mountanous habitats was reported by Curatolo and Moore (1975) (Table 27).

Table 26. Index of grizzly bear vegetation type use (level II) in the Aretic National Wildlife Refuge, 1982-1983 (from Phillips 1985).

\begin{tabular}{|c|c|c|c|c|c|c|}
\hline \multirow[b]{2}{*}{$\begin{array}{c}\text { Vegetation Type } \\
\text { (Level II) }\end{array}$} & \multirow{2}{*}{$\begin{array}{c}\text { Spring } \\
25 \text { May- } \\
7 \text { June }\end{array}$} & \multicolumn{3}{|c|}{ Summer } & \multicolumn{2}{|c|}{ Fall } \\
\hline & & $\begin{array}{l}22 \text { June- } \\
5 \text { July } \\
\end{array}$ & $\begin{array}{l}6 \text { July- } \\
19 \text { July } \\
\end{array}$ & $\begin{array}{l}20 \text { July- } \\
2 \text { Aug } \\
\end{array}$ & $\begin{array}{l}3 \text { Aug- } \\
16 \text { Aug }\end{array}$ & $\begin{array}{l}17 \text { Aug- } \\
29 \text { Aug }\end{array}$ \\
\hline Sedge-grass tundra & 0.1 & 1.4 & 1.4 & 1.1 & 1.1 & 0.5 \\
\hline Herbaceous tundra & - & 5.8 & 4.2 & 12.9 & 32.7 & 0.2 \\
\hline Tussock tundra & 1.9 & 0.5 & 0.6 & 0.6 & 0.1 & 0.2 \\
\hline Shrub tundra & - & 3.2 & 4.1 & 2.2 & 1.4 & 2.8 \\
\hline Mat/cushion tundra & 0.2 & 0.1 & 0.2 & 0.4 & 1.0 & 1.5 \\
\hline Tall shrubland & 1.3 & 4.6 & 0.6 & 4.1 & 1.1 & 2.4 \\
\hline Low shrubland & 8.0 & 0.7 & 0.2 & 0.2 & 0.4 & 8.4 \\
\hline
\end{tabular}


Table 27. Seasonal observations of 10 grizzly bears in 2 habitat types, 1984 (from Curatolo and Moore 1975).

\begin{tabular}{lccc}
\hline & \multicolumn{3}{c}{ Percent of observations } \\
\cline { 2 - 4 } & $\begin{array}{c}\text { River } \\
\text { Valley }\end{array}$ & Mountain & (n) \\
\hline $\begin{array}{l}\text { Spring } \\
\text { (10 May-22 June) }\end{array}$ & 68 & 32 & 66 \\
$\begin{array}{l}\text { Summer } \\
\quad \text { (23 June-29 July) }\end{array}$ & 20 & 80 & 69 \\
$\begin{array}{l}\text { Early Fall } \\
\text { (30 July-3 Sept) }\end{array}$ & 43 & 57 & 53 \\
$\begin{array}{l}\text { Late Fall } \\
\text { (4 Sept-1 Oct) }\end{array}$ & 54 & 45 & 42 \\
\hline
\end{tabular}

Roots, berries and ground squirrels constituted major fall food items (Hechtel 1985). The fruit of A. rubra was most important although Vaccinium uliginosum, V. vitisidaea, and Empetrum nigrum were present in the study area. Principal foraging areas in the Arctic National Wildlife Refuge during fall were mat/cushion tundra, shrub tundra and river shrublands (Phillips 1985) where roots and berries were consumed. Bears in the eastern Brooks Range appeared to be equally distributed between river valley and mountain habitats (Curatolo and Moore 1975).

Caribou did not appear to be a major food item in the western Brooks Range (Hechtel 1985) although carcasses were consumed when available. Reynolds (1980) believed that bears did not move far to hunt caribou, but did take advantange of this protein source when present within a bear's normal home range. The relationship between bears and ground squirrels was complex, and bear distribution and habitat use was correlated to this food source. Similar ecological requirements between bears and squirrels for preferred feeding and digging sites was felt to be the primary association (Hechtel 1985).

\section{Canada}

\section{Coastal British Columbia}

Primary grizzly bear habitat studies in British Columbia have been conducted in the Kimsquit River basin (Hamilton and Archibald 1986) and the Knight Inlet area (Wray and Hebert 1975, Smith 1977). Grizzly bear research in each area was prompted by the potential impacts of extensive logging activity occurring in the coastal zone.

Both study areas contain an upper valley and a lower watershed with heavy rainfall on the outer coastline decreasing toward the mountainous interior. Climate in the upper valleys is influenced by coastal factors while the lower watershed has been termed a "coast-interior transitional climate." Tsuga heterophylla is the primary climax species, although it may be co-dominant or replaced by Pseudotsuga menziesii, Pinus contorta, Thuja plicata, Picea sitchensis and Abies amabilis on certain sites. In the lower valley, deciduous forests occupy considerable area (Banner et al. 1986) typically dominated by Alnus rubra and Populus spp. Ten floodplain Picea spp.-Oplopanax horridus associations were described by Banner et al. (1986). Shrub dominated vegetation is found in avalanche tracts, riparian areas, organic bog fringes, subalpine and recently logged areas. Bedrock, icefields and talus slopes are present in the alpine tundra zone. The Kimsquit River is an important spawning area for pink (Oncorhynchus gorbusha), sockeye (O. nerka) and chum (O. keta) salmon.

Smith (1978) divided the Sims Creek (Knight Inlet) study area in to 6 broad categories: areas clearcut between 1969 . 1974 , selective cuts between 1950-52, natural early successional areas, near-climax forest, swamp and tidal areas. Based on plot data, Smith estimated habitat quality, food availability and cover quality for each category. Grizzly bear hunting in this area may reduce bear use of logged areas.

Preliminary habitat-use studies (Hamilton and Archibald 1986) suggest that low elevation habitats are important to grizzly bears. Sixty-four percent of 112 feeding activity records were in the floodplain Picea spp.Oplopanax horridus association and, variations of this association. Floodplain habitats are important because of their proximity to salmon spawning channels and because a high diversity of food plants exist in the mosaic of floodplain comunities (Hamilton and Archibald 1986, Banner et al. 1986).

Verified foods of Kimsquit valley grizzly bears (Hamilton and Archibald 1986) include 7 fruit bearing shrubs and herbs (e.g., Cornus sericea, Lonicera involucrata, Rubus spp., Vaccinium spp. and Viburnum edule). Bears in this area dig the roots of Osmorhiza chilensis and Angelica genuflexa. Heracleum lanatum, grassses, sedges, and Equisetum spp. were herbaceous foods use by grizzlies. Bears relied heavily on salmon.

Smith (1978) examined 175 scats from the Sims Creek area. The succulent shoots of $R$. spectabilis and grasses were primary vegetative components of scats. As fruits ripened during summer, a shift in diet to the fruit of $R$. spectabilis, Vaccinium spp., Rubus idaeus, and R. leucodermis was evident. Lysitchiton $\mathrm{spp}$. was not a major item in scat collections (Smith 1978) although Wrey and Hebert (1977) cite this plant as an important food. Salmon became important in August. Lloyd et al. (1977) provided evidence of bears securing salmon eggs from redds that were exposed by low water levels.

\section{Interior British Columbia}

\section{Glacier National Park}

Mundy and Flook (1970) investigated grizzly bear habitat use and food habits in Glacier National Park, British Columbia. Precipitation from Pacific airmasses is greater in this Park than in the Rocky Mountains to the east. Habitat descriptions provided here were detailed by Butter (1941).

The study area was mountainous and heavily forested. Dominant coniferous species, by increasing elevation, include: Tsuga heterophylla, Thuja plicata, Pseudotsuga menziesii, Picea spp., Abies lasiocarpa and Pinus albicaulis. Forest openings suport numerous herbaceous and shrub species including Rhododendron spp., Vaccinium membranaceum, V. ovalifolim, Ribes spp. and Rubus parviflora. Openings along streams contain Salix sitchensis, Alnus sitchensis, Sambucus spp. and Heracleum lanatum. 
Erythronium grandiflorum is found in open avalanche tracks. Alpine vegetation is also represented in the study area.

Current grizzly bear habitat use information in Glacier National Park is based on direct observations of Mundy (1963) and a synopsis of warden obervations grouped into 3 broad categories of habitat: forest, avalanche slope and alpine meadow. Data suggest that grizzly bears use avalanche slopes and forest predominantly in the spring and early summer with increased use of alpine meadows in July and August. An autumn return to avalanche slopes was correlated with ripening of berries at lower elevations. During 1961-1962 bears were attracted to, and secured food from, 4 garbage dumps. The distribution of numerous bears in the Park was related to the location of these dumps.

Studies of the natural food habits (excluding dump foods) of Glacier National Park bears, showed that ungulate carrion is most important in the spring Grasses sedges, and Equisetum spp. were prominent food items during the spring and early summer while Vaccinium spp. was eaten mid-summer throughout autumn. Sorbus spp. and Ribes spp. were other fruit shrubs eaten by bears. Warden observations suggest that the roots of Hedysarum spp. were eaten as well.

\section{Columbia Mountains}

Simpson et al. (in prep) recently completed studies on grizzly bear ecology in the Columbia Mountains, Columbia River Basin. Situated north of Revelstoke, the study area lies between the Monashee and Selkirk mountain ranges. The topography of the Columbia Valley is U-shaped with steep glacially scoured valley walls, resulting in the formation of avalanche slides (Simpson et al. in prep). The Columbia Mountains lie within the Interior Wet Belt and 3 broad zones of vegetation are present (Krajina 1969). The Interior Cedar Hemlock Zone supports a dense coniferous forest. Above this Zone, the Picea engelmannii - Abies lasiocarpa parkland is characteristic. Alpine Tundra covers approximately $27 \%$ of the study area above $2300 \mathrm{~m}$. South and west facing slopes that burned in the 1930s and 1940s support Vaccinium spp., Rubus spp., Amelanchier alnifolia and Berberis aquifolium. Some higher elevation logged areas also contain berry producing shrubs (Simpson et al. in prep).

Avalanche paths, valley bottom meadows, riparian areas and alpine parkland-tundra areas are the primary sites of grasses, sedges and succulent herbs. Ungulates include moose caribou and a small population of mule deer (Odocoileus hemionus).

Grizzly bears of the Columbia Mountains were efficient as predators and scavengers, depending on mammals during early spring (Simpson et al. in prep.). Predation and scavenging on moose, mule deer and caribou was apparent. Porcupines (Erethizon dorsatum), beavers (Castor canadensis), mountain goats (Oreamnos americanus) and small rodents were also eaten.

In spring, instrumented bears moved to the Columbia Valley and fed principally on Trifolium spp., grasses, and Equisetum spp. Two instances of directed foraging on Pachistima myrsinites were observed. Closed forests were considered indirectly important to grizzly bears because such areas were essential to ungulates which bears consumed. Logged areas did not produce plant foods attractive to bears in the spring (Simpson et al. in prep.). During the latter part of spring, avalanche paths and tributary riparian areas greened up and bears moved to these habitats (Table 28). Plant foods on avalanche paths included $H$. lanatum and Claytonia lanceolata. H. lanatum use increased in late June. Vaccinium spp. comprised the bulk of autumn diet, however, the fruit of Oplopanax horridus and Chimaphila umbellata were also frequently eaten by bears in forested areas. Hedysarum spp. and Shepherdia canadensis rarely occurred in the study area and were not food items.

Differences in habitat selection among individuals or between sexes, was not observed, however, no females with young were instrumented (Simpson et al. in prep.). Strong selection towards avalanche paths occurred in spring and summer. Cedar-hemlock forests and riparian zones were also key spring habitats. The cedar-hemlock forests produced Erythronium grandiflorum, H. lanatum, C. lanceolata and Equisetum spp.

Immature forests and slash areas were either avoided or used as expected as cover or for bedding. Bears left avalanche paths in the summer and foraged primarily in parklands and burns. Seventy-five percent of observed bedding areas were within $100 \mathrm{~m}$ of feeding sites.

Table 28. Seasonal habitat selection in the Columbia Mountains (Simpson et al. in prep).

\begin{tabular}{lcc}
\hline & \multicolumn{2}{c}{ Season $^{\mathrm{a}}$} \\
\cline { 2 - 3 } Habitat component & Spring & Summer \\
\hline Valley bottom cedar/hemlock & + & 0 \\
Spruce/balsam forest & + & + \\
High elevation types & 0 & 0 \\
Avalanche paths & + & + \\
Logging slash & 0 & 0 \\
Burns & 0 & + \\
Immature forests & + & + \\
Riparian & + & + \\
Alpine tundra & + & + \\
Barren areas &
\end{tabular}

$a_{+}=$use signifcantly different than available at $p<.05$. $o=$ use not significantly different than available.

\section{Canadian Rockies}

Grizzly bear habitat and food habits studies in Banff National Park were conducted by Hamer and Herrero (1983b, 1986). The food habits of grizzly bears in Jasper National Park were discussed by Pearson and Nolan (1976) and Russell et al. (1979). Grizzly bear foraging habitat and food item selection in the Akamina-Kishinena drainages (Flathead River) of southern British Columbia were reported by McLellan (1986). A food habits study in southern British Columbia (Lloyd and Fleck 1977) did not distinguish between black and grizzly bear scats and therefore is not included here. An intensive habitat investigation in the Highwood Valley was conducted by 
Wielgus (1986). A reconnaissance of habitat, distribution of foods and feeding evidence were reported by McCrory and Herrero (1981) in the Highwood area (Kananaskis Country) of Alberta.

\section{Banff and Jasper National Park}

Research by Hamer and Herrero (1983b) in Banff National Park, and by Russell et al. (1979) in Jasper National Park was conducted in the relatively arid eastern and western slopes, respectively, of the Front Range of the Rocky Mountains. Climate is generally continental, with winter chinook winds. The vegetation of the Banff area is comprised of 2 major zones; the Picea spp. - Abies lasiocarpa forest zone, and the alpine zone $(2200-2300 \mathrm{~m})($ Ogilvie 1976). Fire-successional Pinus contorta is the characteristic conifer on warmer slopes of the subalpine forest zone, with Picea spp. and A. lasiocarpa occurring in more moist habitats. Larix lyallii is found near the treeline. Because of climate and topography, extensive stands of even-aged $P$. contorta do not occur, rather there exists extensive areas of mountain grassland meadows or Shepherdia canadensis. Betula glandulosa-Salix spp. - S. canadensis shubfields are widespread at lower elevations.

The alpine zone was unimportant as foraging habitat in Banff National Park (Hamer and Herrero 1983b). With the exception of Equisetum arvense, major foods were secured in a variety of open and seral vegetation types. Habitat use as related to major food items was reported by Hamer and Herrero (in press) for Banff and is summarized in Table 29.

Hedysarum alpinum and $H$. sulphurescens roots were most important in April, May, June, September and October although summer use was evident. $H$. alpinum roots were secured primarily in mesic to subhydric willow shrubfields below $2000 \mathrm{~m}$. H. sulphurescens roots were dug in mesic to xeric, steep meadow slopes. These dry meadows were above $1900 \mathrm{~m}$ where $66 \%$ of the records were on southeastern to western aspects.

Bears selected digging habitats of increasing elevation as spring progressed. Equisetum arvense was important to Banff bears from June through August, and were found in mesic to hydric habitats of moderate slope. Riparian areas such as seeps, springs and streamsides were primary foraging sites.

Contrary to other major plant foods, $E$. arvense was often secured in mature forest types. The elevation of $E$. arvense foraging activity also increased through the summer, as bears preferred immature stems having a high nutritive value. Information on graminoid foraging sites limited because feeding evidence was difficult to discern (Hamer and Herrero in press a).

Open, immature forests created by wildfire were foraging sites for the fruit of $V$. scoparium and $V$. myrtillus. Such sites were on east-facing slopes were vegetation regenerated slowly (Hamer and Herrero in press a). S. canadensis berries were eaten in late summer and autumn on southfacing slopes; use was inversely related to Hedysarum spp. use during the later seasons. The seasonal nutritional value of these foods has been reported (Hamer and Herrero 1983b).

\section{Southern British Columbia}

McLellan's (1984) study area in the extreme southeastern corner of British Columbia (and portions of Glacier National Park, Montana) was situated primarily within the dry $P$. engelmannii-A. lasiocarpa biogeoclimatic zone (Krajina 1965). P. albicaulis is found at higher elevations with alpine tundra vegetation found at highest elevations in the Clark Mountains. Most of McLellan's study area is within the A. lasiocarpa habitat type of Pfister et al. (1977), although Picea spp. and Pseudotsuga menziesii types are also present. Natural fire dramatically altered the study area in the late 1800 s and early 1900 s.

$P$. contorta dominates lower elevations adjacent to the North Fork of the Flathead River and its tributaries. The wide valley bottom is of a gently rolling topography with small ridges, and mature Picea spp. stands occupying moist habitats. Intensive logging has occurred at lower to mid-elevations in response to spruce bark beetle (Dendroctonus obesus) and mountain pine beetle ( $D$. ponderosae) epidemics. Communities of Hedysarum sulphurescens occur on sandbars. Shepherdia canadensis, Cornus stolonifera and Rhamnus alnifolia are conspicuous shrubs in

Table 29. Vegetation types associated with feeding activity for 11 major foods, Banff National Park. Highest ranking vegetation types per food item only (from Hamer and Herrero in press).

\begin{tabular}{|c|c|c|c|c|c|c|c|c|c|}
\hline \multirow[b]{2}{*}{ Vegetation Type } & \multicolumn{9}{|c|}{ Food } \\
\hline & $\begin{array}{l}\text { Hedysarum } \\
\text { alpinum }\end{array}$ & $\begin{array}{c}\text { Hedysarum } \\
\text { sulphurescens }\end{array}$ & $\begin{array}{c}\text { Arctostaphylos } \\
\text { spp. }\end{array}$ & Graminoids & $\begin{array}{l}\text { Equisetum } \\
\text { arvense }\end{array}$ & $\begin{array}{l}\text { Oxyria } \\
\text { digna }\end{array}$ & $\begin{array}{c}\text { Heracleum } \\
\text { lanatum }\end{array}$ & $\begin{array}{l}\text { Shepherdia } \\
\text { canadensis }\end{array}$ & $\begin{array}{l}\text { Vaccinium } \\
\text { spp. }\end{array}$ \\
\hline Salix spp. shrubfields & $\mathbf{x}$ & $\mathbf{x}$ & & $\mathbf{x}$ & $\mathbf{x}$ & $\mathbf{x}$ & $\mathbf{x}$ & $\mathbf{x}$ & \\
\hline Picea/Salix spp. & $\mathbf{x}$ & & & & & & & $\mathbf{x}$ & \\
\hline $\begin{array}{l}\text { Picea spp./Ledum } \\
\text { glandulosum }\end{array}$ & $\mathbf{x}$ & & & & & & & & \\
\hline $\begin{array}{l}\text { Bromus/Festuca spp. } \\
\text { meadow types }\end{array}$ & & $\mathbf{x}$ & $\mathbf{x}$ & $\mathbf{x}$ & & & $\mathbf{x}$ & & \\
\hline $\begin{array}{l}\text { Shepherdia/Bromus } \\
\text { spp. shrubfield }\end{array}$ & & $\mathbf{x}$ & $\mathbf{x}$ & $\mathbf{x}$ & & & & & \\
\hline Picea/Equisetum spp. & & & & & $\mathbf{x}$ & $\mathbf{x}$ & & & \\
\hline Wet meadows & & & & & $\mathbf{x}$ & $\mathbf{x}$ & $\mathbf{x}$ & & \\
\hline $\begin{array}{l}\text { Picea or Pinus spp./ } \\
\text { shepherdia }\end{array}$ & & & & & & & & $\mathbf{x}$ & \\
\hline $\begin{array}{l}\text { Picea or Pinus spp./ } \\
\text { Vaccinium } \\
\text { scoparium }\end{array}$ & & & & & & & & & $\mathrm{x}$ \\
\hline
\end{tabular}


the floodplain. Vaccinium globulare occurs in post-fire shrubfields at higher elevations.

McLellan (1981) presented habitat use and availablity data obtained from 10 grizzly bears monitored in 1981 (Table 30) and described 4 seasonal habitat use patterns (McLellan 1986). During early spring, timber is the most commonly used habitat component. Hedysarum spp. is unevenly distributed within the timber component and is used as food. Grizzly bear predation and scavenging on elk (Cervus elaphus), deer (Odocoileus spp.) and moose occur most often in timber because of ungulate concentrations there. Snow-tracking records of McLellan (1986) show that during the first 3 weeks of April some bears travel extensively through timber, only rarely eating or defecating. Ungulates were the primary diet item from April through May (McLellan 1981).

In mid-May, vegetation began to green-up and use of timbered habitats was reduced. Root digging still occurred and succulent vegetation appeared in the diet. Not all grizzly bears occupied early spring and summer ranges in the valley; some individuals foraged in upland riparian zones and avalanche chutes (McLellan 1982). Dominant foods during the spring included Equisetum spp., Angelica spp., $H$. lanatum spp. and grasses/sedges. Early ripened berries of $S$. canadensis were consumed in July.

During the summer berry season, timber was rarely used (McLellan 1986), and at this time, bears foraged on Vaccinium spp. in open to open-timbered burn shrubfields (McLellan 1981). Other fruits eaten at this time were $S$. canadensis, $R$. alnifolia and Crataegus spp. From the end of the berry season to den-up (autumn), scat analysis showed that Trifolium spp., Taraxacum spp., roots and grasses were important. Hunter-killed or crippled ungulates and gut piles were a major source of protein (McLellan 1986).

Table 30. Habitat component availabity and use for 10 grizzly bears in southern British Columbia (from McLellan 1981).

\begin{tabular}{lccc}
\hline & \multicolumn{3}{c}{ Seasonal Use } \\
\cline { 2 - 4 } Component & Spring Summer & Fall \\
\hline Timber & - & - & - \\
Open timber & - & - & - \\
Clear cut & - & - & - \\
Ridgetop & - & + & - \\
Riparian & + & - & + \\
Slabrock & - & + & + \\
Snowchute & + & + & - \\
Meadow & + & - & + \\
Burn & - & + & - \\
\hline
\end{tabular}

$a_{+}=$habitat use exceeded availability, $-=$use of habitat was less than available (no statistical tests conducted)

\section{Highwood Valley, Southern Rocky Mountains}

Wielgus (1986) reported habitat use/preference results and developed a habitat prediction model for the Highwood Valley region. Habitat preference by instrumented ani- mals was inferred by comparisons between random habitat points and radio location points. Logistic regression techniques were selected to discriminate between random and radio location points and to develop a predictive model of habitat use (Wielgus 1986). Habitat variables used were forest cover type, percent canopy closure, forest stand age, mean stand height, elevation, aspect, slope, distance to free water, distance to slope greater than 45 percent, closest stand characteristics and distance to closest stand. Four forest cover types were used: alpine, early seral, pine dominant and spruce dominant (Wielgus 1986). Two hundred eighty-eight scats were analyzed for food habits inferences.

The study area selected by Wielgus (1986) was rugged mountain terrain along the Continental Divide, exhibiting continental climate situated within a rainshaddow of the interior mountains. Biogeoclimatic zones of the area included the subalpine and alpine zones and the Abies lasiocarpa-Picea engelmannii forest zone (Bickerstaff et al. 1981). Jacques (1980) identified 3 subszones of the subalpine forest. The first low-elevation subzone was dominated by Picea spp. with intrusions of Populus tremuloides. The mid-subzone was codominated by Picea engelmannii and A. lasiocarpa. A. lasiocarpa dominated the high-subzone with interspersed local occurrences of Larix lyallii and $P$. albicaulis. $P$. contorta stands occurred throughout the study area as a seral stage of the Picea spp.-Abies spp. forest.

Grizzly bear use of the Highwood Valley was stratified by 5 seasons: spring, early summer, late summer, fall and late fall (Wielgus 1986). Frequency of occurrence and percent composition data indicated that Hedysarum sulpherescens, $H$. alpinum and grasses were the major spring food plants. Hedysarum spp. use continued into early summer; use of Deschampsia caespitosa, Vicia americana, Equisetum spp. and Heracleum lanatum also increased in early summer. Analyses of spring habitat use indicated that male grizzly bears preferred pine and early seral types (Table 31), using relatively young, dense stands heavily. Alpine and Picea spp. sites were used less than as available. Female grizzly bear habitat use during this season was similiar to males although females tended to use old Picea spp. cover types more frequently.

During early summer, males preferred old, dense, Pinus spp. and Picea spp. cover types while early seral types and alpine zones were avoided. Conversely, female bears preferred seral types and alpine, while avoiding forested cover types (Wielgus 1986). Young dense Pinus spp. and young open Pinus spp. were used by males in the late summer. Early seral types and open Pinus spp. cover types were important to females in late summer. No statistical differences between sexes was discovered during this season. Major food items in the late summer were Equisetum spp., H. lanatum, D. caespitosa, Erythronium grandiflorum and Carex spp.

Scat analyses indicated that Hedysarum spp. roots gained importance again in the fall. The fruit of Shepherdia canadensis and Vaccinium spp. also became prevalent in scat samples.

Male preference for young, open Pinus spp. types was evident in the fall. Once again, males avoided alpine and Picea spp. cover types. Females used young Picea spp. and early seral types on moderately mesic slopes. Old, dense Picea spp. was preferred by males in the late fall while 
Table 31. Habitat preference in the Highwood Valley (Wielgus 1986).

\begin{tabular}{|c|c|c|}
\hline Season $\quad$ Habitat $^{a}$ & Male $^{\mathbf{b}}$ & Female $^{b}$ \\
\hline $\begin{array}{l}\text { Spring: } \\
\text { Young dense Pinus } \\
\text { Early seral } \\
\text { Alpine } \\
\text { Young open Pinus } \\
\text { Old dense Picea }\end{array}$ & $\begin{array}{l}\mathbf{x} \\
\mathbf{x} \\
\mathbf{x}\end{array}$ & $\begin{array}{l}x \\
x \\
x \\
x\end{array}$ \\
\hline $\begin{array}{l}\text { Early Summer: } \\
\text { Old dense Pinus } \\
\text { Old dense Picea } \\
\text { Young open Pinus } \\
\text { Early seral } \\
\text { Alpine }\end{array}$ & $\mathrm{x}$ & $\begin{array}{l}\mathrm{x} \\
\mathrm{x} \\
\mathrm{x}\end{array}$ \\
\hline $\begin{array}{l}\text { Late Summer: } \\
\text { Young open Pinus } \\
\text { Early seral } \\
\text { Alpine }\end{array}$ & $\begin{array}{l}x \\
x\end{array}$ & $\begin{array}{l}\mathbf{x} \\
\mathbf{x} \\
\mathbf{x}\end{array}$ \\
\hline $\begin{array}{l}\text { Fall: } \\
\text { Young open Pinus } \\
\text { Early seral } \\
\text { Alpine }\end{array}$ & $\begin{array}{l}x \\
x \\
x\end{array}$ & $\begin{array}{l}\mathbf{x} \\
\mathbf{x} \\
\mathrm{x}\end{array}$ \\
\hline $\begin{array}{l}\text { Late Fall: } \\
\text { Old dense Pinus } \\
\text { Old dense Picea } \\
\text { Young open Pinus } \\
\text { Early seral } \\
\text { Alpine }\end{array}$ & $\begin{array}{l}x \\
x\end{array}$ & $\begin{array}{l}x \\
x \\
x \\
x\end{array}$ \\
\hline
\end{tabular}

aelevation and slope between sexes often differed within the same habitat category.

${ }^{b} \mathbf{x}=$ habitat category used $>5 \%$ over random availability.

females used cover types within the early seral and alpine stratifications. The highest elevations in the study area were avoided, except during the late fall (Wielgus 1986).

Wielgus (1986) stated that "In general, males shifted habitat preferences over the seasons more than females." Males also tended to use the "best" food-producing habitats throughout the year. Regression models of habitat prediction varied from $71-89 \%$ depending on season. Cover type, density, slope and aspect were universally important classification variables.

\section{Boreal Forest}

Pearson (1975) and Nagy and Russell (1978) conducted research on the boreal forest grizzly bear centered in the Swan Hills area of central Alberta. The area is comprised of gently-rolling to mountainous topography bisected by bogs and muskeg. Extensive stands of Picea spp. and Pinus contorta are present. Deciduous blocks of Populus spp. and Betula spp. are also present. The climate in the Swan Hills area is continental in origin and exhibiting cold winters and wet, cool, summers. Timber harvest and petrochemical exploration and development were major land use activities in the area during the study period.

Habitat use and food habit studies were not the primary emphasis in the Swan Hills investigations. Two general patterns of habitat use, however, arose from capture and telemetry data (Nagy and Russell 1978). Grizzly bears were attracted to, and frequented, refuse dumps on the periphery of the Swan Hills townsite; this unnatural food source also lured bears into the townsite where several were destroyed. The second pattern was related to erosion control along road and pipeline right-of-ways, and at well sites. Such developments were reseeded with grasses and clovers. Scat analysis (Nagy and Russell 1978) suggested that both grizzly and black bears made significant use of these "improved habitats." Such artificial habitats may have been a factor contributing to expansion of the black bear population (Nagy and Russell 1978).

Based on a sample of 97 scats, Nagy and Russell (1978) made preliminary conclusions on the food habits of the Swan Hills grizzly bear. Heracleum lanatum, Trifolium spp., Equisetum spp. and monocots were major food items. Vaccinium spp. and Viburnum spp. were important during September through October, however, during a berry crop failure in 1977, bears apparently used Trifolium spp. as an alternate food. Roots and bulbs did not occur in scat samples; ground squirrels were not found in the Swan Hills.

\section{Northern Interior}

Two major grizzly bear habitat studies have been conducted in the Northern Interior: Pearson's (1975) work in the Kluane Game Sanctuary (St. Elias Mountains) and Miller et al. (1982) in the Mackenzie Mountains.

\section{Kluane Game Sanctuary}

The climate in the Kluane Game Sactuary is dry, averaging approximately $25 \mathrm{~cm}$ of precipitation annually, with chinook winds during winter. The St. Elias Mountains in the area reach $2400 \mathrm{~m}$ and drop precipitously into lower valleys. Higher elevation slopes contain alpine glaciers. Several braided-river systems are present in the Kluane area, and exhibit a riparian successional structure. Seral communities include Hedysarum alpinum-Salix spp. Older segments of the river system contain Populus balsamifera and Picea glauca. Prairie vegetation occurs on stream outwash areas with $H$. mackenzii, Potentilla fruiticosa, Shepherdia canadensis, Salix spp. and Populus tremuloides. Mid-elevation areas are dominated by stands of $P$. glauca. Communities in the subalpine zone generally lack conifer cover.

Pearson's (1975) analysis of food habits and habitat use was based on 970 observations and 128 scat samples collected from 1964 through 1969. Open sidehills near the winter den were used upon emergence. The primary food at this time was Hedysarum alpinum roots. Some individual bears remained in subalpine and alpine meadows during May, feeding on roots and Salix spp. catkins. Other green vegetation was used as snow cover retreated (Pearson 1975).

As snow cleared from valleys, bears moved to vegetated alluvial flats and continued foraging on Hedysarum spp. and winter-killed ungulates. Subalpine Salix spp. fields were used during June; $74 \%$ of telemetry fixes were from such sites. Salix spp. catkins occurred most frequently in scats during this month, with some use of over-wintered Arctostaphylos uva-ursi berries. Pearson (1975) believed that these berries were locally important.

Bears reduced their intake of catkins in June and increased consumption of grasses. Grizzly bears began using $S$. canadensis immediately upon ripening (mid to late July); the transition zone between forest and alluvial 
flats was the primary foraging habitat. In only 15 of 77 observations during this time $(19 \%)$ were bears not in habitats associated with $S$. canadensis. Roots, wasps, carrion and grassses were apparently consumed in July.

Bears continued to eat berries into August, and as berries dried at lower elevations, either moved in to higher elevation creek bottoms to continue $S$. canadensis foraging or switched to Hedysarum spp. roots. By September, bears were digging roots or foraging on berries in concentrated areas of the alpine zone. Roots replaced $S$. canadensis in years of berry crop failure. Roots and late developing berries constituted the major food items in September and October, although ground squirrel (Spermophilus undulatus) predation also occurred. This predation was the only time when bears actively sought a protein diet (Pearson 1975).

\section{Mackenzie Mountains}

The climate in the Mackenzie Mountain region is continental in origin with an annual precipitation of $47 \mathrm{~cm}$. The area studied by Miller et al. (1982) is of rugged topography with maximum elevations of $2500 \mathrm{~m}$. Three habitat zones were recognized. Open stands of stunted Picea glauca with intervening areas of grass and shrub vegetation characterized the forest zone and Betula glandulosa and Salix spp. were dominant indicators of the subalpine shrub zone. The alpine heath-meadow zone constituted $32 \%$ of the study area. Erect shrubs in the area included Vaccinium uliginosum, Salix spp. and V. vitis-idaea.

Bears used alpine habitats in June and July (Miller et al. 1982). H. alpinum roots, Equisetum spp., grasses and sedges constituted $85 \%$ of their diet at this time. Meat comprised $3 \%$ of the diet in June and July. Subalpine areas were used in August, with Equisetum spp., V. uliginosum, Shepherdia canadensis, Empetrum nigrum, and $H$. alpinum roots being the major items consumed.

In September, bears used both subalpine and alpine areas and selected against forested areas. From September until bears entered their dens, fruit and roots were consumed. Miller et al. (1982) did not consider Mackenzie bears to be active predators on either large or small mammals.

\section{Canadian Arctic Region}

Two major brown bear investigations have been conducted in the Canadian Arctic region, 1 (Nagy et al. 1983b) in the Mackenzie River delta and Beaufort Sea area (Tuktoyaktuk Peninsula), and the other (Nagy et al. 1983a) in the Arctic Mountains of central northern Yukon.

\section{Mackenzie River Delta-Tuktoyaktuk Peninsula}

The landscape of the Delta area varies from alluvial plains near sea level, to relatively high mountains on Richards Island. The vegetation of the Mackenzie River study area has been broadly categorized as boreal forest, tundra and transitional between the 2 (Lambert 1973). Lakes and pingos are numerous. Dominant plants such as Betula glandulosa, Empetrum nigrum, Ledum glandulosum and $V$. vitis-idaea are dispersed on well drained slopes, high-centered polygons, in forested zones and on hummock borders (Lambert 1973). The coastal areas are vegetationally diverse; relatively well-drained sites are dominated by B. glandulosa, Salix spp., Dryas integrifolia, V. uliginosum, and $V$. vitis-idaea. Sphagnum spp. mosses occupy depressed portions of tussocks with standing water may be present throughout the summer in poorly drained sedge meadows.
The vegetation of the Caribou Hills portion of the study area varies from open forest to poorly drained sites colonized by Picea glauca, P. mariana, and Betula paperifera. The Reindeer (Rangifer tarandus tarandus) Grazing Herd, of some 5000 animals utilizes both the Tuktoyaktuk Peninsula and Richards Island.

Food habits from the Tuktoyaktuk Peninsula were based primarily on samples obtained from April through May, although some scats were also collected from June through September. Limited opportunity for ground work later in the year precluded further collections (Nagy et al. 1983b). Reindeer and roots of Hedysarum alpinum were major spring food items. Observations showed that as many as 15-20 calves were killed in 1 foray.

Monocots and Equisetum spp. were major diet items in the summer. These food items were abundant in the floodplains of the Delta. Reindeer, Arctostaphylos uva-ursi, and $V$. uliginosum were also important items during summer (Nagy et al. 1983b). Arctic ground squirrels (Spermophilus undulatus), believed to be a very important food source, and monocots were predominant foods during August and September. Berries were not a major food item at this time, however, sampling error or a poor berry crop may have influenced observations (Nagy et al. 1983b). Several bears appeared to focus on ground squirrel colonies in relatively high and well-drained habitats. Nagy et al. (1983b) believed that small mammals (e.g., lemmings (Lemmus spp.)) and muskrats (Ondatra zibethicus) were underrepresented in fecal samples. Muskrats were dug from "push-ups" in the spring. Observations also suggest that bears may cause isolated colony failure of nesting snow geese (Chen caerulescens) by foraging on eggs.

\section{Arctic Mountains, Yukon Territory}

Portions of the Arctic Mountains study area (Nagy et al. 1983a) are of rugged mountain topography $(1500 \mathrm{~m})$, and include the Arctic Plateau between 2 mountain ranges and a portion of the coastal plain. The study area occurs within the zone of continuous permafrost. The coastal plain is generally devoid of trees, however, Picea glauca, $P$. mariana and Betula balsamifera occupy protected valleys. These coastal plain lowlands are extremely moist during the summer and support Eriophorum angustifolium and sedge meadows. Salix spp. thickets are present along river, stream and lake margins, with higher sites generally dominated by Vaccinium spp., B. balsamifera, Empetrum nigrum and Oxytropis spp.

Grizzly bear food habits in the Arctic Mountains were similar to those of Tuktoyaktuk Peninsula (Nagy et al. 1983a). Bears fed primarily on E. nigrum and Hedysarum alpinum roots in late May. Grasses were the major diet item in June and July. Roots, E. nigrum fruit, and Arctic ground squirrels were also consumed at this time. Shepherdia canadensis was occasionally eaten. There was an apparent segregation of habitat use by various age and sex classes. Females with young were most often found at lower elevations relative to other classes (Nagy et al. 1983a).

Scavenging or predation on the barren ground caribou (Rangifer tarandus groenlandicus) was infrequent (Nagy et al. 1983a), which was surprising because the Porcupine caribou herd migrates through the study area. Two instances of bears feeding on dead beluga whales (Delphinapterus leucus) were recorded. 



\section{MANAGEMENT TECHNIQUES AND STRATEGIES}

\section{TIMBER}

While many studies document reduced grizzly bear use of logged areas (Perensovich 1966, Russell 1974, Lyon and Basile 1980, Mace and Jonkel 1980b, Zager et al. 1983), others report no evidence that logging impacts grizzlies (Meehan 1974, Zager 1980a). Aerial surveys over a 6 year period in the northwestern U.S. and southern Canada showed no changes in grizzly bear populations and little reduction in the number of cubs produced per year as logging pressure increased, however, bear home ranges were substantially reduced during this period (Mace and Jonkel $1980 \mathrm{~b})$. These conflicting results suggest that while bear numbers may not be immediately affected by logging activites, their behavior is almost certainly modified.

\section{Timber Harvest}

Alterations in timber cover can affect the quality of grizzly bear food and cover (Blanchard 1983, USFS 1985a) causing bears to change their use of an area. Grizzly habitat can be affected by timber harvesting in 3 ways:

- vegetation arrangement and abundance can be changed affecting the quality and quantity of food and cover (Ruediger and Mealey 1978, Sigman 1985, USFS 1985i).

- human use patterns may be altered (Ruediger and Mealey 1978, USFS 1985i). Logging practices make grizzly habibat much more accessible to man (Craighead 1980).

- existing water regimes may be indirectly impacted; surface and/or subsurface water movement and/or distribution may be changed (Archibald 1983, Ruediger and Mealey 1978). Logging in carex meadows substantially alters water levels by increasing runoff and blockage of water by slash (Russell 1974).

Nevertheless, changes in vegetation can be predicted and timber management coordinated to benefit grizzlies and their habitat (Ruediger and Mealey 1978, Servheen et al. 1981, USFS 1985a); vegetation changes can, in some cases, actually enhance grizzly bear habitat (USFS $1983 \mathrm{~b}$, 1985aci, 1986, Holland 1986) and the impacts of human disturbance can be mitigated by temporal constraints, shortened contract periods, providing displacement areas and managing access (USFS 1985a). The U.S. Forest Service and National Park Services presently evaluate all logging activities for their potential impact on grizzly bears (Mealey 1979, 1986, USFS 1983b, 1985ab) and permit no activities which adversely affect grizzlies (Mealey 1979, 1986, USFS 1983b). Although management strategies differ between Management Situations 1 and 2 (Contreras 1983, USFS 1983b, 1985b), emphasis will be on the conservation of grizzly habitat and foods (Ruediger and Mealey 1978, Contreras 1983). If funds are available, timber sale project plans should include proposals for grizzly bear habitat improvement (USFS 1985c). Timber sale receipts (Knudsen-Vandenberg Act funds) can, and should, be used for this purpose (Mealey 1979, 1986, USFS 1983b, 1985bci, Garcia 1986, Holland 1986).
Management of habitat for grizzly use should be designed to provide food (fruits, succulent herbs, grasses and sedges), cover (thermal and hiding) and living space (home range) (Ruediger and Mealey 1978, Contreras 1983).

Timber harvesting practices which can be manipulated to provide the above are timing, location and type of cut (size, shape, species); use of buffer zones or leave strips and post-harvest treatments (slash disposal, revegetation). These are discussesd in more detail in the following sections.

\section{Timing of Cut}

In as much as logging disturbances are cumulative, timber sales must not be planned as isolated events; past and future activities must be evaluated (Jonkel et al. 1979) and harvest planning should consider long term consequences (Hillis 1986). Cumulative effects analysis procedures are useful for determining the impacts of proposed logging activities on bear populations (USFS 1985a). Specific suggestions for scheduling harvesting activities follow:

- logging should take place at a time of little or no biological importance to bears (Jonkel et al. 1978, Ruediger and Mealey 1978, Mealey 1979, 1986, Zager 1980a, Jonkel 1982a, USFS 1983a, Garcia 1986).

- if possible, logging should take place in winter to minimize soil disturbance and compaction (Meyers 1978, Orme and Williams 1986). If winter logging is infeasible, operations should take place primarily in summer (Mealey 1979, 1986).

- logging should be concentrated into the shortest time frame possible (USFS 1985ci, Orme and Williams 1986).

- operations should not take place simultaneously on adjacent areas (same or next drainage) (Jonkel et al. 1979, Servheen et al. 1981, Jonkel 1982a, Perensovich 1984, USFS 1985i). Erickson (1975) suggests a series of belt cuts at spaced periods to allow regeneration between harvest periods. Large scale sales should not be planned on adjacent lands (same or next drainage) within short (10-15 years) time intervals (Jonkel 1982a). Coordination between adjacent landowners may be required (Jonkel 1982a).

- timber harvest schedules should be coordinated with other land activities to reduce simultaneous impacts (Mace and Jonkel 1980a).

- harvesting should be scheduled to optimize vegetational responses beneficial to grizzlies (Contreras 1983, Garcia 1986).

\section{Location of Cuts}

Cuts should not be located near grizzly bear biological centers (Meyers 1978). Specific suggestions are:

- cuts should be limited to areas where the slope is less than $35 \%$ and tractor yarding is possible (USFS 1985c). 
- adequate timber cover must be maintained near foraging areas and den sites (Lyon and Basile 1980).

- cuts should not take place near travel corridors, feedings sites, or denning areas (Zager 1980, Jonkel 1982a, USFS 1985a).

- areas adjacent to core grizzly management areas should not be cut as this may draw bears away from the core and into closer contact with man (Erickson 1977, 1978).

- cuts should not take place in hydric stream bottoms, wet meadows, marshes or bogs where soil disturbance may be high.

\section{Logging in or Near Riparian Areas}

Riparian zones are heavily used by grizzlies for feeding and as travel corridors. While stream bottoms can be opened up to produce bear foods such as wet site forbs and graminoids (Bratkovich 1986, Hillis 1986), special consideratiaons must be taken when logging in, or near, these areas. Specifically:

- soil disturbance should be minimized particularly on mesic or hydric sites (USFS 1985i).

- hydrophilic vegetation should not be altered (USFS 1985i).

- broadcast burning or hand piling and spot burning are recommended as site preparation methods (USFS 1985i).

- in some areas, strips of uncut timber should be left along rivers to protect salmon streams (Archibald 1983).

- cover should be maintained at 4-6 sight distances around riparian zones (USFS 1985i).

- slash should be piled to reduce alder regeneration and allow the site to be occupied by forbs and grasses (Hillis 1986).

\section{Type of Cut}

Timber stands can be managed for size, shape, interspersion, degree of crown closure, age structure and edge contrast (Zager 1980a, Contreras 1983, Zager et al. 1983) to provide for bear needs. Size and shape are important as they relate to distance to escape cover. Size and spacing considerations are:

- boundaries of all cuts should be irregular (Zager 1980, Jonkel 1978).

- cuts should be shaped so that cover is within $46 \mathrm{~m}$ (150 ft) of all points in the opening (USFS 1985i).

- cuts should have a width of $91 \mathrm{~m}(300 \mathrm{ft})$, but be no wider than $183 \mathrm{~m}$ (600 ft) (USFS 1985ci).

Silvicultural methods commonly used in timber management are clearcuts, seed tree, shelterwood and single- or group-tree selection (Contreras 1983). These methods can be used to enhance both grizzly food and cover (Tables 32a and $\mathrm{b}$ ) and are discussed in more detail below.

\section{Clearcuts}

Clearcuts ranked second in importance among logged sites used by grizzly bears in a study by Mealey et al. (1976).
Their size, shape and arrangement should, to the degree possible, resemble natural openings to attract bears (Zager 1983, USFS 1985i). Specific recommendations concerning clearcuts are:

- plan smaller cut areas ( $<50$ acres) leaving cover nearby (Zager 1983, Horejsi 1986a).

- large clearcuts (>10 acres) may be planned incorporating 1 or more leave patches of at least 5 acres, well developed understories and no visible access points (Mealey et al. 1977, Mealey 1979, 1986, USFS 1983b, Zager 1983).

- if clearcuts exceed 40 acres, cutting configuration must allow grizzly access to cover within $91 \mathrm{~m}$ (300 $\mathrm{ft}$ ) for over $80 \%$ of the unit (Orme and Williams 1986) with openings of $100 \mathrm{~m}$ (328 ft) in width (Meyers 1978, Orme and Williams 1986).

- edge can be maximized (Blancharad 1983) and sight distance reduced by creating an undulating edge (USFS 1985i, Orme and Williams 1986).

- minimum soil scarification should occur (Mealey et al. 1977, Mealey 1979, 1986, USFS 1983a) in habitat types where soil disturbance hinders regeneration ( $20 \%$ or less in strip configuration) and broadcast burns should be used (Mealey et al. 1977, Mealey 1979, 1986 USFS 1983b).

- cuts should be planned so that adjacent harvested units qualify as summer hiding cover (USFS $1985 \mathrm{c}$ ). This may require $25-30$ years in moist forests and much longer on more xeric sites (Zager 1983).

- cover strips should be left around clearcuts and other open grizzly feeding areas (Orme and Williams 1986, Jonkel 1982a). Timbered strips between cuts should be at least $100 \mathrm{~m}(328 \mathrm{ft})$ wide between clearings (Meyers 1978, Blanchard 1983).

- clearcuts should be screened from roads by leaving a strip of trees to promote bear use of early vegetative stages and to minimize poaching from access roads (Servheen et al. 1981).

- livestock should be excluded from clearcuts as they graze on forbs valuable to grizzly bears. Livestock exclusion will also reduce bear/human conflicts (Meyer 1978, Contreras 1983).

- northern slopes are the most productive clearcut sites (Jonkel et al. 1982) probably because mesic conditions accelerated recovery of shrub (Mealey et al. 1976).

- clearcut areas adjoining meadows only when $20 \%$ or less of the periphery of the meadow is affected (USFS 1985i).

Clearcuts can benefit grizzlies in vegetation types such as:

- shrubfield sites - douglas fir/blue huckleberry, subalpine fir/beargrass/blue huckleberry, grand fir/beargrass (Hillis 1986).

- lodgepole pine stands (followed by extensive soil scarification) (Contreras 1983, Orme and Williams 1986). 
Table 32a. Habitat and grizzly bear considerations in forested grizzly habitat components in northwestern Montana and northern Idaho, 1977 (adapted from Ruediger and Mealey 1978).

\begin{tabular}{|c|c|c|c|c|c|c|c|c|}
\hline $\begin{array}{l}\text { Forest Habitat } \\
\text { Type Component }\end{array}$ & $\begin{array}{l}\text { Timber } \\
\text { Product- } \\
\text { ivity }\end{array}$ & $\begin{array}{l}\text { Timber } \\
\text { Suit- } \\
\text { ability }\end{array}$ & $\begin{array}{l}\text { Grizzly } \\
\text { Bear Food } \\
\text { Product- } \\
\text { ivity }\end{array}$ & $\begin{array}{l}\text { Grizzly } \\
\text { Bear Use } \\
\text { Period }\end{array}$ & Important Food Items & $\begin{array}{c}\text { Important } \\
\text { Features }\end{array}$ & $\begin{array}{l}\text { Acceptable } \\
\text { Silvicultural } \\
\text { Methods }\end{array}$ & $\begin{array}{l}\text { Suggested } \\
\text { Site } \\
\text { Preparation }\end{array}$ \\
\hline \multicolumn{9}{|l|}{ PIAL/ABLA } \\
\hline $\begin{array}{l}\text { Pinus albicaulis } \\
\text { Abies lasiocarpa }\end{array}$ & $\mathrm{L}$ & $\mathbf{L}$ & M & Summer, Fall & $\begin{array}{l}\text { Pinus albicaulis, Lomatium spp. } \\
\text { Erythronium qrandiflorium, } \\
\text { Claytonia lanceolata }\end{array}$ & ridgetop & none & none \\
\hline \multicolumn{9}{|l|}{ ABLA/CACA } \\
\hline $\begin{array}{l}\text { Abies lasiocarpa } \\
\text { Calamagrostis } \\
\text { canadensis }\end{array}$ & M & $\mathbf{L}$ & $\mathrm{H}$ & $\begin{array}{l}\text { Spring, } \\
\text { Summer, Fall }\end{array}$ & $\begin{array}{l}\text { Heracleum lanatum, Angelica } \\
\text { arguta, Osmorhiza occidentalis, } \\
\text { Mesic grasses }\end{array}$ & $\begin{array}{l}\text { stream- } \\
\text { bottoms, } \\
\text { wet } \\
\text { meadows }\end{array}$ & $\begin{array}{l}\text { salvage or } \\
\text { selection }\end{array}$ & lop, scatter \\
\hline \multicolumn{9}{|l|}{ ABLA/LUHI/MEFE } \\
\hline $\begin{array}{l}\text { Abies lasiocarpa } \\
\text { Luzula hitchcockii h.t. } \\
\text { Menziesia ferruginea } \\
\text { phase }\end{array}$ & $\mathrm{L}$ & $\mathbf{L}$ & $\mathrm{H}$ & Summer, Fall & $\begin{array}{l}\text { Heracleum lanatum, Angelica } \\
\text { arguta, Osmoryhiza occidentalis, } \\
\text { Mesic grasses, Vaccinium } \\
\text { globulare }\end{array}$ & $\begin{array}{l}\text { gently } \\
\text { sloping } \\
\text { topography, } \\
\text { upper basin } \\
\text { mesic sites }\end{array}$ & none & none \\
\hline \multicolumn{9}{|l|}{ ABLA/LUHI/VASC } \\
\hline $\begin{array}{l}\text { Abies lasiocarpa } \\
\text { L. hitchockii, h.t. } \\
\text { Vaccinlum scoparium }\end{array}$ & $\mathrm{L}$ & L & M & $\begin{array}{l}\text { Late } \\
\text { Summer, Fall }\end{array}$ & $\begin{array}{l}\text { Claytonia lanceolata, Vaccinium } \\
\text { globulare, Vaccinium scoparium, } \\
\text { Pinus albicaulis albicaulis }\end{array}$ & $\begin{array}{l}\text { subalpine } \\
\text { burns }\end{array}$ & none & none \\
\hline \multicolumn{9}{|l|}{ ABLA/XETE/VASC } \\
\hline $\begin{array}{l}\text { Abies lasiocorpa/ } \\
\text { Xerophyllum tenax h.t. } \\
\text { Vaccimium scoporium }\end{array}$ & $\mathrm{L}$ & $\mathbf{L}$ & M & $\begin{array}{l}\text { Late } \\
\text { Summer, Fall }\end{array}$ & $\begin{array}{l}\text { Vaccinium globulare, } \\
\text { Vaccinium scoparium }\end{array}$ & burns & $\begin{array}{l}\text { salvage, } \\
\text { selection }\end{array}$ & $\begin{array}{l}\text { broadcast } \\
\text { burn, lop } \\
\text { and scatter, } \\
\text { or trample }\end{array}$ \\
\hline \multicolumn{9}{|l|}{ ABLA/XETE/VAGL } \\
\hline $\begin{array}{l}\text { Abies lasiocorpa/ } \\
\text { Xerophyllum tenax h.t. } \\
\text { Vaccinium globulare }\end{array}$ & $\mathbf{M}$ & $\begin{array}{l}\mathrm{L} \\
\mathrm{M}\end{array}$ & $\mathrm{H}$ & $\begin{array}{l}\text { Mid-Summer, } \\
\text { Early Fall }\end{array}$ & $\begin{array}{l}\text { Vaccinium globulare, } \\
\text { Vaccinium scoparium }\end{array}$ & burns & $\begin{array}{l}\text { salvage, group } \\
\text { selection or } \\
\text { clearcut }\end{array}$ & $\begin{array}{l}\text { broadcast } \\
\text { burn, strip } \\
\text { scarify if } \\
\text { necessary, } \\
\text { but don't } \\
\text { exceed } 35 \% \\
\text { of site }\end{array}$ \\
\hline \multicolumn{9}{|l|}{ ABLA/LIBO/XETE } \\
\hline $\begin{array}{l}\text { Abies lasiocorpa/ } \\
\text { Linnaea borealis h.t. } \\
\text { Xerophyllum tenax }\end{array}$ & $\mathbf{M}$ & $\begin{array}{l}\mathbf{L} \\
\mathbf{M}\end{array}$ & $\mathrm{H}$ & $\begin{array}{l}\text { Mid-Summer, } \\
\text { Fall }\end{array}$ & $\begin{array}{l}\text { Vaccinium globulare, } \\
\text { Shepherdlia canadensis, } \\
\text { Arctostaphylos uva-ursi }\end{array}$ & $\begin{array}{l}\text { seral stages } \\
\text { are the } \\
\text { most } \\
\text { productive } \\
\text { food sites }\end{array}$ & $\begin{array}{l}\text { clearcut group } \\
\text { selection, } \\
\text { shelterwood, } \\
\text { selection } \\
\text { thinning }\end{array}$ & $\begin{array}{l}\text { broadcast } \\
\text { burn, strip } \\
\text { scarify if } \\
\text { necessary, } \\
\text { but don't } \\
\text { exceed } 35 \% \\
\text { of site }\end{array}$ \\
\hline \multicolumn{9}{|l|}{ ABLA/CLUN/MEFE } \\
\hline $\begin{array}{l}\text { Abies lasiocarpa/ } \\
\text { Clintonia uniflora h.t. } \\
\text { Menziesa ferruginea }\end{array}$ & $\mathbf{H}$ & $\begin{array}{l}\mathrm{L} \\
\mathrm{M}\end{array}$ & $\begin{array}{l}\mathbf{H}^{\mathrm{a}} \\
\mathbf{L}^{\mathrm{b}}\end{array}$ & $\begin{array}{l}\text { Late } \\
\text { Summer, } \\
\text { Early Fall }\end{array}$ & $\begin{array}{l}\text { Vaccinium globulare, Sorbus } \\
\text { scopulina }\end{array}$ & $\begin{array}{l}\text { early } \\
\text { successional } \\
\text { stage } \\
\text { openings } \\
\text { without } \\
\text { over- scarifi- } \\
\text { cation }\end{array}$ & $\begin{array}{l}\text { clearcut, group } \\
\text { selection, } \\
\text { shelterwood, } \\
\text { selection } \\
\text { thinning }\end{array}$ & $\begin{array}{l}\text { broadcast } \\
\text { burn, strip } \\
\text { scarify if } \\
\text { necessary, } \\
\text { but don't } \\
\text { exceed } 35 \% \\
\text { of site }\end{array}$ \\
\hline \multicolumn{9}{|l|}{ ABLA/CLUN/XETE } \\
\hline $\begin{array}{l}\text { Abies lasiocarpa/ } \\
\text { Clintonia uniflora h.t. } \\
\text { Xerophyllum tenax }\end{array}$ & M & $\begin{array}{l}\mathrm{L} \\
\mathrm{M}\end{array}$ & M & $\begin{array}{l}\text { Mid-Summer, } \\
\text { Early Fall }\end{array}$ & $\begin{array}{l}\text { Vaccinium globulare, Sorbus } \\
\text { scopulina, Shepherdia } \\
\text { canadensis }\end{array}$ & burns & $\begin{array}{l}\text { clearcut, group } \\
\text { selection, } \\
\text { shelterwood, } \\
\text { selection } \\
\text { thinning }\end{array}$ & $\begin{array}{l}\text { broadcast } \\
\text { burn, strip } \\
\text { scarify if } \\
\text { necessary, } \\
\text { but don't } \\
\text { exceed } 35 \% \\
\text { of site }\end{array}$ \\
\hline \multicolumn{9}{|l|}{ ABLA/CLUN/CLUN } \\
\hline $\begin{array}{l}\text { Abies lasiocarpa/ } \\
\text { Clintonia uniflora h.t. } \\
\text { Clintonia uniflora phase }\end{array}$ & $\mathrm{H}$ & $\mathbf{H}$ & M & $\begin{array}{l}\text { Spring, } \\
\text { Summer, Fall }\end{array}$ & $\begin{array}{l}\text { Osmorhiza occidentalis, } \\
\text { Erythronium grondiflorium, } \\
\text { Heracleum lanatum, Angelica } \\
\text { arguta, Mesic grasses }\end{array}$ & $\begin{array}{l}\text { mesic sites, } \\
\text { stream- } \\
\text { bottoms }\end{array}$ & $\begin{array}{l}\text { clearcut, group } \\
\text { selection, } \\
\text { shelterwood, } \\
\text { selection } \\
\text { thinning }\end{array}$ & $\begin{array}{l}\text { broadcast } \\
\text { burn, strip } \\
\text { scarify if } \\
\text { necessary, } \\
\text { but don't } \\
\text { exceed } 35 \% \\
\text { of site }\end{array}$ \\
\hline
\end{tabular}


Table 32a. (Continued)

\begin{tabular}{|c|c|c|c|c|c|c|c|c|}
\hline $\begin{array}{c}\text { Forest Habitat } \\
\text { Type Component }\end{array}$ & $\begin{array}{l}\text { Timber } \\
\text { Product- } \\
\text { ivity }\end{array}$ & $\begin{array}{l}\text { Timber } \\
\text { Suit- } \\
\text { ability }\end{array}$ & $\begin{array}{c}\text { Grizzly } \\
\text { Bear Food } \\
\text { Product- } \\
\text { ivity } \\
\end{array}$ & $\begin{array}{c}\text { Grizzly } \\
\text { Bear Use } \\
\text { Period }\end{array}$ & Important Food Items & $\begin{array}{c}\text { Important } \\
\text { Features }\end{array}$ & $\begin{array}{l}\text { Acceptable } \\
\text { Silvicultural } \\
\text { Methods } \\
\end{array}$ & $\begin{array}{c}\text { Suggested } \\
\text { Site } \\
\text { Preparation } \\
\end{array}$ \\
\hline \multicolumn{9}{|l|}{ ABLA/CLUN/ARNU } \\
\hline $\begin{array}{l}\text { Abies lasiocarpa/ } \\
\text { Clintonia uniflora h.t. } \\
\text { Aralia nudicaulis phase }\end{array}$ & $\mathrm{H}$ & $\mathrm{H}$ & M & $\begin{array}{l}\text { Spring, } \\
\text { Summer, Fall }\end{array}$ & $\begin{array}{l}\text { Vaccinium globulare, Mesic } \\
\text { grasses, and forbs, Cornus } \\
\text { stolonifera }\end{array}$ & $\begin{array}{l}\text { mesic sites, } \\
\text { stream- } \\
\text { bottoms }\end{array}$ & $\begin{array}{l}\text { salvage, group } \\
\text { selection }\end{array}$ & $\begin{array}{l}\text { broadcast } \\
\text { burn, do not } \\
\text { scarify }\end{array}$ \\
\hline \multicolumn{9}{|l|}{ ABLA/MEFE } \\
\hline $\begin{array}{l}\text { Abies lasiocarpa/ } \\
\text { Mensiesia ferruginea }\end{array}$ & M & $\mathrm{L}$ & $\mathbf{L}$ & Negligible & Few & $\begin{array}{l}\text { security } \\
\text { habitat and } \\
\text { mesic sites }\end{array}$ & \multicolumn{2}{|c|}{$\begin{array}{l}\text { not important consideration } \\
\text { in grizzly management }\end{array}$} \\
\hline \multicolumn{9}{|l|}{ PSME/VAGL } \\
\hline $\begin{array}{l}\text { Pseudotsuga mensiesii, } \\
\text { Vaccinium globulare }\end{array}$ & M & M & M & Fall & Vaccinium globulare & $\begin{array}{l}\text { burns, good } \\
\text { berry } \\
\text { production }\end{array}$ & $\begin{array}{l}\text { clearcut, group } \\
\text { selection, } \\
\text { shelterwood, } \\
\text { salvage }\end{array}$ & $\begin{array}{l}\text { broadcast } \\
\text { or } \\
\text { understory } \\
\text { burn, strip } \\
\text { scarify if } \\
\text { necessary }\end{array}$ \\
\hline \multicolumn{9}{|l|}{$\begin{array}{l}\text { PSME/FIED } \\
\text { PSME/CARLI }\end{array}$} \\
\hline $\begin{array}{l}\text { Pseudotsuga mensiesii } \\
\text { Festuca idahoensis } \\
\text { Calamagrotis rubescens }\end{array}$ & $\mathrm{L}$ & $\mathbf{L}$ & M & Early Spring & Grass, Arctostaphylos uva ursi & $\begin{array}{l}\text { sidehill } \\
\text { parks }\end{array}$ & $\begin{array}{l}\text { selection, group } \\
\text { selection, } \\
\text { salvage }\end{array}$ & $\begin{array}{l}\text { lop and } \\
\text { scatter or } \\
\text { pile and } \\
\text { burn }\end{array}$ \\
\hline \multicolumn{9}{|l|}{ PSME/AGSP } \\
\hline $\begin{array}{l}\text { Pseudotsuga menziesii } \\
\text { Agropyron spicatum }\end{array}$ & $\mathrm{L}$ & $\mathrm{L}$ & M & Spring & Grass, Arctostaphylos uva ursi & $\begin{array}{l}\text { sidehill } \\
\text { parks }\end{array}$ & $\begin{array}{l}\text { selection, } \\
\text { salvage }\end{array}$ & $\begin{array}{l}\text { lop and } \\
\text { scatter or } \\
\text { trample. Do } \\
\text { not burn. }\end{array}$ \\
\hline \multicolumn{9}{|l|}{$\begin{array}{l}\text { PICEA/CLUN } \\
\text { PICEA/EQAR }\end{array}$} \\
\hline $\begin{array}{l}\text { Picea/Clintonia uniflora } \\
\text { Picea/Equisetum arvense }\end{array}$ & $e^{H-M}$ & $\mathbf{H}$ & M & $\begin{array}{l}\text { Spring, } \\
\text { Summer, Fall }\end{array}$ & $\begin{array}{l}\text { Sorbus scopulina, Cornus } \\
\text { stolonifera, Mesic grasses and } \\
\text { forbs }\end{array}$ & $\begin{array}{l}\text { stream- } \\
\text { bottoms }\end{array}$ & $\begin{array}{l}\text { clearcut, group } \\
\text { selection, } \\
\text { shelterwood }\end{array}$ & $\begin{array}{l}\text { prescribe } \\
\text { burn }\end{array}$ \\
\hline
\end{tabular}

${ }^{a} \mathrm{~L}=$ Low, $\mathbf{M}=$ Medium, $\mathrm{H}=$ High

bEarly successional stages

cMid-Late successional stages

Table 32b. Habitat and grizzly bear considerations in nonforested habitat components in northwestern Montana and Northern Idaho, 1977 (adapted from Ruediger and Mealey 1978).

\begin{tabular}{|c|c|c|c|c|c|c|c|c|}
\hline $\begin{array}{c}\text { Habitat Type } \\
\text { Component }\end{array}$ & $\begin{array}{l}\text { Timber } \\
\text { Product- } \\
\text { ivity }\end{array}$ & $\begin{array}{l}\text { Timber } \\
\text { Suit- } \\
\text { ability }\end{array}$ & $\begin{array}{c}\text { Grizzly } \\
\text { Bear Food } \\
\text { Product- } \\
\text { ivity }\end{array}$ & $\begin{array}{c}\text { Grizzly } \\
\text { Bear Use } \\
\text { Period }\end{array}$ & Important Food Items & $\begin{array}{l}\text { Important } \\
\text { Features }\end{array}$ & $\begin{array}{c}\text { Acceptable } \\
\text { Silvicultural } \\
\text { Methods }\end{array}$ & $\begin{array}{c}\text { Suggested } \\
\text { Site } \\
\text { Preparation }\end{array}$ \\
\hline Avalanche chutes & $\mathrm{L}$ & L & $\mathrm{H}$ & $\begin{array}{l}\text { Spring, Early } \\
\text { Summer, Fall }\end{array}$ & Mesic grasses and forbs & $\begin{array}{l}\text { south slope- } \\
\text { spring, } \\
\text { north slope- } \\
\text { summer }\end{array}$ & none & none \\
\hline Burns & M-L & variable & $\mathrm{H}$ & $\begin{array}{l}\text { Mid-Summer, } \\
\text { Late Fall }\end{array}$ & Fruiting shrubs & $\begin{array}{l}\text { important } \\
\text { on south } \\
\text { slopes }\end{array}$ & $\begin{array}{l}\text { salvage, high } \\
\text { risk }\end{array}$ & burning \\
\hline Wet meadows & $\mathrm{L}$ & L & $\mathbf{H}$ & Spring & Mesic grasses, sedges and forbs & & & \\
\hline Sidehill parks & $\mathrm{L}$ & $\mathrm{L}$ & M & Spring & Grass & & & \\
\hline $\begin{array}{l}\text { Low gradient } \\
\text { streambottom }\end{array}$ & $\mathrm{H}$ & variable & $\mathrm{H}$ & $\begin{array}{l}\text { Spring, } \\
\text { Summer, Fall }\end{array}$ & $\begin{array}{l}\text { Mesic grasses and forbs, fruiting } \\
\text { shrubs }\end{array}$ & & & \\
\hline
\end{tabular}

${ }^{a} \mathrm{~L}=$ Low, $\mathrm{M}=$ Medium, $\mathrm{H}=$ High

${ }^{\mathrm{b}}$ Early successional stages

${ }^{c}$ Mid-Late successional stages 
- $\mathrm{AF} / \mathrm{CLUN} / \mathrm{MEFE}$ habitat types (with no slash piling or mechanical scarification (Mealey et al. 1977).

Clearcuts will probably not produce beneficial grizzly habitat when combined with soil scarification and slash piling (Jonkel 1982). Habitat types which do not benefit grizzlies following clearcutting are:

- ponderosa and lodgepole pine where high soil temperatures inhibit regeneration (Zager 1983).

- riparian areas such as stream bottoms, wet meadows, marshes and bogs (Russell 1974, USFS 1983b, Bratkovich 1986).

The disadvantages of clearcuts are that substrate debris may impede bear movements, thermal cover is less available than in uncut, or selecive cut areas, and the lack of canopy cover may shorten the berry season (Smith 1978).

\section{Selection Cuts}

Selection cuts ranked highest in grizzly food production and mainten ance of adequate cover when the forest canopy was opened by selective tree removal for areas in the northwestern United States and southern Canada (Mealey et al. 1976). Zager (1983) notes that selectively logged sites may be the most productive bear habitat in the northwest. In general, important herbs and fruit bearing shrubs are benefitted by selection cuts (Mealey et al. 1977, Mealey 1979, 1986, Zager 1983, USFS 1983b, 1985i, Orme and Williams 1986).

Specific recommendations for selection cuts are:

- remove $20 \%$ of the stands basal area (USFS 1985i).

- do not harvest adjacent stands before 10-15 years after a selective cut (USFS 1985i).

Habitat types where selective cuts produce valuable grizzly habitat are:

- $\quad$ spruce/fir types (Zager 1983, Contreras 1983).

- ALBA/CLUN/MEFE (without site preparation) (Ruediger and Mealey 1978).

- subalpine fir and cedar/hemlock (no slash piling and no mechanical scarification) (USFS 1983b).

- ponderosa and lodgepole pine sites (remaining trees moderate soil temperature and allow understory recovery) (Zager 1983).

- in douglas fir/ponderosa pine and grand fir forests.

- in areas where heavy concentrations of pine beetle damaged trees constitute a fire threat (Orme and Williams 1986).

Selection cuts may not be appropriate in lodgepole pine stands when quick regeneration is needed (Orme and Williams 1986) or near clearcuts where adequate cover for travel, escape, and rest may not be available (Meyer 1978).

Seed-tree cuts provide adequate food and cover in shrubfield sites. While Mealey et al. (1976) found that shelterwood cuts ranked lowest in food and cover production, this technique may be beneficial if used in douglas fir habitat types (Contreras 1983).

\section{Age Structure}

Long-term grizzly habitat management should maximize vegetation diversity, approximate natural conditions and include all successional stages (Mattson 1983, USFS 1983b, Zager 1983). Specifically, managers should work toward a minimum percentage $(10 \%)$ of the following size/age classes (USFS 1985bc):

- old growth.

- mature.

- young (or immature).

- pole/sapling.

- shrub/seedling.

- grass/forbs.

\section{Seral Stages}

Diversity of seral stages is generally the rule when managing forested lands for wildlife, however, some seral stages are of more value as grizzly habitat components than others. Specifically:

- early successional stages are valuable in producing grizzly foods (grasses, herbs, and fruits) (Erickson 1976, 1978, Servheen et al. 1981).

- mid-successional stages and pole-size stands of timber are of less value, particularly if they are dense, single species, even-aged stands (Erickson 1976, 1978).

- mature stands are less effective as habitat barriers (Erickson 1978).

- $\quad$ some over-mature and mixed aged stands should be retained for thermal cover and denning habitat (Mattson 1983).

Uneven-aged management should be used as it reduces disturbance and produces valuable food and cover species after each stand entry (Jonkel 1982a, Contreras 1983, Zager and Jonkel 1983, USFS 1985c).

\section{Species to be Cut}

Logging can also be used to favor plant/timber species important to grizzlies for food and cover (Contreras 1983). Recommendations for management of timber and habitat types that benefit bears are:

- clearcut sitka spruce and western hemlock; bears prefer 15-25 year old sites (Montana) (Zager 1983).

- maintain mid-volume hemlock stands on slopes $>20$ degrees at elevations of $>300 \mathrm{~m}(984 \mathrm{ft})$ for den habitat (Alaska) (Schoen et al. in press).

- maintain pacific silver fir and western hemlock stands for thermal cover (British Columbia) (Smith 1978).

- maintain Oplopanax horridus, Rubus spectabilis and Athyrium filix-femina to provide food and security cover (British Columbia) (Smith 1978).

- maintain lodgepole pine stands (YGBE) (Orme and Williams 1986) and thin to allow browse and grass growth (NCDE) (Holland 1986). 
- maintain subalpine fir/beargrass/huckleberry which provide good grizzly food (NCDE, YGBE) (Mealey 1979, 1986, Bratkovich 1986).

- maintain subalpine fir/beadlily (Montana) (Zager et al. 1983).

- maintain subalpine fir/menziesia (Montana) (Zager et al. 1983).

- maintain western hemlock/beadlily/beadlily type habitats which provide good foods (Montana) (Bratkovich 1986).

- maintain subalpine fir/bluejoint habitat (YGBE) (Mealey 1979, 1986).

- maintain or plant aspen stands for quick growing cover around wet sites (NCDE, YGBE) (Contreras 1983, Holland 1986).

- maintain or reestablish whitebark pine in late successional, climax stands for cone production and as den habitat (NCDE, YGBE) (Mealey 1979, 1986, USFS 1985bc, Eggers 1986, Mattson and Reinhart 1986):

- do not cut unless it is expected to die before the next scheduled cutting (Mealey 1979, 1986, Contreras 1983, USFS 1985b).

- expand stands above $2500 \mathrm{~m}$ (8500 ft) (USFS 1985h).

- maintain pure stands which are not favorable to squirrels and hence are more valuable to bears (Mattson and Reinhart 1986).

- provide a variety of age classes over time (USFS 1985h).

- maintain engelmann spruce stands above $2440 \mathrm{~m}$ (8000 ft) (YGBE) (USFS 1985h).

- maintain late successional stands of ALBA/VASC-PIAL phase and ALBA/CACA habitat types as they are prime late summer and fall habitats (YGBE) (Mattson and Reinhart 1986).

- maintain recently logged shrub communities as they provide hiding cover (British Columbia) (Smith 1978).

\section{Use of Buffer Zones, Leave Strips}

Buffer zones can be used to limit human access into grizzly use areas and provide effective movement barriers for grizzlies (Erickson 1975, 1977). Timber management in buffer zones should make the habitat less attractive to grizzly bears (i.e., create expansive stands with little or no herbaceous or shrubby vegetation or 'dog hair' or pole-aged stands managed on a short- to medium rotation) (Erickson 1975, 1978).

Strict fire control and control of insect infestation are important to maintaining continuous forest buffer zones (Erickson 1975). Several recommendations follow:

- leave buffers of at least $90 \mathrm{~m}$ wide around existing bear trails (Lloyd and Fleck 1977).

- leave buffers of at least $110 \mathrm{~m}$ wide next to lowlands, mountain meadows and snowslides (Lloyd and Fleck 1977).
- provide a buffer of 1-2 miles between all areas of prime grizzly habitat and human use areas (Erickson 1975,1978$)$.

- avoid timber cuts in managed buffer zones (Erickson 1978).

- timber harvesting in buffer zones should be done in a series of narrow belts paralleling prime grizzly habitat. Allow reforestation of 1 belt before harvesting the next (Erickson 1976, 1978).

- discourage intermixing cuts across or through buffer zones which break the continuity of the forest stand (Erickson 1975, 1978).

\section{Leave Strips}

Leave strips can function as effective buffer zones and should be maximized in harvest areas. Their size and location should determine the size and shape of any cuts (Jonkel et al. 1978). They are important as travel corridors, resting cover (Jonkel et al. 1978) and visual screens which reduce intraspecific stress (Archibald 1983). They should be located (Jonkel et al. 1978):

- along salmon rivers to protect anadromous fish which constitute a large part of grizzly bear diets in some areas (Archibald 1983).

- to encompass open feeding sites (avalanche chutes, meadows, shrubfields, sidehill parks, creek bottoms) (Mealey et al. 1977, Jonkel 1982a).

- to allow continuous travel cover in and between drainages (Jonkel et al. 1978, Zager 1980a, Servheen et al. 1981, USFS 1985a).

- along road edges (Jonkel 1978, Jonkel et al. 1978).

- in mature conifer stands with moderately dense understory shrubs (Jonkel et al. 1978).

- so that their shape and size act to reduce the possibility of windthrow (Jonkel et al. 1978).

- so that cutting units are a maximum of 50 acres and have irregular boundaries (Jonkel et al. 1978).

\section{Security Areas}

Escape and resting cover can be maintained by coordinating cuts between adjacent landowners, timber sale layout and road management (Zager 1980a, Jonkel 1982a, USFS 1985a). Security areas should:

- be at least 5000 acres adjacent to timber sale areas (USFS 1982).

- be maintained around $75 \%$ of the perimeter of any opening (USFS 1985ac) and hiding cover should have a minimum width of 3 sight distances.

- be maintained to provide a minimum of $40 \%$ cover ( $20 \%$ summer hiding and $20 \%$ thermal cover) (USFS 1982, 1985ci).

- be maintained around wet areas such as streams, meadows, marshes, and around ridgetops, snow chutes, shrub fields, sidehill parks and slabrock areas (Servheen et al. 1981).

- provide cover to hide $90 \%$ of a grizzly bear at $61 \mathrm{~m}$ (200 ft) (Contreras 1983, USFS 1985i). 
- be a minimum of 4 sight distances across (183-244 $\mathrm{m}$ : $600-800 \mathrm{ft}$ ) and on riparian sites $6-8$ sight distances, (274-488 m: 900-1600 ft) (USFS 1985i).

- provide a thermal cover of conifers $12 \mathrm{~m}$ (40 ft) wide with a $70 \%$ canopy cover (USFS $1985 \mathrm{i}$ ).

- provide thermal canopy cover of $50 \%$ on north facing slopes higher than $2440 \mathrm{~m}(8000 \mathrm{ft})$ (USFS 1985i).

- $\quad$ provide a minimum cover of 50-300 stems at least 7 feet tall/acre depending on other site characteristics such as topography, percent brush and percent stocking (USFS 1982i).

\section{Post Harvest Treatment}

Site treatment following logging can greatly enhance grizzly bear habitat by improving food species and other habitat components (Jonkel 1980a, Archibald 1983). Possible site preparation methods include soil scarification, slash disposal and prescribed burning. These can be followed by herbicide treatment and artificial regeneration to produce stands compatible with grizzly management objectives.

\section{Soil Scarification}

Although soil scarification is a commonly used method of preparing logged areas for timber regeneration, its value in enhancing grizzly food plants is questionable. In general, scarification should be minimized (Jonkel 1980a, Zager 1980a, Jonkel 1982a) because studies indicate that:

- while scarification increased regeneration of bear foods such as grasses, sedges, and clover, it decreased shrubs which provided food and cover (Zager and Jonkel 1983, Bratkovich 1986).

- scarification of sites retarded establishment of perennial shrubs and herbs (Mealey et al. 1976).

- recovery of vegetation was slower (greater than 25 years) on scarified sites (Zager 1983).

- scarification may destroy rhizomatous plants (e.g., vaccinium spp.) and the roots of other species (e.g., buffalo berry) (Jonkel et al. 1978, Zager et al. 1983).

- scarification on drier rounded side slopes may prevent shrub response (Bratkovich 1986).

- the percent cover of globe huckleberry, red-osier dogwood and service berry was lower on scarified (Zager et al. 1983).

Where soil scarification is required for adequate regeneration, it should be restricted to highly disturbed sites or planned in a strip configuration through clearcuts. Soil scarification and compaction can also be an artifact of timber practices which can be ameliorated by:

- carefully supervising machine operators (Jonkel 1978).

- using high-lead cable yarding systems (Zager et al. 1983).

- using single-end log suspension (Jonkel 1978, Mealey 1979, 1986).

- using horse logging and skidding (Jonkel 1982a).

\section{Slash Disposal}

Slash disposal can be accomplished mechanically by dozer piling, through the use of prescribed burns or by both methods. Slash not piled may physically hinder bear use of an area (Russell 1974, Smith 1978) or may limit establishment of bear foods (Bratkovich 1986). However, the merits of dozer piling are questionable for the following reasons (Table 33).

- increased soil scarification and compaction occur (Jonkel et al. 1978).

- if areas are to be burned later, unequal burn intensities and extreme temperatures may result in regeneration problems (Jonkel et al. 1978, Zager et al. 1983).

- $\quad$ o key shrubs may decline in areas where slash was piled before burning (Zager et al. 1983).

- dozer piling does not appear to aid in the establishment of desirable forbs and graminoids (Bratkovich 1986).

If piling is necessary:

- operators should use a brush blade to minimize disturbance of rhizomatic vegetation (Lyon and Basile 1980).

- use of light, rubber tired equipment will minimize soil compaction (Jonkel 1980a, Zager 1980a, Jonkel 1982a).

- piling should be limited to less than $20 \%$ on sites containing globe huckleberry (USFS 1985i).

- dozers should avoid areas where reasonable ground cover remains (Jonkel et al. 1978).

- dozer piles should be small and scattered throughout the cutting unit (Jonkel et al. 1978).

- hand piling may be feasible. Logs should be evenly distributed among size and decomposition classes and can be crisscrossed. Such piles should be distributed over $10-20 \%$ of the area at a fuel loading rate of 25-50 tons/acre (USFS 1982).

\section{Burning}

Slash can be broadcast burned or piled and burned. Because piling slash has several negative effects on regeneration (see previous section), broadcast burns are often recommended (Jonkel et al. 1978, Lyon and Basile 1980, Zager 1980a, Zager et al. 1983, USFS 1985) for the following reasons (Jonkel 1978, Jonkel et al. 1978, Zager 1980a, Servheen et al. 1981, Jonkel 1982a, Bratkovich 1986, Holland 1986):

- foraging opportunities for grizzlies are enhanced as broadcast burns encourage the growth of fruiting shrubs (Lyon and Basile 1980, Bratkovich 1986).

- slash accumulations pose fire hazards (Meyer 1978, Zager et al. 1983).

- slash accumulation may inhibit regeneration (Zager et al 1983). 
Table 33. Shrub revegetation response to 3 kinds of disturbance in 4 habitat types used by grizzly bears in north western Montana (from Zager et al. 1983).

\begin{tabular}{|c|c|c|c|c|}
\hline \multirow[b]{2}{*}{ Habitat type } & \multirow[b]{2}{*}{ Shrub species } & \multicolumn{3}{|c|}{ Change in \% canopy coverage } \\
\hline & & Wildfire & $\begin{array}{c}\text { Clearcuts, no } \\
\text { piled slash }\end{array}$ & $\begin{array}{l}\text { Clearcuts with } \\
\text { piled slash }\end{array}$ \\
\hline Subalpine fir/beadlily & $\begin{array}{l}\text { Amelanchier alnifolia } \\
\text { Cornus stolonifera } \\
\text { Shepherdia canadensis } \\
\text { Sorbus spp. } \\
\text { Vaccinium globulare } \\
\text { V. scoparium } \\
\end{array}$ & $\begin{array}{r}+0.2^{\mathrm{a}} \\
+14.5 \\
0 \\
+0.4 \\
-8.3 \\
+2.0 \\
\end{array}$ & $\begin{array}{l}+6.8 \\
-0.5 \\
-0.5 \\
-3.1 \\
-4.1 \\
-3.9 \\
\end{array}$ & $\begin{array}{r}-0.9 \\
-0.5 \\
-0.1 \\
-4.1 \\
-16.3 \\
-2.9 \\
\end{array}$ \\
\hline Subalpine fir/menziesia & $\begin{array}{l}\text { A. alnifolia } \\
\text { S. canadensis } \\
\text { Sorbus spp. } \\
\text { V. globulare } \\
\text { V. scoparium } \\
\end{array}$ & $\begin{array}{r}0 \\
-3.0 \\
+2.9 \\
+4.5 \\
+11.6 \\
\end{array}$ & $\begin{array}{r}0 \\
-3.0 \\
+8.1 \\
+4.9 \\
-2.4 \\
\end{array}$ & $\begin{array}{r}+3.0 \\
-2.5 \\
+0.2 \\
-10.3 \\
-1.9 \\
\end{array}$ \\
\hline Subalpine fir/beargrass & $\begin{array}{l}\text { A. alnifolia } \\
\text { S. canadensis } \\
\text { Sorbus spp. } \\
\text { V. globulare } \\
\text { V. scoparium }\end{array}$ & $\begin{array}{r}+7.9 \\
+0.5 \\
+0.8 \\
+11.8 \\
+4.3\end{array}$ & & \\
\hline Subalpine fir/wood rush & $\begin{array}{l}\text { Sorbus. spp. } \\
\text { V. globulare } \\
\text { V. scoparium }\end{array}$ & $\begin{array}{r}-0.9 \\
-0.3 \\
+3.4\end{array}$ & $\begin{array}{l}-1.3 \\
-5.3 \\
-5.8\end{array}$ & \\
\hline
\end{tabular}

aIncrease (+) or (-) in \% canopy cover on plots when compared with that on plots in undisturbed, old-growth stands in the same habitat.

\section{Regeneration}

Sites can be regenerated either naturally (by using natural silvicultural methods such as seedtree, selection cuts, etc.) or artificially either by seeding or planting (Eggers 1986). Within 5 years of logging, production of bear foods should increase (Meehan 1974). Moist sitka spruce, cedar/ hemlock and spruce/fir sites may produce adequate food and cover within 10 years of harvest while recovery on drier sites (douglas fir and ponderosa pine) may be much slower (Zager 1983). Recovery will also be retarded where soil scarification has occurred and may take up to 25 years on heavily scarified soils (Zager 1983). To enhance natural regeneration plans should incorporate seedtree, shelterwood or other selection regeneration methods; coordinate site preparation activities with cone crops (Eggers 1986) and increase cone production (Eggerrs 1986).

Where natural regeneration is not adequate, or where it is desirable to alter dominant species, artificial means can be used to reforest a logged area (Garcia 1986). Areas can be revegetated with grasses, legumes and shrubs (USFS 1985a).

Clover can be seeded to reclaim roads and landings (Servheen et al. 1981, Holland 1986) and riparian areas can be revegetated to improve or maintain water tables, resulting in stream stabilization and/or water spreading (USFS 1983b).

Herbicide treatments to control shrubs are available, but not advised as they eliminate berry plants (Archibald 1983, Zager 1983).

After logging operations have ceased, roads should be closed and revegetated (see Roads in this Compendium).
Bear populations should be monitored to determine if any logging has impacted populations (Perensovich 1984).

\section{Human Impacts}

Changes in human use of a logged area may be even more detrimental to grizzly bears than actual alterations in vegetation. Logging operations greatly increase access to, and therfore human use of, an area which may lead to increased grizzly/human interactions (Chadwick 1974, Meehan 1974, Russell 1974, Erickson 1976, Craighead 1980, Archibald 1983, Horejsi 1986). Activity in grizzly habitat can be changed by modifying road management plans and carefully following guidelines for camps. Suggestions are:

- modify road management (Erickson 1978, Jonkel et al. 1978, Jonkel 1982a, USFS 1983b, 1985i, Zager 1983, Horejsi 1986a) (see Roads in this Compendium).

- manage work crew camps to minimize garbage and conflicts within prime grizzly habitat (Perensovich 1966, Jonkel et al. 1978, Mealey 1979, 1986, Craighead 1980, USFS 1983b, 1985i, Perensovich 1984) (see Outfitters in this Compendium).

- inform timber managers and work crews of the possible risks associated with working in grizzly habitat (Perensovich 1966, Jonkel et al. 1978, Mealey 1979, 1986).

- include information on bear use and problems in each timber sale inspection report. 


\section{ROADS}

The USFS (1982) indicated that "the initiation of a viable road management plan is probably the most important factor influencing the long-term impacts on grizzlies in habitat influenced by timber harvesting." Elgmork (1978a) and Jonkel (1982a) report grizzly avoidance of roads and areas with high road densities. However, Almack (1986) found no significant difference between distance to nearest road measurements from bear locations and random points, while Erickson (1977) even suggests that grizzlies may use roads preferentially as travel corridors. Even if roads do not directly impact grizzly habitat, they allow easy human access to grizzly use areas (or adjacent areas) and provide travel corridors for bears into human developments and areas where bears will not be tolerated (Erickson 1977).

For all projects, existing and proposed roads should be evaluated by a biological review process to determine their potential for affecting grizzly bear habitat (USFS 1985a). In general, the road system should be limited to what is necessary to enhance and protect grizzly habitat (Meyer 1978).

\section{Road management criteria should:}

- minimize the number of miles of road needed to achieve each objective. Ruediger and Mealey (1978) suggest $<=1 \mathrm{mile} /$ square mile.

- maximize use of local roads, minimize use of arterials and collectors (USFS 1985g).

Road density can be managed effectively in three ways: careful planning of new roads and restrictions or closures of existing roads. These are discussed in detail below.

\section{Building New Roads}

Jonkel (1982a) suggests that new roads have the greatest impact on grizzlies because bears eventually avoid the surrounding area and a block of habitat is lost. All new roads should be constructed to facilitate their eventual closure and obliteration. Several suggestions for minimizing the impacts of new road construction follow:

- build roads to minimum specifications to discourage high use but maintain safety and environmental conditions (Zager 1980a, Jonkel 1982a, Contreras 1983, Zager and Jonkel 1983, Aune and Stivers 1985).

- minimize clearing widths, low cuts and fills; maximize diversity in horizontal and vertical alignment (USFS 1985abc):

$\checkmark$ - keep road clearance to what is necessary for construction (Contreras 1983, USFS 1985a).

$\checkmark$ - provide cover as close as possible on both road edges (Jonkel et al. 1981).

- delete $3 \mathrm{ft}$ paved shoulders (Jonkel et al. 1981).

- delete gravelled side slopes and ditches (Jonkel et al. 1981).

- store top soil for later use in restorataion. All unusable material should be moved from the area and disposed of properly (Contreras 1983).
- locate roads to avoid moist areas, ridgetops, saddles or creekbottoms as grizzlies use such areas for feeding and as travel corridors (Meyer 1978, Zager 1980a, Jonkel 1982a, Zager and Jonkel 1983).

- allow a buffer of $100 \mathrm{~m}$ between important grizzly use areas and new roads to provide adequate cover (Zager and Jonkel 1983, Aune and Stivers 1985). Wider buffer strips may ie necessary in open habitat or on steep slopes.

- reduce sight distances using "dog legs" or "crooks" (Jonkel 1982a, Zager and Jonkel 1983, Brannon 1984, Aune and Stivers 1985).

- avoid constructing "loop" roads as these are more heavily used by people (Jonkel 1982a, Zager and Jonkel 1983).

- schedule construction times to avoid seasonal use periods (Anonymous 1980).

- construct roads with takeoffs on cutbanks or steep slopesides to facilitate closure and obliteration (Contreras 1983).

- upper road reaches should be seeded with woody trees or shrubs to discourage bear use of roads as travel corridors (Erickson 1977).

\section{Road Closures}

Jonkel (1982a) suggests an aggressive road closure program of already established roads. Public education on the reasons for limiting access, and a strong enforcement program are essential to road closure programs. Roads which should be closed include:

- specified access roads should be closed after harvest and restocking (Ruediger and Mealey 1978, Contreras 1983, USFS 1985abc).

- temporary roads and landings should be obliterated allowing natural conifer regeneration or conifer restocking where shrubs are not suitable (Contreras 1983).

- collector roads should be closed except for emergencies or harvest re-entry (Contreras 1983).

- local roads should be closed within 1 season after use (Contreras 1983).

- "loop" roads should be closed when possible (Zager and Jonkel 1980).

- $\quad$ seismic trails and roads created during seismic operations should be closed after operations have ceased (Aune and Stivers 1983).

Open road densities should be reduced as determined in the biological evaluation. This generally involves closure of all local roads resulting in an average density not to exceed .75 miles/section (USFS 1985g). The Gallatin National Forest, Proposed Forest Plan (USFS 1985b) recommends density levels equivalent to $>80 \%$ elk habitat effectiveness (the measure of how road density effects elk habitat) in Situation 1 areas and $>60 \%$ in Situation 2 (as density increases, habitat effectiveness decreases).

Roads can be closed by physical barriers, gates or other means (Anonymous 1980, USFS 1985g, Holland 1986) but permanent closure with obliteration is more effective than 
just posting or gating the road (Jonkel 1982a, Zager and Jonkel 1983). The Bridger-Teton Forest Plan (Contreras 1983) specifies alterations to be made on closed roads. These include:

- obliterate roads, including scarification, waterbarring and revegetation of exposed soil.

- pull downfall back over the road.

- operate equipment carefully during restoration to protect adjacent shrubs and trees.

- reshape a length of the roadbed to natural conditions to reduce road visibility from open roads.

- pull culverts and remove bridges.

\section{Road Use Restrictions}

When roads cannot be permanantly closed, restrictions can be placed on their use to minimize disturbance to grizzlies. Road restrictions other than permanant closure can be (Ruediger and Mealey 1978):

- closed permanantly to the public, regulated use by park or forest personnel.

- regulated use by park or forest personnel, intermittently open for public use.

- intermittently open to both the public and park or forest personnel.

Restrictions might include:

- seasonal closing if grizzly use is seasonal (USFS 1983b, 1985a).

- opening roads for short time periods such as for wood cutting (USFS 1983b, 1985b).

- limiting nonessential traffic during logging operations (Zager and Jonkel 1983).

- $\quad$ restricting speed using speed bumps and strict enforcement (Jonkel et al. 1981).

In addition to careful management of existing and potential road systems, roadless timber harvest alternatives such as long distance skidding, aerial yarding, helicopter logging and use of helicopters in energy exploration should be encouraged (Ruediger and Mealey 1978, Anonymous 1980, Contreras 1983).

\section{RECREATION}

Recreational use of public lands, both consumptive and nonconsumptive, is increasing and wild land users are penetrating into more remote areas (Schallenberger and Jonkel 1979). Public use of backcountry may be detrimental to grizzly bear populations and will almost certainly create grizzly/human conflicts. Recreational camping increases the availability of food and garbage and camps are often located in prime grizzly use areas such as stream and river bottoms (Schallenberger and Jonkel 1980). In some areas, hunting pressure and nonconsumptive uses of grizzlies (i.e., observing, photographing) may allow direct impacts to bear populations in the future (Anonymous 1980). To promote visitor safety, and reduce the risks of grizzly bear mortality, National Parks and Forests are providing public education programs, regulating campgrounds, campsites and other recreational facilities and restricting visitor use of certain areas. All campgrounds, campsites, picnic areas, trails, roads, visitor centers, proposed resorts, cabins and base camps should be evaluated for their compatibility with grizzly management objectives (Table 34) (USFS 1982, 1985abc).

\section{Campground/Campsite Management}

Public education may be the most effective method of managing campgrounds and backcountry campsites. Information should be distributed to the public about proper food and garbage storage and removal and appropriate camping practices (USFS 1982, 1985abc, Brannon 1984). Campgrounds should be kept clean and free of food and refuse and should be located away from prime grizzly habitat (Schallenberger and Jonkel 1980). Specific recommendations for campground/campsite management are:

- food and food odors should be kept away from sleeping areas (Schallenberger and Jonkel 1980).

- traditional campsites should be avoided in grizzly habitat as bears may have become habituated to such areas (Schallenberger and Jonkel 1980).

- tent camping should be encouraged over sleeping in the open with no protection. Although a tent while not provide safety from marauding bears, it may act as an early warning device (Schallenberger and Jonkel 1980).

- use of established, nondeveloped, campsites should be adjusted to prevent odor buildup and/or habitual use by grizzlies (USFS 1982, 1985abc).

- only essential facilities should be developed at designated campsites and minimal public facilities should be provided at popular locations (USFS 1985i).

- solid waste disposal facilitites should not be provided at campgrounds; all solid waste should be packed out (USFS 1985i).

- garbage containers at developed campgrounds should be made bearproof and garbage pickup should occur frequently to prevent odor buildup or spillage (USFS 1982, 1985abc).

- recreational cabins create problems through improper food and garbage handling and storage (Schallenberger and Jonkel 1980). All cabins should be bearproofed in grizzly bear country (Zager and Jonkel 1980).

\section{Trails and Backcountry Management}

Roads and trails are usually constructed to follow the easiest travel routes through backcountry areas. Likewise, these travel routes are preferentially used by other wildlife, including grizzly bears (Schallenberger and Jonkel 1980). Roads and trails should be evaluated for their impact on grizzly bear habitat quality. Specific recommendations for regulating trail and backcountry use are:

- provide signs at trailheads and backcountry sites identifying grizzly habitat and recommending appropriate human conduct (USFS 1982, 1985abc). 
Table 34. Management actions and monitoring levels following bear sightings and/or incidents in the Targhee National Forest (Matejko 1985).

\begin{tabular}{|c|c|c|c|c|c|c|}
\hline & \multicolumn{6}{|c|}{ Management Situation 1} \\
\hline & \multicolumn{3}{|c|}{ Sighting } & \multicolumn{3}{|c|}{ Incident } \\
\hline & $>2$ miles & $<2$ miles & on site & $>2$ miles & $<2$ miles & on site \\
\hline Campgrounds & A. 3 & A - 2 & $\mathrm{C}-2$ & $\mathrm{C}-1$ & $\mathrm{C} \cdot 1$ & $\mathrm{C}-1$ \\
\hline Summer Home Areas & - & - & - & - & - & - \\
\hline Dispersed Recreation & A -3 & $\mathrm{~A}, \mathrm{~B}-2$ & $\mathrm{~A}, \mathrm{~B}, \mathrm{C}-2$ & $\mathrm{C}-1$ & $\mathrm{C}-1$ & $\mathrm{C}-1$ \\
\hline Timber Harvest & A -3 & $\mathrm{~A}, \mathrm{~B}-2$ & A,B,C-2 & C - 1 & C - 1 & $\mathrm{C}-1$ \\
\hline Outfitter-Guides & A -3 & $\mathrm{~A}, \mathrm{~B}-2$ & $\mathrm{~A}, \mathrm{~B}, \mathrm{C}-2$ & C - 1 & C - 1 & $\mathrm{C}-1$ \\
\hline Firewood Areas & - & - & - & - & - & - \\
\hline Livestock Grazing & - & - & - & - & - & - \\
\hline
\end{tabular}

Management Situation 2

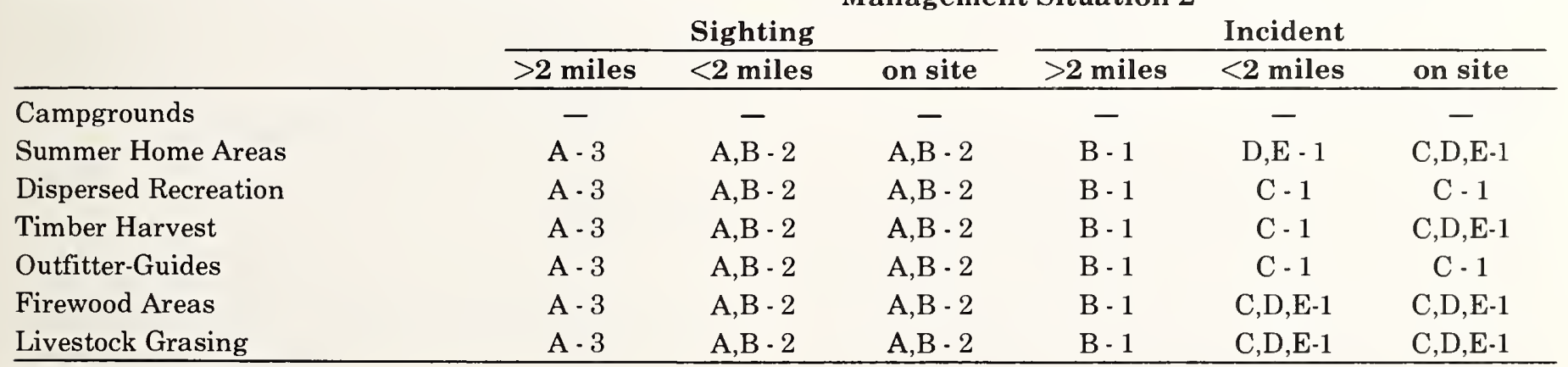

Management Strategies

A - Personal Contact, alert to bear(s) presence, check for compliance regulations

$\mathrm{B}-$ Close area to tent camping

$\mathrm{C}-$ Close area until bear status is resolved

D - Consider use of repellents (noise or electric fence) or baiting with approval of the IGBC to avoid human/bear incident

E - Trap and relocate bear(s) if situation meets GYE Guidelines for nuisance status

Monitoring Levels

1 - Intensive - Continuous, while bears are active

2-Moderate - Daily: morning and evening locations

3 - Limited Daily aerial flight or ground check for location
- trails or backcountry sites with a history of grizzly/human encounters and a documented increase in grizzly use may be closed temporarily in Management Situations 1 and 2 or permanently in Management Situation 1 (USFS 1982, 1985abc).

- when grizzly bear tolerance levels have been exceeded, backcountry use can be restricted through permit systems or reevaluation of commercial uses (USFS 1982, 1985abc).

- backcountry travel may be restricted to large parties (4+ people), parties on horseback or parties with motorized vehicles as most grizzlies avoid larger (and noisier) groups (USFS 1985b).

\section{Consumptive Recreational Use Management}

Recreational hunting is the primary consumptive use of grizzly bears throughout Alaska (Anonymous 1980). As hunting pressure increases, stronger regulations may be imposed to affect the number of hunters, season lengths and transportation methods. Such regulations can be properly used to allow an optimum sustained yield (see Harvest Strategies in this Compendium). In areas where harvesting grizzlies is not permitted, accidental mortality may still affect grizzlies populations. The following steps can be taken to reduce the risk of hunter induced grizzly mortality:

- eliminate the spring black bear season in grizzly habitat as untrained hunters may mistake a small 
grizzly for a black bear (Schallenberger and Jonkel 1980).

- provide information to hunters on distinguishing black and grizzly bears (USFS 1982, 1985abc).

- modify black bear hunting regulations to reduce or avoid areas or times when they may conflict with grizzly use of an area (USFS 1982, 1985abc).

- issue special warnings to hunters in grizzly bear country (USFS 1982, 1985abc).

- provide anglers with information about grizzly use of streams and other riparian zones. Anglers should avoid fostering fish odors (Schallenberger and Jonkel 1980).

- hunters should keep camps clean and store game meat appropriately (see Outfitters in this Compendium).

\section{GRAZING}

The "Interagency Grizzly Bear Guidelines" state that grazing activities which adversely impact bear populations or their habitat will not be permitted in Management Situation 1 areas and establish conditions to ensure that grazing activities are compatible with grizzly management objectives. They specify that the bear population must not be reduced, bears must not become conditioned to livestock as food and livestock management must not interfere with the grizzly bears natural activities (USFS $1985 \mathrm{e})$.

Proposed livestock and ranching operations within grizzly habitat will be evaluated for such impacts (Mealey 1979,1986 , USFS 1983b, 1985abc) before permits are issued. Specific problems encountered with livestock in grizzly habitat include:

- livestock competition for early spring browse (Servheen et al. 1981).

- livestock trampling and degradation of wetland sites used by bears (Servheen et al. 1981). Livestock may reduce the vigor or destroy fruit producing shrubs by compacting soil on wetland sites (Jonkel 1982a).

- attraction of bears to livestock and livestock boneyards increases their vulnerability to man-caused mortality as they become habituated to killing livestock (Johnson and Griffel 1982).

Range management plans in grizzly habitat should specify measures to protect (partially, or fully, depending on the management situation) important grizzly bear use areas (Mealey 1979, 1986, USFS 1982, 1983b, 1985bc). Where conflicts arise between grazing operations and grizzly objectives, adjustments will be made in favor of grizzly conservation in both Situations 1 and 2 (Mealey 1979, Contreras 1983, USFS 1982, 1985aabc, Knight and Judd (int. conf.)). General management guidelines for grazing allotment plans will:

- reflect the ecological needs of the grizzly bear.

- specify measures to meet Forest Service grizzly management objectives (Mealey 1979, 1986, USFS 1983b, 1985i).
- designate areas to be grazed and their season of use (Orme and Williams 1986).

- evaluate the potential for grizzly/livestock conflict (USFS 1985).

- include a clause for cancellation of permits if conflicts cannot be resolved (Mealey 1979, 1986, USFS 1983b, 1985i).

Specific suggestions for minimizing livestock damage to grizzly use areas include:

- regulate the number of livestock and season of use in important grizzly feeding, loafing and travelling areas (Summerfield 1978, Mealey 1979, 1986, Jonkel 1982, Zager and Jonkel 1983, USFS 1983b).

- defer livestock grazing in important spring habitat until after June 15 (Servheen et al. 1981) or July 1 (Aune and Stivers 1982, 1985, USFS 1985c).

- use a rotation grazing system (Summerfield 1978 , Contreras 1983).

- exclude cattle from sensitive grizzly areas (Mealey 1979, 1986, USFS 1983c, 1985abc).

- exclude cattle from clearcuts (Meyer 1978, Contreras 1983).

- fence riparian areas to exclude livestock if turnout date is prior to $1 \mathrm{July}$ (Mealey 1979, 1986, Servheen et al. 1981, Aune and Stivers 1985). Drinking and crossing areas should be placed to avoid bear use areas.

- $\quad$ protect areas of aspen regeneration; do not allow grazing of aspen seedlings in more than 1 out of every 3 years (Contreras 1983).

- seed erosion areas and protect from damage by fencing or placement of slash and logs (Summerfield 1978).

- manipulate habitat by burning to maintain transitional habitat for both grizzlies and cattle (Summerfield 1978) (see FIRE in this Compendium).

- close roads not essential for grazing allotments (see $R O A D S$ in this compendium) (Summerfield 1978).

Riparian areas - including streamsides, seeps and springs and mesic stands of aspen are especially important to grizzlies and may also receive a high level of grazing use. The Forest Service suggests designating streamsides as distinct management areas for specific grazing practices. Their recommendations follow:

- streamside pastures may benefit most from a deferred rotational grazing system or may require complete rest to restore damaged vegetation.

- utilization or trampling of grizzly food plants (especially succulent herbs, starchy roots and fruiting shrubs should not exceed $40 \%$ of what is available.

- $\quad$ streambank stability should be maintained for at least $80 \%$ of the linear distance along streamsides.

- stock driveways and herding areas should be kept away from streamsides. 
- diet supplements (salt/mineral blocks) and shade trees should be used to draw livestock away from streams.

Bear depredation of livestock is a problem where rangeland overlaps important grizzly use areas or where poor range practices attract bears to grazing allotments. Management practices designed to minimize bear depradation on livestock are listed below:

- only qualified herders should be used in grizzly habitat (USFS 1981).

- camps should be maintained in conditions that reduce the chances of attracting bears; food and garbage should be made unavailable (Griffel 1978, Lee and Weaver 1981, Servheen et al. 1981, Franklin and Matejko 1983, USFS 1983b, 1985bc) (see Outfitters in this Compendium).

- bedding grounds should be changed at least every 2-3 days and preferrably each day; traditional bedding grounds should be avoided (Lee and Weaver 1981, Mehrhoff 1981, Griffel 1982, Franklin and Matejko 1983).

- herders should maintain tight groups so that sheep become conditioned to not leaving bedding grounds without herder initiation (Mehrhoff 1981, Griffel 1982).

- herders should "teepee out" with their herd (Griffel 1978, Lee and Weaver 1981, Mehrhoff 1981, Franklin and Matejko 1983).

- allotment plans should specify measures for removal and treatment of livestock carrion and boneyards (Griffel 1978, Mealey 1979, 1986, Servheen et al. 1981, Aune and Stivers 1982, 1985, Zager and Jonkel 1983, USFS 1982, 1983b, 1985b).

- carcasses should be removed immediately after death (Servheen et al. 1981).

- carcasses may be treated chemically, although close monitoring for chemical impacts must take place (Servheen et al. 1981).

- diseased livestock should be confined away from houses, livestock enclosures and calving grounds, but should not be abandoned to be "cleaned-up" by bears (Jonkel 1982a, Zager and Jonkel 1983).

- an electric fence can be used to keep bears away from sheep (Matejko and Franklin 1983).

- monitoring level should be intensive; areas should be searched for bear sign before entering and after leaving; sheep losses should be noted and reported (Griffel 1978, Summerfield 1978, Mehrhoff 1981, Franklin and Matejko 1983, Matejko 1985, USFS 1985, Orme and Williams 1986).

Where depredation has occurred, options range from changing herding practices to removal of the nuisance bear. Specific suggestions follow:

- season of livestock use, bedding practices or grazing area should be changed (Mealey 1979, 1986, USFS 1982, 1983b, 1985be).

- berry patches which often occur on steep, brushy slopes and are generally unsuitable as sheep range should be avoided (Jorgenson 1983).
- livestock should be moved to another part of the allotment (USFS 1985b).

- livestock should be moved and allotments should be closed (Mealey 1979, 1986, Mehrhoff 1981, Lee and Weaver 1981, Servheen et al. 1981, Johnson and Griffel 1982, USFS 1982, 1983b, 1985b, Matejko 1985, Orme and Williams 1986); restock only after the allotment has been reevaluated.

- livestock class should be changed from sheep to cattle if the range is suitable; sheep are more susceptible to bear predation. Move sheep outside Management Situation 1 sites (Knight and Judd 1978, Lee and Weaver 1981, USFS 1982, 1985b).

- a monitoring system should be implemented (Mehrhoff 1981, USFS 1982, 1985b, Orme and Williams 1986).

- portable corrals, sheep protecting dogs or other aversion methods should be used (Jorgenson 1983).

- the grizzly should be relocated away from the allotment if it is determined to be a nuisance (i.e., if the bear follows sheep after they have been relocated to another area of the alottment resulting in 2 or more attacts) (USFS 1985b).

- use repellents and baiting only with IGBC approval (Matejko 1985). Alternate management methods, less acceptable, or feasible include:

- converting sheep allotments to cattle allotments because of unsuitable terrain, forage or fencing costs (Lee and Weaver 1981).

- damage payments to permit holders for bear depredation (Lee and Weaver 1981).

- shooting or governmental trapping of nuisance bears (Lee and Weaver 1981):

- a unit should be closed if a herder shoots or shoots at a bear (Mehrhoff 1981).

- permittees should not use traps, snares or poison to control black bear predation as these may accidentally take grizzlies (Lee and Weaver 1981, Matejko and Franklin 1983, USFS 1985b, Orme and Williams 1986).

- hazing bears (Matejko and Franklin 1983, USFS 1985b).

Grazing permits will include a statement warning that any violation of the ESA (including shooting a grizzly) would be grounds for cancelling the permit (Summerfield 1978, Lee and Weaver 1981, Orme and Williams 1986).

\section{SUBDIVISION}

Housing construction in bear habitat inevitably creates conflict. Because bears are not inhibited by the presence of subdivisions in their traditional habitat as long as surrounding cover is available, the introduction of man. related foods (garbage, swine, fruit trees and livestock) often leads to behavioral changes in the bears and related human/bear confrontations (Jonkel et al. 1978, Servheen et al. 1981). Habituation to man, with concurrent behav- 
ioral chanages, can be passed down through maternal training and thus will continue until the offending bear is moved or eliminated. The best way to minimize such conflicts is to identify potential development areas (Servheen et al. 1981) and allow wildlife agencies to review subdivision plans (Johnson and Jonkel 1976). However, these lands are private, and are not subject to any direct agency management requirements. Thus, the management strategies available for private lands are:

- zoning (although this has not generally met with acceptance).

- conservation easement of important habitat.

- acquisition (the Nature Conservancy and other organizations have been active in acquiring ecologically significant habitat) (Servheen et al. 1981).

Floodplains are popular for subdivision construction, particularly in mountainous areas where other large, flat expanses of land are unavailable. Jonkel et al. (1978) suggest that subdivisions on floodplains in the North Fork Ranger District of Montana will permanantly alter grizzly use of these areas. They indicate that housing developments will reduce bear use of riparian feeding sites, reduce travel cover for bears moving through the area, reduce general "roaming" areas and cause a dramatic increase in grizzly/human conflicts. This suggests that cabin and subdivision construction should be discouraged in sensitive grizzly use areas, particularly riparian areas and travel corridors such as creek bottoms, ridgetops, narrow canyons and timber corridors (Zager and Jonkel 1980). In areas where human development and grizzly habitat already overlap, subdivisions should be managed in cooperation with landowners to minimize attractive foods near residences. Specific recommendations are:

- remove fruit trees or harvest fruit in a timely manner (Servheen et al. 1981).

- remove or incinerate garbage quickly (Zager and Jonkel 1980).

- $\quad$ store odiferous foods in jars or metal containers; do not leave food in unattended cabins unless it is properly stored (Zager and Jonkel 1980).

- use discretion when feeding dogs bones, meat scraps, etc. (Zager and Jonkel 1980).

An effective public relations program should also be initiated to explain the importance of low elevation habitats to grizzlies (Servheen et al. 1981).

\section{FIRE}

Management practices that encourage fire suppression have substantially altered the natural succession of many western forests (Lee and Jonkel 1981, USFS 1985e Holland 1986). In most cases, the elimination or reduction of early successional stages has had a negative impact on grizzly bear habitat, particularly on grizzly food production (Martin 1980, Zager 1980a, USFS 1983b, Zager et al. 1983, Holland 1986). Mesic sites have been particularly affected by fire suppression. Natural fire frequency appears necessary to maintain or expand habitat components positively influenced by burning (Mealey et al. 1977, Mealey 1979,
1985, USFS 1983b). New let-burn policies and management prescription burns will simulate traditional fire regimes and allow the growth of seral shrub stages that are more compatible with grizzly bear requirements (Davis et al. 1976, Mealy et al. 1976, USFS 1985a). These new policies are often applicable in wilderness areas. Forest fire guidelines in wilderness areas permit lightning caused fires to burn and allow prescribed burns to reduce levels of fuel in excess of that which would exist before fire suppression regimes (USFS 1985e).

The evaluation of fire management activities by Forest Service district rangers or biologists can ensure that grizzly bear requirements are considered in management plans (USFS 1982, 1985abc). Forest level fire management plans should be developed to incorporate prescribed burning as a management tool where it can benefit grizzly habitat and not conflict with other resources (e.g., watersheds, old growth, regulated timberlands) (USFS 1985a). Planned ignitions may become necessary where lightning fires do not occur frequently enough, or where the risks of allowing unplanned fires to burn are unacceptable. Unplanned fires in areas where excessive fuel has accumulated due to historic fire suppression may result in single age class stands which provide less habitat diversity for grizzly bears.

Prescribed burning can be used to improve grizzly habitat both as a direct habitat management technique and as a site preparation technique, particularly at higher elevation sites not managed for timber production (Mealey et al. 1977, Martin 1980, Mealey 1979, 1985, USFS 1983b, $1985 \mathrm{ab}$ ). Such activities should be scheduled during seasons and at times of low grizzly activity (USFS 1982, 1983b) and security areas should be provided immediately adjacent to burn activities (USFS 1985b). Prescribed burning can be used as a tool to:

- approximate natural fire frequency (USFS $1983 \mathrm{~b}$, 1985b).

- reduce conifer litter, release nutrients tied up in the litter and rejuvenate plants (Zager 1980a).

- create openings which support berries, bulbs and other important grizzly foods (USFS 1985ae).

- reverse the loss of seral brushfields by reducing conifer encroachment (Zager et al. 1983, Holland 1986).

- convert old, decadent stands of whitebark pine to younger age classes (Eggers 1986).

Burning will be beneficial in improving grizzly habitat in:

- mesic, montane sites (Zager et al. 1983).

- WBF/AF, AF/LUHI/MEFE, AF/LUHI/VASC, and AF/XETE/VAGL habitat types (Mealey et al. 1977).

- $\quad$ whitebark pine stands (Eggers 1986).

- subalpine fir/whitebark pine, pine/grouse whortleberry and subalpine fir/huckle berry habitat types (USFS 1985b).

- aspen and willow stands (when maintenance of stand dominance is desired) (USFS 1985bi).

- $\quad$ ABLA-PIAL/VASC habitat types (USFS 1985b). 
Garcia (1986) presents a detail summary of fire management activities conducted on Kootenai National Forest. Several successful projects are described as to procedures, costs and personnel.

For fire crew safety, the following procedures are recommended:

- Fire management contractors should be informed when working in bear country (USFS 1985b).

- Temporary living facilities should be closely monitored; refuse removal will be required by all contracts (USFS 1985abc) (see Outfitters in this Compendium).

\section{MINING, OIL AND GAS DEVELOPMENT}

Current research shows that limited energy and mineral development can take place in grizzly use areas without adverse affect on grizzly bears (USFS 1980). Mineral, gas, oil and geothermal exploration require operating plans and special use permits which must include specific measures to protect, maintain or improve grizzly habitat where applicable (USFS 1979, 1983b, 1985b). Permits must include a provision for cancellation or temporary cessation of activities if deemed necessary to prevent conflicts with grizzlies.

Exploration/development activities which would adversely affect grizzly populations or habitat quality, or quantity, will not be permitted in Management Situation 1 areas and should be avoided in Management Situation 2 areas (USFS 1979, 1983b, 1985b). Adverse impacts include:

- land surface disturbance.

- water table alteration.

- reservoirs, rights-of-ways, roads, pipelines, landings, transmission lines or other structures.

- increased availability of human food.

- reduced availability of natural food.

Oil, gas and mineral exploration/development operations may be compatible with grizzly management if the following conditions are adhered to:

\section{Seasonal or Temporal Constraints}

In general, activities should occur at a time or season of little biological importance to grizzly bears (mid-summer and winter months) (USFS 1979, 1980, 1983b, 1985b, Zager and Jonkel 1980, 1983). Pipeline activity/construction should be restricted to periods of low bear activity (Aune and Stivers 1983). Seasons during which activity should be avoided are:

- denning season (approximately mid-October through mid-May) (USFS 1980, Aune and Stivers 1982, Aune and Stivers 1983, Schoen et al. in press a).

- no seismic activities or drilling should take place within 2 miles of den sites between 15 October and 15 April (Aune and Stivers 1982, 1983).
- activity should be prohibited within 1 mile of identified denning habitat from 15 November10 May (USFS 1980).

- seismic lines travelling through denning habitat or within 1 mile on either side should not be run until after den emergence (approximately May 10) (USFS 1980).

- den entry (October - mid-November) (Schoen et al. in press a).

- den emergence (April-May) (Schoen et al. in press a).

- breeding season (April 1 - 30 June) (USFS 1980, USFS and BLM 1985).

- 10 days prior to the start through the end of big game hunting season (USFS 1980).

Other recommendations for reducing energy development impacts on grizzly bears by means of temporal restrictions are:

- $\quad$ seismic activity should be postponed if den monitoring indicates that family groups remain in the area (USFS 1980).

- drilling schedules can be staggered on adjacent sites to provide a disturbance-free zone for displaced bears (Aune and Stivers 1983, USFS 1985c).

- helicopter flights and blasting should take place only between 1 hour after sunrise and 1 hour before sunset (Aune and Stivers 1983).

\section{Location of Activities}

Field operation centers should not be placed in seasonally important habitat (Aune and Stivers 1983). Specific spatial considerations for energy exploration in grizzly habitat are:

- seismic lines should be located away from wallows, mineral licks, water holes, bedding sites, nests and dens (USFS 1980).

- concurrently active seismic lines should be spaced at least 8-10 air miles apart to provide a disturbance free zone for displaced animals (Aune and Stivers 1982, 1983, 1985):

- lines should be separated by a topographic screen or other cover (Aune and Stivers 1982). McLellan and Mace (1985) found that bears were not displaced by seismic activity if they were in cover.

- survey crews from one line can work between active lines (Aune and Stivers 1982).

- directional drilling and remote mine mouths can be used in sensitive areas (Zager and Jonkel 1980, 1983).

- reserve pits can be fenced or flagged (USFS 1979).

\section{Waste Disposal}

Solid waste disposal transfer stations should be made compatible with grizzly management objectives (USFS $1985 \mathrm{~b}$ ) and the integrity of aquatic systems and riparian 
zones should be maintained. All waste water associated with drilling should be disposed of in an approved manner (USFS 1979, 1983b). Lessees will be responsible if systems are polluted or damaged (USFS 1979, 1983b).

\section{Roads}

Road management plans should be integrated in the operations plan (Zager and Jonkel 1980, 1983, Aune and Stivers 1985, USFS 1985b) (see ROADS in this Compendium). Specific recommendations are:

- minimum road standards should be used (USFS 1983b, Aune and Stivers 1985, Horejsi 1986a).

- roads should be located to avoid important bear use areas (Aune and Stivers 1985).

- road construction should be scheduled to minimize disturbance seasonally (Aune and Stivers 1985).

- roads should be single purpose and closed to the public (USFS 1979, Aune and Stivers 1983, 1985).

V. roads should be reclaimed using native plants where possible after operations cease (USFS 1979, $1983 \mathrm{~b}$, Aune and Stivers 1983, 1985).

\section{Alternatives to Roads}

There are several alternatives to road construction for servicing mineral exploration areas. These include:

- servicing well heads by helicopter to reduce road construction (Aune and Stivers 1985, Horejsi 1986a). However, as aircraft may disturb grizzly bears and their habitat, requirements for helicopter use are:

- establish helicopter flight patterns before flying (Aune and Stivers 1983, USFS 1985c) (See Aircraft in this Compendium).

- locate flight corridors to avoid seasonally important grizzly habitat; breeding areas (1 May - 1 July), denning areas (15 October - 15 April) and open alpine areas (1 July - 15 September).

- make flight corridors no more than $1 / 2$ mile wide along seismographic lines, between landing zones and lines and between landing zones and other operations unless safety precludes this (Aune and Stivers 1985).

- well facilities can be operated by computer (Horejsi 1986a) and monitored using telemetry (USFS and BLM 1985) to reduce the need for accessing the well site.

\section{Camps}

Off-site camps should be encouraged, but on-site camps can be made compatible with grizzly management objectives if camp regulations are carefully followed (Zager and Jonkel 1980, 1983, USFS 1985bc) (see Outfitters in this Compendium). A brief summary of camp regulations follows:

- food should be properly stored.
- garbage should be disposed of properly (USFS 1979, 1985bc).

- dogs should be prohibited from camps (Aune and Stivers 1985).

- firearms should be prohibited from camps (Zager and Jonkel 1980, 1983, Aune and Stivers 1985, Horejsi 1986a).

- camps should be located a way from riparian areas or other known or suspected travel routes (Zager and Jonkel 1980, 1983).

- crews can be bussed to, and from, camp and drill sites to minimize activity (Zager and Jonkel 1980, 1983, Aune and Stivers 1985).

\section{General}

Other general recommendations for making energy exploration compatible with grizzly bear management objectives are:

- hunting should be prohibited in exploration areas (Zager and Jonkel 1980, 1983, Aune and Stivers 1985, Horejsi 1986a).

- $\quad$ permit holders should log their daily activities to assess wildlife impacts (Aune and Stivers 1983). Records should be kept on shift change times, shut down/start up times, changes in noise or activity levels, and location of seismic crews (Aune and Stivers 1985).

- noise levels should be kept to a minimum by muffling engines, generators and production facilities (Aune and Stivers 1985).

- drilling pads and other areas in Management Situation 1 denuded by mining exploration should be reclaimed by lessee as directed by the Forest Service (USFS 1983b).

\section{AIRCRAFT}

While little information is available about the direct effects of air traffic on grizzly bears, studies of brown bears in Alaska indicate that aircraft disturbance may be a sig. nificant problem, particularly in areas where helicopters are used as alternatives to new road construction and for logging and energy exploration/development (Aune and Stivers 1980). Heavy helicopter traffic may disturb bears particularly during the denning season (Schoen et al. in press a). Suggestions for minimizing aircraft disturbance are:

- minimize traffic during the denning period, particularly during den entry (October - midNovember) and emergence (April - May) (Schoen et al. in press a).

- schedule helicopter flights between 1 hour after sunrise to 1 hour before sunset from 15 April to 15 October (Aune and Stivers 1982, 1983).

- maintain a minimum helicopter altitude of $183 \mathrm{~m}$ $(600 \mathrm{ft}$ ) (Aune and Stivers 1980). 
- establish helicopter flight patterns of less than $1 / 2$ mile width along all seismic lines, between landing zones and between landing zones and other operations except where flight safety precludes this (Aune and Stivers 1980).

- designate landing zones with adequate visual or topographic barriers (Aune and Stivers 1980).

Helicopter use, while discouraged in wilderness settings, may become necessary to move bears for genetic, demographic or behavioral purposes. Helicopters will not be permitted in wilderness areas unless it is deemed to be the only feasible method to meet grizzly recovery objectives (USFS 1985).

\section{CUMULATIVE EFFECTS ANALYSIS}

Cumulative effects has been defined as "the combined effect upon a species or its habitats caused by the activities or programs at hand, as well as other reasonably foreseeable events which are likely to have similar effects upon that species or its habitats" (Weaver et al. 1985, USFS 1986). Such effects can result from "individually minor but collectively significant events taking place over time" (Weaver et al. 1985, USFS 1986). Cumulative effects analysis (CEA) is "an assessment of how the combination of natural processes and events and man's activities cause resources and environmental conditions in an area to change over time" (Salwasser and Sampson 1985). It has becoming an integral part of evaluating the impacts of man's activities on grizzly bears and grizzly bear habitat both temporally and spatially (Hadden and Jonkel 1983, Christensen et al. 1984, 1985, Salwasser and Samson 1985).

The purpose of cumulative effects analysis is to help managers make optimal land use decisions and allow them to simulate additive, as well as individual effects of various activities. It serves as a resource assessment and prediction tool for agencies (Hadden and Jonkel 1983, Salwasser and Samson 1985). Specifically, it can be used to:

- analyze the effects of existing and proposed activities on grizzly bear habitat (Christensen and Madel 1982).

- serve as a tool for coordinating diverse land man. agement activities to provide adequate habitat for bears (Christensen and Madel 1982).

- provide a method of comparing watersheds (quantitatively and cartographically) (Christensen and Madel 1982).

- provide recognizable boundaries for managing bears (Christensen and Madel 1982).

- help managers identify permit requirements, schedule demands and identify constraints necessary to preserve important grizzly habitat while meeting other resource needs (Christensen et al. 1985).

- $\quad$ set upper and lower limits of grizzly spatial needs (Christensen and Madel 1982).
- help managers determine which land uses contribute the most to cumulative effects and whether habitat per se, habitat use or grizzly survivorship is influenced (Christensen et al. 1985).

Criteria for focusing CEA procedures are to recognize all ongoing management activities which may impact grizzlies (Christensen and Madel 1982), address a large enough area to encompass all major factors affecting grizzlies (Salwasser and Samson 1985), but consider only major causes and effects (Salwasser and Samson 1985) and distinguish between natural and man-induced causes and effects (Salwasser and Samson 1985).

Christensen et al. (1985) identified the following steps needed to carry out a CEA:

- $\quad$ identify and quantify habitat both spatially and temporally.

- quantify the effects of forest uses.

- define a procedure to measure these combined effects (for example, scoring systems).

- relate the results of the CEA to grizzly bear population viability and recovery.

Cartographic modelling has been used in some CEA appraisals (Winn and Barber 1986). A cumulative effects model of this type can enhance management decision by providing managers with a quantified and graphic representation of habitat values and mortality risks for existing and potential situations (USFS 1986). Mapping of all available grizzly habitat, habitat components and CEA data has also been identified as a priority by Christensen and Madel (1982), Haddon and Jonkel (1984) and Christensen et al. (1983). They indicate that mapping should:

- identify components on the basis of bear foods and den site availability (Christensen and Madel 1982, Christensen et al. 1985).

- describe other important factors such as cover and isolation (Christensen and Madel 1982).

- provide overlays which depict road access, zones of influence, land management activities, recreational and mineral activities and other influences which impact grizzly habitat (Christensen et al. 1985).

- divide habitat into subunits based on USFS Management Situation stratification to (Weaver et al. 1985, Winn and Barber 1986):

- assess existing and proposed activities without having the diluting effect of an overly large area (Weaver et al. 1985).

- match individual bear-use patterns and habitat ecology (Weaver et al. 1985).

- prioritize areas where management would require CEA (Weaver et al. 1985).

- calculate subunit habitat values according to the value of the following habitat components (Weaver et al. 1985):

- presence of ungulates.

- presence of trout spawning streams. 
- interspersion of forest and nonforest components.

- equity of seasonal feeding opportunities.

- habitat diversity.

The Greater Yellowstone Ecosystem and the Rocky Mountain Front cumulative effects models consist of 3 submodels (USFS 2986, Winn and Barber 1986); habitat the capacity to support bears based on food, cover and edge indices; displacement - the measure of grizzly bear's ability to use the area based on human activity; and mortality an assessment of the grizzly mortality risks associated with human activities.

The habitat submodel is designed to indicate year long habitat quality and includes information on (Weaver et al. 1985):

- food and thermal cover.

- habitat diversity.

- seasonal equity.

- denning suitability.

The displacement submodel quantifies the displacement effects associated with human use and activities on grizzly bear ability to use an area (USFS 1986). It includes data on (Weaver et al. 1985):

- type of activity - motorized, nonmotorized, explosive.

- nature of activity - linear, point, dispersed.

- length of activity - diurnal, 24 hour.

- disturbance intensity - high vs. low.

The mortality submodel quantifies the risk of mortality associated with human activities (USFS 1986). Data includes (Weaver et al. 1985):

- habitat quality.

- nature of activity.

- intensity of use.

- availability of attractants.

- presence of firearms.

The habitat and displacement models are used to derive a habitat effectiveness index while the mortality model provides data for a mortality risk index. The completion of cumulative effects models involves establishing and validating threshold levels (Weaver et al. 1985) which represent the minimum acceptable levels of habitat effectiveness and mortality risks required for a species to recover and should include energetic and spatial needs of grizzly bears under worst case situations (Weaver et al. 1985, USFS 1986, Winn and Barber 1986). Because the Endangered Species Act requires cumulative effects analysis of all land uses and management activities that might impact listed species (Weaver et al. 1985, USFS 1986), use of CEA has become standard procedure. The results have benefitted grizzly habitat management, enhanced public appreciation of U.S. Forest Service land management credibility and decreased the number of legal actions against the USFS (Christensen et al. 1985). The details of specific cumulative effects analysis models and procedures are presented in the papers cited in this narrative. The reader is referred to these papers for a more detailed description of CEA.

\section{OUTFITTERS}

Human food and refuse, livestock food and wildlife carcasses associated with outfitter camps provide strong attractants for grizzly bears. Bears can become positively conditioned to associate human camps with these attractants, increasing the opportunity for grizzly/human conflicts. Grizzly/human interactions can be minimized by proper storage, handling and disposal of these attractants.

In 1985, the National Park Service and the Forest Service listed provisions for grizzly bear protection to be considered in Outfitter Operations Management Plans or Special Use Permits. The following points should be considered and will be elaborated upon in the following sections.

1. Camp location and time period of use

2. Areas to avoid

3. Seasonal or other human activity limitations

4. Restrictions on livestock or pets by location, numbers, types, and treatment of carcasses

5. Food storage for livestock, pets, and humans

6. Garbage and refuse disposal

7. Game meat storage

8. Legal provision

\section{Camp Location}

- use of established campsites will be adjusted to prevent odor build-up (Mealey 1979, 1986, USFS 1983b, 1985a).

- each outfitter will prepare an operating plan that details camp layout and specifies arrangements that will be made to make human food, garbage, livestock and pet food and game meat unavailable (USFS 1985abc).

- camp layout should maximize distances between food sources and human quarters and bear cover (Hoak et al. 1983).

- all sleeping tents and sleeping areas will be located at least 100 yards from any wildlife carcass or parts (Hoak and Clark 1979, NPS and USFS 1985).

- quotas should be established to limit the total surface area of outfitting areas (Lortie 1978).

- impacts of outfitter camping and livestock grazing will be evaluated to assure that important grizzly habitat is not degraded or compromised (USFS 1982, 1983b).

\section{Areas to Avoid}

- hunters will be issued special warnings when using habitat frequented by grizzly bears and will be provided with information on distinguishing black and grizzly bears (USFS 1985abc). 
- black bear hunting regulations can be modified to reduce or avoid areas that conflict with grizzly habitat (USFS 1985a).

\section{Temporal Limitations}

- all permits will include provisions for cancellation or temporary cessation of activities if grizzly/human conflicts arise (USFS 1983b).

- black bear hunting regulations can be modified to reduce or avoid time periods sensitive to grizzlies (USFS 1985abc).

\section{Restrictions on Livestock or Pets}

- the impact of livestock grazing will be evaluated to assure that important grizzly habitat is not compromised (USFS 1982, 1983b).

- livestock carcasses must be destroyed or removed from within $1 / 4$ mile of trails and $1 / 2$ mile from camps (NPS and USFS 1985).

- dogs can actually be an asset in camp by discouraging bears and warning campers of bear approaches (Wood 1985a).

\section{Food Storage}

- a pack in-pack out philosophy should be adopted by all outfitters, and no livestock or human food should be available to bears (USFS 1985b).

- outfitters will be encouraged to limit the quantity of horse and human food to that necessary for each trip (USFS 1985b).

- managers may wish to restrict the use of horse grain mixtures containing sweeteners such as molasses which act as attractants (Henry 1984).

- food should be properly stored in a manner which is reasonably safe in the presence of humans, has been demonstrated to be bear proof and is unobtrusive (NPS and USFS 1985).

- native materials should be used when possible. Facilities constructed of non-native materials should be removed from wilderness areas at the end of each season (NPS and USFS 1985).

Four types of bear-proof storage facilities are: storage boxes, raised platforms or cargo net platforms, electric fences, and meat poles (Wood 1985a). The Interagency Grizzly Bear Commission Task Force requirements for these storage facilities follow (Henry 1984):

- Bear proof food storage boxes should be:

- not more than 150 pounds

- completely or partially pre-fabricated to facilitate assemblage in backcountry

- constructed of 12 gauge steel or material of similar strength

- tested to be grizzly proof
- Raised platforms appear to be a reasonable method of securing large quantities of foods or other bear attractants. They are the most appropriate means of storing horse food (Wood 1985a). Platforms should be:

- replaced by a 50-55 gallon barrel if this is more appropriate. The barrel can be suspended or buried. If it is stored above ground, several barrels can be attached together and secured to a tree (Henry 1984).

- approved by the resource manager on a case by case basis as a variety of designs are available

- made of native material with a ladder for access

- used in conjunction with stovepipes tacked around trees to prevent platform access by bears

- Electric fences can be used for isolating horse and human food and refuse but:

- a much greater risk is involved due to human error, weather conditions and mechanical failure (Wood 1985a)

- they cannot be used near cooking, dining or tent areas (Wood 1985a)

- caution is necessary as some bears respond to electric shock by looking for something to strike out against (Henry 1984)

- While various designs are available for camp poles, several requirements are necessary:

- poles should be at least 15 feet tall (from the ground) so that all items are suspended at least 10 feet from the ground and 4 feet from any vertical surface (NPS and USFS 1985)

- poles should be inconspicuous so they need not be dismantled (NPS and USFS 1985)

- poles must be able to support 1000 lbs. on a 20 ft. span (Henry 1984)

- support lines should be made from cable, steel or material of similar strength (Henry 1984)

- poles should be located a minimum of 100 yards from sleeping tents or sleeping areas unless a district ranger a pproves a shorter distance (NPS and USFS 1985)

- poles should be tested to be bear proof (Henry 1984)

- Where food sources cannot be bear-proofed or where odors remain, mothballs or napthalene crystals can be used as repellents (Hoak et al. 1979, 1983).

\section{Garbage and Refuse Disposal}

- food containers or emptied containers should not be buried unless they are stored in bear proof drums. Even empty food cans can be associated with food (Hoak and Clark 1979). 
- food or food containers should not be left in caches between seasons (Hoak and Clark 1979, Hoak et al. 1983, NPS and USFS 1985).

- all combustible garbage should be burned (Hoak and Clark 1979).

\section{Game Meat Storage}

Suggestions for hanging game meat vary widely, but all sources agree that meat should be:

- hung at least 100 yards from camp and moved within 48 hours unless stored at least $1 / 2$ mile from camp (Lortie 1978, Mealey 1979, 1986, NPS and USFS 1985, USFS 1983, 1985b, USFS and NPS 1985, Wood 1985a).

- A variety of requirements for suspension are:

- no less than $4.6 \mathrm{~m}$ (15 ft.) from the ground with suspension ropes at least $3.1 \mathrm{~m}(10 \mathrm{ft}$.) from the ground (Hoak and Clark 1979).

- no less than $3.3 \mathrm{~m}$ (10 ft.) from the ground, at least $1 \mathrm{~m}$ ( $3 \mathrm{ft}$.) from the nearest lateral object, and with suspension ropes tied off $2 \mathrm{~m}(6 \mathrm{ft}$.) or higher to an object other than that supporting the meat (USFS and NPS 1979).

- at least $2.2 \mathrm{~m}$ (10 ft.) from the ground and $1.3 \mathrm{~m}$ (4 ft.) from the nearest lateral object (Wood 1985a).

- at least $4.6 \mathrm{~m}$ from the ground, a minimum of 2 $m$ between the meat and the nearest lateral object and $3.1 \mathrm{~m}$ between the suspension ropes and the highest access point (Wood 1985a).

\section{Legal Provision}

The NPS and USFS (1985) state that any failure to comply with the Outfitter Policy which results in injury or death to a grizzly may cause administrative or criminal action to be taken against the permit holder. Under the Endangered Species Act, an offender could be assessed a civil penalty of "not more than $\$ 10,000$ for each violation upon conviction, be fined not more than $\$ 20,000$ or imprisoned for not more than one year, or both."

\section{GARBAGE}

Grizzly bears are opportunistic feeders, and human supplied food and refuse may serve as attractants to bears, particularly in dry years (Hoak and Clark 1977). A large percentage of Yellowstone grizzly bears depend on human supplied food at garbage dumps (J.J. Craighead and F.C. Craighead, Jr. 1972). Success at obtaining food from campsites, campgrounds, recreational facilities, outfitter camps and cabins or summer homes reinforces this behavior often to the detriment of both grizzlies and humans; high grizzly bear mortality rates are associated with their attraction to human food sources (Anonymous 1980). Proper handling and disposal of garbage in human use areas can reduce the incidence of such conflicts. The following are recommendations for handling and disposing of garbage in an appropriate manner:

- all combustible garbage should be burned in enclosed campstoves at backcountry campsites. No garbage should be buried, including empty cans or other food containers as bears will still associate these with food (Hoak and Clark 1977).

- all garbage containers should be bearproofed and pickup should be frequent to minimize buildup of odors or spillage (USFS 1985abc).

- existing and potential garbage dumps should be evaluated to determine if a problem exists (or will exist). County officials should be asked to coordinate with Park and Forest Service personnel if a problem arises (USFS 1985a).

- operators with special use permits should be required to make all garbage unavailable to bears through the use of bearproof storage facilities and regular collection (USFS 1985a).

- nondeveloped campsite use should be adjusted to control improperly handled garbage and concurrent odor buildup (USFS 1985a).

- garbage pickup should be late in the day, every day, at developed sites where bears are known to frequent the area (USFS 1985b).

- trashcans which are not bear resistant (i.e, at employee residences, administrative offices, recreational residences) should be made unavailable to bears (USFS 1985b).

- loaded trash vehicles should proceed directly to transfer stations unless it is very late in the evening and the truck is stored in a closed building or fenced area (USFS 1985b). 


\section{COMMON AND SCIENTIFIC NAMES OF PLANTS DISCUSSED IN THE NARRATIVES}

SCIENTIFIC NAME

Pseudotsuga menziesii

Pinus contorta

Thuja plicata

Picea sitchensis

Picea engelmannii

Picea glauca

Picea mariana

Abies amabilis

Alnus rubra

Alnus sitchensis

Alnus crispa

Arctostaphylos uva-ursi

Betula glandulosa

Cornus stolonifera

Empetrum nigrum

Dryas octopetala

Rhamnus alnifolia

Sambucus spp.

Oplopanax horridus

Cornus sericea

Ledum glandulosum

Lonicera involucrata

Viburnum edule

Rhododendron spp.

Vaccinium membranaceum

Vaccinium ovalifolim

Vaccinium myrtillus

Eriophorum angustifolium Eriophorum vaginatum

Trifolium spp.

Hedysarum alpinum

Hedysarum sulphurescens

Hedysarum mackenzii

Oxytropis spp.

Claytonia lanceolata

Osmorhiza chilensis

Angelica genuflexa

Angelica lucida

Heracleum lanatum

Equisetum spp.

COMMON NAME

SCIENTIFIC NAME

COMMON NAME

Trees

Douglas fir

lodgepole pine

western red cedar

sitka spruce

Englemann spruce

white spruce

black spruce

amabilis fir

red alder

sitka alder

mountain alder

bearberry

dwarf birch

flowering dogwood

crowberry

dryas

buckthorn

alderberry

devil's club

dogwood

Labrador tea

black twin-berry

cranberry

Rhododendron

blueberry

blueberry

blueberry

\section{Forbs-Monocots-Ferns}

cotton grass

cotton grass

clover

pink hedysarum

yellow hedysarum

vetch

vetch

spring beauty

mountain sweet-cicely

wild celery

cow parsnip

horsetail
Populus balsamifera

Abies lasiocarpa

Pinus albicaulis

Pinus flexilis

Larix lyallii

Populus tremuloides

Betula spp.

Shrubs

Vaccinium scoparium

Vaccinium globulare

Vaccinium uliginosum

Vaccinium vitis-idaea

Ribes spp.

Rubus parviflora

Rubus spectabilis

Salix spp.

Sorbus spp.

Amelanchier alnifolia

Berberis aquifolium

Pachistima myrsinites

Prunus virginiana

Chimaphila umbellata

Shepherida canadensis

Betula nana

Cassiope tetragona

Rosa spp.

Taraxacum spp.

Erythronium grandiflorum

Lupinus nootkatensis

Boykinia richardsonii

Lysichitum americanum

Oxyria digyna

Athyrium filix-femina

Mitella brewerii

Tiarella trifoliata

Circium scariosum

Polygonum spp.

Perideridia gairdneri balsam poplar

subalpine fir

whitebark pine

limber pine

alpine larch

trembling aspen

birch

grouseberry

globe huckleberry

alpine blueberry

lignonberry

currant

thimbleberry

salmonberry

willow

mountain ash

serviceberry

shining oregongrape

pachistima

chokecherry

prince's pine

soap,buffaloberry

dwarf birch

cassiope

rose

dandelion

glacier lily

lupine

Alaska boykinia

yellow skunk cabbage

mountain sorrel

lady fern

Brewer's mitrewart

trefoil foamflower

elk thistle

smartweed

Gairdner's yampah 



\section{SUBJECT KEYWORDS, ABBREVIATIONS AND DEFINITIONS}

\section{KEYWORD}

Activity Patterns

Age Determination

Age/Sex

Agonistic

Agricultural Impacts

Aircraft Impacts

Aversive Conditioning

Avoidance \& Attractants

Behavior Patterns

Bibliographies

Breeding Age

Beetle management

Burn Use/Mgt

Camping management

Cannibalism

Capture

Carcass

Carrying capacity

Census methods

Census/Trend

Climate

Closure

Control

Copulation

Courtship

Cover

Cumulative effects analysis

Cut use

Day bed
ABBREVIATION

ACT PATT

AGE DETERM

AGE/SEX

AGON

AGR IMP/MGT

AIRCRAFT IMP

AVER COND

AVOID/ATTRAC

BEHAV PATT

BIBLIO

BRD AGE

BTLE MGMT

BURN USE/MGT

CAMP MGMT

CANNIBAL

CAPTURE

CARCASS

CARR CAP

CENSUS METH

CENSUS/TREND

CLIMATE

CLOSURE

CONTROL

COPULATE

COURT

COVER

CUM EFF

CUT USE

DAY BED
DEFINITION

Daily rhythms, diel patterns of activity and inactivity and associated behaviors.

Sectioning teeth, skull size, testes condition, etc. to determine age.

Age/sex ratio data.

Intraspecific agonistic encounters; especially physical.

Impacts and relationships to agricultural practices and associated management.

Disturbance due to airplanes, helicopters and associated uses.

Modifying behavior by pairing undesirable behavior with negative stimulus.

How humans can avoid bear encounters (e.g., noise) or attract (e.g., odors).

Behavioral patterns travel and rest, usually including temporal analysis of these activities.

Other bibliographies containing information on grizzly bears.

Minimum and maximum breeding ages.

Pine beetles and management.

Use of, influence onbear distribution, and management of burn areas.

Backcountry and developed; including warning systems, proper garbage handling.

Instances of cannibalism in grizzly bears.

Techniques for trapping grizzly bears (e.g., traps, snares).

Use and importance of, including scavenging one carrion.

Carrying capacity of habitats and regions; theories and data.

Methods for counting bears and assessing population size and trends (e.g. bait stations).

Surveys (recent and historical), raw counts or trend monitoring, not population estimates.

As a limiting factor (see also population regulation).

Of areas, trails, etc. as a management strategy.

Control actions: general, administrative decisions, procedures, number of bears killed, etc.

Descriptions of copulations and associated behaviors.

Breeding behavior, breeding season, pair bonds.

As in concealment, not cover types; use and importance of cover.

Analysis procedures; may incorporate many "impact" keywords.

Use of logged areas.

Use, location, and occurrence of day beds. 
Demographic analysis

DEMOG ANAL

Den

DEN

Den characteristics

Denning chronology

Den site

Dentition

Depredation

Deterrents \& repellents

Digestion

Distribution

Diurnal behavior

Diversity

Drugs

Education

Energy impacts

Energy management

Feeding behaviors

Fire management

Food

Foraging strategies

Garbage management

Garbage

General biology

General data

Genetics

Girth

Growth \& Development

Habitat analysis

Habitat effectiveness

Habitat reconnaissance

Habitat sampling

Habitat use
DEN CHAR

DEN CHRON

DEN SITE

DENT

DEPRED

DETER/REPEL

DIGEST

DISTR

DIUR BEH

DIVERSITY

DRUGS

EDUC

ENERGY IMP

ENERGY MGMT

FEED BEH

FIRE MGMT

FOOD

FOR STRAT

GARB MGMT

GARBAGE

GEN BIOL

GEN DATA

GENETICS

GIRTH

GROW/DEV

HAB ANAL

HAB EFFECT

HAB RECON

HAB SAMPL

HAB USE
Pop. trends, projections; including reproductive rates, mortality rates, age/sex, census, population estimates.

Including general data on den sites characteristics and chronology, dimensions, shape, etc.

Specific information on den dimensions, shape, etc.

Specific information on dates of entrance, emergence, and use.

Description of location, habitat, exposure around a den site.

Tooth eruption and pattern.

On livestock, property damage, "marauding" bears; may discuss associated control actions.

Sprays, electric fences intended to repel grizzly bears.

Information on digestion and comparison with other species.

Present and historical distribution.

Behavior during the daylight hours.

Importance of habitat diversity to grizzly bears.

Types, dosages, effects and uses.

Educating people regarding bears, and associated educational materials.

Impacts from oil, gas and mining exploration and development; also pipelines and industrial developments.

Oil, gas and mining management to lessen impacts.

Digging for worms, grazing and other feeding activities.

Management of natural fire and using fire as a management tool.

Food habit studies including scat analysis.

Theories and studies concerning foraging.

Management of garbage (refuse) to lessen availability to bears.

Use of, influence on behavior, movements in relation to, and impacts resulting from availability.

Including distribution, morphology, physiology, food, habitat, etc. all in general terms.

Including data on home range, food, habitat use, distribution, movement.

Genetic makeup of grizzly bears, and influences on population biology.

Measurements of girth, and relation to other size measurements.

Weight gains by time increment: individual size gains.

Analysis of habitat in relation to grizzly bears.

Habitat ratings, suitability values; actual values; not description of types.

Surveys of areas for suitability as grizzly habitat, with limited observational data.

Techniques for collecting and analyzing vegetation data, use data, etc.

Basic use data; may refer to habitat types vegetation types, component types, etc. 
Hair

Harvest data

Harvest impacts

Harvest management

Heart

Hematology

Hibernation physiology

Historical account

Historical

Home range

Human impacts

Human injury

Identification \& recog

Introduction/reintro

Interspecific

Intraspecific behavior

Legal

Length

Litter Frequency

Litter size

Livestock impacts

Livestock management

Longevity

Mapping

Marking

Maternal behavior

Measurements

Management, general

Management plan

Minimum population

Miscellaneous

Monitoring systems

Morphology \& physiology

Mortality data

Morrality management
HAIR

HARV DATA

HARV IMP

HARV MGMT

HEART

HEMAT

HIB PHYS

HIST ACGT

HIST DISTR

HOME RNG

HUMAN IMP

HUMAN INJ

IDENT/RECOG

INT/REINT

INTERSP COMP

INTRASP BEH

LEGAL

LENGTH

LITR FREQ

LITR SIZE

LIVESTK IMP

LIVESTK MGMT

LONGEV

MAP/TYPE

MARK

MATERNAL

MEAS/QUANT

MGMT GEN

MGMT PLAN

MIN POP

MISC QUANT

MONIT SYS

MOPH/PHYS

MORT DATA

MORT MGMT
Micromorphology, not color patterns (see pelage).

Numbers legally taken through hunting.

Actual and theoretical impacts from harvest.

Setting seasons, quotas, fees, etc.

Heart-rate and effects on it from stress, drugs, etc.

Blood analysis.

Physiology as influenced by hibernation (e.g., heartrate, temperature).

Typically narratives of historical data.

Pre-1965, both local and distribution general.

Size, area, shape, theories, systems, techniques to determine home range.

Miscellaneous impacts.

Mauling and what to do if attacked.

Gross morphology; black vs. grizzly; chromotography, electrophoresis.

Management techniques associated with introducing, or reintroducing, grizzlies to an area.

Competition with black competition bears and wolves.

Hierarchies, social relationships; may include many other key words.

Legal and quasi-legal status; applicable statutes; administrative designations and procedures.

Measurements of length.

Interval between litters.

Number young/litter.

Competition and problems; (see also depredation).

Avoiding depredation and conflict by active management.

Numbers on age of individuals.

Techniques habitat/component mapping or descriptions of types mapped.

Bear trees, trails, etc.

Mother/young relationships and behavior.

Various size measurements.

General statements of goals, philosophies, with some specific issues discussed.

For forests, parks, etc.; will include goals of management and associated keywords.

Analyses of miniumum viable population size and associated theories.

Feet, claws, muscles, etc. quantities and measurements.

For handling information on sightings, complaints, etc. (not telemetry).

Descriptions and functions.

Number dead from all causes; may include harvest, poaching, road kill, control.

Overall management: especially illegal kills and law enforcement. 
Mortality rate

Motorized impacts

Motorized management

Movements

Nocturnal behavior

Nonmotorized impacts

Nonmotorized

management

Nutrition

Nutritional analyses

Orphan

Outfitter management

Parasites \& diseases

Pelage

Physical chemistry

Poaching \& illegal mort.

Poisoning

Political \& admin. mgmt.

Population augmentation

Population biology

Population density

Population estimate

Population regulation

Predation

Present distribution

Public attitudes

Reaction

Recreational impacts

Recreational management

Relocation

Reproductive rate

Reproduction

Reproductive physiology

Research mortality

Research techniques

Road impacts
MORT RATE

MOTOR IMP

MOTOR MGMT

MOVE

NOCT BEH

NONMOTOR IMP

NONMOT MGMT

NUTR

NUTR ANAL

ORPHAN

OUTFIT MGMT

PARAS/DIS

PELAGE

PHYS CHEM

POACH/ILLEG

POISON

POL/ADM MGMT

POP AUG

POP BIOL

POP DENS

POP EST

POP REG

PRED

PRES DISTR

PUBLIC ATT

REACTION

RECR IMP

RECR MGMT

RELOC

REP RATE

REPRO

REPRO PHYS

RES MORT

RES TECH

ROAD IMP
Mortality/survivorship analyses, usually includes support data; not just raw data.

Motorized recreation and associated impacts.

Motorized recreation management.

Distances, patterns of movement, daily, seasonally, year-round.

Behavior during night hours.

Nonmotorized recreation and associated impacts.

Nonmotorized recreation management.

Nutritional requirements.

Nutritional and energetic content of forage items.

Orphaned cubs, survival of, etc.

Management of impacts associated with outfitter activities.

Diseases, parasites and other natural mortality factors.

Color phases, patterns of coat.

Physical chemistry, except for hematology.

Significance of and degree of all illegal kills, includes raw data.

Direct or indirect impacts of poison.

Administrative strategies, coordination.

Rationale, methods of augmenting populations.

Data on age/sex, longevity, mortality and reproductive rates, etc.

Number per unit area; regionally or population wide.

Often included in demographic analysis.

Controlling factors, including compensatory factors, nutrition and other regulators.

Accounts, degree, importance of predation; includes predation on ungulates, rodents and fish.

Post-1965, both local and region wide.

Questionnaires, surveys of public attitude.

Reaction of bears to human encounters, includes habituation.

General, including both motorized and nonmotorized activities; also recreational developments.

General, includes both motorized and nonmotorized activities.

Relocation of problem bears.

General and population specific; includes breeding age, litter size, litter frequency.

Includes reproductive physiology, behavior, litter size, strategies and other reproduction topics.

Includes morphology and physiology.

Overdoses and other research-related mortality and injury.

General research techniques.

Impacts of construction and use on habitat and bears. 
KEYWORD

Road management

Road mortality

Scat analysis

Seasonal behavior

Sensory

Sibling behavior

Sight

Skull

Smell

Subdivision management

Supplemental feeding

Taxonomy/evolution

Telemetry

Temperature

Temporary baiting

Territoriality \& spacing

Threat

Timber impacts

Timber management

Timber use

Timber (mgmt by)

entrance

Timber (mgmt by) habitat

Timber (harvest) method

Timber (mgmt) post

harvest

Type descriptions

Ungulate competition

Urban development

Vegetative succession

Vocalizations

Weaning

Weight

Zoning

Zoo techniques
ROAD MGMT

ROAD MORT

SCAT ANAL

SEAS BEH

SENSE

SIB BEH

SIGHT

SKULL

SMELL

SUBDIV MGMT

SUPPL FEED

TAXON/EVOL

TELEM

TEMP

TEMP BAIT

TERR/SPACE

THREAT

TIMB IMP

TIMB MGMT

TIMB USE

TIMB-ENTRY

TIMB-HAB

TIMB-METH

TIMB-POST

TYPE DESCRIP

UNG COMP

URBAN DEV

VEG SUCC

VOCAL

WEAN

WEIGHT

ZONING

ZOO TECH
Use times, closures, construction, design.

Bear mortality associated with roads.

Techniques of scat analysis.

Variation in behavior by season, may discuss movements, habitat use, distribution.

General discussion of senses.

Behavior of litter mates, and related young.

Sight capabilities.

Skull descriptions, measurements and use in aging and sexing.

Olfactory capabilities.

Management of developments and associated impacts.

Techniques for providing supplemental food sources.

Taxonomy and evolution of bear species.

Systems and equipment and uses of telemetry.

Internal temperatures.

Providing baits for trapping and censusing.

Includes concentrations, territorial defense.

Threat displays and behavior, especially intraspecific.

Impacts of logging and associated impacts.

Management of logging and associated impacts.

Importance of timber to grizzlies.

Harvest management temporally.

Timber management by habitat.

Methods of timber harvest and impacts.

Post harvest management for grizzlies.

Descriptions of vegetation components, or habitat types (not mapping).

Indirect competition with relationships to, ungulates.

Impacts of urban development.

Use of areas, described by vegetative succession.

Vocalizations and associated behaviors.

Timing, behavior; actual weaning (end of lactation) and family breakup.

Weight data.

Delineation of critical habitat, management zones, etc.

Captive rearing, housing, special procedures, reviews of measurements. 



\section{APPENDIX C \\ GEOGRAPHIC DESCRIPTORS AND \\ ABBREVIATIONS}

STATE

\begin{tabular}{llll}
\hline ABBREVIATION & \multicolumn{1}{c}{ DESCRIPTION } & ABBREVIATION & \multicolumn{1}{c}{ DESCRIPTION } \\
\hline ABC & Alaska \& British Columbia & ID & Idaho \\
ABM & Alberta, British Columbia \& Montana & IDMT & Idaho \& Montana \\
AK & Alaska & IDWA & Idaho \& Washington \\
AT & Alberta & IDWY & Idaho \& Wyoming \\
ATBC & Alberta \& British Columbia & IMW & Idaho, Montana \& Wyoming \\
ATMT & Alberta \& Montana & MEX & Mexico \\
ATSA & Alberta \& Saskatchewan & MNTB & Manitoba \\
AZNM & Arizona \& New Mexico & MT & Montana \\
BC & British Columbia & MTWY & Montana \& Wyoming \\
BCIW & British Columbia, Idaho \& Washington & NM & New Mexico \\
BCMT & British Columbia \& Montana & NWT & Northwest Territories \\
BCWA & British Columbia \& Washington & NWYK & Northwest Territories \& Yukon Territory \\
BIM & British Columbia, Idaho \& Montana & ONT & Ontario \\
CA & California & SK & Saskatchewan \\
CAN & Canada (general) & SWMX & Southwestern United States \& Mexico \\
CAUS & Canada/United States border areas & US & United States (general) \\
CO & Colorado & WA & Washington \\
ECAN & Eastern Canada (Lab, Que, Nova \& Newf) & WY & Wyoming \\
GEN & General & YK & Yukon Territory \\
& & &
\end{tabular}

ECOSYSTEM

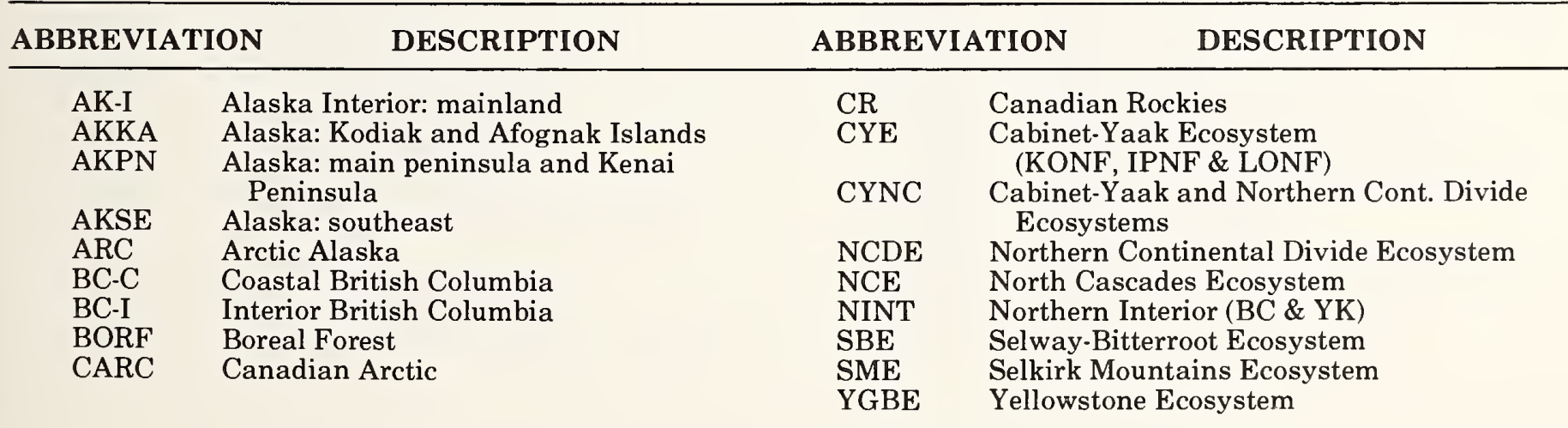




\begin{tabular}{|c|c|c|c|}
\hline ABBREVIATION & DESCRIPTION & ABBREVIATION & DESCRIPTION \\
\hline AINM & $\begin{array}{l}\text { Admiralty Island National Monument } \\
\text { (SE AK) }\end{array}$ & $\begin{array}{l}\text { KGPP, } \\
\text { KGNP }\end{array}$ & Kokanee-Glacier Provincial Park (BC) \\
\hline ANWR & Arctic National Wildlife Refuge (N AK) & KLGS & Kluane Game Sanctuary (YK) \\
\hline ATPP & Alberta Provincial Parks & KNWR & Kodiak National Wildlife Refuge (S AK) \\
\hline BANP & Banff National Park (AT) & $\mathrm{KONF}$ & Kootenai National Forest (MT) \\
\hline BINF & Bitterroot National Forest (ID \& MT) & LCNF & Lewis and Clark National Forest (MT) \\
\hline BLIR & Blackfeet Indian Reservation (MT) & LONF & Lolo National Forest (MT) \\
\hline BLM & Bureau of Land Management & MCGS & McNeil River Game Sanctuary (AK) \\
\hline BTNF & Bridger-Teton National Forest (WY) & NCNP & North Cascades National Park (WA) \\
\hline CGNP & Canadian Glacier National Park (BC) & NPNF & Nez Perce National Forest (ID) \\
\hline CLNF & Clearwater National Forest (ID) & NPR & National Petroleum Reserve (Árctic AK) \\
\hline DENP & Denali National Park (central ÁK) & NPS & National Park Service \\
\hline FLIR & Flathead Indian Reservation (MT) & $\mathrm{PC}$ & Parks Canada \\
\hline FLNF & Flathead National Forest (MT) & RGNF & Rio Grande National Forest (CO) \\
\hline GANF & Gallatin National Forest (MT) & SHNF & Shoshone National Forest (WY) \\
\hline GINF & Gila National Forest (NM) & SJNF & San Juan National Forest (CO) \\
\hline GLNP & Glacier National Park (MT) & SPPP & Spatsizi Provincial Park (BC) \\
\hline GTNP & Grand Teton National Park (WY) & SRGR & Sun River Game Range (MT) \\
\hline IPNF & Idaho Panhandle National Forest & TANF & Targhee National Forest (ID \& WY) \\
\hline JANP & Jasper National Park (AT) & THGS & Thelon Game Sanctuary (NWT) \\
\hline \multirow[t]{2}{*}{ JDR } & John D. Rockefeller Memorial Parkway & TONF & Tongass National Forest (AK) \\
\hline & (WY) & USFS & United States Forest Service \\
\hline & Katmai National Monument (penin AK) & VAPP & Valhalla Provincial Park (BC) \\
\hline \multirow{2}{*}{ KANP } & Kananaskis Provincial Park (AT) & WANP & Waterton Lakes National Park (AT) \\
\hline & & YNP & Yellowstone National Park (WY) \\
\hline
\end{tabular}


LOCALE

\begin{tabular}{|c|c|c|c|}
\hline \multicolumn{2}{|c|}{ ABBREVIATION } & ABBREVIATION & \multirow[t]{2}{*}{ DESCRIPTION } \\
\hline ADIS & Admiralty Island (AK) & MADR & \\
\hline AHNU & Ahnuhati Watershed (BC-I) & MANY & Many Glacier (GLNP, MT) \\
\hline AKKI & $\begin{array}{l}\text { Akamina-Kishinena Creek drainage } \\
\text { (NFLT, ABM) }\end{array}$ & $\begin{array}{l}\text { MCNE } \\
\text { MCPK }\end{array}$ & $\begin{array}{l}\text { McNeil River (by Kamishak Bay, AKPN) } \\
\text { McDonald Peak (MT) }\end{array}$ \\
\hline AKRG & Alaska Range (southcentral AK-I) & MISS & Mission Valley/Mountains (FLNF \& \\
\hline AKSC & Susitna (southcentral AK-I) & & FLIR, MT) \\
\hline ALSE & Alsek River (YK) & MMTN & Mackenzie Mountains (NINT, NWT) \\
\hline AMER & American River (AKPN) & NAKR & Nakina River (BC-C) \\
\hline ANBU & Antelope Butte (NCDE, MT) & NESU & Nelchina Basin (AK-I) \\
\hline APGR & Apgar Mountains (GLNP, MT) & NFLT & North Fork Flathead River (MT) \\
\hline ASHT & Ashton Ranger District (TANF, IDWY) & NSLP & North Slope (northern AK-1) \\
\hline BACR & $\begin{array}{l}\text { Badger Creek/Medicine Two area } \\
\text { (LCNF. MT) }\end{array}$ & OMIN & Omineca Region (eastern BC-I) \\
\hline & & PACR & Pack Creek area (AKSE) \\
\hline BARN & Barn Mountains (CARC, YK) & PELI & Pelican Valley (YNP, WY) \\
\hline BLKL & Black Lake (AKPN) & PIBU & Pine Butte (RMEF, MT) \\
\hline BMWA & Bob Marshall Wilderness Area (MT) & PRWM & Prince William Sound (south AK) \\
\hline BRKR & Brooks Range (AK-I) & RATT & Rattlesnake Wildlife Area (NCDE \& \\
\hline $\mathrm{BROO}$ & Brooks Camp (KANM, AK) & & LONF, MT) \\
\hline $\mathrm{CAB}$ & Cabinet Mountains (MT) & REVL & Revelstoke (CR, BC) \\
\hline CAMA & Camas Creek (GLNP, MT) & $\mathrm{RICH}$ & Richards Island (by TUKP, NWT) \\
\hline CASC & Cascade Valley (BANP, AT) & RMEF & Rocky Mountain East Front (MT) \\
\hline CENT & Centennial Mountains (MT) & SBWA & Selway-Bitterroot Wilderness Area \\
\hline CHIG & Chignak Lake (AKPN) & & (IDMT) \\
\hline CLAR & Clark Fork Hydro Projects (MT) & SCAP & Scapegoat Wilderness Area (NCDE) \\
\hline CLCR & Clear Creek (YNP, WY) & SEEL & Seeley Lake area (MT) \\
\hline COPR & Copper River Delta (southern AK-I) & SFLT & South Fork Flathead River (MT) \\
\hline CUWI & Cuthead-Wigmore area (BANP, AT) & SIMP & Fort Simpson (NWT) \\
\hline CYPR & Cypress Hills (AT \& SK) & SJMT & San Juan Mountains (CO) \\
\hline EBRK & Eastern Brooks Range (AK-I) & SKEE & Skeena Region (BC-I) \\
\hline ELLK & Elizabeth Lake (GLNP, MT) & SKYL & Ski Yellowstone (MT) \\
\hline FISH & Fishing Bridge (YNP, WY) & SLCK & Sullivan Creek (MT) \\
\hline GALL & Gallatin Range (MT) & STEE & Steese-Taylor Highway (AK/YK border) \\
\hline GIWA & Gila Wilderness Area (NM) & STMR & St. Mary's (GLNP, MT) \\
\hline HAYD & Hayden Valley (YNP, WY) & SUNR & Sun River (MT) \\
\hline HUNG & Hungry Horse Reservoir (MT) & SWAN & Swan-Clearwater area (MT) \\
\hline ISLP & Island Park (GLNP, MT) & SWAP & South Wapiti area (S. Grand Prairie, AT) \\
\hline JARD & Jardine (YGBE) & SWHI & Swan Hills (AT) \\
\hline JIML & Jim Lakes (AK-1) & TERL & Terror Lake area (AKKA) \\
\hline KANA & Kananaskis Country (AT) & TEWI & Teton Wilderness (WY) \\
\hline KARL & Karluk Lake (KNWR, AK) & TROU & Trout Creek (YNP, WY) \\
\hline KENA & Kenai Peninsula (AKPN) & TUKP & Tuktoyaktuk Peninsula (NWT) \\
\hline KIMS & Kimsquit Valley (BC-C) & TWOM & Two Medicine drainage (GLNP, MT) \\
\hline KOIS & Kodiak Island (AKKA) & WBRK & Western Brooks Range (northern AK-I) \\
\hline $\mathrm{KOOC}$ & Lake Koocanusa (between NCDE \& & WGLA & West Glacier (MT) \\
\hline & CYE, MT) & WHIL & White Lake (YNP, WY) \\
\hline LAKE & Yellowstone Lake (YNP, WY) & WHR & Whitefish Range (KONF \& FLNF, MT) \\
\hline LOUI & Lake Louise (BANP, AT) & YAKR & Yaak River drainage (CYE, MT) \\
\hline LSWA & Lincoln-Scapegoat Wildlife area (MT) & YUKR & Yukon River (AK-I \& YK) \\
\hline
\end{tabular}





\section{APPENDIX D \\ CITATION INDEX (WITH SUBJECT AND \\ GEOGRAPHIC KEYWORDS)}


00001

AHLQUIST, D.A., R.A. NELSON, D.L. STEIGER, J.D. JONES AND R.D. ELLE FSON.

1984

GLYCEROL METABOL ISM IN THE HIBERNATING BLACK BEAR.

J. COMP. PHYSIOL. 155(1):75-79.

HIB PHYS

PHYS CHEM

MORPH/PHYS

HEMAT

, GEN, , ,

$\mathrm{COOO} 2$

ALASKA DEPARTMENT OF FISH AND GAME.

1976

ALASKA WILOLIFE MANAGEMENT PLANS: A PUBLIC PROPOSAL FOR THE MANAG EMENT OF ALASKA'S WILDL IFE.

DRAFT PROPOSALS FOR 7 GEOGRAPHIC REGIONS (BROWN BEAR SECTIONS). A LASKA DEP. FISH AND GAME, JUNEAU.
MGMT PLAN
HARV MGMT
HUMAN IMP

$$
, A K, \quad,
$$

00003

ALASKA DEPT. OF FISH AND GAME.

1986

ALASKA GAME REGULATIONS. NO. 27.

ALASKA DEPT. OF FISH AND GAME. 45 P P.

HARV MGMT

, AK, , ,

00004

ALBERTA FISH AND WILDLIFE DIVISION.

1986

SUMMARY OF BIG GAME REGULATIONS.

ALBERTA FISH AND WILDLIFE DIV.

HARV MGMT

, AT, , , 
C0005

ALBERTA FISH AND WILDLIFE.

STATUS OF THE FISH AND WILOLIFE RESOURCE IN ALBERTA.

ALBERTA ENERGY AND NAT. RESOUR.. FISH AND WILDL. DIV. EDMENTON.

LEGAL POP EST MGMT GEN

,AT,,$\quad$

00006

ALBERTA RECREATICN, PARKS AND WILDLIFE.

1978

ALBERTA PROVINCIAL PARKS BEAR CONFLICT PREVENTION PROGRAMME.

ALBERTA RECREATION PARKS AND WILOL. EDMONTCN. 21 PP.

$\begin{array}{llll}\text { MGMT PLAN } & \text { GARB MGMT } & \text { RECR MGMT } & \text { CAMP MGMT } \\ \text { EDUC } & \text { MONIT SYS } & \text { CONTROL } & \end{array}$

CR , AT , ATPP, ,

00007

ALLENDORF, F.W. AND R.F. LEARY.

IN PRESS

CHAPTER 4 IN: M.E SOULE, ED. CONSERVATION BIOLCGY- THE SCIENCE O F SCARCITY AND DIVERSITY.

GENETICS

, GEN , , ,

00008

ALMACK, J.

1983

GRIZZLY BEAR HABITAT USE, MOVEMENTS, AND DISTR IBUTION IN THE SELK IRK MOUNTAINS OF NORTH IDAHO AND NORTHEAST WASHINGTON, 1983 FIELD SEASON: DRAFT SUMMARY.

UNIV. IDAHO, MOSCOW. $22 \mathrm{PP}$.

HOME RNG
CUT USE

SME, IDWA, KONF, 
60009

ALMACK, J.A. 1985 AN EVALUATION OF GRIZZLY BEAR HABITAT IN THE SELKIRK MOUNTAINS OF

M.S. THESIS, UNIV. IDAHO, MOSCOW. 87 PP.

\begin{tabular}{|c|c|}
\hline $\begin{array}{l}\text { TYPE DESCRIP } \\
\text { DEN }\end{array}$ & $\begin{array}{l}\text { REACTION } \\
\text { DAY BED }\end{array}$ \\
\hline
\end{tabular}

SME IO ,KONF, ,

C0010

ALMACK, J.A.

1986

GRIZZLY BEAR HABITAT USE, FODD HABITS, AND MOVEMENTS IN THE SELKI RK MOUNTAINS, NORTHERN IDAHD.

PP 150-157 IN: G.P. CONTRERAS AND K.E. EVANS, EDS PROCEEDINGS-G RIZZLY BEAR HABITAT SYMPOSIUM. U.S.D.A., FOREST SERV. INTERMOUNTA IN RES. STAT. DGDEN, UTAH. GEN. TECH. REP. INT-207.
TYPE DESCRIP
HAB EFFECT
DEN
DAY BED
HAB USE
GEN DATA

SME, ID ,KONF, ,

00011

ALT, G.L. AND J.J. BEECHAM.

1984

REINTRODUCTION DF ORPHANED BLACK BEAR CUBS INTO THE WILD.

WILDL. SOC. BULL. 12:169-174.

ORPHAN

, GEN , , ,

00012

ANONYMOUS.

1942 "SUN BEAR": GRIZZLY BEAR, MOUNTAIN GOAT AND MOOSE SURVEY, FLA THEAD AND KOOTENAI MANAGEMENT UNITS.

MONT. DEP. FISH AND GAME, HELENA. 25 PP.

$\begin{array}{lll}\text { HIST DISTR PEP EST } & \text { FOOD }\end{array}$

NCDE, MI ,FLNF, KONF, 
00013

ANONYMOUS.

1973 GRIZLY BEAR MANAGEMENT PLAN.

MONT. DEP. FISH AND GAME, HELENA. 7 PP.

MGMT PLAN

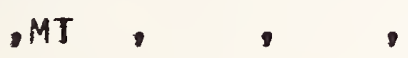

00014

ANONYMOUS.

1975 GRILY BEAR BIBLIOGRAPHIES: I. FOOD HABITS. II. HABITAT REQUIREM ENTS AND COMPONENTS.

BORDER GRIZZLY PROJ., UNIV. MONT. , MISSOULA. SPEC. REP. NO. 2. 3 PP.

BIBLIO FOOD HAB USE

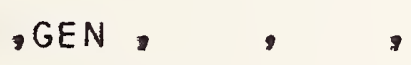

00015

ANDNYMOUS.

1976

SAFER BEAF TRAP DESIGNED.

WILDL. REV. 7(9):12-14.

CAPTURE

$, G E N, \quad$,

00016

ANONYMOUS.

1979

PLAN FOR DETERMINING GRIZZLY BEAR NUISANCE STATUS AND FOR CONTROL LING NUISANCE GRIZZLY BEARS ON NATIONAL FOREST LAND.

APPENDIX 4, PP. 57-64 IN: S.P. MEALEY, ED. GUICELINES FOR MANAGEM ENT INVOLVING GRIZZLY BEARS IN THE GREATER YELLOWSTONE AREA. U. S. D.I. NATL. PARK SERV. AND U.S.D.A., FOREST SERV.

CONTROL RELOC

YGBE, IMW, USFS, YNP, 
00017

ANONYMOUS.

ALASKA WILDLIFE MANAGEMENT PLANS - SPECIES MANAGEMENT POLICIES.

ALASKA DEP. FISH AND GAME, JUNEAU.

$\begin{array}{lll}\text { MGMT GEN } & \text { INT/REINT } & \text { CONTROL } \\ \text { RECR MGMT } & \text { GARB MGMT } & \text { LIVESTK MGMT } \\ \text {,AK }, & ,\end{array}$

00018

ANDNYMOUS.

BRIIISH COLUMBIA WILDLIFE ACT.

GUEEN'S PRINTER FOR B.C., VICTORIA. 55 PP.

LEGAL

$, B C, \quad, \quad$,

00019

ANDNYMOUS.

$1983 A$

CABINET MOUNTAINS SHRUB FIELD SURVEYS FOR BLACK AND GRIZZLY BEARS 1983.

MONT. FISH, WILDL . AND PARKS, HELENA. 5 PP.

CENSUS/TREND

CYE, IOMT, , ,

00020

ANONYMOUS.

19838 RELOCATION OF BEAR NO. $2382 / 83$, SWAN/CLEARWATER AREA.

BORDER GRIZZLY PROJ., UNIV. MONT. MISSOULA. SPEC. REP. NO. $65 A$.
4 PP. AVER COND RELDC

NCDE,MT ,FLNF, ,SWAN 
00021

ANONYMOUS.

$1984 \mathrm{~A}$

BEAR MANAGEMENT PLAN. \begin{tabular}{l} 
U. S.D.I. \\
A. \\
\hline 0
\end{tabular} MGMT PLAN RECR MGMT DETER/REPEL EDUC NONMOT MGMI

AKPN,AK ,KANM,

00022

ANONYMOUS.

$1984 B$

SIGNIFICANT EVENTS IN BEAR MANAGEMENT.

U.S:D.I.: NATL. PARK SERV., KATMAI NATL. PARK AND PRESERVE, ALASK CCNTROL HUMAN INJ DEPRED RECR MGMT

AKPN,AK , KANM.

00023

ANONYMOUS.

1985

CRAFT OF THE STATEMENT OF THE GENETICS WORKSHCP.

PREP FOR THE U.S=D.I. INTERAGENCY GRIZZLY BEAR STUDY TEAM BOZEM AN, MONT.

GENETICS POP AUG

GEN

00024

APPLEGATE, R.D., L.L. RCGERS, D.A. CASTEEL AND J.M. NDVAK. 1979

GERMINATION OF COW PARSNIP SEEDS FRCM GRIZZLY BEAR FECES.

J. MAMMAL. 60(3):655.

FOOD

-GEN, , , 
00025

ARCHIBALD, W.R.

PRCBLEM ANALYSIS: GRIZZLY BEARS AND COASTAL DEVELOPMENT WITH PART ICULAR REFERENCE TO INTENSIVE FORESTRY.

B.C. FISH AND WILDL. BRANCH, VICTORIA. BULL. NC. B-26, 24 PP.

$\begin{array}{lll}\text { MGMT GEN } & \text { TIMB IMP } & \text { COVER } \\ \text { CENSUS/TREND } & \text { DEMOG ANAL } & \text { MORT DATA }\end{array}$

$B C-C, B C, \quad$,

00026

ARCHIBALD, W.R., R. ELLIS, AND A.N. HAMILTON.

IN PRESS

RESPONSES OF GRIZZLY BEARS TO LDGGING TRUCK TRAFFIC IN THE KIMSQU IT RIVER VALLEY, BRIT ISH COLUMBIA.

INT. CONF. BEAR RES. AND MANAGE. 7.

TIMB IMP

$B C-C, B C, \quad, \quad, K I M S$

00027

ARCHIBALD, W.R. AND A.N. HAMILTON.

1983

WDRKING PLAN: COASTAL GRIZZLY RESEARCH PROJECT.

B.C. FISH AND WILDL. BRANCH, VICTORIA. 33 PP.

MGMT GEN EDUC

$B C-C, B C, \quad, \quad, K I M S$

00028

ARCHIBALD, W.R., A.N. HAMILTON AND E. LOFROTH.

1985

COASTAL GRIZZLY RESEARCH PROJECT: PROGRESS REPORT - YEAR 3 - 198 4, WORK ING PLAN - YEAR 4 - 1985 .

WILDL IFE WORKING REP. NO. WR-17, WILDL IFE HABITAT RESEARCH REPORT

ND: WHR-22, MINISTRY OF ENV. AND MINISTRY OF FORESTS, VICTORIA,

DAY BED

COVER

$B C-C, B C$
FOOD

HOME RNG

, KIMS
MARK

TIMB IMP
PRED

ROAD IMP 
00029

ARCHIBALD, W.R., M. SONDHEIM AND A. ^. HAMILTON.

1984

COMPUTERIZED MAPS AS AN AID TO GRIZZLY BEAR HABITAT DEFINITION.

PP. $215-223$ IN: WEST PROC, 64TH ANNU, CONF, OF THE WEST. ASSOC.
OF FISH AND WILOL. AOENCIES, $16-19$ JULY 1984, VICTORIA, B.C.

MAP/TYPE

$B C-C, B C, \quad$,

00030

ARNOLD, B.

1930

CANNIBAL BEAR.

YELLOWSTONE NAT. NOTES $7(8): 54$.

INTER SP COMP

YGBE,IMW, YNP,

00031

ASHLEY, $K$.

1976

FINDINGS OF BOARD OF INQUIRY REGARDING DEATH OF MARY PATRICIA MAH ONEY, GLACIER NATIONAL PARK, SEPTEMBER 23, 1976.

GUIRY.I REP. NATLPP PARK SERV., GLACIER NATL. PARK, MONT. BOARD OF IN HUMAN INJ RECR MGMT

NCDE,MT ,GLNP, ,MANY

00032

ASHLEY, K.R. D. GILHAM, D. HARMS, S. HERRERO, F. NEWBY AND C. MENE $1980^{\circ}$ FATAL GRIZZLY BEAR MAUL ING OF KIM EBERLY AND JANE AMMERMAN, JULY
24,1980 .

U.S.D.I. NATL: PARK SERV., GLACIER NATL. PARK, MONT. BOARC OF RE
VIEW REP! IO PP. HUMAN INJ RECR MGMT

NCDE,MI ,GLNP,BLIR, STMR 
00033

ASHLEY, K.R. F. NEWBY, D. HARMS, T. BULL, W. SALOIS AND C. MENEFEE i 981

PRCBABLE FATAL GRIZZLY BEAR MAULING OF LAWRENCE BYRON GORDON, SEP
JEMBER 26 OR $27,1980$. VIEWDPI: NATL. PARK SERV., GLACIER NATL. PARK, MONT. BOARD OF RE HUMAN INJ RECR MGMT

NCDE,MT, GLNP, ,ELLK

00034

ATWELL, G., D.L. BCCNE, J. GUSTAFSON AND V.D. BERNS. 1980

BROWN BEAR SUMMER USE OF ALPINE HABITAT ON THE KODIAK NATICNAL WI LDLIFE REFUGE.

INT. CONF. BEAR RES. AND MANAGE. 4:297-305.

$\begin{array}{llll}\text { HAB USE TERR/SPACE MOVE FOOD } & \end{array}$

AKKA,AK ,KNWR, ,KOIS

00035

AUNE, $K$.

1985

ROCKY MOUNTAIN FRONT GRIZZLY BEAR MONITORING AND INVESTIGATION.

MONT. DEP. FISH, GAME AND WILDL., HELENA. 139 PP.

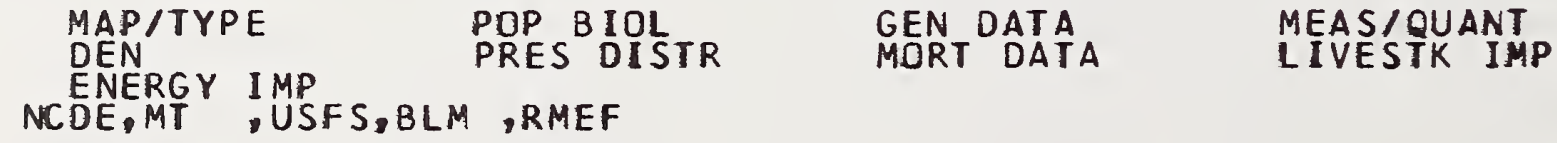

00036

AUNE, K., M. MADEL AND C. HUNT.

ROCKY MOUNTAIN FRONT GRIZZLY BEAR MONITORING AND INVESTIGATION.

MONT. DEP. FISH, WILDL. AND PARKS, HELENA. 175PP.

$\begin{array}{llll}\text { POP BIOL } & \text { HOME RNG } & \text { ENERGY IMP } & \text { ROAD IMP } \\ \text { PRES DISTR } & \text { DEN } & \text { HAB EFFECT } & \text { MAP/TYPE } \\ \text { MGMT GEN } & & \end{array}$
NCDE,MT, USFS, BLM, RMEF 
00037

AUNE, K. AND T. STIVERS.

ROCKY MOUNTAIN FRDNT GRIZZLY BEAR MONITORING AND INVESTIGATION.

MONT. DEP. FISH, WILDL. AND PARKS, HELENA. 68 PP.

\begin{tabular}{|c|c|c|}
\hline $\begin{array}{l}\text { DEPRED } \\
\text { MEAS/QUANT }\end{array}$ & $\begin{array}{l}\text { DEN } \\
\text { CLIMATE }\end{array}$ & $\begin{array}{l}\text { MAP/TYPE } \\
\text { GEN DATA }\end{array}$ \\
\hline
\end{tabular}

NCDE,MT ,USFS,BLM ,RMEF

00038

AUNE, K. AND T. STIVERS.

1982
ROCKY MOUNTAIN FRONT GRIZZLY BEAR MCNITORING AND INVESTIGATION.

MONT. DEP. FISH, WILDL. AND PARKS, HELENA. 143 PP.
GEN DATA
LIVESTK MGMT
$\begin{array}{ll}\text { POP } & \text { BIOL } \\ \text { ACT } & \text { PATT }\end{array}$
ENER GY IMP
DEN
ENERGY MGMT
HAB USE

NCDE, MT ,USFS,BLM, RMEF

00039

AUNE, K. AND T. STIVERS.

1983 ROCKY MOUNTAIN FRONT GRIZZLY BEAR MCNITORING AND INVESTIGATION.

MONT. DEP • FISH, WILDL - AND PARKS, HELENA. 180 PP.
GEN DATA
ACT PATT
ENERGY IMP
DEN
HAB USE
LIVESTK IMP

NCDE, MT ,USFS, BLM, RMEF

00040

AUNE. K. AND T. STIVERS.

1985

ECOLOGICAL STUDIES OF THE GRIZZLY BEAR IN THE PINE BUTTE PRESERVE

MONT. DEP. FISH, WILDL. AND PARKS, HELENA. 154 PP.
GEN DATA
LIVESTK IMP
ACT PAT T
ROAD IMP
DEN PCP BIOL
HAB USE

NCDE, MT ,USFS,BLM ,RMEF 
00041

AUNE, K., T. STIVERS AND M. MADEL.

ROCKY MOUNTAIN FRONT GRIZZLY BEAR MONITORING AND INVESTIGATION.

MONT. DEP. FISH, WILDL. AND PARKS, HELENA. 239 PP.
GEN DATA
ROAD IMP
ACT PATT
LIVESTK IMP
DEN
HAB EFFECT
ENERGY IMP
POP BIOL

NCDE,MT, USFS,BLM, RMEF

00042

AVRIN, D.E.

1976

A NUMERICAL MODEL DF THE YELLOWSTONE GRIZZLY BEAR POPULATICN AND ITS MANAGEMENT IMPLICATIONS.

M.S. THESIS, UNIV. MICH., ANN ARBCR, 51 PP.

DEMOG ANAL POP REG REP RATE AGE/SEX
MORT RATE

YGBE, IMH, , ,

00043

AZIZI, F., J.E. MANNIX, D. HOWARD AND R.A. NELSON.

1979 9 CFT OF WINTER SLEEP CN PITUITARY-THYROID AXIS IN AMERICAN BLAC K BEAR.

AM. J. PHYSIOL. 237131:E227-E230.

HEMAT HIB PHYS

GEN , , , ,

00044

BAGGLEY, G.F.

1936 STATUS AND DISTRIBUTION OF THE GRIZZLY BEAR (URSUS HORRIBILIS) IN THE UNITED STATES.

TRANS. NORTH AM. WILDL. CONF. 1:646-650.

HIST DISTR

CENSUS/TREND 
00045

EAILEY, E.P. AND N.H. FAUST.

1984 DISTR IBUTION AND ABUNDANCE OF MARINE BIRDS BREEDING BETWEEN AMBER AND KAMISHAK BAYS, ALASKA, WITH NOTES ON INTERACTIONS WITH BEARS

WEST. BIRDS 15:161-174.

PRED

AKPN,AK, , ,

00046

EAILEY, $V$.

1932

MAMMALS OF NEW MEXICO. U.S PD.A.A' BUR, OF BIOLOGICAL SURVEY. NORTH AM. FAUNA NO. 53. GOV.

HIST DISTR HIST ACCT

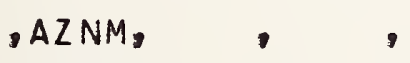

00047

BALDWIN, S.B. B.R. BUTTERFIELD, R.G, WRIGHT AND G.E. MACHLIS. 1985

HABITAT AND VISITOR MAPPING IN THE TWO MEUICINE AREA OF GLACIER N ATIONAL PARKS: COMBINIAG INFORMATION-GATHER ING IECHNIQUES.

IDAHO COOP. PARK STUDIES UNIT, UNIV. IDAHO, MOSCOW. 110 PP.

MAP/TYPE HAB EFFECT MOTOR MGMT NONMOT MGMT

NCDE,MT ,GLNP, ,THOM

00048

BALL, R.E.

1976

THE USE OF TIME-LAPSE CAMERAS IN DISTRIBUTION AND POPULATICN STUD IES OF GRIZZLY BEARS (URSUS ARCTOSI IN THE SHOSHONE NATIONAL FORE M.S. THESIS, UNIV. WYO., LARAMIE. 34 PP.

CENSUS METH

YGBE,WY , SHNF, 
00049

$B A L L, R \cdot E$.

1980 -LAPSE CAMERAS AS AN AID IN STUDYING GRIZZLY BEARS IN NORTHWE ST WYOM ING.

INT. CONF. BEAR RES. AND MANAGE. 4:331-335.

CENSUS METH

YGBE,WY, SHNF,

00050

BALLARD, W.B.

1980

BRDWN BEAR KILLS GRAY WOLF.

CAN. FIELD-NAT . $94(1): 91$.

PRED INTERSP COMP

$A K S C, A K, \quad, N E S U$

00051

BALLARD, W.B.

1981 A

GRAY WOLF - BROWN BEAR RELATIONSHIPS IN THE NELCHINA BASIN OF SOU THCENTRAL ALASKA.

APPENDIX III PP. $182-196$ IN: W.B. BALLARD ET AL. NELCHINA BASIN WOLF STUDIES: FED. AID WILDL. REST. PROJ. W-17-8, $W-17-9, W-17-10$ AND W-17-11, JOBS 14.8R, 14.9R AND 14.10R. ALASKA DEP. FISH AND GAME JUNEAU: INTERSP COMP

AKSC,AK, , , NESU

00052

BALLARD, W. B.

1982

GRAY WOLF - BROWN BEAR RELATIONSHIPS IN THE NELCHINA BASIN OF SOU TH-CENTRAL ALASKA.

PP 71-80 IN: F.H. HARR INGTON AND P.C. PAQUET, EDS. WOLVES OF THE WORLD. NOYES PÜBL. PACK RIDGE, N.J.

INTERSP COMP PRED CARCASS

AKSC,AK, , NESU 
00053

BALLARD,W.B., A.W. FRANZMANN, K.P. TAYLUR, T.H. SPRAKER, C.C. SCHW $\triangle R Z$ AND R.D. PETERSON.

$1980 A$

COMPARISON OF TECHNIQUES UTILIZED TC DETERMINE MOOSE CALF MORTALI TY IN ALASKA.

APPENDIX I PP. 22-39 IN: H.B. BALLARD ET.AL. NELCHINA MOOSE CALF MORTALITY STUDIES. FED. AID WILDL REST, PROJ W-17-9, W-17-10. W-17-11 AND W-21-1, JOB 1.23R. ALASKA DEP. FISH AND GAME JUNEAU.

PRED

$A K S C, A K, \quad, N E S U$

00054

BALLARD, W.B. C.L. GARDNER, S. EIDE AND R. TCBEY.

$1980 B$

NELCHINA YEARLING MOOSE MORTALITY STUDY.

FED. AID WILDL. REST. PROJ. W-21-1 1 AND $1-21-1, J O B 1.2 R$. PROG. R
EP. ALASKA DEP. FISH AND GAME, JUNEAU. 22 PP. PRED

AKSC,AK, , , NESU

00055

BALLARD, W.B. C.L. GARDNER AND S.D. MILLER.

$1982 A$

NELCHINA YEARLING MOOSE MORTALITY STUDY.

FED. AID WILDL REST. PROJ $W-21-1$ AND $W-21-2, J O B$ I $27 R$. FINAL R
EP., VOL. II. ALASKA DEP. FISH AND GAME JUNEAU. 24 PP.

PRED

AKSC,AK, , NESU

00056

BALLARD, W.B., S.D. MILLER AND T.H. SPRAKER.

$1982 B$

HOME RANGE, DAILY MOVEMENTS, AND REPRODUCTIVE BIOLOGY OF BRDWN BE AR IN SOUTHCENTRAL ALASKA.

CAN. FIELD-NAT. 96(1):1-5.

HOME RNG

LITR FREQ

AKSC,AK
MOVE SITE

- NESU
DEN CHRON
COURT

BRD AGE 
00057

BALLARD, W. B., S.D. MILLER, T.H. SPRAKER, K.P. TAYLOR AND S.H. EIDE i980C

BIG GAME INVESTIGATIONS, NELCHINA MOOSE CALF MORTALITY STUDY.

FED AID NILDL. REST. PROJ. W-17-9, W-17-10, W-17-11 AND W-21-1 ${ }_{J}$ $S H$ AND GAME, JUNEAU. I 23 PP.

$\begin{array}{cccc}\text { PRED } & \text { CONTROL } & \text { RELOC } & \text { POP EST } \\ \text { HEMAT } & \text { MEAS/QUANT } & \text { HOME RNG } & \text { AGE/SEX } \\ \text { MOVE } & & \end{array}$

00058

BALLARD, W.B. AND T. SPRAKER.

1979

UNIT 13 WOLF STUDIES.

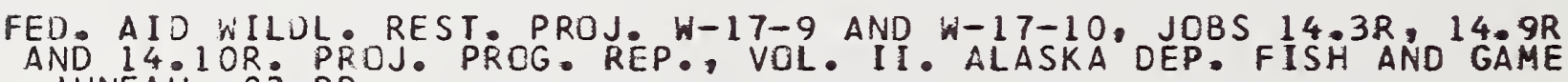
, JUNEAU. 83 PP.

INTERSP COMP PRED

AKSC,AK, , NESU

00059

BALLARD, W.B. , T.H. SPRAKER AND K.P. TAYLOR.

1981 AAS OF NEONATAL MOCSE CALF MORTALITY IN SOUTH CENTRAL ALASKA.

J. HILDL. MANAGE. 45(2):335-342.

PRED

ARC, AK, , NESU

00060

RALLARD, W.B..R.O. STEPHENSON AND T.H. SPRAKER.

$1981 \mathrm{~B}$

NELCHINA BASIN WOLF STUDIES. FED. A IO WILDL. REST. PROJ. H-17-8, W-17-9, W-17-10 AND W-17-11 E, JUNEAU. 204 PP. PRED INTERSP COMP

AKSC,AK, , , NESU 
00061

BALLARD, $\mathrm{H}_{\bullet} B$. AND K.P. TAYLOR.

MODSE CALF MORTALITY STUDY, GAME MANAGEMENT UNIT 13.

FED: AID WILDL. REST. PROJ. W-17-9 (2ND HALF) AND W-1 7-10 (1ST HA EF, JUNEAU. 43 PP.

PRED

AKSC,AK, , NESU

00062

BANFIELD, A.W.F.

1958 DISTRIBUTION OF THE BARREN-GROUND GRIZZLY BEAR IN NORTHERN CANADA $\bullet$

NATL. MUS, CAN. BULL. NO, 166:47-59.

HIST DISTR HIST ACCT

, NWT , , ,

00063

BANNER, A., J. POJAR, R. TROWBRIDGE AND A. HAMILION.

1986 GR IZLY BEAR HABITAT IN THE KIMSQUIT RIVER VALLEY, COASTAL BRITIS H COLUMBIA: CLASSIFICATION, DESCRIPTION, AND MAPPING.

PP. 36-49 IN G.P. CONTRERAS AND K.E. EVANS, EDS. PROCEEDINGS-GRIZ ZLY BEAR HABITAT SYMPOS IUM. U.S. D. A. FCREST SERV. INTERMCUNTAIN RES. STAT., DGDEN, UTAH. GEN• TECH. REP. INT-207.

MAPITYPE

TYPE DESCRIP

$B C-C, B C, \quad, \quad, K I M S$

00064

BARNES, R. AND C. JCNKEL.

WILDFIRE IN THE DEVELOPMENT AND MAINTENANCE OF GRIZZLY BEAR HABIT AT.

$P P, 12-22 I N$ : C JONKEL, ED. ANNUAL REPORT • BORCER GRIZZLY PROJ.9 UNIV. MONT.: MISSOULA. ANNU. REP. NO. 2.

FIRE MGMT

NCDE,MT ,FLNF, , 
00065

BARNES, V.G., JR.

1984

BROWN BEAR STUDIES.

U.S.D.I. FISH AND WILDL. SERV. DENVER WILDL. RES. CENT., ALASKA WILDL. RES. PROJ., PRCG: REP. 28 PP.

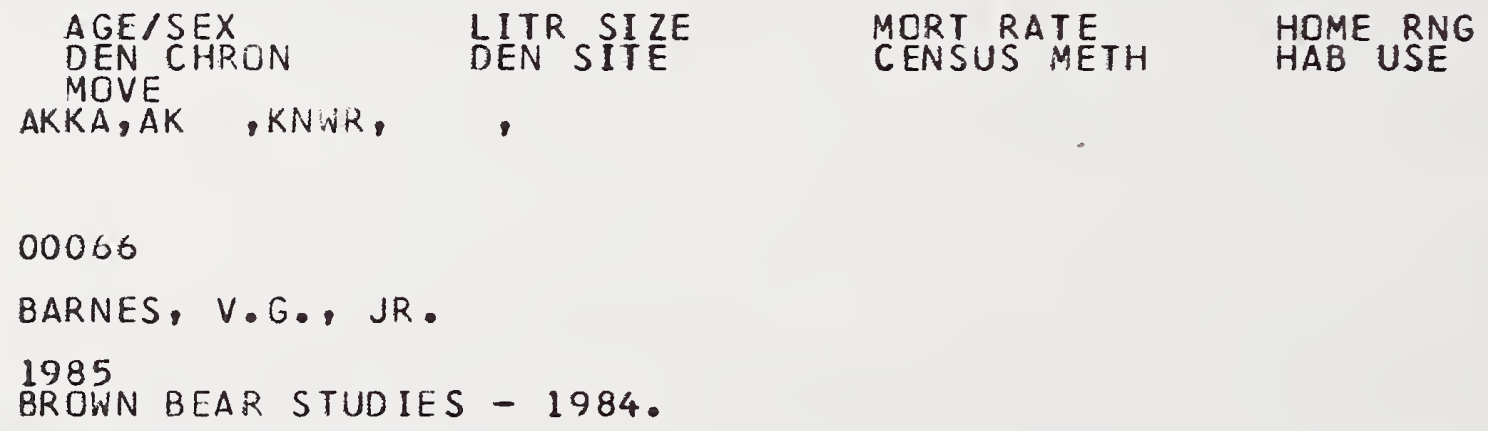

00066

BARNES, V.G., JR.

1985

BROWN BEAR STUDIES - 1984.

U.S.D.I - F FISH AND WILDL. SERV. 38 DENVER WILOL. RES. CENT. ALASKA
AGE/SEX
HOME RNG
WEAN
MOVE
L ITR SIIZE
MORT RATE
CENSUS/TREND

AKKA,AK ,KNNR,

00067

EARNES, V.G., JR., R.M. ANTHONY, K.A. FAGERSTONE AND J. EVANS. 1985

HAZARDS TU GRIZZLY BEARS TO STRYCHNINE BAITING FOR POCKET GCPHER CONTROL.

WILDL. SOC. BULL. 13:552-558.

POISON

$$
\text { , GEN, , , }
$$

00068

BARNES, V.G., JR. AND D.E. BRAY.

1967 POPUATION CHARACTERISTICS AND ACTIVITIES OF BLACK BEARS IN YELLO WSTONE NATIONAL PARK.

COLORADO COOP. WILDL. RES. UNIT, CDLORADO STATE UNIV. 199 PP.

INTERSP COMP CENSUS METH INTRASP BEH

YGBE, IMW, YNP, , 
00069

BASILE, J.V.

GRIZZLY BEAR DISTRIBUTION IN THE YELLOWSTCNE AREA, 1973-79.

U.S.D.A. FOREST SERV I INTERMCUNTAIN FOR. AND RANGE EXPT. STAT., PRES DISTR

YGBE, IMW, YNP , USFS,

00070

BEATTIE, J.B.

1983 BROWN BEAR/HUMAN INTERACTIONS AT KATMAI NATIONAL PARK AND PRESERV E: IMPL ICATIONS FOR PLANNING AND MANAGEMENT.

B.A. THESIS (SENIOR), UNIV. CALIF., SANTA CRUZ. 32 PP.

RECR IMP REACTION RECR MGMT

AKPN, AK ,KANM, ,BROO

00071

BEATY, D.

1979A AELEMY QUESTIONS AND ANSWERS.

PROC. WEST. BLACK BEAR WORKSHOP $1: 137-166$.

\section{TELEM}

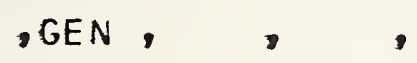

00072

BEATY, D.W.

$1979 B$

ANTENNA CONSIDERATIONS FOR BIOMEDICAL TELEMETRY.

PROC. WEST. BLACK BEAR WORKSHOP $1: 267-281$.

TELEM

,GEN, ,, 
00073

BEECHAM, J.J.

1980

POPULATION CHARACTERISTICS, DENNING, AND GRCWTH PATTERNS CF BLACK BEARS IN IDAHO.

PH.D. DISS., UNIV. MONTANA, MISSCULA. 95 PP.

CENSUS METH POP REG

, CEN, ,

00074

BEMRICH, W.J. AND T.P. C.LEARY.

1979

A COCCIOIAN FROM A GRIZZLY BEAR.

VET. MED. SMALL ANIM. CLIN. 74(3):389-390.

\section{PARAS/DIS}

, GEN, , , ,

00075

BEN SHAUL, D.M.

NOTES ON HAND-REARING VARIOUS SPECIES OF MAMMALS.

INT. ZOO YEARB. $4: 300-342$.

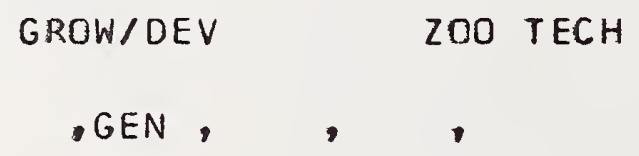

00076

BERGERUD, A.T.. H.E. BUTLER AND D.R. MILLER.

ANTIPREDATOR TACTICS OF CALVING CARIBOU: DISPERSION IN MOUNTAINS.

CAN. J. ZOOL. 62:1566-1575.

PRED

$B C-I, B C, S P P P, \quad$, 
00077

BERNS, V.D., G.C. ATWELL AND D.L. BCONE.

BROWN BEAR MOVEMENTS AND HABITAT USE AT KARLUK LAKE, KODIAK ISLAN D.

INT. CONF. BEAR RES. AND MANAGE • 4:293-296.

DEN CHRON MOVE

AKKA, AK, KNWR, ,KARL

00078

BERNS, $V \rightarrow D$. AND R.J. HENSEL.

RADIO TRACKING BROWN BEARS ON KODIAK ISLAND.

INT . CONF. BEAR RES. AND MANAGE . 2:19-25.

HOME RNG MOVE HAB USE

AKKA, AK , KNWR,

00079

BEVINS, J.S., C.C. SCHWARTZ, E.E. BANGS AND K.J. NELSON.

1985 KENAI PENINSULA BROWN BEAR STUDIES: REPORT OF THE INTERAGENCY BRO WN BEAR STUDY TEAM, 1984.

ALASKA DEP. FISH AND GAME, MISC. PUBL. $103 P P$.

$\begin{array}{lll}\text { PRED } & \text { PRES DISTR } & \text { CENSUS/TREND HAB RECON } \\ \text { HARV DATA } & \text { MGMT PLAN } & \text { FOOD } \\ \text { AKPN,AK, }, \text { KENA } & \end{array}$

00080

BIELANSKA-OSUCHOWSKA, Z. AND S. SZANKOWSKA.

1970 IISLOGICAL AND HISTOCHEMICAL STUDIES ON THE ALIMENTARY TRACT IN THE BROWN BEAR.

ACTA THER IOL . 15(13-23):303-342.

MORPH/PHYS DIGEST

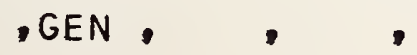


00081

BISSELL, S.

1978 ESSENTIAL HABITAT FOR THREATENED OR ENDANGERED WILDLIFE IN COLORA DO, PART III - MAMMALS.

COLO. DIV. WILDL, DENVER.
PRES DISTR
LEGAL

$, \mathrm{CO}, \quad$,

00082

BJORKLUND, J.

1978 PRELIMINARY INVESTIGATION OF THE FEASIBILITY OF REESTABLISHING A GRIZZLY BEAR POPULATION IN THE NORTH CASCADES NATIONAL PARK COMPL EX.

U.S.D.I. , NATL. PARK SERV, NORTH. CASCADES NATL. PARKS, WASH. MI SC. RES: PAPER NCT-8. 35 PP.

INI/REINT
HAB RECDN DISTR PCP EST

NCE ,WA ,NCNP, ,

00083

BJORKLUND, J.

1980 A

HABITAT AND VEGETATIVE CHARACTERISTICS OF A REMCTE BACKCOUNTRY AR EA AS RELATED TO REESTABLISHMENT OF A GRIZZLY POPULATION IN THE N ORTH CASCADES NATIONAL PARK COMPLEX.

U.S $. D . I .$, NATL. PARK SERY., NORTH. CASCADES NATL. PARKS, WASH. MI SC. RES: PAPER NCT-10. 38 PP.

INT/REINT

HAB RECON

NCE ,WA, ,NCNP, ,

00084

BJORKLUND, J.

$1980 \mathrm{~B}$ HISTORICAL AND RECENT GRIZZLY BEAR SIGHTINGS IN THE NORTH CASCADE
S.

U.S.D I "NATL. PARK SERV. NORTH. CASCADES NATL. PARKS, WASH. MI

$$
\text { HIST DISTR PRES DISTR HIST ACCT }
$$

NCE ,WA ,NCNP, USFS, 
00085

ELANCHARD, B.

1978

GRIZZLY BEAR DISIRIBUTIDN IN RELATICN TO HABITAT AREAS AND RECREA TIONAL USE: CABIN CREEK - HILGARD MOUNTAINS.

M.S. THESIS, MONT. STATE UNIV., BOZEMAN. 75 PP.
PRES DISTR
HAB USE
BEHAV PATT
RECR IMP
PUBLIC ATT
REACTION

YGBE,MT , GANF, ,MADR

00086

BLANCHARD, B.

1983

GRIZZLY BEAR-HABITAT RELATIONSHIPS IN THE YELLOWSTONE AREA.

INT C CONF. BEAR RES. AND MANAGE. 5:118-123.
HAB USE
COVER
TIMB USE
DAY BED
FCOD
CARCASS
FEED BEH
DIVERSITY

YGBE,IMW

00087

BLANCHARD, B.M.

IN PRESS GRWTH PATTERNS OF THE YELLOWSTONE GRIZZLY.

INT. CONF. BEAR RES. AND MANAGE.

$\begin{array}{llll}\text { WEIGHT } & \text { GROW/CEV } & \text { LENGTH } & \text { GIRTH } \\ \text { FOOD } & \text { GARBAGE } & \text { MISC QUANT } & \\ \text { YGBE,IMW } & ,\end{array}$

00088

BLANCHARD, B.M. AND R.R. KNIGHT.

1979 RECONNAISSANCE INVENTORY OF GRIZZLY BEAR ACIIVITY IN THE CENTENNI AL MOUNIAIN RANGE.

U.: -D.I.. INTERAGENCY GRIZZLY BEAR STUDY TEAM, BOZEMAN, MONT. 13

PRES DISTR FOOD

YGBE,IDMT, $\quad, \quad$, CENT 
00089

BL ANCHARD, B.M• AND R.R. KNIGHT.

$1980 \mathrm{~A}$

STATUS OF GRIZZLY BEARS IN THE YELLOWSTONE SYSTEM.

TRANS. NOFTH AM. WILDL. AND NAT• RESOUR. CONF. 45:263-267.
POP EST
POP DENS
BRD AGE
MORT RATE
LITR SIZE
LITR FREQ

YGBE,IMN, NPS, USFS,

$\mathrm{CO090}$

BLANCHARD, B.M•AND R.R.KNIGHT•

MOVEMENTS OF GRIZZLY BEARS IN THE YELLOWSTONE SYSTEM DURING 1978 AND 1979.

PP. 5-12 IN: R.R KNIGHT, B.M BLANCHARD, K.C. KENDALL AND L.E. OL INTERAGENCY GRIZZLY BEAR STUDY TEAM, BOZEMAN, MCNT. 9 I PP.
MOVE
AGE / SEX
WE IGHT
HOME RNG

YGBE,IMW, , ,

00091

BLANCHARD, B.M॰, R.R. KNIGHT AND E.M• YOUNT.

1980

MOR TAL I TY.

PP 20-23 IN: R.R KNIGHT, B. M. BLANCHARD, K.C, KENDALL AND L.E. OLDENBURG EDS YELLOWSTONE GRIZZLY BEAR INVESTIGATIONS- U.S.D.I. - INTERAGENCY GRIZZLY BEAR STUDY TEAM, BOZEMAN, MONT. 9 I PP. MORT DATA POACH/ILLEG CCNTROL

YGBE,IMW, , ,

00092

BLANCQUAERT, A.-M.B., R.E. PORTER, JR., H.J. BRUYNINCKX AND R.C. CA MBRE.

1984

LYMPHOCARCOMA WITH PERFORATION OF THE ILEUM IN A GRIZZLY BEAR.

J. AM. VET. MED. ASSOC. 185(11):1433-1435.

PARAS/DIS

GEN


00093

BLEICH, $V . C$.

1974

ABNORMAL DENTITICN IN A GRIZZLY BEAR.

MURRELET 55(1):11.

DENT

, GEN, , ,

00094

BOERTJE, R.D. W.C., GASAWAY, S.D. DUBOIS, D.G. KELLYHOUSE, D.V. GR ANGAARD, D.J. 'PRESTÓN ANDR.D. STEPHENSON:

1985 FACTORS LIMITING MOOSE POPULATION GROWTH IN GANE MANAGEMENT UNIT 2OE.

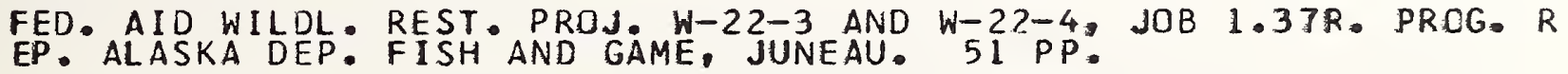

$$
\text { POP DENS PRED }
$$

$A K-I, A K, \quad$,

00095

BOEVER, W.J.

1974 USE OF LEVAMISOLE AS AN ANTHELMINTIC IN EXOTIC CARNIVORA.

VET. MED. SMALL ANIM. CLIN. 69(2):183-185.

PARASIDIS ZOO TECH

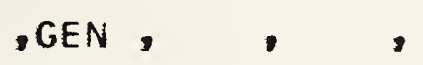

C0096

BORDER GRIZZLY TECHNICAL COMMITTEE.

1975

MAJOR NATURAL RESOURCE ACTS - CONFLICTS HITHIN THEM, AND THEIR AP PLICATION TO THE WELFARE OF THE GRIZZLY BEAR. BORDER GRIZZLY TECH. COMM
SSOULA. WORE BORDER GRIZZLY PROJ., UNIV. MONT., MI
SO PAP. 24 P.

\section{LEGAL}

- GEN . 
00097

BOWMER, E.J.

1973

URSINE TRICHINOSIS IN BRITISH COLUMBIA, 1971.

CAN. J. PUBLIC HEALTH 64(1):84.

PARAS/OIS

, GEN , , $\quad$

00098

BOYD, 0 .

1952 COMPILATIUN OF DATA ON WILDLIFE HARVEST.

FED AID WILDL REST, PROJ JE W-3-R-7, JOB NO, 2, WORK PLAN D. ALAS
KA DEP. FISH AND GAME, JUNEAU. 6 PP: HARV DATA

-AK, , ,

C0099

BOYD, 0.

1953

BIG GAME, SMALL GAME AND FUR TAKE REPORT, JULY 1, 1952, TO JUNE 2 0, 1953, TERRITORY OF ALASKA.

FED AID WILOL REST; PROJ. $W-3-R-8$, WORK PLAN D. ALASKA DEP. FIS H AND GAME, JUNEAU. I PP.

HARV DATA

, AK, ,

00100

BRADY, J.R. AND D.S. MAEHR.

1982 A NEW METHOD FOR DEALING WITH APIARY-RAIDING BLACK BEARS.

PROC. ANNU. CONF. SOUTHEAST. ASSOC. FISH AND WILDL. AGENCIES $36: 5$ 71-577.

AVER COND DETER/REPEL

, GEN, , ,


00101

BRANNON, R.D.

1983A SERUM CHEMISTRY OF CENTRAL AND NORTHERN ALASKA GRIZZLY BEARS.

ALASKA COOP. WILDL. RES. UNIT, UNIV. ALASKA, FAIRBANKS. 35 PP.

HEMAT MORPH/PHYS

$A K-I, A K, A N A R$,

00102

BRANNON, R.D.

BLOOB PROFILE OF GRIZZLY BEARS IN CENTRAL AND NCRTHERN ALASKA.

M.S. THESIS, UNIV. ALASKA, FAIRBANKS. 154 PP.

$\begin{array}{lll}\text { HEMAT } & \text { MORPH/PHYS } \\ \text { DEMP } & \text { HEAGS }\end{array}$

$A K-I, A K, A N W R$,

00103

BRANNCN, R.D.

1984

INFLUENCE OF ROADS AND DEVELOPMENTS ON GRIZZLY BEARS IN YELLOWSTO NE NATIONAL PARK.

U.S.D.I. INTERAGENCY GRIZZLY BEAR STUDY TEAM, BOZEMAN, MCNT. 52
ROAD IMP
URBAN DEV
HAB USE
RECR IMP

YGBE, IMW, YNP, ,

00104

BRANNON, R.D.

1985

HEMATOL OGICAL CHARACTERISTICS OF GRIZZLY BEARS (URSUS ARCTCS) IN CENTRAL AND NORTHEASTERN ALASKA.

CAN. J. ZOOL. 63(1):58-62.

HEMAT

$A K-I, A K, \quad$, 
00105

BRATKOVICH, A.A.

1986

GRIZZLY BEAR HABITAT COMPONENTS ASSOCIATED WITH PAST LOGGING PRAC TICES DN THE LIBBY RANGER DISTRICT, KOOTENAI NATIONAL FOREST.

PP 180-184 IN: G.P - CONTRERAS AND K.E. EVANS, EDS. PROCEEDINGS-G RIZZLY BEAR HABITAT SYMPOSIUM U.S.D.A. FOREST SERV. INTERMOUNTA IN RES. STAT., OGDEN, UTAH. GEN. TECH. REP. INT-2OT.

$$
\text { TIMB-HAB TIMB-METH TIMB-POST }
$$

CYE, MT, , KCNF,

00106

BREWSTER, W.G.

1985

BICLOGICAL OPINION ON MEATRACK-CARBONATE SHEEP ALLOTMENT, GALLATI $N$ NATIONAL FOREST.

U.S.D.I. FISH AND WILDL. SERV.. HELENA, MONT. 5 PP.

\section{LIVESTK MGMT}

YGBE,MT , GANF, ,

00107

BREWSTER, W. G.

$1986 A$

BIOLOGICAL OPINION ON JARDINE JOINT VENTURE PROJECT.

U.S.D.I., FISH AND WILDL. SERV., HELENA MONT. 5 PP.

\section{ENERGY IMP ENERGY MGMT}

YGBE,MT, GANF, ,JARD

C0108

BREWSTER, W.G.

$1986 \mathrm{~B}$

FORMAL CONSULTATION-INTERIM MANAGEMENT PLAN FOR OPERATION OF FIS HING BRIDGE AND GRANT VILLAGE, YELLOWSTONE NATIONAL PARK.

U.S.D.I., FISH AND WILD. SERV॰, HELENA, MONT. 13 PP.

NONMOT MGMT MOTOR MGMT

YGBE,WY, YNP, ,FISH 
00109

BRITISH COLUMBIA MINISTRY OF ENVIRONMENT.

$1979 \mathrm{~A}$

PRCPOSED WILDLIFE MANAGEMENT PLAN FCR BRITISH COLUMBIA.

B.C. WILDL. BRANCH, VICTORIA. 89 PP.

MGMT GEN MGMT PLAN POL/ADM MGMT LEGAL

$, \mathrm{BC}, \quad$,

CO110

BRITISH COLUMBIA MINISTRY OF ENVIRCNMENT.

PRELIMINARY GRIZZLY BEAR MANAGEMENT PLAN FOR BRIIISH COLUMBIA.

B.C. FISH AND WILDL. BRANCH, VICTORIA. 25 PP.

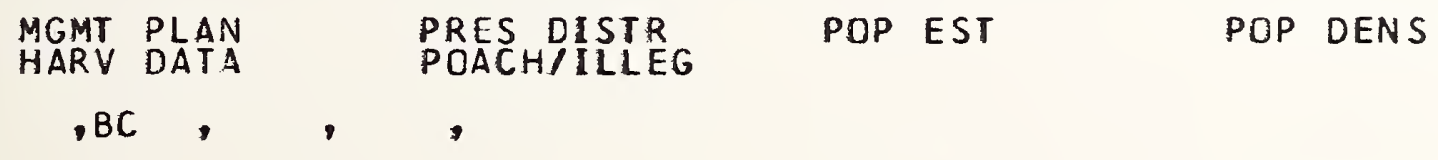

00111

BRITISH COLUMBIA MINISTRY OF ENVIRONMENT.

1986

BRITISH COLUMBIA HUNTING REGULATIONS SYNOPSIS $1985-1986$.

B.C. MINISTRY OF ENVIRONMENT. $63 \mathrm{PP}$.

HARV MGMT

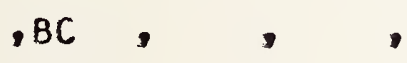

00112

BROMLEY, B.

SAFETY IN BEAR COUNTY: A REFERENCE MANUAL.

NORTHWEST TERRITORIES, DEP. OF RENEWABLE RESOUR., YELLOWKNIFE.

$\begin{array}{lll}\text { GEN BIOL } & \text { REACTION } & \text { AVOID/ATTRAC CAMP MGMT } \\ \text { GARB MGMT } & \text { ENERGY MGMT } & \text { DETER/REPEL }\end{array}$


00113

BROMLEY, B.

1986 $9 A F Y$ IN GRIZZLY AND BLACK BEAR CCUNTRY.

NORTHEAST TERRIT., DEP. DF RENEWABLE RESOUR •, YELLOWKNIFE • 24 PP.

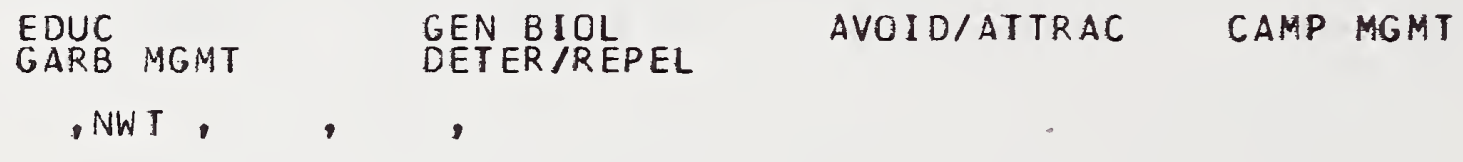

00114

BROMLEY, $M_{\text {. }}$

1985

HILOLIFE MANAGEMENT IMPLICATIONS OF PETROLEUM EXPLORATION AND DEV ELOPMENT IN WILDLAND ENVIRONMENTS.

U.S.DiA : FOREST SERV., INTERMOUNTAIN RES • STAT. GEN. TECH. REP •, $B I B L I O$ ENERGY IMP

, GEN , , ,

00115

BROWN, D.E.

1985

THE GRIZZLY IN THE SCUTHWEST.

UNIV. OKLA. PRESS, NORMAN. 274 PP.
HIST ACCT
HIST DISTR
PRES DISTR
GEN BIOL

, SWMX, , ,

00116

BROWN, G.W., H.J. CROSS AND S.J. RILEY.

1984
BIG GAME SURVEY AND INVENTORY. WILDLIFE INVESTIGATIONS, REGION ON
E.

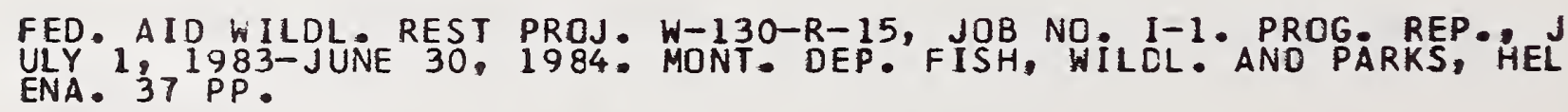

HARV DATA

MORT DATA

NCDE, MT , 
00117

BROWN, G.W., H.J. CROSS AND S.J. RILEY. 1985
BIG GAME SURVEY AND INVENTORY. WILDLIFE INVESTIGATIONS, REGION ON
E. FED. A ID WILDL REST PROJ. W-130-R-16, JOB NO, I-1. PROG REP • HEL ENA. 46 PP.

HARV DATA

NCDE,MT , , ,

00118

BROWN, R.L.

1959

INVESTIGATIONS OF REPORTED BEAR DEPREDATICNS CN LIVESTOCK.

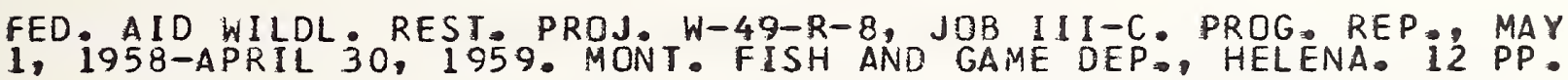

DEPRED CONTROL LIVESTK IMP

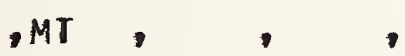

00119

BROWN, R.L.

$1960 \mathrm{~A}$

PREDATOR AND WILDLIFE DAMAGE SURVEYS.

FED. AID WILDL. REST PROJ. W-49-R-9, JOB III-B. JOB COMPLETION R EP. MAY 1, 1959-APRIL 30, 1960. MONT. FISH AND GAME DEP. H HELENA - 104 PP.

DEPRED

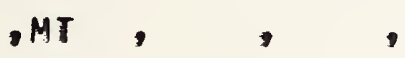

00120

BROWN, R.L.

$1960 \mathrm{~B}$

INVESTIGATION OF REPORTED BEAR DEPREDATIONS ON LIVESTDCK.

FED. AID WILDL REST, PROJ., W-49-R-9, JOB III-C. JOB COMPLETION R - I' PP.

CONTROL

DEPRED

LIVESTK IMP

.MT , 
00121

BROWN, R.L.

STUOCY OF PREDATOR ECOLOGY IN SUN RIVER AREA.

FED. AIO WILOL. REST.PROJ. W-49-R-9, JOB III-D. JOB COMPLETION R EP: MAY 1. 1959-APRIL 30,1960. MONT. FISH AND GAME DEP.. HELENA PRED

NCDE,MT , , , SUNR

00122

BROWNE, S.D.

LIST OF PARASITES REPORTED FROM BEARS.

FED. AID WILDL. REST. PROJ. W-89-R-7, JOB VI-C. N.Y. DIY. FISH AN D GAME, ALBANY. 7 PP.

PARAS/DIS

, GEN, ,

00123

BRYAN, R.B. AND M.C. JANSSON.

1973

PERCEPTION OF WILDLIFE HAZARD IN NATIONAL PARK USE.

IRANS. NORTH AM. WILDL. AND NAT. RESOUR. CONF. 38:281-295.

PUBLIC ATT

, AT, , ,

00124

BUMGARNER, T.

1979

NUTRIENT AND HABITAT EVALUATION OF INFERRED GRIIZLY BEAR FOODS.

B.S. THESIS, UNIV. MONT•, MISSOULA. 49 PP.

NUTR ANAL

NCDE,MT ,FLNF, ,WHR 
00125

BUMGARNER, $T$, R.D. MACE AND C. JONKEL.

1980

CAMBIUM USE BY GRIZZLY BEARS.

PP. 196-203 IN: C. JONKEL, ED. ANNUAL REPORT. BORDER GRIZZLY PROJ

$\because$ UNIV. MONT.: MISSOULA. ANNU. REP. NO. 5.

FOOD TIMB USE

NCDE, MT , , ,

00126

BUNNELL, F.L. AND T. HAMILTON.

1983 FORAGE DIGESTIBILITY AND FITNESS IN GRIZZLY BEARS.

INT. CONF. BEAR RES. AND MANAGE. 5:179-185.

NUTR ANAL
MORPH/PHYS
. GEN, WIGEST WEIGHT GROW/DEV

00127

BUNNELL, F.L. AND D.E.N. TAIT.

1980

BEARS IN MODELS AND IN REALITY - IMPLICATIONS TO MANAGEMENT.

INT - CONF. BEAR RES. AND MANAGE. 4:15-23.

DEMOG ANAL HARV MGMT

, GEN, , ,

00128

BUNNELL, F.L. AND D.E.N. TAIT.

1981

POPULATION DYNAMICS OF BEARS - IMPLICATIONS.

PP. 75-98 IN: T-D. SMITH AND C FOWLER, EDS DYNAMICS OF LARGE MA MMAL POPULATIONS. JOHN WILEY AND SONS, NEW YORK.

WEIGHT REP RATE
AGE/SEX MORT RATE POP REG


00129

BUNNELL, F.L. AND D.E.N. TAIT.

1985

MOR TALITY RATES OF NORTH AMERICAN BEARS.

ARCTIC $38(4): 316-323$.

$\begin{array}{ccc}\text { DEMOG ANAL } & \text { AGE/SEX } & \text { MORT RATE } \\ \text { HARV DATA } & \text { HCME RNG } & \\ \text {, GEN, } & ,\end{array}$

00130

EURBRIDGE, B. AND L. KRUCKENBERG (CHAIRMEN)

1985 GRIZLY BEAR US IN MIND: INFORMATION/EDUCATION ACTION PLAN.

INTERAGENCY GRIZZLY BEAR COMM. PUBLIC INF./EDUC. TASK FORCE. REP.

EDUC

$$
\text { US , , }
$$

00131

BUREAU OF INDIAN AFFAIRS AND CONFEDERATED SALISH AND KOOTENAI TRIBE S. 81

FLATHEAD INDIAN RESERVATION GRIZZLY BEAR MANAGEMENT PLAN. REVIEW CRAFT.

CONFEDERATED SALISH AND KOOTENAI TRIBAL COUNCIL AND U.S.D.I., BUR - OF INDIAN AFFAIRS, FLATHEAD AGENCY, MONT. 121 PP.

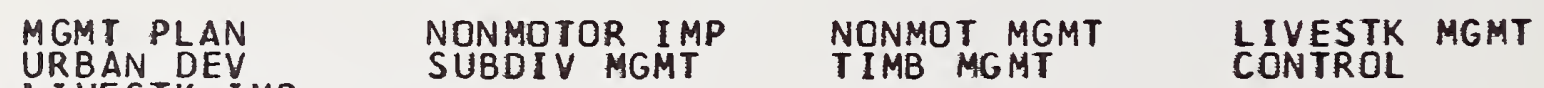
NCDE,MTTK IMP IR,

00132

BURNS, J.E.

1986

MANAGING POLITICAL HABITAT FOR GRIZZLY BEAR RECOVERY.

PP. 2-13 IN: GPP CONTRERAS AND K-E. EVANS, EDS PROCEEDINGS-GR IZ ZLY BEAR HABITAT SYMPOS IUM, U. S.D.A: ROREST SERV
RES. STAT. OGDEN, UTAH: GEN. TECH. REP. INT-2OT.

POL/ADM MGMT MGMT GEN MORT DATA LIVESTK IMP


00133

BUSH, M., R.S. CUSTER AND E.E. SMITH.

USE OF DISSOCIATIVE ANESTHETICS FCR THE IMMOBILIZATION OF CAPTIVE BEARS: BLOOD GAS, HEMATOLOGY AND BIOCHEMISTRY VALUES.

J. WILDL. DIS. $16(4)): 481-489$.

DRUGS

HEMAT

, GEN, , ,

00134

BUSKIRK, S. AND L.A. JOHNSON.

CHRONOLOGY OF HUMAN INJURIES INFLICTED BY BEARS.

U.S.D.I. NATL. PARK SERV. DENALI NATL. PARK, ALASKA. UPDATED AN NUALLY. 4 PP.

HUMAN INJ

$A K-I, A K \quad$ DENP,

00135

BUSKIRK, S. AND L.A. JCHNSON.

$1976 B$

GEAR HANDLING ACTICNS.

U.S.D.I NATL. PARK SERV., DENALI NATL. PARK. ALASKA. UPDATED AN NUALLY. $8 \mathrm{PP}$.

CONTROL RELOC POACH/ILLEG DEPRED

$A K-I, A K \quad$ DENP,

00136

BUTTERFIELD, B.R. AND J.A. ALMACK. 1985

EVALUATION DF GRIZZLY BEAR HABITAT IN THE SELWAY-BITTERROOT WILDE RNESS AREA.

IDAHO COOP. WILDL. RES. UNIT, UNIV. IDAHO, MOSCCW, 66 PP.

HAB RECON TYPE DESCRIP

SBE, IDMT,USFS, ,SBWA 
00137

EUTTERFIELD, B.R. AND C.H. KEY. 1986

MAPPING GRIZZLY BEAR HABITAT IN GLACIER NATIONAL PARK USING A STR ATIFIED LANDSAT CLASSIFICATION: A PILUT STUDY.

PP. 58-66 IN: G•P. CONIRERAS AND K.E. EVANS, EDS PROCEEDINGS-GRI ZZLY BEAR HAEITAT SYMPOSIUM U.S. DA: FOREST SERV. INTERMCUNTAIN RES. STAT., CGDEN, UTAH. GEN. TECH. REP. INT-2JO.

MAPITYPE TYPE DESCRIP

NCDE,MT, GLNP, ,TWCM

00138

CAHALANE, V.H.

1948 THE STATUS OF MAMMALS IN THE U.S. NATIONAL PARK SYSTEM, 1947.

J. MAMMAL. 29(3):247-259.

HIST DISTR

, GEN, , ,

00139

CAHALANE, $\mathrm{V} \cdot \mathrm{H}$.

1964 A PRLIMINARY STUDY OF DISTRIBUTION AND NUMBERS OF COUGAR, GRIZZL $\checkmark$, AND WOLF IN NORTH AMER ICA.

N.Y. ZOOL. SOC., BRONX, N.Y. 12 PP.

HIST DISTR

$$
\text { GEN, , , }
$$

00140

CAMPBELL, B.H.

1985 RROWN BEAR ACTIVITY AND IMPACTS ON NESTING GEESE ON THE WEST COPP ER RIVER DELTA - 1984 .

ALASKA DEP. FISH AND GAME, ANCHCRAGE. PROG. REP. 25 PP.

$\begin{array}{ccc}\text { PRED } & \text { AGE/SEX } & \text { HCME RNG } \\ \text { FOOD } & \text { AIRCRAFT IMP } & \text { POP DENS } \\ \text { AKSC,AK } & , \text { COPR } & \end{array}$


00141

CAMPBELL, B.H. AND T.C. ROTHE.

1985

ANNUAL REPURT OF SURVEY-INVENTORY ACTIVITIES. FED. AID WILDL. REST PROJ. W-22-3 JOB 11.0. ANNUAL REP.. VDL. X
Y. ALASKA DEP. FISH AND GAME, JUNEAU.
PRED
$A G E / S E X$
HCME RNG
HAB USE

$A K-I, A K, \quad, \quad, C O P R$

00142

CARLSON, K.

AN AN ANALSIS OF INFORMATION HANDLING FOR BEAR MANAGEMENT.

U.S.D.I. NATL. PARK SERV., GLACIER NATL. PARK, MONT. 5 PP.

MONIT SYS

NCDE,MT, GLNP, ,

00143

CASEY, D., C.A. YDE AND A. OLSEN.

\section{4}

WILDLIFE LOSS ESTIMATES AND SUMMARY OF PREVIOUS MITIGATION RELATE D TO HYDROELECTRIC PREJECTS IN MONTANA.

FINAL REP • PREP - FOR BONNEVILLE POWER ADM PROJ NO $83-464$ - PREP - BY MONT: DEP. FISH, WILDL. AND PARKS, HELENA. 66 PP.

\section{ENERGY IMP}

NCDE, MT ,FLNF, ,HUNG

00144

CAUGHLEY, G.

1974

INTERPRETATION OF AGE RATIOS.

J. WILDL. MANAGE. 38(3):557-562.

DEMOG ANAL AGE/SEX HARV MGMT

,$G E N$


00145

CAUGHLEY, G. AND J. GCDCARD.

1972

IMPROVING THE ESTIMATES FROM INACCURATE CENSUSES.

J. WILDL. MANAGE. $36(1): 135-140$.

CENSUS METH

, CEN, , ,

00146

CHADWICK, O. H.

1974

GRIZZLY BEAR SURVEY IN A SELECTED PCRTION OF THE SWAN RANGE OF WE STERN MUNTANA.

NANUSCRIPT. $21 \mathrm{PP}$.

PRES DISTR CENSUS/TREND MORT DATA TIMB IMP

NCDE,MT ,FLNF, ,SWAN

00147

CHAMBER S, M.

NUIS ISANCE BEARS • • WHY???

WLDL. REV. 7(7):20-22.

CAPTURE

, GEN, , ,

00148

CHAPMAN, J.A., J.I. ROMER AND J. STARK.

LAOYBIRD BEETLES AND ARMY CUTWORM ADULTS AS FOCD FOR GRIZZLY BEAR S IN MONTANA.

ECOLOGY $36(1): 156-158$.

FODD

FEED BEH

NCDE, MT ,FLIR, ,MCPK 
00149

CHATELAIN, E. F.

1950
BEAR-MOOSE RELATIONSHIPS ON THE KENAI PENINSULA.

TRANS. NORTH AM. WILDL. CONF. 15:224-234.

FOOD PRED

AKPN,AK, , ,

$\operatorname{Col} 50$

CHESTER, J.M.

1976

HUMAN WILDLIFE INTERACTIONS IN THE GALLATIN RANGE, YELLCWSTCNE NA TIONAL PARK, 1973-1974.

M.S. THESIS, MONT. STATE UNIV., BOZEMAN. 114 PP.

REACTION
NONMOT MGMT PUBLIC ATT AVOID/ATTRAC NONMOTOR IMP
YGBE,WY, YNP, ,GALL

00151

CHESTER, J. M.

1980

FACTORS INFLUENCING HUMAN-GRIZZLY BEAR INTERACTIONS IN A BACKCOUN TRY SETT ING.

INT. CONF. BEAR RES. AND MANAGE. 4:351-357.

NONMDTOR IMP REACTION

YGBE,MT, YNP, ,GALL

00152

CHILDRESS, $M$.

1985

RECREATION MANAGEMENT IN GRIZZLY COUNTRY. 1985 ACTION PLAN.

U.S.D.A. FOREST SERV., BRIDGER-TETON NATL. FOREST, JACKSON, WYO.

EDUC
GARB MGMT CAMP MGMT MOTOR MGMT NONMOT MGMT

YGBE, WY ,BINF, , 
00153

CHOQUETTE, L. P. E., G. G. GIBSDN AND A. M. PEARSON.

1969

HELMINTHS OF THE GRIZZLY BEAR, URSUS ARCTOS L. IN NORTHERA CANAD A.

CAN. J. 20OL. 47:167-170.

PARAS/DIS

, YK , , ,

00154

CHR ISTENSEN, A.G.

1982

CUMULATIVE EFFECTS ANALYSIS PROCESS.

SECIION I, 22 PP IN: CUMULATIVE EFFECTS ANALYSIS PROCESS GR IZZL Y HABITAT COMPGNENT MAPPING. U.S.D.I.S NATL. PARK SERV . KCOTENAI NATL. FOREST, MONT.

MAP/TYPE CUM EFF

CYE, IDMT,KONF, ,CAB

00155

CHR ISTENSEN, A.G.

1986

CUMULATIVE EFFECTS ANALYSIS: ORIGINS, ACCEPTANCE, AND VALUE TO GR IZZLY BEAR MANAGEMENT.

PP 213-216 IN: G.P. CONTRERAS AND K.E. EVANS, EDS. PROCEEDINGS-G RIZZLY BEAR HABITAT SYMPOSIUM. U.S.D.A., FOREST SERV. INTERMOUNTA IN RES. STAT., OGDEN, UTAH. GEN. TECH. REP. INT-207.

CUM EFF

CYNC,MT ,KONF, ,

00156

CHRISTENSEN, A., R. ESCANO, P. HARRINGTON, C. HRUSKA, T. PUCHLERZ A ND L. YOUNG. $1984^{\circ}$

TECHNOLOGY TRANSFER PLAN, GRIZZLY BEAR CUMULATIVE EFFECTS ANALYSI S. NORTHERN REG ION.

U.S.D.A. FOREST SERV.. NORTH— REG., MISSOULA, MONT • 15 PP.

MAP/TYPE CUM EFF MGMT GEN POL/ADM MGMT

EDUC

IDMT, , ,


00157

CHR I STENSEN, A.G. AND M.J. MADEL.

1982 CUMULATIVE EFFECTS ANALYSIS PROCESS, GRIZZLY HABITAT COMPCNENT MA PPING.

U.S.D.A., FOREST SERV., KODTENAI NATL. FOREST, MONT. 99 PP.

CUM EFF MAP/TYPE

CYE, IOMT,KONF, ,CAB

00158

CHRISTENSEN, A.G. AND M.J. MADEL.

1984

A CUMULATIVE EFFECTS ANALYSIS PROCESS FOR GRIZZLY BEAR HAEITAT, C ABI NET MOUNTAINS, MONTANA.

THORNE ECOL. INST. TECH. PUBL. 14:142-132.

COVER HOME RNG CUM EFF MAP/TYPE

CYE, MT, KCNF, ,CAB

00159

CHURCHER, C.S. AND A.V. MORGAN.

1976 A GRIZZLY BEAR FROM THE MIDDLE WISCONSIN OF WOOCBRIDGE, ONTARIO.

CAN. J. EARTH SCI. 13(2):341-347.

HIST DISTR

, ONT,

00160

CLAAR, J.J., R.W. KLAVER ANC C. SERVHEEN.

GRI ZZLY BEAR/LIVESTOCK RELATIONSHIPS: A MANAGEMENT CHALLENGE ON T HE FLATHEAD INDIAN RESERVATION.

PRES. AT WILDLIFE/LIVESTOCK RELATIONSHIPS SYMPOSIUM. 20-22 APR - 1 981 , COEUR D'ALENE, IDAHO. 9PP.

DEPRED LIVESTK IMP

NCDE, MT ,FLIR, , 
00161

CLAAR, J. J., R. W. KLAVER AND C. W. SERVHEEN.

IN I PRESS NA.

INT. CONF. BEAR RES. AND MANAGE. 6.

\begin{tabular}{|c|c|}
\hline $\begin{array}{l}\text { MORT MGMT } \\
\text { CONTROL }\end{array}$ & $\begin{array}{l}\text { MORT LATA } \\
\text { MCNIT SYS }\end{array}$ \\
\hline
\end{tabular}

NCDE,MT ,FLIR, ,

00162

CLARK, T., M. WELLS, J. HOAK AND J. WEAVER.

STATUS OF GRIZZLY BEARS IN BRIDGER-TETON NATIONAL FOREST, WYOMING - PART 1:TETON WILDERNESS.

WEST. ENVIRCN. RES. ASSOC , POCATELLO, IDAHO, PROG. REP . 23 PP.

$\begin{array}{lll}\text { PRES DISTR } & \text { CENSUS/TREND AGE/SEX LITR SIZE } \\ \text { POPDENS } & \text { FOOD }\end{array}$

YGBE,WY ,BTNF,

00163

CLARK, w.K.

1955
BEAR STUDY - KARLUK LAKE, 1955.

U.
41 P PUREAU OF COMMERCIAL FISHERIES, KODI AK NATL. WILDL. REFUGE.

$\begin{array}{lll}\text { CENSUS/TREND } & \text { HARY } \\ \text { FOOD } & \text { PRED } & \text { AGE/SEX MOVE }\end{array}$

AKKA, AK, , ,,$\quad$ ARL

00164

CLARK, W.K.

1957 SEASONAL FOOD HABITS OF THE KODIAK BEAR.

TRANS. NORTH AM. HILDL. CONF. 22:145-151.

FOOD

AKKA,AK, KNWR, ,KOIS 
00165

CLARK, W.K.

1959

KODIAK BEAR-RED SALMON RELATIONSHIPS AT KARLUK LAKE, ALASKA.

TRANS. NORTH AM. WILDL. CONF . 24:337-345.

FOOD CENSUS/TREND PRED

AKKA,AK, , , , , IS

00166

CLARK, W.K.

1960 THE ELECTRIC FENCE AS A DETERRENT TO USE OF SALMON STREAMS BY KOD IAK BEAR.

PRDC. ALASKA SCI. CONF. 8:24-26.

DETER/REPEL

AKKA, AK, , , ,

00167

CLARKSON, P.

1986

SAFETY IN BEAR COUNTRY: INSTRUCTORS GUIDE.

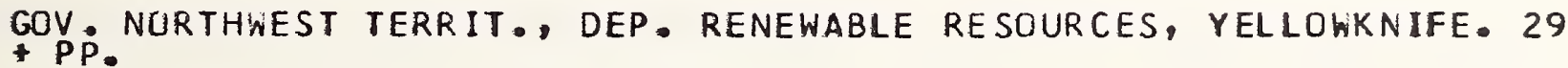

EDUC

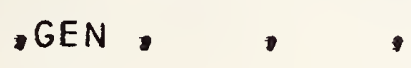

00168

CLARKSON, P. AND L. SUTTERLIN.

1984 BEAR ESSENTIALS: A SOURCE BOOK AND GUIDE TO PLANNING BEAR EDUCATI CN PROGRAMS.

DISTRIBUTED BY C. JONKEL, SCHOOL OF FOR,, UNIV. OF MONT \& MISSOUL A. 67 PP.

EDUC GEN BIOL

-GEN, , , 
00169

COE, D.L.

1967 EEAR MANAGEMENT ACTIVITIES.

MEMO. TO SUPERINTENDENT, KATMAI NATL. PARK AND PRESERVE, ALASKA.
DEPRED
HUMAN INJ
CONTROL

AKPN, AK, KANM, ,

00170

COFFEY, M.A.

PRELIMINARY REPORT ON BEAR-PROOF BACKPACK FOOD CANISTER, 1983.

U•S.D.I. NG NATL. PARK SERV., SEQUOIA AND KINGS CANYON NATL. PARKS, CAMP MGMT

, GEN ,

00171

COLE, G.F.

PROG1 19 RESS IN RESTORING A NATURAL GRIZZLY BEAR POPULATION IN YELLOW STONE NATIONAL PARK.

PP. 183-193 IN: RESEARCH IN THE PARKS, TRANS. OF THE NATL. PARKS CENTENNIAL SYMP.? U.S.D.I., NATL. PARK SERV• SYMP. SER. NO. 1.
MGMI GEN
GARB MGMT
POP REG
GARB AGE
POP EST
CONTROL
CAMP MGMT

YGBE, IMW, YNP,

00172

COLE, G.F.

INT2AA IM REPORT ON GRIZZLY BEAR MANAGEMENT IN YELLOHSTONE NATIONAL PARK, 1972.

U.S.D.I.. NATL. PARK SERV., YELLOWSTONE NATL. PARK, WYO 13 PP.

HUMAN INJ

REP RATE

YGBE,IMW , YNP ,

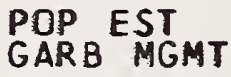

GARB MGMT
CCNT ROL
MGMT GEN

REL OC

GARBAGE 
00173

COLE, G.F.

GRIZZLY BEAR-ELK RELATIONSHIPS IN YELLOWSTONE NATIONAL PARK.

J. WILDL. MANAGE. 36(2):556-561.

$\begin{array}{lll}\text { PRED SEAS BEH FEED BEH CARCASS } & \end{array}$

YGBE, IMW, YNP, ,

00174

COLE, G.F.

$1972 \mathrm{C}$

RESTORATION OF A NATURAL GRIZZLY BEAR POPULATION IN YELLOWSTONE N ATIONAL PARK.

U.S.D.I, NATL. PARK SERV., YELLOWSTCNE NATL. PARK, WYO. INF. PA P. NO. is. I PP.

MGMT GEN GARB MGMT HARBAGE
GARAMAN INJ

YGBE,IMW, YNP, ,

00175

COLE, G.F.

P972D NAL PARK.

INT. CONF. BEAR RES. AND MANAGE - 2:274-288.
CONTROL
RELOC
HUMAN INJ
GARB MGMT
POP EST
CAMP MGMT
MGMT GEN
POP DENS

YGBE, IMW , YNP , ,

00176

COLE, G.F. 1973
MANAGEMENT INVOLVING GRIZZLY BEARS IN YELLOWSTONE NATIONAL PARK,
$1970-72$.

U.S.D.I ' NATL. PARK SERV-, YELLOWSTONE NATL. PARK, WYO. RES. REP - NO. 6, 'YELL-N-38, 32 PP.

$\begin{array}{llll}\text { MGMT GEN } & \text { CONTRDL } & \text { POP REG } & \text { POP DENS } \\ \text { HUMAN INJ } & \text { MORT DATA } & \text { POP EST } & \text { DEMOG ANAL }\end{array}$

YGBE,IMW, YNP, USFS, 
00177

COLE, G.F.

1974

MANAGEMENT INVOLVING GRIZZLY BEARS AND HUMANS IN YELLOWSTONE NATI CNAL PARK, 1970-73.

BIOSCIENCE 24(6):335-338.

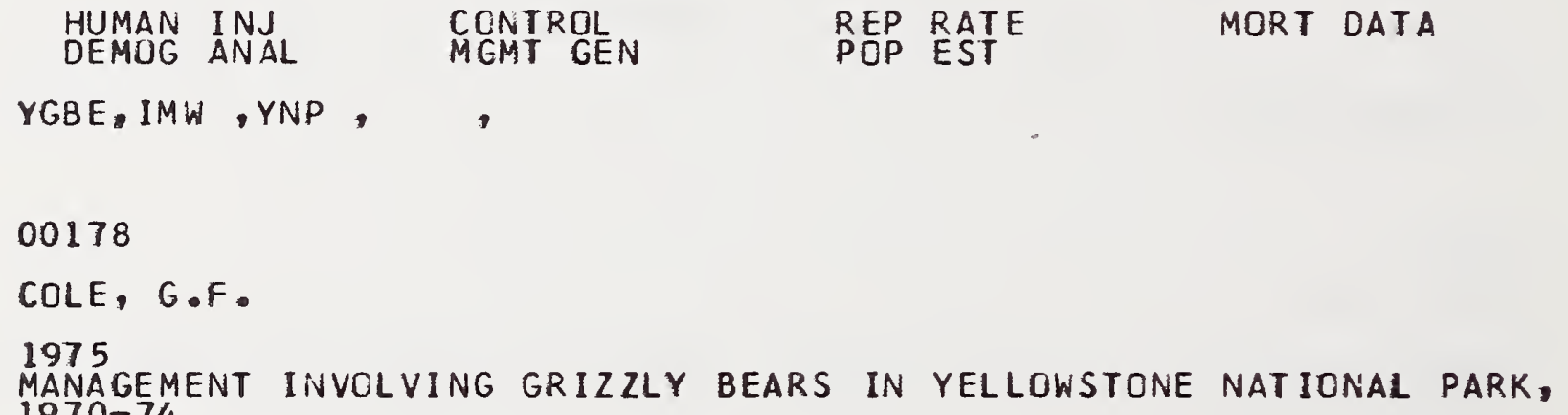

PRES AT 26TH ANNU. AM. INST. BIOL. SCI. MEET., OREGON STATE UNIV $\rightarrow$ CORVALLIS, OREG: 34 PP.

$\begin{array}{lll}\text { MGMT GEN } & \text { MONIT SYS } & \text { HUMAN INJ } \\ \text { REP RATE } & \text { POP EST } & \text { DEMOG ANAL } \\ \text { YGBE,IMW, YNP } & , & \end{array}$

00179

COLE, G.F.

1976

MANAGEMENT INVOLVING GRIZZLY AND BLACK BEARS IN YELLOWSTONE NATIO NAL PARK, 1970-75.

U.S.D.I. NATL. PARK SERV. YELLOWSTONE NATL. PARK, WYO. RES. REP $\begin{array}{llll}\text { MONIT SYS } & \text { MGMT GEN } & \text { HUMAN INJ } & \text { SEAS BEH } \\ \text { CONTROL } & \text { REP RATE } & \text { DEMDG ANAL } & \text { RECR MGMT }\end{array}$ YGBE,IMW, YNP, ,

CO180

COLMENARES, F. AND H. RIVERO.

1983A

DISPLAYS OCCURR ING DUR ING CONFLICT SITUATIONS CONVEY CHEMICAL AND VISUAL INTIMIDATICN MESSAGES IN BEARS LIVING UNDER CAPTIVE GROUP CONDITIONS.

ACTA 20OL. FENN. 174:145-148.

THREAT

MARK

$\triangle G O N$

, GEN, , ,


00181

COLMENARES, F. AND H. RIVERO.

19838 MALE TOLERANCE, MATE SHARING AND SOCIAL BCNDS AMONG ACULT MA LE BROWN BEARS LIVING UNDER GROUP CONDITIONS IN CAPTIVITY.

ACTA ZOOL. FENN . 174:149-151.

INTRASP BEH COURT AGON

$$
\text { GEN, , , }
$$

$\mathrm{CO} 82$

COLORADO WILDLIFE COMMISSION.

1982 RESOLUTION REGARDING INTRODUCTION OF GRIZZLY BEAR AND GRAY ITIMBE RI HOLF IN COLDRADO.

COLO. DEP. NAT. RESOUR., DIV. OF WILDL , DENVER. 1 PP.

LEGAL POL/ACM MGMT INT/REINT

$$
, \mathrm{CO}, \quad,
$$

00183

COMPUHEAT SERVICES CANADA LTD.

1986

INFRA-RED DETECTION AND ACOUSTIC DETERRENT STUDY, CAPE CHURCHILL, MANITOEA, 1984 .

PREP. FOR GOV OF NORTHWEST TERRIT: DEP, RENEWABLE RESOUR Y YELL OWKNIFE BY CDMPUHEAT SERV. CAN. INC , CALGARY, ALBERTA. REP. NO. DETER/REPEL

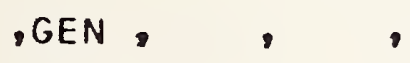

C0184

CONOVER, M.R., J.G. FRANCIK AND D.E. MILLER.

1977

AN EXPERIMENTAL EVALUATION OF AVERSIVE CONDITIONING FOR CONTROLLI NG COYOTE PREDATION.

J. WILDL. MANAGE. 41(4):775-779.

A VER COND

, GEN 
00185

CONTRERAS, G.P. AND K.E. EVANS, (EDS.).

1986

PRCCEEDINGS - GRIZZLY BEAR HABITAT SYMPOSIUM. U.S.D.A. REOREST SERV.
- INTECH. REP. INT-207. 252 PP.
HAB USE
HAB EFFECT
HAB ANAL
TIMB M METH
HAB RECON
TIMB-POST $, G E N, \quad$,

00186

CDONEY, R. F.

GRIZLLY BEAR STUDY.

FED: AID WILDL; REST. PROJ. COMPLETION REP. MONT. DEP. FISH AND G
AME: HELENA. IT PP. CENSUS/TREND POP DENS FOOD DEN CHRON

NCDE,MT ,LCNF,FLNF,

00187

COONEY, R.F.

1947

GRIZZLY BEAR NOTES.

PROC ANNU. CONF. WEST. ASSDC. STATE FISH AND GAME COMMISSIONERS 27:122-126.

CENSUS/TREND POP DENS FDOD

NCDE,MT ,LCNF, FLNF,

00188

COUEY, F.M. AND R.P. WECKWERTH.

1965

BIG GAME SURVEYS AND INVESTIGATIONS.

FED. AID WILDL. REST. PROJ, W-71-R-10, JOB A-1. JOB COMPLETION RE P. JULY I. $1964-J U N E$ 30, 1965 . MONI. FISH AND GAME DEP. HELENA. 24 PP.

CONTROL

DEPRED

HARV DATA

POACH/ ILLEG

NCDE,MT 
00189

COUEY, F.M. AND R•P. WECKWERTH.

1966 BIG GAME SURVEYS AND INVESTIGATIONS.

FED. AID WILDL. REST. PROJ $W-71-R-11$, JOB A-1. JCB COMPLETION RE P. JULY 1, 1965-JUNE 30, 1966. MONT. FISH AND GAME DEP.. HELENA. HARV DATA

$\mathrm{NCDE}, \mathrm{MT} \quad, \quad$,

CO190

COUEY, F.M. AND R.P. WECKWERTH.

1968 BIG GAME SURVEYS AND INVESTIGATIONS.

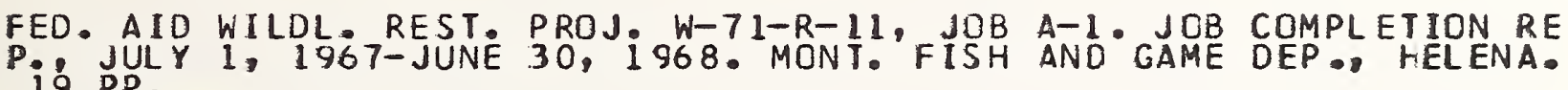
HARV DATA

NCDE,MT , , ,

00191

COURTNEY, J.

NOTES ON THE BEHAVIOR OF A MATING PAIR OF GRIZZLY BEARS IURSUS AR CTOS).

MANUSCRIPT. 22 PP.

COURT

CR ,AT , BANP, ,CASC

00192

COURTRIGHT, A.M.

1965

1963-1964 REPORT ON GAME HARVEST.

FED. AID WILDL. REST PROJ. W-6-R-5, WORK PLAN K PROJ. SEGMENT R EP.: VOL. V, NO. 2. ALASKA DEP. FISH AND GAME, JUNEAU. 25 PP.

HARV DATA AGE/SEX

, AK 
00193

CDURTRIGHT, A.M.

1968

GAME HARVESTS IN ALASKA.

FED AID WILDL. REST. PROJ. W-6-R-7. ALASKA DEP. FISH AND GAME, J
LNEAU. 70 PP. HARV DATA

, AK , , ,

00194

COWAN, I.M.

IHE 27 STATUS ANO CONSERVATION OF BEARS (URSIDAE) OF THE WORLO - 197

INT. CONF. BEAK RES. AND MANAGE. 2:343-367.

$\begin{array}{llll}\text { PRES DISTR } & \text { POP EST } & \text { HARV DATA } & \text { POP DENS } \\ \text { HARV MGMT } & \text { HARV IMP } & \text { MGMT GEN }\end{array}$

00195

COWAN, I.M., D.G. CHAPMAN, R.S. HOFFMAN, D.R. MCCULLOUGH, G.A. SWAN SON AND R.E. WEEDEN.

REPORT OF THE COMMITTEE ON THE YELLCWSTONE GRIZZLIES.

NATL. ACAD. SCI., WASHINGTON, D.C. 61 PP.

$\begin{array}{llll}\text { HIST DISTR } & \text { POP EST } & \text { PCP OENS } & \text { CONTROL } \\ \text { REP RATE } & \text { MORT RATE } & \text { DEMOG ANAL } & \text { POP REG } \\ \text { MGMT GEN } & & \end{array}$

YGBE,IMW, YNP, USFS,

00196

CRAIGHEAD, F.C., JR.

GRIZZLY BEAR RANGES AND MOVEMENT AS DETERMINED BY RADIOTRACKING.

INT. CONF BEAR RES. AND MANAGE. 3:97-109.

HOME RNG

POP DENS

JERR/SPACE

MGMT GEN
MCVE
RELOC

\section{CARCASS
CONTROL}


00197

CRAIGHEAD, F.C., JR.

TR79 9 TK OF THE GRIZZLY.

SIERRA CLUB BOOKS, SAN FRANCISCO. 262 PP.

$\begin{array}{llll}\text { DEN } & \text { COURT } & \text { HOME RNG } & \text { MOYE } \\ \text { INTRASP,BEH } & \text { POP BIOL } & \text { HIB PHYS } & \text { MATERNAL } \\ \text { TERR/SPACE } & & & \\ \text { YGBE,IMW ,YNP }, & , & & \end{array}$

00198

CRAIGHEAD, F.C., JR. AND J.J. CRAIGHEAD.

1963 RADIOTRACKING OF GRIZZLY BEARS IN YELLOWSTONE NATIONAL PARK, WYOM ING.

PP. 59-67; IN: P.H. OEHSER, ED. NATL GEOGR. SCCIETY RES. REP. 1 964. NATL: GEOGR. SOC., WASHINGTON, D. C.

DEN CHRON HOME RNG MOVE FOOD

YGBE,WY, YNP, ,

00199

CRAIGHEAD, F.C., JR $\rightarrow J . J . C R A I G H E A C$ AND R.S. DAVIES.

1963

RADIDTRACKING OF GRIZZLY BEARS.

BIOTELEMETRY: $133-148$.

TELEM

YGBE, IMW, YNP, ,

C0200

CRAIGHEAD, F.C., JR. AND J.J. CRAIGHEAD.

1964 GRIZZLY BEAR ECOLOGICAL FINDINGS OBTAINED BY BIC-TELEMETRY.

MONT. COOP. WILDL. RES. UNIT, UNIV. MONT, MISSDULA. 31 PP.

$\begin{array}{llll}\text { IELEM } & \text { HCME RNG } & \text { MOVE } & \text { PRED } \\ \text { INTRASP } & B E H & \text { REACTION } & \text { SIGHT }\end{array}$

YGBE, IMW, YNP , 
00201

CRAIGHEAD, F.C., JR. AND J.J. CRAIGHEAD.

1965

TRACKING GRIZZLY BEARS.

BIOSCIENCE $15(2): 88-92$.

$\begin{array}{lll}\text { DEN TELEM HOME RNG } & \text { MOVE }\end{array}$

YGBE,WY, YNP, ,

00202

CRAIGHEAD, F.C., JR. AND J.J. CRAIGHEAD.

RA69 IUTRACKING OF GRIZZLY BEARS IN YELLOWSTONE NATIONAL PARK, WYOM ING, 1964.

PP. 35-43 IN: P.H. OEHSER, ED. NAT IONAL GEOGRAPHIC SOCIETY RESEAR CH REPORTS, 1964. NATL. GEOGR: SOC.. WASHINGTON, D.C.

HOME RNG DEN SEAS BEH MOVE
TELEM

YGBE,IMW, YNP, ,

00203

CRAIGHEAD, F.C., JR. AND J.J. CRAIGHEAD.

RADIOTRACKING OF GRIZZLY BEARS IN YELLONSTONE NATIONAL PARK, WYOM ING, 1962.

PP. 63-71 IN: P,H, OEHSER, ED NATIONAL GEOGRAPHIC SOCIETY RESEAR CH REPORTS, 1961-1962. NATL. GEOGR. SOC.. WASHINGTON, D.C.
POP BIOL
MOVE
CONTROL
WEIGHT
HARV DATA
AGE DETERM
SEAS BEH
INTRASP
BEH

YGBE,WY, YNP, ,

00204

CRAIGHEAD, F.C. JR. AND J.J. CRAIGHEAD.

BI OTELEMETRY RESEARCH WITH GRIZZLY BEARS AND ELK IN YELLOWSTONE N ATIONAL PARK, WYOMING, 1965.

PP. 49-62 IN: P.H. OEHSER, ED. NATICNAL GEOGRAPHIC SOCIETY RESEAR CH REPORTS, 1965. NATL. GEOGR. SOC.. WASHINGTON, D.C.

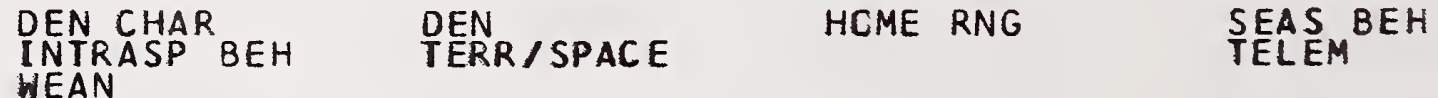


00205

CRAIGHEAD, F.C., JR. AND J.J. CRAIGHEAD.

GRIZZLY BEAR PREHIBERNATION AND DENNING ACTIVITIES AS DETERMINED BY RADIOTRACKING.

WILOL. MONOGR. NO. 32. 35 PP.

$\begin{array}{llll}\text { HIB PHYS } & \text { TELEM } & \text { DEN CHAR } & \text { DEN SITE } \\ \text { MOVE } & \text { DEN CHRON } & \text { DAY BED } & \text { HOME RNG } \\ \text { INTRASP BEH } & & \end{array}$

$Y G B E, W Y, Y N P$, ,

00206

CRAIGHEAD, F.C, JR. AND J.J. CRAIGHEAD.

19728 RADIOTRACKING OF GRIZZLY BEARS AND ELK IN YELLOWSTONE NATIONAL PA RK, WYOMING, 1959-1960.

PP. 55-62 IN: P.H, OEHSER, ED, NATIONAL GEOGRAPHIC SOCIETY RESEAR CH REPORTS, $1955-1960$. NATL! GEOGR. SOC., WASHINGTON, D.C.

TELEM RES TECH DRUGS

YGBE,WY ,YNP , ,

00207

CRAIGHEAD, $F . C . J R$. AND J.J. CRAIGHEAD.

$1972 \mathrm{C}$

DATA ON GRIZZLY BEAR DENNING ACTIVITIES AND BEHAVIOR OBTAIAED BY USING WILDLIFE TELEMETRY.

INT. CONF. BEAR RES. AND MANAGE • 2:84-106.

$\begin{array}{llll}\text { TELEM } & \text { DEN SITE } & \text { ORPHAN } & \text { DEN CHAR } \\ \text { DENCHRON } & \text { DAY BED } & \text { MCVE } & \text { INTRASP BEH } \\ \text { REACYION } & & & \\ \text { YGBE,WY , YNP } & , & & \end{array}$

00208

CRAIGHEAD, F.C, JR. AND J.J. CRAIGHEAD.

1973 RADIORACKING OF GRIZZLY BEARS AND ELK IN YELLOWSTONE NATIONAL PA RK, WYOMING, 1966 .

PP. 33-48 IN: P.H. OEHSER, ED. NAT IONAL GEOGRAPHIC SOCIETY RESEAR CH REPORTS, 1966. NATL. GEOGR: SOC. WASHINGTCN, D.C.
DEN
DEN CHAR
DEN CHRON
INTRASP BEH

YGBE,WY, YNP, , 
00209

CRAIGHEAD, F.C. JR. AND J.J. CRAIGHEAD.

1974 RADIOTELEMETRY RESEARCH ON LARGE WESTERN MAMMALS IN YELLOWSTONE N ATIONAL PARK, WYOMING, 1967 .

PP. 35-51 IN: P.J. OEHSER, ED. NATIONAL GEOGRAPHIC SOCIETY RESEAR CH REPORTS, 1967. NATL. GEOGR: SOC. WASHINGTON, D.C.

HOME RNG HIB PHYS TELEM

YGBE, IMW, YNP, USFS,

$\operatorname{co2} 10$

CRAIGHEAD, J.J.

1977 A DELINEATION OF CRITICAL GRIZZLY BEAR HABITAT IN THE YELLOWSTONE REGION.

MONT . COOP . WILDL. RES. UNIT, UNIV. MONT. MISSOULA.

$\begin{array}{llll}\text { DISTR } & \text { GEN DATA } & \text { GARBAGE } & \text { MORT DATA } \\ \text { DEN SITE } & \text { RECR IMP } & \text { LIVESTK IMP } & \text { TIMB IMP } \\ \text { IONING } & & & \end{array}$

00211

CRAIGHEAD, J.J.

1980

A PROPOSED DELINEATION OF CRITICAL GRIZZLY BEAR HABITAT IN THE YE LLOWSTONE REGION.

BEAR BIOL. ASSOC. MONOGR. SER . NO. 1. 20 PP.

$\begin{array}{llll}\text { GEN DATA } & \text { HAB USE } & \text { RECR IMP } & \text { LIVESTK IMP } \\ \text { TIMB IMP } & \text { MORT DATA } & \text { HARV DATA } & \text { ZONING } \\ \text { PRES DISIR } & & \end{array}$

00212

CRAIGHEAD, J.J.

1984

A DEFINITIVE SYSTEM FOR ANALYSIS OF GRIZZLY BEAR HABITAT AND OTHE $R$ WILDERNESS RESOURCES.

PP $153-162$ IN: P.H. OEHSER, J.S LEA AND N:L. POWARS, EOS NATIO GR. SOC.: WASHINGTON, D.C. HAB EFFECT MAP/TYPE FOOD

NCDE,MT ,FLNF, LCNF, LSWA 
00213

CRAIGHEAD, J.J. AND F.C. CRAIGHEAD, JR •

1967

MANAGEMENT OF BEARS IN YELLOWSTONE NATIONAL PARK.

MONT. COOP. WILDL. RES. UNIT, UNIV. MONT. MISSCULA. 113 PP.

$\begin{array}{llll}\text { DISTR } & \text { HUMAN INJ } & \text { ZONING } & \text { GARB MGMT } \\ \text { RECR MGMT } & \text { HARV MGMT } & \text { DEMOG ANAL } & \text { CONTROL } \\ \text { DEPRED } & & \end{array}$

YGBE,IMW, YNP, USFS,

00214

CRAIGHEAD, J.J. AND F.C. CRAIGHEAD, JR.

1970 FOOD HABITS OF YELLCWSTONE GRIZZLY BEARS.

UNPUBL. REP. 35 PP.

FOOD

YGBE, IMW, YNP, ,

00215

CRAIGHEAD, J.J. AND F.C. CRAIGHEAD, JR.

GRI'ZZLY BEAR-MAN RELATIONSHIPS IN YELLOWSTONE NATIONAL PARK。

INT . CONF. BEAR RES. AND MANAGE. 2:304-332.

$\begin{array}{llll}\text { TERR/SPACE } & \text { MOVE } & \text { PCP DENS } & \text { GARBAGE } \\ \text { CCNTROL } & \text { HUMAN INJ } & \text { RELOC } & \text { GARB MGMT } \\ \text { CAMP MGMT } & & & \\ \text { YGBE,IMW,YNP, } & , & & \end{array}$

00216

CRAIGHEAD, J.J., F.C. CRAIGHEAD AND D.J. CRAIGHEAD. USING SATELLITES TO EVALUATE ECOSYSTEMS AS GRIZZLY BEAR HABITAT.

PP 101-112 IN: G.P - CONTRERAS AND K.E. EVANS, EDS PROCEECINGS-G IN RES. STAT., DGDEN, UTAH. GEN. TECH. REP. INT-2OT.

MAP/TYPE

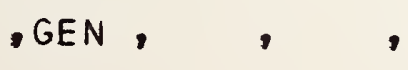


00217

CRAIGHEAD, J.J., F.C. CRAIGHEAD, JR. AND M. HORNOCKER. 1962 AN ECOLOGICAL STUDY OF THE GRIZZLY BEAR.

FOURTH ANNUAL REP., SUMMARY OF WORK ACCOMPLISHED 1959-1962. MONT. COOP. WILDL. RES: UNIT, MUNT. STATE UNIV . MISSOULA. 38 PP.

$\begin{array}{lll}\text { RES TECH } & \text { POP BIDL } & \text { POP EST } \\ \text { HEMAT } \\ \text { MOVE } & \text { MEAS/QUANT } & \text { MORPHJPHYS }\end{array}$

YGBE,WY, YNP, ,

00218

CRAIGHEAD, J.J., F.C. CRAIGHEAD, JR. AND H.E. MCCUTCHEN. 1970 AGE DETERMINATION OF GRIZZLY BEARS FROM FOURTH PREMOLAR TOCTH SEC TIONS.

J. WILDL. MANAGE. 34(2):353-363.

AGE DETERM GROW/DEV DRUGS MORPHIPHYS , GEN,,

00219

CRAIGHEAD, J.J., F.C. CRAIGHEAD JR. AND R.L.RUFF• 1964 AN ECOLOGICAL STUDY OF THE GRIZZLY BEAR: SIXTH ANNUAL REPORT, SUM MARY OF WORK ACCOMPLISHED, 1964.

MONT. COOP. WILDL. RES. UNIT, MONT. STATE UNIV., MISSOULA. 18 PP.

$\begin{array}{llll}\text { RES TECH } & \text { MOVE } & \text { FOOD } & \text { CENSUS/TREND } \\ \text { AGEISEX } & \text { REP RATE } & \text { MORT DATA } & \text { AGE DETERM }\end{array}$

YGBE,WY, YNP,

C0220

CRAIGHEAD, J.J., F.C. CRAIGHEAD, JR. AND J. SUMNER.

REPRODUCTIVE CYCLES AND RATES IN THE GRIZZLY BEAR, URSUS ARCTOS H ORR IBILIS, OF THE YELLOWSTONE ECOSYSTEM.

INT. CONF. BEAR RES. AND MANAGE. 3:337-356.

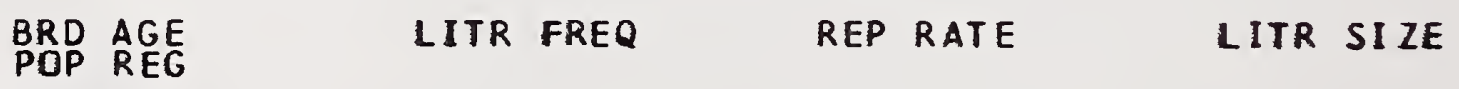

YGBE,IMW, YNP, , 
00221

CRAIGHEAD, J.J., M.G. HORNOCKER AND F.C. CRAIGHEAD, JR. 1969

REPRODUCT IVE BIOLOGY OF YOUNG FEMALE GRIZZLY BEARS.

J. REPROD. FERT. (SUPPL. 6):447-475.
LOURT FITR FRE
REPRO PHYS
$B R D \quad A G E$
LITR SIZE

YGBE,WY ,YNP, ,

00222

CRAIGHEAD, J.J., M.G. HCRNOCKER, W. WOODGERD AND F.C. CRAIGHEAD, JR 1960

TRAPPING, IMMOBILIZING, AND COLOR-MARKING GRIZZLY BEARS.

TRANS. NORTH AM. WILDL. AND NAT. RESOUR - CONF. 25:347-363.
HIST ACCT
RES TECH
DRUGS
WE IGHT
CAPTURE

YGBE,WY, YNP, ,

00223

CRAIGHEAD, J.J. AND J.A. MITCHELL.

\section{2}

GRIZZLY BEAR (URSUS ARCTOS).

PP. 515-556 IN: J.A. CHAPMAN AND G. A. FELDHAMER, EDS. WILD MAMMAL S OF NORTH AMERICA: BICLOGY MANAGEMENT, ECONCMICS HOPKINSS, BALTI MORE, MD.
GEN BIOL
RES TECH
GEN DATA
DEMOG ANAL
POP DENS

TAXON/EVOL

YGBE, IMW, YNP

00224

CRAIGHEAD, J.J. AND D.S. STOCKSTAD.

1960

COLOR MARKER FOR BIG GAME.

J. HILDL. MANAGE, 24(4):435-438.

\section{RES TECH}

GEN , 
00225

CRAIGHEAD, J.J., J.S. SUMNER AND G.B. SCAGGS.

1982 A DEFINITE SYSTEM FOR ANALYSIS OF GRIZZLY BEAR HABITAT AND OTHE $R$ WILDERNESS RESDURCES.

WEST WILOLANDS INST, UNIV. MONT. FOUNDATION, UNIV. MONT., MISSOU LA. MONOGR. NG. I. 279 PP.
MAP/TYPE
NUTR ANAL
FOOD GEN
$\begin{array}{ll}\text { HAB } & \text { USE } \\ \text { HAB } & \text { EFFECT }\end{array}$
TIMB MGMT

NCDE,MT ,FLNF, LCNF, LSWA

00226

CRAIGHEAD, J.J., J. VARNEY AND F.C. CRAIGHEAD, JR.

1973 COMPUTER ANALYSIS OF THE YELLOWSTONE GRIZZLY BEAR POPULATION.

MONT. COOP. WILDL. RES. UNIT, UNIV. MONT. MISSOULA. 146 PP.

$\begin{array}{llll}\text { DEMOG ANAL } & \text { POP EST } & \text { AGE/SEX } & \text { REP RATE } \\ \text { LONGEV } & \text { MORT RATE } & \text { CCNTROL } & \text { HARV DATA } \\ \text { MGMT GEN } & \text { MER } & \end{array}$

YGBE.IMW, YNP, USFS,

00227

CRAIGHEAD, J.J., J.R. VARNEY AND F.C. CRAIGHEAD, JR. 1974 A POLLATION ANALYSIS OF THE YELLOWSTONE GRIZZLY BEARS.

MONT. COOP. WILDL. RES. UNIT, UNIV. MONT. " MISSOULA. BULL. NO. 40
20 PP.
DEMOG ANAL
MORT RATE
AGE/ SEX
POP EST
$\begin{array}{ll}\text { REP } & \text { RATE } \\ \text { POP } & \text { REG }\end{array}$
MORT RATE
MGMT GEN

LONGEV

YGBE, IMW, YNP, ,

00228

CRAIGHEAD, J.J., J.R. VARNEY, F.C. CRAIGHEAD, JR. AND J.S. SUMNER. 1976

TELEMETRY EXPERIMENTS WITH A HIBERATING BLACK BEAR.

INT. CONF. BEAR RES. AND MANAGE. 3:357-371.

TELEM

HIB PHYS

TEMP

WEI GHT 
00229

CROOK. J. L.

1971

DETERMINATION OF ABUNDANCE AND DISTRIBUTION OF BROWN BEAR IURSUS ARCTOS I NORTH OF THE BROOKS RANGE. ALASKA.

M.S. THESIS, UNIV. ALASKA, FAIRBANKS. $78 \mathrm{PP}$.

$\begin{array}{llll}\text { CENSUS METH } & \text { CENSUS/TREND } & \text { POP DENS } & \text { PRES DISTR } \\ \text { FOOD } & \text { SEAS BEH } & \text { ACE/SEX } & \text { REP RATE } \\ \text { HARV DATA } & \text {,NSLP } & & \\ \text { ARC AK , } & \text {, NSLP }\end{array}$

00230

CROOK. J.L.

1972

GRIZZLY BEAR SURVEY AND INVENTORY.

FED. AID WILDL. REST. PROJ. W-17-38, JUB 4 JOB COMPLETION REP.
JAN: 1, $1970-D E C .31,1971$. ALASKA DEP. FISH AND GAME, JUNEAU. 38
PP: $\begin{array}{llll}\text { HARV DATA } & \text { PRES DISTR } & \text { SEAS BEH } & \text { FOOD } \\ \text { POP DENS } & & \text { PRED } & \text { RES TECH }\end{array}$

$A K-I, A K, \quad, N S L P$

00231

CUMBAA, S.L. AND J.V. SCISCENTI.

1978

NOTES ON SIX CRANIA OF THE GRIZZLY BEAR, URSUS ARCTOS, FROM THE C YPRESS HILLS REGION OF SASKATCHEWAN AND ALBERTA.

J. MAMMAL. 59(2):431-433.

DISTR SKULL

,ATSA, , , CYPR

00232

CURATOLD, J.A. AND G.D. MOORE.

1975

HOME RANGE AND POPULATION DYNAMICS OF GRIZZLY BEAR IN THE EASTERN BROOKS RANGE, ALASKA.

CHAPTER 1,79 PP IN: R D. JAKIMCHUK, ED. STUDIES OF LARGE MAMMA LS ALONG THE PROPOSED MACKENZIE VALLEY GAS PIPELINE ROUTE FROM AL ASKA TO BRITISH COLUMBIA. ARCTIC GAS BIOL. REP. SER. VOL. 32.
HOME RNG
POP BIOL
DEN SEAS BEH
WAB USE
POP DENS
MEASIQUANT

$A R C, A K, \quad, E B R K$ 
00233

CUSHING, B. S.

1983 RESPONSES OF POLAR BEARS TO HUMAN MENSTRUAL ODCRS.

INT. CONF. BEAR RES. AND MANAGE= 5:270-274.

AVOID/ATIRAC

, GEN,,$\quad$

00234

DALLE-MCLLE, J.

1984 FIELD TESTS AND USERS OPINIONS OF BEAR RESISTANT BACKPACK FOOD C CNTAINERS IN DENALI NATIONAL PARK, ALASKA, 1982 AND 1983.

U.S.D.I., NATL. PARK SERV., DENALI NATL. PARK, ALASKA. 25 PP.

CAMP MGMT

$A K-1, A K$ DENP,

00235

CALLE-MOLLE, J.

1984 DETERRING BEARS FROM BACKCOUNTRY CAMPSITES: TESTS IN DENALI NATIO NAL PARK IN 1984.

PRES. IST ALASKA INTERAGENCY BEAR BIOL. CONF. AND WORKSHOP, 5-6 D ECEMBER 1984.1 PP.

DETER/REPEL AVER COND

$A K-I, A K$, DENP,

00236

CALLE-MOLLE, J., M.A. COFFEY AND H.W. WERNER.

IN PRESS

U.S.D.A. FOREST SERY INTERMOUNTAIN FOREST AND RANGE EXP. STAT. , OGDEN, UT: GEN. TECH: REP?

NONMOT MGMT CAMP MGMT DETER/REPEL

$A K-I, A K, D E N P$, 
00237

DARLING, L.M.

INABITAT USE BY GRIZZLY BEAR FAMILY GROUPS IN INTERIOR ALASKA.

INT - CONF. BEAR RES. AND MANAGE. 7 .

HAB USE FOOD MOVE

$A K-I, A K, D E N P$,

00238

DASMANN, R.F.

APP ARENT EXTINCTION OF GRIZZLY BEAR IN MEXICO.

BIOL. CONSERV $1(4): 336-337$

PRES DISTR

, MEX , , ,

00239

CAVEY, J.T.

1971 A CASE OF ANISAKIS SP. INFECTION IN A BROWN BEAR FROM ALASKA.

TRANS. ROYAL SOC. TROP. MED. AND HYG. 65(4):433-434.

PARAS/OIS

, GEN, , ,

$\mathrm{CO} 240$

CAVIS, D.D.

1964

THE GIANT PANDA, A MORPHOLOGICAL STUDY OF EVOLUTIONARY MECHANISMS

FIELDIANA ZOOL. MEM., VOL. 3. CHICAGO NAT. HIST. MUS, CHICAGO.

MORPH/PHYS

- GEN, , 
00241

DAVIS, D.L., W.E. MELQUIST AND D. GRAHAM.

1986 THE SELWAY-BITTERRCOT ECOSYSTEM AS GRIZZLY BEAR HABITAT. PP $158-162$ IN: G.P. CONTRERAS AND K.E. EVANS, EDS. PROCEECINGS-G IN RES. STAT., CGDEN, UTAH. GEN. TECH. REP. INT-207.

MGMT GEN

FIRE MGMT

SBE, ID, ,

00242

DAVIS, J.L. AND P. VALKENBURG.

1981

NATURAL MORTALITY OF WESTERN ARCTIC CARIBOU.

FED A ID WILDL. REST. PROJ. W-21-1, JOB $3.24 R$ PROG. REP, JULY 1 .
1979-JUNE 30, 1980. ALASKA DEP. FISH AND GAME, JUNEAU. I9 PP. PRED

$A R C, A K, \quad, W B R K$

00243

DAVIS, J.L. AND P. VALKENBURG.

1985

QUALITATIVE AND QUANTITATIVE ASPECTS OF NATURAL MORTALITY CF THE WESTERN ARCTIC CARIBOU TERD.

FED. AID WILDL, REST, PROJ. W-17-11,W-21-2,W-22-1, W-22-2 AND W $-22-3$, JOB $3.24 R$ FINAL REP, JULY 1, $1981-$ JUNE 30,1984 . ALASKA

PRED

$A R C, A K, \quad, W B R K$

00244

CAVIS, $M$.

1950

HYBRIDS OF THE POLAR AND KODIAK BEAR.

J. MAMMAL. $31(4): 449-450$.

REPRO

GENETICS

, GEN, , 
00245

DAY, G., C. JONKEL AND T. HERNER.

RELOCATIONS OF GRIZZLIES IN THE BORDER GRIZZLY AREA.

BORDER GRIZZLY PROJ., UNIV. MONT., MISSOULA. SPEC.REP. NC. 14. 7

RELOC CONTROL

NCDE,MT, , ,

00246

CEAN, F.C.

INVE

ALASKA COOP. WILDL. RES. UNIT QUART. REP. 9(4):61-71.

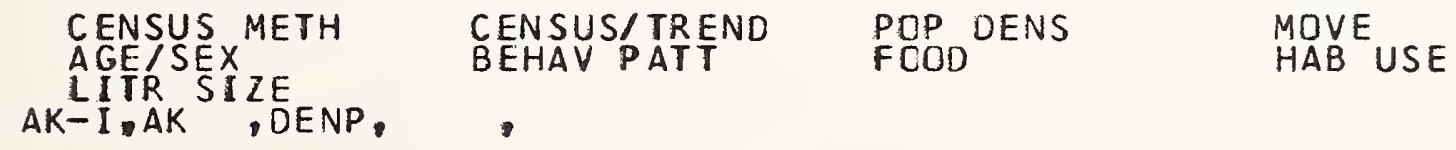

00247

DEAN, F.C.

1962

INVESTIGATICNS ON GRIZZLY BEARS IN INTERICR AND ARCTIC ALASKA.

ALASKA COOP. WILDL. RES. UNIT QUART. REP • 14111:9-16.

CAPTURE DRUGS

$A K-I, A K, \quad, \quad$,

00248

DEAN, F.C.

1968

BROWN BEAR - HUMAN INTERRELATIONSHIP STUDY.

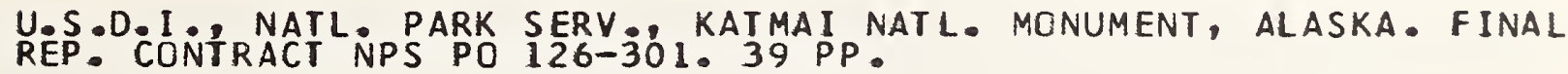

FOOD RECR MGMT PRED

GARB MGMT

AKPN,AK, KANM, ,BROD
REACTION

POP EST

POL/ADM MGMT 
00249

DEAN, F.C.

1975 A LAND USE PHILOSOPHY PROPOSAL FOR BEAR MANAGEMENT. PRES. AT NORTHWEST. SECT. WILDL. SCC. MEET , 4 APRIL 1975, ANCHOR
AGE, ALASKA. 20 PP:

$\begin{array}{llll}\text { PQACH/ILLEG } & \text { MGMT GEN } & \text { RECR MGMT } & \text { POL/ADM MGMT } \\ \text { LEGAL } & \text { GARB MGMT } & \text { ZCNING } & \end{array}$

, AK, , ,

00250

DEAN, F.C.

1976
ASPECTS OF GRIZZLY BEAR POPULATION ECOLOGY IN MOUNT MCKINLEY NATI
CNAL PARK.

INT. CONF. BEAR RES. AND MANAGE. 3:111-119.

$\begin{array}{llll}\text { POP DENS } & \text { AGE/SEX } & \text { LITR SIZE } & \text { COURT } \\ \text { RECR IMP } & \text { HARV DATA } & \end{array}$

00251

DEAN, F.C., L.M. DARLING AND A.G. LIERHAUS.

1985
I.

CAN. FIELD-NAT. 99.

CANNI BAL

$A K-I, A K \quad, D E N P$,

00252

CEAN, F.C. AND I.F. GRESEHOVER.

1983

BROWN BEAR BIBLIOGRAPHY: SUPPLEMENT NO. 1.

ALASKA COOP. PARK STUDIES UNIT, UNIV. ALASKA, FAIRBANKS.

BIBLIO

, GEN $\quad, \quad$ 
00253

$D E A N, F \cdot C$.

IN PRESS BROWN BEAR DENSITY IN DENALI NATIONAL PARK, ALASKA: SIGHTING EFF IC I ENC Y TECHNIQUES.

INT. CONF. BEAR RES. AND MANAGE. 7 .

$$
\text { POP DENS CENSUS METH }
$$

AK-I, AK ,DENP,

00254

DELL INGER, P. (ED.)

1985

INDENITIF ICATION MANUAL VOLUME I: MAMMALIA.

CONVENTION INT. TRADE ENDANGERED SPECIES WILD FAUNA AND FLORA.

\section{DENT / RECOG}

$$
\text { , GEN , , , }
$$

00255

DELSORDO, D.

1981

A REVIEW OF LITERATURE RELATED TO WHITE PINE BLISTER RUST, WHITE BARK PINE, AND GRIZZLY EEARS.

B.S. THESIS, UNIV. MONT,, MISSOULA. 20 PP.

FOOD HAB USE MGMT GEN

$$
\text { GEN, },
$$

00256

DEMARCHI, R.A.

PROTECTING FEMALE AND JUVENILE GRIZZLY BEARS FROM HUNTING MORTALI TY.

B.C. FISH AND WILDL. BRANCH, VICTORIA. 3 PP.

HARV IMP

HARV MGMT

,$B C$ 
00257

DEMASTER, D.P. M.C.S. KINGSLEY AND I. STIRLING.

1980

A MULTIPLE MARK AND RECAPTURE ESTIMATE APPLIED TO POLAR BEARS.

CAN.J. ZOCL. 58:633-638.

CENSUS METH

, GEN, ,

00258

DEROCHER, A.E. AND J.S. MILLER

1986 DETERRENT STUDY (TWELVE GAUGE FERRET SHELL TESTS) CAPE CHURC HILL, MANITOBA, 1984. GOV. OF NORTHWEST TERRIT. . DEP. RENEWABLE RESOUR • YELLOWKNIFE. R
EP. NO. $54.40 \mathrm{PP}$.

DETER/REPEL

$, G E N, \quad$,

00259

DESPAIN, D.G.

1986

HABITAT TYPE AND COVER TYPE AS A BASE FOR GRIZZLY BEAR HABITAT MA PPING AND EVALUATION.

PP 230-233 IN: G.P CONTRERAS AND K.E. EVANS, EDS PROCEEDINGS-G RIZZLY BEAR HABITAT SYMPOSIUM U.S.D.A. FOREST SERV. INTERMOUNTA IN RES. STAT., OGDEN, UTAH. GEN. TECH. REP. INT-207.

TYPE DESCRIP MAP/TYPE

YGBE, IMH, , ,

00260

DIDRICKSON, J.C. AND K.P. TAYLOR.

LOWER SUSITNA VALLEY MOOSE POPULATICN IDENTITY STUDY.

FED. AID WILDL. REST. PROJ.W-17-8,AND W-17-9, JOB 1.16R. FINAL R EP. ALASKA DEP: FISH AND GAME. JUNEAU. 26 PP.

PRED

$A K-I, A K, \quad, N E S U$ 
00261

DOLL, D., W.P. MCCRORY ANO J.D. FEIST.

1974

CBSERVATIONS OF MOOSE, WOLF AND GRIZZLY BEAR IN THE NORTHERN YUKO $\Lambda$ TERRITORY.

CHAP. 3 IN: K.H. MCCOURT AND L.P. HORSTMAN, EDS. STUDIESOF LARGE MAMMAL POPULATIONS IN NORTHERN ALASKA, YUKON AND NORTHWEST TERRIT ORIES, 1973. ARCTIC GAS. BIOL. REP. SER. VOL. 22.

$\begin{array}{lll}\text { PRES DISTR } & \text { PELAGE } \\ \text { DEN CHRON } & \text { AIRCRAFT IMP } & \text { AGE/SEX ITR SIZE }\end{array}$

CARC, YK, , ,

00262

DCOD, A.R.R.D. BRANNON AND R.D. MACE.

FIN6 PROGRAMMATIC ENVIRONMENTAL IMPACT STATEMENT: THE GRIZZLY B EAR IN NORTHWESTERA MCNTANA.

MONT. DEP. FISH, WILDL AND PARKS, HELENA. 287 PP.

$\begin{array}{llll}\text { HARV IMP } & \text { HARV DATA } & \text { HARV MGMT } & \text { POP BIOL } \\ \text { MORT RATE } & \text { DEMOG ANAL } & \text { MGMT PLAN } & \text { GEN DATA } \\ \text { RECR MGMT } & & & \\ \text { NCDE,MT }, & & & \end{array}$

00263

DOOD, A.R., R.D. BRANNON AND R.D. MACE.

IN PRESS CSYSTEM, MONTANA.

TRANS. NORTH AM. WILDL. NAT.RESOUR• CONF• 51.

$\begin{array}{llll}\text { HARV MGMT } & \text { HARV DATA } & \text { HARV IMP } & \text { MGMT GEN } \\ \text { POP BIOL } & \text { POACHIILLEG } & \text { MORT DATA } & \text { RDAD IMP } \\ \text { DEPRED } & & & \\ \text { NCDE,MT } & , & & \end{array}$

00264

DORRANCE, M.J. AND B.K. GILBERT.

1977 CONSIDERATIONS IN THE APPLICATION OF AVERSIVE CONDITIONING.

PP. 136-144 IN: W.B. JACKSON AND R.E. MARSHA, EDS. TEST METHODS F OR VERTEBRATE PEST CONTROL AND MANAGEMENT MATERIALS. AM. SOC. FOR TESTING AND MATERIALS. SPEC. TECH. PUBL. 625.

AVER COND 
00265

DORRANCE, M.J. AND L.D. ROY.

ATVR̊RIVE CONDITIONING TESTS OF BLACK BEARS IN BEEYARDS FAILED.

PROC. VEP.TEBR. PEST CONF . 8:251-254.

AVER COND

GEN, , ,

00266

DOUGLASS, R.J., J.M. WRIGHT, S.G. FANCY, E.H. FCLLMAN, J.L. HECHTEL i980 ASSESSMENI OF THE KNCWLEDGE OF POTENTIAL EFFECTS OF THE NORTHWEST $Y$ INPUT.

PREP FOR NORTHWEST ALASKAN PIPELINE CO. CONIRACI 478085-9-KO71 BY LGL ECCL. RES. ASSCC.? INC! AND UNIV: ALASKA. FAIRBANKS. 150 P P.

ENERGY IMP ROAD IMP GARBAGE HUMAN IMP

AK , , ,

00267

DOWNING, C.

1975

WILDLIFE ACTIVITY AT THE MCKINLEY PARK AREA GARBAGE DUMPS - A GUID E FOR MANAGEMENT.

REP PREP • FOR U.S.D.I NATL PARK SERV , DENALI NATL P PARK AND PRESERVE, ALASKA. PREP. BY ALASKA CCOP. PARK STUDIES, UNIV• ALASK A, FAIRBANKS. $67^{\circ} \mathrm{PP}$.

GARBAGE

GARB MGMT

$A K-I, A K$,DENP,

00268

DRABELLE, D.

1985 THE ENDANGERED SPECIES PROGRAM. PP. 73-9O IN: R.LL: DISILVESTRO, ED. AUBUDON WILDLIFE REPORT 1985.
NATL: AUDUBON SOC.? N.Y.

LEGAL

US 
00269

DUFF, S.

1980

KAH MOUNTAIN INVESTIGATIONS.

PP. 205-216 IN: C. JONKEL, ED. ANNUAL REPORT. BORDER GRIZZLY PROJ

$\because$ UNIV. MONT.: MISSOULA. ANNU. REP. NO. 5 .

PRES DISTR HAB USE

NCDE, MT , , , , ,

C0270

DUNCAN, M•P.

1978

FORMAL SECTION 7 CONSUL TATION REGARDING THE POIENTIAL EFFECT OF G EDTHERMAL LEASING WITHIN THE TARGHEE AND GALLATIN NATIONAL FOREST

U.S.D.I., FISH AND WILDL. SERV., DENVER, COLO. 3 PP.

ENERGY IMP

YGBE, IDMT, TANF, GANF, ISLP

00271

EAGLE, T.C. AND M.R. PELTON.

1983 SEASONAL NUTRITION OF BLACK BEARS IN THE GREAT SMOKY MOUNTAINS NA TIONAL PARK.

INT . CONF . BEAR RES. AND MANAGE 5:94-101.

NUTR ANAL NUTR

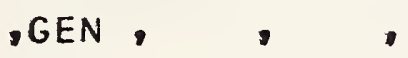

00272

EBERHARDT, L.L., R.R. KNIGHT AND B.M. BLANCHARD.

1986

MONITORING GRIZZLY BEAR POPULATICN TRENDS.

J. WILDL. MANAGE. 50141:613-618.

MORT DATA DEMOG ANAL CENSUS/TREND 
$\mathrm{CO} 273$

EDGE, $W \cdot D$.

IN PRESS IMATING CARRYING CAPACITY OF GRIZZLY BEAR POPULATIONS. DRAFT R.EP PREP * FOR U.S. FISH AND WILDL, SERV, OFFICE OF GRIZZL
Y BEAR RECOVERY COORDINATOR, MISSOULA, MONT. IG PP.

MIN POP POP REG

$, G E N, \quad$,

00274

EDWARDS, R.Y. AND D.E. GREEN.

THE MEASUREMENT OF TRACKS TO CENSUS GRIZZLY BEARS.

MURRELET $40(2): 14-16$

CENSUS METH

$B C-C, B C, \quad$,

00275

EGBERT, A.L.

1978 THE SOCIAL BEHAVIOR OF BROWN BEARS AT MCNEIL RIVER, ALASKA.

PH.D. DISS., UTAH STATE UNIV., LOGAN. 117 PP.

$\begin{array}{lccc}\text { FEED BEH } & \text { TERR/SPACE } & \text { THREAT } & \text { VOCAL } \\ \text { AGON } & \text { INTRASP BEH } & \text { MATERNAL } & \text { COURT } \\ \text { PRED } & & \\ \text { AKPN,AK , }, & \text { MCNE } & & \end{array}$

00276

EGBERT, A.L. AND A.W. STOKES.

1976

THE SOCIAL BEHAVIOUR OF BROWN BEARS ON AN ALASKAN SALMON STREAM.

INT. CONF. BEAR RES. AND MANAGE. 3:41-56.

$\begin{array}{lll}\text { TERR/SPACE } & \text { AGE/SEX } & \text { THREAT } \\ \text { INTRASP BEH } & \text { ACT PATT } & \text { MATERNAL }\end{array}$

AKPN, AK ,MCGS, ,MCNE 
00277

EGGERS, D.E.

1986

MANAGEMENT OF WHITEBARK PINE AS POTENTIAL GRIZZLY BEAR HABITAT. PP. $170-175$ IN: G.P. CONTRERAS AND K. E. EVANS, EDS. PROCEEDINGS-G IN RES. STAT • DGDEN, UTAH. GEN. TECH. REP. INT-207.

TIMB MGMT FIRE MGMT

GEN, , , , ,

00278

EIDE, $S$.

1965

THE NATURE OF BROWN BEAR PREDATION ON CATTLE, KODIAK ISLAND, ALAS KA. PROC ANNU. CONF. WEST. ASSOC. STATE GAME AND FISH COMMISSICNERS
45:113-118.

DEPRED CONTROL AGE/SEX

AKKA, AK, , ,

00279

ELGMORK, $K$.

$1978 \mathrm{~A}$

HUMAN IMPACT ON A BROWN BEAR POPULATION (URSUS ARCTOS L=).

BIOL. CONSERV. $13(2): 81-103$

ROAD IMP TIMB IMP HUMAN IMP GEN , , ,

C0280

ELGMORK, $K$.

$1978 B$

STRIKING BLOWS BY THE BROWN BEAR. (ENGLISH SUMMARY)

FAUNA $31: 157-164$

PRED

$$
\text { GEN, }
$$


00281

ELGMORK, $K$.

CACHING BEHAVIOR OF BROWN BEARS (URSUS ARCTOS).

J. MAMMAL. 63(4):607-612.

PRED

FEED BES

, GEN

CO282

ELGMORK, $K$.

1983

INFLUENCE OF HOLIDAY CABIN CONCENTRATIONS ON THE OCCURRENCE OF BR

ACT ZOOL. FENNICA $174: 161-162$.

URBAN DE

. GEN .

00283

ELTON, C.S.

1954

FURTHER EVIDENCE ABOUT THE BARREN GROUND GRIZZLY BEAR IN NORTHEAS
TLABRADOR AND QUEBEC.

J. MAMMAL. $35(3): 345-357$.

HIST DISTR

- ECAN,

00284

ENTERS, $A . C$.

1963

DELAYED IMPLANTATION.

UNIV. CHICAGO PRESS, CHICAGO. 318 PP.

REPRO PHYS

- GEN ,
CARCASS 
00285

ERICKSON, A.W.

1960

BROWN BEAR STUDIES, ALASKA PENINSULA.

PP. 301-312 IN: GAME INVESTIGATIONS OF ALASKA. FED. AID WILCL. RE

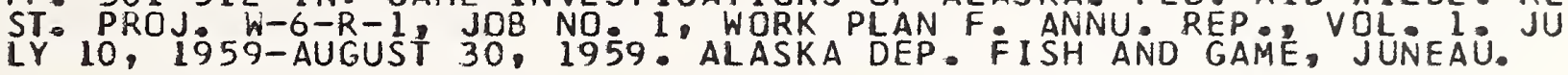
$A G E / S E X$
LITR SIZE
CENSUS/TREND

AKPN,AK , , ,

$\mathrm{C0286}$

ERICKSON, A.W.

1961

BROWN BEAR STUDIES, ALASKA PENINSULA.

PP. 1-9 IN: ALASKA WILDLIFE INVEST IGATIONS. FED. AID WILD. REST IO -OCT: 13, 1960. ALASKA DEP. FISH AND GAME. JUNEAU:
AGE/SEX
LITR SIZE
CENSUS/TREND

AKPN.AK,

00287

ERICKSON, A.W.

$1962 A$

BROWN BEAR SIUDIES, ALASKA PENINSULA.

FED AID WILDL. REST.PROJ W-6-R-3, JOB 1-A, WORK PLAN F. AUGUST 6-25, 1961 . ALASKA DEP. FISH AND GAME, JUNEAU. 6 PP.

AGE/SEX REP RATE LITR SIZE CENSUS/TREND

$A K P N, A K, \quad$,

00288

ER ICKSON, A.W.

$1962 B$

CHARACTERISTICS OF THE BROWN AND GRIZZLY BEAR HARVEST.

FED. AID WILDL - REST. PROJ. W-6-R-3, JOB 2, WORK PLAN F. SEPT. 1 , 1961-JUNE 30, 1962. ALASKA DEP. FISH AND GAME, JUNEAU. 11 PP.
HARV DATA
AGE/SEX
MISC QUANT
SKULL 
00289

ERICKSON, A. H.

1963

1962-63 REPORT ON BEARS.

FED. AID WILDL REST. PROJ. W-6-R-4, JOB NOS, 1, 2-A, 2-B, 3, 4 , WORK JUNEAU. 32 PP.
ACT PATT
$A G E / S E X$
BEHAV PATT
CENSUS METH
HARV DATA
AK , .

00290

ERICKSON, A.W.

1964

A MIXED-AGE LITTER OF BROWN BEAR CUBS.

J. MAMMAL. $45(2): 312-313$.

MATERNAL WEAN

AKPN,AK , , ,,$\quad M E R$

00291

ERICKSON, A.W.

1965

THE BROWN-GKIZZLY BEAR IN ALASKA. ITS ECOLOGY AND MANAGEMENT.

FED. AID WILDL REST PROJ. W-6-R-5, HORK PLAN F, VOL. V. ALASKA DEP: FISH AND GAME: JUNEAU: 42 PP.

$\begin{array}{llll}\text { GEN BIOL } & \text { INTRASP BEH } & \text { HARV DATA } & \text { CENSUS METH } \\ \text { POP BIUL } & \text { DEN } & \text { MEASIQUANT } & \text { MGMT GEN }\end{array}$

INTRASP BEH
DEN

MGMT GEN AK

00292

ER ICKSON, A. W.

1974

EVALUATION OF THE GILA WILDERNESS FOR RE-ESTABLISHMENT OF THE GRI ZZLY BEAR.

U.S.D.A., GILA NATL. FOREST, SILYER CITY, N.M. 40 PP.

HIST DISTR

HAB RECON

LIVESTK IMP

I NT / RE I NT

GINF, NM , , , GIWA 
00293

ERICKSON, A.W.

1975 GRIZLLY BEAR MANAGEMENT IN THE SEELEY LAKE RANGER DISTRICT.

U.S.D.A.; FOREST SERV., LOLO NATL. FCREST, MONT. F.S. PUBL. NO. R

$\begin{array}{lll}\text { DISTR } & \text { HAB RECON } & \text { TIMB-MEIH } \\ \text { HARV MGMI } & \text { MGMT GEN } & \text { CENSUS/TREND }\end{array}$

NCDE, MT LLONF, ,SEEL

00294

ERICKSON, A. W.

1976 GRIZLY BEAR MANAGEMENT IN THE THOMPSON FALLS AREA AND ADJACENT E NVIRONS.

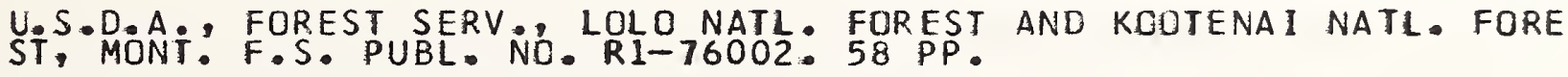

$\begin{array}{llll}\text { HIST DISTR } & \text { HARV DATA } & \text { PRES DISTR } & \text { HAB RECCN } \\ \text { ROAD IMP } & \text { MGMT GEN } & \text { ZONING } & \text { TIMB-METH }\end{array}$

CYE ,MT ,KONF,LONF,

00295

ERICKSON, A.W.

1977

CABINET MOUNTAINS GRIZZLY BEAR MANAGEMENT STUDY.

U.S.D.A., FOREST SERV. CONTRACT ND. 262-46. 25 PP.

$\begin{array}{llll}\text { HAB RECON } & \text { DISTR } & \text { TIMB MGMT } \\ \text { ROAD IMP } & \text { TIMB IMP } & \text { RCAD MGMT } & \text { ENERGY IMPP } \\ \text { MGMT GEN } & , & \end{array}$

00296

ERICKSON, A.W.

1978 GRIZZLY BEAR MANAGEMENT IN THE CABINET MOUNTAIN OF WESTERN MONTAN A.

U.S.D.A. FOREST SERV. CONTRACT NO. 262-46. 82 PP.

HAB RECON

TIMB MGMT

CYE MT ,USFS,
ROAD MGMT

MGMT GEN
FIRE MGMT

ROAD IMP
ENERGY IMP 
00297

ERICKSON, A.W. AND L.H. MILLER.

1963 CUB ADOPTION OF THE BROWN BEAR.

J. MAMMAL. $44(4): 584-585$.

INTRASP BEH MATERNAL AGON

AKPN, AK, , , MCNE

00298

ERICKSON, A.W., H.W. MOSSMAN, R.J. HENSEL AND W.A. TROYER • 1968 THE BREEDING BIOLOGY OF THE MALE BROWN BEAR (URSUS ARCTOS).

ZOOLOGICA 53(3):85-105.

$\begin{array}{lll}\text { REPRO PHYS } & \text { MISC QUANT } & \text { BRD AGE } \\ \text { AGE DETERM } & \text { SKULL } & \text { MORPHIPHYS }\end{array}$

00299

ERICKSON, A.W. AND C.B. SINIFF.

1963 A STAISTICAL EVALUATION OF FACTORS INFLUENCING AERIAL SURVEY RES ULTS ON BROWN BEARS.

TRANS. NORTH AM. WILDL. AND NAT. RESOUR. CONF. 28:391-409.

\section{CENSUS METH}

AKPN,AK, , ,CHIG

00300

ERICKSON, A.W. AND W.G. YOUATT.

SEASONAL VARIATIONS IN THE HEMATOLOGY AND PHYSIOLOGY OF BLACK BEA RS.

J. MAMMAL $=42(2): 198-203$.

HIB PHYS WEIGHT HEMAT


00301

ERICKSON, G.L., C.R. WATTS, F.G. FEIST AND J.J. MCCARTHY.

1974 BIG GAME SURVEY AND INVENTORY REGION FOUR - ANTELOPE, MDUNTAIN GO ATS, BIGHCRN SHEEP, MOOSE AND BEAR.

FED A AID WILDL, REST. PROJ. W-130-R-5, JOS I-4. PROG. REP \& JULY
$1,1973-J U N E 30,1974$. MONT. DEP. FISH AND GAME, HELENA. 85 PP.

PRES DISTR

NCDE, MT , , ,

00302

ERICKSON, G.L., C.R. WATTS, A.D. SCHALLENBERGER AND F.G. FEIST. 1973 GIG GAM SURVEY AND INVENTORY REGION FOUR - ANTELOPE, MOUNTAIN GO ATS, BIGHORN SHEEP, MOOSE AND BEAR.

FED AI D WILDL, REST, PROJ. W-130-R-4, JOB I-4, PROG, REP
1, 1972 -JUNE 30, JULY

PRES DISTR

NCOE,MT

00303

EWER, R.F.

1973

THE CARNI VORES.

CORNELL UNIV. PRESS. ITHACA. 494 PP.

$\begin{array}{llll}\text { MORPH/PHYS } & \text { DENT } & \text { PELAGE } & \text { TERR/SPACE } \\ \text { REPRO PHYS } & & \\ \text {,GEN, }, & ,\end{array}$

00304

FANCY, S.G.

1980

PREPARATION OF MAMMALIAN TEETH FOR AGE DETERMINATION BY CEMENTUM LAYERS: A REVIEW.

HILDL. SOC. BULL. $8(3): 242-248$.

AGE DETERM

, GEN , 
00305
FARO, J.B. AND S.H. EIDE.

1974 MANGEMENT OF MCNEIL RIVER STATE GAME SANCTUARY FOR NONCONSUMPTIV E USE OF ALASKAN BROWN BEARS.

PROC. ANNU. CONF. WEST. ASSOC. GAME AND FISH COMMISSIONERS 54:113
-118 .

REC IMP REC MGM

AKPN, AK ,MEGS, ,MENE

00306

FINLEY, J.S., A.H. HARRIS, D.E. WILSON AND C. JONES.

1975

MAMMALS OF NEW MEXICO.

UNIV. N.M. PRESS, ALBUQUERQUE. 360 PP.

DISTR

NM ,
00307
FINEGAN, R.P.
1970
GRIZZLY BEAR HARVESTS BY RESIDENT HUNTERS, $1965-1969$.

B.C. FISH AND WILL. BRANCH, VICTORIA.

HART DATA

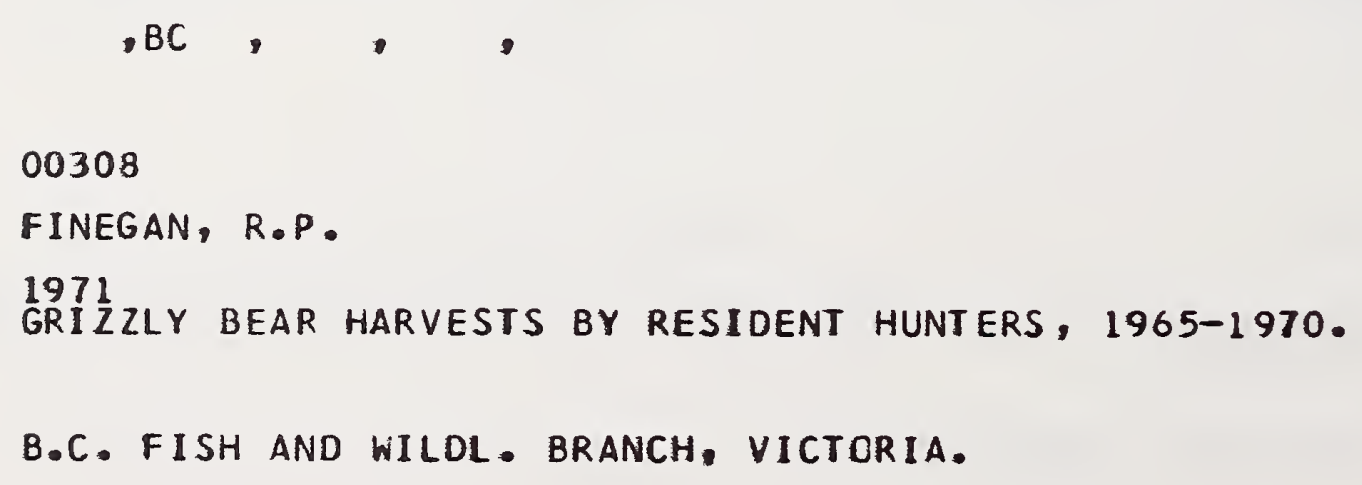

HART DATA

246 
C0309

FISHER, A.H.

1922

THE GRIZZLY BEAR AS A TREE CLIMBER.

J. MAMMAL. $3: 53$.

BEHAV PATT

$$
, \text { GEN, , , }
$$

00310

FLOWERS, R.

1977 THE ART AND TECHNIQUE OF SNARING BEARS.

WASH. FOR . PROT. ASSOC., SEATTLE. 37 PP.

$$
\begin{aligned}
& \text { CAPTURE } \\
& \text {,GEN, }
\end{aligned}
$$

00311

FOLK, G.E., JR.

1967

PHYSIOLOGICAL OBSERVATICNS OF SUBARCTIC BEARS UNDER WINTER DEN CO NDI TIONS.

PP $75-85$ IN: K. FISHER, A.R DAWE, C,P LYMAN, E SCHONBAUM AND F.E. SOUTH JR.' EDS. MAMMAL IAN HIBERNATION I I I PROC 3RD INT SY MPOSIUM.13-16'SEPT: 1965. TORONTO. AMERICAN ELSEVIER PUBL- CO.. INC. N.Y. HEART HIB PHYS TEMP

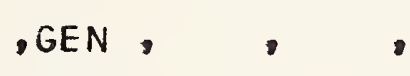

00312

FOLK, G.E., JR.

1980

PROTEIN AND FAT METABOL ISM DURING MAMMALIAN HYPOPHAGIA AND HIBERN ATION.

FED. PROC. 39(12):2953-2954.

HIB PHYS

, GEN , 
00313

FOLK, G.E., JR., M.A. FOLK AND W.O. ESSLER. EXPERIENCES WITH IMPLANTED PHYSIOLOGICAL RADIO-CAPSULES.

PP $=76-77$ IN: DIGEST OF PAPERS. PROC INT SYMPOSIUM ON BIOTELEME TRY, VOL. VIII-4, 5-8 MAY 1971, NIJMEGEN, NETHERLANDS.

TELEM

, GEN, ,

00314

FOLK, G.E..JR•, M.A. FOLK AND J.J. MINOR.

PHYSIOLOGICAL CONDITIONS OF THREE SPECIES OF BEARS IN WINTER DENS -

INT. CONF. BEAR RES. AND MANAGE. 2:107-124.

HIB PHYS HEART

, GEN, , ,

00315

FOLK, G.E, JR., J.M. HUNT AND M.A. FOLK.

1980 FUR THER EVIDENCE FOR HIBERNATION OF BEARS.

INT. CONF. BEAR RES. AND MANAGE. 4:43-47.

HIB PHYS HEART TEMP

, GEN, , ,

00316

FOLK, G.E., JR, A.M. LARSON AND M.C. BREWER.

PHY 96 A IOLOGICAL MEASUREMENTS ON GRIZZLY AND POLAR BEARS IN EXTREME COLD.

PP. 2-6 IN: INT SYMPOSIUM ALTITUDE AND COLD, PROC, NO, 26, 2-6 S HIB PHYS HEART 
00317

FOLK, G.E. JR., A. LARSON AND M.A. FULK.

1976 PHYSIOLOGY OF HIBERNATING BEARS.

INT . CONF. BEAR RES. AND MANAGE. 3:373-380.

HEART HIB PHYS

GEN, , ,

00318

FOLK, G.E., JR, AND R.A. NELSON.

1982

THE HIBERNATION OF POLAR BEARS: A MODEL FOR THE STUDY OF HUMAN ST ARVATION.

PP. 617-619 INEB. HAR VALD AND JP P HART HANSEN, EDS CIRCUMPOLAR HEALTH 81 PROC. 5TH INT. SYMPOSIUM CIRCUMPOLAR HEALTH, 9-13 AUG
UST 1981 , COPENHAGEN. NORDIC COUNCIL FOR ARCTIC MED. RES. REP. SE R. 33 . PHYS

GEN, ,

00319

FOLK, G•E., JR•, R.C. SIMMONDS, M.C. BREWER AND M.A. FOLK. $1968 \mathrm{~B}$

PHYSIOLOGY OF WINTER DENNING OF POLAR AND GRIZZLY BEARS.

PROC. ALASKA SCI. CONF. 9:26-27.

HIB PHYS HEART

GEN,,$\quad$,

00320

FOLK, G.E., JR., R.C. SIMMONDS AND R.S. HEDGE.

1965

TELEMETERED PHYSIOLOGICAL MEASUREMENTS OF SUB-ARCTIC BEARS DURING NATURAL COLD EXPOSURE.

AM. 200L. $5(2): 239-240$.

HEART

, GEN, , 
00321

FOLLMANN, E.H., R.A. DIETERICH AND J.L. HECHTEL.

1980

RECOMMENDED CARNIVORE CONTROL PROGRAM FOR THE NORTHWEST ALASKAN P IPEL INE PROJECT INCLUDING A REVIEW OF HUMAN-CARNIVORE ENCCUNTER P ROBLEMS AND ANIMAL DETERRENT METHODOLOGY.

FINAL REP. PREP. FOR NORTHWEST ALASKAN PIPELINE CO. PREP.BY INST. OF ARCTIC BIOL: UNIV. ALASKA, FAIREANKS. 113 PP.

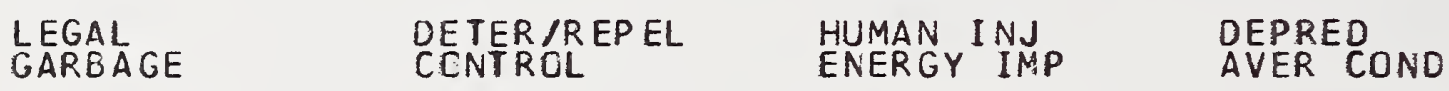
, AK, , ,

00322

FOLLMANN, E.H., A.E. MANNING AND J.L. STUART.

1982 A LONG RANGE IMPLANTABLE HEART RATE TRANSMITTER FOR FREE-RANGING ANIMALS.

BIOTELEMETRY PATIENT MONITG. 9:205-212.

TELEM

, GEN, , ,

00323

FOLLMAN, E.H॰ L.M. PHILO AND H.V. REYNOLDS. 1979

ANNUAL VARIATIONS IN BODY TEMPERATURE OF GRIZZLY BEARS.

PROC. ALASKA SCI. CONF, 29:647.

HIB PHYS TEMP TELEM

$, G E N, \quad$

00324

FOR BES, R.B.

1983

GRIZZLY BEAR SPECIES STATEMENT, REGION II.

B.C. FISH AND WILDL BRANCH, VICTORIA. 5 PP.

MGMT GEN POP EST HARV MGMT

$\mathrm{BC}-\mathrm{C}, \mathrm{BC}$, 
00325

FORESMAN, K.R. AND J.C. DANIEL, JR. 1983 PLA PROGESTERONE CONCENTRATIONS IN PREGNANT AND NON-PREGNANT B LACK BEARS (URSUS AMER ICANUS).

J. REPROD. FERT. $68(1): 235-239$.

REPRO PHYS HEMAT

$$
, G E N, \quad,
$$

00326

FORTIER, B.G.

1983

BEAR MANAGEMENT AT YELLCWSTONE NATIONAL PARK: EFFECTIVENESS OF IN FORMATION DISSEMINATION TO VISITORS.

M.S. THESIS, COLO. STATE UNIV., FT. COLLINS. 189 PP.

PUBLIC ATT EDUC RECR MGMT

YGBE, IMW, YNP, ,

00327

FOSS, A.J.

1963 BIG GAME SURVEYS AND INVESTIGATIONS - ANTELOPE, BIGHORN SHEEP, MO UNTAIN GOATS AND BEAR.

FED AID WILDL. REST. PROJ. NO W-74-R-8, JOB A-1, PART 1 . MAY 1, 1962-APRIL 30, 1963. MONT: FISH AND GAME DEP.? HELENA.9 PP.

HARV DATA

NCDE,MT, , ,

00328

FOSS, A.J. AND C.A. WHITNEY.

BIG GAME SURVEYS AND INVESTIGATIONS.

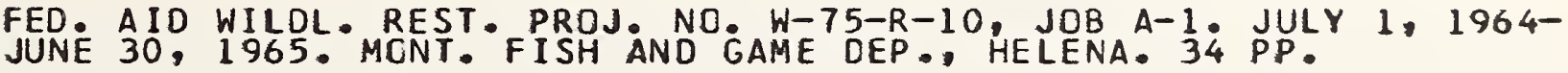

HARV DATA

MT $\quad \bullet$ 
00329

FOWLER, C.W.

1981

COMPARATIVE POPULATION DYNAMICS IN LARGE MAMMALS.

PP. $437-455$ IN: C.W. FOWLER AND T.D. SMIIH, EDS. DYNAMICS IN LARG
E MAMMAL POPULATIONS. JOHN WILEY AND SONS, N.Y. DEMOG ANAL HARV IMP

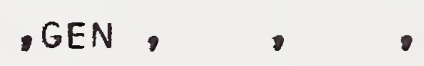

00330

FRANKEL, G.H. AND M.E. SOULE.

1981

CONSERVATION AND EVOLUTION.

CAMBRIDGE UNIVERSITY PRESS, CAMBRIDGE• 327 PP.

GENET ICS

GEN,,$\quad$

00331

FRANKLIN, B. AND G. MATEJKO.

1983 GRIZZLY BEAR/LIVESTOCK MONITORING, ISLAND PARK RANGER DISTRICT, T ARGHEE NATIONAL FOREST, FISCAL YEAR I983.

$U_{6} S_{P}: D_{P} . A ., F O R E S T$ SERV. TARGHEE NATL. FOREST, ST. ANTHONY, IDAHO.
LIVESTK IMP
DEPRED
LIVESTK MGMT

YGBE,ID, ,TANF, ,ISLP

00332

FRANZMANN, A.W., A. FLYNN, C.C. SCHWARTZ, D.G. CALKINS AND L. NICHO LS JR.

1981

BETA-ENDORPHINE LEVELS IN BLODD FROM SELECTED ALASKAN MAMMALS.

J. WILLL. DIS. $17(4): 593-596$.

HIB PHYS HEMAT

, GEN , , ,


00333

FRANZMANN, A.W. AND C.C. SCHWARTZ.

KENAI PENINSULA MOOSE CALF MORTALITY STUDY.

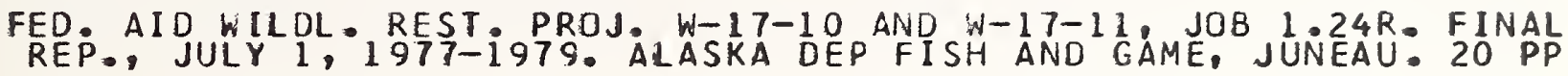

PRED

AKPN,AK, , , , ENA

00334

FRANZMANN, A.W., C.C. SCHWARTZ AND C.C. JCHNSCN. KENAI PENINSULA MOOSE CALF MORTALITY STUDY.

FED - AID WILDL \& REST. PROJ. W-22-1 AND W-22-2, JOB 1.33R. PROGR. REP:, VOL. I. ALASKA DEP. FISH AND GAME, JUNEAU. 15 PP.

PRED

AKPN, AK , ,,$\quad$ KENA

00335

FRANZMANN, A.W., C.C. SCHWARTZ AND R.O. PETERSCN. 1979

KENAI PENINSULA MOOSE CALF MORTALITY STUOY.

FED AID WILDL. REST PROJ. W-17-10 AND W-17-11, JOB $1-24 R$ FINAL REP. 20 JULY 1. 1977-JUNE 20, 1979. ALASKA DEP. FISH AND GAME, JUN PRED

AKPN,AK, , , , ,

00336

FRANZMANN, A.W., C.G. SCHWARTZ AND R.O. PETERSCN. 1980

MOOSE CALF MORTALITY IN SUMMER ON THE KENAI PENINSULA, ALASKA.

J. WILDL. MANAGE. 44(3):764-768.

PRED

AKPN, AK, , , , , 
00337

FRASER, D.

1976

AN ESTIMATE OF HUNTING MORTALITY BASED ON THE AGE AND SEX STRUCTU

RE OF THE HARVEST.

PROC. NORTH AM. MOOSE CONF. 12:236-273.

CENSUS METH HARV MGMT AGE/SEX

, GEN,

00338

FRASER, D.

1984 A IMPLE RELATIONSHIP BETWEEN REMOVAL RATE AND AGE-SEX COMPOSITIO N OF REMOVALS FOR CERTAIN ANIMAL POPULATIONS.

J. APPL. ECOL. 21:97-101.

CENSUS METH AGE/SEX HARV MGMT

GEN, , ,

00339

FRASER, D., J.F. GARDNER, G•B. KOLENOSKY AND S. STRATHEARN. 1982

ESTIMATION OF HARVEST RATE OF BLACK BEARS FROM AGE AND SEX DATA.

HILDL. SOC . BULL. $10: 11: 53-57$.

AGE/SEX HARV MGMT CENSUS METH

, GEN , ,

$\operatorname{Co3} 40$

FREEMAN-HAET, M.F.

1973

GLACIER NATIONAL PARK VISITOR IMAGES OF GRIZZLY BEARS.

M.S. PAPER, MICH. STATE UNIV., LANSING. 29 PP.

PUBLIC ATT

NCDE,MT ,GLNP, , 
00341

FREIHEIT, C.F. AND M.J. CROTTY.

1969

HAND REARING KODIAK BEARS.

INT. ZOO YEARB. $9: 158-160$

$200 \mathrm{TECH}$

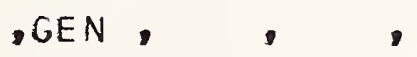

00342

FROST, J.R.

LIVING WITH THE GRIZZLY: PERCEPTIONS OF MISSION VALLEY RESIDENTS.

M.S. THESIS, UNIV. MONT., MISSOULA. 96 PP.

PUBLIC ATT DEPRED ECUC

NCDE,MT ,FLIR,USFS, MISS

00343

FUJ INO, K. K.

OMINECA GRIZZLY BEAR STATUS REPORT.

B.C. FISH AND WILDL. BRANCH, VICTORIA. 7 PP.

HARV DATA AGE/SEX HARV MGMT HARV IMP

CR , BC, , , OMIN

00344

FUJINO, K.K. AND K.N. CHILD.

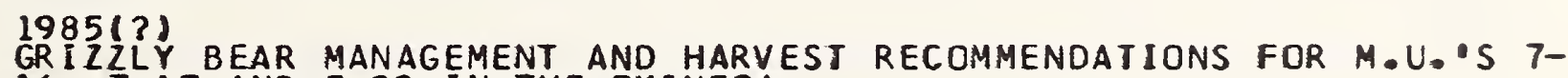
16, 7-17 AND $7-23$ IN THE OMINECA.

B.C. FISH AND WILDL. BRANCH, VICTORIA. 8 PP.
POP EST
HARV DATA
POP DENS
HARV IMP
HAR V MGMT

CR, BC, , ,OMIN 
00345

GARCIA, E.R.

1986

GRIZZLY BEAR DIRECT HABITAT IMPROVENENT OA THE KOOTENAI NATIONAL FOREST.

PP. 185-189 IN: G.P. CONTRERAS AND K.E. EVANS EDS PROCEECINGS-G RIZZLY BEAR HABITAT SYMPOSIUM. U.S.D.A., FOREST SERVICE. INTERMOU NTAIN RES. STAT., OCDEN, UTAH: GEN, TECH. REP. INT-207.

TIMB-METH TIMB-HAB

TIMB-POST

FIRE MGMT

CYE ,MT ,KONF, ,

00346

GARD, R •

1971

BROWN BEAR, PREDATION CN SOCKEYE SALMON AT KARLUK LAKE, ALASKA.

J. WILDL. MANAGE. 35(2):193-204.

$\begin{array}{lll}\text { SEAS BEH PRED } & \text { FEED BEH DETER/REPEL }\end{array}$

AKKA,AK, ,KARL,KOIS

00347

GARNER, G.W., H.V. REYNOLDS, L.D. MARTIN, T.J. WILMERS AND T.J. DOY LE:

ECOLOGY OF BROWN BEARS INHABITING THE COASIAL PLAIN AND ACJACENT FOOTHILLS AND MOUNTAINS OF THE NORTHEASTERN PORTION OF THE ARCTIC NATIONAL WILDLIFE REFUGE.

PP.330-358 IN: ARCTIC NATL. WILDL. REFUGE PROG. REP. FY84-11.
AGE'SEX
POP DENS
MEAS IQUANT

$A R C, A K, A N W R$, ,

00348

GARSHELIS, D.L., H.B. QUIGLEY, C.R. VILLARRUBIA AND M.R. PELTON. 1982 ASSESSMENT OF TELEMETRIC MOTION SENSORS FOR STUDIES OF ACTIVITY.

CAN. J. ZOOL. 60:81:1800-1805.

TELEM

, GEN, , , 
00349

GASAWAY, W.C., R.D. BOERTJE, D.V. GRANGAARD, D.G. KELLEYHCLSE AND R IOQ STEPHENSON.

FACTORS LIMITING MOOSE POPULATION GROWTH IN GAME MANAGEMENT UNIT 2OE.

FED. AID WILDL. REST PROJ. W-22-4 AND $W-22-5, J O B \quad 1.37 R . \quad P R O G$.
REP. ALASKA DEP. FISH AND GAME, JUNEAU.

PRED

$A K-I, A K, \quad$,

00350

GATESMAN, T. AND H. WIESNER.

1982

IMMOBILIZATION OF POLAR (THALARCTOS MARITIMUS) AND BROWN IURSUS A RCTOS) BEARS USING ETORPHINE AND XYLAZINE.

J. ZOO ANIM. MED. 13:11-18.

DRUGS

, GEN, , ,

00351

GEBHARD, J.G.

1982

ANNUAL ACTIVITIES AND BEHAVIOR OF A GRIZZLY BEAR (URSUS ARCTOS) F AMILY IN NORTHERN ALASKA.

M.S. THESIS, UNIV. ALASKA, FAIRBANKS. 218 PP.

$\begin{array}{llll}\text { BEHAV PATT } & \text { ACTPATT } & \text { FEED BEH } & \text { MATERNAL } \\ \text { PRED } & \text { AIRCRAFT IMP } & \text { VOCAL } & \text { SIB BEH } \\ \text { AGON } & \text {,WBRK } & & \end{array}$

00352

GEIST, 0.W.

1934

BROWN BEAR SEEN ON ST. LAWRENCE ISLAND.

J. MAMMAL. $15(4): 316-317$.

HIST DISTR HISI ACCT

,AK, , , 
00353

GEIST, $V$.

1978

BEHAVIOR.

CHAPTER 19 PP $283-296$ IN: J.L SCHMIDT AND D.L. GILBERT, EDS.B - HARRI SBURG, PENN.

HUMAN IMP MURPH/PHYS

$, G E N, \quad$,

00354

GILBERT, J.R., W.S. KORDEK, J. COLLINS AND R. CONLEY. 1978

INTERPRETING SEX AND AGE DATA FROM LEGAL KILLS OF BEARS.

PROC. EAST. WORKSHOP BLACK BEAR MANAGE. AND RES. 4:253-262.

HARV MGMT AGE/SEX

, GEN, , ,

00355

GILBERT, B.K. AND L.D. ROY.

1977

PREVENTION OF BLACK BEAR DAMAGE TO BEEYARDS USING AVERSIVE CONDIT IONING.

PP. 93-102 IN: R:L PHILLIPS AND C JONKEL, EDS. PROC. OF THE 197 5 PREDATOR SYMPOSIUM MONT. FOR. AND CONSERV. EXP. STAT., UNIV. MO NT., MIS SCULA.

AVER COND

$$
\text { , GEN, , }
$$

00356

GILLESPIE, D. AND C. JONKEL.

1979

GRIZZLY BEAR DENS IN THE BORDER GRIZZLY AREA.

PP. 105-121 IN: C. JONKEL, ED. ANNUAL REPORT. BORDER GRIZZLY PROJ , UNIV. MONT. MISSOULA. ANNU. REP. NO. 4.
DEN CHAR
MGMT GEN
DEN CHRON
DEN SITE

NCDE,MT, , , 
00357

GILLESPIE, D. AND C. JONKEL.

1980

GRIZZLY BEAR DENNING IN THE SOUTH FCRK OF THE FLATHEAD RIVER.

PP. 178-195 IN: C JONKEL, ED. ANNUAL REPORT. BORDER GRIZZLY PROJ , UNIV. MONT., MISSCULA. ANNU. REP. NO. 5 .

DEN MAP/TYPE

NCDE,MT , , ,SFLT

00358

GILLHAM, C.E.

1948

WILDLIFE INVESTIGATIONS OF ALASKA.

FED. AID WILDL REST PROJ. W-3-R-3, WORK PLAN 3. QUART. REP V VOL

. 3: NO. 1. ALASKA DEP. FISH AND GAME, JUNEAU. 3 PP.

FOOD PRED

AKPN, AK, , , KENA

00359

GLENN, L.P.

1971

REPORT ON 1970 BROWN BEAR STUDIES. FED. AID WILDL REST:PROJ. W-17-2, JOBS $4.1 R, 4.2 R$ AND $4.3 R$ 12ND ALASKA DEP. FISH AND GAME, JUNEAU. 67 PP.

$\begin{array}{llll}\text { CAPTURE } & \text { LITR SIZE } & \text { PRED } & \text { CANNIBAL } \\ \text { MATERNAL } & \text { RECR IMP } & \text { ACT PATT } & \text { AGEISEX }\end{array}$

MEASIQUANT

AKPN,AK, , BLKL

00360

GLENN, L.P.

1972 REPORT ON 1971 BROWN BEAR STUDIES.

FED. AID WILOL. REST.PROJ. $W-17-R-3$ AND $W-17-R-4$. PROG. REP. ALA SKA DEP. FISH AND GAME, JUNEAU. 109 PP.
AGE/SEX
PRED
MEAS/QUANT
ORUGS
MOVE
CAPTURE
BRD AGE
AKPN, AK, , , BLKL 
00361

GLENN, L.P.

1973A REPORT ON 1972 BROWN BEAR STUDIES: BRONN BEAR LIFE HISTORY.

FED. AID WILDL REST. PROJ. $W-17-4$ AND $W-17-5$, JOB 4.2R, PRCG. RE Pis JAN. 1, 1972-DEC: 31-1972. ALASKA DEP. FISH AND GAME, JUNEAU.

LITR SIZE

MORT DATA
WEIGHT

LITR FREQ

- BLKL

00362

GLENN, L.P.

19738

REPORT UN 1972 BROWN BEAR STUDIES: DISTRIBUTION AND MOVEMENTS DF ALASKA PENINSULA BROWN BEARS.

FED. AID WILDL REST PROJ W-17-4 AND W-17-5, JOB 4, 4R, PROG RE P. JAN. 1, 1972-DEC. 31-1972. ALASKA DEP. FISH AND GAME, JUNEAU. MOVE

HARV DATA POP ESI

AKPN,AK, , , BLKL

00363

GLENN, L.P.

\section{4}

REPORT ON 1973 BROWN BEAR STUDIES: OISTRIBUTION AND MOVEMENTS OF ALASKA PENINSULA BROWN BEARS.

FED. AID WILDL REST PROJ. W-17-5 AND W-17-6, JOB $4=4 R$ PROGR R EP. JAN. 1, 1973-DEC. 31, 1973. ALASKA DEP. FISH AND GAME, JUNEA U. ID PP.

HARV DATA

AKPN,AK, , , BLKL

00364

GLENN, L.P.

1975

REPORT ON 1974 BROWN BEAR STUDIES: CISTRIBUTION AND MOVEMENT OF A LASKA PENINSULA BROWN BEARS.

FED. AID WILDL REST. PROJ $W-17-6$ AND $W-17-7$, JOB 4. 4R, PROG. RE P. JAN. I, I974-DEC: 31. I974. ALASKA DEP. FISH AND GAME, JUNEAU - 54 PP.

MOVE

HARV DATA

$A K P N, A K$,
FOOD
SKULL

- BLKL
PRED

MISC QUANT
AGE / SEX 
00365

GLENN, L.P.

1976

REPORT ON 1975 BROWN BEAR STUDIES: CISTRIBUTICN AND MOVEMENTS OF ALASKA PENINSULA BROWN BEARS.

FED. AID WILDL, REST: PRDJ. W-17-7, AND W-17-8, JOB 4. 4R ME: JUNEAU. I 8 PP:

MOVE

AKPN,AK, , , $, \quad, \quad$ BKL

00366

GLENN, L.P.

1980

MOR PHOMETRIC CHARACTERISTICS CF BRCWN BEARS ON THE CENTRAL ALASKA PENINSULA.

INT. CONF. BEAR RES. AND MANAGE. 4:313-319.
GROW/DEV
LENGTH
SKULL
GIRTH
AGE DETERM
WEIGHT

AKPN,AK,

00367

GLENN, L.P., J.W. LENTFER, J.B. FARC AND L.H• MILLER.

1976

REPRODUCTIVE BIOLOGY OF FEMALE BRCWN BEARS IURSUS ARCTOSI, MCNEIL RIVER, ALASKA.

INT. CONF. BEAR RES. AND MANAGE. 3:381-390.
LITR AGE
MITR FREQ
WEAN
$S I B$ BEH
COURT
MATERNAL

AKPN, AK ,MCGS, , MCNE

00368

GLENN, L.P. AND L.H. MILLER •

\section{0}

REPORT ON 1969 BROWN BEAR STUDIES EVALUATION AND DEYELOPMENT OF BROWN BEAR CENSUS TECHNIQUES. BROWN BEAR LIFE HISTORY STUDY. COMP ARISON OF HARVEST DATA AND POPULATION STATUS.

FED. AID WILDL REST:PROJ.W-17-2, WORK PLAN R, JOB NOS.4.1R, 4. 2REP? FISH AND GAME, JUNEAUP. 63 JAN.

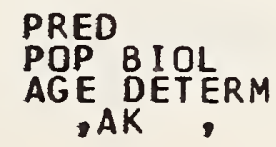

MATERNAL

GROW/DEV

CENSUS/TREND

MEAS/QUANT

HARV DATA

CENSUS METH 
00369

GLENN, L.P. AND L.H. MILLER.

1980 SEASONAL MOVEMENTS OF AN ALASKA PENINSULA BROWN BEAR POPULATION.

INT. CUNF. BEAR RES. AND MANAGE . 4:307-312.

MOVE PRED HOME RNG MATERNAL

AKPN,AK, , ,

$\cos 370$

GOODHIN, E. AND S. MILLER.

1982

PRELIMINARY RESULTS TESTING TECHNIQUE TO CHEMICALLY DIFFERENTIATE BETWEEN SCATS OF BLACK AND BROWN BEAR.

APPENDIX 6 PP 230-233 IN: S.D. MILLER AND D.C. MCALLISTER BIG CAME STUDIES, VOL VI BLACK BEAR AND BROWN BEAR. SUSIINA HYOROEL
ECTRIC PRCJECT PHASE I FINAL REPORT. ALASKA DEP. FISH AND GAME, J UNEAU

SCAT ANAL

IDENT / RECOG

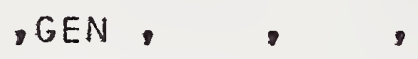

00371

GORDON, K.R.

1977

MOLAR MEASUREMENTS AS A TAXONOMIC TOOL IN URSUS.

J. MAMMAL. 58121:247-248.

DENT IDENT/RECOG SKULL

, GEN, , ,

00372

GRAHAM, D.C.

1978

GRIZZLY BEAR DISIRIBUTION USE OF HABITATS, FOOD HABITS AND HABITA I CHARACTER IZATION IN PELICAN AND HAYDEN VALLEYS, YELLONSTONE NAT IONAL PARK.

M.S. THESIS, MONT. STATE UNIV., BOZEMAN. 89 PP.

NUTR ANAL

HAB USE

FOR STRAT

YGBE,WY ,YNP
FOOD

SEAS BEH

, HAYD
AIRCRAFT IMP PRED
TIMB USE

UNG COMP 
00373

GREENE, ROBERT $\downarrow$.

1982 AN APPL ICATION OF BEHAVIORAL TECHNOLOGY TO THE PROBLEM DF NUISANC E BEARS.

PSYCHOL - REC. 32:501-511.

DETER/REPEL

, GEN, , ,

00374

GREER, K.R.

1959

WILOLIFE INVESTIGATIONS LABORATORY.

FED AID WILDL. REST. PROJ. W-83-R-2 JOB COMPLETION REP FOOD

NCDE, MT ,USFS, ,MISS

00375

GREER, K.R.

1968

GRIZZLY BEAR HARVEST IN MONTANA DURING 1967.

APPENOIX 2 PP. 11-20 IN: WILDL IFE INVESI IGATICNS LABORATCRY-LABO

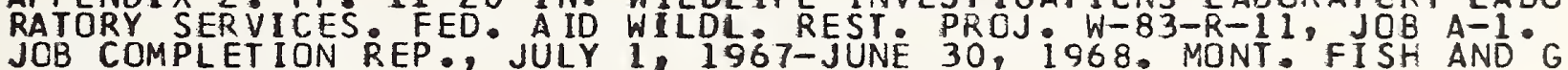
JOB COMPLETION REP.

HARV MGGMT HELENA.

MORT DATA

HARV DATA

CONTROL

MISC QUANT

AGE DETERM

-MT

00376

GREER, $K \bullet R$.

1969

GRIZZLY BEAR HARVEST IN MONTANA DURING 1968.

APPENDIX 2 PP 20-29 IN: WILDLIFE INVESTIGATICNS LABORATCRY - LA BORATORY SER VICES. FED A ID WILDL, REST. PRQJ. W-83-R-12. JOB CDM
PLETION REP. JULY 1, I968-JUNE 30, 1969. MONT. FISH AND GAME DEP $\because$ HELENA.

HARV DATA

SKULL

MORT DATA

WEI GHT

CONTROL

LENGTH

MISC QUANT

EGAL

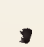


00377

GREER, K.R.

1970 GRIZZLY BEAR AND BLACK BEAR HARVEST IN MONTANA DURING 1969.

APPENDIX 3. PP. 15-28 IN: STATEWIDE WILDL IFE RESEARCH - LABORATOR $Y$ SERVICES FED. AID WILDL. REST PROJ. W-120-R-I, JOB 3.1. JULY 1969-JUNE 1970 . MONT. FISH AND GAME DEP.? HELENA.

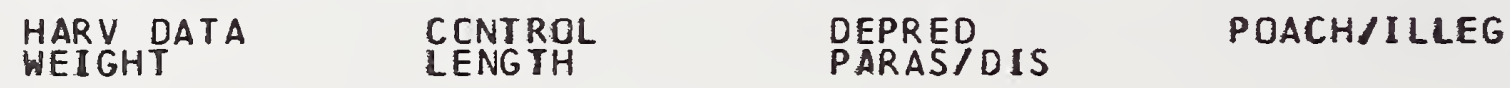

, MT , , ,

00378

GREER, K.R.

1971

GRIZZLY BEAR HARVEST IN MONTANA DURING 1970. APPENDIX III P PP. 15-28 IN: STATEWIDE WILDLIFE RE SEARCH - LABORAT B COMPLETION REP., JULY 1969-JUNE 1970. MONT. FISH AND GAME DEP.? HELENA.

HARV DATA

AGE/SEX

$\begin{array}{ll}\text { CCNT ROL } & \text { DEPRED } \\ \text { MEASIQUANT } & \text { MCRPH/PHYS }\end{array}$

GARBAGE

HAR V DATA

PARAS/DIS

00379

GREER, $K \bullet R$.

$1972 \mathrm{~A}$

GRIZZLY BEAR MORTALITY AND STUDIES IN MONTANA.

INT. CONF. BEAR RES. AND MANAGE 2 2:53-66.

\begin{tabular}{|c|c|c|}
\hline $\begin{array}{l}\text { HARV CATA } \\
\text { PARAS/OIS }\end{array}$ & $\begin{array}{l}\text { IDENT/RECOG } \\
\text { AGE/SEX }\end{array}$ & $\begin{array}{l}\text { MORT DATA } \\
\text { MEAS/QUANT }\end{array}$ \\
\hline
\end{tabular}

, MT , , .

00380

GREER， $K \bullet R$.

GRIZZLLY BEAR MORTALITY AND MANAGEMENT PROGRAMS IN MONTANA DURING 1971 .

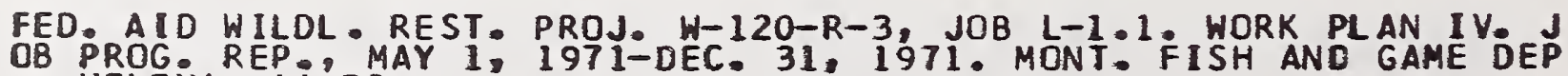
$\rightarrow$ HELENA. $44^{\circ} \mathrm{PP}$.

RELOC

DENT

GARBAGE
MORT DATA

SKULL
MEAS/QUANT

AGE/SEX
RES TECH
PARAS/DIS 
00381

GREER, $K \cdot R$.

1974 GRIZZLY BEAR MORTALITY AND MANAGEMENT PROGRAMS IN MONTANA CURING 1972 .

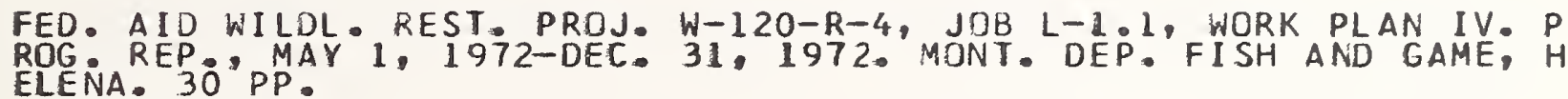

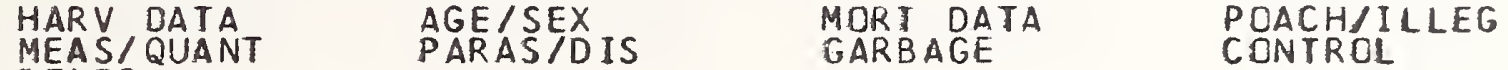

RELOC

MT , ,

00382

GREER, K.R.

GRI 192 ZL BEAR MCRTALITY AND MANAGEMENT PROGRAMS IN MONTANA CURING 1974 .

FED。 AID WILDL REST, PROJ. W-120-R-6, JOB L-1, 1, WORK PLAN IV. P ELENA. $23^{\circ} \mathrm{PP}$.

$\begin{array}{llll}\text { HARV DATA } & \text { AGEISEX } & \text { GARBAGE } & \text { MORT DATA } \\ \text { PRES DISTR } & \text { LIVESTK IMP } & \text { MORT MGMT } & \text { WEAN }\end{array}$

MT,,

00383

GREER, $K \bullet R$ 。

1976A GR BEAR MORTALITY AND MANAGEMENT PROGRAMS IN MONTANA CURING

FED. AIU WILDL REST, PROJ. W-120-R-7, JOE L-1 I I WORK PLAN IV. P ELENA. $20^{\circ} \mathrm{PP}$.

$\begin{array}{llll}\text { HARV DATA } & \text { WEAN } & \text { MORT DATA } & \text { POACH/ILLEG } \\ \text { CCNTROL } & \text { ACE/SEX } & \text { PARASIDIS } & \text { WEIGHT }\end{array}$

00384

GREER, K.R.

$1976 B$

MANAGING MONTANA'S GRIZZLIES FOR THE GRIZZLIES.

INT. CONF. BEAR RES. AND MANAGE. 3:177-189.

$\begin{array}{lll}\text { MORT DATA } & \text { POACH/ILLEG } & \text { CONTROL } \\ \text { AGE/SEX } & \text { GARBAGE } & \text { DEPRED }\end{array}$


00385

GREER, K.R.

1977 GR Y BEAR MORTALITY AND MANAGEMENT PROGRAMS IN MONTANA DURING 1976.

FED. AID WILDL- REST PROJ.W-120-R-8, JOB L-1-1, WORK PLAN IV. P ROG: REP MAY 1, 1976-DEC: 31, 1976, MONT. FISH AND GAME CEP: H ELENA. $20^{\circ} \mathrm{PP}$.

$\begin{array}{llll}\text { MORT DATA } & \text { CCNTROL } & \text { POACH/ILLEG } & \text { PARAS/DIS } \\ \text { AGE/SEX } & \text { HARV DATA } & \text { HARV MGMT } & \text { WEIGHT } \\ \text { GARBAGE } & & \end{array}$

00386

GREER，K.R.

GRIZZLY BEAR MORTALITY AND MANAGEMENT PROGRAMS IN MONTANA DURING

FED. AID WILDL. REST PROJ. W-120-R-9, JOB L-1.1, WORK PLAN IV. P ROG REP MAY 1, 1977-DEC. 31, 1977. MONT. FISH AND GAME CEP, H ELENA. $18 \mathrm{PP}$.

\begin{tabular}{|c|c|c|}
\hline $\begin{array}{l}\text { HARV DATA } \\
\text { SKULLL MGMT } \\
\text { HARV MGMT }\end{array}$ & $\begin{array}{l}\text { MORT DATA } \\
\text { CCNTROL }\end{array}$ & $\begin{array}{l}\text { RELOC } \\
\text { PARAS/DIS }\end{array}$ \\
\hline
\end{tabular}

00387

GREER, K.R 。

1979

GRIZZLY BEAR STUDIES.

FED. AID WILDL REST: PROJ. $W-120-R-10$, JDB 2 , WORK PLAN Y STUDY NO L-1.1. PROG REP MAY 1, 1978-DEC. 31, 1978. MONT. FISH AND GAME DEPT:, HELENA. IS PP.

\begin{tabular}{|c|c|c|}
\hline $\begin{array}{l}\text { HARV DATA } \\
\text { CONTROL }\end{array}$ & $\begin{array}{l}\text { MORT DATA } \\
\text { RELOC }\end{array}$ & $\begin{array}{l}\text { POACH/ILLEG } \\
\text { AGE/SEX }\end{array}$ \\
\hline
\end{tabular}

00388

GREER, $K \bullet R$.

1980

GRIZZLY BEAR STUDIES DURING 1979.

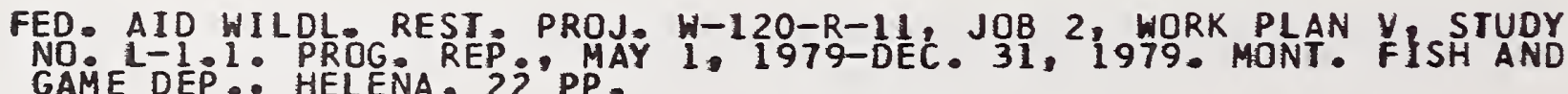

\begin{tabular}{|c|c|c|}
\hline $\begin{array}{l}\text { HARY DATA } \\
\text { RELOC } \\
\text { DEMOG ANAL }\end{array}$ & $\begin{array}{l}\text { POACH/ILLEG } \\
\text { DEPRED }\end{array}$ & $\begin{array}{l}\text { CONTROL } \\
\text { PARASIDIS }\end{array}$ \\
\hline
\end{tabular}


00389

GREER, $K \bullet R$.

1981

GRIZZLY BEAR MORTALITY STUDIES 119801.

FED. AID WILDL. REST: PROJ. W-120-R-12, JCB NO. 2, STUDY ND. HL-1 ISH AND GAME DEP.; HELENA. $22^{\prime} \mathrm{PP}$.

\begin{tabular}{|c|c|}
\hline $\begin{array}{l}\text { MORT DATA } \\
\text { AGE/SEX }\end{array}$ & $\begin{array}{l}\text { POACH/ILLEG } \\
\text { DEPRED }\end{array}$ \\
\hline
\end{tabular}

, MT, , ,

00390

GREER, K.R.

1982

GRIZZLY BEAR MORTALITY STUDIES 11981$).$

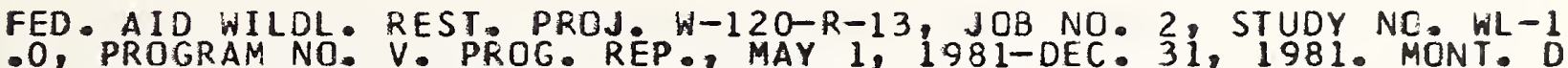
EP. FISH, WILDL. AND PARKS, HELENA. 20 PP.
MORT DATA
RECR IMP
PARAS /DIS
HARV DATA
POACH/ILLEG
RELOC
DEPRED

MT,$\quad$,

00391

GREER, K.R.

1983

GRIZZLY BEAR MORTALITY STUDIES (1982).

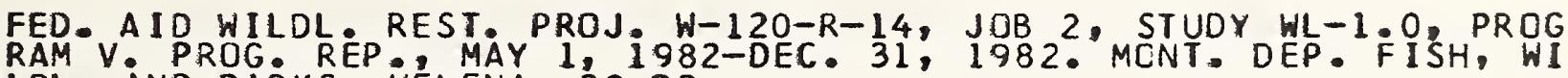
LDL. AND PARKS, HELENA. 29 PP.
MORT DATA
ROAD MORT
PARAS/DIS
HARV DATA
CCNTROL
POACH/I LLEG
AGE/SEX
RES MOR T
, MT ,

00392

GREER, K.R.

1985

MONTANA STATEWIDE GRIZZLY BEAR MORTALITIES 1983-1984.

MONT. DEP. OF FISH, WILDL., AND PARKS. 51 PP.

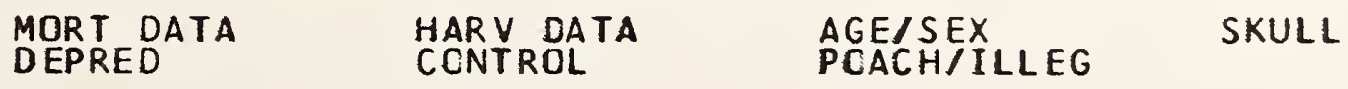


00393

GREER, K.R. AND V. CRAIG.

I971 HUNTING IN MONTANA.

MONT. FISH AND GAME DEP ., HELENA. 7 PP.

IDENT/RECOG PELAGE MISC QUANT DENT

- MT, , ,

00394

GREER, K.R. AND C.J. JONKEL.

1975

ENVIRONMENTAL IMPACT STATEMENT ON THE SPORT HUNTING OF THE GRIZZL Y BEAR: ADDENDUM TO 1972 EIS ON STATEWIDE BIG GAME HUNTING SEASON S.

MONT. FISH AND GAME DEP. HELENA. 10 PP.

HARV MGMT MGMT GEN

MT , ,

00395

GRIFFEL， D.

BEAT-LIVESTOCK INTERACTIONS OF THE TARGHEE NATIONAL FOREST.

U.S.D.A. FOREST SERV., TARGHEE NATL. FOREST, IDAHO. 15 PP.

DEPRED CONTROL

YGBE, ID , TANF, ,ASHT

00396

GR I FFEL , D.

1977
BEAR-LIVESTOCK INTERACTION STUDY - 1977.

U.S.D.A. FOREST SERV., TARGHEE NATL. FOREST, IDAHO. 27 PP.

DEPRED

YGBE,ID , TANF,, ASHT 
00397

GR IFFEL, D.

1982 PREDATOR-LIVESTOCK RELATIONSHIPS IN SUMMER ON THE TARGHEE NATIONA LFOREST, IDAHO. PP. 295-305 IN: J.M.M. PEEK AND P.D. DALKE, EDS. PROC. WILDLIFE-LIV
ESTOCK RELAT IONSHIPS SYMPOSIUM, VOL. IO.
DEPRED
LIVESTK IMP
LIVESTK MGMT

YGBE, ID , TANF, ,

00398

GRIFFEL, D.E. AND J.V. BASILE.

1981

IDENTIFYING SHEEP KILLED BY BEARS.

U. SED.A FO FOREST SERV ' INTERMOUNTAIN FOREST AND RANGE EXPT. STAT DEPRED

FEED BEH

CARCASS

YGBE, ID ,TANF,

00399

GRITMAN, J.C.

1979

FORMAL SELECTION 7 CONSULTATION ON GRANT VILLAGE, YELLOWSTONE PAR

U.S.D.I.. FISH AND WILDL. SERV. 28 PP.

RECR IMP

YGBE,IMW, YNP,

00400

GUILIDAY, J. E.

1968

GRIZZLY BEARS FROM EASTERN NORTH AMERICA.

AM. MIDL. NAT. 79(1):247-250.

HIST DISTR

, GEN ,

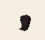


00401

GUNN, A. AND F.L. MILLER.

MUSKOX BULL KILLED BY A BARREN-GROUND GRIZZLY BEAR, THELON GAME S ANCTUARY, N.W.T.

ARCTIC 35(4):545-546.

PRED FEED BEH

, NWT, IHGS, ,

00402

GUNSON, J.R.

1981 COMMENIS ON STATUS AND MANAGEMENT OF GRIZZLY BEARS IN ALBERTA.

ALBERTA FISH AND WILDL. DIV.. EDMONTON. 4 PP.

$\begin{array}{llll}\text { PRES DISTR } & \text { POP EST } & \text { HARV MGMT } & \text { DEPRED } \\ \text { POACH/ILLEG } & \text { AGE/SEX } & \text { HUMAN INJ } & \text { CONTROL }\end{array}$

00403

GUNSON, J.R., R.B. SCHAUFELE AND B.H॰ TREICHEL.

1985

MOR TAL ITIES OF GRIZZLY BEARS IN ALBERTA: $1972-84$.

ALBERTA FISH ANO WILDL. DIV॰, EDMONTON. 48 PP.

$\begin{array}{llll}\text { HARV DATA } & \text { MORT CATA } & \text { PCACH/ILLEG } & \text { AGEISEX } \\ \text { CONTROL } & \text { RES MORT } & \text { HUMAN INJ } & \text { REACTION } \\ \text { RECR IMP } & & & \end{array}$

00404

GUNTHER, $K$.

$1984 A$

THE EFFECTS OF BACKCOUNTRY RECREATIONAL USE ON BEAR USE IN THE PE LICAN VALLEY AREA OF YELLOWSTONE NATIONAL PARK.

U.S.D.I., NATL. PARK SERV, YELLOWSTONE NATL. PARK, WYO. 20 PP.

NONMOTOR IMP ACT PATT INTRASP BEH REACTION
CLOSURE

YGBE,WY, YNP, ,PELI 
00405

GUNIHER, K.

RELATIONSHIP BET WEEN ANGLER AND BEAR USE IN THE CLEAR CREEK AREA

CF YELLOWSTONE LAKE. U.S.D.I 9 . NATL. PARK SERV., YELLOWSTONE NATL. PARK, WYO. INFO. PA

CLOSURE PRED NONMOTOR IMP
PLOT

YGBE,WY, YNP, ,CLCR

00406

GUNTHER, K. AND R. RENKIN.

1985

THE EFFECTS OF BACKCOUNTRY RECREATIONAL ACTIVITY ON BEAR USE IN T HE PELICAN VALLEY AREA CF YELLOWSTCNE NATIONAL PARK.

U.S.D.I.' NATL. PARK SERV., YELLOWSTONE NATL. PARK, WYO. PRELIMIN $A R Y P R O G=R E P: 36$ PP.

$\begin{array}{llll}\text { NONMOTOR IMP } & \text { TIMB USE } & \text { COVER } & \text { HAB USE } \\ \text { REACTION } & \text { ACT PATT } & \text { PRED } \\ \text { NONMOTOR IMP } & \text { CLOSURE } & \text { ACT } & \\ \text { YGBE,WY ,YNP } & \text {,PELI } & & \end{array}$

00407

GUSTAVSON, C.R., D.J. KELLY AND J. GARCIA.

PREDATION AND AVERSIVE CONDITIONING IN COYOTES.

SCIENCE 187:1096.

A VER COND

GEN , , ,

00408

GUSTAVSON, C.R.. D.J. KELLY AND M. SWEENEY.

1976

PREY-LITHIUM AVERSICNS I: COYOTES AND WOLVES.

BEHAY • BIOL. $17: 61-72$.

AVER CONO

, GEN, , , 
00409

HADDEN, D.A., W.J. HANN AND C.J. JONKEL.

1986

AN ECOLOG ICAL TAXONOMY FOR EVALUATING GRIZZLY BEAR HABITAT IN THE WHITEFISH RANGE OF MONTANA.

PP. 67-77 IN: G.P. CONTRERAS AND K.E. EVANS, EDS P PROCEEDINGS-GR I ZZLY BEAR HABITAT SYMPOSIUM. U.S.D.A., FOREST SERVICE. INTERMOUNT AIN RES. STAT:, OGDEN, UTAH: GEN. TECH. REP. INT-20T.
MAP/TYPE
TYPE DESCRIP
HAB SAMPL
HAB EFFECT

NCDE,MT, KONF, FLNF, WHR

$\operatorname{co} 410$

HADDEN, D. AND C. JONKEL.

1983 ANVENTORY AND EVALUATION OF WILOLIFE AND WILDLIFE HABITAT ON T HE BIG MOUNTAIN, MONTANA.

BORDER GRIZZLY PROJ., UNIV. MONT., MISSOULA. SPEC. REP. NC. 64.1
29 PP.

$\begin{array}{llll}\text { RECR IMP } & \text { MAP/TYPE } & \text { HAB RECCN } & \text { HUMAN IMP } \\ \text { CUM EFF } & \text { TIMB MGMT } & \text { SUBDIV MGMT } & \text { ROAD MGMT } \\ \text { MOVE } & & \end{array}$

00411

FAGLUND, B.

1974 MODSE RELATIONS WITH PREDATORS IN SWEDEN, WITH SPECIAL REFERENCE TO BEAR AND WOLVERINE.

NATURAL ISTE CAN. 101:457-466.

PRED

, GEN, , ,

00412

HAIGH, J.C. AND G.B. STENHOUSE.

1985 FATAL TRAUMA CAUSED BY A DETERRENT DEVICE FOR BEARS.

J. WILDL. DIS. $21(3): 330-331$.

DETER/REPEL CCNTROL 
00413

HAIGH, J.C. I. STIRLING AND E. BROUGHTON.

1984 CLINICAL EXPERIENCES WITH TELAZOL (R) FOR PCLAR BEAR IURSUS MARIT CLINICAL EXPER IENCES WITH TELA
IMUS PHIPPSI IMMCBILIZATION.

ANNU. PROC. AM. ASSOC . ZOO VET. 1984:130-131.

DRUGS

$\rightarrow$ GEN, ,

00414

HAIGH, J.C.. I. STIRLING AND E. BROUGHTON.

1985

IMMOBILIZATION OF POLAR BEARS (URSUS MARITIMUS PHIPPS) WITH A MIX TURE OF TILETAMINE HYDROCHLORIDE.

J. HILDL. DIS. $21(1):: 43-47$.

DRUGS

,$G E N$,

00415

$H A L L, E, R$.

1928
RECORDS OF SUPERNUMERARY TEETH IN BEARS.

UNIV. CALIF. PUBL= ZOOL. 301111:243-250.

DENT

, GEN,

00416

HALL, E.R.

DENTAL CARIES IN WILD BEARS.

TRANS. KANS. ACAD. SCI. 48(1):79-85.

DENT

PARAS/DIS

, GEN . 
00417

$H A L L, E \cdot R$.

1981

THE MAMMALS OF NORTH AMERICA. VOL. II.

JOHN WILEY AND SONS, NY. $181 \mathrm{PP}$.

TAXCN/EVOL HIST DISTR

GEN, , , ,

00418

HALL, E.R.

1984

GECGRAPHIC VARIATION AMONG BRCWN AND GRIZZLY BEARS (URSUS ARCTOS) IN NOR.TH AMER ICA.

MUS. NAT . HIST. UNIV. KANSAS, LAWRENCE. SPEC. PUBL . 13. 16 PP.

TAXON/EVOL DENT SKULL DISTR

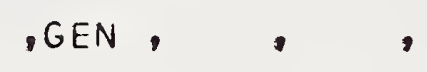

00419

HALLORAN, D.W. AND A.M. PEARSON.

1972 BLOOD CHEMISTRY OF THE BROWN BEAR (URSUS ARCTOS) FROM SOUTHWESTER $N$ YUKON TERRITORY, CANADA.

CAN. J. ZOOL. $50(6): 827-833$.

HEMAT HIB PHYS

, GEN, ,

00420

HAL VORSON, G.L.

SOME GRIZZLY BEAR OBSERVATIONS.

U.S.D.A., FOREST SERV. LOLO NATL. FOREST, MONT, 5 PP.

HAB USE SEAS BEH FOOD

CYE, MT , LONF, , 
00421

HAMER, D.

1974

THE GRIZZLY BEAR IN MOUNT REVELSTOKE PARK.

PARKS CANADA, REVELSTOKE NATL. PARK, B.C. 6 PP.

HAB RECON HAB USE MOVE NONMOT MGMT

$B C-I, B C \quad, R E V L, \quad$,

00422

HAMER, J.D.W.

DIISTR IBUTION, ABUNDANCE, AND MANAGEMENT IMPLICATIONS OF THE GRIZZ LY BEAR AND MOUNTAIN CAR IBOU IN THE MCUNTAIN CREEK WATERSHED OF G LACIER NATIONAL PARK, BRITISH COLUMBIA.

M.S. THESIS, UNIV. CALGARY, ALBERTA. 164 PP.

$\begin{array}{lll}\text { HAB USE MOVE FOOD MGMT GEN } & \end{array}$

RECR MGMT

$B C-I, B C$, CGNP,

00423

HAMER, J.D.W.

1985

FEED ING ECOLOGY OF GRIZZLY BEARS IN THE CASCADE AND PANTHER VALLE Y OF BANFF NATIONAL PARK.

PH.D. DISS., UNIV. CALGARY, ALBERTA. 247 PP.

$\begin{array}{cccc}\text { HAB USE } & \text { MOVE } & \text { FOOD } & \text { FIRE MGMT } \\ \text { COVER } & \text { PRED } & \text { CARCASS } & \text { DIGEST } \\ \text { NUTR ANAL } & \text { CAR } & \\ \text { CR AT }, \text { BANP, } & \text {,CASC } & & \end{array}$

00424

HAMER, D. AND S. HERRERO.

$1983 A$

MOVEMENTS, FOOD, AND HABITAT OF GRIZZLY BEARS IN THE CASCADE AND PANTHER VALLEYS OF BANFF NATIONAL PARK.

PP. 9-263 IN: D. HAMER AND S. HERRERO, ED, ECOLOGICAL STUDIES OF THE GRIZZLY BEAR, BANFF NAT IONAL PARK: PREP. FOR PARKS CANADA CON TRACT WR 4-80. UNIV. CALGARY, ALBERTA. FINAL REP.
HAB USE
COURT
REACTION
MGMT GEN
GEN DATA
NUTR ANAL
PRED

CR, AT, BANP, ,CASC 
00425

HAMER, D. AND S. HERRERD (EDS).

1983B

FINAL REP PREP FOR PARKS CANADA. CONTRACT WR 4-80. PREP. BY UNIV - of CALGARY, alberta. 303 PP.

$\begin{array}{llll}\text { MAP/TYPE } & \text { HAE USE } & \text { MGMT GEN } & \text { PRED } \\ \text { CARCASS } & \text { REACTION } & \text { GEN DATA } & \text { DEN } \\ \text { COURT } & & \\ \text { CR MAT BANP, } & \text {,CASC } & \end{array}$

00426

HAMER, D. AND S. HERRERO.

IN PRES SA

FOOD AND HABITAT USED BY GRIZZLY BEARS IN THE FRONT RANGES OF BAN FF NATIONAL PARK, ALBERTA.

INT. CONF. BEAR RES. AND MANAGE. 7.

$\begin{array}{lll}\text { HAB USE, FOOD } & \text { NUTR ANAL NEG SUCC } \\ \text { BURN USE/MGT FOR STRAT } & \\ \text { CR ,AT ,BANP, ,CASC } & \end{array}$

00427

HAMER, D. AND S. HERRERD.

IN PLRESSB IRE INFLUENCE ON GRIZZLY BEAR FEEOING ECOLOGY IN THE FRONT RANGES OF EANFF NATIONAL PARK, ALBERTA.

INT. CONF. BEAR RES. AND MANAGE. 7.
HAB USE
FIRE MGMT
BURN USEIMGT FOOO
VEG SUCC
CR , AT ,BANP, ,

00428

HAMER, D.S. HERRERO AND K. BRADY.

1982 THE GRIZZLY BEAR IN WATERTON LAKES NATIONAL PARK.

YEAR 1. PROGR REP 1981 PREP FOR PARKS CANADA. CONTRACT HR 6681. PREP. BY UNIV. CALGARY, ALBERTA. 51 PP.

$\begin{array}{llll}\text { HOME } & \text { MNG } \\ \text { PRED } & \text { ROVE } & \text { FORTION }\end{array}$

CR , AT , WANP, 
00429

HAMER, D., S. HERRERO AND K. BRADY.

1983

THE GRIZZLY BEAR IN WATERTON LAKES NATIONAL PARK.

YEAR 2. PROG. REP 1982. PREP. FOR PARKS CANADA. CONTRACT WR 70-82 - PREP. bY UNIV. CALGARY, ALBERTA. 59 PP.

FOOD RET MGMT GACTION GARBAGE HUMAN INJ
NONMOT

CR , AT WANP, ,

00430

HAMER, D. S. HERRERO AND K. BRADY.

STUDIES OF THE GRIZZLY BEAR IN WATERTON LAKES NATIONAL PARK.

FINAL REP. PREP. FOR PARKS CANADA. CONTRACT WR 149-83. PREP BY U NIV. CALGARY, ALBERTA. 163 PP.
FOOD
CARCASS
HAB USE
FEED BEH
DEN REACTION
PRED

CR , AT OWANP,

00431

HAMER, D., S. HERRERO AND R.T. OGILVIE.

1977
ECOLOGICAL STUDIES OF THE BANFF NATIONAL PARK GRIZZLY BEAR, CUTHE
ADIWIGMORE REGION 1976 . PRELIMINARY REP. PREP - FOR PARKS CANADA. CONTRACT WR 34-76. PREP. BY UNIV. CALGARY, ALBERTA. 234 PP.

$\begin{array}{llll}\text { FCOD } & \text { PRED } & \text { CARCASS } & \text { FEED BEH } \\ \text { NUTR ANAL } & \text { HABUSE } & \text { DEN } & \text { COPULATE } \\ \text { COURT } & \end{array}$

00432

HAMER, D., S. HERRERO AND R.T. OGILVIE.

1978

ECOLOGICAL STUDIES OF THE BANFF NATIONAL PARK GRIZZLY BEAR, CUTHE AD/WIGMORE REGION 1977.

YEAR 2 PRELIMINARY REP PREP . FOR PARKS CANADA. CONTRACT HR 35-7 7. BY UNIV. CALGARY, ALBERTA. 50 PP.
FOOD
NUTR ANAL
MAP / TYPE
COURT
HAB USE
WEAN
PRED
$S I B$ BEH

CR ,AT ,BANP,

, CUWI 
00433

HAMER, D., S. HERRERO, R.T. OGILVIE ANO T. TOTH.

ECOOLOGICAL STUDIES OF THE BANFF NATIONAL PARK GRIZZLY BEAR, CASCA DEIPANTHER REGION 1978. YEAR 3. PRELIMINARY REP, PREP FOR PARKS CANADA. CONTRACT WR 96-7
8. PREP. BY UNIV. CALGARY, ALBERTA. 86 PP.
AIRCRAFT IMP
NUTR ANAL
HCME RNG
HAB USE
DEN
FOOD
COURT

$C R$, AT , BANP,

, CASC

00434

HAMER, D., S. HERRERD, R.T. OGILVIE, T. TOTH AND A.H. MARSH. 1980

ECOLOGICAL STUDIES OF THE BANFF NATIONAL PARK GRIZZLY BEAR, CASCA DE/PANTHER REGION 1979 IYEAR 4).

YEAR 4. PRELIMINARY REP. PREP. FOR PARKS CANADA. CONTRACT WR 48-7 9. PREP. BY UNIV. CALGARY, ALBERTA. 51 PP.

$\begin{array}{llll}\text { HOME RNG } & \text { DEN } & \text { FCOD } & \text { HAB USE } \\ \text { BURN USE/MGT } & \text { MAP/TYPE } & \text { COURT } & \text { WEAN } \\ \text { MARK } & & \\ \text { CR } \text { AAT ,BANP, } & \text {,CASC } & & \end{array}$

00435

HAMER, D., S. HERRERO AND L. ROGERS.

DIFFERENTIATING BLACK AND GRIZZLY BEAR FECES.

WILDL. SOC. BULL.9(3):210-212.

SCAT ANAL IDENT/RECOG

CR , AT, BANP, ,

00436

HAMER, D., S. HERRERO AND G.W. VRCCM.

$1981 \mathrm{~B}$

SELECTIVE CAPTURE OF GRIZZLY BEARS.

HILDL. SOC. BULL. $9(2): 132-141$.

CAPTURE

CR ,AT ,BANP, ,CASC 
00437

HAMER, $J=D . W$.

1974

DISIRIBUTION, ABUNDANCE AND MANAGEMENT IMPLICATICNS OF THE GRIZZL $Y$ BEAR AND MOUNTAIN CAR IBOU IN THE MOUNTAIN CREEK WATERSHED OF GL ACIER NATIONAL PARK, BRITISH COLUMBIA.

M.S. THESIS. UNIV. CALGARY, ALBERTA. 164 PP.

$\begin{array}{lll}\text { HAB USE } & \text { MOVE } & \text { FCCD } \\ \text { RECR MGMT } & \end{array}$

00438

HAMILTON, A.N.

1984

PROGRESS REPORT: COASTAL GRIZZLY RESEARCH PROJECT, YEAR 1 - 1982.

B.C. FISH AND WILDL, BRANCH, VICTCRIA. 32 PP.

$\begin{array}{llll}\text { HARV DATA } & \text { RES MORT } & \text { MCVE } & \text { HOME RNG } \\ \text { HAB USE } & \text { FOOD } & \text { DAY BED } & \text { MARK } \\ \text { DEN } & & \end{array}$

00439

HAMILTON, A.N. AND W.R. ARCHIBALD.

1984

COASTAL GRIZZLY RESEARCH PROJECT, PROGRESS REPCRT, 1983, YEAR 2.

B.C. WILDL. BRANCH AND RESEARCH BRANCH, VICTORIA. WILDL = WCRKING PAP: NO. WR-2, WILDL. HABITAT RES. REP? NO. WHR-IO. 27 PP.

$\begin{array}{lll} & \text { DAY BED } & \text { GEN DATA } \\ \text { AGE/SEX MARK } & \text { DEN }\end{array}$

$B C-C, B C, \quad, \quad, \quad, \quad, \quad, M S$

00440

HAMILTON, A.N. AND H.R. ARCHIBALD. 1986
GRIZZLY BEAR HABITAT IN THE KIMSQUIT RIVER VALLEY, COASTAL BRITIS
H COLUMBIA: EVALUATION.

PP. 50-57 IN G.P. CONTRERAS AND K. E. EVANS, EDS. PROCEECINGS-GRIZ ZLY BEAR HABITAT" SYMPOSIUM. U.S.D.A. FOREST SERV. INTERMCUNTAIN RES. STAT., OGDEN, UTAH. GEN. TECH. REP. INT-2C7.

FOOD

HAB USE

TELEM

$B C-C, B C, \quad, \quad, \quad, \quad, \quad, M S$ 
00441

HAMILTON, A.N. AND F.L. BUNNELL.

IN PRESS STRATEGIES OF COASTAL GRIZZLY BEARS IN THE KIMSQUIT RIVE R VALLEY, BRITISH COLUMBIA.

INT. CONF. BEAR RES. AND MANAGE. 7.

$\begin{array}{lccc}\text { HOME RNG } & \text { HAB USE } & \text { FOOD } & \text { MOVE } \\ \text { FOR STRAT } & , \text { KIMS } & \end{array}$

00442

HAMILTON, T. AND B. SMITH.

1981 AIEL CUIDE TO YUKON BEARS FOR THE EXPLORATION AND PLACER INDUS TRIES.

YUKON WILDL. BRANCH, WHITEHORSE. 58 PP.
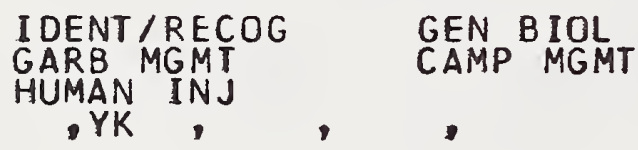

EDUC

GEN DATA

GARB MGMT

CAMP MGMT

AVOI D/ATTRAC

00443

HAMLIN, K. L. AND M. FRISINA.

1975

SPECIAL GRIZZLY SURVEY.

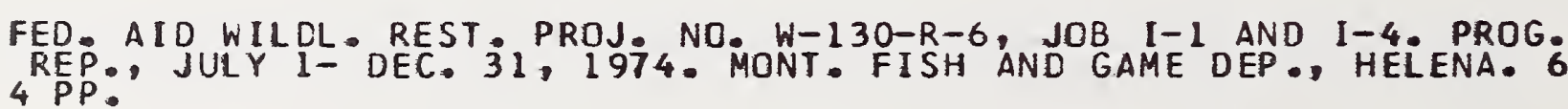
HAB RECON DISTR HAB USE CENSUS/TREND FOOD MT , ,

00444

HANSEN, J.M.

1981

VEGETAT I ONAL BEAR-FOOD AND COVER CHARACTER ISTICS OF MISSION YALLE Y RIPARIAN SEEP COMPLEXES AND OTHER LOW ELEVATION HABITAT TYPES.

B. S. THESIS (SENIOR), UNIV. MONTANA, MISSOULA.

COVER

TYPE DESCRIP

NCDE,MI ,FLNF,FLIR,MISS 
00445

HARDING, L.E.

1976

DEN-SITE CHARACTERISTICS OF ARCTIC COASTAL GRIZZLY BEARS IURSUS A RCTOS L.) CN RICHARO'S ISLAND, NORTHWEST TERRITORIES, CANACA.

CAN. J. ZOOL. 54:1357-1363.

DEN SITE DEN CHAR DEN CHRON DOP DENS
ENERGY IMP DOR D D

$C A R C, N W T, \quad, \quad, \quad I C H$

00446

HARDING, L. AND J.A. NAGY.

1980

RESPONSES OF GRIZZLY BEARS TO HYOROCARBON EXPLCRATION ON RICHARDS ISLAND, NORTHWEST TERR ITOR IES, CANADA.

INT . CONF. BEAR RES. AND MANAGE. 4:277-280.

ENERGY IMP

CARC,NWT,

00447

HAR ESTAD, A.S.

1981

COMPUTER ANALYSIS OF HOME RANGE DATA.

B.C E FISH AND WILDL BRANCH, VICTORIA, WILDL, RES. AND TECH, SERV HOME RNG

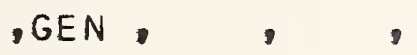

00448

HARESTAD, A.S. AND F.L. BUNNELL.

1979 HOME RANGE AND BODY WEIGHT - A REEVALUATION.

ECOLOGY $60121: 389-402$.

HOME RNG

. GEN

AIRCRAFT IMP

$\mathrm{RICH}$ 
00449

HAR CLDSON, M.

1980

PHENOLOGY OF GRIZZLY BEAR FOOD PLANTS: SEASCNAL IMPORTANCE VALUES OF GRIZZLY HABITAT COMPONENTS.

B.S. THESIS (SENICR) \& UNIV. MONT, MISSOULA. 22 PP.

$\begin{array}{lll}\text { CUT USE HAB USE FGOD HAB EFFECT } & \text { HST }\end{array}$

NCDE,MT, FLNF, ,SFLT

00450

HAROLDSUN, M.

TEST OF TEMPORARY BAITING OF GRIZZLY BEARS.

U.S.D.I. INTERAGENCY GRIZZLY BEAR STUDY TEAM, BOZEMAN, MONT. 15

AVOID/ATTRAC

YGBE,IMW, YNP, USFS,

00451

HAROLDSON, M. AND R. MACE.

IN PREP

DRAFT MANUSCRIPT PREP. FOR U.S. FISH AND WILDL. SERV. GRIZZLY BEA R RECOVERY COURDINATOR, MISSOULA, MONT. 15 PP.

POP AUG RELOC

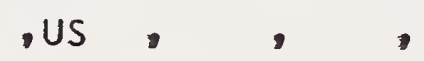

00452

HARCLDSON, M. AND D. MATTSON.

1985 RESPONSE OF GRIZZLY BEARS TO BACKCOUNTRY HUMAN USE IN YELLOWSTONE NATIONAL PARK.

U.S.D.I. INTERAGENCY GRIZZLY BEAR STUDY TEAM, BOZEMAN, MONT. 37

MOVE

FOR STRAT

NONMOTOR IMP
ACT PATT

YGBE, IMW, YNP,

FOOD

REACTION 
00453

HARPER, $F$.

1961

LAND AND FRESHWATER MAMMALS OF THE LNGAVA PENINSULA.

UNIV. KANSAS MUS. NAT. HIST, LAWRENCE. MISC, PUBL. NO. 27. 178 PP $\bullet$
HISI DISTR
HIST ACCT

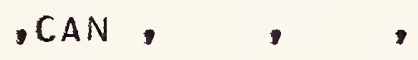

00454

HARRIS, R. B.

$1984 A$

PRELIMINARY EXPERIMENTS ON A SCENT-STATION INDEX FOR GRIZZLY BEAR S.

FINAL REP PREP FOR U.S.DI FISH AND WILDL. SERV OFFICE OF GR IZZLY BEAR RECOVERY CODRDINATOR PREP. BY MCNT. CCOP. WILCL. RES. UNIT, UNIV. MONT., MISSOULA. 30 PP.

CENSUS METH

NCDE, ATMT, , ,

00455

HARRIS, R•B.

$1984 \mathrm{~B}$

HARVEST AGE-STRUCTURE AS AN INDICATOR OF GKIZZLY BEAR POPULATION STATUS.

M.S. THESIS, UNIV. MONT., MISSOULA. 204 PP.
DEMOG ANAL
HARV IMP
AGE/SEX
HARV MGMT

, GEN, ,

00456

HARRIS, R. B.

$1985 A$

MODELING SUSTAINABLE HARVEST RATES FOR GRIZZLY BEARS. (DRAFT).

MANUSCRIPT. 16 PP.
DEMOG ANAL
HARV MGMT
HARV IMP

NCDE,MT 
00457

HARRIS, R.B.

1985B $N$ WE DO IT?

PP. 137-146 IN: R. LAMBERSON, ED. MATHEMATICAL MODELS OF RENEWABL E RESOURCES, VOL: III ASSOC: OF RESOURCE MODELERS, HUMBOLCT STAT

HARV IMP HARV MGMT DEMOG ANAL

$, G E N, \quad$,

00458

HARRIS, R.B.

$1986 \mathrm{~A}$

GRIZZLY BEAR POPULATICN MONITORING: CURRENT OPTIONS AND CONSIDERA TIONS. MONTANA FOR. CONSERV. EXP. STAT, SCHOOL OF FORESTRY, UNIV. MONT.
MISSOULA. MISC. PUBL. $45.944 \mathrm{P}$. CENSUS METH HARV MGMT DEMOG ANAL , GEN, , , ,

00459

HARRIS, R.B.

$1986 B$

REL IABILITY OF TREND LINES OBTAINED FROM VARIABLE COUNTS.

J. WILOL. MANAGE. 50(1):165-171.

CENSUS METH

, GEN, , ,

00460

HARRIS, R. (ED.).

$1986 \mathrm{C}$

RESULTS OF THE WORKSHOP ON GRIZZLY BEAR POPULATION GENETICS.

SPONSORED BY U.S D.I. FISH AND WILDL, SERV, CFF. OF GRIZZLY BEA
R RECOVERY COORDINATOR, MISSOULA, MONT, 8 PP! GENETICS POP AUG

MIN POP

,GEN,


00461

HARRIS, R.B. AND L.H. METZGAR.

1986A STOCHASTIC INFLUENCES ON SUSTAINED YIELOS OF GRIZZLY BEAR POPULAT IONS.

MONTANA COOP. WILDL. RES. UNIT, MISSOULA, MONT. DRAFT MANUSCRIPT - $32 \mathrm{PP}$.

HARV MGMT DEMOG ANAL PCP REG

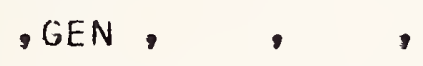

00462

HARRIS, R.B. AND L•H• METZGAR.

$1986 \mathrm{~B}$

REPRODUCTIVE VALUES OF GRIZZLY BEARS: A CONTRIBUTION TOWARDS THE CUMULATIVE EFFECTS ANALYSIS.

FINAL REP. TO U.S. FOREST SERV., REGION 1, MISSCULA, MONT, 16 PP

DEMOG ANAL REPRO

, GEN, , ,

00463

HARRIS, R.B. AND L.H. METZGAR.

IN PRESSA

ESTIMATING HARVEST RATES OF BEARS FROM SEX RATIO CHANGES: BIAS AN D VARIABILITY.

J. WILDL. MANAGE.

HARV MGMT DEMOG ANAL

, GEN,

00464

HARRIS, R.B. AND L.H. METZGAR.

IN PRESSB

HARVEST AGE STRUCTURES AS INDICATORS OF DECLINE IN SMALL PCPULATI ONS OF GRIZZLY BEARS.

INT - CONF - BEAR RES. AND MANAGE - 7: •

HARV MGMT

AGE / SEX

DEMOG ANAL

GEN, , , ,


00465

HARRISON, J.L.

1958

RANGE OF MOVENENT OF SONE MALAYAN RATS.

J. MAMMAL. 39(2):190-206.

HOME RNG

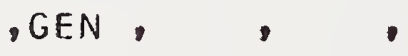

00466

HARTHOORN, A.M.

1965 APPLICATION OF PHARMACOLOGICAL AND PHYSIOLOGICAL PRINCIPLES IN RE STRAINT OF WILD ANIMALS.

WILDL. MCNOGR. NO. 14:78 PP.

CAPTURE DRUGS

, GEN, , ,

00467

HARTING, A.L., JR.

1985

RELATIONSHIPS BETWEEN ACTIVITY PATTERNS AND FORAGING STRATEGIES O F YELLOWSTONE GRIZZLY BEARS.

M.S. THESIS, MONT, STATE UNIV., BCZEMAN, $130 \mathrm{PP}$.

SENSE

GEN DATA

MGMT GEN

ACT PATT

PRED

BEHAV PATT

HAB
FOR SFECT

YGBE.IMN

00468

HARTKORN, F.

BIG6 GAME SURVEYS AND INVEST IGATIONS - BLACKFOOT UNIT RECHECK.

FED. AID WILDL REST. PROJ, W-72-R-11, JOB A-2, JOB COMPLETION RE 47 PULY 1. 1965-JUNE 30, i966. MONT. FISH AND GAME DEP . HELENA. HARV DATA

NCDE,MT , 
00469

HARTKORN, F.L. AND R. JANSON.

1974

BIG GAME SURVEY AND INVENTORY.

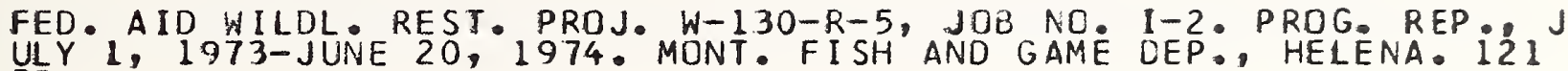
UPY

HARV DATA

, MT , , NCDE

00470

HARVEY, M.J. AND R.W. BARBOUR.

1965 HOME RANGE OF MICROTUS OCHROGASTER AS DETERMINED BY A MODIFIED MI NIMUM AREA METHOD.

d. MAMMAL. $46(3): 398-402$.

HOME RNG

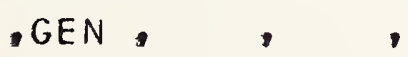

00471

HASTINGS, B.C. AND B.K. GILBERT.

1981

AVERSIVE CONDITIONING OF BLACK BEARS IN THE BACKCOUNTRY OF YOSEMI TE NATIONAL PARK.

PROC. CONF. SCI . RES. NATL. PARKS 2:294-303.

AVER COND NCNMOT MGMT CAMP MGMT

$$
, \text { GEN , , , }
$$

00472

HASTINGS, B.C., B.K. GILBERT AND D.L. TURNER.

1981 BLACK BEAR BEHAVIOR AND HUMAN-BEAR RELATICNSHIPS IN YOSEMITE NATI ONAL PARK.

FINAL REP PREP. FOR U.S.D. I NATL PARK SERV, WESTERN REGION, CONIRACI CX-1200-9-BO5 I PREP: BY UTAH COCP. RE SOUR. STUDIES UNIT UTAH STATE UNIV.: LOGAN. 42 PP.

AVER COND NONMOT MGMT CAMP MGMT EDUC

, GEN, , ,


00473

HAYNE, D.'ं.

1949 CALCULATION OF SIZE CF HOME RANGE.

J. MAMMAL. $30(1): 1-18$.

HOME RNG

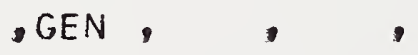

00474

HAYNES, B. D. AND E. HAYNES.

1966 THE GRIZZLY BEAR - PORTRAITS FROM LIFE.

UNIV. OKLA. PRESS, NORMAN. 386 PP.

HIST ACCT

$, G E N, \quad, \quad$,

C0475

HEBERT, D.M., O. EASTMAN AND H. LANGIN.

1983 AN EVALUATION OF CENSUS METHODS FOR GRIZZLY BEAR.

B.C. WILOL. BRANCH, VICTORIA. INTERNAL DRAFT REPORT - 13 PP.

CENSUS METH

$, G E N, \quad$,

00476

HEBERT, D..M., D.W. LAY ANO W.G. TURNBULL.

1980

IMMOBILIZATION OF COASTAL GRIZZLY BEARS WITH ETORPHINE HYOROCHLOR IDE.

J. WILDL. DIS. $16(3): 339-342$.

DRUGS

$B C-C, B C$, 
00477

HECHTEL, J.

1977

THE FOOD HABITS AND HABITAT SELECTION UF A FEMALE GRIZZLY AND HER TWO YEARLINGS, BROCKS RANGE, ALASKA, MAY 28-SEPTEMBER 10, 1977.

MONT . COOP. WILDL. RES. UNIT, UNIV. MONT . MISSCULA. 8 PP.

$\begin{array}{lll}\text { FOOD } & \text { CARCASS HAPED USE }\end{array}$

$A R C, A K, N P R$,,$W B R K$

00478

HECHTEL, J.

1978

BEHAVIURAL ECOLOGY OF A BARREN-GROUND GRIZZLY BEAR FEMALE AND HER YOUNG IN THE NATIONAL PETROLEUM RESERVE - ALASKA.

PRELIMINARY REP. MONT • COOP - WILDL. RES. UNIT, UNIV . MONT , MISSO ULA. II PP.
MOYE
HOME RNG
HAB USE
DEN CHRON
FOOD
NUTR ANAL

$A R C, A K$,NPR , ,WBRK

00479

HECHTEL, J.L.

1985

ACTIVITY AND FOOD HABITS OF BARREN-GROUND GRIZZLY BEARS IN ARCTIC ALASKA.

M.S. THESIS, UNIV. MONTANA, MISSOULA. 74 PP.
ACT PATT
FOOD
FEED BEH
PRED
MATERNAL

$A R C, A K, N P R, \quad, W B R K$

00480

HEDGE, R.S. G.E. FCLK, JR. AND M.C. BREWER.

1965

STUDIES ON WINTER LETHARGY OF BLACK AND GRIZZLY BEARS.

PROC. ALASKA SCI. CONF. 16:31-32.

HIB PHYS

-GEN , 
00481

HENDERSON, L.

BEAR-HUMAN INTERACTICNS IN THE COMMERCIAL SALMON FISHING CAMPS AL CNG THE YUKCN RIVER.

YUKUN WILDL. BRANCH, WHITEHCRSE. 56 PP.

CAMP MGMT AVOID/ATTRAC

$, Y K, \quad$, YUKR

00482

HENRY, D. (CHAIRMAN).

1984

MINUTES UF TASK FORCE MEEETING RELATED TO BEAR PROOF STORAGE FACI LITIES.

PREP BY INTERAGENCY GRIZZLY BEAR COMM TASK FORCE, U.S.D.I.I INT EPAGENCY GRIZZLY BEAR STUDY TEAM, BCZEMAN.. 20 PP

OUTFIT MCMT CAMP MGMT

- GEN, , $\quad$

00483

HENSEL, R.J., D.L. SPENCER AND D.E. TRUDGEN.

1981

AN EVALUATION OF BROWN BEAR DENNING IN THE AREA OF THE PROPOSED T ERROR LAKE HYDKDELECTRIC PROJECT, KODIAK ISLAND, 1980.

PRES AT 2ND CARNIVCRE/FURBEARER RES. AND MANAGE, WORKSHOP, MARCH $11-12,1981$, UNIV. ALASKA, FAIRBANKS, AK., I9 PP.

DEN CHAR DEN SITE

AKKA, AK ,KNWR, ,TERL

00484

HENSEL, R.J., W.A. TROYER AND A.W. ERICKSON.

1969

REPRODUCTION IN THE FEMALE BROWN BEAR.

J. WILDL. MANAGE. 33(2):357-365.

REPRO PHYS

LITR FREQ

BRD AGE

COURT

LITR SI ZE

$A K P N, A K$, 
00485

HEPBURN, R.

1974 AN ELETRIC FENCE CHARGER TO DISCOURAGE BEARS.

U.S.D.I., NATL. PARK SERV., YELLOWSTONE NATL. PARK, WYO.

DETER/REPEL

YGBE,IMW, YNP, ,

00486

FERRERD, $S$.

1970 MAN ANO THE GRIZZLY BEAR (PRESENT, PAST, BUT FUTURE?).

BIOSCIENCE 20(21):1148-1153.

HUMAN INJ MGMT GEN PUBLIC ATT RECR MGMT

GEN, , ,

00487

HERRERO, $S$.

$1970 A$

HUMAN INJURY INFLICTED BY GRIZZLY BEARS.

SCIENCE $170: 593-598$

HUMAN INJ
AVOID/ATTRAC RECR MGMT REACTION
GEN,

00488

HERRERO, S.

1972 ASPECTS OF EVOLUTION AND AOAPTATION IN AMERICAN BLACK BEARS IURSU

S AMERICANUS PALLAS) AND BROWN AND GRIZZLY BEARS (U. ARCJOC LINNE I OF NORTH AMERICA.

INT - CONF. BEAR RES. AND MANAGE. 2:221-231.

TAXON/EVOL 
C0489

HERRERO, S.

1976

CONFLICTS BETWEEN MAN AND GRIZZLY BEARS IN THE NATIONAL PARKS OF NCRTH AMERICA.

INT. CONF. BEAR RES. AND MANAGE. 3:121-145.

HUMAN INJ
MGMT GEN AVID/ATTRAC GARBAGE
, GEN,

00490

HERRERO, S.

$1978 \mathrm{~A}$

PEOPLE ANU GRIZZLY BEARS: THE CHALLENGE OF COEXISTENCE.

PP. 167-179 IN: WILOLIFE AND PEOPLE PROC. OF JOHN S P WRIGHTFOR: URDUE UNIV:; WEST LAFAYETTE, INDI ANA.

HUMAN INJ RECR MGMT MGMT GEN GARBAGE

$, G E N, \quad$,

00491

HERRERO, S.

$1978 B$

A COMPARISON OF SOME FEATURES OF THE EVOLUTION, ECOLOGY, AND BEHA VIOR OF BLACK AND GRIZZLYIBROWN BEARS.

CARNIVORE $1(1): 7-17$

$\begin{array}{llll}\text { TAXON/EVOL } & \text { MATERNAL } & \text { FOOD } & \text { REPRO } \\ \text { REP RATE } & \text { TERR/SPACE } & \text { PCP REG } & \text { INTERSP COMP } \\ \text { IGEN, } & , & & \end{array}$

00492

HERRERO, S.

1979

BLACK BEARS: THE GRIZZLY'S REPLACEMENT?

PP. 179-195 IN: D. BURK, ED. THE BLACK BEAR IN MODERN NOR TH AMERI CA PROC WORKSHOP ON MANAGE. BIOL OF NORTH AM. BLACK BEAR, 17-1 9 FEB 1977, KALISPELL, MONT. BOONE AND CROCKETI CLUB AND CAMP FI RE CLUB OF AMER ICA. INTRASP BEH TAXON/EVOL
CANNIBAL

WE IGHT

INTERSP COMP , GEN, 
00493

HERRERO, S.

1982 BEARS AND THE PROPOSED CANADIAN PACIFIC RAILWAY CONSTRUCTICN CAMP S IN GLAC IER NATIONAL PARK, BRITISH COLUMBIA, DECEMBER, ISEZ. PREP. FOR MACLARGEN PLANSEARCH CORP: VANCOUVER, B.C. PREP BY 81
CS ENVIRON. RES. AND PLANNING ASSOC: LID.: CALGARY, ALBERTA. 47
PP.

HUMAN INJ

MORT DATA

GARBAGE

CAMP MGMT

ENERGY IMP

CONTROL

CR , BC, CGNP,

00494

IERRERO, S.M.

1985

BEAR ATTACKS - THEIR CAUSES AND AVOIDANCE.

WINCHESTER PRESS, PISCATAWAY, N.J. 287 PP.

$\begin{array}{llll}\text { HUMAN INJ } & \text { REACTION } & \text { GARBAGE } & \text { AVOIDIATTRAC } \\ \text { CAMP MGMT } & \text { RECR MGMT } & \text { GARB MGMT } & \text { INTRASP EEH } \\ \text { GEN BIOL } & & \end{array}$

00495

HERRERO, S. AND D. HAMER。

1977

COURTSHIP AND COPULATION OF A PAIR CF GRIZZLY BEARS, WITH COMMENT $S$ ON REPRODUCTIVE PLAST ICITY AND STRATEGY.

J. MAMMAL. $58(3): 441-444$.

COURT COPULATE REPRO

CR , BC ,BANP, ,

00496

HERRERO, S., W. MCCRORY AND B. PELCHAT.

IN PRESS

THE APPLICATION OF GRIZZLY BEAR HABITAT EVALUATION TO TRAIL AND C AMPSITE LOCATIONS IN KANANASKIS PRDVINCIAL PARK, ALBERTA.

INT - CONF. BEAR RES. AND MANAGE.6.

HAB ANAL

NONMOT MGMT

CR ,AT ,KANP, 
00497

HERROLD, J. AND J. BLYTHE.

1955 COMPILATIAN OF DATA ON WILDLIFE HARVEST.

FED. AID WILDL.REST.PROJ. W-3-R, WORK PLAN D. ALASKA DEP. FISH
AND GAME, JUNEAU. 2 PP. HARV DATA

, AK, , ,

00498

HEYWARD,., R.G. WRIGHT AND E.E. KRUMPE.

1984A STUDY. VOL. I: A NARRATIVE DESCRIPTICN OF SCIENTIFIC STUDIES.

U.S. MAN AND THE BIOSPHERE PROGRAM, UNIV. IDAHC, MOSCOW. U.S. MAB
KEP. NO. 9. 137 PP. $\begin{array}{llll}\text { GEN DATA } & \text { CENSUS/TREND } & \text { HUMAN INJ } & \text { POP EST } \\ \text { AVOIDIATTRAC } & \text { PUBLIC ATT } & \text { RECR IMP } & \text { RECR MGMT }\end{array}$

NCDE,MT, GLNP, ,

00499

HEYWARD, P., R.G. WRIGHT AND E.E. KRUMPE.

$1984 B$ GLACIER NATIONAL PARK BIOSPHERE RESERVE: A HISTORY OF SCIENTIFIC STUDY VOL. $2:$ BIBLIOGRAPHY, SUBJECT ANNOTATIONS, TABULAR DATA SU MMARIES, AND APPENOICES.

U.S. MAN AND THE BICSPHERE PROGRAM, UNIV. IDAHO, MOSCOW. U.S. MAB REP. NO. S. I99 PP.

BIBLIO

NCDE,MT , GLNP, ,

C0500

HICKIE, P.

1953
INYENTORY OF BIG-GAME ANIMALS OF THE UNITED STATES, 1952.

U.S.D.I.. FISH AND WILDL. SERV., WILDL. LEAFLET 348. 3 PP.

HIST DISTR HARV DATA

, GEN, ,


00501

HICKMAN, J.

REGICN ONE - STRATEGIC PLAN, NCNGAME.

WASH. DEP. GAME, SPOKANE. 15 PP.

MGMT GEN

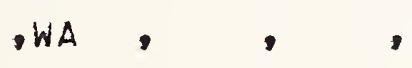

00502

HICKMAN, J.

1984

IDENTIFYING WASHINGTON'S BEARS.

WASH. WILDL. 1984 (DEC.):11-12.

IDENT/RECOG EDUC MARK

00503

HICKMAN, J.

1985 GUIDELINES FOR THE REPORTING OF GRIZZLY BEAR OBSERVATIONS FOR THE

WASH. DEP . GAME, SPOKANE. 6 PP.

MONIT SYS

-WA , ,

00504

HICKS, L.L.

1985

MULTIPLE-USE UN WESTERN PRIVATE INDUSTRIAL TIMBERLANDS.

TRANS. NORTH AM. WILDL. AND NAT. RESOUR. CONF. 50:211-214.

MGMT GEN

-US, , , 
00505

HILLIS, M.

1986

ENHANCING GRIZZLY BEAR HABITAT THROUGH TIMBER HARVESTING. PP 176-179 IN: G.P D CONTRERAS AND K. E. EVANS, EDS. PROCEEDINGS-G IN RES. STAT.: OGDEN, UTAH. GEN. TECH. REP. INT-207.

TIMB-POST TIMB-METH TIMB-HAB

CYNC, MT , LONF, ,

00506

HINMAN, R.

1974

THE IMPACT OF OIL DEVELOPMENT ON WILDLIFE POPULATIONS IN NCRTHERN ALASKA.

PROC. ANNU. CONF. WEST. ASSOC. STATE GAME \& FISH COMM. 54:156-164

ENERGY IMP

$A R C, A K, \quad$,

00507

HINMAN, $R=$, (ED.)

1977

SUR VEY-IN VENTORY ACTIVITIES, PART II. BLACK BEAR, BROWN BEAR, POL $A R$ BEAR, CARIBOU.

FED. AID WILOL. REST. PROJ. W-17-8, JOBS NO, $3,4,5,17$ AND 22.
ANNU. REP. VOL. VII. ALASKA DEP. FISH AND GAME, JUNEAU. 156 PP.

HARV DATA SKULL MISC QUANT AGE/SEX
GARB MGMT A

- AK, , ,

00508

HINMAN, R.A. (ED.).

1978

SUR VEY-INVENTORY ACTIVITIES, PART II. BLACK BEAR, BROWN BEAR, POL AR BEAR, CARIBOU.

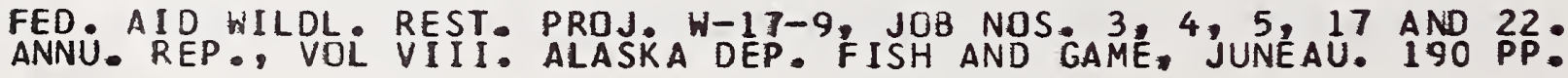

$\begin{array}{llll}\text { HARV DATA } & \text { MEAS/QUANT } & \text { SKULL } \\ \text { LITR SIZE } & \text { MORT DATA } & \end{array}$


00509

HINMAN, R. (ED.).

1979 SURVE-INVENTORY ACTIVITIES, PART I. BLACK BEAR, BROWN BEAR, POLA R BEAR, CARIBDU. FED. AID. WILDL. REST PROJ. W-17-11, JOB NOS, $17.0,4.0$ AND 22.0.
ANNU. REP., VOL. X. ALASKA DEP. FISH AND GAME, JUNEAU. IIS PP.

$\begin{array}{llll}\text { HARV DATA } & \text { MEAS/QUANT } & \text { SKULL } & \text { PRED } \\ \text { MORT DATA } & \text { AGEISEX } & \text { LITRSIZE } & \end{array}$

AK,,

$\cos 10$

HINMAN, R•, (ED.)

1982

SURVEY-INVENTORY ACTIVITIES, PART I. BLACK BEARS AND BROWN BEARS.

FED. AID WILDL. REST. PROJ. $W-19-2$ AND $W-22-1$, JOB NOS. 17.0 AND 4.0. ANNU REP. J VOL: XIII: ALASKA DFP. FISH ANC GAME, JUNEAU. 93

$\begin{array}{llll}\text { HARV DATA } & \text { GARBAGE } & \text { CENSUS/TREND } & \text { AGE/SEX } \\ \text { SKULL } & \text { HARV MGMT } & \end{array}$

00511

HOAK, J.H. AND T.W. CLARK.

1979 THE STATUS OF GRIZZLY BEARS IN BRIDGER-TETON NATIONAL FGREST, WYO MING.

FINAL REP. WEST. ENVIRON. RES. ASSOC., POCATELLO, IDAHO. 39 PP.

$\begin{array}{llll}\text { DISTR } & \text { CENSUS/TREND } & \text { POP EST } & \text { FOOD } \\ \text { HABUSE } & \text { DUTFIT MGMT } & \text { GARBAGE } & \text { CAMP MGMT }\end{array}$

YGBE,WY, BTNF, ,

00512

HOAK, J.H., T.W. CLARK AND J.L. WEAVER.

1983

CF GRIIZLY BEARS AND COMMERCIAL OUTFITTERS IN BRIDGER-TETCN NATIO NAL FOREST, WYOMING.

INT - CONF. BEAR RES. AND MANAGE • 5:110-117.

$\begin{array}{lll}\text { PRES DISTR CAMP MGMT OUTFIT MGMT DEPRED } & \text { OUT }\end{array}$

YGBE,WY , BTNF, , 
00513

HOAK, J.H., T.W. CLARK AND B. WOOD.

GRIZZLY BEAR DISTRIBUTION, GRAND TETON NATICNAL PARK AREA, WYOMIN G.

NOR THWE ST SCI . 55(4):245-247.

DIS IR

YGBE,WY, JDR, GTNP,

00514

HOOGSON, R. W.

1974

SOME EFFECTS OF THREAT APPEAL IN MESSAGES ABOUT HAZARDS OF GRIZZL Y BEARS IN NATIONAL PARKS: AN EXPERIMENT.

PH.D. DISS., MICH. STATE UNIV., LANSING.

RECR MGMT EDUC PUBLIC ATT

, GEN, , ,

00515

HOLCROFT, A.C. AND S. HERRERO.

1984

GRIZZLY BEAR DIGGING SITES FOR HEDYSARUM SULPHURESCENS ROOTS IN $S$ DUTHWESTERN ALBERTA.

CAN. J. ZCOL. 621121:2571-2475.

FOOD FEED BEH HAB SAMPL

CR ,AT ,KANP, ,

00516

HOLLAND, T.M.

1986 GRIZZLY BEAR HABITAT IMPROVEMENT PRCJECTS ON THE SOUTH AND MIDDLE FORK FLATHEAD RIVER.

PP 190-194 IN: G.P. CONTRERAS AND K.E. EVANS, EDS. PROCEEDINGS-G RIZZLY BEAR HABITAT SYMPOSIUM. U.S.D.A. FOREST SERV. INTERMDUNTA IN RES. STAT., OGDEN, UTAH. GEN. TECH. REP. INT-207.

FIRE MGMI

TIMB-POST

RCAD MGMT

NCDE,MT ,FLNF, , 
00517

HOREJSI, B.L.

1986 A

INDUSTRIAL AND AGRICULTURAL INCURSION INTO GRIZZLY BEAR HABITAT:

THE ALBERTA STORY.

PP. 116-123 IN: G.P. CCNTRERAS AND K.E. EVANS, EOS. PROCEECINGS-G RIZZLY BEAR HABITAT SYMPOSIUM U.S.D.A. FOREST SERV. INTERMOUNTA IN RES. STAT., OGDEN, UTAH. GEN. TECH. REP. INT-207.

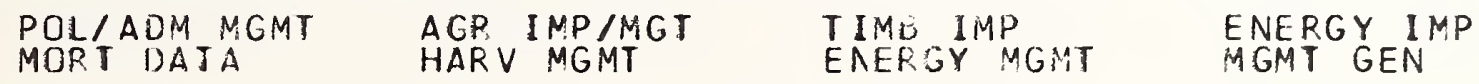

$C R, A T, \quad$,

00518

HOREJSI, B.L.

19868

STATUS OF THE GRIZZLY BEAR IN THE SOUTH CASTLE-WATERTON LAKES NAT IONAL PARK REGION OF ALBERTA.

WEST. WILDL. ENVIRUN. CCNSULTING LTO., CALGARY. 28 PP.

\begin{tabular}{|c|c|}
\hline $\begin{array}{l}\text { ENERGY I MP } \\
A G E / S E X\end{array}$ & $\begin{array}{ll}\text { ROAD } & \text { IMP } \\
\text { TIMB } & \text { IMP }\end{array}$ \\
\hline
\end{tabular}

CR , AT , WANP, ,

$\operatorname{co5} 19$

HOREJSI, B.L. AND R.M. RAINE.

1983

AN INVESTIGATION OF THE DISTRIBUTICN, MOVENENTS, AND ACTIVITIES O F GRIZZLY BEARS IN THE SOUTH WAPITI REGION CF ALBERTA. YEAR THREE

PROGR P REP. NO. 3. WEST - WILDL. ENVIRON. CONSULTING LTD. CALGARY - 56 PP.

PRES DISTR MOVE HCME RNG BEHAV PATT

FOOD

CR AT, , SWAP

$\cos 20$

HOREJSI, B.L. AND G. SLATTER.

1982

AN INVESTIGATION OF THE DISTRIBUT ION, MOVEMENTS, AND ACIIVITIES O F GRIZZLY BEARS IN THE SOUTH WAPITI REGION CF ALBERTA. YEAR TWO.

PROGR P PEP NO. 2. WEST - WILOL. ENVIRCN. CONSULTING LTD., CALGARY - 38 PP.
PRES DISTR
MOVE
HCME RNO
BEHAV PAIT

FOOD

CR

,AT, , SWAP


00521

HOREJSI, B.L. AND L.R. STEGENGA.

1981 ANVESTIGATION CF THE DISTRIBUTION, MOVEMENTS AND ACTIVITIES OF GRIZZLY BEARS IN THE PINTO CREEK-MUUDOY CREEK AREA OF ALBERTA. YE $A R$ ONE.

PROGP. REP. NO. 1. WEST. WILDL. ENVIRON. CONSULTING LTD., CALGARY

\section{-}

PRES DISTR MOVE HOME RNG BEHAV PATT

CF ,AT, , , SWAP

00522

HORNOCKER, M.G.

1962

PCPULATION CHARACTERISTICS AND SOCIAL AND REPRCDUCTIVE BCHAVIOR O F THE GRIZZLY BEAR IN YELLOWSTONE NATIONAL PARK.

M.S. IHESIS, MONT. STATE UNIV., MISSOULA. 94 PP.

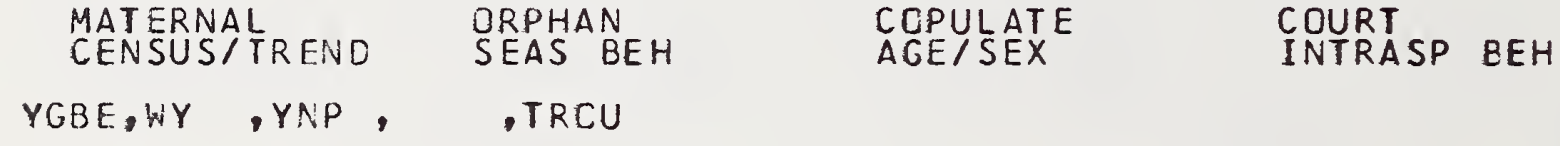

00523

HOSKINS, W.P.

1974

YELLOWSTONE LAKE TRIBUTARY SURVEY PROJECT.

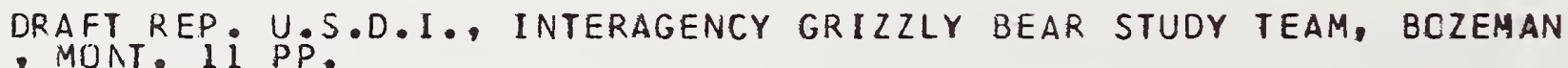
PREO

YGBE,WY, YNP, ,LAKE

00524

HOSKINS, W.P.

YELLOWSTONE LAKE TRIBUTARY STUDY.

1975 SUMMER REP
OZEMAN, MONT. 3 I PP. D. I. INTERAGENCY GRIZZLY BEAR SJUOY TEAM, B PRED

RECR IMP

FEED BEH

YGBE,HY, YNP, ,LAKE 
00525

HCUSTON, D.B.

1978 ELK AS WINTER-SPRING FOOD FOR CARNIVORES IN NORTHERN YELLCWSTONE
AATIDNAL PARK.

J. APPL. ECOL. 15(3):653-661.

CARCASS FOOD

YGBE, IMW, YNP, ,

00526

HUUSTDN, D.8.

1982 ELK-CARNIVORE RELATIONSHIPS. CHAPTER 11 PP $186-195$ IN: D HOUSTON. THE NORTHERN YELLOWSTONE
ELK. ECOLOCY AND MANACEMENT. MACMILLAN PUBLISHING CO. I INC. N.Y. CARCASS PRED

YGBE, IMW, YNP, ,

00527

HOWELL, A.H.

1940

BROWN BEAR KILLED ON ST. LAWRENCE ISLAND.

J. MAMMAL. $21(2): 216$.

HIST DISTR HIST ACCT

- AK, ,,

00528

HUNT, C.L.

1982 ACTIVITY - WEST GLACIER DUMPSTER SITE AND SURROUNDING AREA-S UMMER AND FALL, 1981.

MONT • COOP. WILOL. RES. UNIT, UNIV. MONT , MISSOULA. 6 PP.

GARBAGE

NCDE,MT, , ,WGLA 
C0529

HUNT, C.L.

DETERRENTS, AVERSIVE CONOITIONING, AND OTHER PRACTICES: AN ANNOTA TED BIBLIOGRAPHY TO AID IN BEAR MANAGEMENT.

MONT - COUP. WILDL. RES. UNIT, UNIV. MONT., MISSCULA. 136 PP.

BIBLIO DETER/REPEL AVER COND

, GEN, , ,

00530

HUNT, C.L.

1984

BEHAVIORAL RESPONSES OF BEARS TO TESTS OF REPELLENTS, DETERRENTS, AND AVERSIVE CONDITIONING.

M.S. THESIS, UNIV. MONT., MISSDULA. 274 PP.

DETER/REPEL AVER COND RELOC

, GEN, , ,

00531

HUNT, $C$.

DESCRIPTION OF FIVE PRCMISING DETERRENT AND REPELLENT PRODUCTS FO R USE ON BEARS. FINAL REP. PREP. FOR U.S.D.I I FISH AND WILDL. SERV., OFFICE OF
GRIZZLY BEAR COORDINATOR, MISSCULA, MONT. 55 PP.

DETER/REPEL AVER COND

$$
\text { , GEN, , , }
$$

00532

HUNT, C. AND C. JONKEL.

EEAR DETERRENT TESTS.

BOROER GRIZZLY PROJ., UNIV. MONT \& MISSOULA. SPEC. REP • NC. 56. 1 $3 \mathrm{PP}$.

DETER/REPEL AVER COND REACTION

, GEN, , , 
C0533

HUNTER, R.G. AND J.R. GUNSGN.

ANALYSIS OF GRIZZLY BEAR COMPLAINTS IN ALBERTA: 1970-79.

ALBERTA FISH AND WILDL. DIV., EDMONTON. 12 PP.

$\begin{array}{llll}\text { CCNTROL DEPREC } & \text { HUMAN INJ } \\ \text { CAMP MGMT } & \text { ENERGY IMP } & \end{array}$

- at , , ,

00534

HUSBY, P., S. MEALEY AND C. JONKEL.

1977 SEASONAL FOOD HABITS OF GRIZZLY BEARS IURSUS ARCTOS HORRIBILIS OR DI IN NORTHWESTERN MONTANA.

PP. 103-117 IN: C JONKEL, ED. ANNUAL REPORT. BORDER GRIZZLY PROJ , UNIV. MONT., MISSOULA. ANNU. REP. NO? 2 .

FOOD

NCDE,MT, , ,

00535

INUKAI, T.

1969 METABOL ISM OF STRYCHNINE NITRATE APPLIED FOR THE CONTROL OF THE $B$ EAR.

RESIDUE REV • 25:315-318.

CONTROL POISCN

, GEN , , ,

00536

IRVING, L. AND J. KROG.

1954 BODY TEMPERATURES OF ARCTIC AND SUBARCTIC BIRDS AND MAMMALS.

J. APPL. PHYSIOL. 6(11):667-680.

TEMP

,AK , , , 
C0537

JAC OBSEN, R.D.

1980

LEGAL ASPECTS OF CRITICAL HABITAT DETERMINATIONS.

INT. CONF. BEAR RES. AND MANAGE. 4:5-8.

LEGAL ZONING MGMT GEN

,US, , ,

00538

JAC CBSON,P.

PRELIMINARY SURVEY FOR GRIZZLY BEAR HABITAT IN THE VICINITY OF TH E LAKE LOUISE SKI AREA.

PARKS CANADA, BANFF NATL. PARK, ALBERTA. 47 PP.

HAB RECON

CR ,AT ,BANP, ,LOUI

00539

JACZEWSKI, Z.J J.GILL AND S. KOZNIEWSKI.

1960 CAPACITY OF THE DIFFERENT PARTS OF THE DIGESTIVE TRACT IN THE BRO WN BEAR.

TRANS. INT. UNION GAME BIOL. 4:146-154.

DIGEST MORPHIPHYS

GEN, , ,

$\operatorname{Co5} 40$

JANSON, R.G.

1967

BIG GAME SURVEYS AND INVESTIGATIONS, DISTRICT-WIDE.

FED. AID WILDL REST PROJ H-72-R-12, JOB A-1, JOB COMPLETION RE P. JULY 1, 1966-JUNE 30, 1967. MCNT: FISH AND GAME OEP. HELENA HARV DATA

NCDE,MT , , 
00541

JANSON, R.G.

1974

BIG GAME SURVEY AND INVENTORY.

PP. 2-13 IN: STATEWIDE WILDLIFE SURVEY ANO INVENTORY-REGICN 2. FE D. AIO WILDL. REST. PROJ. W-130-R-4, JOS NO. I-2. PROG.REP. JUL Y 1, 1972-JUNE 30, 1973. MONT. FISH'AND GAME DEP:. HELENA.

HARV DATA

NCDE, MT , ,

00542

JENNESS, K., A.W. ERICKSON AND J.J. CRAIGHEAD.

1972
SOME COMPARATIVE ASPECTS OF MILK FROM FDUR SPECIES OF BEARS.

J. MAMMAL. $53(1): 34-47$.

MORPH/PHYS REPRO PHYS

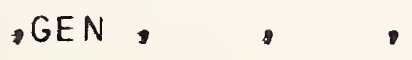

00543

JENNRICH, R.I. AND F.B. TURNER.

1969 MEASUREMENT OF NON-CIRCULAR HOME RANGE.

J. THEORET. BI:

HOME RNG

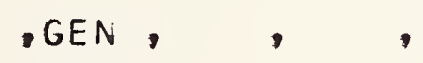

00544

JESSUP, D.A. AND D.B. KCCH.

SURGICAL IMPLANTATICN OF A RADIOTELEMETRY DEVICE IN WILD BLACK BE ARS, URSUS AMER ICANUS.

CALIF. FISH AND GAME 70(3):163-166.

\section{TELEM}

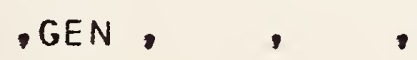


00545

JOHNSON, L.

1980
BRONN BEAR MANAGEMENT IN SOUTHEASTERN ALASKA.

INT. CONF B BEAR RES. AND MANAGE. 4:263-270.

HARV MGMT HARV CATA HUMAN IMP

AKSE,AK, , ,ADIS

00546

JCHNSON, L.J. AND P. LEROUX.

AGE OF SELF-SUFFICIENCY IN BROWN/GRIZZLY BEAR IN ALASKA.

J. WILDL. MANAGE. 37(1):122-123.

ORPHAN WEAN

$A K-1, A K, \quad, \quad$,

00547

JOHNSON, R. AND C. JCNKEL.

1976 A STUY OF SUBDIVISIONS AND SIMILAR DEVELOPMENTS IN GRIZZLY HABIT AT.

PP. 35-39 IN: C. JONKEL, ED. ANNUAL REPORT. BORCER GRIZZLY PROJ., UNIV. MONT., MISSCULA. ANNU. REP. NO. 1.

SUBDIV MŨMT

NCDE, MT , , ,

00548

JOHNSON, R. AND C. JONKEL.

1977 A SUOY OF SUBDIVISIONS AND SIMILAR OEVELOPMENTS IN THE RANGE DF THE BDRDER GRIZZLIES.

PP. 118-129 IN: C. JONKEL, ED. ANNUAL REPORT. BCRDER GRIZZLY PROJ $\because$ UNIV. MONT. MISSOULA. ANNU. REP. NO. 2 .

SUBDIV MGMT

NCDE, MT 


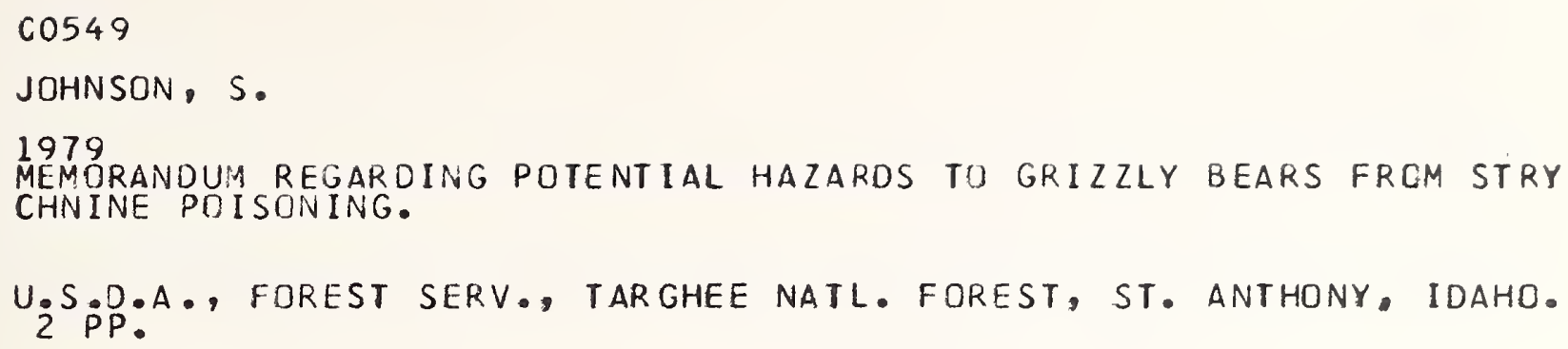

POISON

C0550

JOHNSON, S.J. AND DEE. GRIFFE.

1982 SHE E LOSSES ON GRIZZLY BEAR RANGE.

J. WILDL. MANAGE. 46(3):786-790.

DEPRED

YGBE, ID ,TANG,

00551

JOLLY, GEM.

1965

EXPLICIT ESTIMATES FROM CAPTURE-RECAPTURE DATA WITH BOTH DEATH AN D IMMIGRATION - STOCHASTIC MODEL.

BIOMETRIKA. 52:225-247.

CENSUS METH

, GEN ,

00552

JCNKEL, C.

BLACK BEAR POPULATION STUDIES.

FED AID WILL. REST PRC $W-49-R-9$, JOB IVA JOB COMPLETION REP 2 'PP. $1,1959-A P R .30,1960$. MONT. FISH AND GAME DEP., HELENA. 2

DRUGS

NODE, MT , , , HR
LIVESTK MGM

FEED BE

GEN BIOL

307 
00553

JONKEL, C.

1976

RECURRENT PROBLEMS IN GRIZZLY MANAGEMENT.

PP. 40-48 IN: C. JONKELLED. ANNUAL REPORT NO. I. BORDER GRIZZLY PROJ., UNIV. MONT., MISSOULA.
GARB MGMT
HUMAN IMP
MCRT DATA

NCDE,MT

00554

JONKEL, C.

1978

GRIZZLY BEARS AND THE MOUNTAIN PINE BEETLE.

BORDER GRIZZLY PROJ., UNIV. MONT = MISSOULA. SPEC. REP. NO. 21.3
PP.

TIMB MGMT BTLE MGMT

$, G E N, \quad$,

00555

JONKEL, C.

$1980 \mathrm{~A}$

THE ANT ELOPE BUTTE-BLACKLEAF AREA AND OIL DEVELOPMENT.

BORDER GRIZZLY PRCJ., UNIV. OF MONT \& MISSOULA. SPEC. REP . NO. 42 - 10 PP.
HAB USE
ROAD MGMT
MGMT GEN
RCAD IMP
TIMB MGMT

NCDE,MT, , ,,$\quad$ ANBU

00556

JONKEL, C.

$1980 B$

WINTER DISTURBANCE AND GRIZZLY BEARS•

BORDER GRIZZLY PROJ., UNIV. MONT., MISSOULA. SPEC • REP. NO. 46.3
DEN
RECR IMP
MOTOR IMP

NCDE,MT , , , 
00557

JONKEL, C.

1980 C S75-1981.

BORDER GRIZZLY PROJ., UNIV. MONT., MISSOULA. 11 PP.

B I BLIO

, GEN, , ,

00558

JONKEL, $C$.

FIVE YEAR SUMMARY REPORT. BORDER GRIZZLY PROJ., UNIV. MONT. , MISSOULA • SPEC. REP. ND. 60, 2

$\begin{array}{llll}\text { GEN DATA } & \text { TYPE DESCRIP } & \text { FOR STKAT } & \text { TIMB MGMT } \\ \text { ROAD MGMT } & \text { LIVESTKMCMT } & \text { AGESSEX } & \text { FOOD } \\ \text { HAB USE } & & \end{array}$

NCDE,MI , ,

00559

JONKEL, C.

$1982 B$

AN AVERSIVE CONDITIONING AND RE-INTRODUCTION PROGRAM FOR GRIZZLIE $S$ NOS. 530 AND 531 .

BORDER GRIZZLY PROJ., UNIV. OF MONT., MISSOULA. SPEC. REP. NO. 62 - 15 PP.

AVER COND RELOC

CYE, MT , ,,$C A B$

C0560

JONKEL, C.

GRIZZLY BEAR HABITAT COMPONENTS IN THE BORDER GRIZZLY AREA.

BORDER GRIZZLY PROJ., UNIV. MONT., MISSOULA. SPEC. REP. NG.67.9

MAP/TYPE

NCDE, MT 
00561

JONKEL, C.

GRIZZLIES ANO BLACK BEAR. INTERRELATIONSHIPS.

BORDER GRIZZLY PROJ., UNIV. MONT., MISSOULA. SPEC. REP. NO. 70.6
PP. INTERSP COMP

NCDE,MT, , NFLT

00562

JONKEL, C.

1985 WARINESS OF HUNTED GRIZZLY POPULATIONS VS NON-HUNTED PCPULATI CNS.

BORDER GRIZZLY PROS, UNIV. MONT., MISSOULA. SPEC. REP. NO. 73.7 HARV IMP REACTION

$, G E N, \quad, \quad$,

00563

JONKEL, C., T. BUMGARNER AND L.C. LEE.

GRIZZLY BEARS AND THE NORTH FORK OF THE FLATHEAD RIVER FLOOC PLAI $\Lambda$.

BORDER GRILZLY PROJ., UNIV. MONT., MISSOULA. SPEC. REP. NO. 54. 4 8 PP.

PRES DISTR

COYER

NCDE, MT

00564

JONKEL, C. AND I.M. COWAN.

1971

THE BLACK BEAR IN THE SPRUCE-FIR FOREST.

WILDL. MONDGR. NO. 27. 57 PP.

INTERSP COMP

NCDE, MT ,FLNF, ,WHR
MORT DATA

ROAD MGMT

TYPE DESCRIP

, NFLT

HOME RNG 
00565

JONKEL, C. AND K.R. GREER.

1975
BLOOD AND TISSUE COLLECTION, AND TOXIC CHEMICAL ANALYSIS TECHNIQU
ES.

BORDER GRIZZLY TECH. COMM., BCRDER GRIZZLY PROJ., UNIV. MCAT. MI SSOULA. WORKING PAP. NC. 5. 6 PP.

HEMAT

PARASIDIS

RES TECH

, GEN,

00566

JONKEL, C.J. AND D. HADDEN.

1986

GRIZZLY BEAF HABITAT RESEARCH NEEDS IN THE BORDER GRIZZLY AREA.

PP 1 124-127 IN: G.P. CONTRERAS ANO K.E. EVANS, EDS PROCEEDINGS-G RIZZLY BEAR HABITAI SYMPOSIUM. U.S. C.A. FCREST SERV. INTERMOUNTA IN RES. STAT. OGDEN, UTAH. GEN. TECH. REP. INT-207.

MGMT GEN

NCDE, MT , , ,

00567

JONKEL, C.P. HUSBY, R. RUSSELL AND J. BEECHAM. 1980 THE REINTRODUCTION OF ORPHANED GRIZZLY BEAR CUBS INTO THE WILD.

INT. CONF • BEAR RES. AND MANAGE * 4:369-372.

ORPHAN RES TECH RELOC INT/REINT

NCDE,MT , , ,

00568

JONKEL, C., S. KISER AND D.B. ROCKWELL.

STATUS OF THE MEXICAN GRIZZLY.

BORDER GRIZZLY PROJ., UNIV. MONT., MISSOULA. SPEC. REP. NC.6. 26 PP.
HIST DISTR
HUMAN I MP
MORT DATA
PRES OISTR

- SWMX, 
C0569

JONKEL, C. AND L. KLASSEN.

TISSUE IMPACTS OF THE "BEAR THUMPER."

BORDER GRIZZLY PROJ., UNIV. MONT., NISSCULA. SPEC. REP. NC. 76.5 DETER./KEPEL

$, G E N, \quad$,

C0570

JONKEL, C., L. LEE, T. THIER, N. MCMURRAY AND R. MACE. SULLIVAN CREEK GRIZZLIES.

BORDER GRIZZLY PROJ., UNIV. MONT., MISSCULA. SPEC. REP. NO. 23.1 $O P P$.
MORT DATA
HAB USE
IIMB $M G M T$
T IMB IMP
PRES DISTR

NCDE, MT ,SLCK,

00571

JONKEL, C., L.C. LEE, P. ZAGER, A. SCHALLENBERGER, C.W. SERVHEEN AN D. MACE.

GRIZZLY BEAR-LIVESTOCK COMPETITION IN RIPARIAN AREAS.

BORDER GRIZZLY PROJ., UNIV. MCNT., MISSCULA. 25 PP.

LIVESTK IMP FOOD

NCDE,MT, , ,

00572

JONKEL, C., N. MCMURRAY, J. PERRY, P. ZAGER AND M. HAROLDSON. 1978 BARK BEETLES, TINBER SALVAGE AND THE GRIZZLY BEAR AT GLACIER VIEW RANGER DISTRICT, U.S.FOREST SERV., COLUMBIA FALLS, MDNTANA. BORDER GRIZZLY PROJ., UNIV. MONT. NISSCULA. SPEC. REP. NO. 12.2
I PP.

IIMB MGMT URBAN DEV TIMB IMP TIMB-METH

TIMB-POST

NCDE, MT ,FLNF, ,NFLT 
00573

JONKEL, C., S. MEALEY AND G. JOSLIN.

DELINEATION OF GRIZZLY HABITAT IN THE BORDER GRIZZLY AREA.

BORDER GRIZZLY PROJ., UNIV. MONT., MISSOULA. SPEC. REP. NO. 3.22 PP.

ZONING MGMT GEN

NCDE,MT , , ,

00574

JONKEL, C. AND F=L. MILLER.

RECENT RECUROS OF BLACK BEARS IURSUS AMER ICANUSI ON THE BARREN GR CUNDS OF CANADA.

J. MAMMAL $51(4): 826-828$.

INTERSP COMP

, ECAN, .

00575

JOPE, K.M.

1982

INTERACTIONS BETWEEN GRIZZLY BEARS AND HIKERS IN GLACIER NATIONAL PARK. MONTANA.

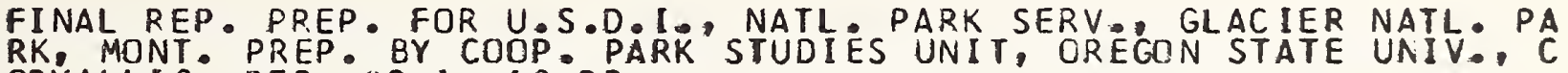
ORVALLIS. REP . 82-1.62 PP.

$\begin{array}{lll}\text { TAXON/EVOL } & \text { INTRASP BEH } & \text { HUMAN INJ } \\ \text { AVOID/ATTRAC } & \text { REACTION } & \text { NONMOTOR IMP } \\ \text { MCNMOT MGMT } & \text { MATERNAL }\end{array}$

NCDE,MT ,GLNP,

00576

JOPE, K.L.M.

1983A

HABITUATION OF GRIZZLY BEARS TO PEDPLE: A HYPCTHESIS.

INT. CONF. BEAR RES. AND MANAGE . 5:322-327.

REACTION

NCDE,MT , GLNP, 
00577

JOPE, K.L.

RESEARCH ON INTERACTIONS BETWEEN BACKPACKERS AND GRIZZLY BEARS IN DENALI NATIONAL PARK AND PRESERYE.

PROGR. REP. U.S.D.I. DENALI NATL. PARK ANS PRESERVE, ALASKA. 15 PP.

HUMAN INJ REACTION NONMOT MGMT AVER COND

DETER/REPEL

CAMP MGMT

$A K-I, A K \quad, D E N P$,

00578

JOPE, K.L.

1984

RESEARCH ON INTERACIICNS BETWEEN BACKPACKERS AND GRIZZLY BEARS IN DENALI NATIONAL PARK ANO PRESERVE.

SUPPL. TO 1982 PROGR. REP. U.S.D.I., DENALI NATL. PARK AND PRESER VE, ALASKA. 26 PP.

REACTION NONMOT MGMT AVOIO/ATTRAC CAMP MGMT

$A K-I, A K \quad D E N P$,

C0579

JOPE, K.

IMPLICATIONS OF GRIZZLY BEAR HABITUATION TO HIKERS.

WILDL. SOC. BULL. 13(1):32-37.

REACTION AVOID/ATTRAC HUMAN INJ NONONOT MGMT
NONMOTOR IMP NONMOT

NCDE, MT ,GLNP,

00580

JOPE, K.L. AND L.B. CASEBEER.

1983
BROWN BEAR POPULATION SURVEY, KATMAI NATIONAL PARK AND PRESERVE.

U.S.D.I. NATL. PARK SERV., KATMAI NATL. PARK, ALASKA. 3 PP.

CENSUS/TREND CENSUS METH

AKPN, AK KANM, 
00581

JOPE, K.L. AND B. SHELBY.

1984 HIKER BEHAVIOR AND THE CUTCOME OF INTERACTICNS WITH GRIZZLY BEARS

LEISURE SCI. 6131:257-270.

PUBLIC ATT REACTION NCNMOTOR IMP AVOID/ATTRAC

NCDE, MT , GLNP,

00582

JORGENSEN, C.

1979

BEAR-LIVESTOCK INTERACTIONS, TARGHEE NATIONAL FCREST.

M.S. THESIS, UNIV. MONT., MISSOULA. 162 PP.

$\begin{array}{llll}\text { DEPRED } & \text { LIVESTK IMP } & \text { RES MORT } & \text { HOME RNG } \\ \text { DRUGS } & \text { HAB USE } & \text { FODD } & \text { INTERSP COMP }\end{array}$

YGBE, IDWY, TANF, ,

00583

JORGENSEN, C.J.

1983

BEAR-SHEEP INTERACTIONS, TARGHEE NATIONAL FOREST.

INT. CONF. BEAR RES. AND MANAGE 5:191-200.

INTERSP COMP LIVESTK IMP LIVESTK MGMT

YGBE, ID , TANF,

00584

JOSLIN, G.

1977 THE GREAT BEAR WILDERNESS AND ITS IMPLICATIONS FOR GRIZZLY BEARS.

BORDER GRIZZLY PROJ.. UNIV. MONT., MISSOULA. SPEC. REP. NO. 5. 6
PP.

PRES DISTR ENERGY MGMT

NCDE,MT ,FLNF, , 
00585

JOSLIN, G. AND J. KAPLER.

1980 A COMPUTERIZED SYSTEM FOR RECORDING AND RECALLING GRIZZLY BEAR RE PORTS.

INT. CONF. BEAR RES. AND MANAGE • 4:33-36.

MONIT SYS

NCDE,MT, , ,

00586

JOSLIN, G. AND N. MCMURRAY.

1977 GRIZZLY BEAR REPORTS FROM WITHIN THE BORDER GRIZZLY AREA - 1976.

PP, 23-38 IN: C. JONKEL, ED. ANNUAL REPORT. BORDER GRIZZLY PROJ., UNIV. MONT:, MISSOULA. ANNU. REP. NO, 2 .

PRES DISTR

NCDE, MT, , ,

C0587

JOSLIN, G., N. MCMURRAY, T. WERNER, S. KISER AND C. JONKEL. 1977

GRIZZLY BEAR RESPONSE TO HABITAT DISTURBANCE.

PP. 39-98 IN: C. JUNKEL, ED. ANNUAL REPORT • BORDER GRIZZLY PROJ., UNIV. MONT., MISSOULA. ANNU. REP. NO: 2 .

$\begin{array}{lccc}\text { MAP/TYPE } & \text { HAB USE } & \text { MEAS/QUANT } & \text { MOVE } \\ \text { HOME RNG } & \text { DEN SITE } & \text { HAB EFFECT } & \text { TIMB-METH } \\ \text { AGE/SEX } & , \text { SFLT } & & \\ \text { NCDE,MT } & , & \end{array}$

00588

JOSLIN, G., J. TITUS AND C. JONKEL.

PAST AND PRESENT DISTRIBUTION OF THE BORDER GRIZZLY BEARS. PP. $51-67$ IN: C
UNIVI MONKEL, ED, ANNUAL REPORT. BORDER GRIZZLY PROJ.,

DISTR

NCDE, MT , , , 
C0589

JUDD, S. AND R. KNIGHT.

1977 DETERMINATIUN AND ANALYSIS CF GRIZZLY BEAR MOVEMENT PATTERAS USIN BIOTELEMETRY.

IN: IST INT - CCNF. CN WILDL. BICTELEMETRY, 27-19 JULY 1977. LARAM IE, WYO.

MOVE HCME RNG

YGBE, IMW , ,

C0590

JUDD, S. AND R.R. KNIGHT.

1980

MOVEMENTS OF RADIO-INSTRUMENTED GRIZZLY BEARS WITHIN THE YELLOWST ONE AREA.

INT . CONF. BEAR RES. AND MANAGE. 4:359-367.

MOVE HCME RNG

YGBE, IMW, , ,

00591

JUDD, S. AND R. KNIGHT AND B. BLANCHARD.

IN PRESS

INT. CONF. BEAR RES. AND MANAGE. 6 .

DEN CHRON DEN CHAR DEN SITE HAB USE

YGBE, IMW , , ,

00592

KASWORM, W., G. BRCWN AND A. OLSEN.

1983

CABINET MOUNTAINS GRIZZLY BEAR STUDY.

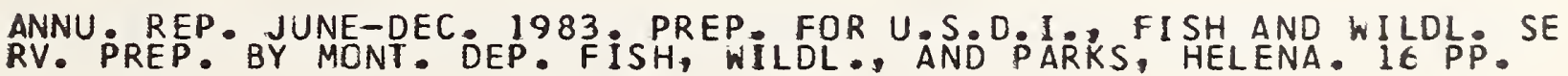
MEAS/QUANT
MOVE
DEN SITE
DEN CHRGN

CYE. IDMT, 
00593

KASWORM, W.

1984

CABINET MOUNTAINS GRIZZLY BEAR STUDY.

ANNU. REP. APRIL $1983-M A R C H 1984$ PREP. FOR U.S.D.IID FISH AND WI
LDL. SERV. PREP. EY MONT. DEP. FISH. WILDL., AND PARKS, HELENA. 5

DISTR HABUSE MEAS/QUANT MOVE HOME RNG

CYE, IDMT, , ,

00594

KASWORM, W.

1985

CABINET MOUNTAINS GRIZZLY BEAR STUDY.

1984 ANNU PROGR REP PREP FOR U.S.D I I FISH AND WILDL. SERV. PREP. BY MONT. DEP. FISH, WILOL. AND PARKS', HELENA. BI PP.
DISTR
HAR V DATA
MEAS/QUANT
ROAD IMP
HOME RNG
MOVE
HAB USE
NONMOTOR IMP

CYE , IDMT,

00595

KAYE, R •

1982

BEAR/HUMAN INTERACTIONS. A BACKGROUND PAPER FOR THE FOUR MOUNTAIN
PAKK PLANNING PROGRAM. PARKS CANADA, JASPER NATL. PARK, ALBERTA. 31 PP.
HUMAN INJ
LEGAL
CR REACTION
GARBAGE
GARB MGMT
CONTROL
EDUC RECR MGMT

C0596

KEATING, K.A.

1983

TRENDS IN GRIZZLY BEAR NUMBERS AND BEHAVIOR (1910-1980) RELATIVE TO SIGHTING AND CONFRONTATION RATES IN GLACIER NATICNAL PAR K, MONTANA.

U.S.D.I., NATL. PARK SERV., GLACIER NATL, PARK, MONT. 44 PP.
HUMAN IN
REACT ION
POP EST
CENSUS/TREND

NCDE,MT ,GLNP, 
00597

KEATING, K.A.

1986

HISTORICAL GRIZZLY BEAR TRENDS IN GLACIER NATIONAL PARK, MONTANA.

WILDL. SOC. BULL. 14:83-87.

CENSUS/TREND REACTION

NCDE,MT ,GLNP,

00598

KEMP, G.A.

1976

THE DYNAMICS AND FEGULATION OF BLACK BEAR, URSUS AMER ICANUS, POPU LATIONS IN NORTHERN ALBERTA.

INT. CONF. BEAR RES. AND MANAGE. 3:191-198.

PUP REG

GEN,

$\cos 99$

KENDALL, $K$.

1977

BIBL IOGRAPHY OF BEAR LITERATURE.

U.S $=D . I$ NATL. PARK SERV., DIV. OF RES. AND SCI. SERV. WASHINGTO

B I BLI O

, GEN, , ,

00600

KENDALL, K.C.

1980

FOOD HABITS OF YELLCWSTONE GRIZZLY BEARS, 1978 AND 1979.

PP. 24-34 IN: R.R KNIGHT, B.M BLANCHARD K.C. KENDALL AND LEE OLDENBURG EDS YELLOWSTONE GRIZZLY BEAR INVESTIGATIONS. U.S FOOD SCAT ANAL

FEED BEH

CARCASS

YGBE, IMW 
00601

KENDALL, $K . C$.

1981

BEAR USE UF PINE NUTS.

M.S. THESIS, MONT. STATE .UNIV., BOZEMAN. 27 PP.
FOOD
FEED BEH
HAB USE
INTERSP COMP

YGBE,MTWY, , ,

00602

KENDALL, K.C.

1983A 9 IZZL BEAR POPULATICN TREND STUDIES, APGAR MOUNTAINS, GLACIER N ATIONAL PARK, 1982 PROGRSS REPORT.

U.S.D.I., NATL. PARK SERV., GLACIER NATL. PARK, MONT 19 PP.
CENSUS/TREND
BURN USEIMGT
CENSUS METH
AGE/SEX
LITR SIZE

NCDE,MT ,GLNP, ,APGR

00603

KENDALL, K.C.

USE OF PINE NUTS BY GRIZZLY AND BLACK BEARS IN THE YELLOWSTONE AR EA.

INT. CONF. BEAR RES. AND MANAGE. 5:166-173.

FOOD FEED BEH INTERSP COMP

YGBE,IMW, , , ,

00604

KENDALL, K.C.

$1984 A$
SUMMARY OF GRIZZLY BEAR RESEARCH IN GLACIER NATIONAL PARK - 1984.

U.S.D.I. NATL. PARK SERV., GLACIER NATL. PARK, MONT. 1 PP.

FOOD CENSUS/TREND RECR MGMT

NCDE,MT ,GLNP, 
00605

KENDALL, K.C.

$1984 B$

GRIZZLY BEAR POPULATION TREND STUDIES, APGAR MOUNTAINS, GLACIER N AT IONAL PARK, 1983 PRCGRESS REPORT.

U.S.D.I. NATL. PARK SERV., GLACIER NATL. PARK, MONT. 37 PP.

CENSUS/TREND

LITR SIZE

BURN USE/MGT

NCDE,MT GLNP,

\section{CENSUS METH
INTERSP COMP} - APGR

00606

KENDALL, K.C.

1985 GRIZZLY BEAR POPULATION TREND STUDIES, APGAR MOUNTAINS, GLACIER N
ATILNAL PARK.

PROGR. REP. $1984 . U . S=D . I *$ NATL. PARK SERV., GLACIER NATL. PARK,
MONT: 23 PP.

CENSUS METH

CENSUS/TREND

NCDE,MT, GLNP,

$A G E / S E X$
HAB USE

INTERSP COMP

\section{AIRCR AFT IMP FOOD} - APGR

00607

KENDALL, K.C.

1986

GRIZZLY AND BLACK BEAR FEEDING ECOLCGY IN GLACIER NATIONAL PARK, MONTANA.

PROGR P.REP. U.S.D.I. NATL. PARK SERV., GLACIER NATL. PARK, MONT. FOOD HAB SAMPL

NCDE,MT , GLNP,

00608

KENDALL, K. C.

IN PRESS ATANA.

INT. CONF. BEAR RES. AND MANAGE. 6 .

$\begin{array}{lll}\text { HUMAN INJ } & \text { REACTION } & \text { CAMP } \\ \text { AVOID/ATTRAC } & \text { MATERNAL } & \text { NONMOTOR IMP }\end{array}$

NCDE,MT , GLNP, 
0.0609

KILGORE, B.M. (CHAIRMAN).

TE81 19 ICAL REVIEW OF THE INTERAGENCY GRIZZLY BEAR STUDY TEAM AND R ECOMMENDATIONS FOR FUTURE RESEARCH.

PREP. FOR INTERAGENCY GRIZZLY BEAR STUDY TEAM STEER ING COMMITTEED PELP 22 PP.

CENSUS METH DEMOG ANAL

YGBE,IMW , , ,

00610

KINGSLEY, M.C.S.

FITTING THE VON BERTALANFFY GROWTH EQUATICN TO POLAR BEAR AGE-WEI GHT DATA.

CAN. J. 20OL. 57:1020-1025.

GROW/ DEV WEIGHT

$$
\text { , GEN, , , }
$$

00611

KINGSLEY, M.C.S., J.A. NAGY AND H.V. REYNOLDS.

IN PRESS ARIATION BETWEEN POPULATIONS.

MANUSCRIPT. 20 PP.

$$
\begin{aligned}
& \text { GROW/DEV WEIGHT LENGTH } \\
& \text {,CAN, , }
\end{aligned}
$$

00612

KINGSLEY, M.C.S., J.A. NAGY AND R.H. RUSSELL.

1983 PATIERNS OF WEIGHT GAIN AND LOSS FOR GRIZZLY BEARS IN NORTHERN CA NADA.

INT. CONF. BEAR RES. AND MANAGE 5:174-178.

$$
\text { GROW/DEV WEIGHT }
$$

CARC, YK 
00613

KITTAMS, W.H.

\section{8}

SUMMARY OF BEAR INCIDENTS, 1957.

MEMO. TO SUPERINTENDENT, U.S.D.I., NATL. PARK SERV•, YELLOWSTONE NATL. PARK, WYO. 4 PP.
HUMAN INJ
DEPRED
CONTROL

YGBE, IMW, YNP,

00614

KLAVER, R.W. AND J.J. CLAAR.

GRIZZLY BEAR DEN SURVEYS, SPRING 1981 ANO 1982, FLATHEAD INDIAN R ESERVATION, MONTANA.

U.S.D.I., BUR, INDIAN AFFAIRS, PABLC, MONT. 5 PP.

\section{CENSUS METH}

NCOE,MI ,FLIR, ,MISS

00615

KLAVER, R.W., J.J. CLAAR, D.B. ROCKWELL, H.R. MAYS AND C.F. ACEVEDO i9 86

GRIZZLY BEARS, INSECTS, AND PEOPLE: BEAR MANAGEMENT IN THE MCDONA LD PEAK REGION: MONTANA. PP $204 Z 204-211$ IN: G GP - CONTRERAS AND K.E. EVANS, EDS P PROCEEDINGS-G NTAIN RES. STAT., OGDEN, UTAH: GEN. TECH. REP. INT-207.
CLOSURE
CENSUS METH
MATERNAL
NCDE, MT FLIR,
POP EST
NCNMOTOR IMP
MCPK
CENSUS/TREND
PUBLIC ATI
FOOD
TERR/SPACE

00616

KLAVER , R.W., L.J. LYON, C.J. MARTINKA, L. METZGAR,J. SWENSON AND D i9: 84 . TAIT.

NORTHERN CONTINENTAL DIVIDE GRIZZLY BEAR ECOSYSTEM POPULATICN SIZ E AND TREND.

SPEC. TASK FORCE REP. PREP. FOR INTERAGENCY GRIZZLY BEAR COMMITTE POP EST 
00617

KLEIN, D.R.

BLACKTAIL DEER STUDIES - SOUTHEAST ALASKA.

FED AID WILOL REST P PROJ. W-3-R-10, WORK PLAN E. ALASKA CEP. FI
SH AND GAME, JUNEAU. 3 PP. HARV DATA

AKSE, AK , , ,

00618

KLEIN, D.R.

1958

SOUTHEAST ALASKA BROWN BEAR STUDIES. FED. AID WILOL REST. PROJ, $1-3-R-13$, WORK PLAN J, JOB 1. JOE COMP
LETION REP. CECEMBER 13,1958 . ALASKA DEP. FISH AND GAME, JUNEAU
- 21 PP. LITR SIZE MISC QUANT $A K S E, A K, \quad, A B C$ CENSUS METH HARV DATA
LENGTH
AGE/SEX
SKULL

00619

KLEIN, D.R.

TRACK DIFFERENTIATICN FOR CENSUSING BEAR POPULATICNS.

J. WILDL. MANAGE, 23(3):361-363.

CENSUS METH

AKSE,AK, , ,ADIS

10620

KLEIN, D.R.

REACTION OF WILOLIFE TO AIRCRAFT DISTURBANCE.

ALASKA COOP. WILDL. RES. UNIT, UNIV. ALASKA, FAIRBANKS• QUART. RE P. 25(1):18-22.

AIRCRAFT IMP

$A K-1, A K, \quad$, 
00621

KLEIN, D.R., W. TROYER AND R.A. RAUSCH.

1958 THE STATUS OF THE BROWN BEAR IN ALASKA.

PROC. ALASKA SCI. CONF.9.11 PP.

$\begin{array}{llll}\text { HARV DATA } & \text { MGMT GEN } & \text { POACHIILLEG } & \text { AGE ISEX } \\ \text { MISC QUANT } & \text { CENSUSITREND } & \text { LITR SIZE } & \text { CENSUS METH } \\ \text { MAK, } & \end{array}$

00622

KLEIN, W.E.

AN ENLIGHTENING AND SOBER ING EXPERIENCE IN CALIFORNIA.

CALIF. DEP. FISH AND GAME, REDDING. 5 PP.

POACH/ILLEG

,$C A$,

00623

KNIGHT, R.R.

1974

GRIZZLY BEAR STUDY TEAM - FIRST INTERIM REPORT. 1974.

U.S.D.I. INTERAGENCY GRIZZLY BEAR STUDY TEAM, BOZEMAN, MCNT. 11
POP DENS
AGE/SEX
LITR SIZE
HAB USE

YGBE,IMW, , ,

00624

KNIGHT, R•R • NOII 19 S ON SOME BEHAVIOR PATTERNS IN RADIO-INSTRUMENTED GRIZZLY BEA
RS.

DRAFT REP - U.S.D.I. INTERAGENCY GRIZZLY BEAR STUDY TEAM BCZEMAN, REACT ION

POACH/ILLEG

DEPRED

CONTROL 
00625

KNIGHT, R.

INI IR 1 RAGENCY GRIZZLY BEAR TEAM DATA ENHANCEMENT PROPOSAL: OPERATIO NAL PLAN. U.S.D.I., INTERAGENCY GRIZZLY BEAR STUDY TEAM, BOZEMAN, MONT. IL
RES TECH
PRES DISTR
DEMOG ANAL
CENSUS METH
CAP TURE

YGBE,IMW ,

00626

KNIGHT, R.R. (CHAIRMAN) •

1984

MONITORING THE YELLOWSTONE GRIZZLY BEAR POPULATION, INTERIN REPOR T: 1983 RESULTS.

U.S.D.I., INTERAGENCY GRIZZLY BEAR STUDY TEAM, BOZEMAN, MONT• 7 P

CENSUS METH

YGBE, IMW, , ,

00627

KNIGHT, R•R• (CHAIRMAN) .

1983

COMMITTEE FINDINGS.

MEMO. TO U.S.D. I INTERAGENCY GRI ZZLY BEAR STEER ING COMMITTEE.P REP BY INTERAGENCY GRIZZLY BEAR AD HOC CCMMITTEE FCR POPULATION ANALYSIS: 8 PP.
POP EST SITR
AGE/SEX
LITR FREQ
CENSUS/TREND
BRD AGE

YGBE, IMW ,

00628

KNIGHT, R.R., J• BASILE, K. GREER, S. JUDD, L. OLDENBURG AND L. ROD

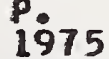

YELLOWSTONE GRIZZLY BEAR INVESTIGATIONS. ANNUAL REPORT OF THE INT ERAGENCY STUDY TEAM, 1974.

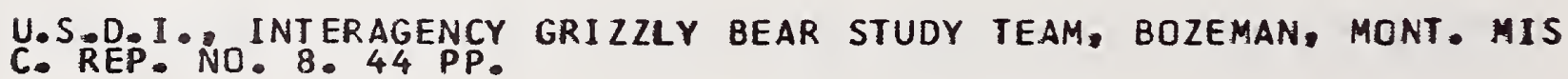

CENSUS METH PRES DISTR

POP DENS

PRED

YGBE,IMW,
PRES DISTR
MORT DATA

AGE/SEX

POP EST 
00633

KNIGHT, R. AND B. BLANCHARD.

POI 84 ENTIAL EFFECTS OF THE SKI YELLOWSTONE DEVELOPMENT ON GRIZZLY B EARS.

U.S-D. I. INTERAGENCY GRIZZLY BEAR STUDY TEAM, BOZEMAN, MCNT. 5 P RECR IMP PRES DISTR HCME RNG

YGBE,MT , GANF, ,SKYL

00634

KNIGHT, R.R. AND B. BLANCHARD.

FIELD TECHNIQUES USED IN THE STUDY CF GRIZZLY BEARS. DRAFT REPORT U.S.D.I.. INTERAGENCY GRIZZLY BEAR STUDY TEAM, BOZEMAN, MONT. 26 $\begin{array}{lll}\text { CAPTURE } & \text { DRUGS } & \text { TELEM } \\ \text { MONITSYS } & \text { HABSAMPL SCAT ANAL } & \text { MEAS/QUANT }\end{array}$ YGBE,IMW, , ,

00635

KNIGHT, R•R. B.M. BLANCHARD AND L.L. EBERHARDT•

IN PRESS POPULATION SINKS AND MORTALITY PATTERNS OF THE YELLOWSTONE GRIZZL

MANUSCRIPT 17 PP.

MOVE MORT MGMT MCRT DATA HUMAN IMP

YGBE, IMW , , ,

00636

KNIGHT, R•R. B. BLANCHARD AND K. KENDALL.

1981

YELLOWSTONE GRIZZLY BEAR INVESTIGATIONS. ANNUAL REPORT OF THE INT ERAGENCY STUDY TEAM, 1980 .

U.S.D.I., INTERAGENCY GRIZZLY BEAR STUDY TEAM, BOZEMAN, MONT. 55
PP.

GEN DATA

DRUGS

GARBAGE

CARCASS

TELEM

YGBE IMW,
MEAS/QUANT

DEMOG ANAL
PELAGE 
00637

KNIGHT, R.R. B.M. BLANCHARD AND K.C. KENDALL.

1982

YELLOWSTONE GRIZZLY BEAR INVESTIGATIONS, ANNUAL REPORT OF THE INT ERAGENCY STUDY TEAM, 1981.

U.S.D.I. INTERAGENCY GRIZZLY BEAR STUDY TEAM, BOZEMAN, MONT. 70 PP.

BURN USE/MGT

GARBACE

YGBE,IMW ,
GEN DATA
MORT RATE
DEMOG ANAL

CCNTROL
CLIMATE

CENSUS/ TREND

00638

KNIGHT, R.R., B.M. BLANCHARD, K.C. KENDALL AND L.E. OLDENBURG. 1980 YELLOWSTONE GRIZZLY BEAR INVESTIGATIONS. ANNUAL REPCRT OF THE INT
ERAGENCY STUDY TEAM, 1978 AND 1979.

U.S.D.I. INTERAGENCY GRIZZLY BEAR STUDY TEAM, BOZEMAN, MCNT. 91
MUVE
DEMDG ANAL
DEPRED
$\begin{array}{ll}\text { MORT } & \text { DATA } \\ \text { TIME USE }\end{array}$
FOOD
HOME RNG

YGBE, IM , , ,

00639

KNIGHT, R,R. B. BLANCHARD, AND D. MATTSON.

1984 A

INF LUENCES OF THE FISHING BRIDGE AREA ON THE YELLOWSTONE GRIZZLY BEAR POPULATICN. U.S.D.I. INTERAGENCY GRIZZLY BEAR STUDY TEAM, BOZEMAN, MCNT. 15

$\begin{array}{llll}\text { HAB EFFECT } & \text { HAB USE } & \text { FOOD } & \text { TIMB USE } \\ \text { NUTR ANAL } & \text { PRES DISTR } & \text { RECR IMP } & \\ \text { YGBE,WY ,YNP, } & , F I S H & & \end{array}$

00640

KNIGHT, R.R., B.M. BLANCHARD AND D.J. MATTSCN.

YELLOWSTONE GRIZZLY BEAR INVESTIGATIONS. ANNUAL REPCRT OF THE INT ERAGENCY STUDY TEAM, 1983 AND 1984.

U.S.D.I. INTERAGENCY GRIZZLY BEAR STUDY TEAM, BOZEMAN, MCNT. 41

AGE/SEX

REP RATE YGBE. IMN ,
HOME RNG

LITR SIZE
PRES DISTR

LITR FREQ
CENSUS/IREND

MORT DATA 
00641

KNIGHT, R.R., B.M. BLANCHARD AND D. MATTSON.

Y986 OWSTONE GRIZZLY BEAR INVESTIGATIONS ANNUAL REPORT OF THE INTE RAGENCY STUDY TEAM 1985.

U. S.D.I.. INTERAGENCY GRIZZLY BEAR STUDY TEAM, BOZEMAN, MCNT. 58
MORT DATA
GROW/ DEV
MOVE
AGE/SEX
CENSUS/TREND
CANNI BAL
REP RATE
FOOD

YGBE, IMW ,

00642

KNIGHT, R.R., G. BROWN, J.J. CRAIGHEAD, M. MEAGHER, L. ROOP AND C. SERVHEEN.

1983

AD HOC COMMITIEE TO INVESTIGATE THE NEED AND FEASIBILITY OF THE S UPPLEMENTAL FEEDING OF YELLOWSTONE GRIZZLY BEARS.

FINAL REP PREP. FOR U.S.D. I. INTERAGENCY GRIZZLY BEAR STUDY TEA
$M$, BOZEMAN, MONT. 13 PP.
SUPPL FEED
MORT DATA
CONTROL
WEIGHT

YGBE, IMW :

00643

KNIGHT, R.R. AND L. EBERHARDT.

1984 PROJECTED FUTURE ABUNDANCE OF THE YELLOWSTONE GRIZZLY BEAR.

J. WILDL. MANAGE. 48(4):1434-1438.

GARBAGE DEMOG ANAL MCRT DATA CENSUS/TREND

YGBE, IMW , , ,

00644

KNIGHT, R.R. AND L. EBERHARDT.

1985

POPULATION DYNAMICS OF YELLOWSTONE GRIZZLY BEARS.

ECOLOGY $66(2): 323-334$

$\begin{array}{llll}\text { DEMOG ANAL } & \text { REP } & \text { RATE } & \text { GARBAGE } \\ \text { CENSUS/TREND } & \text { PCP REG } & \text { MORT RATE }\end{array}$ YGBE, IMW 
00645

KNIGHT, R.R. AND L.L. EBERHARDT.

IN PROSPESS

INT - CONF - BEAR RES. AND MANAGE. 7 .

DEMOG ANAL CENSUS METH MORT RATE CENSUS/TREND

YGBE,IMW, YNP, ,

00646

KNIGHT, R.R. AND S.L. JUDD.

1983 GRIZZLY BEARS THAT KILL LIVESTOCK.

INT. CONF. BEAR RES. AND MANAGE. 5:186-190.

DEPRED LIVESTK IMP MCVE POACHJILLEG

YGBE, IMW, , ,

00647

KNIGHT, R.R., D. MATTSON AND B. BLANCHARD.

1984B

MOVEMENTS AND HABITAT USE OF THE YELLONSTONE GRIZZLY BEAR.

U.S.D.I., INTERAGENCY GRIZZLY BEAR STUDY TEAM, BCZEMAN, MCNT. 177

$\begin{array}{llll}\text { HAB EFFECT } & \text { HAB USE } & \text { VEG SUCC } & \text { DIVERSITY } \\ \text { FOOD } & \text { NUTR ANAL } & \text { HCME RNG } & \text { MOVE }\end{array}$

YGBE, IMW , ,

00648

KNUDSEN, K.L. AND F.H. ALLENDORF.

1985 PRELIMINARY SURVEY OF GENETIC VARIATION IN GRIZZLY BEARS.

UNIV. MONT., MISSOULA. 17 PP.

GENETICS RES TECH

,US , , , 
00649

$K O B Y, F, E$.

1963

GUELQUES CONSIDERATIONS SUR LA DESCENDANCE DE LOURS BRUN. ISOME VIEWS ON THE BROWN BEAR S PEDIGREE.I

SAU GETIERK MITT. $11(2): 58-62$

TAXON/EVOL

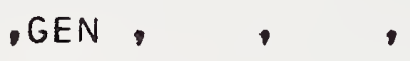

00650

$\mathrm{KOCH}, \mathrm{E}$.

1941 BIG GAME IN MCNTANA FROM EARLY HISTCRICAL RECCRDS.

J. WILDL. MANAGE, $5(4): 357-370$.

HIST ACCT HIST DISTR

, MTWY, , ,

00651

KOF ORD, $C .8$.

1968

STATUS OF THE GRIZZLY BEAR IN CHIHUAHUA, MEXICO.

REP . TO A.S. LEOPOLD, UNIV. CALIF., BERKELEY.

HIST DISTR PRES DISTR

MEX , , , ,

00652

KOFORD, C.E.

1969

THE LAST OF THE MEXICAN GRIZZLY BEAR.

INT. UNION CONSERV. NAT. RESOUR. BULL. $21(2): 95$.

HIST DISTR

, MEX, , , 
00653

KOLZ, A.L., L.J. ROOP AND K.R. GREER.

1978

DEATH OF A RADIO-MARKED GRIZZLY.

ง. WILDL. MANAGE. $42(2): 462$.

TELEM MORT DATA

YGBE, WY, SHNF, ,

00654

KOW ALSKA, $Z$.

1969 A NOTE ON BEAR HYBRIDS.

INT. 200 YEARB. $9: 89$.

REPRO GENETICS

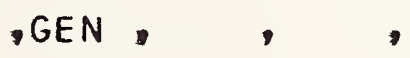

00655

KRAMER, R.J.

1958

ADULT BROWN BEARS CLIMB TREES.

J. MAMMAL. $39(4): 588$.

MATERNAL BEHAV PATT

AKKA, AK, , , , , $A R L$

00656

KUROZUMI, K., T. HARANO, K. YAMASAKI AND Y. AYAKI. 1973

STUDIES CN BILE ACIDS IN BEAR BILE.

J. BIOCHEM. 74(3):489-495.

PHYS CHEM

. GEN 
00657

KURTEN, B. AND E. ANDERSON.

1974 ASSOCIATION OF URSUS ARCTOS AND ARCTOOUS SIMUS IMAMMALIA: URSIDAE I IN THE LATE PLEISTOCENE OF WYOMING.

BREVIORA $426: 1-6$.

HIST DISTR

,WY,,

00658

LACAVA, J. AND J. HUGHES.

1984 DETERMINING MINIMUM VIABLE POPULATION LEVELS.

WILDL. SOC. BULL. 12:370-376, 1984.

MIN POP

GEN, , , ,

00659

LAUCKHART, J.8. AND E.F. LAYSER.

1974-1975 BIG GAME STATUS REPORT: GRIZZLY BEAR SECTION.

FED. AID WILDL. REST. PROJ. W-79-R6 AND W-84-R2. WASH. DEP. GAME,
OLYMPIA. 8 PP. HIST DISTR MGMT GEN PCL/ADM MGMT ,WA, , ,

00660

LAYSER, E.F. 19722 NOIES ON GRIZZLY BEAR SIGHTINGS IN NORTHEASTERN WASHINGTON AND AD
JACENT NORTHERN IDAHD.

MURRELET $53(1): 8-9$.

HIST ACC T

, IDWA, , 
00661

LAYSER, E.F.

GRIZZLY BEARS IN THE SOUTHERN SELKIRK MOUNTAINS.

NOR THWEST SCI. 52(2):77-91.

HIST DISTR PRES DISTR HARV DATA

SME ,ECIW, ,

00662

LEACH, R.

GRIZZLY BEAR HABITAT COMPONENT MAPPING IN THE NORTHERN REGICN.

PP. 32-35 IN: G.P. CONTRERAS AND K.E. EVANS, EDS. PROCEEDINGS-GRI ZZLY BEAR HABITAT SYMPCSIUM. U.S.D.A. FOREST SERV. INTERMCUNTAIN RES. STAT., OGDEN, UTAH. GEN. TECH. REP. INT-2OT.

MAP / TYPE

$$
\text { ,IDMT,USFS, }
$$

00663

LECOUNT, A.L.

1982 SCENT-STATION LOCATIONS AFFECT ON ESTIMATING BLACK BEAR ABUNDANCE -

PROC. WEST. ASSOC. FISH WILDL. AGENCIES 62:408-422.

CENSUS METH

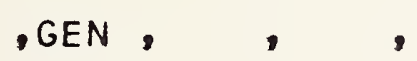

00664

LECOUNT, A.L.

EVIDENCE OF WILD BLACK BEARS BREEDING WHILE RAISING CUBS.

J. WILDL. MANAGE. 47(1):1983.

REPRO REPRO PHYS LITR SIZE LITR FREO

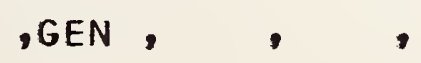


00665

LECOUNT, A.L.

I9838 SE.

WILDL. DIGEST ABSTRACT 14. 7 PP.

DP.UGS

, GEN, ,

00666

LECOUNT, A.L. AND K.L. BALDWIN.

IN PRE BEAR IN THE CLASSROOM.

INT - CONF. BEAR RES. AND MANAGE. 6: -

EDUC

$, G E N, \quad, \quad$,

00667

LEE, J., K. RONALD AND N.A. ORITSLAND.

1977 SOME BLOOD VALUES OF WILD PCLAR BEARS.

J. WILDL. MANAGE. 41(3):520-526.

HEMAT

,$G E N$

00658

LEE, L.C.

1979 TARGET DIAGRAM MODELS: A TECHNIQUE FOR DISPLAYING HABITAT TYPE DI STR IBUTIONS SAMPLED WITHIN SPECIFIC STUDY AREAS.

BORDER GRIZZLY PROJ., UNIV. MONT., MISSOULA. SPEC. REP. NO. 34.5 1 PP.
H.AB SAMPL
MAP/TYPE

NCDE,MT 
00669

LEE, L. AND C.J. JONKEL.

1980 THE VEGTATION STRUCTURE AND ECOLOGY OF GRIZZLY BEAR HABITAT IN T HE PINE AND ANTELOPE BUTTE WETLANDS, MONTANA. BORDER GRIZZLY PROJ., UNIV. MONT. MISSOULA. SPEC. REP. NO. 36.6
6 PP.
HAB USE
HUMAN IMP
HAB RECON
$A G R$ IMP/MGT
I IVESTK IMP
ENERGY IMP

NCDE,MT $\quad, \quad, P I B U$

10670

LEE, L. AND C. JONKEL

1981

GRIZZLIES AND WETLANDS.

WEST. WILDLANDS $7(4): 26-30$

$\begin{array}{lll}\text { HAB USE } & \text { LIVESTK IMP FIRE MGMT N } \\ \text { MGMT GEN } & \text {,PIBU }\end{array}$

00671

LEE,$L$. AND T. THIER.

MEXICAN GRIZZLY STUDIES: AN INTERIM REPORT.

BORDER GRIZZLY PROJ., UNIV. MONT., MISSOULA, UNPUBL. REP., 62 PP.
HAB RECON
HIST DISTR
PRES DISTR
HIST ACCT

, MEX , , ,

00672

LEE, P.L. AND J. WEAVER.

1981

BIOLOGICAL EVALUATION MAN/GRIZZLY BEAR CONFLICTS RELATED TO SHEEP GRAZING IN ESSENTIAL GRIZZLY BEAR HABITAT ON THE TARGHEE NATIONA L FOREST.

U.S.P.A.. FOREST SERV., TARGHEE NATL. FOREST, ST. ANTHONY, IDAHO.
LIVESTK MGMT
LIVESTK IMP

YGBE, IDWY, TANF, 
00673

LENSINK, C.J.

1954 DEFORMED JAW IN AN ALASKAN BROWN BEAR.

J. MAMMAL. $35(3): 438-439$.

DENT SKULL

AKPN, AK, , ,

00674

LENTFER, J.W.

1965

BRUWN BEAR HARVEST STATISTICS IN ALASKA.

PROC. ANNU. CONF. WEST. ASSOC. STATE GAME \& FISH COMM. 45:134-139 HARV DATA

AGE/SEX

, AK ,

.

00675

LENTFER, J.W.

1965

EEAR STUDIES.

FED. AID WILDL REST. PROJ. W-6-R-6, JOB 6, WORK PLAN F. ANNU. RE P. VOL VI JAN. I, 1964-DEC 31, 1964. ALASKA DEP. FISH AND GAM E; JUNEÄU. II PP.

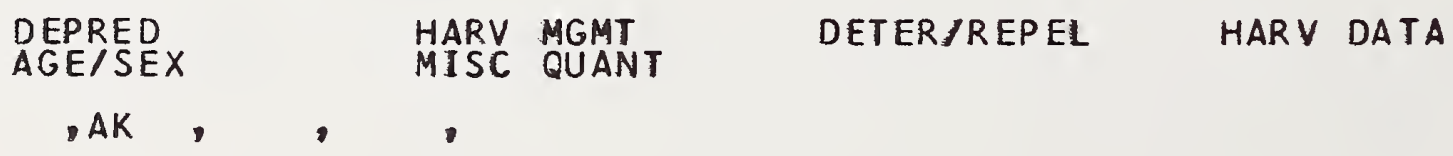

DETER/REPEL

HARV DATA

, AK,

,

00676

LENTFER, J.W.

1966

BEAR STUDIES.

FED. AID WILDL. REST. PROJ. W-6-R-7 AND $W-15-R-1$, WORK PLAN F AND P. FISH AND GAME, JUNEAU. 31 PP.
HARV DATA
DEPRED
AGE/SEX
DEN
MISC QUANT
POACHIILLEG
CENSUS/TREND
PRED 
00677

LENTFER, J.W.

1967

REPORT ON 1966 BEAR STUOIES.

FED AID WILDL. REST, PROJ, W-15-R-1 AND2, WORK PLAN M ANNU RE PP: VOL VUNEAU. 54 PP:

\begin{tabular}{|c|}
\hline $\begin{array}{ll}\text { HARV } & \text { DATA } \\
\text { LITR } & \text { SIZE }\end{array}$ \\
\hline
\end{tabular}
$A K$

00678

LENTFER, J.W.

1968

REPORT ON 1967 BEAR STUDIES.

FED. AID WILDL. REST. PROJ. $W-15-R-2$ AND 3, WORK PLAN M. ANNU. RE P. JAN. 1, $1967-D E C$. 31, i 967 . ALASKA FISH ANC GAME DEP. JUNEAU

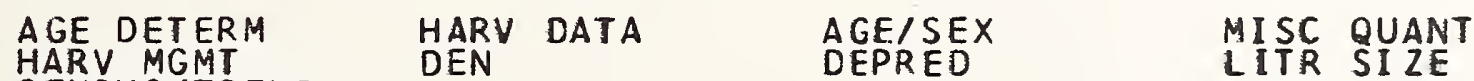
HARV MGMT
CENSUSITREND

00679

LENTFER, J.W. AND L.R. BEIER.

1985

BROWN BEAR WINTER DEN SITE CHARACTERISTICS NORTH ADHIRALTY ISLAND - SOUTHEAST ALASKA, 1982-83.

APPENDIX D. PP. 70-83, IN: J.W. SCHCEN AND L. BEIER BROWN BEAR H ABI TAT PREFERENCES AND BROWN BEAR LOGGING ANO MINING RELATICNSHIP $S$ IN SOUTHEAST ALASKA. FED. AID WILDL. REST. PROJ. W-22-3. ALASKA DEPT. FISH AND GAME: DEN CHAR

AKSE,AK, , , $, \quad, \quad I S$

C0680

LENTFER, J•W., R.J. HENSEL, L॰H, MILLER, L.P. GLENN AND V.D. BERNS. 1972

REMARKS ON DENNING HABITS OF ALASKA BROWN BEARS.

INT. CONF. BEAR RES. AND MANAGE. 2:125-132.

DEN SITE DEN CHAR

AKKA, AK ,KNWR, , 
00681

LENTFER, J.W., L.H. MILLER AND G.N. BOS.

1969

REPORT ON 1968 BEAR STUDIES.

FED. AID NILOL REST, PROJ. W-15-R-4 AND H-17-1, WORK PLAN MAANN UNEEP. 41 AN. 1,1968 -DEC. 31, 1968. ALASKA DEP. FISH AND GAME, J
LNEAU. 41 .

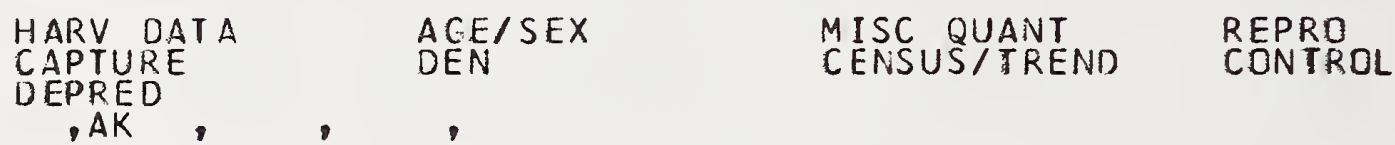

00682

LEONARD, R.D. (ED.).

1983

A REVIEW UF BEAR MANAGEMENT IN PRAIRIE REGION NATIONAL PARKS AND NATIONAL HISTORIC PARKS AND SITES.

PARKS CANACA, DEP. OF ENVIRON., PRAIRIE REGION. 114 PP.

$\begin{array}{ccc}\text { MGMT GEN } & \text { MGMT PLAN } & \text { EDUC } \\ \text { HUMAN INJ } & \text { GARB MGMT } & \\ \text {,CAN, } & ,\end{array}$

00683

LEOPOLD, A.S.

GRIZZLIES OF THE SIERRA DEL NIDO.

PACIFIC DISCOVERY $20(5): 30-32$

HIST DISTR

, MEX, , ,

00684

LEOPOLD, A.S.

A B 99 ER MANAGEMENT POLICY AND PROGRAM FOR YELLOWSTONE NATIONAL PAR K.

OIRECIOR:S REP RESULTING FROM YELLOWSTONE NATL PARK MEETING, 67 SEPT 1969 PREP. FOR U.S.D.I.I NATL. PARK SERV. PREP. BY NAT: SCI. ADVISORY COMM: 8 PP.

GARB MGMT

CAMP MGMT

CONTROL

YGBE, IMW, YNP, , 
00685

LERESCHE, R.E.

1966

BEHAVIOR ANO CALF SURVIVAL IN ALASKA MOOSE.

M.S. THESIS, UNIV. ALASKA, FAIRBANKS, $84 \mathrm{PP}$.

PRED

$A K-I, A K, \quad, \quad J I M L$

00686

LERESCHE, R.E.

SPRING-FALL CALF MORTALITY IN AN ALASKA MOOSE PCPULATION.

J. WILDL. MANAGE • 32(4):953-956.

PRED

$A K-I, A K, \quad$,

00687

LIGHT, J.T.

1986

THR EATENED AND ENDANGERED SPECIES BIOLOGICAL EVALUATION OPERATING PLAN-HOMESTAKE (JOINT VENTURE), DRAFT ENVIRONMENTAL IMPACT STAT EMENT.

U.S.D.A., FOREST SERVICE, GALLATIN NATL• FOREST, BOZEMAN, MONT. 2 $4 \mathrm{PP}$.

ENERGY IMP $\quad$ ENERGY MGMT

YGBE,MT, ,GANF, ,JARD

00688

LINDERMAN, S.

1974

GROUND TRACKING DF ARCTIC GRIZZLY BEARS.

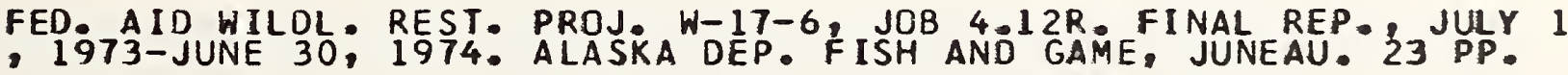

$\begin{array}{llll}\text { AIRCRAFT IMP } & \text { FOOD } & \text { CARCASS } & \text { BEHAY PATT } \\ \text { ACT PATT } & \text { MOVE } & \text { COURT } & \text { DAY BED } \\ \text { HOME RNG } & , \text {,EBRK } & & \\ \text { ARC IAK }, & & \end{array}$


00693

LONG, CAA.

1965 THE OCCURRENCE OF SUPERNUMERARY BONES IN SKULLS OF NORTH AMERICAN
BROWN BEARS. URUS ARCTOS LINNAEUS.

2. SAEUGETIERKD. $30(1): 30-36$.

SKULL

00694

LORIE, GAM.

1978 THE QUOTA - A NEW MANAGEMENT SYSTEM FUR YUKON GRIZZLY BEAR. PRES. TO YUKON OUTFITTERS ASSOC B 22 APRIL 1978 P PREP A BY YUKON T
ERRITORIAL GOV. WILDE. BRANCH. WHITEHORSE. 14 PP.

HART MGM

BRO AGE
OUTFIT MGM LIT SIZE

POP DENS

LIT FREQ

HART IMP
POP EST

, YR ,

00695

LORIE, G.M. AND J. MCDONALD.

1977

A TWENTY-THREE YEAR ANALYSIS OF GRIZZLY HARVESTS IN THE YUKON TER RI TORY.

APPENDIX III. 32 PP. IN: GAM. LORIE AND J. MCDONALD. GAME HARES I REPORT AND QUEST $C N N A I R E$ ANALYSIS. YUKON TERRITORIAL GOV. GAME BRANCH, WHITEHORSE.

$$
\begin{aligned}
& \text { HARD DATA } \\
& \text { HART IMP }
\end{aligned}
$$

CONT REL

YR

HART MGM

PCACH/ILLEG

AGE/SEX

00696

LUNDBERG, D.A., RA. NELSON, HaW. WAHNER AND J.D. JONES.

1976

PROTEIN METABOLISM IN THE BLACK BEAR BEFORE AND DURING HIBERNATIO N.

MAYO OLIN. PROC. $51: 716-722$

LIB PHYS

HEMAL

- GEN ,

343 
00697

LUQUE, M.H.

1978

FISHING BEHAVIOR OF ALASKA BROWN BEAR, URSUS ARCTOS.

M.S. THESIS, UTAH STATE UNIV., LOGAN, 49 PP.

PRED INTRASP BEH FEED BEH MATERNAL

$A K-I, A K, \quad, M C N E$

00698

LUQUE, M.H. AND A.W. STOKES.

1976 FISHING BEHAVIOUR OF ALASKA BROWN BEAR.

INT. CONF. BEAR RES. AND MANAGE. 3:71-78.

FEED BEH PRED

AKPN, AK , MCGS, ,MCNE

00699

LYON, L.J.

1984 ROAD EFFECTS AND IMPACTS DN WILDLIFE AND FISHERIES.

PRES. AT FOREST TRANSPORTAION SYMP. 11-13 DEC. 1984, CASPER, HYO - $20 \mathrm{PP}$

ROAD IMP TIMB IMP

, GEN, ,

00700

LYON, L.J. AND J.V. BASILE. INF LUENCES OF TIMBER HARVESTING AND RESIDUE MANAGEMENT IN BIG GAM

PROC. ENYIRON. CONSEQUENCES TIMBER HARVESTING IN ROCKY MT. CONIFE ROUS FOR. 1980:441-453.
ROAD IMP
I IMB IMP
TIMB-POST

, GEN , 
00701

MACARTHUR, R.H. AND E.D. WILSON.

1967 THE THEORY OF ISLAND BIOGEOGRAPHY.

PRINCETON UINIV. PRESS, PRINCETON, N.J.

MIN PDP MGMT GEN

$, G E N, \quad, \quad$,

00702

MACE, R.

1982 SOUTH SAN JUAN MOUNTAINS GRIZZLY EEAR SURVEY.

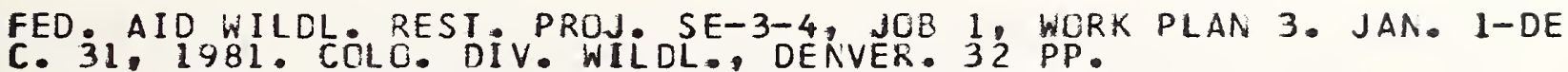
PRES DISTR HAB RECON

RGNF, CO , SJNF, SJMT,

00703

$M A C E, R, D$.

1984

IDENTIFICATION AND EVALUATION OF GRIZZLY BEAR HABITAT IN BCB MARS HALL WILDERNESS AREA, MT.

M.S. THESIS, UNIV. MONT., MISSOULA. 176 PP.

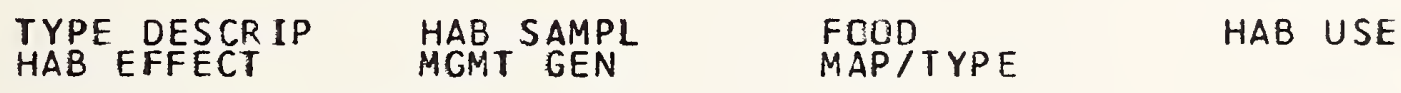

NCDE,MT ,FLNF,LONF,

00704

MACE, R.D.

1986

ANALYSIS OF GRIZZLY BEAR HABITAT IN THE BCB MARSHALL WILDERNESS, MONTANA.

PP. 136-149 IN: G.P. CONTRERAS AND K.E. EVANS, EDS. PROCEEDINGS-G RIZZLY BEAR HABITAT SYMPOSIUM U.S.D.A. FOREST SERV. INTERMOUNTA IN P.ES. STAT.: OGDEN, UTAH. GEN. TECH. REP. INT-207.

HAB EFFECT TYPE DESCRIP FCOD

NCDE,MT ,FLNF, LCNF, BMHA 
00705

MACE, R.D., K. PUNE, W. KASWORM AND R . KLAVER.

IN PREP

INCIDENCE OF HUMAN CONFLICTS BY RESEARCH GRIZZLY BEARS.

DRAFT MANUSCRIPT.

HUMAN IMP

CONTROL

NCDE,MT

00706

MACE, RaD. AND G.N. BISSELL.

1986

GRIZZLY BEAR FOOD RESOURCES IN THE FOOD PLAINS AND AVALANCHE CHIT ES OF THE BOB MARSHALL WILDERNESS, MONTANA.

$$
\begin{aligned}
& \text { PP. 18-91 IN: G.P. CONTRERAS AND K.E. EVANS, EDS PROCEEDINGS-GRI } \\
& \text { ZZLY BEAR HABITAT SYMPOSIUM U. SiD. A FOREST SERVe. INTERMCUNTAIN }
\end{aligned}
$$

NCDE,MT ,FLNF, LONG, BMW

00707

MACE, R. AND C. JONKEL. 1979 A
SEASONAL FOOD HABITS OF THE GRIZZLY BEAR (URUS ARCTOS HORRIBILIS
ORD.) IN NORTHWESTERN MONTANA. PP. 28-46 IN: CO ̊. JONKEL ED. ANNUAL REPORT NO. 4. BORDER GRIZZLY

FOOD

NCDE, MT

00708

MACE, R. AND C. JONKEL.

1979 192 Y Y BEAR RESPONSE TO HABITAT DISTURBANCE.

PP. 48-77 IN: C. JONKEL, ED. ANNUAL REPORT NO. 4. BORDER GRIZZLY

HOME LNG
PRES DISTR

MEASIQUANT
RELIC

AGE/SEX

MOVE

NCDE,MT, , ,FLT

346 
00709

MACE, R.D. AND C. JONKEL.

$1980 A$

FOOD HABITS OF THE GRIZZLY BEAR IURSUS ARCTOS HORRIBILIS DRD.) IN MONTANA.

PP. 49-69 IN: C JONKEL ED. ANNUAL REPORT NO. 5. BORDER GRIZZLY PRDJ., UNIV. MONT., MISSOULA.

FOOD

NCDE,MT, , ,

C0710

MACE, R.D. AND C. JCNKEL.

19808 THEFFCTS OF LOGGING ACTIVITY ON GRIZZLY BEAR MOVEMENTS.

BORDER GRIZZLY PROJ.॰ UNIV. MONT •, MISSOULA. SPEC.REP. NO. 38 . 1 $1 \mathrm{PP}$.

TIMB IMP MOVE PRES DISTR HOME RNG

NCDE,MT, , , ,,$\quad$ FLT

00711

MACE, R.D. AND C. JONKEL.

GRIZZLY BEAR RESPONSE TO HABITAT DISTURBANCE.

PP. 70-98 IN: C. JONKEL, ED. ANNUAL REPORT NO. 5. BORDER GRIZZLY PROJ., UNIV. MONT., MISSOULA.

$\begin{array}{llll}\text { HOME RNG } & \text { MOVE } & \text { MEAS/QUANT } & \text { AGE/SEX } \\ \text { TERR/SPACE } & \text { FOOD } & \text { RELOC } & \text { POP DENS }\end{array}$

NCDE,MT , , , SFLT

00712

MACE, R., J.L. PERRY AND C. JONKEL.

1979 VEGETATION STUDIES OF DISTURBED GRIZZLY HABITAT.

PP. 16-27 IN: C JONKEL, ED. ANNUAL REPORT NO. 4. BORDER GRIZZLY PRDJ., UNIV. MONT. MISSOULA.

MEAS/QUANT HAB USE BURN USE/MGT

NCDE,MT, , , , , 
00713

MACE, R.D. S. RILEY AND K. AUNE.

IN PREPOCATION OF PROBLEM GRIZZLY BEARS IN NORTHWESTERN MONTANA.

DRAFT MANUSCRIPT • 15 PP.

RELOC

NCDE,MT, , ,

00714

MACE, $R$. C. SERVHEEN ANO G. DAY.

1978

GRIZZLY RELCCATIONS IN THE YAAK RIVER DRAINAGE.

PP. 215-227 IN: C

RELOC MEAS/QUANT MOVE HAB USE

CYE, BIM, , ,

00715

MACEY, A.

1979 THE STATUS OF THE GRIZZLY BEAR (URSUS ARCTOS HORRIBILIS) IN CANAD A.

NATL. MUS, OF NAT, SCI, OTTAWA, CANADA. 54 PP.

$\begin{array}{lll}\text { GEN BIOL } & \text { DISTR } & \text { POP BIOL } \\ \text { POP DENS } & & \\ \text {,CAN, } & \end{array}$

00716

MACLENTZ, W., R.L. MARCHINTON AND R.E. SMITH.

1983

THERMODYNAMIC ANALYSIS OF NORTHEASTERN GEORGIA BLACK BEAR DENS.

J. WILDL. MANAGE. 47121:545-549.

DEN CHAR TEMP

$, \mathrm{GEN}, \quad$, 
00717

NACPHER SON, A.H.

1965 THE BARREN-GROUND GRIZZLY.

CAN. AUDUBON 27(1):2-8.

LEGAL HIST CISTR MGMT GEN HARV MGMT

00718

MACPHER SON, A.H.

1966

GRIZZLY BEAR IN DANGER.

ORYX 8(5):295-301.

HIST DISTR HARV MGMT LEGAL MGMT GEN NWT, , ,

00719

MADEL, M.J.

1982

GRIZZLY BEAR HABITAT DELINEATION AND RECONNAISSANCE IN THE CABINE T MOUNTAINS: $\triangle$ PROCEDURAL DESCRIPTION.

SECTION II - 37 PP. IN: CUMULATIVE EFFECTS ANALYSIS PROCESS GRIZZ LY HABITAT COMPQNENT MAPPING. U.S.D.A., FOREST SERV., KOOTENAI NA TL. FOREST, MONT.

MAF/TYPE

CYE, IOMT,KDNF, ,CAB

00720

MADEL, M.

1983

BIOLOGICAL ASSESSMENT FOR THE PROPCSED GREAT NCRTHERN MOUNTAIN SK I DEVELDPMENT.

U.S.D.A. FOREST SERV., KOOTENAI NATL. FOREST, LIBBY, MONT • 62 PP.

CUM EFF RECR IMP RECR MGMT

CYE.MT, KONF, , 
00721

MAGOUN, J.

1976

SUMMER SCAVENGING ACTIVITY IN NORTHEASTERN ALASKA.

M.S. THESIS, UNIV. ALASKA, FAIRBANKS. 168 PP.

CARCASS FEED BEH INTERSP COMP ACT PATT
AGON

$A R C, A K, \quad, E B R K$

00722

MAGUIRE, L.A.

1985

AN ANALYSIS OF AUGMENTATION STRATEGIES FOR GRIZZLY POPULATIONS: T HE CABINET-YAAK ECOSYSTEM AS AN EXAMPLE. (DRAFT).

PREP. FOR U.S.D.A., FOREST SERV. CONTRACT 40-3187-4-1748.

POP AUG RELOC

CYE, IDMT, , ,

00723

MAJOR, M., M.K. JOHNSON, W.S. DAVIS AND T.F. KELLOGG. 1980

IDENTIFYING SCATS BY RECOVERY DF BILE ACIDS.

J. WILDL. MANAGE. 44(1):290-293.

SCAT ANAL

$$
, \text { GEN , , , }
$$

00724

MANLOVE, M.N.R. BACCUS, M.R. PELTON, M•H. SMITH AND D. GARBER. 1980

BIOCHEMICAL VARIATION IN THE BLACK BEAR.

INT. CONF. BEAR RES. AND MANAGE. 4:37-41.

GENETICS

, GEN, , , , 
00725

MARCH, K.S.

1980

OEERS, BEARS, AND BLOOD: A NOTE ON NONHUMAN ANIMAL REPSONSE TO ME ASTRUAL ODOR.

AM. ANTHROP. $82(1): 125-127$.

AVOID/ATTRAC

, GEN, , ,

00726

MARSH, J.S.

BEARS AND MAN IN GLACIER NATIONAL PARK, BRITISH COLUMBIA, 1880-19 80 .

INT. CONF. BEAR RES. AND MANAGE . 2:289-296.

HIST ACCT HIST DISTR PUBLIC ATT

CR ,BC , CGNP, ,

00727

MARSH, J.

1970

BEARS AND THE PUBLIC IN OUR NATIONAL PARKS - A SURVEY OF ATTITUDE $S$ TO BEARS AND THEIR MANAGEMENT.

CAN. AUDUBON $32(2): 43-45$

PUBLIC ATT EDUC

CR , AIBC, BANP, CGNP,

00728

MAR SHALL, P.B.

1955 GRIZLY BEAR SURVEY. FED AID WILDL. REST PROJ. H-60-R-2, JOB I-D, WORK PLAN I. MONT.
FISH AND GAME DEP. HELENA. 20 PP.
CENSUS/TREND
HARV DATA
AGE/SEX
HIST DISTR

NCDE,MT , 
C0729

MARTIN, N.

1966 BIG GAME SURVEYS AND INVESTIGATIONS - ANTELOPE, BIGHORN SHEEP, MO UNTAIN GOATS AND BEAR.

FED. AID WILDL. REST. PROJ W-74-R-10, JOB A-1. JOB COMPLETION RE Pi JULY 1, $1964-J U N E$ 30, i 965 . MONT. FISH AND GAME DEP.. HELENA. HARV DATA

NCOE,MT,

00730

MARTIN, N. 1967
BIG GAME SURVEYS AND INVESTIGATIONS - ANTELOPE, BIGHORN SHEEP, MO
UNTAIN GOATS AND BEAR.

FED. AID WILDL REST. PROJ, $W-74-R-12$, JOB A-1. JOB COMPLETION RE Pí JULY 1, 1965-JUNE 30, i966. MONT. FISH AND GAME DEP. HELENA. HARV DATA

NCDE,MT, , ,

00731

MARTIN, N.

1968 BIG GAM SURVEYS AND INVESTIGATIONS - ANTELOPE, 8 IGHORN SHEEP. MO UNTAIN GUATS AND BEAR.

FED. AID WILDL REST. PROJ W-74-R-12, JOB A-1 JOB COMPLETION RE P I5 JULY 1, 1966-JUNE 30, 1967. MONT. FISH AND CAME DEP. HELENA. HARV DATA

NCDE,MT, , ,

00732

MARTIN,P.

1978

VACCINIUM PRODUCTIVITY AND TAXONOMY STUDY.

PP $P$ P 135-159 IN: C JONKEL, ED. ANNUAL REPORT NO. 3. BORDER GRIZZL FOOD

HAB SAMPL

VEG SUCC

NCDE,MT , , , 
00733

MARTIN, S.

1983 B.S. BORAXO AND CHEMICAL CORPORATION GRIZZLY BEAR STUDY.

PREP. FOR ECON INC., HELENA, MONT. PROJECT 323-85-A.

HAB RECON PRES DISTR

CYE, MT ,KONF, ,

00734

MARTIN, P.

1983 FACTORS INFLUENCING GLOEE HUCKLEBERRY FRUIT PRODUCTION IN NCRTHWE STERN MONTANA.

INT. CONF. BEAR RES. AND MANAGE * 5:159-165.
YEG SUCC
FODD
FIRE MGMT
TIMB MGMT
TIMB-POST

NCDE,MT ,FLNF,

00735

MARTINKA, C.J.

1968

TERRESTRIAL ECOLOGY STUDIES, GLACIER NATIONAL PARK.

PROG. REP $1967-68$, U.S.D.I, NATL. PARK SERV., GLACIER NATL= PAR
K, MONT. 58 PP. $\begin{array}{llll}\text { PRES DISTR } & \text { POP DENS } & \text { POP EST } & \text { AGE/SEX } \\ \text { HAB USE MUMAN INJ } & \text { INTRASP BEH } & \text { DRPHAN } \\ \text { NONMOT MGMT } & & & \\ \text { CDE,MT GLNP. } & & & \end{array}$

007.36

MARTINKA, C.J.

1969

GRIZZLY ECOLOGY STUDIES, GLACIER NATIONAL PARK.

PRDG. REP 1968, U.S.D.I. NATL. PARK SERV., GLACIER NATL. PARK, MONT. 43 PP.

GEN DATA
POP BIOL
DEN
NCDE,MT, GLNP


00737

MARTINKA, C.J.

1970

GRIZZLY ECOLOGY STUDIES, GLACIER NATIONAL PARK.

PROG. REP
MONT: ${ }_{4} 3969$, U.S.D.I. NATL. PARK SERV. GLACIER NATL. PARK, GEN DATA

NONMOT MGMT

POP DENS

NCDE,MT ,GLNP,

POP BIOL
GARBAGE

HUMAN INJ

INTRASP BEH
CONTROL MORT DATA

00738

MARTINKA, C.J.

1971 MONTANA.

TRANS. NORTH AM. WILDL. AND NAT - RESOUR. CONF . 36:312-322.

POP DENS

CONTROL

NCDE,MT ,GLNP.

00739

MARTINKA, C.J.

1972
HABITAT RELATIONSHIPS OF GRIZZLY BEARS IN GLACIER NATIONAL PARK.

PROG. REP. 1972, U.S.D.I. NATL. PARK SERV., GLACIER NATL. PARK,
MONT: 19 P.

HAB USE

BURN USE/MGT

FCOD

INTERSP COMP

CARCASS

PRED

NCDE,MT , GLNP,

00740

MARTINKA, C.J.

$1973 \mathrm{~A}$

INTERIM REPORT ON GRIZZLY BEAR RESEARCH.

MEMO TO SUPERINTENDENT, U.S.D.I. NATL. PARK SERV \& GLACIER NATL - PARK, MONT. 12 PP.

$\begin{array}{llll}\text { CENSUS/TREND } & \text { POP EST } & \text { LITR SIZE } & \text { AGE/SEX } \\ \text { POP DENS } & \text { MORT DATA } & \text { HUMAN INJ } & \text { CONTROL }\end{array}$

NCDE,MT ,GLNP, 
00741

MARTINKA, C.J.

$1974 A$ POPULATION CHARACTERISTICS OF GRIZZLY BEARS IN GLACIER NATIONAL P
ARK, MONTANA.

J. MAMMAL • 55(1):21-29.

$$
\begin{array}{llll}
\text { POP EST } & \text { POP DENS } & \text { AGE/SEX } & \text { LITE SIZE } \\
\text { WEAN } & \text { INTRASP BE } & \text { MORT DATA } & \text { CONTROL } \\
\text { NCDE,MT , GLNP, } & , & &
\end{array}
$$$$
00742
$$

MARTINKA, Co.

1974R 9 RE RING THE NATURAL STATUS OF GR IZZLIES IN GLACIER NATIONAL PA RR.

HILDL, SOC. BULL. 2(1):13-17.

HUMAN INS

DEPRED

NONMOT MGM

CONTROL

NCDE,MT, GLNP,

00743

MARTINKA, C.J.

1974C

PP. $195-206$ IN: RESEARCH IN THE PARKS TRANS, OF THE NATL. PARK C
ENTENNIAL SYMP. U.S.D.I., NATL. PARK SERV. SYMP. SER. NO. 1.

$$
\begin{array}{llll}
\text { POP EST } & \text { POP DENS } & \text { AGE/SEX } & \text { LITE SIZE } \\
\text { WEAN } & \text { INTRASP BE } & \text { MORT DATA } & \text { CONTROL }
\end{array}
$$

NCDE,MT , GLNP,

00744

MARTINKA, C.J.

1976 9 LOGICAL ROLE AND MANAGEMENT OF GRIZZLY BEARS IN GLACIER NATION AL PARK.

INT - CONF - BEAR RES - AND MANAGE • 3:147-156.

DISTR
HUMAN

NCOE,MT ,GLNP,
POP EST CONTROL

POP DENS

REL OC

TERR/SPACE

355 
00745

MARTINKA; C.J.

A SUMAAARY OF GRIZZLY BEAR RELOCATIONS IN GLACIER NATIONAL PARK.

U.S.D.I., NATL. PARK SERV., GLACIER NATL. PARK, MONT. I PP.

RELOC

NCDE, MT ,GLNP, ,

00746

MAR IINKA, C.J.

19828 EFFECTS CF CONTERMINOUS LAND USE ON GRIZZLY BEARS IN GLACIER NATI CNAL PARK. PRES. AT AM. ASSOC FOR ADVANCEMENT OF SCI. SYMPOSIUM ON EXTERNAL
THREATS TO ECOSYSTEMS OF NATL. PARKS, 3-8 JANUARY 1982, WASHINGT ON, D.C.

ROAD IMP

CCNTROL

MORT DATA

CENSUS/TREND MOVE

NCDE,MT, GLNP,

00747

MARTINKA, C.J.

$1982 C$

RATIDNALE AND OPTIONS FOR MANAGEMENT IN GRIZZLY BEAR SANCTUARIES.

TRANS. NORTH AM. WILDL. AND NAT, RESOUR, CONF. 47:470-475.

HUMAN INJ CONTROL NONMOT MGMT

NCDE,MT ,GLNP, ,

00748

MARTINKA, C.J. AND K.C. KENDALL.

1986

GRIZZLY BEAR HABITAT RESEARCH IN GLACIER NATIONAL PARK, MONTANA.

PP. 19-23 IN: G.P. CONTRERAS AND K.E. EVANS, EDS. PROCEEDINGS-GR I ZZLY BEAR HABITAT SYMPOSIUM. U.S. D. A. FOREST SERV. INTERMOUNTAIN RES. STAT., OGDEN, UTAH. GEN. TECH. REP. INT-2O7.

RECR MGMT FOOD

NCDE,MT ,GLNP, , 
00749

MATEJKO, G. AND B. FRANKLIN.

1983

SUMMARY OF THE GRIZZLY BEAR NO. 38/SHEEP INCIDENT, AUGUST 23 TO $S$ EPTEMBER 9, 1983, TWO TOP $S \& G$ ALLOTMENT.

$U_{8}$ S $_{P_{\bullet}} P_{\bullet} A_{.}$, FOREST SERV., TARGHEE NATL. FOREST, ST. ANTHONY, IDAHO. DEPRED DETER/REPEL LIVESTK MGMT LIVESTK IMP

YGBE,ID, ,TANF, ,ISLP

00750

MATTSON, D.J.

1983 PRINARY ASSESSMENT OF SHORT-ROTATION (70-120 YEARS) TIMBER MA NAGEMENT EFFECTS ON FOREST COVER TYPE COMPOSITION AND GRIZZLY BEA R.

U.S.D.I.. INTERAGENCY GRIZZLY BEAR STUDY TEAM, BOZEMAN, MONT. 9 P $\begin{array}{lll}\text { FOOD } & \text { HAB USE } & \text { TIMB USE } \\ \text { TIMB-HAB } & \text { COVER } & \text { VEG SUCC } \\ \text { TYPE DESCRIP HAB EFFECT }\end{array}$ YGBE, IMW, ,

00751

MATTSON, D.J.

1984

CLASSIFICATION AND ENVIRONMENTAL RELATICNSHIPS OF WETLAND VEGETAT ION IN CENTRAL YELLOWSTONE NATIONAL PARK, WYOMING.

M.S. THESIS, UNIV. IDAHC, MOSCOW. 409 PP.

HAB USE FOOD FEED BEH MAP/TYPE

YGBE,WY , YNP, ,

00752

MATTSON, D.J., B.M. BLANCHARD AND R.R. KNIGHT.

IN PRESSA

FOOD HABITS OF THE YELLCWSTONE GRIZZLY BEAR.

INT. CONF • BEAR RES. AND MANAGE. T.

FOOD

NUTR ANAL

FOR STRAT

PRED

CARCASS

YGBE,HY, YNP, 
00753

MATTSON, D.J. AND D.G. DESPAIN.

1985

GRIZZLY BEAR HABITAT COMPONENT MAPPING HANDBOOK FOR THE YELLOWSTO NE ECOSYSTEM.

U.S.D.A., FOREST SERV., YELLOWSTONE NATL. PARK, WYO. 37 PP.

MAP/TYPE

YGBE, IMW,

00754

MATTSON, D.J. R.R • KNIGHT AND B.M. BLANCHARD.

1986 DERIVATION OF HABITAT COMPONENT VALUES FOR THE YELLOWSTONE GRIZZL

PP. 222-229 IN: G.P. CONTRERAS AND K.E. EVANS, EDS, PROCEEDINGS-G RIZZLY BEAR HABITAT SYMPOSIUM U.S. D.A. FOREST SERV. INTERMOUNTA IN RES. STAT. OGDEN, UTAH. GEN. TECH. REP. INT-207.

HAB EFFECT

YGBE, IMW ,

00755

MATTSON, D.J., R.R. KNIGHT AND B.M. BLANCHARD.

IN PRESSB YELLGWSTONE NATIONAL PARK. WYOMING.

INT • CONF. BEAR RES. AND MANAGE • 7. (PAPER PRESENTED)

$\begin{array}{llll}\text { ROAD IMP } & \text { MOTOR IMP } \\ \text { MORT DATA } & & \end{array}$

YGBE, IMH, YNP,

00756

MATTSON, D.J. AND D.P. REINHART.

1986 GRIZZLY BEAR, RED SQUIRRELS, AND WHITEBARK PINE: SECOND YEAR PROG RESS REPORT.

PP 39-5I IN: R.R. KNIGHT B.M.BLANCHARD AND D. MATISON YELLOHS TONE GRIZZLY BEAR INVESTIGATIONS ANNUAL REPORT OF THE INTERAGENCY STUDY TEAM, 1985. U.S.D.I. INTERAGENCY GRIZZLY BEAR STUDY TEAM BOZEMAN, MONT.
FOOD

TIMB USE

TIMB MGMT

YGBE,IMW, , 
00757

MAW, R.

1986

VISITOR KNOWLEDGE AND PERCEPTION OF BEARS ANC BEAR MANAGEMENT PRA CTICES, WATERTON LAKE NATIONAL PARK, CANADA.

PH.D. DISS., UNIV. ALBERTA, EDMONTCN. 173 PP.

PUBLIC ATT RECR MGMT ECUC

CR , AT , WANP,

00758

MAYNARD, J.E. AND I.G. KAGAN.

1964

INTRADERMAL TEST IN THE DETECTION CF TRICHINCSIS. FURTHER OBSERVA TIONS ON TWO OUTBREAKS DUE TO BEAR MEAT IN ALASKA.

NEW ENGLAND J. MED. $270(1): 1-6$

PARAS/DIS

$A K-I, A K, \quad$,

00759

MAYNARD, J.E. AND F.P. PAULS.

1962 TRICHINOSIS IN ALASKA. A REVIEW AND REPORT OF TWO OUTBREAKS DUE T

C BEAR MEAT WITH OBSERVATIONS CN SERODI AGNOSIS ANC SK IN TESTING.

AM. J. HYG. $76(3): 252-261$.

PARAS/OIS

$A K-I, A K, \quad$,

00760

MCALLISTER, F.D.

1977

GRIZZLY BEARS AND PUBLIC ATTITUDES.

B.S. THESIS, UNIV, OF B.C , VANCOUVER, 25 PP.

PUBLIC ATT

,$B C$ 
00761

MCARTHUR, $K=L$.

1978 UF BEAR OBSERVATIONS TO QUANTIFY AND PREDICT BEAR HALARDS, GL ACIER NATIONAL PARK.

PROG P. REP., U.S.D.I., NATL. PARK SERV., GLACIER NATL. PARK, MONT. MONIT SYS R.EACTION RECR MGMT

NCDE,MT , GLNP, ,

00762

MCARTHUR, K.L.

I979A BEAR HAZARD INDEX SYSTEM GLACIER NATIONAL PARK.

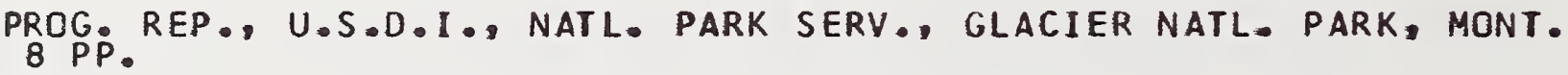
MONIT SYS RECR MGMT REACTION

NCDE,MT ,GLNP, ,

00763

MCARTHUR, K.L.

1979B

METHODS IN THE STUDY OF GRIZZLY BEAR BEHAVIOR IN RELATICN TO PEOP LE IN GLACIER NATIONAL PARK.

PRES AT SECOND CONF, SCI. RES. IN NATL. PARKS, 26-30 NOVEMBER 19 79, SAN FRANCISCO. 14 PP.

$\begin{array}{llll}\text { HUMAN INJ } & \text { DEPRED } \\ \text { MONIT SYS RECTION }\end{array}$

NCDE,MT , GLNP, ,

00764

MCARTHUR, K.L.

1979 C TIONAL PARK - A LITERATURE REVIEW.

PROG 70 P. REP., U.S.D.I. NATL. PARK SERV., GLACIER NATL. PARK, MONT. INTRASP BEH HUMAN INJ AVER COND GEN BIOL 
00765

MCARTHY, T.

1986

SUMMARY OF 1984 BROWN BEAR FOOD HABITS.

PP. 44-45 IN: J.W. SCHCEN AND L. BEIER, BROWN BEAR HABITAT PREFER ENCES AND BROWN BEAR LOGGING AND MINING RELATICNSHIPS IN SOUTHEAS TALASKA. FED. AID WILDL. REST. PROJ. ALASKA DEP. FISH AND GAME. JUNEAU. FOOD PRED

AKSE,AK, , , ADIS

00766

MCCOURT, K.H., J.D. FEIST, D. DOLL AND J.J. RUSSELL.

1974 ATUY OF THE REACTIONS OF CARIBOU, MOOSE AND GRIZZLY BEAR TO AI RCRAFT DISTURBANCE.

ARCTIC GAS BIOL. REP. SER. 5:181-215.

\section{AIRCRAFT IMP}

$A R C, A K, \quad, E B R K$

00767

MCCRACKEN, H.

1955

THE BEAST THAT WALKS LIKE A MAN.

HANOVER HOUSE, GARDEN CITY, N.Y. 319 PP.

HIST ACCT

$$
, \text { GEN, , , }
$$

00768

MCCRORY, W.

1984

GRIZZLY BEAR HABITAT CAPABILITY AND USE IN RELATION TO RECREATION AL FACILITIES IN VALHOLLA PROVINCIAL PARK.

PREP. FOR VALHOLLA PROVINCIAL PARK. $158 \mathrm{PP}$.

$\begin{array}{llll}\text { HAB RECON HAB USE FOOD RECR MGMT } & \end{array}$

$C R, B C$, VAPP, 
00769

MCCRDRY, W.

1985 GRIZZLY BEAR HABITAT AND OUTDOOR RECREATION IN KOKANEE GLACIER PR OVINCIAL PARK, CONFLICTS AND RECOMMENDATIONS.

SUBMITTED TO B.C. PARKS AND OUTDOOR RECREATION DIV., KAMLOCPS. 11 8 PP.

$\begin{array}{llll}\text { HAB RECON } & \text { HAB USE } & \text { NONMOT MGMT } & \text { FOOD } \\ \text { GARBAGE } & \text { GARB MGMT } & \text { CAMP MGMT } & \end{array}$

CR ,AT ,KGPP,

00770

MCCRORY, W. AND S. HERRERO.

1981

AN EVALUATION OF GRIZZLY BEAR AUTUMN FEEDING SIGN AND HABITAT IN THE UPPER HIGHWDOD RIVER VALLEY, ALBERTA.

PREP. FOR ALBERTA FISH AND WILDL. DIV., CALGARY. 178 PP.

HAB RECON FOOD HAB USE PRED

CR , AT, , KANA

00771

MCCRORY, W. AND $S$. HERRERO.

1982 A REIEW OF THE HISTORICAL STATUS OF THE GRIZZLY BEAR IN KANANASK IS COUNTRY, ALBERTA.

PREP FOR ALBERTA FISH AND WILDL. DIV - CALGARY PREP - BY BIOS EN VIRON. RES. AND PLANNING ASSOC. LTD. CALGARY 123 PP:

$\begin{array}{llll}\text { HIST ACCT } & \text { HIST DISTR } & \text { LIVESTK IMP } & \text { HGR IMP/MGT } \\ \text { CONTRDI } & \text { HARV IMP } & \text { HARV DATA } & \\ \text { CR OAT, }, ~ & \end{array}$

00772

MCCRORY, W. AND S. HERRERO.

1983 A AND SPRAY LAKES VALLEYS AND AREAS FROM CANMORE TO MT: ALLAN.

PREP. FOR ALBERTA FISH AND WILDL. DIV C CALGARY PREP. BY BIOS EN
VIRON. RES. AND PLANNING ASSOC. LTD- CALGARY. 249 PP: HAB RECON HAB USE HON
NONMOT

CR , AT , , KANA 
00773

MCCRORY, W. AND S. HERRERO.

19838 THE CAPABIITY AND USE OF GRIZZLY BEAR HABITATS IN THE HEACWATERS

OF THE LITTLE ELBCW. ELBOW. SHEEP, ANO HIGHWCCL VALLEYS, 1982.

PREP. FOR ALBERTA FISH AND WILDL. DIV. CALGARY PREP. BY BIOS EN VIRON. RES. AND PLANNING ASSOC. LTD., CALGARY. 173 PP.
HAB RECON
HAB USE
FCOD
RECR IMP

CR

- AT, ,

00774

MCCRORY, W. S. HERRERC AND T. TOTH.

1982 GRIZZLY BEAR HABITAT POTENTIAL AND FEEDING AREAS IN THE KANANASKI S AND SPRAY LAKES VALLEYS.

PREP. FOR ALBERTA FISH AND WILDL. DIV , CALGARY PREP B BY BIOS EN VIRON. RES. AND PLANNING ASSOC. LTD. CALGARY. 372 PP:

$\begin{array}{llll}\text { HAB RECON } & \text { HABUSE } & \text { FCOD } & \text { NONMOT MGMT } \\ \text { MOTOR MGMT } & \text { MGMT GEN } & \\ \text { CR AT, , KANA } & \end{array}$

00775

MCCRORY, W. S. HERRERO AND P. WHITFIELD.

1986

USING GRIZZLY BEAR HABITAT INFORMATION TO REDUCE HUMAN-GR IZZLY BE AR CONFLICIS IN KOKANEE GLACIER AND VALHALIA PROVINCIAL PARKS, BC $\bullet$

PP. 24-30 IN: G.P. CONTRERAS AND K.E. EVANS, EDS PROCEEDINGS-GRI ZZLY BEAR HABITAT SYMPOSIUM. U.S.D.A., FOREST SERV. INTERMCUNTAIN RES. STAT., OGDEN, UTAH. GEN. TECH. REP. INT-207.
HAB USE
HAB SAMPL
HAB EFFECT
RECR IMP
RECR MGMT

$B C-I, B C, K G N P, V A P P$,

00776

MCC ULLOUGH, D.R.

1981

POPULATION DYNAMICS OF THE YELLOWSTCNE GRIZZLY BEAR.

PP. 173-196 IN: C.W. FOWLER, ED. DYMAMICS OF LARGE MAMMAL FOPULAT IONS. JOHN WILEY AND SONS.
POP EST
DEMOG ANAL
PQP REG
MCRT RATE
AGE/SEX

YGBE, IMW , 
MCC ULLOUGH, D.R.

1982

BEHAVIOR, BEARS AND HUMANS.

WILDL. SOC • BULL. 10(1):27-33.

AVER COND HUMAN INJ DETER/REPEL

, GEN, , ,

00778

MCC ULLOUGH, D.R.

IN PRES S

INTERPRETATION OF THE CRAIGHEADS' DATA ON YELLOWSTONE GRI ZZLY BEA $R$ POPULATIONS, AND ITS RELEVANCE TO CURRENT RESEARCH AND MANAGEME NT.

INT. CONF BEAR RES. AND MANAGE • 6 •

DEMOG ANAL POP EST POP REG PGE
MGMT GEN

YGBE, IMW,

00779

MCKNIGHT, D.E. (ED.).

1970

SURVEY-INVENTORY ACTIVITIES. PART II \& CARIBOU, BROWN BEAR, SHEEP, FURBEARERS, MAR INE MAMMALS, BISON, GOAT, WOLF, AND BLACK BEAR.

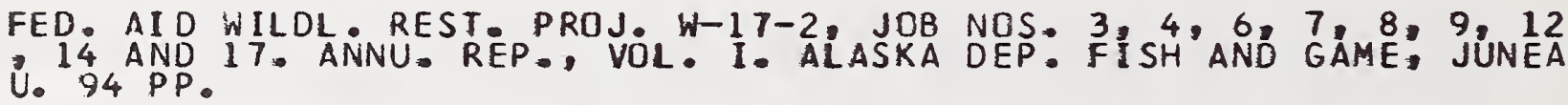

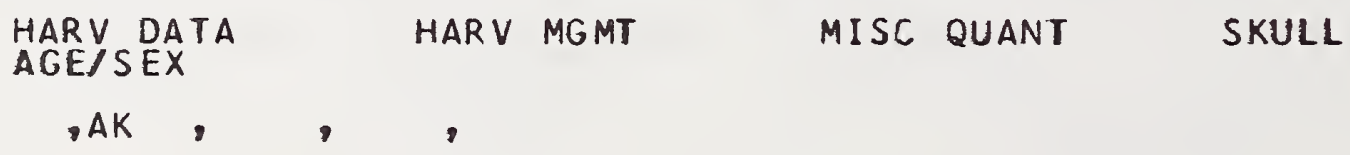

00780

MCKNIGHT, D.E. (ED.).

1971

SURVEY-INVENTORY ACITIVITES. PART II - CARIBOU, BROWN-GRIZZLYBEA R, SHEEP, FURBEARERS, MAR INE MAMMALS, BISON, GCAT, WOLF, WOLVER IN
E AND BLACK BEAR.

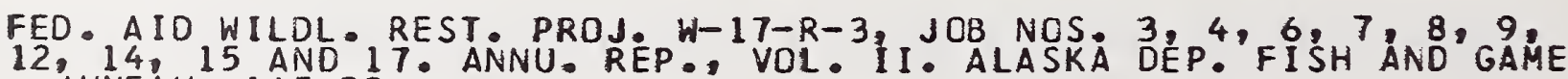
12 JUNEAU. 145 PP.
HARV DATA
MEAS/QUANT
SKULL
AGE/SEX 
00781

MCKNIGHT, D.E. IED.).

1973

SUR VEY - INVENTCRY ACTIVITIES PART II - CARIBOU, BROWN-GRIZZLY BEA R. SHEEP, MUSKOXEN, MARINE MAMMALS, BISON, GOAT AND BLACK BEAR.

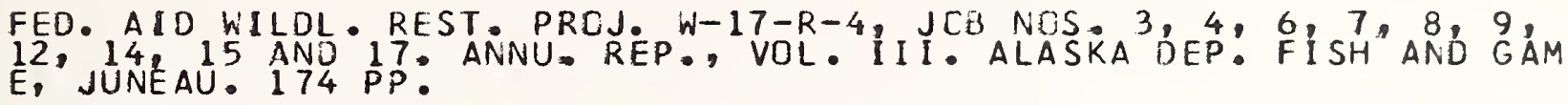
HARV DATA MCRT CATA

AGE/SEX

MEAS/QUANT SKULL , AK

00782

MCKNIGHT, D.E. (ED.).

$1974 A$

SUR VEY-INVENTORY ACTIVITIES. PART I. DEER, BRCWN-GRIZZLY BEAR, SH EEP, BISUN, ELK AND MUSKOXEN.

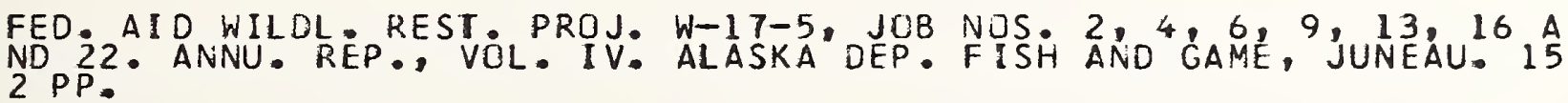

HARV DATA
AGE/SEX HARV MGMT
AK,

00783

MCKNIGHT, D.E. (ED.).

$1974 B$

SURVEY-INVENTORY ACTIVITIES, PART I. DEER, BROWN-GRIZZLY BEAR, SH EEP, BISON, ELK AND MUSKOXEN.

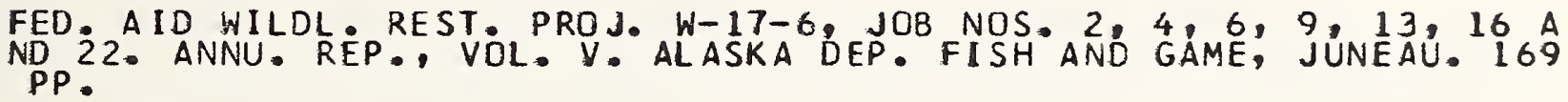

HARV DATA
AGE/SEX HARV MGMT
AK,

00784

MCKNIGHT, D.E. (ED.).

1976

SURVEY-INVENTORY ACTIVITIES. PART III. CARIBOU, BROWN BEAR, POLAR BEAR AND BLACK BEAR.

FED. AID WILDL. REST. PROJ. W- 17-7, JOB NOS, 3, $4,5,17$ AND 22.
ANNU. REP.? VOL. VI. ALASKA DEP. FISH AND GAME, JUNEAU. 157 PP.
HARV DATA
HARV MGMT
AGE/SEX
SKULL 
00785

MCLELLAN,,.$N$.

1981 A HOD FOR ESTIMATING THE WEIGHT CF GRIZZLY BEARS FROM BODY MEA SUREMENTS.

CAN. BORDER GRIZZLY PROJ., CRANBRCCK, B.C. 8PP.

WEIGHT LENGTH GIRTH

$$
, \text { GEN, , , }
$$

00786

MCLELLAN, B.N.

1981 B C).

B.C. FISH AND WILDL. BRANCH, VICTORIA. 88 PP.

$\begin{array}{llll}\text { GEN DATA } & \text { POP BIOL } & \text { MEAS/QUANT } & \text { REACTION } \\ \text { ROAD IMP } & & \\ \text { DEN } & & \end{array}$

C0787

MCLELLAN, B.N.

1983 ASPECTS OF THE BEHAVIOUR OF GRIZZLY BEARS IN RESPONSE TO HYOROCAR BON EXPLCRATION AND THE PRESENCE OF HUMANS.

ORAFT REP: CAN. BORDER GRIZZLY PROJ., B.C. WILDL. BRANCH, CRANBR
OCK• 50 PP:

ENERGY IMP ROAD IMP AIRCRAFT IMP REACTION
COVER

NCDE,BCMT, , ,NFLT

00788

MCLELLAN, B.N.

1984 POPULATION PARAMETERS OF THE FLATHEAD GRIZZLIES.

B.C. FISH AND WILDL. BRANCH, VICTORIA. 28 PP.

$\begin{array}{llll}\text { BRD AGE } & \text { LIIR FREQ } & \text { LITR SIZE } & \text { MORT RATE } \\ \text { POP DENS } & \text { AGE/SEX } & \text { DEMOG ANAL } & \\ \text { CR } B C, \quad, \quad \text {,NFLT } & \end{array}$


00789

MCLELLAN, B.N.

USE-AVAILABILITY ANALYSIS AND TIMBER SELECTION BY GRIZZLY BEARS.

PP. 163-166 IN: G.P. CONTRERAS AND $K$. E. EVANS, EDS. PROCEEDINGS-G RIZZLY BEAR HAEITAT SYMPOSIUM.U.S. C.A., FCREST SERV. INTERMOUNTA IN RES. STAT. DGDEN, UTAH. GEN. TECH. REP. INT-207.

HAB SAMPL

TIMB USE

$C R, B C, \quad, N F L T$

00790

MCLELLAN, B.N. AND C. JONKEL.

1980

AKAMINA-KISHINENA GRIZZLY PROJECT.

PP. 9-48 IN: C JONKEL, ED. ANNUAL REPORT NC. 5. BORDER GRIZZLY P ROJ., UNIV. MONT.: MISSCULA.

$\begin{array}{lll}\text { AGE/SEX } & \text { MEAS/QUANT } & \text { HCME RNG } \\ \text { MOVE } & \text { CUT USE } & \text { HABUSE }\end{array}$

NCDE, ABM, ,,$\quad$ AKKI

00791

MCLELLAN, B.N. AND R.D. MACE.

1985

BEHAVIOR OF GRIZZLY BEARS IN RESPONSE TO ROADS, SEISMIC ACTIVITY,
AND

PRELIMINARY REP. . CAN. BORDER GRIZZLY PROJ., CRANBRCOK, B.C. 53 P P.

$\begin{array}{llll}\text { ROAD IMP } & \text { ENERGY IMP } & \text { AIRCRAFT IMP } & \text { NONMOTOR IMP } \\ \text { MOTOR IMP } & \text { CCVER } & \text { REACTION } & \end{array}$

NCDE, BCMT, , , NFLT

00792

MCMURRAY, N., T. WERNER, T. THIER AND C. JONKEL. 1978

GRIZZLY BEAR RESPONSE TO HABITAT DISTURBANCE. PP $231-247$ IN: CO JONKEL ED. ANNUAL REPCRT NO. 3. BORDER GRIZZL
Y PROJ., UNIV. MONT.: MISSOULA.

DRUGS

MEAS/ GUANT

AGE / SEX

NCDE,MT, , , SFLT 
00793

MCNAMEE, T.

1984 THE GRIZZLY BEAR.

ALFRED A. KNCPF, NEW YCRK. 308 PP.

GEN BIDL MGMT GEN

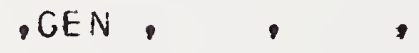

00794

MEAGHER, M.

1977

EVALUATICN OF BEAR MANAGEMENT IN YELLOWSTCNE NATIONAL PARK, 1976.

U.S.D. 1 NO NATL. PARK SERV.. YELLONSTONE NATL. PARK, WYO. RES. NOT CONTROL MGMT GEN PRES DISTR HUMAN INJ

YCBE,IMW, YNP,

00795

MEAGHER, M.

1978

EVALUATION OF BEAR MANAGEMENT IN YELLOWSTONE NATIONAL PARK, 1977. U.S.D.I: NATL. PARK SERV., YELLCWSTONE NATL. PARK, WYO. RES. NOT

$\begin{array}{llll}\text { MGMT GEN } & \text { HUMAN INJ AGNTROLISEX }\end{array}$

YGBE,IMW , YNP, ,

00796

MEAGHER, M. AND J.R. PHILLIPS.

RESTORATION OF NATURAL POPULATIONS CF GRIZZLY AND BLACK BEARS IN YELLOWSTONE NATIONAL PARK.

INT. CONF. BEAR RES. AND MANAGE. 5:152-158.

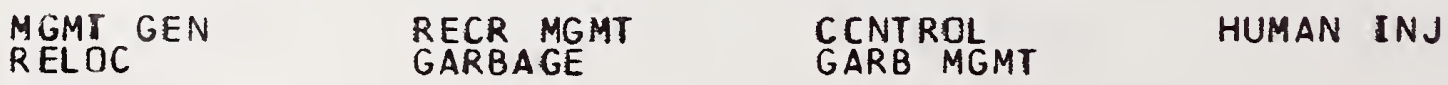

YGBE, IMW, YNP, , 
00797

NEALEY, S.P.

1975

THE NATURAL FUOD HABITS OF FREE RANGING GRIZZLY BEARS IN YELLOWST

CNE NAT IONAL PARK, 1973-1974.

M.S. THESIS, MUNT. STATE UNIV., BOZEMAN. 158 PP.
FOOD
PRED
HAB USE
SEAS BEH
NUTR ANAL
DIGEST

YGBE,WY, YNP,

00798

MEALEY, S•P.

1976

A SURVEY FOR GRIZZLY BEAR HABITAT ON THE MOUNT HEGBEN WINTER SPOR IS SPECIAL USE APPLICATION SITE AND ADJACENT AREAS.

PREP. FOR SKI YELLOWSTONE INC., WEST YELLOWSTONE, MONT. 22 PP.

HAB RECON HAB EFFECT MGMT GEN

YGBE,MT ,GANF, ,SKYL

00799

MEALEY, S.P.

$1979 A$

METHOD FOR DETERMINING GRIZZLY BEAR HABITAT QUALITY AND ESTIMATIN $G$ CONSEQUENCES DF IMPACTS ON GRIZZLY HABITAT QUALITY.

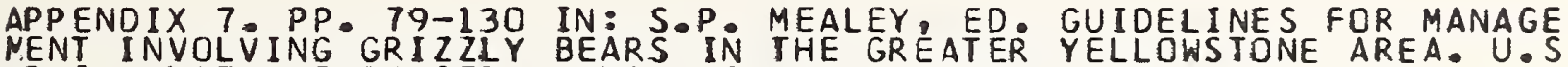
-D.I. NATL. PARK SERV. AND U.S.D.A., FOREST SERV.

HAB SAMPL MAP/TYPE CUM EFF FOD

HAB USE FIRE MGMT LIVESTK MGMT TIMB MGMT

TERR / SPACE
YGBE, IMW USFS, YNP,

00800

MEALEY, S.P. IED.I.

$1979 B$

GUIDELINES FOR MANAGEMENT INVOLVING GRIZZLY BEARS IN THE GREATER

YELLOWSTONE AREA.

U.S.D. I NATL. PARK SERV YELLOWSTONE NATL. PARK, WYO. AND U.S. D.A. FOREST SERV, BRICGER-TETON, SHOSHONE, CUSTER, GALLATIN AND TARGHEE NATL. FORESTS. 136 PP.
MGMT PLAN
ZONING
LIVESTK MGMT
TIMB MGMT
NONMOT MGMT
FIRE MGMT
CAMP MGMT
MOTOR MGMT

ENERGY MGMT

YGBE,IMW USFS, YNP. 
00801

MEALEY, S.P.

THE NATURAL FOOD HABITS OF GRIZZLY BEARS IN YELLOWSTONE NATIONAL PARK, $1973-74$.

INT - CONF. BEAR RES. AND MANAGE . 4:281-292.

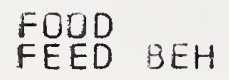
SCAT ANAL
SEAS BEH
NUTR ANAL
HAB USE

YGBE,IMN, YNP,

$\mathrm{CO} 802$

MEALEY, S.P. (ED.).

INO

U.S.D.A., FOREST SERV., U.S.D.I., NATL. PARK SERV , BUREAU CF LAN D MGMT W IDAHO FI SH AND GAME, MONTANA DEPT FISH WH ILDLIFE, AND P

$\begin{array}{llll}\text { MGMT PLAN } & \text { ZONING } & \text { TIMB MGMT } & \text { FIRE MGMT } \\ \text { LIVESTK MGMT } & \text { CAMP NGMT } & \text { NONAOT MGMT } & \text { MOTOR MGMT } \\ \text { ENERGY MGMT } & & & \end{array}$

00803

MEALEY, S.P. C. JOAKEL AND R. DEMARCHI.

1977

HABITAT CRITERIA FOR GRIZZLY BEAR MANAGEMENT.

PROC. INT. CONGR. GAME BIOL. 13:27t-289.

$\begin{array}{llll}\text { HAB EFFECT } & \text { FOOD } & \text { FIRE MGMT } & \text { TIMB-METH } \\ \text {,CAUS, IMP } & ,\end{array}$

00804

MEALEY, S.P., L. MARCUM, R. RIGHTER, C. JONKEL AND G. JOSLIN. 1976

VEGETATION STUDIES OF DISTURBED GRIZZLY HABITAT. PP. 5-34 IN: C DONKEL, ED. ANNUAL REPORT NO. 1. BOROER GRIZZLY P
ROJ.1 UNIV. MONT. MISSCULA.
HAB EFFECT
TIMB-METH
BURN USE/MGT
RUT USE
TIMB-HAB
FIRE MGM

NCDE,MT ,LONF, FLNF, WHR 
00805

MECH, L.D., R.C. CHAPMAN, W.W. COCHRAN, L. SIMMONS AND U.S. SEAL. RADIO-TRIGGERED ANESTHETIC-DART CCLLAR FOR RECAPTUR ING LARGE MAMM ALS.

WILDL. SOC. BULL. 12:69-74.

DRUGS

CAPTURE

TELEM

$$
\text { GEN, }
$$

00806

MEEHAN, W.R.

CBSIERVATIONS ON FEEOING HABITS AND BEHAVIOR OF GRIZZLY BEARS.

AM. MIDL. NAT. $65(2): 409-412$

FOOD CARCASS INTRASP BEH AGON

$B C-C, B C, \quad, N A K R$

00807

MEEHAN, W.R •

1974

THE FOREST ECOSYSTEM OF SOUTHEAST ALASKA, PART 4 - WILOLIFE HABIT ATS.

U.S.D.A. FOREST SERV : PACIFIC NORTHWEST FOR. AND RANGE EXPT. ST AT., PORTLAND, DREG. GEN. TECH. REP. PNW-16.

T IMB IMP

AKSE,AK, ,

00808

MEEHAN, W.R. AND J.F. THILENIUS. SAFETY IN BEAR COUNTRY: PROTECTIVE MEASURES ANC BULLET PERFORMANC

U.S.D.A. FOREST SERV PACIFIC NORTHWEST FOR • AND RANGE EXPT. ST AT.: PORTLAND, OREG. GEN. TECH. REP. PNW-152. 16 PP.

C CNTROL

, AK 
00809

MEHRHOFF, L.A.

1981

FORMAL SECTION 7 CONSULTATION REGARDING SHEEP GRAZING IN ESSENTIA L GRIZZLY BEAR HABITAT CN THE TARGHEE NATIONAL FOREST.

U.S.D.I. FISH AND WILOL. SERV. BOISE, IDAHO. CONSULTATICN NO. I LIVESTK IMP LIVESTK MGMT

YGBE, IDWY, TANF, ,

00810

MELQUIST, W.

1985

A PRELIMIARY SURVEY TO DETERMINE THE STATUS OF GRIZZLY BEARS IURS US ACTOS HORRIBILISI IN THE CLEARWATER NATIONAL FOREST CF IDAHO.

IDAHD COOP. WILDL. RES • UNIT, UNIV • IDAHO, MOSCOW. 54 PP.

PRES DISTR CENSUS/TREND HIST DISTR

SEE, ID ,CLNF, ,

00811

MERRIAM, C.H.

1904

FOUR NEW BEARS FROM NORTH AMERICA.

PROC. BIOL. SOC. WASH. 17:153-155.

TAXON/EVOL

$$
, G E N
$$

00812

MERRIAM, C.H.

DE 194 SIPTIONS OF THIRTY APPARENTLY NEW GRIZZLY AND BROWN BEARS FRO M NORTH AMER ICA.

PROC. BIOL. SCC . WASH. 27:173-196.

TAXON/EVCL 
00813

MERRIAM, C.H.

1916 NINETEEN APPARENTLY NEW GRIZZLY ANO BROWN BEARS FROM WESTERN AMER ICA.

PROC. BIOL. SOC, WASH. 29:133-154.

TAXON/EVOL

$$
\text { , GEN, , , }
$$

00814

MERRIAM, C.H.

1918

REVIEW OF THE GRIZZLY AND BIG BROWN BEARS OF NORTH AMERICA IGENUS URSUS, WITH DESCRIPTION OF A NEW GENUS, VETULARCTOS.

$U_{P P} . S . D . A .$, BUR. OF BICL. SURVEY, NORTH AM. FAUNA SER. NO. 41. 133

TAXON/EVOL

$$
, \text { GEN, , , }
$$

00815

MERRIAM, $\mathrm{C} \cdot \mathrm{H}$.

OISTRIBUTION OF GRIZZLY BEARS IN U.S.

CUTDOOR LIFE 50(6): 405-406.

HIST DISTR

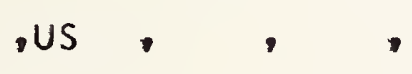

00816

MERRILL, E.H.

1978 DEPREDATIONS AT BACKCOUNTRY CAMPGROUNDS IN GLACIER NATIONAL BEAR DEP
PARK.

WILDL. SOC. BULL. $6(3): 123-127$.

DEPRED HUMAN INJ CAMP MGMT

NCDE,MT ,GLNP, , 
C0817

MEYER, W.H.

1978 FORMAL SECTION 7 CONSUL TATION REGARDING THE EFFECT OF TIMBER MANA CMENT ON THE TARGHEE NATIONAL FOREST ON GRIZZLY BEARS.

U.S.D.I $9 . F I S H$ AND WILOL. SERV., PCRTLAND, OREGCN. CONSULIATION N ROAD MGMT TIMB-METH TIMB-ENTRY TIMB-POST

YGBE,ID ,TANF, ,

C0818

MEYER, W.H.

1980 FCRMAL SECTION 7 CONSULTATION ON THE USE UF STRYCHNINE BAITS FOR NATIONAL FOREST.

U.S.D.I., FISH AND WILDL. SERV., PORTLAND, OREGCN. 12 PP.

POISON

YGBE, ID , TANF, ,

00819

MIHALIC, D.A.

1974

VISITUR ATTITUDES TOWARD GRIZZLY BEARS IN GLACIER NATIONAL PARK, MONTANA.

M.S. THESIS, MICH. STATE UNIV., EAST LANSING. 131 PP.

MGMT GEN

PUBLIC ATT ELUC

NCDE,MT ,GLNP, ,

00820

MILLER, G.0.

1980

BEHAVIORAL AND PHYSICLOGICAL CHARACTERISTICS OF GRIZZLY AND POLAR BEARS AND THEIR RELATICN TO BEAR REPELLENTS.

M.S. THESIS, UNIV. MONT, MISSOULA. 106 PP.

TEMP HEART DETER/REPEL 
C0821

MILLER, GoD. 1983
RESPONSE OF CAPTIVE GRIZZLY AND POLAR BEARS TO POTENTIAL REPELLEN
TS.

INT. CONF. BEAR RES. ANC MANAGE. 5:275-279.

DETER/REPEL

00822

MILLER, GD.

IN PRESS

INT - CONF. BEAR RES. AND MANAGE. 6.

DETER/REPEL

, GEN ,

00823

MILLER, G.S., JR.

1924 LIST OF NORTH AMERICAN RECENT MAMMALS.

U. S. NATL. MUS. BULL. NO. 128, GOV. PRINTING OFF, WASHINGTCN, D.
C. 673 PP.

TAXON/EVOL

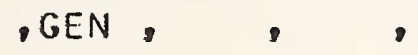

00824

MILLER, ReL. AND G.B. WILL.

1976

USE OF M99 ETORPHINE AND ANTAGONISTS TO IMMOBILIZE AND HANDLE BL CK BEARS.

INT - CONF. BEAR RES. AND MANAGE • 3:225-234.

DRUGS

, GEN, , ,

375 
00825

MILLER, $S, D$.

BIG GAME STUDIES: VOL. VI BLACK BEAR AND BRCWN BEAR.

SUSITNA HYDROELECTRIC PROJECT PHASE II, PROG. REP. ALASKA DEP. FI SH ANO GAME, JUNEAU.

$\begin{array}{llll}\text { AGE/SEX } & & \text { WEIGHT } & \text { REP RATE } \\ \text { MORT RATE } & \text { HOME RNG } & \text { FOOD } & \text { DEN } \\ \text { ENERGY IMP } & , \text {,NESU } & & \\ \text { AKSC,AK } & & \end{array}$

00826

MILLER, S.D.

1984

BIG GAME STUDIES: VOL. VI BLACK BEAR AND BROWN BEAR.

SUSIINA HYDRDELECTRIC PROJECT 1983 ANNUAL REP. ALASKA DEP. OF FIS H AND GAME, JUNEAU. 174 PP.

$\begin{array}{rlll}\text { REP RATE } & \text { HARV DATA } & \text { MOVE } & \text { HOME RNG } \\ \text { POP DENS } & \text { DEN } & \text { WEIGHT } \\ \text { POP BIOL } & \text { INTRASP BEH } \\ \text { AKSC,AK , , NESU } & & \end{array}$

00827

MILLER, S.D.

BIG GAME STUDIES: VOL. VI BLACK BEAR AND BROWN BEAR.

SUSITNA HYDROELECTRIC PROJECT PHASE II PROG. REP. ALASKA DEP. FIS H AND GAME. JUNEAU, AK. 142 PP.

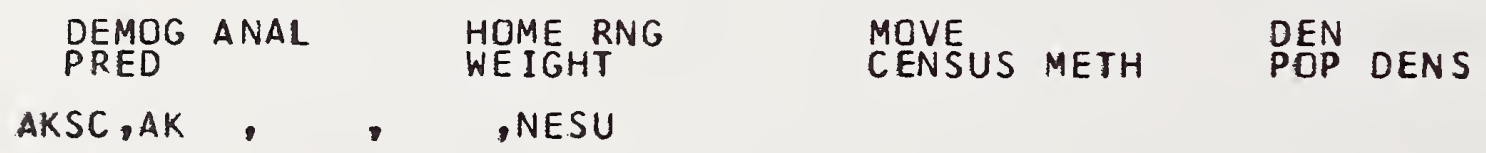

00828

MILLER, S.D.

$1985 B$

AN OBSERVATION OF INTER- AND INTRA-SPECIFIC AGGRESS ION INVOLVING BROWN BEAR, BLACK BEAR, AND MOOSE IN SOUTHCENTRAL ALASKA.

J. MAMMAL. $66(4): 805-806$.

INTRASP BEH INTERSP COMP PRED
AGON

TERR/SPACE

$A K S C, A K, \quad, N E S U$ 
$\cos 29$

MILLER, S. AND W.B. BALLARD.

1980 ESTMATES OF THE DENSITY, STRUCTURE AND BIONASS OF AN INTERIOR AL ASKA BRCWN BEAR POPULATION.

APPENDIX V.PP.82-123 IN: W.B. BALLARD. NELCHINA MOOSE CALF MORTA LITY STUDIES. FED. AID WILDL. REST. PREJ. W-17-9, $W-17-10, W-17-1$ 1 ANO W-2l-1, JOB 1.23R. ALASKA DEP. FISH ANU GAME, JUNEAU.

$\begin{array}{cccc}\text { CENSUS METH } & \text { POP EST } & \text { PCP DENS } & \text { HEMAT } \\ \text { MEAS/QUANT } & \text { WEIGHT } & \text { HCME RNG } & \text { MOVE } \\ \text { AGE/SEX } & \text {,NESU } & & \\ \text { AKSC,AK } & & \end{array}$

$\operatorname{CO} 830$

MILLER, S.D. AND W.B. BALLARD.

DENSATY AND BIOMASS ESTIMATES FOR AN INTERIOR ALASKAN BROWN BEAR, URSUS ARCTUS, POPULATION.

CAN. FIELD - NAT. $96(4): 448-454$

POP EST CENSUS METH PCP DENS

AKSC,AK, , NESU

00831

MILLER, S.D. AND W.B. BALLARD.

$1982 B$

HOMING OF TRANSPLANTED ALASKAN BROWN BEARS.

J. WILDL. MANAGE. 46(4):869-876.

RELOC MOVE ROAO IMP MATERNAL

AKSC,AK, , NESU

00832

MILLER, S.D., E.F. BECKER AND W.B. EALLARD.

IN PRESS

DENSITY ESTIMATES USING MODIFIED CAPTURE-RECAPTURE TECHNIQLES FOR BLACK AND BROWN BEAR POPULATIONS IN ALAKSA.

INT. CONF. BEAR RES. AND MANAGE. 7.

CENSUS METH POP DENS AGE/SEX

AKSC,AK, , NESU 
00833

MILLER, S.D. AND M.A. CHIHULY.

IN PRESS

INT. CUNF. BEAR RES. AND MANAGE. 7 .

MORT DATA HARV DATA HGE/SEX HUMAN IMP , AK, , ,

00834

MILLER, S.D. AND D.C. MCALLISTER.

BIG GAME STUDIES: PART VII, BLACK BEAR AND BROWN BEAR.

SUS ITNA HYDROELECTRIC PROJECT. ALASKA DEP. FISH AND GAME, JUNEAU.

$\begin{array}{llll}\text { AGE/SEX } & \text { WEIGHT } & \text { HARV DATA } \\ \text { DEN SITE } & \text { PCP DENS } & \\ \text { AKSC,AK, }, & \text {,NESU }\end{array}$

00835

MILLER, S.J., N. BARICHELLO AND D. TAIT.

1982 THE GRIZZLY BEARS OF THE MACKENZIE MOUNTAINS, NORTHWEST TERRITORI ES.

COMPLETION REP. N.W.T. WILDL. SERV., YELLOWKNIFE. 118 PP.

$\begin{array}{cccc}\text { GEN DATA } & \text { MEAS/QUANT } & \text { DEN } & \text { REP RATE } \\ \text { MORT RATE } & \text { POP DENS } & \text { PRED } & \text { MORT DATA } \\ \text { NINT,NWT } & , & \text { MMTN } & \end{array}$

00836

MODAFERRI, R.D.

1984

REVIEK OF ALASKA PENINSULA BROWN BEAR INVESTIGATIONS.

FED, AID WILDL REST PROJ W-17-10, W-17-1 $1, W-21-1, W-21-2$ AND W3 2 PP.

$\begin{array}{lccc}\text { COURT } & \text { REPRO } & \text { BRD AGE } & \text { REPRO PHYS } \\ \text { LITR SIZE } & \text { MORT RATE } & \text { WEAN } & \text { AGE/SEX } \\ \text { HARV DATA } & , B L K L & & \\ \text { AKPN,AK , } & , \text { BLE } & & \end{array}$


00837

MOEN, A.N. AND L. ROGERS.

1985 RADIANT SURFACE TEMPERATURES AND HAIR DEPTHS OF A BLACK BEAR, URS US AMERICANUS.

CAN. FIELD-NAT. $99(1): 47-50$.

TEMP PELAGE MGRPH/PHYS

, GEN, , ,

00838

MOHR, $\mathrm{C} . \mathrm{O}$.

TA47 OF EQUIVALENT POPULATIONS OF NORTH AMERICAN SMALL MANMALS.

AM. MIDL. NAT. 37:223-249.

HOME RNG

, GEN, , ,

00839

MONTANA DEPT. OF FISH, WILDLIFE AND PARKS.

1985 IGN FOR TOMORROW 198501190: A STRATEGIC PLAN FOR MANAGEMENT OF MONTANA.

MONTANA DEPT. FISH AND WILDL. PARKS, HELENA. 88 P.

MGMT GEN

, MT , , ,

00840

MONTANA DEPARTMENT CF STATE LANDS.

1986

PRELIMINARY FINAL JARDINE JOINT VENTURE EIS.

MONTANA DEPT. STATE LANDS, HELENA. (INTERNAL REVIEW DRAFT).

ENERGY IMP ENERGY MGMT

YGBE,MT , GANF, , JARD 
00841

MONTANA DEPI. OF FISH, WILDLIFE AND PARKS.

$1986 A$

1986 GRIZZLY HUNTING SEASON CLOSED.

MONT. DEPT. FISH, WILDL. AND PARKS. NEWS RELEASE, 17 OCT. 1976. $2 P P$

HARV MGMT HARV DATA

MT , , ,

00842

MONTANA DEPT. OF FISH, WILDLIFE AND PARKS.

$1986 B$

1986 GRIZZLY BEAR REGULATIONS.

MONTANA DEPT. OF FISH, WILDL. AND PARKS. 6 PP.

HARV MGMT

.MT , , ,

00843

MOORE, G.L. AND S.M. GILBERT.

1977

GRIZZLY BEAR HABITAT STUDY.

PREP. FOR U.S.D.A. FOREST SERV CONTRACT 262-50. PREP. BY CLSONELLIOTT AND ASSOC: HELENA, MONT. 73 PP.

MAP/TYPE HAB RECON

CYE , IDMT, KONF, ,

00844

MOORE, T.D., L.E. SPENCE AND C.E. DUGNOLLE.

1974 IDENTIFICATION OF THE DCRSAL GUARD HAIRS CF SOME MAMMALS OF WYOMI NG.

WYO. GAME ANO FISH DEP. LARAMIE. BULL. NO. 14. 186 PP.

HAIR

GEN, 
00845

MOORE, $W \cdot R$.

LAST OF THE BITTERROOT GRIZZLY.

MONTANA MAG. $68: 8-12$.

HIST DISTR HIST ACCT HUMAN IMP

SBE, IDMT, , ,

00846

NOULTON, J.E.

BILE DUCT CARCINCMAS IN TWO BEARS.

CORNELL VET. 61(2):285-293.

PARAS/DIS

, GEN, ,

00847

MUMMA, J.W.

1979

MINUTES FROM GRIZZLY BEAR MEETING - FEBRUARY 8, 1979, ST. ANTHONY - IDAHO.

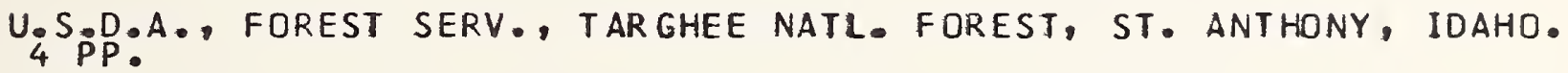
TIMB MGMT POISON

YGBE, ID, TANF, ,

00848

MUNDY, K.R.D.

1963

ECOLOGY OF THE GRIZZLY BEAR IURSUS ARCTOS, L.) IN GLACIER NATIONA L PARK, BRITISH COLUMBIA.

M. S. THESIS, UNIV. ALBERTA, EDMONTON. 103 PP.

GEN DATA

GROW/ DEV

$A G O N$

$B C-I, B C$, CGNP,
MEAS/ QUANT

AGE DETERM
REP RATE

PARAS/OIS
POP EST
REPRO PHYS 
C0849

MUNDY, K.R.D.

1971

BIBLIOGRAPHY OF BEARS.

B.C. FISH AND WILDL. BRANCH, CRANBROOK. TECH. BULL. NO. 1.30 PP.

BI BLIO

GEN,,$\quad$

00850

MUNDY, K.R.D. AND D.R. FLOOK.

1965 NOTES ON THE MATING ACTIVITY OF GRIZZLY AND BLACK BEARS.

J. MAMMAL. 45(4):637-638.

COPULATE THREAT CCURT

$\mathrm{EC}-I, \mathrm{BC}, \mathrm{CGNP}$,

00851

MUNDY, K.R.D. AND D.R. FLOOK. 1970
ECOLOGICAL STUDIES OF GRIZZLY BEARS IN THE NATIONAL PARKS CF CANA
CA.

CAN. WILDL. SERV. 99 PP.

$\begin{array}{lll}\text { GEN DATA } & \text { PCP BIOL } & \text { MEASIQUANT } \\ \text { NONMOT MGMT } & \text { HUMAN INJ MGMT } \\ \text { INTRASP BEH }\end{array}$

$B C-I, B C, C G N P$.

00852

MUNDY, $K \bullet R, D . A N D$ D.R. FLOOK.

1973 GACKGROUND FOR MANAGING GRIZZLY BEARS IN THE NATIONAL PARKS OF CA NADA.

CAN. WILDL. SERV. REP. SER. NO. 22. 35 PP.

POP EST

INTRASP BEH

$B C-1, B C, C G N P$,
POP DENS
PARASIDIS

REP RATE

GARB AGE
GEN DATA

CONTROL 
00853

MUNDY, K.R.D. AND W.A. FULLER.

1964

AGE DETERMINATION IN THE GRIZZLY BEAR.

J. WILDL. MANAGE. 28(4):863-866.

AGE DETERM SKULL DENT

GEN, , ,

00854

MURIE, A.

1944 THE WOL VES OF MOUNT MCKINLEY.

U.S.D.I . NATL. PARK SERV. FAUNA SER. NO. 5, U.S. GOV. PRINTING OFF., WASHINGTON, D.C. 238 PP.

INTERSP COMP PRED

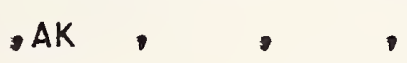

00855

MURIE, A.

1948

CATTLE ON GRIZZLY BEAR RANGE.

J. WILDL. MANAGE, $12(1): 57-72$.

DEPRED HIST ACCT

YGBE, WY ,BTNF, ,

00856

MURIE, A.

1981 THE GRIZZLIES OF MOUNT MCKINLEY.

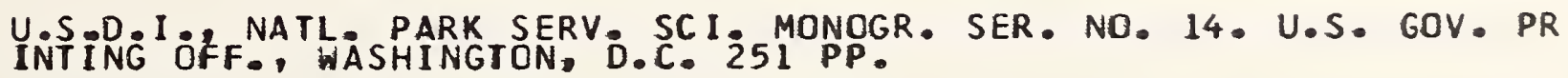

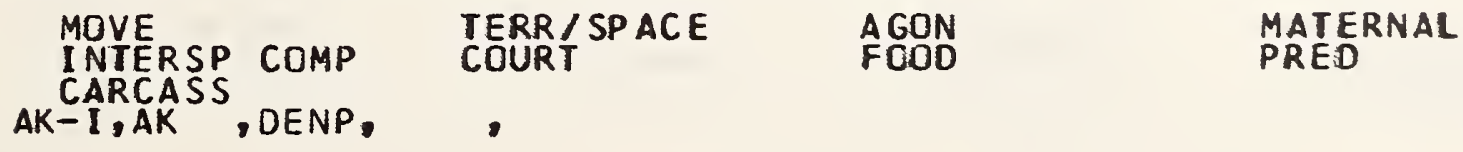


00857

MURIE, O.J.

1944

PROGRESS REPORT ON THE YELLOWSTONE BEAR STUCY.

U.S.D.I., NATL. PARK SERV., YELLCWSTONE NATL. PARK, WYO. 13 PP.
MGMT GEN
FOOD
GARBAGE
GARB MGMT

YGBE,WY , YNP, ,

00858

MYSTERUD, I .

1973

BEHAVIOR OF THE BROWN BEAR (URSUS ARCTOS) AT MOOSE KILLS.

NORW. J. ZOOL. 21:267-272.
PRED
FEED BEH
INTERSP COMP

$$
\text { , GEN , , , }
$$

$\operatorname{Cos} 59$

$N A G Y, J . A$.

RELATIONSHIP OF WEIGHT TO CHEST GIRTH IN THE GRIZZLY BEAR.

J. WILDL . MANAGE • 48(4):1439-1440.

WEIGHT

GIRTH

,CAN, , ,TUKP

C0860

NAGY, J.A. AND R.H. RUSSELL.

1978

ECOLOGICAL STUDIES OF THE BOREAL FOREST GRIZZLY BEAR IURSUR ARCTO S L.) - ANNUAL REPORT FOR 1977.

CAN. WILDL. SERV. 72 PP.

GEN DATA

MEAS/QUANT BORF,AT

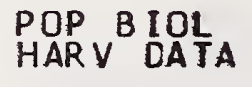

SWHI
POP DENS
GROW/DEV

INTERSP COMP WEAN 
00861

NAGY, J.A., R.H. RUSSELL, A.M. PEARSON, M.C. KINGSLEY, AND B.C. GOS KI

$1983 A$

ECOLOGICAL STUDIES OF THE GRIZZLY BEAR IN ARCTIC MOUNTAINS, NORTH ERN YUKON TERRITORY, 1972 TO 1975.

CAN.WILDL. SERV. 104 PP.

$\begin{array}{lccc}\text { DRUGS } & \text { MEAS/GUANT } & \text { GEN DATA } & \text { DEN } \\ \text { REP RATE } & \text { MORT DATA } & \text { POP DENS } & \text { POP BIDL } \\ \text { COURT } & & & \end{array}$

00862

NAGY, J.A., R.H. RUSSELL, A.M. PEARSON, M.C. KINGSLEY, AND C.B. LAR SEN.

19838

A STUDY OF GRIZZLY BEARS ON THE BARREN GRCUNDS CF TUKTOYAKTUK PEN INSULA AND RICHARDS ISLAND, NORTHWEST TERRITORIES, 1974 TC 1978.

CAN. WILDL. SERV. 136 PP.

$\begin{array}{lccc}\text { REP RATE } & \text { GEN DATA } & \text { PCP BIOL } & \text { HARV IMP } \\ \text { HARV MGMT } & \text { MEASIQUANT } & \text { MCRT DATA } & \text { DEN } \\ \text { POP DENS } & & \end{array}$

00863

NATIONAL PARK SERVICE.

1967

GRIZZLY BEAR ATTACKS AT GRANITE PARK AND TROUT LAKE IN GLACIER NA TIONAL PARK, AUGUST $13,1967$.

U.S.D.I., NATL. PARK SERV, GLACIER NATL. PARK, MONT. 22 PP.

HUMAN INJ

NCDE,MT, GLNP, ,

00864

NATIONAL PARK SERVICE.

FINAL ENVIRONMENTAL IMPACT STATEMENT GRIZZLY BEAR MANAGEMENT PROG RAM.

U.S.D.I., NATL. PARK SERV., YELLOWSTONE NATL. PARK, WYO. 202 PP.

$\begin{array}{lll}\text { MGMT PLAN } & \text { DEPRED } & \text { GARB MGMT } \\ \text { CONTROL } & \text { GEN DATA } & \text { CLOSURE }\end{array}$

YGBE,IMW , YNP , 
00865

NATIONAL PARK SERVICE.

$1984 \mathrm{~A}$

REAR/HUMAN CONFLICT MANAGEMENT ACTION PLAN.

U.S.D.I., NATL. PARK SERV., DENALI NATL. PARK, AK.

$\begin{array}{llll}\text { MGMT PLAN } & \text { RECR MGMT } & \text { CLOSURE } & \text { AVER COND } \\ \text { RELOC } & \text { GARB MGMT } & \text { EDUC } & \text { LEGAL } \\ \text { MONIT SYS } & & & \end{array}$

00866

NATIONAL PARK SERVICE.

$1984 B$

YELLOWSTONE OPERATING PROCEDURE: BEAR MANAGEMENT POLICY.

U.S.D.I., NATL. PARK SERV., YELLOWSTONE NATL. PARK, WYO. 7 PP.

EDUC MOTDR MGMT NONMUT MGMT GARB MGMT

YGBE, IMW, YNP, ,

00867

NATIONAL PARK SERVICE.

BOARD OF INQUIRY INTO THE DEATH OF: BRIGITTA FREDENHAGEN.

U.S.D.I. NATL. PARK SERV. 4 PP.

HUMAN INJ

YGBE,WY, YNP, ,WHIL

00868

NATIONAL PARK SERVICE.

19840 FISHING BRIDGE AND THE YELLOWSTDNE ECOSYSTEM. A REPORT TO THE DIR ECTCR. NOVEMBER 1984.

U.S.D.I. NATL. PARK SERV., YELLCWSTONE NATL. PARK, WYO. 151 PP.

CONTROL

MORT DATA

PRES DISTR

YGBE,WY YNP,

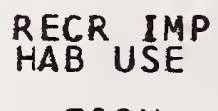

, FISH
HUMAN INJ

FDOD
RELOC
PRED 
C0869

NATIONAL PARK SERVICE.

$1984 E$

BROWN BEAR INCIDENT AND MANAGEMENT ACTION REPORT.

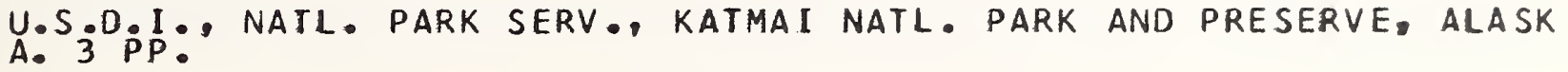
CONTROL HUMAN INJ DEPRED

AKPN,AK, KANM, ,

00870

NATIONAL PARK SERVICE.

$1985 A$

BEAR MANAGEMENT PLAN.

U.S.D.I. N NATL. PARK SERV., GLACIER NATL. PARK, MONT. 19 PP + APP
S.

$\begin{array}{llll}\text { MGMT PLAN } & \text { EDUC } & \text { GARB MGMT } & \text { CAMP MGMT } \\ \text { CONTROL } & \text { RELOC } & \text { CLOSURE } & \text { MONIT SYS } \\ \text { NONMOT MGMT } & & & \\ \text { NCDE.MT }, \text { GLNP, } & , & \end{array}$

00871

NATIONAL PARK SERVICE.

19858 9 AN BEL BEAR MANAGEMENT PLAN, YELLOWSTONE NATIONAL PARK, 1985 SEAS CN.

U.S.D.I. NATL. PARK SERV. YELLOWSTONE NATL. PARK, WYO. 5 PP.

MGMT PLAN RECR MGMT ECUC

YGBE, IMW, YNP, ,

00872

NATIONAL PARK SERVICE.

BEAR MANAGEMENT HUMAN USE ADJUSTMENT, YELLOWSTONE NATIONAL PARK.

U.S.0.I.. NATL. PARK SERV., YELLOWSTONE NATL. PARK, WYO. 20 PP.

NONMOT MGMT CLOSURE

YGBE, IMW, YNP, 
00873

NATIONAL PARK SERVICE.

19850

SUMMARIES OF BEAR CENTROL ACTIONS, MANAGEMENT REMOVALS, BEAR INJU RIES, AND CONFRONTATIONS.

U.S.D.I. NATL. PARK SERV., YELLCWSTONE NATL. PARK, WYO. 19 PP.

CONTRDL RELOC HUMAN INJ REACTION

YGBE, IMW', YNP, ,

00874

NATL. PARK SERVICE AND U.S. FOREST SERVICE

1985

OUTFITTER POLICY: GREATER YELLCWSTONE AREA.

U.S.D.I. NATL. PARK SERV. AND U.S.D.A., FOREST SERV. 76 PP.

OUTFIT MGMT CAMP MGMT

YGBE, IMW , , ,

00875

NEILAND, K.A.

$1974 \mathrm{~A}$

CARIBOU DISEASE REPORT.

FED AID WILDL REST. PROJ W-17-5 AND $W-17-6$, JOB 3.9R PRCG RE P. VOL XV. JAN. 1, 1973-DEC. 31, 1973. ALASKA DEP. FISH AND GAM E, JUNEAU. 33 PP.

PARAS/DIS REPRO

$A R C, A K, \quad, B R K R$

00876

NEILAND, K.A.

$1974 B$

FURIHER SEROLOGIC OBSERVATICNS ON THE OCCURRENCE OF RANGIFERINE B RUCELLOSIS IN SOME ALASKAN CARNIVCRES.

PP. 4-25 IN: K.A NEILAND. CAR IBOU DISEASE REPORT FED AID HILDL AN. 1, 1973-DEC. 31, 1973. ALASKA DEP. FISH AND GAME: JUNEAU.

PARAS/DIS REPRO

$A R C, A K, \quad, B R K R$ 
$\cos 87$

NEILAND, K.A.

1975

FURTHER OBSERVATIONS ON RANGIFERINE BRUCELLOSIS IN ALASKAN CARNIV CRES.

J. WILDL. DISEASES 1111):45-53.

PARAS/DIS REPRO

$A R C, A K, \quad, B R K R$

00878

NEILAND, $K \cdot A$.

1979

CARIBOU DISEASE STUDIES.

FED. AID WILDL. REST. PROJ.W-17-4 TO W-17-6, JOB 3.9R . FINAL REP 33 JULY 1, 1971-JUNE 20, 1978. ALASKA DEP. FISH AND GAME, JUNEAU. PARAS/DIS

AK , , ,

00879

NEILAND, K.A. AND L.G. MILLER.

1979

OBSERVATIONS ON EXPERIMENTAL RANGIFERINE BRUCELLOSIS INFECTIONS I $N$ DOMESTIC AND WILD ALASKAN CARNIVORES.

APPENDIX II PP. 39-68 IN: K.A. NEILAND. CARIBOU DISEASE STUDIES.

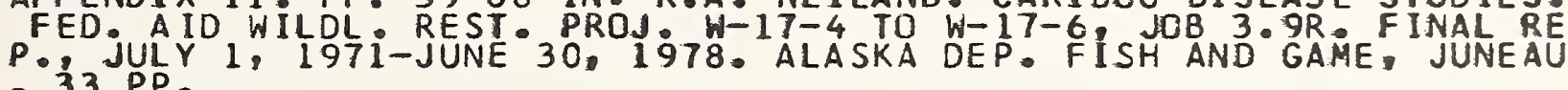
- PARASIDIS

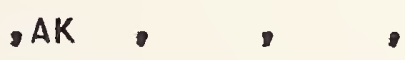

C0880

NEILAND, K.A. AND L.G. MILLER.

1981

EXPERIMENTAL BRUCELLA SUIS TYPE 4 INFECTIONS IN DOMESTIC AND WILD ALASKAN CARN IVORES.

J. WILDL. DIS. $17(2): 183: 189$.

PARAS/DIS

, AK , 
00881

NELSON, D.C.

1976

RUSSIAN RIVER RED SALMON STUDY.

ANADROMOUS FISH STUDIES, STUDY AFS 44-2. ANNU. PERFGRMANCE REP $Y$ CL. 17. ALASKA DEP. FISH AND GAME, JUNEAU. 71 PP.

PRED

$\triangle K P N, A K, \quad, K E N A$

00882

NELSON, R•A.

1973

WINTER SLEEP IN THE BLACK BEAR. A PHYSIOLOGIC AND METABOL IC MARVE L.

MAYO CLIN. PROC. 48:733-737.

HIB PHYS HEMAT TEMP HEART

GEN, , ,

00883

NELSON, R.A.

UREA METABOL ISM IN THE HIBERNATING BLACK BEAR.

KIDNEY INTER • 13(SUPPL. 8): \$177-\$179.

HIB PHYS HEMAT

, GEN , ,

00884

NELSON, R.A.

1980 PROTEIN AND FAT METABOLISM IN HIBERAATING BEARS.

FED. PROC. 39(12):2955-2958.

HIB PHYS TEMP HEMAT

GEN, , , 
00885

NEL SON, R.A.

1984

HUMAN SPACE TRAVEL AND STRESS MANAGEMENT: LESSCNS FROM HIBERNATIN G BEARS.

PP. 5-20 IN: J.E HAMNER II I, ED. THE 1984 DISTINGUISHED VISI TING HI S.

HIB PHYS HEMAT

$$
\text { GEN, , , }
$$

00886

NELSON, R.A. AND T.D.I. BECK.

1984

HIBERNATION ADAPTATION IN THE BLACK BEAR: IMPLICATIONS FOR MANAGE MENT.

PROC. EAST. WORKSHOP BLACK BEAR MANAGE. AND RES. 7:48-53.

HIB PHYS HEMAT MGMT GEN SUPPL FEED

GEN,

00887

NELSON, R.A., T.D.I. BECK AND D.L. STEIGER.

1984

RATIO OF SERUM CREATININE IN WILD BLACK BEARS.

SCIENCE 226(4676):841-842

HIB PHYS HEMAT

, GEN, , ,

00888

NELSON, R.A. G.E.FOLK, JR, E.W. PFEIFFER, J.J. CRAIGHEAC, C.J.J CNKEL 1983 A

BEHAVIOR, BIOCHEMISTRY, AND HIBERNATION IN BLACK, GRIZZLY, AND PO
LAR BEARS.

INT. CONF. BEAR RES. AND MANAGE . 5:284-290.

HIB PHYS

SEAS BEH

HEMAT

$$
\text { , GEN , }
$$

\section{,}




\section{C0889}

NELSON, R.A., J.D. JCNES, H.W. WAHNER, D.B. MCGILL AND C.F. CODE. 1975

NITROGEN METABOLISM IN BEARS: UREA METABOLISM IN SUMMER STARVAT IO $N$ AND IN WINTER SLEEP AND ROLE OF URINARY BLADDER IN WATER AND NI TROGEN CONSERVATION.

MAYO CLINIC PROC. 50:141-146.

HIB PHYS HEMAT PHYS CHEM

$$
\text { , GEN, }
$$

C0890

NELSON, R.A., D.L. STEIGER AND T.D.I. BECK.

1983B $K$ BEAR.

ACTA ZOOL. FENN = 174:137-141.

HIB PHYS

$$
\text { , GEN, },
$$

00891

NELSON, R.A., N.W. WAHNER, J.D. JONES, R.D. ELLEFSON AND P.E. ZOLLM AN.

1973

METABOLISM OF BEARS BEFORE, DURING, AND AFTER WINTER SLEEP.

AM. J. PHYSIOL. 224121:491-496.

HIB PHYS HEMAT

$$
, \text { GEN , , , }
$$

00892

NEL SON, U.C.

1948

INVESTIGATIONS OF THE HISTORICAL AND CURRENT HARVEST OF FUR AND G AME, PREDATORS TAKEN AND BOUNIIES PAID AND OTHER STATISTICS OF PE RTINENT VALUE FOR THE MANAGEMENT OF ALASKAN WILOL IFE.

FED. AID WILDL REST. PROJ W-3-R-4, JOB NO. 1, WORK PLAN 6. ALASK A GAME COMMISSION, JUNEAU. 7 PP.

HARV DATA

AK, , , 
00893

NELSON, U.C.

1951

INVESTIGATIONS AND COMPILATION OF THE HISTORIC AND CURRENT HARVES STICS OF VALUE FOR THE MANAGEMENT OF ALASKAN WILDLIFE. FED: AID WILDL: REST: PROJ W-3-R-5, WORK PLAN 7. ALASKA GAME COMM
ISSION, JUNEAU: 4 PP:

HARV DATA

, AK, , ,

00894

NELSON, U. C. 1955
COMPILATION OF DATA ON WILDLIFE HARVEST JULY 1,1954 TO JUNE 30,
1955 .

FED AID WILDL, REST PROJ. W-3-R-10, WORK PLAN D. ALASKA GAME CO HARV DATA

, AK, , ,

0.0895

NEWBURN, A.M.

BIG GAME, SMALL GAME AND FUR TAKE REPORT.

FED
3 PP. HARV DATA

AK , ,

00896

NIELSDN, P.L.

1975 PAST AND PRESENT STATUS OF THE PLAINS AND BCREAL FOREST GRIZZ LY BEAR IN ALBERTA.

CAN. WILDL. SERV. AND ALBERTA FISH AND WILDL. DIV. 65 PP.

HIST DISTR

HIST ACCT

PRES DISTR 
00897

NOB LE, $L . B$.

1972 MAN AND GRIZZLY BEAR IN BANFF NATIONAL PARK, ALBERTA.

M.A. THESIS, UNIV. CALGARY, CALGARY, 119 PP.

$\begin{array}{llll}\text { HIST DISTR } & \text { HIST ACCT } & \text { POACH/ILLEG } & \text { HARV IMP } \\ \text { HARV DATA } & \text { CCNTROL } & \text { GARBAGE } & \text { RECR IMP } \\ \text { RECR MGMT } & & \\ \text { CR IAT } \text {,BANP, } & & \end{array}$

00898

NOBLE, W.

1985

SHEPHERDIA CANADENSIS: ITS ECOLOGY, DISTRIBUTION AND UTILIZATION BY THE GRIZZLY BEAR.

SENIOR THESIS, UNIV, MONTANA, MISSOULA. 29PP.
FIRE MGMT
FOOD
HAB USE
TIMB-POST

NCDE,BCMT, , , NFLT

00899

NOLAN, J.W., R.H. RUSSELL AND F. ANDERKA.

1984

TRANSMITTERS FOR MONITORING ALDRICH SNARES SET FOR GRIZZLY BEARS.

J. WILDL. MANAGE. 48(3):942-945.

CAPTURE TELEM

CR AT JANP, ,

$\operatorname{co9} 90$

NORTHWEST TERRITORIES RENEWABLE RESOURCES.

1986

SUMMARY OF HUNTING REGULATIONS.

NORTHWEST TERRIROTIES RENEWABLE RES.

HARV MGMT

NWT, , 
00901

QGILVIE, R.T. AND T. TOTH.

1983

VEGETATION CLASSIFICATION IN THE CASCADE VALLEY.

PP 264-286 IN: D. HAMER AND S HERRERO, EDS. ECOLGGICAL STUDIES

OF THE GPIZZLY BEAR, BANFF NATIONAL PARK. PREP. FOR PARKS CANADA CONTRACT WR4-80. UNIV. CALGARY, ALBERTA. FINAL REP.

MAP/TYPE HAB USE

CR -AT ,BANP, ,CASC

C0902

OLSON, S.T.

1953 WINTER MORTALITY OF BLACK-TAILED DEER. FACTORS AFFECTING, EXTENT AND FREQUENCY. FED A AID WILDL: REST:PRDJ:W-3-R-7, JUB 1, WORK PLAN E. ALASKA G
AME COMMI SSION, JUNEAU. 2 PP.

\section{CARCASS PRED}

AKSE, AK, , ,

00903

CLSON, S.T.

1956

MANAGEMENT STUDIES OF ALASKA CARIBOU CALVING STLDIES - STEESE FOR TYMILE HERD.

FED. AID WILDL REST. PROJ. W-3-R-1 1, JOB NO. 3-B, WORKPLAN NO. B - ALASKA GAME COMMISSICA, JUNEAU. 5 PP.

PRED

AK-I, AK , , STEE

00904

OLSON, S.T.

1957

MANAGEMENT STUOIES OF ALASKA CARIBOU, SAMPLING OF KILL BY HUNTERS

- STEESE-FORTYMILE HERD.

FED. AID WILDL: REST. PROJ W-3-R-11, JOB 1B. ALASKA GAME CCMMISSI
CN, JUNEAU. 4 PP. HARV DATA

AK-I,AK, , STEE 
$\operatorname{cog} 05$

CNISHAK, M. AND D.S. STCCKSTAD.

1957

PRELIMINARY GRIZZLY BEAR INVESTIGATIONS.

FED. AID WILDL REST. PROJ. $W-71-R-3, J O B 3$, WORK PLAN A. JCB COM PLETION REP., JUNE 1-CCT. 1, 1957. MONT. DEP. FISH AND GAME, HELE NA. 12 PP.

HIST DISTR

NCDE, MI

C0906

CRME, M.L. AND R.G. WILLIAMS.

1986

COORDINAT ING LIVESTOCK AND TIMBER MANAGEMENT HITH THE GRIZZLY BEA $R$ IN SITUATION I HABITAT, TARGHEE NATIONAL FOREST. PP $195-203$ IN: G:P - CQNIRERAS AND K.E. EVANS, EDS. PROCEECINGS-G IN RES. STAT., OGDEN, UTAH. GEN. TECH. REP. INT-207.

TIMB - METH

TIMB-HAB

TIMB-ENTRY

LIVESTK MGMT

POISON

LIVESTK IMP

TIMB-POST

YGBE, IDWY, TANF,

C0907

CSMUNDSON, C.

1983

THE RELOCATION UF TWO GRIZZLY YEARLINGS INTO THE YAAK, 1981.

BORDER GRIZZLY PROJ., UNIV. MONTANA, MISSOULA. 23 PP.

$\begin{array}{ccll}\text { RELOC } & \text { INT/REINT } & \text { PUBLIC ATT } & \text { MOVE } \\ \text { HOME RNG } & \text { HABUSE } & \text { ACT PATT } & \text { DEN CHRCN } \\ \text { HIST DISTR } & \text {,YAKR } & & \\ \text { CYE ,MT } & , & & \end{array}$

00908

OTT, J.

TRI ICHINELLA SPIRALIS AND ITS POSSIBLE RELATIONSHIP TO ABNORMAL BE HAVIOR IN BEARS.

PREP. FOR SELKIRK COLLEGE, WILDLAND RECREATION II • 16 PP. 
00909

PALMISCIANC, D.

1986

GRIZZLY MORTALITIES UPDATE.

MONT. DEP. DF FISH, WILCL,, AND PARKS, BCZEMAN, MONT. 2 PP.

MORT DATA HARV DATA CCNTROL POACH/ILLEG

,MT , , ,

$\operatorname{cog} 10$

PALOHEIMO, J.E. AND D. FRASER.

ESTIMATION OF HARVEST RATE AND VULNERABILITY FRCM AGE AND SEX DAT

A.

J. WILDL. MANAGE. 45(4):948-958.

CENSUS METH HARV MGMT AGE/SEX

GEN, , , ,

00911

PALUMBO, P.J., N.A. BAGLEY, D.L. WELLIK AND R.A. NELSCN.

1983

INSULIN AND CLUCAGON RESPONSES IN THE HIBERNATING NORTH AMERICAN BLACK BEAR.

INT . CONF. BEAR RES. AND MANAGE. 5:29l-296.

HIB PHYS HEMAT

, GEN, , ,

00912

PARKS CANADA.

1984

BEAR MANAGEMENT PLAN, WATERTON LAKES NATIONAL PARK.

PARKS CANADA, WATERON LAKES NATL. PARK WARDEN SERVICE.

MGMT PLAN

CONTROL

CR , AT, WANP,
MGMT GEN

MON IT SYS
GARB MGMT

CLOSURE 
00913

PARSONS, L.D.

1976

THE POSSIBLE AFFECT ON A RELICT GRI ZZLY BEAR POPULATION OF LOOK-A

LIKE BLACK BEAR HUNTING IN WASHINGICN'S SELKIRK MOUNTAINS.

BORDER GRIZZLY TECHN. COMM., BORDER GRIZZLY PROJ., UNIV. MCNT., M ONT. HORKING PAP. 16 PP.

HARV IMP IDENT/RECOG ECUC

SME ,WA, ,

$\operatorname{cog} 14$

PARSONS, L.D.

GRIZZLYY BEAR SECTION.

PP. 62-72 IN: BIG GAME STATUS REPORT, 1976-1977. WASH. STATE GAME DEP., OL YMPIA.

PUBLIC ATT EDUC IDENT/RECOG

SME, WA, ,

00915

PEACOCK, D.A.

1978 CBSERVATIONS OF GRIZZLY BEARS IN THE APGAR MOUNTAINS, GLACIER NAT IONAL PAKR, MCNTANA.

MANUSCR IPT, 45 PP.

$\begin{array}{llll}\text { GEN DATA } & \text { CENSUS METH } & \text { INTRASP BEH } & \text { REACIION } \\ \text { BEHAV PATT } & \text { MGMT GEN } & \text { AIRCRAFT IMP } & \text { POACH/ILLEG } \\ \text { PELAGE } & & \\ \text { NCDE,MT GLNP, } & \text {,APGR } & & \end{array}$

00916

PEARSON, A.M.

1965 A

STUDY OF THE GRIZZLY BEAR IN THE YUKON.

CAN. WILDL. SERV. PROJ. NO. M5-1-2. 1964 PROG. REP . 13 PP.

$\begin{array}{llll}\text { PELAGE } & \text { ACT PATT } & \text { FOOD } & \text { REACTION } \\ \text { CENSUS METH } & \text { MISC QUANT } & \\ \text { INT,YK ,KLGS, } & \text {, ALSE } & \end{array}$


00917

PEAR SON, A.M.

STUOB OF THE GRIZZLY BEAR.

CAN. WILOL. SERV. PROJ. NO. M5-1-2. 1965 PROG. REP. 32 PP.

$\begin{array}{cccc}\text { FOOD } & \text { HAB USE } & \text { CAPTURE } & \text { AGE/SEX } \\ \text { MISC QUANT } & \text { WEIGHT } & \text { LENGTH } & \text { DRUGS } \\ \text { NINT,YK ,KLGS, } & \text {,ALSE } & & \end{array}$

00918

PEARSON, A.M.

1967
PROGRESS REPORT ON 1966 STUOY OF THE GRIZZLY BEAR - YUKON TERRITO
RY. CAN. WILDL. SERV. PROJ. NO. 96-5-5-122. 40 PP.

$\begin{array}{lll}\text { HAB USE } & \text { AGE/SEX } & \text { MEAS/QUANT } \\ \text { MOVE } & \text { AGE DETERM } & \text { WEHT } \\ \text { NINT,YK ,KLGS, } & \text { ALSE }\end{array}$

$\cos 19$

PEARSON, A.M.

1968 A

GRIZZLY BEARS IN THE YUKON TERRITORY.

PP. 40-42 IN: TRANS. 32ND FED.-PROV. WILOL. CONF. 99-11 JULY 1968
WHITEHORSE, YUKON TERR. CAN. WILDL. SERV. REP. SER. NO. 32.
AGE/SEX
LITR SIZE
REP RATE
FOOD

NINT,YK ,KLGS, ,ALSE

C0920

PEARSON, A.M.

PROGRESS REPORT ON 1967 STUDY OF THE GRIZZLY BEAR.

CAN. HILDL . SER. . PROJ. NO. 122. 83 PP.

\begin{tabular}{|c|c|c|}
\hline $\begin{array}{l}\text { AGE DETERM } \\
\text { MOVE }\end{array}$ & $\begin{array}{l}\text { SKULL } \\
\text { HAB USE }\end{array}$ & $\begin{array}{l}A G E / S E X \\
F G O D\end{array}$ \\
\hline
\end{tabular}

NINT, YK ,KLGS, ,ALSE 
$\cos 21$

PEARSON, A.M. (ED.)

PROCEEDINGS OF THE FIRST BEAR WORKSHOP.

PQOC. FIRST INT CONF, BEAR RES AND MANAGE, AUGUST 1968, WHIJEH CRSE: CAN. WILDL. SERV. INT. ASSOC. BEAR RES: AND MANAGE. 63 PP.

$\begin{array}{clll}\text { GEN DATA } & \text { MGMT GEN } & \text { CENSUS/TREND } & \text { RECR MGMT } \\ \text { AGE DETERM } & \text { TELEM } & \text { DRUGS } & \text { DEN } \\ \text { POP BIOL } & & \\ \text {,GEN } & & \end{array}$

00922

PEARSON, A.M.

1972

POPULATION CHARACTERISTICS OF THE NCRTHERN INTERIOR GRIZZLY IN TH E YUKON TERRITCRY, CANADA.

INT • CONF. BEAR RES. AND MANAGE. 2:32-35.
LITR SIZE
BRD $A G E$
MOVE
HOME RNG

NINT,YK ,KLGS, ,

00923

PEARSON, A.N.

1975

THE NORTHERN INTERIOR GRIZZLY BEAR URSUS ARCTOS L.

CAN. WILDL. SERV. REP. SER. NO. 34, OTTAWA. 86 PP.

$\begin{array}{llll}\text { DEMOG ANAL } & \text { GEN DATA } & \text { INTRASP BEH } & \text { MEAS/QUANT } \\ \text { REPRO PHYS } & \text { RES TECH } & \text { BEHAV PATI } & \text { REACTION }\end{array}$

NINT,YK, KLGS, ALSE

00924

PEARSON, A.M.

1976A

CAN. WILOL. SERV. $18 \mathrm{PP}$.

$\begin{array}{cccc}\text { AGE/SEX } & \text { HOME RNG } & \text { DEN } & \text { FOOD } \\ \text { WEIGHT } & \text { LENGTH } & \text { MISC QUANT } & \text { SKULL } \\ \text { BORF,AT } & , \text { SWHI } & & \end{array}$


00925

PEARSON, A.M.

19768

POPULATION CHARACTERISTICS OF THE ARCTIC MOUNTAIN GRIZZLY EEAR.

INT. CONF. BEAR RES. AND MANAGE = 3:247-260.

$\begin{array}{lccc}\text { GEN DATA } & \text { POP DENS } & \text { AGE/SEX } & \text { COURT } \\ \text { LITR SILE } & \text { WEAN } & \text { CANNIBAL } & \text { DEN SITE } \\ \text { WEIGHT } & & & \end{array}$

C0926

PEARSON, A.M.

1977

HABITAT, MANAGEMENT AND THE FUTURE CF CANADA'S GRIZZLY BEARS.

PP. 33-40 IN: PROC. SYMP. CANADA॰S THREATENED SPECIES AND HABITAT
PRES DISTR
FOOD
HARV MGMT
HOME RNG

$, C A N, \quad$,

00927

PEARSON, A.M.

1980

THE POTENTIAL IMPACT OF THE DEMPSTER LATERAL GAS PIPELINE CN GRIZ ZLY BEAR AND FOX IN THE MACKENZIE DELTA.

PREP. FOR FOOTHILLS PIPE LINES (YUKCN) LTD., CALGARY, ALBERTA. 17
PP. $\begin{array}{lll}\text { HAB USE } & \text { FODD EN ENERGY IMP }\end{array}$

CARC,NWT, , , $, \quad, I C H$

00928

PEARSON, A.M., R.M. BRACLEY AND T.R. MCLAUGHLIN.

1968 EVALUATION OF PHECYCLIDINE HYDROCHLORIDE AND OTHER DRUGS FOR IMMO BILIZING GRIZZLY AND BLACK BEARS.

J. WILDL. MANAGE. 32(3):532-537.

DRUGS

NINT, YK , , , 
00929

PEARSON, A.M. AND D.W. HALLORAN.

HEMATTOLOGY OF THE BROWN BEAR IURSUS ARCTOSI FRCM SOUTHWESTERN YUK ON TERR ITORY, CANADA.

CAN. J. ZOOL. 50:279-286.

HEMAT

NINT,YK, , ,

$\operatorname{Cog} 30$

PEARSON, A.M. D.C. MORRISON AND N. CLSEN.

1967 A RCCRO OF INTRASPECIFIC MORTALITY IN URSUS ARCTOS.

CAN. WILDL. SERVICE, EDNONTCN. 4 PP.

AGON CANNIBAL

NINT, YK , , ,

00931

PEARSON, A.M. AND J. NOLAN.

1976 THE ECOLOGY OF THE GRIZZLY BEAR (URSUS ARCTOS L.) IN JASPER NATIO NAL PARK - REPORT FOR 1975.

CAN. WILDL. SERV. 15 PP.

$\begin{array}{lll}\text { WEIGHT } & \text { FOOD } & \text { LENCTH } \\ \text { DEN } & \text { AGE DETERM } & \text { GIRTH }\end{array}$

CR ,AT JANP, ,

$\operatorname{cog} 32$

PELTON, M.R. AND L.C. MARCUM.

1977 THE POTENTIAL USE OF RADIOISOTOPES FOR DETERMINING DENSITIES OF 8 LACK BEARS AND OTHER CARNIVORES.

PP $221-236$ IN: RIL. PHILLIPS AND C JONKEL EDS. PROC. 1975 PRED SSOULA.

CENSUS METH

, GEN, , 
00933

PERENSOVICH, M.M.

1963

BROWN BEAR PREGRESS REPORT. 1960 THRU 1962.

U.S.D.A., FOREST SERV., NORTH TONGASS NATL. FOREST, JUNEAU. 40 PP $\rightarrow$

CENSUS/TREND HAB USE HARV DATA

AKSE,AK ,TONF, ,

C0934

PERENSOVICH, M.M.

1964

BROWN BEAR STUOIES.

INTERIM REP $1958-1963$ B. U.S.D.A. FOREST SERV. NORTH TCNGASS NAT
L. FOREST, JUNEAU. 42 P. $\begin{array}{llll}\text { CENSUS METH TITR SIZE } & \text { TIMB IMP }\end{array}$

AKSE,AK ,TONF,

00935

PERENSOVICH, M.M.

1966

BROWN BEAR STUDIES.

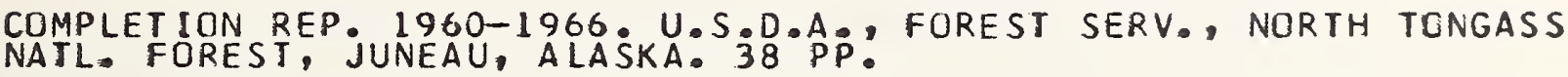

$\begin{array}{clll}\text { POP DENS } & \text { HAB USE } & \text { MORT DATA } & \text { GARBAGE } \\ \text { HARV DATA } & \text { TIMB IMP } & \text { LITR SIZE } & \text { AGE/SEX } \\ \text { TIMB MGMT } & & \end{array}$

00936

PERRY, J.L.

1977

PUBLIC DPINION ON GRIZZLY BEARS, NORTH FORK OF THE FLATHEAD STUDY AREA.

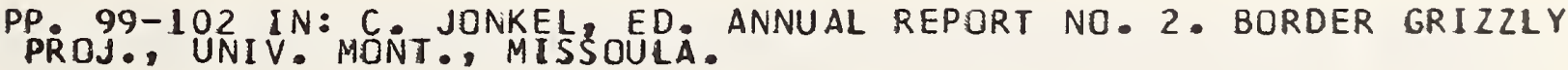

PUBLIC ATT

NCDE,MT, , ,NFLT 
$\cos 37$

PERRY, J.

1978

HANDLING CAPTURED BEARS: CAPTURE, DRUGGING, AND RADIO-CCLLARING. BORDER GRIZZLY TECH. COMM, BORDER GRIZZLY PRCJ., UNIV. MCNT.. MI
SSOULA. WORKING PAP: NO. 31.17 PP.

CAPTURE DRUGS

GEN, , ,

00938

PETERSON, R.L.

1965

A WELL-PRESERVED GRIZZLY BEAR SKULL RECOVEREO FROM A LATE GLACIAL

NATURE 208(50161:1233-1234.

HIST DISTR

, ONT, ,

00939

PETKO-SEUS, P.A., B.C. HASTINGS, W.E. HAMMITT AND M.R. PELTCN. 1985

PUBLIC ATTITUDES TOWARD COLLARS AND EAR MARKERS ON WILDLIFE.

WILDL. SOC. BULL. 13:283-286.

PUBLIC $\triangle T T$ GEN BIOL

GEN, , ,

$\operatorname{cog} 40$

PHILLIPS, M.K.

1983

HABITAT USE AND BEHAVIOR OF GRIZZLY BEARS IN THE ARCTIC NATIONAL hILDLIFE REFUGE.

ARCTIC NATL: WILDL REFUGE PROG REP. FY84-1: PP. 45-69 IN: G.W. GARNER AND P. E.REYNDLDS, ED, 1983 UPDATE REPORT BASELINE STUDY ERV FO̊ด ANCHORAGE. FO̊̊D HAB USE

BEHAV PATT

INTRASP BEH

$A R C, A K, A N W R$, 
00941

PHILLIPS, M.K.

1986

BEHAVIOR AND HABITAT USE OF GRIZZLY BEARS IN NORTHEASTERN ALASKA.

M.S. THESIS, UNIV. ALASKA, FAIRBANKS. 115 PP.

$\begin{array}{llll}\text { ACT PATT } & \text { COURT } & \text { BEHAV PATT } & \text { INTRASP BEH } \\ \text { FEED BEH } & \text { FCOD } & \text { CARCASS } & \text { PRED } \\ \text { HAB USE } & & \\ \text { ARC ,AK , ANNR, } & , & \end{array}$

00942

PHILLIPS, M.K.

IN PRESS
BEHAVIOR ANO HABITAT USE OF GRIZZLY BEARS IN NORTHEASTERN ALASKA.

INT. CONF. BEAR RES. AND MANAGE. 7 .

ACT PATT BEHAV PATT FOOD HAB USE

ARC, AK ANWR, ,

00943

PHILO, L.M., E.H. FCLLMANN AND H.V. REYNOLDS.

1981 FIELD SURGICAL TECHNIQUES FOR IMPLANTING TEMPERATURE-SENSITIVE RA FIELD SURGICAL TECHNIQUES FOR IMPLANI

J. WILDL. MANAGE. 45(3):772-775.

TELEM TEMP

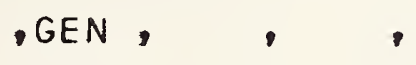

00944

PICTON, H.D.

1975

AN ASSESSMENT OF THE PROBABLE GRIZZLY BEAR AMINO ACID AND PROTEIN REQUIREMENTS. PREP. FOR INTERAGENCY GRIZZLY BEAR STUOY TEAM, BOZEMAN, MCNT. 8 P
P.

NUTR

, GEN 
00945

PICTON, H.D.

CLIMATE AND REPRODUCTION OF GRIZZLY BEARS IN YELLOWSTONE NATIONAL PARK.

NATURE 274(5674):888-889.
CLIMATE
FCOD
GARB AGE
LITR SIZE

YGBE, IMW, YNP, ,

00946

PICTON, H.D.

IN PRESS

CRIZZLY LINK? YELLOWSTONE AND GLACIER, ITS BIOLOGY AND DYNAMICS.

INT. CONF. BEAR RES. AND MANAGE. 6 .

$\begin{array}{llll}\text { CLIMATE } & \text { MOVE } & \text { PCP DENS } \\ \text { MGMIGEN } & & \end{array}$

C0947

PICTON, H.D. AND R.R. KNIGHT.

1961 BIG GAME SURVEYS AND INVESTIGATIONS. ELK AND BEAR SURVEYS.

FEO. AID WILDL REST.PROJ. NO, W-74-R-6, JOB A-1 JOB COMPLETION A. $38^{\prime} P \dot{P}$. HARV DATA

NCUE,MT ,SRGR, ,

00948

PICTON, H.D. AND R.R. KNIGHT.

1980

OBTAINING BIOLOGICAL INFORMATION FROM GRIZZLY BEAR IURSUS ARCTOS HORRIBILIS) HAIR.

PROC NORTHWEST SECTION OF WILDL. SCC., APRIL 8-10, 1980, BANFF, ALBERTA. 20 PP.

HAIR

AGE DETERM

, GEN, , ,


$\cos 49$

PICTON, H.D. AND R.R. KNIGHT.

IN PRESS

INT. CONF. BEAR RES. AND MANAGE. 6 .

CLIMATE LITR SIZE CARCASS

YGBE, IMin, ,

C0950

PICTON, H.D. D.M. MATTSON, B.M. BLANCHARD AND R.R. KNIGHT. 1986 CLIMATE, CARRYING CAPACITY, AND THE YELLCWSTCNE GRIZZLY BEAR.

PP 129-135 IN: G.P. CCNTRERAS AND K.E. EVANS, EDS PROCEECINGS-G RIZZLY BEAR HABITAT SYMPOSIUM U.S.D.A. FOREST SERVICE. INTERMOU ATAIN RES. STAT. OGDEN, UTAH. GEN. TECH. REP. INT-207.

$\begin{array}{lll}\text { CLIMATE MOVE } & \text { FCCD } & \\ \text { MGMT GEN } & \text { MORT DATA USE USE }\end{array}$

YGBE,IMW, , ,

00951

PICTON, J. AND P. ZAGER.

19855 WESTERN CABINET MOUTAINS GRIZZLY BEAR HABITAT SURVEY, 1985.

IDAHO FISH AND GAME, COEUR D'ALENE. $78 \mathrm{PP}$.
$\begin{array}{ll}\text { HIST } & \text { DISTR } \\ \text { TYPE DESCRIP }\end{array}$
PRES DISTR
RCAD MGMT
MGMT GEN

CYE, ID,

00952

PIRTLE, R.B.

1979

A COMP ILATION OF INCIDENTAL OBSERVATIONS OF BLACK AND BROWN BEAR IN PRINCE WILLIAM SCUND. ALASKA.

ALASKA DEP. FISH AND GAME, DIV . COMMERICAL FISHERIES, PRINCE WILL IAM SOUND MANAGE. AREA. DATA REP. NC. 12.15 PP.

PRES DISTR CENSUS/TREND

$A K-I, A K, \quad, \quad, P R W M$ 
$\operatorname{Cog} 53$

POCOCK, R.I.

1914
CN. THE FEET AND OTHER EXIERNAL FEATURES OF THE CANIDAE AND URSIDA
E. PROC. ZOOL. SOC. LONDON 1914(PART III):913-341.

MORPH/PHYS

, GEN , ,

C0954

POCOCK, R.I.

1928 STRUCTURE OF THE AUDITORY BULLA IN THE PRCCYONIDAE AND THE UR SIDAE, WITH A NOTE ON THE BULLA CF HYAENA.

PROC. ZOOL. SOC. LONDCN 1928 (PART IV):963-974.

MORPH/PHYS

, GEN , , ,

00955

POLACHECK, T.

1985

THE SAMPLING DISTRIBUTION OF AGE-SPECIFIC SURVIVAL ESTIMATES FROM AN AGE DISTRIBUTION.

J. WILDL. MANAGE. 49(1):180-184.

AGE/SEX CENSUS METH

$, G E N, \quad, \quad$,

00956

POST, K.L.

1982

HUMAN AND BEAR MOVEMENT, ACTIVITY AND INTERACTILN AT PACK CREEK, ALASKA.

M.S. THESIS, UNIV. IDAHC, MOSCOW. 174 PP.

NONMOT MGMT

BEHAV PATT

AKSE,AK ,AINM,
PUBLIC ATT

REACTION

- PACR
HAB USE
ACT PATT

MDVE

NDNMOTOR IMP 
PRUITT, C.H. AND G.M. BURGHARDT.

1977

COMMUNICATION AND URSIDAE.

PP. 767-793 IN: I.A. SEBEOK ED. HCW ANIMALS COMMUNICATE. VOL. 2. INNDIANA UNIV. PRESS, BLOOMINGTON.

$\begin{array}{llll}\text { SMELL } & & \text { BEHAV PATT } & \text { AGON } \\ \text { INTRASP BEH } & \text { VOCAL } & \text { MARK } & \text { THREAT } \\ & \text { SIGHT }\end{array}$

, GEN, , ,

00958

QUICK, R.

1969

HAND-REARING KODIAK BEARS.

INT. 200 YEARB. 9:160-16.3.

GROW/DEV ZCE TECH

$, G E N, \quad, \quad$,

$\operatorname{cog} 59$

QUIMBY, R.

1974

GRIZZLY BEAR.

CHAPTER II, 97 PP IN: R.D. JAKIMCHUK, ED MAMMAL STUDIES IN NORT HEASTERN ALASKA WITH EMPHAS IS WITHIA THE CANNING RIVER DRAINAGE. ARCTIC GAS BIOL. REP. SER. VOL. 24 .
POP BIOL
CARCASS
POP DENS
HAB USE
FOOD
AIRCRAFT IMP

CARCASS

$A R C, A K, \quad, E B R K$

00960

QUIMBY, R. AND D.J. SNARSKI •

1974

A STUDY OF FUR-BEARING MAMMALS ASSOCIATED WITH GAS PIPLINE ROUTES IN ALASKA.

CHAPTER 2 IN: R,D JAKIMCHUK, ED, DISTRIBUT ION OF MOOSE, SHEEP, M
USKOX AND FURBEARING MAMMALS IN NORTHEASTERN ALASKA. ARCTIC GAS B IOL. REP. SER. VOL. 6 .
PRES DISTR
PELAGE
POP DENS
CENSUS/TREND
FOOD
AGE/SEX
DEN SITE

$A R C, A K, \quad, E B R K$ 
C0961

RAINE, R.M. AND B.L. HOREJSI.

1984

AN INVESTIGATION OF THE DISTRIBUTION, MOVEMENTS, AND ACTIVITIES O F GRIZZLY BEARS IN THE SOUTH WAPITI REGICN OF ALBERTA. PRCG. REP. WESTERN WILDLIFE ENVIRONMENTS CONSULTING LTD., CALGARY. 81 PP.
PRES DISTR
MOVE
FCOD
HAB USE

CR .AT, , SWAP

00962

RAU, A. S.

1925

CONTRIBUTIONS TO OUR KNOWLEDGE OF THE STRUCTURE OF THE PLACENTA O F MUSTELIDAE, URSIDAE, AND SCIURIDAE.

PROC. ZOOL. SOC. LONDON 2925IPART III):1027-1069.

REPRO PHYS

GEN, , ,

00963

RAUSCH, R.A.

ÁLASKA PENINSULA BROWN BEAR STUDIES.

PP. 22-42 IN: ALASKA BROWN BEAR STUDIES. FED. AID WILDL. REST. PR CJ. W-3-R-13, WORK PLAN J. JUNE 20, 1958- SEP. 1, 1958. ALASKA GA ME COMMISSICN, JUNEAU.

$\begin{array}{llll}\text { AGE/SEX } & \text { CENSUSITREND } & \text { CENSUS METH } & \text { LITR SIZE } \\ \text { REP RATE } & \text { MORT RATE } & \text { CANNIBAL } & \text { HIST CISIR } \\ \text { POACHIILLEG } & & & \\ \text { AKPN,AK } & & \end{array}$

00964

$\mathrm{RAUSCH}, \mathrm{R} \oplus \mathrm{A}$.

1972
APPENDIX XV。 PREDATOR CONTROL AND BOUNTIES IN ALASKA IA 1971 REPO RT TO THE COMMITTEE).

PAGES 173-182; IN: S.A. CAIN, CHAIRMAN PREDATCR CONTROL-1971. REPORT TO COUNCIL ON ENVIRON, QUALITY AND DEP. OF INTERIOR. ADVIS - MICH., ANN ARBOR. LEGAL CCNTRCL DEPRED 
00965

RAUSCH, R.L.

1953 CN THE STATUS OF SOME ARCTIC MAMMALS.

ARCTIC 6:91-148.

$\begin{array}{lll}\text { MORPH/PHYS } & \text { TAXON/EVOL } & \text { SKULL } \\ \text { PELAGE } & \text { HIST DISTR } & \end{array}$

$A R C, A K, \quad$,

00966

RAUSCH, R.L.

1963

GEOGRAPHIC VARIATION IN SIZE IN NORTH AMERICAN BROWN BEARS, URSUS ARCTOS L., AS INDICATEC BY CONDYLOEASAL LENGTH.

CAN. J. ZCOL. $41: 33-45$.

SKULL TAXON/EVOL

, GEN . , , ,

00967

RAUSCH, R.L.

1969

MORPHOGENESIS AND AGE-RELATED SIRUCTURE OF PERMANENT CANINE TEETH IN THE BROWN BEAR, URSUS ARCTOS L., IN ARCTIC ALASKA.

2. MORPHOL. TIERE 66(2):167-188.

DENT SKULL AGE DETERM

ARC,AK , BROO, ,

00968

RAUSCH, R.L.

1973

RABIES IN ALASKA, PREVENTION AND CONTROL.

U. S. DEPT HEALTH, EDUCATION AND WELFARE, ARCTIC HEALTH RESEARCH CENTER, FAIRBANKS.

PARAS/DIS

, AK , 
00969

REID, M.M. AND S.D. GEHMAN.

1986

A COMMON SENSE APPROACH TO GRIZZLY BEAR HABITAT EVALUATION.

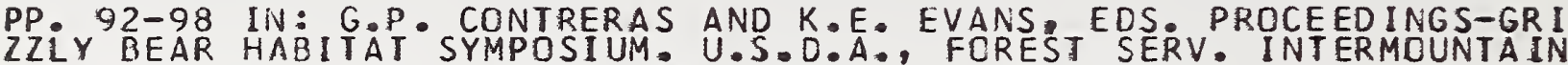
RES. STAT. OGDEN, UTAH. GEN. TECH•REP. INT-2C7.
HAB RECON
HAB SAMPL
RES TECH
RECR IMP

YGBE,IMW ,

C0970

REID, M., R. MULE AND B. RENFRCW.

19833 ASSESSMENT OF GRIZZLY BEAR UTILIZATION AND HABIJAT QUALITY IN THE CLARKS FORK SNOWMOBILE TRAIL CORRIDOR.

PREP. FOR DOUGLAS HART B-4 RANCH. PREP. BY KRA NAT. RESOUR . CONSU LTANTS, BOZEMAN, MCNT. 54 PP.

HAB RECON MCTOR IMP PRES DISTR

YGBE,WY, SHNF, ,

00971

REIGER, I.

SCENTT RUBBING IN CARNIVORES.

CARNIVORE $2(1): 17-25$.

MARK

TERR/SPACE

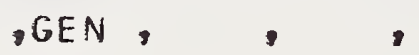

$\operatorname{cog} 72$

REINECKE, K.J. AND R.B. OWEN. 1980 FOCD USE AND NUTRITION OF BLACK DUCKS NESTING IN MAINE.

J. WILD. MANAGE. 44(3):549-555.

FOOD

, GEN , , , 
00973

REINHART, D. AND D. MATTSON.

1986

YELLOWSTONE LAKE TRIBUTARY STUOY.

PP. 52-66. IN: R PP. KNIGHTR B.M BLANCHARD AND D. MATTSON EDS RAGENCY STUDY TEAM 1985. U.S.D.I.. INTERAGENCY GRIZZLY BEAR STUD $\checkmark$ TEAM, BOZEMAN, MONT

PRED

YGBE,WY, YNP, ,LAKE

00974

REMINGTON, J.C.

EXTENT OF BEAR RANGE IN COLORADO.

COLO. DIV. OF WILOL . DENVER. 15 PP.

HIST DISTR

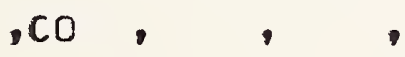

00975

RETFALVI, L.I.

1975

FOOD OF GRIZZLY BEARS IN BANFF NATIONAL PARK, 1972-73.

CAN. WILDL. SERV. 31 PP.

FOOD

CR ,AT ,BANP,

00976

REVENTLOW, A.

THE KODIAK BEAR CUB "URSULA."

ZOOL. GART. 20(4-5):279-282.

ZOO TECH

, GEN 
$\cos 77$

REVUSKY, S. AND E.W. BEDARF.

1967 ASSOCIATION OF ILLNESS WITH INGESTION OF NOVEL FOOO.

SCIENCE 155:219-220.

AVER CONO

, GEN, , ,

00978

PEYNOLDS, H.V.

1975 GAME INVESTIGATIONS. MOVEMENTS AND POPULATICN DISCRETENESS OF NORTH SLOPE GKILZLY BEARS. COMPARISON OF CENSUSING TECHNICUES OF NORTH SLDPE GRIZZLY BEARS: FOOD HAEITS OF NORTH SLOPE GRIZZLY BE ARS. AIO WILDL. REST. PROJ.W-17-6, JOB NOS, 4.8R, 4. IOR AND 4.11 FED AID WILDL. REST PROJ. W-17-6, JOB NOS, $4.8 R, 4$. IOR AND 4.11 NO GAME, JUNEAU. 26 PP.
AGE/SEX
MEAS/QUANT
REP RATE
$A G O N$
CENSUS METH
FOOD
MOVE

ARC AK, ,, ,EBRK

00979

REYNOLDS, H.V.

1976 BIG GAME INVESTIGATIONS. MOVEMENTS AND POPULATION DISCRETENESS DF NORTH SLOPE GRIZZLY BEARS. CCMPARISON OF CENSUSING TECHNIGUES OF ARS. AID WILDL REST PROJ W-17-6, JOB NOS 4.8R, 4.10R AND 4.11 FED A AID WILDL REST, PROJ. W-17-6, JOB NOS $4.8 R, 4$. $10 R$ AND $4=11$ AME, JUNEAU. 21 PP.
AGE/SEX
HOME RNG
REP RATE
CENSUS METH
MEAS/QUANT
MOVE

ARC,AK, , ERRK

$\cos 80$

REYNOLDS, H.V.

1978

STRUCTURE, STATUS, REPRCDUCTIVE BIOLOGY, MOVEMENT, DISTRIBUTION A ND HABITAT UTILIZATION OF A GRIZZLY BEAR POPULATION IN NPR-A.

FEU. AIO WILDL. REST PROJ, 105C STUDIES, WORK GROUP NO. 3. FINA LREP. APR. 1, 1977-SEP. 30, 1978. 61 PP.

$\begin{array}{lcll}\text { GEN DATA } & \text { POP EST } & \text { PCP DENS } & \text { CENSUS METH } \\ \text { AGE/SEX } & \text { REP RATE } & \text { MORT RATE } & \text { CARCASS } \\ \text { DEN } & \text {,WBK ,NPR, WRE } & & \end{array}$


00981

REYNOLDS, H.V.

1980

BIG GAME INVESTIGATICNS CHARACTER ISTICS OF GRIZZLY BEAR PREDATIO N ON CARI ECU IN THE CALVING GRCUNDS OF THE WESTERN ARCTIC FERD.

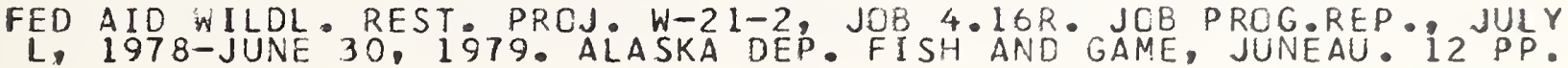
PRED
PUP DENS
CARCASS
FEED BEH

$A R C, A K, \quad, B R K R$

$\operatorname{cog} 82$

REYNOLDS, H.V.

1981

NORTH SLOPE GRIZZLY BEAR STUDIES.

FED. AID WILDL REST PROJ. W-2 - I, JOB $4.14 R$. JOB PROG. REP., VO
1. II. ALASKA DEP. FISH AND GAME, JUNEAU. 27 PP.
POP EST
MORT DATA
POP DENS
A GE / SEX
HEME RNG
REP RATE

$A R C, A K, \quad, B R K$

00983

REYNOLDS, H.V.

1982

ALASKA RANGE GRIZZLY BEAR STUDIES.

FED. AID WILDL. REST. PROJ W-21-2, JOE 4.16R. PROJ P PROG = REP .

VOL. I. ALASKA DEP. FISH AND GAME, JUNEAU. 12 PP.
POP DENS
HARV DATA

$A K-I, A K, \quad, \quad, \quad, \quad, \quad, \quad, \quad$,

00984

REYNOLDS, H.V.

1984

GRIZZLY BEAR POPULATION BIOLOGY IN THE WESTERN BROOKS RANGE, ALAS $\mathrm{KA}$.

APP A PP 2-19 IN: H,V REYNOLDS AND J.L. HECFTEL,EDS S STRUCTUR E, STATUS, REPRCDUCTIVE BIOLOGY, MCVEMENT, CISTR IBUT ION, ANC HABI TAT UTILIZATION OF A GRIZZLY BEAR POPULATION. FED. AID WILCL. RES T. PROJ. FINAL REP.
POP DENS
POP EST
BRD AGE
LITR SIZE
$A G E / S E X$
LITR FREQ
MCR T RATE

$A R C, A K, \quad, W B R K, B R K R$ 
00985

REYNOLDS, H.V., J.A. CURATOLO AND R. QUIMBY.

1976 DENNING ECCLOGY OF GRIZZLY BEARS IN NORTHEASTERN ALASKA.

INT. CONF. BEAR RES. AND MANAGE. 3:403-409.

DEN SITE DEN CHAR DEN CHRON

ARC, AK, , ,EBRK

00986

REYNULDS, H.V. AND J.L. HECHTEL.

1980 BIG GAME INVESTIGATIONS. STRUCTURE, STATUS, REPRODUCTIVE BIOLOGY, MOVEMENTS, DISTRIBUTICN AND HABITAT UTILIZATICN OF A GRIZZLY BEA R POPULATIÓN. FED. AID NILOL. REST. PROJ. W-17-11, JOB $4.14 R \cdot$ JOB PROG. REP.
ULY 1. 1978 JUNE $20,1979$. ALASKA DEP. FISH AND GAME, JUNEAU. 66
PP.

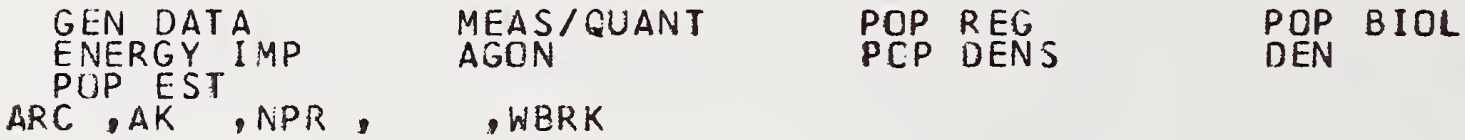

$\operatorname{cog} 87$

REYNOLDS, H.V. AND J. HECHTEL.

KORITH SLOPE GRI ZZLY GEAR STUDIES.

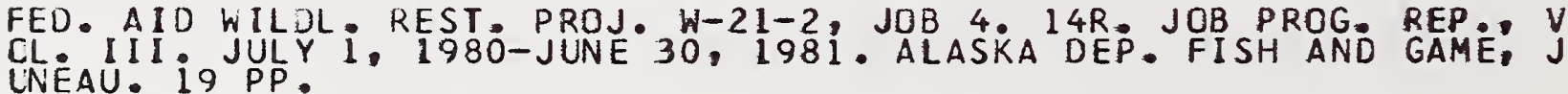
LNEAU. 19 PP.

REP RATE

HE IGHT

$A R C, A K$
MORT DATA MORT RATE

MCVE

- WBRK

00988

REYNOLDS, H.V. AND J•L. HECHTEL.

$1983 A$

POPULATION STRUCTURE, REPRODUCTIVE BIOLOGY, AND MOVEMENT PATTERNS OF GRIZZLY BEARS IN THE NDRTHCENTRAL ALASKA.

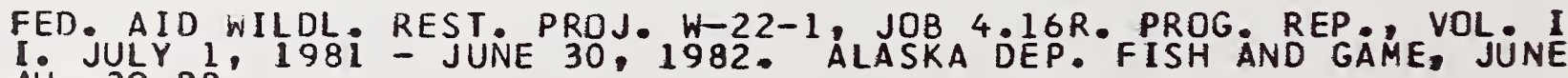
AU. JULY 29 PP:
POP DENS
AGE/SEX
MOVE
BRD AGE
HCME RNG

$A K-I, A K, \quad, A K R G$ 
00989

REYNOLDS, H.V. AND J.L. HECHTEL.

$1983 B$ STRUCTURE, STATUS, PEPRCDUCJ IVE BIOLOCY, MOVEMENT, DISTRIBUTION,
AND HABITAT UTILIZATION OF A GRIZZLY BEAR POPULATION.

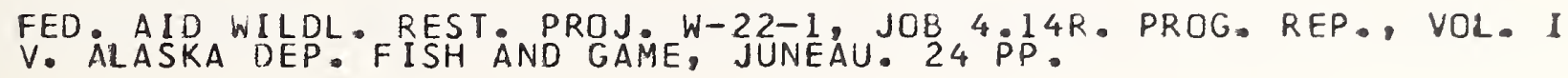

$\begin{array}{lll}\text { REP RATE } & \text { MORT DATA } & \text { DEN CHRON } \\ \text { HOME RNG } & \text { AGE/SEX } & \text { WEIGHT }\end{array}$

$A R C, A K, \quad, B R K$

$\operatorname{co9} 90$

REYNOLDS, H.V. AND J.L. HECHTEL.

1984A

POPULATION STRUCTURE, REPRODUCTIVE BIOLOGY, AND MOVEMENT PATTERNS OF GRIZZLY BEARS IN THE NORTHCENTRAL ALASKA RANGE.

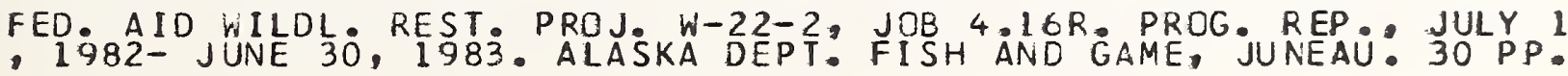

$\begin{array}{llll}\text { POP DENS } & \text { AGE/SEX } & \text { REP RATE } & \text { MORT DATA } \\ \text { MOVE } & \text { HOME RNG } & \text { DEN } & \text { WEIGHT }\end{array}$

$A K-I, A K, \quad, A K R G$

00991

REYNOLDS, H.V. AND J.L. HECHTEL.

STR4B B AND HABITAT UTILIZATION OF A GRIZZLY BEAR POPULATION.

FED. AID WILDL. REST.PROJ $W-21-1, W-21-2, W-22-1, W-22-2, J O B \quad 4$ NDR FINAL REP. JULY 1, 1979- JUNE 30, 1983. ALASKA DEP. FISHA

$\begin{array}{lccc}\text { POP DENS } & \text { POP EST } & \text { AGE/SEX } & \text { MORT RATE } \\ \text { BRDAGE } & \text { LITR SIZE } & \text { LITR FREQ } & \text { CANNIBAL } \\ \text { WEIGHT } & \text {,WBRK } & & \end{array}$

00992

REYNOLDS, P., H.V. REYNOLDS AND E.H. FOLLMANN.

IN PREESS LASKA.

INT. CONF. BEAR RES. AND MANAGE. 6 .

HEART

ENERGY IMP

AIRCR AFT IMP

ENERGY MGMT

$A R C, A K, N P R, \quad, B R K R$ 
00993

RIDLEY, J.

1976

REAR-HUMAN MANAGEMENT AT THE PROPOSED KANANASK IS PROVINCIAL PARK (DRAFT).

ALBERTA RECREATION PARKS AND WILDL. 30 PP.

EDUC GARB MGMT DETER/REPEL NONMOT MGMT
CLOSURE
CR AT, KANP,

$\operatorname{co994}$

RIEGELHUTH, R.

1966 GRIZZLY BEAPS AND HUMAN VISITATION.

M.S. THESIS, COLO. STATE UNIV., FT. COLLINS, 80 PP.

RECR IMP

$$
\text { GEN, , , }
$$

00995

RIGGS, R.A.

1979

AN ALTERNATIVE MANAGEMENT DESIGN FOR REDUCING HUMAN/BEAR CONFLICT $S$ IN THE CAMAS CREEK DRAINAGE.

U.S=D.I \& NATL. PARK SERV., GLACIER NATL. PARK, MONT • 14 PP.

CAMP MGMT NONMOT MGMT

NCDE,MT, GLNP, ,CAMA

00996

RIGGS, R.A. AND C. ARMOUR.

1981

A HYPOTHESIS FOR PREDICTING GRIZZLY BEAR HABITAT USE IN SPRING FL CODPLAIN HABITAT MOSAICS WITH SPECIAL REFERENCE TO REDUCING HUMAN - BEAR CONTACT RATES.

U.S.D.I. NATL. PARK SERV=, GLACIER NATL. PARK, MONT. 28 PP.

HAB USE MOVE

NCDE,MT ,GLNP, , 
00997

ROBERGE, A. AND R. CHARBONNEAU.

ACTIVITIES OF UREA CYCLE ENZYMES IN LIVER CF BRONN BEARS.

COMP. BIOCHEM. PHYSIOL. 38(B):295-298.

MORPH/PHYS

$$
\text { GEN, , , }
$$

00998

ROBINSON, R.

1972
HYBRIDIZATION AMONG THE URSIDAE.

CARNIVORE GENETICS NEWSL. 2(3):61-63.

GENETICS

$, G E N, \quad$,

00999

ROCKWELL, S.K.. J.L. PERRY, M. HAROLDSON AND C. JCNKEL. 1978

VEGETATION STUDIES OF DISTURBED GRIZZLY HABITAT.

PP 17-68 IN: C. JONKEL, ED. ANN. REP. NO. 3. BORDER GRIZZLY PROJ

$\because$ UNIV. MENT. MISSOULA.
HOME RNG
HAB USE
MEAS/QUANT
HAB EFFECT
$A G E / S E X$
DEN SITE

NCDE,MT, , , NFLT

01000

ROGERS, L.L.

1976

EFFECTS OF MAST AND BERRY CROP FAILIURES ON SURVIVAL, GROWTH AND REPRODUCTIVE SUCCESS FCR BLACK BEARS.

PROC. NORTH AM. WILDL. AND NAT, RESOUR - CONF. 41:431-438.

$\begin{array}{lll}\text { POP REG } & \text { FOOD } & \text { NUTR }\end{array}$


01001

ROGERS, L.L.

1978

EFFECTS OF FOOD SUPPLY, PREDATION, CANNIBALISM, PARASITES, AND OT FER HEALTH PROBLEMS ON BLACK BEAR PCPULATIONS.

PP. 194-211 IN: F.L BUNNELL, D.S. EASTMAN AND, J.M.PEEEK, ECS SY CUVER, B.C:

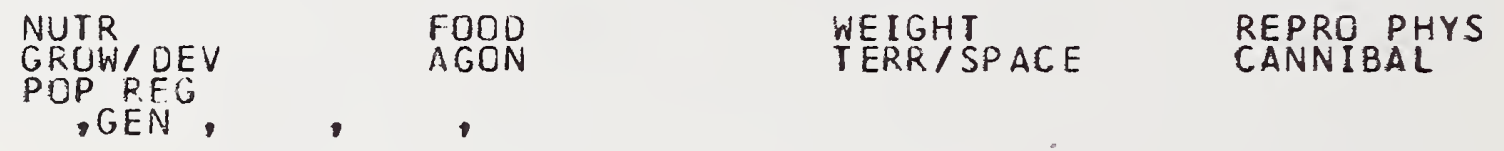

01002

ROGERS, L.L.

1980

INHERITANCE UF COAT COLOR AND CHANGES IN PELAGE COLORATION IN BLA CK BEARS IN NORTHEASTERN MINNESOTA.

J. MAMMAL. $61(2): 324-327$.

PELAGE

GEN, , ,

01003

ROGERS, L.L. 1984
REACTIONS OF FREE-RANGING BLACK BEARS TO CAPCAICIN SPRAY REPELLEN
T.

WILDL. SOC. BULL. $12: 59-61$.

DETER/REPEL

$$
\text { , CEN, , }
$$

01004

ROGERS, L.

1986

EFFECTS OF TRANSLOCATICN DISTANCE CN FREQUENCY OF RETURN BY ADULT BLACK BEARS.

WILDL. SOC. BULL. 14:76-80.

RELOC

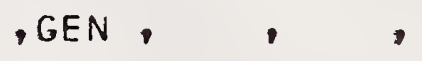


01005

ROGERS, L., D. KUEHN, A. ERICKSON, E. HARGER, L. VERME AND J. OZOGA 1976

CHARACIER ISTICS AND MANAGEMENT OF BLACK BEARS THAT FEED IN GARBAG E DUMPS, CAMPGROUNDS OR RES IDENTIAL AREAS.

INT. CONF. BEAR RES. AND MANAGE. 3:169-175.

GARBAGE WEIGHT

, GEN, , ,

01006

ROGERS, L.L. AND S.M. ROGERS.

PARASITES OF BEARS: A REVIEW.

INT. CONF. BEAR RES. AND MANAGE, 3:411-430.

PARAS/DIS

$, G E N, \quad, \quad$,

C1007

ROGERS, L.L., C.M. STOWE AND A.W. ERICKSON.

SUCCINYLCHOL INE CHLORIDE IMMOBILIZATION OF BLACK BEARS.

INT - CONF. BEAR RES. AND MANAGE - 3:431-446.

DRUGS

, GEN, ,

01008

ROGNURD, M.

1956

GRIZZLY BEAR SURVEY.

FED. AID WILDL. REST: PROJ, W-71-R, W-72-R, W-74-R, JOB A-T JOB ME DEP. HELENA: 9 PP.
HARV DATA
AGE/SEX
CENSUS/TREND
LITR SIZE

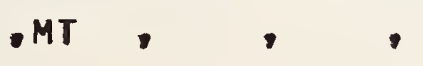


ROOP, L.

1975

GRIZZLY BEAR STUDY.

FED. AID WILDL. REST PROJ. W-87-R-1, JOB NOS
REP. WYO. GAME AND FISH DEP., GAME DIV., LARAMIE. 20 AND 3. PROG. $\begin{array}{llll}\text { PRES DISTR } & \text { CENSUS METH } & \text { MORT DATA } & \text { HARV DATA } \\ \text { AGE/SEX } & \text { LITR SIZE } & \text { MOVE } & \text { FOOD }\end{array}$

YGBE,WY ,SHNF, BTNF,

01010

ROOP, L.

1976

GRIZZLY BEAR STUDY.

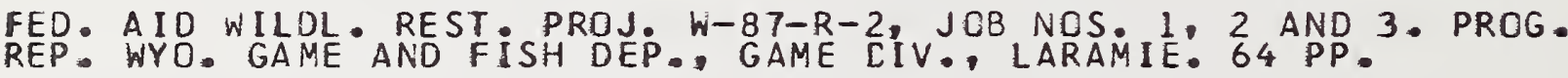
PRES DISTR
HARV DATA
HAB USE
AGE/SEX
CENSUS METH
MORT DATA

YGBE, MT ,BTNF, SHNF,

01011

ROOP, L.

1977

GRIZZLY BEAR.

FED. AID WILDL. REST. PROJ. W-87-R-2, JOB NOS, 1, 2 AND 3. PROU. REP: WYO. GAME AND FISH DEP.. GAME CIV., LARAMIE. 47 PP.

$\begin{array}{llll}\text { PRES DISTR } & \text { CENSUS METH } & \text { DEPRED } & \text { MORT DATA } \\ \text { POACH/ILLEG } & \text { RES MORT } & \text { MOVE } & \text { HOME RNG }\end{array}$

YGBE,MT, SHNF, BTNF,

01012

ROUP, L.

1978

GRIZZLY BEAR。

FED. AID WILDL. REST. PROJ. W-27-R-30, JOB NOS. I AND 2. PROG. RE P. WYO. GAME AND FISH DEP., GAME DIV., LARAMIE: 61 PP.

$\begin{array}{llll}\text { DEPRED } & \text { NONMOTOR IMP } & \text { MORT DATA } & \text { HOME RNG } \\ \text { MOVE } & \text { AGE/SEX } & \text { ORPHAN } & \text { PRES DISTR }\end{array}$

YGBE, WY, SHNF, BTNF, 
01013

ROOP, L.

1979

GRIZZLY BEAR.

FED. AID WILOL. REST PROJ.W-27-R-30, JOB NOS I, 2 AND 3. PROG.
REP. WYO. GAME AND FISH DEP. GAME DIV LARAMIE. 26 PP. PRES DISTR DEPRED MORT DATA WEIGHT

YGBE,WY ,SHNF, BTNF,

01014

ROOP, L.

$1980 \mathrm{~A}$

GRIZZLY BEAR.

FED AID. WILDL. REST \& PROJ $W-27-R-30$, JOB NOS 1,2 AND 3. PROG

PRES DISTR COPULATE NCNMOTOR IMP MORT DATA

YGBE,WY , BTNF, SHNF,

01015

ROOP, L.

$1980 B$

THE YELLOWSTONE GRIZZLY BEAR: A REVIEW OF PAST AND PRESENT POPULA TION ESTIMATES.

PP. 61-75 IN: R.R KNIGHT:B.M. BLANCHARD, K.C. KENDALL AND L.E. CLDENBURG, EDS. YELLOWSTONE GRIZZLY BEAR INVESTIGATIONS ANNUAL R EPORT OF THE INTERAGENCY STUDY TEAM, 1978 AND 1979. BOZEMAN, MONT

- CENSUS METH POP EST MORT DATA DEMOG ANAL

YGBE, IMW, , ,

01016

ROOP, L.

1981

GRIZZLY BEAR.

FEO. AID WILDL. REST. PROJ. $W-27-R-30, J O B$ NOS, 1,2 AND 3. PROG. REP: WYO. GAME AND FISH DEP. GAME CIV., LARAMIE. 33 PP.
PRES DISTR
MORT DATA
PUBLIC ATT
DEPRED
NCNMOTOR IMP
LITR SIZE 
01017

ROOP, L.

1982

GRIZZLY BEAR.

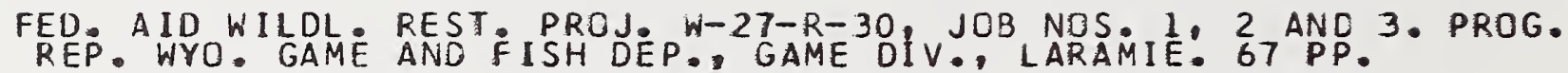

$\begin{array}{llll}\text { CLIMATE } & \text { PRES DISTR } & \text { MCRT DATA } & \text { POACH/LLEG } \\ \text { RELOC } & \text { NONMOTOR IMP } & \text { AGE/SEX } & \text { WEIGHT }\end{array}$

YGBE,WY, SHNF, BINF,

01018

ROOP, L.

1983

GRIZZLY BEAR.

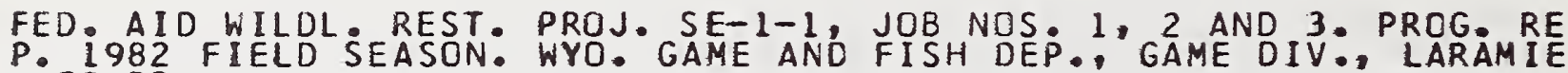
$\because 59$ PP.

PRES DISTR

$A G E / S E X$

RES MORT

YGBE,WY , SHNF, BINF,

01019

ROTH, H.U.

1980 DEFECATION RATES OF CAPTIVE BROWN BEARS.

INT. CONF. BEAR RES. AND MANAGE. 4:249-253.

DIGEST

, GEN ,

01020

ROTH, H.U.

1983 DIEL ACTIVITY OF A REMNANT POPULATION OF EUROPEAN BROWN BEARS.

INT. CONF. BEAR RES. AND MANAGE. 5:223-229.
RELOC
WEIGHT

PCACH/ILLEG
MOTOR IMP

MORT CATA

NONMOTOR IMP 
01021

ROTHWEILER, RA.

1964 BIG GAME SURVEYS AND INVESTIGATIONS - ANTELOPE, BIGHORN SHEEP, MO UNTAIN GOATS AND BEAR.

FED. AID WILL. REST.PROJ. $W-74-R-9$, JOB AT JOB COMPLETION REP - mar 1, 1963-APF. 30, 1964. MONT. FISH AND GAME DEP. HELENA. 9

HARE DATA

NCDE,MT , , ,

01022

RUEDIGER, W. AND S. MEDLEY.

1978

COORDINATION GUIDELINES FOR TIMBER HARVESTING IN GRIZZLY BEAR HAB ITAT IN NORTHWESTERN MONTANA.

U.S.D.A F FOREST SER, KOOTENAY NATL. FOREST, MONT. AND SHOSHONE
NATL. FOREST, WYO. $44^{\circ}$ PP.

ROAD IMP ROAD MGM

TIMB-METH

YGBE, WY, SHNF,

01023

RUSSELL, A.

GRIZZLY COUNTRY.

$$
\begin{array}{ll}
\text { TIME IMP } & \text { TIME MGM } \\
\text { COVER } & \text { HAB USE }
\end{array}
$$

JARROLDS PUBLISHERS LTD., LONDON. 302 PP.

HIST ACCT

, GEN,

01024

RUSSELL, D. 1974 GRIZZLY BEAR MOUNTAIN GOAT INVESTIGATIONS IN KNIGHT INLET, B.C.,
SUMMER 1974.

PROS. REP. B. C. FISH AND WILL. BRANCH, VICTORIA. 84 PP.

$$
\begin{array}{lll}
\text { CENSUS METH } & \text { CENSUS/TREND } & \text { MOVE } \\
\text { FOOD } & \text { TIME USE } & \text { TIME IMP } \\
B C-C, B C, H A B &
\end{array}
$$

425 
C1025

RUSSELL, R.H., J.H. NOLAN, N.G. WOOCY AND G.H. ANDERSON.

1979 A STOY OF THE GRIZZLY BEAR IN JASPER NATIONAL FARK, 1975 TO 1978 -

PREP. FOR PARKS CANADA. PREP. BY CAN. NILDL. SERV., EDMONTCN. 136 PP.

$\begin{array}{llll}\text { GEN DATA } & \text { MEAS/QUANT } & \text { AGEJSEX } & \text { ORPHAN } \\ \text { POP BIDL } & \text { POP DENS } & \text { NCNMOT MGMT } & \text { DEN } \\ \text { CDURT } & & \\ \text { CRT , JANP, } & , & & \end{array}$

01026

RUSSELL, R.H., J.W. NOLAN, N.G. WOOOY, G.H. ANCERSON AND A.M. PEARS CN.

1978

A STUOY OF THE GRIZZLY BEAR (URSUS ARCTOS) IN JASPER NATICNAL PAR K: A PROGRESS REPORT 1976 AND 1977 .

PREP. FUR PAKKS CANACA. PREP. BY CAN. 'NILDL. SERVICE, EDMONTON, A LEERTA. 95 PP.

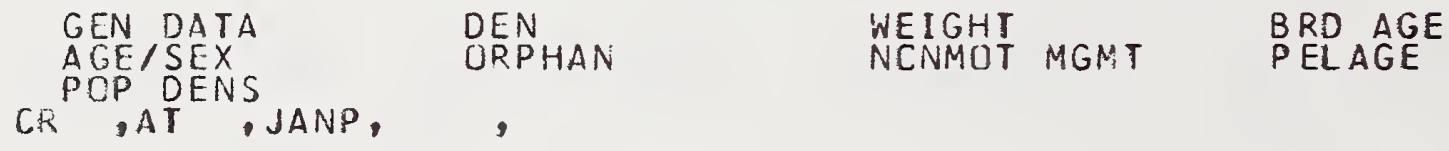

01027

RUSSELL, W.C.

1970

HYPOTHYROIDISM IN A GRIZZLY BEAR.

J. AM. VET . MED. ASSOC . 157151:656-662.

PARAS/DIS NUTR

, GEN, , ,

01028

RUTTAN, R.A.

1974

CBSERYATIONS OF GRIZZLY BEAR IN THE NORTHERN YUKON TERRITORY AND MACKENZIE RIVER VALLEY, 1972.

CHAPTEF VII IN: R.A.RUTTAN AND D.R WOLLEY, EDS STUDIES CF FURB EARERS ASSOCIATED WITH PROPOSED PIPELINE ROUTES IN THE YUKON AND NOR THWEST TERRI TORIES. ARCTIC GAS BICL. REP. SER. VOL. 9.

PRES DISTR

PELAGE $A$ IRCRAFT IMP
MOVE

ACE / SEX

PRED
DEN

INTERSP COMP 
01029

SALWASSER, H.

1983

WILDLIFE POPULATION VIABILITY: A QUESTION OF RISK.

TRANS NORTH AM. WILDL. AND NAT. RESCUR CONF. 49:421-439.

MGMT GEN GENETICS

, GEN, ,

01030

SALWASSER, H. AND F.B. SAMSON.

1985

CUMULATIVE EFFECJS ANALYSIS: AN ADVANCE IN WILDLIFE PLANNING AND MANAGEMENT.

PRES. AT 5OTH N. AM. WILDL. NAT. RES. CONF. WASHINGTON, D.C. 14 PP.

CUM EFF

, GEN, , ,

01031

SAMSON, F.B.

1983

MINIMUM VIABLE POPULATICNS - $\triangle$ REVIEW.

NATURAL AREAS JUURNAL 3(3):15-23.

MIN POP GENETICS

, GEN, , ,

01032

SAMSON, F.B., F. PEREZ-TREJO, H. SALWASSER, L.F. RUGGIERO AND M.L. SHAFFER .

1985

CN DETERMINING AND MANAGING MINIMUM POPULATICN SIZE.

HILL. SOC. BULL. 13:425-433.

MIN POP

, GEN . 
01033

SAMUEL, M.D. AND E. O. GARTON.

1985 HCME RANGE: A WEIGHTED NORMAL ESTIMATE AND TESTS DF UNDERLYING AS SUMPTIONS.

J. WILDL. MANAGE. 49(2):513-519.

HOME RNG

$$
, G E N \text {, }
$$

01034

SCAGGS, G.B.

VEGETATION DESCRIPTION OF POTENTIAL GRIZZLY BEAR HABITAT IN THE S ELWAY-BITTERRUOT WILDERNESS AREA, MCNTANA AND IDAHO.

M.S. THESIS, UNIV. MONTANA, MISSCULA, 148 PP.

HAB EFFECT

SBE, IDMT, BINF, NPNF, SBWA

01035

SCHALLENBERGER, A.

1974

RECDNNAISSANCE SURVEY OF GRIZZLY BEAR HABITAT, ROCKY MOUNTAIN DIV ISION, LEWIS AND CLARK NATIONAL FOREST.

BORDER GRIZZLY PROJ.: UNIV. MONT., MISSOULA. 14 PP + APP.

$$
\text { HAB RECON HAB USE PRES DISTR }
$$

NCDE,MT ,LCNF, ,

01036

SCHALLENBERGER, A.

1976

GRIZZLY BEAR HABITAT SURVEY BADGER CREEK-SOUTH FORK TWO MEDICINE MANAGEMENT UNIT, LEWIS AND CLARK NATIONAL FOREST.

BORDER GRIZZLY PROJ. UNIV. MONT., MISSOULA. 21 PP + APP.

$\begin{array}{llll}\text { HAB EFFECT } & \text { LIVESTK IMP } & \text { PRES DISTR } & \text { HAB USE } \\ \text { POP DENS } & \text { CAMP MGMT } & \text { MOVE }\end{array}$

NCDE,MT ,LCNF, ,BACR 
01037

SCHALLENBERGER, A.

REVIEW OF OIL AND GAS EXPLOITATION IMPACTS CN GRIZZLY BEARS.

INT - CONF. BEAR RES. AND MANAGE • 4:271-276.

ENERGY IMP HUMAN IMP

NCDE,MT, ,

01038

SCHALLENBERGER, A. AND C. JONKEL.

1978 A

CRITIQUE OF THE U.S.F.S. ROCKY MOUNTAIN FRONT PLAN.

BORDER GRIZZLY PROJ., UNIV. MONT. MISSOULA. SPEC. REP. NC. 12.2 5 PP.
RDAD IMP
ROAC MGMT
FIRE MGMT
MGMT GEN

NCDE, MT ,USFS,BLM, RMEF

01039

SCHALLENBERGER, A. AND C.J. JONKEL.

$1978 B$

ROCKY MOUNTAIN EAST FRONT GRIZZLY STUDIES, 1977.

BORDER GRIZZLY PROJ., UNIV. MONT . MISSOULA. SPEC. REP. NO. 18. 6 9 PP.
MOVE
HOME RNG
HAB USE
FOOD

NCDE, MT USFS, BLM RMEF

C1040

SCHALLENBERGER, A. AND C.J. JONKEL.

1979A MOUKY MOUNAIN EAST FRONT GRIZZLY STUDIES, 1978.

BORDER GRIZZLY PRCJ., UNIV. MONT., MISSOULA. SFEC. REP. NO. 27.1

$\begin{array}{llll}\text { HUMAN IMP } & \text { MEASIQUANT } & \text { AGE/SEX } & \text { TYPE DESCRIP } \\ \text { MOVE } & \text { FOOD } & \text { HABUSE } & \text { HOME RNG }\end{array}$

NCDE,MT ,USFS,BLM, ,RMEF 
01041

SCHALLENBERGER, A. AND C. JCNKEL.

$1979 B$

ANTELOPE BUTTE-MUDOY CREEK GRIZZLY BEAR HABITAT.

BORDER GRIZZLY PROJ., UNIV. MONT • MISSOULA. SPEC. REP = NC. 35.2 C PP.

$\begin{array}{lccc}\text { HAB USE } & \text { PRES DISTR } & \text { RECR IMP } & \text { LIVESTK IMP } \\ \text { HUMAN IMP } & \text { ROAD IMPP } & \text { MCMT GEN } & \\ \text { NCDE,MT , , ,ANBU } & & \end{array}$

01042

SCHALLENBERGER, A. AND C. JCNKEL.

1980

ROCKY MOUNTAIN EAST FRCNT GRIZZLY STUDIES, 1979.

BQRDER GRIZZLY PROJ., UNIV. MONT., MISSOULA. SPEC. REP. NC. 39. 2 C7 PP.
GEN DATA
RECR IMP
MEAS/QUANT
LIVESTK IMP
DEN
MGMT GEN
ROAD IMP

TYPE DESCR IP

NCDE,MT , USFS, BLM, RMEF

01043

SCHERREN, H.

SOME NOTES ON HYBRID BEARS.

PROC. ZOOL. SOC. LONDON 1(MARCH/APRIL):431-435.

GENETICS ZOO TECH

, GEN, , ,

01044

SCHLEYER, B. O.

DAILY ROUTINE OF GRIZZLY BEARS IN THE YELLONSTONE SYSTEM.

PP $35-41$ IN: R.R. KNIGHT, B,M BLANCHARD, K.C, KENDALL AND L,E. CLDENBURG EDS YELLOWSIONE GRIZZLY BEAR INVESTIGATIONS U.S.D.I.
ACT PATT
DAY BED
MATERNAL
REACTION
AIRCRAFT IMP
MCVE
HOME RNG

YGBE, IMW , 
01045

SCHLEYER, B.O.

1983 ACTIVITY PATTERNS OF GRIZZLY BEARS IN THE YELLOWSTONE ECOSYSTEM A ND THEIR REPRODUCTIVE BEHAVIOR, PRECATION AND THE USE OF CARRION.

M.S. THESIS, MONT. STATE UNIV., BOZEMAN. 130 PP.

$\begin{array}{llll}\text { ACT PATT } & \text { BEHAV PATT } & \text { PRED } & \text { AGON } \\ \text { FEED BEH } & \text { NOCT BEH } & \text { DIUR BEH } & \text { REACTION } \\ \text { COURT } & & & \\ \text { YGBE,IMW } & & & \\ 01046 & & & \end{array}$

SCHLEYER, B.O., J.J. JONKEL, K.G. RHOADES AND D.M. DUNBAR.

1984 THE EFECTS OF NONMOTURIZED RECREATION ON GRIZZLY BEAR BEHAVIOR A ND HABITAT USE.

U.S.D.I $\Rightarrow$ INTERAGENCY GRIZZLY BEAR STUDY TEAM, BOZEMAN, MCNT. 83 $P P$.

NONMOTOR IMP REACTION HUMAN INJ COVER
HAB USE
TIMB USE
ACT PATT

YGBE,IMW, , ,

01047

SCHMIDT, D.R.

1982 AROWN BEAR (URSUS ARCTOS) - HUMAN ENCOUNTER IN THE BROOKS RANGE - ALASKA.

CAN. F[ELD-NAT. 96(3):347.

REACTION

$A R C, A K, \quad, B R K R$

01048

SCHNOES, R. AND E. STARKEY.

1978

BEAR MANAGMENT IN THE NATIONAL PARK SYSTEM.

CREGON COOP. PARK STUDIES UNIT, OREGON STATE UNIV,, CORVALLIS.

RECR MGMT MGMT GEN GARB MGMT

,US , , 
01049

SCHDEN, J.

1982 BROWN BEAR HABITAT PREFERENCES AND BRUWN BEAR LOGGING AND MINING RELATIONSHIPS IN SOUTHEAST ALASKA.

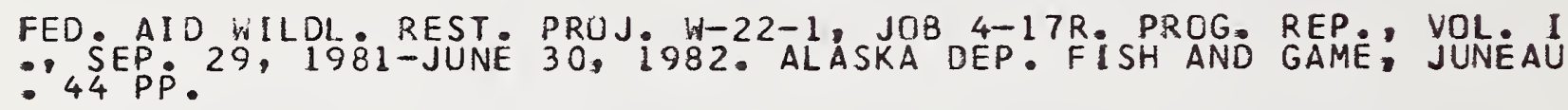

$$
\begin{aligned}
& \text { RES MURT } \\
& \text { DRUGS }
\end{aligned}
$$

AKSE,AK,
DEN SITE

01050

SCHOEN, J.

1986

REVIEW OF POPULATICN SIATUS, FORESTRY RELATIONSHIPS, AND PREDATOR MANAGEMENT CF BROWN/GRIZZLY BEARS IN NCRIH AMERICA:

PP. 31-43. IN: J.W. SCHOEN AND L. BEIER, BROWN BEAR HABITAT PREFE RENCES AND BRCWN BEAR LCGGING AND MINING RELATICNSHIPS IN SOUTHEA ST ALASKA. FED. AID WILDL. REST. PRCJ. ALASKA DEP. FISH AND GAME, JUNEAU.

PRES DISTR

TIMB-HAB

HARV MGMT

POP EST

TIMB - ME TH

TIMB IMP

TIMB-ENTRY

ROAD IMP

RDAD MGMT

01051

SCHOEN, J.W. AND L.R. BEIER.

1983

BR CWN BEAR HABITAT PREFERENCES AND BROWN BEAR LOGGING AND MINING RELATIONSHIPS IN SOUTHEAST ALASKA.

FED AID WILDL REST. PROJ. W-22-2 JOB 4-17R. PROG. REP , VOL II 39 JULY 1 , $1982-J U N E$ 30, 1983. ALASKA DEP. FISH AND GAME; JUNEAU.

HOME RNG

WEIGHT

AK SE, AK
DEN CHRON
PRES DI STR

,ADIS

01052

SCHOEN, J.N. AND L. BEIER.

1985

BROWN BEAR HABITAT PREFERENCES AND BROWN BEAR LOGGING AND MINING RELATIONSHIPS IN SOUTHEAST ALASKA.

FED A AID WILDL REST PROJ. $W-22-3$ JOB 4-17R, 1 JULY $1983-30$ JUN E 1984. ALASKA DEPT: FISH AND GAME, JUNEAU.' 83 PP.
HAB USE
DEN CHRON
REP RATE
HOME RNG
AGE/SEX
POP DENS
WEIGHT
DEN SITE
COVER

AKSE, $A K$ 
01053

SCHOEN, J.W. AND L. BEIER.

1986

BRCWN BEAR HABITAT PREFERENCES AND BROWN BEAR LOGGING AND MINING

RELATIONSHIPS IN SOUTHEAST ALASKA.

FED AID WILDL R REST. PROJ W-22-4, JOB $4,17 R$ PROG REP , JULY 1 -1984-JUNE 30; 1985. ALASKA DEP. FISH AND GAME, JUNEAU.

$\begin{array}{rccc}\text { GEN DATA } & \text { CENSUS/TREND } & \text { POP DENS } & \text { MORT RATE } \\ \text { REP RATE } & \text { CANNIBAL } & \text { DEN } & \\ \text { WEIGHI } & & & \text { AGE/SEX } \\ \text { AKSE,AK }, & , \text {,ADIS } & & \end{array}$

01054

SCHOEN, J•hi, L.R. BEIER AND J•W. LENTFER •

IN PRESSA

INT - CONF. BEAR RES. AND MANAGE. 7.
DEN CHRON
DEN SITE
DEN CHAR
MORT DATA
AIRCR AFT IMP

$A K S E, A K, \quad, \quad, A B C$

01055

SCHOEN, J.W•, J•W. LENTFER AND L. BEIER.

IN PRESSE THEAST ALASKA: A PRELIMINARY ASSESSMENT.

INT. CONF. BEAR RES. AND MANAGE.6.

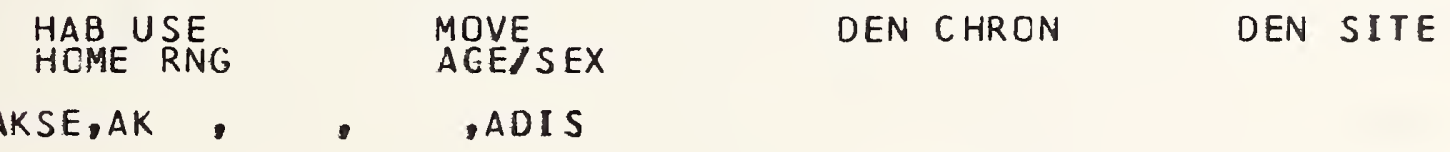

01056

SCHOENWALD-COX, C.M., S.M. CHAMBERS, B. MACBRYDE AND L. THOMAS.

GENETICS AND CONSERVATION, A REFERENCE FOR MANAGING WILD ANIMAL A ND PLANT POPULATIONS.

BEN JAMIN/CUMMINGS, LONDON. 722 PP.

GENETICS

GEN, 
01057

SCHULLERY, P.

1980

THE BEARS OF YELLOWSTCNE. YELLOWSTONE LIBRARY \& MUSEUM ASSOC., YELLOWSTGNE NATL. PARK, WYO.
I7G PP.

GENBIOL MGMTGEN PCLAADM MGMT CENSUS/TREND

YCBE, IMW, YNP, ,

01058

SCOTTER, G.W.

1975 GIZZLY BEAR (URSUS ARCTOS) RECORC NEAR FORT SIMPSON, NORTHWEST TERRITORIES.

CAN. FIELD-NAT. $89(3): 324$.

PRES DISTR

BORF,NWT, , SIMP

01059

SEAL, U.S. A.W. ERICKSON AND J.G. MAYO.

1970

CRUG IMMOB ILIZATION OF THE CARNIVORA.

INT. ZOO YEARB. 10:157-170.

DRUGS

$$
\text { , GEN, , , }
$$

C1060

SEAL, U.S., W.R. SWAIM AND A.W. ERICKSON.

1967

HEMATOLOGY DF THE URSIDAE.

COMP. BIOCHEM. PHYSIOL. 22:451-460.

REPRO PHYS HEMAT

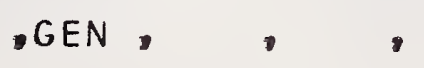


01061

SEBER, G.A.F.

1965 A NOTE ON THE MULII I PLE-RECAPTURE CENSUS.

BIOMETRIKA • $52: 249-259$.

CENSUS METH

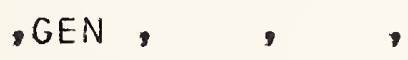

$\mathrm{Cl} 062$

SEITZ, B.

1983

SOUTH SAN JUAN MOUNTAINS GRILZLY BEAR SURVEY.

FED. AID WILDL. REST PRCJ. SE-3-4, WORK PLAN 3 , JOB 1 FINAL REP. - JAN. 1 - DEC. 3I, 1982. COLO. DIV. WILDL.. DENVER. IO PP.

HAB RECON PRES DISTR

$, \mathrm{CO}, \quad$,

01063

SER VHEEN, $C$.

1977 A

THE RELOCATION OF PROBLEM BEARS ON THE FLATHEAD INDIAN RESERVATIO $\Lambda$.

BORDER GRIZZLY PROJ., UNIV. MONT, MISSOULA. SPEC. REP. NC. 7A. 5

RELOC MOVE

NCDE,MT ,FLIR, ,

01064

SER VHEEN, C.

19778

THE RELOCATION OF GRIZZLY NO. 110.

BORDER GRIZZLY PROJ., UNIV. MONT., MISSOULA. SPEC. REP. NO. 7C. 5
PP.

DEPRED

RELOC

AVER COND

NCDE, MT 
01065

SER.VHEEN, C.

1978

THE GRI ZZLY BEAR IN THE RATTLESNAKE MOUNTAINS.

PP. 3-16 IN: C. JONKEL ED. ANNUAL REPORT NO. 3. BORDER GRIZZLY P ROJ., UNIV. MCNT., MISSCULA.

OISTR HAB PECON HUMAN IMP RECR IMP

NCDE,MT, , , , ,

01066

SERVHEEN, C.

GRIZZLY BEAR ECOLOGY AND MANAGEMENT IN THE MISSION MOUNTAINS, MON TANA.

PH.D. DISS., UNIV. MONT., MISSOULA. 139 PP.
MOVE
MGMT PLAN
HAB USE
FOOD
POP DENS
HCME RNG DIVERSITY
DEN

NCDE,MT ,FLIR,USFS, MISS

01067

SERVHEEN, C.W.

1983 GRIZLY BEAR FOOD HABITS, MOVEMENTS, AND HABITAT SELECTION IN THE MISSION MCUNTAINS, MCNTANA.

J. WILDL. MANAGE. 47(4):1026-1035.
FOUD RNG
MOVE
MEAS/QUANT
SEAS BEH
AGEISEX
HAB USE
POP DENS

NCDE, HT ,FLIR,FLNF,MISS

01068

SERVHEEN, C。

1984

A BRIEF GUIDE TO REPORIING GRIZZLY BEAR OBSERVATIONS, SIGN MORTAL ITIES, AND $8 E A R-R E L A T E D$ PROBLEMS IN THE CONTIGUDUS 48 STATES.

APPENDIX 6, PP 73-78 IN: J PICTON AND P ZAGER 1985. WESTERN C ABINET MOUNTAINS GRIZZLY BEAR HABITAT SURVEY, 1985. IDAHO FISH AN D GAME, COEUR D.ALENE.

MONIT SYS

IDENT / RECOG

,US, , ,


01069

SER VHEEN, C.

1985 INVOLVEMENT OF CAPTIVE POPULATIONS IN THE RECOVERY OF IHE THR EATENED GRIZILY BEAR (URSUS ARCTOS HORRIBILIS ORD.) IN THE LOWER 48.

PP, 499-506 IN: PROC. 1985 ANNU. CONF. AM. ASSOC. ZOOL. PARKS AND AQUAR I UMS.

POP AUG

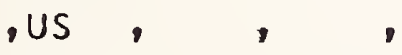

C1070

SERVHEEN, $C$.

1986

HABITAT RESEARCH NEEDS FOR GRIZZLY BEAR RECOVERY.

PP. 14-18 IN: G.P. CONTRERAS AND K.E. EVANS, ECS. PROCEEDINGS-GRI ZZLY BEAR HABITAT SYMPOSIUM. U. S.D.A. FOREST SERV. INTERMOUNTA IN RES. STAT., UCDEN, UTAH. GEN. TECH. REP. INT-207.

MGMT GEN

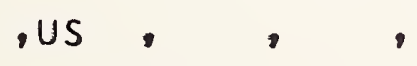

01071

SERVHEEN, C.

IN PRESS

THE MANAGEMENT OF THE THREATENED GRIZZLY BEAR IN THE CONTERMINOUS UNITED STATES.

PROC. INT. CONF. BEAR RES. AND MANAGE. 7. (PAPER PRESENTED)

$\begin{array}{llll}\text { DISTR } & \text { POP EST } & \text { MGMT GEN } & \text { PCL/ACM MGMT } \\ \text { MIN POP } & \text { CENSUS METH } & \text { GENETICS } & \text { POP AUG } \\ \text { HUMAN IMP } & , & & \end{array}$

01072

SER VHEEN, C., W. KASWORM AND A. CHRISTENSEN.

IN PRESS MOUNTAINS OF MONTANA.

INT. CONF. BEAR RES. AND MANAGE. 7: •

POP AUG

CYE , MT, 
01073

SERVHEEN, C. AND R. KLAVER.

GRIZZLY BEAR DENS AND DENNING ACTIVITY IN THE MISSION AND RATTLES MAKE MOUNTAINS, MONTANA.

INT. CJNF. BEAR RES. AND MANAGE . 5:201-207.

$$
\text { DEN SITE DEN CHAR DEN CHRCN }
$$

NCDE,MT, USFS,FLIR,

01074

SER VHEEN, C. AND L.C. LEE.

$1979 A$

AN ASSESSMFNT OF THE GRIZZLY BEAR PCPULATICN SIZE AND STATUS, AND $A$ DESCRIPTION OF IMPOR TANT GRIZZLY USE
$\wedge G$ UNIT, FLATHEAD RESERVATION, MONTANA.

BORDER GRIZZLY PROJ.. UNIV. MONT., MISSOULA. 64 PP.

$\begin{array}{llll}\text { TYPE DESCRIP } & \text { HAB USE } & \text { PRES DISTR } & \text { MOVE } \\ \text { HAB RECON } & \text { POP EST } & \text { ZCNING }\end{array}$

NCOE,MT ,FLIR,

01075

SERVHEEN, C. AND L.C. LEE.

MISSION MUUNTAINS GRIZZLY BEAR STUDIES, AN INTERIM REPORT, 1976-7 8.

BORDER GRIZZLY PROJ., UNIV. MONT., MISSOULA. 299 PP.
HAB
PDSE
HCME RNG
DEN
TYPE DESCRIP $\quad$ FOOD
MOVE

NCDE,MT, FLIR, ,MISS

01076

SER VHEEN, C. T.T. THIER, C.J. JONKEL AND D. BEATY. 1981 AN EAR-MOUNTED TRANSMITTER FOR BEARS.

WILL. SOC. BULL. $9(1): 56-57$.

TELEM

, GEN, , , 
01077

SER VHEEN, C. AND T. WOJCIECHOWSKI.

GRIZZLY BEAR FOOD LIST.

PP 83-107 IN: C
ISSOULA. ANNUEL, REP. NO. 3. B. BORDER GRIZZLY PRCJ., UNIV. MCNT. M FOOD

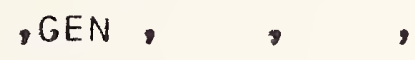

01078

STENHOUSE, G. AND M. CATTET.

1984

BEAR DETECTION AND DETERRENT STUDY CAPE CHURCHILL, MANITOBA, 1983 -

NOR THWEST TERRIT. WILDL. SERV. YELLOWKNIFE. REP. NO. 44.59 PP $\bullet$

DETER/REPEL

NWT, , ,

01079

SHAFFER, M.L.

1978

DETERMINING MINIMUM VIABLE POPULATICN SIZES: A CASE STUDY CF THE GRIZZLY BEAR (URSUS ARCTOS L.).

PH.D. DISS., DUKE UNIV., DURHAM, N.C. 190 PP.

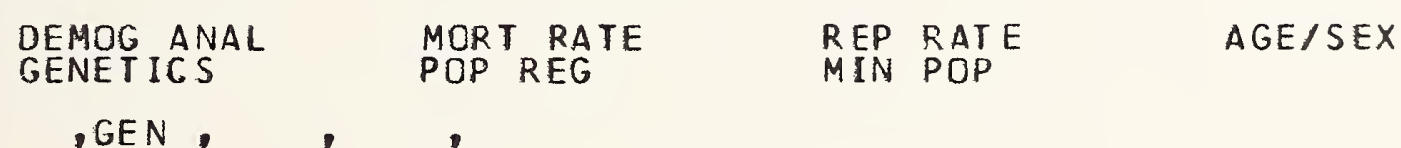

01080

SHAFFER, M.L.

1981

MINIMUM POPULATION SIZES FOR SPECIES CONSERVATICN.

BIOSCIENCE $31(2): 131-134$

MIN POP

, GEN, , , 
01081

SHAFFER, M.L.

1983 DETERINING MINIMUM VIABLE POPULATICN SIZES FOR THE GRIZZLY BEAR.

INT. CDNF. BEAR RES. AND MANAGE. 5:133-139.

MIN PDP

YGBE, IMH, , ,

01082

SHAFFER, M.L.

1986

ASSESSMENT OF APPLICATICN OF SPECIES VIABILITY THEORIES.

PREP. FOR OFF. TECHNOLOGY ASSESSMENT, U.S. CONGRESS. DRAFT REP.

DEMOG ANAL MIN POP GENETICS

, CEN, ,

01083

SHAFFER, M.L. AND F.B. SAMSON.

1985

POPULATION SIZE AND EXTINCTION: A NOTE ON DETERMINING CRITICAL PO PULATION SIZES.

AM. NAT - 125(1):144-152.

MIN POP

$$
, G E N, \quad, \quad,
$$

01084

SHAFFER, S.C.

1971 SOME ECOLOGICAL RELATIONSHIPS OF GRIZZLY BEARS AND BLACK BEARS OF THE APGAR MOUNTAINS IN GLACIER NATIONAL PARK. MONTANA.

M.S. THESIS, UNIV. MONT., MISSOULA. 133 PP.

$\begin{array}{llll}\text { VEG SUCC } & \text { MARK } & \text { CENSUS/TREND } & \text { FOOD } \\ \text { HAB USE } & \text { CARCASS } & \text { ACT PATT } & \text { INTERSP COMP } \\ \text { DEN } & & \\ \text { NCDE,MT , GLNP, } & \text {,APGR } & & \end{array}$


01085

SHANK, C.C.

1979

HUMAN-RELATED BEHAVIOURAL DISTURBANCE TO NORTHERN LARGE MANMALS:

A BIBLICGRAPHY AND REVIEW.

PREP. FCR FOOJHILLS PIPE LINES (YUKCN) LTO. CALGARY. 253 PP.

BIBLIO ENERGY IMP

GEN, , ,

01086

SHER WOOD, H.W.

1981

MORPHOLOGICAL VARIATION OF GRIZZLY BEAR SKULLS FROM YELLOHSTONE N ATIONAL PARK.

M.S. THESIS, UNIV. MONT., MISSCULA. 96 PP.

DENT SKULL TAXON/EVCL

YGBE, IMW, , ,

01087

SHOOK, G.L. AND G.E. FCLK, JR.

1965

BODY MOISTURE AND THE CPERATING LIFE OF IMPLANTABLE HEART RATE TR ANSMITTERS.

IEEE TRANS. BIC-MEDICAL ENG. BME-12(1):44-46.

TELEM

, GEN , , ,

01088

SHUMAN, R.F.

1950

BEAR DEPREDATIONS ON RED SALMON SPAWNING POPULATIONS IN THE KARLU K RIVER SYSTEM, 1947.

J. WILDL . MANAGE . 14111:1-9.

PRED

AKKA, AK, , , , KARL 
01089

SIDOFOWICZ, G.A. AND F.F. GILBERT.

1981 MHE MANAGEMENT OF GRIZZLY BEARS IN THE YUKON, CANADA.

WILDL. SOC. BULL. $9(2): 125-135$.

$$
\begin{aligned}
& \text { HARV DATA } \\
& \text { HARV IMP } \\
& \text {,YK , }
\end{aligned}
$$

C1090

SIGMAN, M.J.

1985 IMP ACTS OF CLEARCUT LOGGING ON THE FISH AND WILCLIFE RESOURCES OF
SOUTHEAST ALASKA. ALASKA DEP. FISH AND GAME, HABITAT OIVISION, JUNEAU. TECH. REP. N
C. 85-3.

T IMB IMP

TIMB MGMT

RCAD IMP

$$
\text { , GEN , }
$$

01091

SIMPSON, K. AND C. HEBERT.

CAEVELSTOKE GRIZZLY-CARIBOU STUDY.

B.C. WILDL. BRANCH, VICTORIA. 24 PP.

$\begin{array}{llll}\text { HOME RNG } & \text { FOOD } & \text { HAB USE } & \text { AGE/SEX } \\ \text { WEIGHT } & \text {, REVL } & \end{array}$

01092

SINGER, F.J.

1978 9 SONAL CONCENTRATIONS OF GRIZZLY BEARS, NORTH FORK OF THE FLATH EAD RIVER, MONTANA.

CAN. FIELD-NAT. $92(3): 283-286$

FOOD

HAB USE

PRED

CARCASS

NCDE, BCMT, GLNP, FLNF, NFLT 
01093

SINGER, F.J.

1982
PRCBLEM ANALYSIS - GRIZZLY BEAR MANAGEMENT, DENALI NATIONAL PARK.

U.S.D.I., NATL. PARK SERV., DENALI NATL. PARK, ALASKA. 41 PP.

$\begin{array}{lll}\text { MONITSYS } & \text { HUMAN INJ } & \text { MCTUR IMP } \\ \text { REACTION } & \text { NAMP MGMT }\end{array}$

$A K-I, A K$,DENP, ,

01094

SINGER, F.J. AND J.B. BEATTIE.

IN PRESS

THE CONTROLLED TRAFFIC SYSTEM AND ASSUCIATED WILDLIFE RESPONSES I A DENALI NATIONAL PARK.

ARCTIC.

MOTOR MGMT MOTOR IMP ROAD IMP

AK-I, AK , DENP, ,

01095

SIZEMORE, D.L.

1980

FORAGING STRATEGIES OF THE GRIZZLY BEAR AS RELATED TO ITS ECOLOGI CAL ENERGETICS.

M.S. THESIS, UNIV. MONT, MISSCULA, 67 PP.

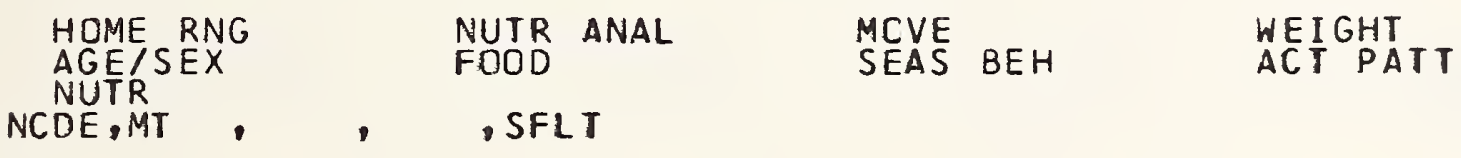

01096

SKJONSBERG, T. AND A. WESTHAVER.

1978 A STOY IN THE CHEMICAL IMMOBILIZATION OF ANIMALS WITH SUGGESTION $S$ FOR APPLICATION IN CANADA SS NATIONAL PARKS.

PROC. WEST. BLACK BEAR. WORKSHOP 1:283-318.

DRUGS

, GEN , , , 
01097

SKOOG, R.

INT4 4 RIOR ALASKA GHECKING STATION OPERATIONS - FIRST SEASON, 1954. FED. AID WILDL RREST: PROJ. JOB NG. 2, WORK PLAN B. ALASKA DEP. F
ISH AND GANE, JUNEAU: 2 PP:

HARV DATA

$A K-1, A K, \quad$, STEE

01098

SLANEY, F.F. AND COMPANY, LTD.

1974-1974 ENVIRONMENTAL PROGRAM, MACKENZIE DELTA.

DISTR. BY PALLISTER RESCUR. MANAGE. LTD.

$\begin{array}{llll}\text { HIST DISTR } & \text { PRES DISTR } & \text { DEN SITE } & \text { HAB USE } \\ \text { DEN CHRON } & \text { PRED } & \text { HARV MGMT } & \text { MISC QUANT } \\ \text { CARC,NWT, } & , R I C H & \end{array}$

01099

SMITH, B.L.

1978

INVESTIGATIONS INTO BLACK AND GRIZZLY BEAR RESPCNSES TO COASTAL L CGGING - 1977 .

B.S. THESIS, SIMCN FRASER UNIV. BURNABY, B.C. 85 PP.

$\begin{array}{llll}\text { FOOD } & \text { TIMB IMP } & \text { CUT USE } & \text { VEG SUCC } \\ \text { CENSUS METH } & \text { ACTPATT } & \text { MARK } & \text { TIMB-METH } \\ \text { COVER } & \text { MC-C,BC , AHNU } & & \end{array}$

C1100

SMITH, B.L.

SOME THREATS TO THE FUTURE OF GRIZZLY BEARS IN WESTERN CANADA.

PP 222-226 IN: R. STACE-SMITH, L. JCHNS AND P. JOSLIN, EDS . THRE ATENED AND ENDANGERED SPECIES AND HABITATS IN BRITISH' COLUMBIA AN
D THE YUKON.

MGMT GEN

HUMAN IMP

HAB EFFECT

, GEN . 
01101

SMITH, B.L.

IN PREPA

REPRODUCT IVE PERFORMANCE OF FEMALE GRIZZLY EEARS IN THE OGILVIE M OUNTAINS, YUKON.

DRAFT ABSTRACT • YUKON DEP. RENEWABLE RESOUR., WHITEHORSE.

REP RATE

$, Y K, \quad$,

01102

SMI TH, B.L.

IN PREPB

VULNERABILITY TO HARVEST IN GRIZZLY BEARS IN THE CENTRAL YUKON, C ANADA.

DRAFT ABSTRACT. YUKON DEP. RENEWABLE RESOUR. WHITEHORSE.

HARV DATA HARV MGMT

$, Y K, \quad$,

01103

SMITH, B.L.

IN PREPC HTED BY BEAR SEX.

DRAFT ABSTRACT. YUKCN DEP. RENEWABLE RESOUK, WHITEHORSE.

HARV MGMT

,YK, , ,

01104

SMITH, J.K.

BIMS - THE BEAR REPORTING NETWORK FCF. THE NATICNAL PARK SERVICE.

INT. CONF. BEAR RES. AND MANAGE. 5:297-301.

MONIT SYS

,US , NPS 
01105

SMITH, M.E.

REPELLENTS AND DETERRENTS FOR BLACK ANU GRIZZLY BEARS, PROGRESS R EPORT.

ACRDEP, GRI IZLY PROJ., UNIV. MONT., MISSOULA. 21 PP.

DETER/REPEL. AVER COND

.GEN, , ,

01106

SMITH, R. H. AND L. VAN DAELE.

1984

TERROR LAKE HYOROELECTRIC PROJECT. 1982 3ROWN BEAR STUDIES.

PREP. BY ALASKA DEP. FISH AND GAME. PREP. FCR ALASKA POWER AUTHOR ITY. 107 PP.

$\begin{array}{lccc}\text { ENERGY IMP } & \text { GEN LATA } & \text { DEN } & \text { LITR SIZE } \\ \text { MDKT DATA } & \text { WEAN } & \text { PCP EST } & \text { AGEISEX } \\ \text { PRED } & & & \end{array}$

C11 107

SMITH, R.B.. L. VAN DAELE AND L.A. METZ.

1984 TERROR LAKE HYDROELECTRIC PROJECT. REPORT CN BROWN BEAR STUDIES, 1983.

PREP B BY ALASKA DEP. FISH AND GAME. PREP. FOR ALASKA POWER AUTHOR ITY. 77 PP.

$\begin{array}{lccc}\text { AGE/SEX } & \text { MORT DATA } & \text { REP RATE } & \text { HAB USE } \\ \text { MOOD } & \text { MOVE } & \text { HOME RNG } & \text { ENERGY IMP } \\ \text { AKKN } & & \text {,TERL } & \end{array}$

01108

SMITS, C.M.M. AND B.L. SMITH.

IN PREP

FEASIBILITY OF THE USE OF OBSERVATICNS OF GRIZZLY BEARS BY CUTFIT TERS AND HUNT ING GUIDES IN GR IZZLY BEAR PQPULATION INVENTORY AND TREND IN REGISTERED GUIDING AREAS OF THE YUKCN.

DRAFT ABSTRACT. YUKON DEP. RENEWABLE RESOUR . WHITEHORSE.

CENSUS METH

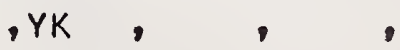


01109

SOULE, M.E. AND B.A. WILCOX.

1980

CONSERVATION BIOLCGY: AN ECOLOGICAL-EVCLUTICNARY PERSPECTIVE.

SENAUER ASSOC., SUNDERLAND, MASS. 395 PP.

GENETICS

, GEN , , ,

01110

SOUTHWODD, T.R.E.

1966

ECOLOGICAL METHOUS.

CHAPMAN AND HALL, LCNDON.

HOME RNG

GEN, , , ,

01111

SPALDING, D., B. GATES, MCKAY AND K. MUNDY.

1972

MANAGEMENT PLAN FOR BRITISH COLUMBIA'S GRIZZLY BEARS. PREP. BY CARNIVORE COMM
$21 \mathrm{PP}$.

$\begin{array}{llll}\text { MGMT PLAN } & \text { MGMT GEN } & \text { HARV DATA } & \text { POP EST } \\ \text { POACH/ILLEG } & \text { HARV MGMT } & \end{array}$

01112

SPARROWE, R. C.

1968

SEXUAL BEHAVIOR OF GRIZZLY BEARS.

AM. MIDL. NAT $80(2): 570-572$.

COPULATE

YGBE, WY, YNP, , 
01113

SPENCE, L.E. JR.

STUOYY OF ICENTIFYING CHARACTERISTICS OF MAMMAL HAIR.

FED. AID WILDL. REST PROJ. FW-3-R-10, JOB. NO. $2 W$ WORK PLAN NO. 10. JOB COMPLETICN REP. JULY 1 1962-JUNE 3021963 WILDL. DISEA SE RES. LABORATURY, WYO GAME AND FISH COMMISSICN. I3I PP. HAIR

$$
, G E N, \quad,
$$

01114

SPENCER, D.L. AND R.J. HENSEL.

ENVIRONMENTAL STUDIES OF THE PROPOSED TERROR LAKE HYOROELECTRIC P ROJECT, KODIAK ISLAND, ALASKA. BROWN BEARS STUEIES. MCUNTAIN GOAT
STUDIES.

PREP FOR KODIAK ELECIRIC ASSOC. INC. PREP. BY ARCTIC ENVIRON. IN F. AND DATA CENT., UNIV. ALASKA; ANCHORAGE: IOO PP.

$\begin{array}{llll}\text { ENERGY IMP } & \text { DEN SITE } & \text { DEN CHAR } & \text { MOVE } \\ \text { SEAS BEH } & \text { HAB USE } & \text { PCP BIOL } & \end{array}$

AKKA,AK ,KNWR,,$T E R L$

01115

SPIESS, A.

1976

LABRADOR GRIZZLY (URSUS ARCTOS L.): FIRST SKELETAL EVIDENCE.

J. MAMMAL. $57(4): 787-790$.

SKULL HIST DISTR

, ECAN, , ,

01116

SPIESS, A. AND S. COX.

1976

CISCOVERY OF THE SKULL OF A GRIZZLY BEAR IN LABRADOR.

ARCTIC 29(4):194-200.

HIST DISTR SKULL

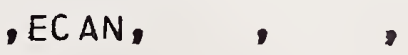


01117

SPRAKER, T. AND W. BALLARD.

FEEOING BEHAVIOR OF INTERIOR BROWN BEARS.

FED. AID WILDL. REST. PRDJ. $W-17-10$ AND $W-17-11$, JOB $4.13 R$. PROG. REP., VOL. I. ALASKA DEP. FISH AND GAME, JUNEAU. 19 PP.
AGE/SEX
LITR SIZE
RES MCRT
PHYS CHEM
DRUGS
HEMAT
BRD AGE

$A K S C, A K$,

- NESU

01118

SPRAKER, T.H., W.B. BALLARD AND S.D. MILLER.

1981

GAME MANAGEMENT UNIT 13 BROWN BEAR SIUDIES.

FED. AID WILDL. REST PROJ W-17-10, W-17-1 $1, W-21-1, J O B \quad 4=13 R$ FINAL REP. SUNEAU.

DRUGS

BRD AGE

HEMAT

AKSC,AK
MEAS/QUANT

PHYS CHEM

, NESU

C1119

SPREADBURY, B.

1984

YUKON GRIZZLY BEAR TRANSPLANT PROJECT.

YEAR 1 PROGRESS REPORT-1984 PRREP FOR THE YUKCN FISH AND WILDL.
BRANCH, ENVIRONENT CANADA, YUKON FISH AND GAME ASSOC. AND UNIV. C ALGARY.

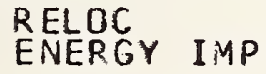

MOVE
REACTION

$A G E / S E X$

LITR SIZE

NINT, YK

C1120

STEBLER, A.M.

1972

CONSERVATION OF THE GRIZZLY - ECOLOGIC AND CULTURAL CONSICERATION $S$.

INT. CONF. BEAR RES. AND MANAGE. 2:297-303.

HIST ACCT

HIST DISTR

, GEN 
01121

STELMOCK, J.J.

SEA SONAL ACTIVITIES AND HABITAT USE PATTERNS OF BROWN BEARS IN DE NALI NATIONAL PARK - 1980 .

M.S. THESIS, UNIV. ALASKA, FAIRBANKS. $118 \mathrm{PP}$.

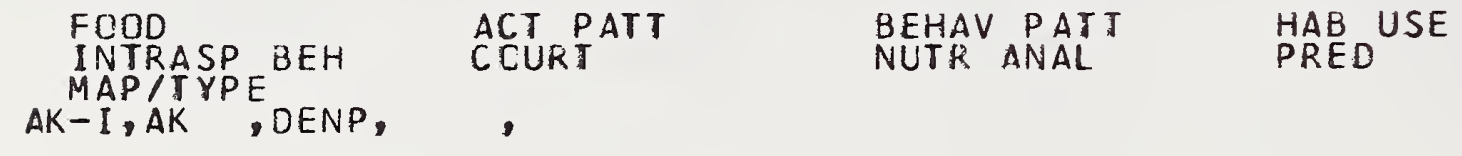

01122

STENHDUSE, G.

1982 DEARTECTION AND DETERRENT STUDY, CAPE CHURCHILL, MANITOBA, 198 1.

NORTHWEST TERRIT • WILDL. SERV., YELLOWKNIFE• REP • NO • 23. 65 PP

DETER/REPEL

GEN, , ,

01123

STENHOUSE, $G$.

198.3

BEAR DETECTION AND DETERRENT STUDY, CAPE CHURCHILL, MANITOBA, 198 NORTHWEST TERRIT • WILDL. SERV., YELLOKKNIFE. REP • NO - 31. 58 PP DETER/REPEL , GEN, , ,

01124

STEPHENSON, R. O.

1978

UNIT 13 WOLF STUDIES.

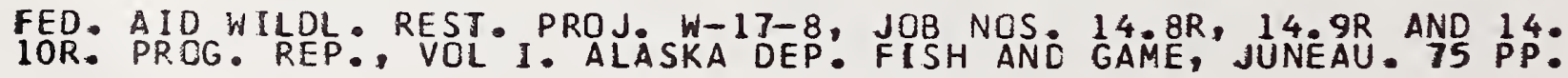
PRED CARCASS INTERSP COMP

$A K-I, A K, \quad, C O P R$ 
01125

STEWART, G.R., J.M. SIPEREK AND V.R. NHEELER.

1980

USE CF THE CATALEPTOID ANESTHETIC CI-744 FOR CHEMICAL RESTRAINT O F BLACK BEARS.

INT - CINF. BEAR RES. AND MANAGE. 4:57-61.

DRUGS

$$
, G E N, \quad, \quad,
$$

C1126

STICKEL, L.F.

1954 A COMPARISCN OF CERTAIN METHOOS GF NEASURING RANGES OF SMALL MAMM ALS.

J. MAMMAL. $35(1): 1-15$.

HDME RNG

$, G E N, \quad$,

01127

STIRLING, I., A.N. PEARSON AND F.L. BUNNELL.

1976

POPULATION ECOLOGY STUDIES CF POLAR AND GRIZZLY BEARS IN NORTHERN CANADA.

TRANS. NURTH AM. WILDL. AND NAT. RESOUR. CONF. $41: 421-430$.

DEMOG ANAL HARV MGMT HARV IMP

$$
\text { , CAN, , , }
$$

01128

STOCKSTAD, D.

1953

GRIZZLY BEAR INVESTIGATION AND RECHECK.

FED. AID KILDL. REST. PROJ, W-60-R-1, WORK PLAN T, JOR 7-A. PROG. ENA. 4 PP.

CENSUS/TREND

NCDE,MT ,FLNF, LCNF, 
01129

STOCKSTAD, D.

1954

GRIZZLY BEAR. INVESTIGATION AND RECHECK.

FED. AID WILDL. REST. PROJ. W-60-R-1, WORK PLAN 7, JOB 7-A. JOB C CMPLETION REP. MONT. DEP. FISH AND GAME, HELENA. 13 PP.

CENSUS/TREND HARV DATA

NCDE, MT ,FLNF, LCNF,

01130

STOKES, A. W.

1970 AN ETHOLOGIST'S VIEWS LN MANAGING GRIZZLY BEARS.

BIOSCIENCE 20(21):1154-1157.

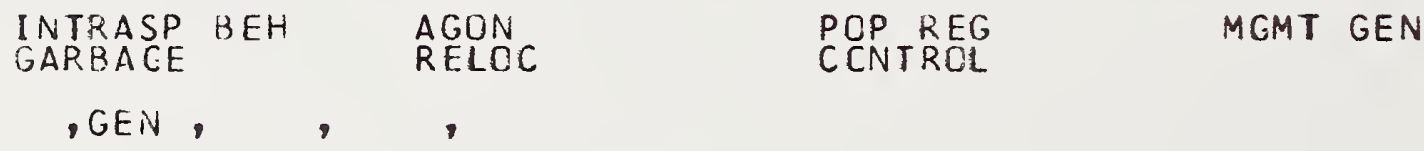

01131

STOKES, A.W., A.L. EGBERT AND M.H. LUQUE.

1981

SOCIAL BEHAVIOR, UF BROWN BEARS AT MCNEIL RIVER, ALASKA

PP 583-590 IN: P.H. OEHSER, J.S. LEA AND N.L. PONARS, EDS. NATION AL GEOCRAPHIC SOCIETY RESEARCH REPORTS, 1971 TO 1972, VOL. 13. NA TL. GEOG. SOC., WASHINGTON, D.C.

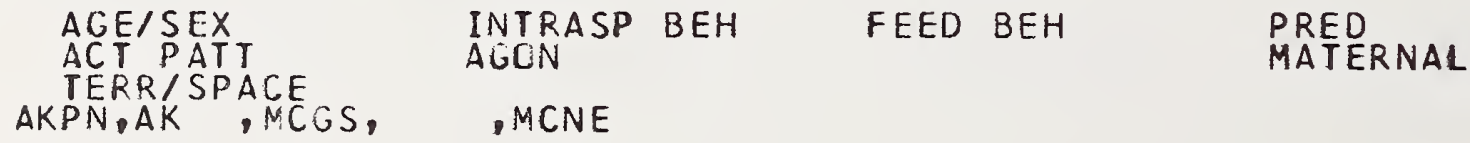

01132

STUNEBERG, R.P. AND C.J. JONKEL.

1966

AGE DFTERMINATION OF BLACK BEARS BY CEMENTUM LAYERS.

J. WILDL. MANAGE. $30(2): 411-414$.

AGE DETERM

, GEN , , , 
01133

STONOROV, D. AND A.W. STOKES.

SOCIAL BEHAVIOR OF THE ALASKAN BRCWN BEAR.

INT. CONF. BEAR RES. AND MANAGE. 2:232-242.

$\begin{array}{lll}\text { TERR/SPACE } & \text { AGE/SEX AGON } & \text { INTRASP BEH } \\ \text { THREAT } & \end{array}$

01134

STORER, I.I. AND L.P. TEVIS, JR.

1978 CAL IFCRNIA GRIZZLY.

UNIV. NEER. PRESS, LINCOLN. 335 PP.

HIST DISTR HIST ACCT GEN BIOL

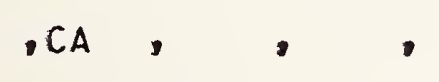

01135

STOVELL, P.L.

BEAR MEAT TRICHINOSIS.

CAN. MED. ASSOC. J. 107(11):1056.

PARAS/DIS

, GEN, ,

01136

STRATHEARN, S.M., J०S. LOTIMER, G.B. KOLEMOSKY AND W.M. LINTACK. AN EXPANDING BREAK-AWAY RADIO COLLAR FOR BLACK BEAR.

J. HILDL. MANAGE. $48(3): 939-942$.

TELEM

, GEN, , 
01137

STRINGHAH, S.F.

1980 POSSIBLE IMPACTS OF HUNTING ON THE GRIZZLY/BROWN BEAR, A THREATEN ED SPECIES.

INT. CONF. BEAR RES. AND MANAGE. 4:337-349.

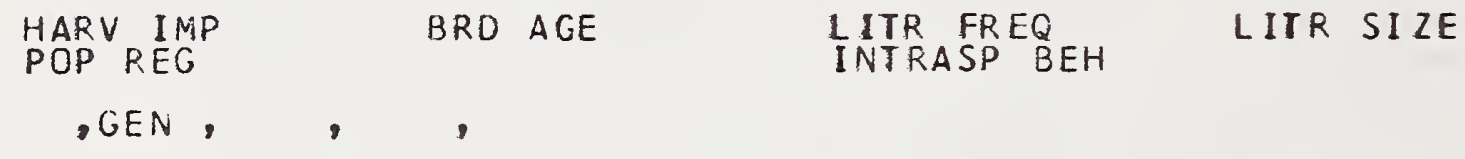

01138

STR INGHAM, S.F.

1983 ROLES OF ACULT MALE IN GRIZZLY BEAR POPULATION BIOLOGY.

INT. CONF B BER RES. AND MANAGE. 5:140-151.

$\begin{array}{lll}\text { DEMOG ANAL POP REG IITR SIZE } & \text { INTRASP BEH } \\ & \text { INEP RATE }\end{array}$

GEN, , ,

01139

STRINGHAM, S.F.

RESPONSES BY GRIZZLY BEAR POPULATION DYNAMICS TC CERTAIN ENYIRONM ENTAL AND BIOSOCIAL FACTORS.

PH.D. DISS, UNIV. TENN, KNOXVILLE. 464PP.

\begin{tabular}{|c|c|c|}
\hline $\begin{array}{l}\text { POP REG RE } \\
\text { CLIMATE }\end{array}$ & $\begin{array}{l}\text { DEMOG ANAL } \\
\text { GARBAGE }\end{array}$ & $\begin{array}{l}\text { REP RATE } \\
\text { INTRASP BEH }\end{array}$ \\
\hline
\end{tabular}
, GEN, ,

C1140

STRINGHAM, S.F.

B986 LORS, LORDS OF THE WILCERNESS: ECOLOGY, BEHAVIOR, AND POPULATION DYNAMICS.

NOYES PUBL., N.J. 570 PP.

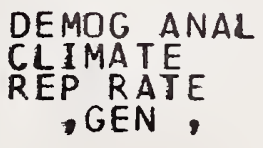


01141

STRINGHAM, S.F.

IN PRESSA

CHANGES IN LITTER SIZE FOR YELLOWSTONE GKIZZLIES RELATIVE TC GARB AGE CONSUMPTION, DUMP CLOSURE AND CLIMATE.

INT. CONF. BEAR RES. AND MANAGE. 6.
GARBAGE
INTRASP BEH
LITR SIZE
REP RATE
CLIMATE

YGBE, IMW ,

01142

STRINGHAM, S.F.

IN PRESSB

BEAR DEMOGRAPHICS AS FUNCTIONS OF FCOD SUPPLY PER UNIT POPULATION BIOMASS, BOOY SIZE, AND OTHER INDICES OF NUTRITIONAL STATLS.

INT. CONF. BEAR RES. AND MANAGE. 7:000-000.

POP REG REP RATE WEIGHT

$$
, G E N, \quad,
$$

01143

STRINGHAM, S.F.

IN PREP

REPRODUCTION BY YELLOWSTONE GRIZZLY BEARS RELATIVE TO FODD AND CL IMATE.

CRAFT MANUSCRIPT.
LITR SI TE
REP RATE
POP REG
CLIMATE

YGBE, IMW, , ,

01144

STUART, T.W.

1977

MUL TIOB JECTIVE ANALYSIS OF WILOERNESS TRAVEL IN GRIZZLY BEAR HABI TAT USING PARAMETR IC LINEAR PROGRAMMING.

PH.D. DISS., UNIV. CALIF., BERKELEY, 241 PP.

NONMOT MGMT CAMP MGMT

NCDE,MT , GLNP, 
01145

STUART, T.W.

1978 MANAGEMENT MODELS FOR HUMAN USE OF GRIZZLY BEAR HABITAT.

TRANS. NORTH AM. WILDL. AND NAT. RESOUR, CONF. 43:434-441.

NONMOT MGMT CAMP MGMT
NCDE,MT ,GLNP,
01146
STUART, T.W.
1980
EX PLORATION OF OPTIMAL BACKCOUNTRY TRAVEL PATIERNS IN GRIZZLY BEA
HABITAT.

INT. CONF. BEAR RES. AND MANAGE. 4:25-32.

NONMOT MGMT

NCDE,MT ,GLNP,

01147

SUCHY, W.J., L.L. MCDONALD, M.D. STRICKLAND AND S.H. ANDERSON. 2985 NEW ESTIMATES OF MINIMUM VIABLE POPULATION SIZE FOR GRIZZLY BEARS NEW ESTIMATES OF MINIMUM VIABLE
OF THE YELLOWSTONE ECOSYSTEM.

WILDL. SOC. BULL. 13:223-228.

MIN POP DEMOG ANAL

YGBE, IMW, , ,

01148

SULLIVAN, P.T.

1983 A PREIMINARY STUDY OF HISTORIC AND RECENT REPCRTS OF GRIZZLY BEA A PRELIMINARY STUDY OF HISTORIC AND RECENT REPCRTS OF GRIZZLY
RS, URSUS ARCTOS, IN THE NORTH CASCADES AREA OF WASHINGTON. WASH. DEP. OF GAME, ORYMPIA. 32 PP.

HIST DISTR HIST ACCT PRES DISTR

NCE ,BCWA, , 
01149

SUMMERFIELD, B.

1978

INVESTIGATICNS OF GRIZZLY BEAR - CATTLE RELATICNSHIPS IN THE COW CREEK AND GRASS CREEK DRAINAGES.

U.S.D.A., FOREST SERV.. IDAHO PANHANDLE NATL. FORESTS. 20 PP.

LIVESTK IMP LIVESTK MGMT

SME, ID , IPNF,

01150

SUMNER, J. AND J.J. CRAIGHEAD.

GRIZZLY BEAR HABITAT SURVEY IN THE SCAPEGOAT WILDERNESS, MONJANA.

MONT. CODP. WILOL. RES. UNIT, UNIV. MCNT. MISSCULA. 68 PP.

FOOD FEED BEH
HAB EFFECT CENSUS METH CENSUS/TREND

NCDE,MT ,USFS,,$S C A P$

01151

SUNDSTROM, T.C.

1985

AN ANALYSIS OF DENALI NATIONAL PARK AND PRESERVE'S MANAGEMENT PRO GRAM TO EDUCATE VISITORS REGARDING BEHAVIOR WHILE IN BEAR CGUNTRY

-

M.S. THESIS, UNIV. WYO., LARAMIE. 291 PP.

PUBLIC ATT EDUC NCNMOT MGMT

$A K-I, A K$, DENP, ,

01152

SUT TERLIN, L.M.

1985

INTERPRETATION OF BEARS IN WATERTON LAKES NATIONAL PARK.

M.S. PROJ., UNIV. OF CALGARY, ALBERTA. 71 PP.

PUBLIC ATT EDUC

CR , AT, WANP, 
01153

SUTTON, R. W.

1967

POSSIBLE RECENT OCCURRENCE OF GRIZZLY IN MANITCEA.

BLUE JAY 24:190-191.

HIST DISTR

, $M$ ANTB, ,

01154

SVIHLA, A., H. BOWMAN AND R. PEARSON.

1955

BLOOD PICTURE OF THE AMERICAN BLACK BEAR, URSUS AMERICANUS.

J. MAMMAL. $36(1): 134-135$

HEMAT

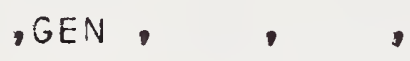

01155

TAIT, D.E.N.

1980

AEANDONMENT AS A REPRODUCTIVE TACTIC - THE EXAMPLE GF GRIZZLY BEA RS.

AM. NAT. $115(6): 800-808$.

REPRO MATERNAL REP RATE

$$
\text { , GEN, }, \quad
$$

C11 156

TAIT, D.E.

1983

AN ANALYSIS OF HUNTER KILL DATA.

PH.D. THESIS, UNIV. OF B.C., VANCOUVER, 129 PP.

HARV MGMT

, GEN . , 
01157

TAYLOR, J.S.

BEAR MANAGEMENT PLANS IN CANADIAN NATIONAL PARKS: FIFTEEN ESSENTI AL ELEMENTS.

M.S. THESIS, UNIV. OF CALGARY, ALBERTA. 345 PP.

$$
\begin{array}{llll}
\text { MGMT PLAN } & \text { NONMOT MGMT } & \text { MOTOR MGMT } & \text { LEGAL } \\
\text { EDUC } & \text { MGMT GEN } & \text { CAMP MGMT } & \text { GARB MGMT } \\
\text { MCNIT SYS } & &
\end{array}
$$

01158

TAYLOR, M., J.S. CARLEY AND F.L. BUNNELL.

INECRRESS L REPRODUCT ICN SCHEDULES.

MANUSCRIPT. 19 PP.

DEMOG ANAL

, GEN , , ,

C1159

TAYLOR, R.A.

1964 COLUMBIAN GROUND SQUIRREL AND CAMBIUM FOUND IN GRIZZLY BEAR STOMA CHS TAKEN IN THE FALL.

J. MAMMAL. $45(3): 476-477$.

FOOD

NCDE,MT ,FLNF, ,MISS

01160

THIER, T.J.

CABINET MOUNTAINS GRIZZLY BEAR STUDIES, 1979-1980.

BORDER GRIZZLY PROJ. UNIV. MONT. NISSOULA. SPEC. REP. NC. 50.6
P .
CAPTURE
FODD
MGMT GEN
IDENT $/ R E C O G$
HAB RECON
MAP / TYPE

CYE, MT, ,, , $A B$ 
01161

THIER, T. ANC D. SIZEMORE.

1981 AN EVAUATION OF GRIZZLY RELOCATIONS IN THE BGP AREA, 1975-1980.

BOROER GRIZZLY PROJ., UNIV. MONT., MISSOULA. SPEC. REP. NO. 47.1
6 PP.

$\begin{array}{ll}\text { RELOC MOVE HUMAN IMP } & \text { MGMT GEN LIVESTK IMP } \\ \text { AGE/SEX } & \end{array}$

NCDE:MT, ,

01162

TIETJE, W.D. AND R.L. RUFF.

1977 ÁNTRIBUTION TOWARDS A CURRENT BIBLIOGRAPHY ON BEAR BIOLCGY, MA AAGEMENT AND RESEARCH.

CEP. WILDL. ECOL, UNIV.WIS, MADISON. 63 PP.

B IBLIO

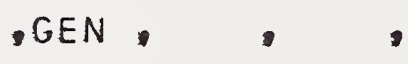

01163

TIRMENSTEIN, D.A.

1983 GRIZZLY BEAR HABITAT AND MANAGEMENT IN THE RATILESNAKE NATICNAL R ECREATION AREA AND WILDERNESS.

M.S. THESIS, UNIV. MONT, MISSOULA. 213 PP.

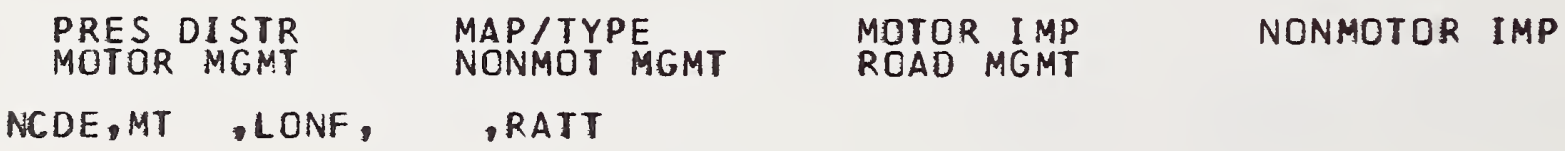

01164

TOLLEFSON, $M$.

1975A MANAGMENT INFORMATION.

MEMO TO ROLLIE OSTERMICK, ALASKA TASK FORCE. FROM KATMAI NATL. $P$ ARK AND PRESERVE, ALASKA. 2 PP.
DEPR.ED
HUMAN INJ
CCNTROL

AKPN,AK, ,KANM, , 
01165

TOLLEFSCN, M.

19758
SUMMARY OF BEAR DAMAGE, SUMMER OF 1975.

MEMO. TO SUPERINTENDENT, KATMAI NATL. PARK AND PRESERVE, ALASKA. $2 \mathrm{PP}$
DEPRED
HUMAN INJ
CCNTROL

AKPN,AK , KANM,

01166

TOMPA, F.S.

GRIZZLY BEARS IN BRITISH COLUMBIA - HARVEST MUST BE REDUCEC. PRES. AT ANNU: CONF: WEST: ASSOC. FISH AND WILDL. AGENCIES, JULY
1984 , VICTORIA, B.C: 9 PP:

HARV IMP HARV MGMT

$, B C, \quad$,

01167

TOTH, T. AND L. SINKEY.

1983

VEGETATION MAPPING IN THE CASCADE VALLEY.

PP 287-303 IN: D. HAMER AND S HERRERO, ED, ECCLOGICAL STUDIES O F THE GRIZZLY BEAR, BANFF NATIONAL PARK: PREP: FOR PARKS CANADA C MAP/TYPE

CR , AT ,BANP, ,CASC

01168

TOVELL, W.M. AND R.E. DUANE.

1966 GRILY BEAR SKULL: SITE OF A FIND NEAR LAKE SIMCOE.

SCIENCE $154(3745): 158$

HIST DISTR

.ONT 
01169

TRACY, D.M. 1977
REACTIONS OF. WILDLIFE TC HUMAN ACTIVITY ALONG MCUNT MCKINLEY NATI
ONAL PARK ROAD.

M.S. THESIS, UNIV. ALASKA, FAIRBANKS. 260 PP.

POP DENS CENSUSITREND REACTION MOTOR IMP
ROAD IMP

$A K-I, A K$ DDENP,

C1170

TRACY, D.M., F.C. DEAN, C.M. ANDERSON AND T.M. JORDAN. 1982

BROWN BEAR BIBLIOGRAPHY.

ALASKA COOP. PARK STUDIES UNIT, UNIV. ALASKA, FAIRBANKS.

BIBLIO

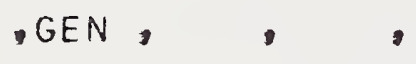

01171

TREVINO, J.C.

NTPATUS OF THE MEXICAN WOLF AND GRIZZLY BEAR IN NORTHERN MEXICO.

U.S.D.A., FOREST SERV. GEN. TECH. REP., WO NO. 36:78-80.

HIST DISTR PRES DISTR

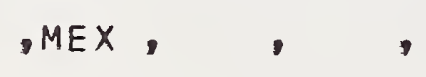

01172

TREVINO, J.C. AND C. JONKEL.

IN PRESS

DO GRIZ ZLIES STILL LIVE IN MEXICO?

INT. CONF. BEAR RES. AND MANAGE. 6 .

PRES DISTR

, MEX, , , 
01173

TROYER, W.A.

1961

THE BROWN BEAR HARVEST IN RELATION TO HANAGEMENT ON THE KODIAK IS LANDS.

TRANS. NORTH AM. WILDL. AND NAT. RESOUR, CONF. 26:460-468.

HARV DATA HARV MGMT AGE/SEX

AKPN, AK ,KNWR, ,KOIS

01174

TROYER, W.A. SIZE, DISTRIBUTION, STRUCTURE AND HARVEST DF A KODIAK BEAR POPULA

M.S. THESIS, MONT. STATE UNIV. BOZEMAN. 48 PP.
HIST DISTR
LITR SIZE
POP DENS
CENSUS/TREND
AGEJSEX
HARV CATA
MISC QUANT

AKKA,AK ,KNWR, ,KARL

01175

TROYER, W.

1974

DISTRIBUTION AND DENSITY OF BROWN BEAR DENING, KATMAI AREA, ALASK

U.S.D.I. NATL. PARK SERV. KATMAI NATL. MONUMENT, ALASKA. $15 P P$.

DEN SITE DEN CHAR

AKPN,AK, KANM, ,

01176

TROYER, $W$.

1978

BROWN BEAR STUDIES - KATMAI.

U.S.D.I., NATL. PARK SERV., ANCHORAGE, ALASKA. 17 PP.

CENSUS/TREND AGE/SEX MEASJQUANT MOVE
MORT DATA MOND MON

AKPN,AK, KANM, , 
01177

TROYER, W.

MOVEMENTS AND DISPERSAL OF BROWN BEAR AT BROOKS RIVER, ALASKA.

U.S.D.I. NATL. PARK SERV., ALASKA AREA DFFICE, ANCHORAGE. 23 PP.

MOVE

PRED

RECR IMP

AKPN,AK ,KANM, ,BROO

01178

TROYER, W.

$1980 B$

DISTRIBUTION AND DENSITIES OF BROWN BEAR ON VARIOUS STREAMS IN KA TMAI NATIONAL MONUMENT.

U.S.D.I. NATL. PARK SERV., ALASKA AREA OFFICE, ANCHORAGE. 15 PP.

CENSUS/TREND PRED PRES DISTR

AKPN,AK ,KANM, ,

C1179

TROYER, W. AND J.B. FARC.

AERIAL SURVEY OF BROWN BEAR DENNING IN THE KATMAI AREA CF ALASKA.

PRES. AT NORTHWEST SECT. WILDL. SOC. MEET • 2-4 APR. 1975, ANCHORA GE, ALASKA. IOPP.

DEN SITE DEN CHAR

AKPN,AK, KANM, ,

C1180

TROYER, W.A. AND R.J. HENSEL.

1962 CANNIBALISM IN BROWN BEAR.

ANIM=BEH. $10(3-4): 231$.

\section{CANNIBAL}

AKKA,AK ,KNWR, ,KOIS 
01181

TROYER, W.A. AND R.J. HENSEL.

$1964 A$

BEHAVIOR OF FEMALE BROWN BEARS UNDER STRESS.

J. MAMMAL $45(3): 488-489$.

MATERNAL

AKKA,AK ,KNWR, ,KOIS

01182

TROYER, W.A. AND R.J. HENSEL.

$1964 \mathrm{~B}$

STRUCTURE AND DISTRIBUTION OF A KODIAK BEAR POPULATION.

J. WILDL. MANAGE, 29(4):769-772.
AGE/SEX
POP EST
POP DENS
CENSUS/TREND

AKKA,AK, , , KOIS

01183

TROYER, W.A. AND R.J. HENSEL.

1969 THE BROWN BEAR OF KODIAK ISLAND.

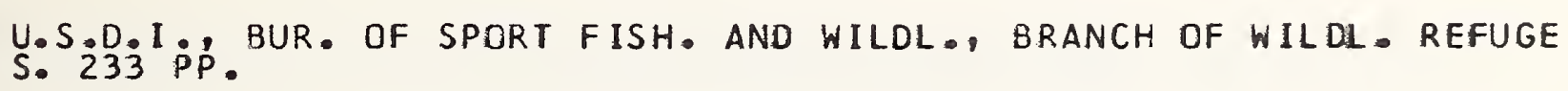

$\begin{array}{llll}\text { MEAS/QUANT } & \text { GEN DATA } & \text { PCP BIOL } & \text { MORT CATA } \\ \text { CENSUS/TREND } & \text { GROW/DEV } & \text { DEN } & \text { REPRO } \\ \text { AGEISEX } & , \text { KOIS } & & \\ \text { AKKA,AK } & & \end{array}$

01184

TROYER, W.A., R.J. HENSEL AND K.E. DURLEY.

1962 LIVE TRAPPING AND HANDLING OF BROWN BEARS.

J. WILDL. MANAGE. $26(3): 330-331$.

CAPTURE

AKKA, AK, KNWR, ,KARL 
01185

TSCHANZ, VLN B., M. MEYER-HOL ZAPFEL AND S. BACHMANN.

1970

CAS INFORMATIONSSYSTEM BEI BRAUNBAREN. (ENGLISH SUMMARY).

ZEITSCHRIFT FUR TEIRPSYCHOLOGIE 27:47-72.

MARK

, GEN, , ,

01186

TULLAR, R.M.

NEW RECORD OF CALIFOPNIA GRIZZLY BEAR.

J. MAMMAL. $39(1): 151-153$

HIST DISTR

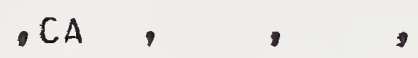

01187

TURNER, J. (CHAIRMAN) 。

$1985 A$

THE GREAT BEAR IN CUR PARKS.

PREP. FOR THE SECRETARY OF THE INTERIOR PREP. BY THE WILDL . COMM
- OF THE NATL. PARK ADVISORY BOARE. $14 \mathrm{PP}$.

$\begin{array}{llll} & \text { MGMT GEN } & \text { CCNTROL } & \text { RELOC } \\ \text { RES MORT } & \text { NCNMOT MGMT } & \text { PCL/ADM MGMT } & \end{array}$

YGBE, IMN , YNP, ,

01188

TURNER, J (CHAIRMAN).

$1985 B$

REPORT OF THE TASK FORCE.

MEMO. TO RESEARCH CHAIRMAN, INTERAGENCY GRIZZLY BEAR COMM FROM G RIZZLY BEAR TASK FORCE CN CLOSURES FOR GRIZZLY BEAR MANAGEMENT IN YELLOWSTONE NATL. PARK. UNIV. MONT. MIS SOULA. 4 PP.

CLOSURE

YGBE, IMW, YNP , 
C1189

U.S. BUREAU OF LAND MANAGEMENT.

1984

BI OLOGICAL ASSESSMENT FOR THE NORTH FORK EXPLORATORY OIL AND GAS WELL (MARATHON) CN THE SHOSHONE NAT IONAL FOREST, CODY, WYOMING.

U.S.D.I. BUREAU OF LAND MANAGEMENT, WARLAND DISTRICT, WYC. 34 P PRES DISTR ENERGY IMP

YGBE,WY, SHNF, ,

C1190

U.S. DEPARTMENT IJF AGRICULTURE.

1984 PROPOSED LEWIS AND CLARK NATIONAL FOREST PLAN.

U.S.D.A., FOREST SERV., LEWIS AND CLARK NATL. FOREST, GREAT FALLS MGMT PLAN

NCDE,MT , LCNF, ,

01191

U.S. FISH AND WILDLIFE SERVICE.

$1982 \mathrm{~A}$

GRIZZLY BEAR RECOVERY PLAN.

U.S.D.I. FISH AND WILDL. SERV., WASHINGTON, D.C.

$\begin{array}{llll}\text { MGMT PLAN } & \text { LEGAL } & \text { MCRT MGMT } & \text { LIVESTK MGMT } \\ \text { RECR MGAT } & \text { PRES DISTR } & \text { EOUC } & \text { TIMB MGMT } \\ \text { POP BIOL } & & \end{array}$

01192

U.S. FISH AND WILDLIFE SERVICE.

ARCIIC NATIONAL WILDLIFE REFUGE COASTAL PLAIN RESOURCE ASSESSMENT : INITIAL REPORT BASELINE STUDY OF THE FISH, WILDLIFE, AND THEIR HAB ITS.

U.S.D.I. FISH AND WILDLIFE SERVICE, ARCTIC NATIONAL WILDLIFE, AL ASKA.

$\begin{array}{llll}\text { WEIGHT } & \text { POP } & \text { DENS } & \text { HCME } \\ \text { REP RATE } & \text { FOOD } & \text { AGE/SEX } \\ & \text { HAB USE } & \text { DEN }\end{array}$

$A R C, A K, A N W R$, 
01193

U.S. FOREST SERVICE.

1980 ENVIRONMENTAL ASSESSMENT, PROSPECT ING PERMIT APPLICATION, CONSOLI CATED GECREX GECPHYSICS.

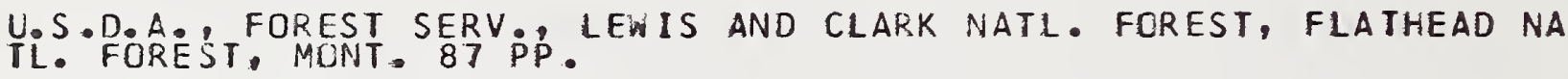

ENERGY MGMT

NCDE,MT ,LCNF,FLNF,

01194

U.S. FOREST SERVICE.

1981 /LEAVESTOCK MONITORING ON THE ASHTON RANGER DISTRICT, TARGHEE MATIONAL FOREST.

$U_{i} S_{15}=D_{P_{0}} .$. FOREST SERV., TARGHEE NATL. FOREST, ST. ANTHONY, IDAHO. DEPRED LIVESTK MGMT

YGBE,ID, TANF, ,ASHT

01195

U.S. FOREST SERVICE.

1982

ENDANGERED THREATENED AND SENSIITIVE PLANT AND ANIMAL SPECIES AND THEIR HABITATS ON THE TARGHEE NATICNAL FOREST.

U.S.D.A.A: FOREST SERV., TARGHEE NATL. FOREST, ST. ANTHONY, IDEAHO

TYPE DESCR IP

LIVESTK MGMT

RECR MGMT

YGBE,IDWY,TANF,

01196

U.S. FOREST SERVICE.

CABIA INET-YAAK ECOSYSTEM GRIZZLY BEAR DATA SHEET.

U.S.D.A., FOREST SERV. 5 PP.

RELOC

CYE, IDMT,
HAB USE
COVER

FIRE MGMT

ENERGY MGMT

TIMB MGMT 
01197

U.S. FOREST SERVICE.

ZONIB GU GUIDELINES FOR MANAGING GRIZZLY BEAR HABITAT IN NORTHERN I CAHO.

UE, IDAHĆ. FOREST SERV., IDAHO PANHANDLE NATL. FOREST, COEUR D'ALE
LIVESTK MGMT
$\begin{array}{ll}\text { TIMB } & \text { MGMT } \\ \text { RECR } & \text { MGMT }\end{array}$
FIRE MGMT
ENERGY MGMT
ROAD MGMT

,ID ,IPNF, ,

01198

U.S. FOREST SERVICE.

GRIZZLY BEAR INITIATIVE, 1984-1988.

U.S.D.A., FOREST SERV., NORTHERN REGION. 9 PP.

MGMT GEN

IDMT, , ,

C1199

U.S. FOREST SERVICE.

$1984 B$

FACILITATING GRIZZLY-HUMAN COEXISTENCE - AN INTEGRATED PROGRAM.

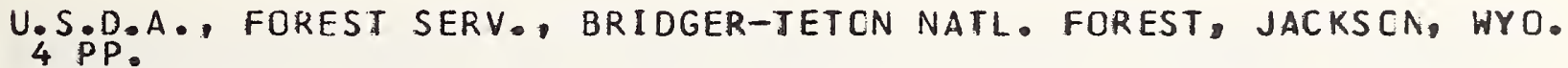
CAMP MGMT EDUC MGMT GEN

YGBE,WY, BTNF, ,

01200

U.S. FOREST SERVICE.

$1984 C$

THREATENED AND ENDANGERED SPECIES STATUS REPORT. KOOTENAI NATIONA

L FOREST - 1984.

U.S.D.A., FOREST SERV., KOOTENAI NATL. FOREST, MONT. 2 PP.

MGMT GEN EDUC MGMT GEN

,MT ,KONF, , 
01201

L.S. FOREST SERVICE.

GRIZZLY MANAGEMENT SITUATION GUIDELINES AND AUGMENTATION DISCUSSI CN.

APPENDIX 8. IN: U.S.D.A.. FOREST SERV. KOOTENAI NATIONAL FOREST P ROPDSED FOREST PLAN. U.S.D.A., FCREST SERV., KCOTENAI NATL. FORES T, LIBBY, MONT.

$\begin{array}{llll}\text { MGMT PLAN } & \text { ZCNING } & \text { TIMB MGMT } & \text { FIRE MGMT } \\ \text { ROAD MGMT } & \text { LIVESTK MGMT } & \text { RECR MGMT } & \text { GARB MGMT } \\ \text { PUP AUG } & & & \\ \text { CYNC,MT ,KONF, } & , & & \end{array}$

01202

U.S. FOREST SERVICE.

$1985 B$

GRIZZLY BEAR STANDARDS AND GUIDELINES.

APPENDIX G IN: U.S.D.A. FOREST SERV PROPOSED FOREST PLAN FOR G ALLATIN NATIONAL FOREST: U.S.D.A. FOREST SERV., GALLATIN MATL. F CREST, MONT.

$\begin{array}{llll}\text { ZONING } & \text { TIMB MGMT } & \text { FIRE MGMT } & \text { LIVESTK MGMT } \\ \text { RECR MGMT } & \text { GARB MGMT } & \text { ENERGY MGMT } & \text { CONTROL } \\ \text { MGMTPLAN } & & & \end{array}$

01203

U.S. FOREST SERVICE.

$1985 C$

FLATHEAD NATIONAL FOREST PLAN: EIS VOL. 1 AND 2.

APPENDIX E. IN: U.S.D.A. FOREST SERVICE. FOREST PLAN: FLATHEAD N ATIUNAL FOREST. U.S.D.A : FOREST SERV.: FLATHEAD NATL. FOREST, KA LISPELL, MONT.
L IVESTK MGMT
TIMB MGMT
MGMT GEN
ROAD MGMT
ENERGY MGMT

NCDE,MT ,FLNF,

01204

U.S. FOREST SERVICE.

19850

KEY FOR GRIZZLY BEAR COMPONENTS OF THE NORTHERN ECOSYSTEMS.

U.S.D.A., FOREST SERV. 23 PP.

MAP/TYPE

$$
\text { IDMT, USFS, }
$$


01205

U.S. FOREST SERYICE.

FOREST SERVICE GRIZZLY BEAR MANAGEMENT POLICY RECOMMENDATICNS. AU GUST 1985 .

U.S.D.A., FCREST SERV. 18 PP.

\begin{tabular}{|c|c|c|c|}
\hline $\begin{array}{l}\text { MGMT GEN } \\
\text { LIVES IK MGMT } \\
\text { TIMB MGM } \\
\text { UUS USFS, }\end{array}$ & $\begin{array}{l}\text { ZONING } \\
\text { FIRE NGMT }\end{array}$ & $\begin{array}{l}\text { MAP/TYPE } \\
\text { NCNMOI MGMT }\end{array}$ & $\begin{array}{l}\text { MORT MGMT } \\
\text { ENERGY MGMT }\end{array}$ \\
\hline
\end{tabular}

01206

U.S. FOREST SEPVICE.

$1985 \mathrm{~F}$

LAND MANAGEMENT PLAN FOR THE TARGHEE NATIONAL FCREST.

U:SPDAA: FOREST SERV., TARGHEE NATL. FOREST, ST. ANTHONY, IDAHO.

MGMT PLAN ZCNING TIMB MGMT MGMT GEN

YGBE, IDWY, TANF,

01207

U.S. FOREST SERVICE.

GRIZZLY BEAR SITUATION AND MANAGMENT GUIDELINES.

APPENDIX D. IN: U.S.D.A., FOREST SERV., KOOTENAI NATIONAL FOREST CRAFT ENYIRCNMENTAL IMPACT STATEMENT. U.S.D.A., FOREST SERV., KDO TENAI NATL. FOREST, LIBBY, MONT.

$\begin{array}{llll}\text { PRES DISTR } & \text { ZONING } & \text { MGMT GEN } & \text { POP AUG } \\ \text { IIMB MGMT } & \text { FIRE MGMT } & \text { LIVESTK MGMT } & \text { RECR MGMT } \\ \text { CAMP MGMT } & & \end{array}$

01208

U.S. FOREST SERVICE.

$1985 \mathrm{H}$

THREATENED AND ENDANGERED SPECIES - GRIZZLY BEAR "GRIZZLY BEAR G UIDELINES").

APPENDIX E. IN: U.S.D.A. FCREST SERV. FOREST PLAN: FLATHEAD NATI ONAL FOREST. U.S.D.A.: FÓREST SERV. FLATHEAD NATL. FOREST, KALIS PELL, MONT.
MGMT PLAN
ZONING
FIRE MGMT
LIVESTK MGMT RECR MGMT
ENERGY MGMT
TIMB MGMT

NCDE,MT ,FLNF, 
01209

U.S. FOREST SERVICE.

GRIZZLIY BEAR.

PP. 60-93 IN: THREATENED, ENDANGERED AND SENSIJIVE PLANTS AND ANI MAL SPECIES AND JHEIR HABITATS IN THE BRIDGER-TETON NATIONAL FORE ST, U.S.D.A., FOREST SERV., JACKSON, WYO.
HAB USE
LIVESTK MGMT
FOOD
MGMT GEN
TIMB-METH
COMBR

YGBE, WY ,BTNF, ,

01210

U.S. FOREST SERVICE.

$1985 \mathrm{~J}$
MANAGEMENT AREA PRESCRIPTION 7.

APPENDIX IV, PP 187-206 IN: U.S FCREST SERV 1985. LAND AND RE SOURCE MANAGMENT PLAN FOR THE BRIDGER-TETON NATIONAL FOREST. U. S. D.A., FOREST SERV., JACKSON, WYO.

TIMB-METH

VEG SUCC

YGBE, WY ,BTNF ,
TIMB-POST

RECR MGMT
TIMB-HAB

LIVESTK MGMT 
01213

U.S. FOREST SERVICE AND BUREAU OF LAND MANAGEMENT.

1985 ENVIRONMENTAL ASSESSMENT ON HALL CREEK APPLICATION FOR PERMIT TO DRILL BY AMERICAN PETROFINA COMPANY OF TEXAS.

U.S.D.A., FOREST SERV., LEWIS AND CLARK NATL. FOREST, GREAT FALLS - MONT.

ENERGY IMP ENERGY MGMT ROAD MGMT

NCDE,MT ,USFS,BLM ,RMEF

01214

U.S. FOREST SERVICE AND U.S. NATIONAL PARK SERVICE.

1985

GREATER YELLOWSTONE AREA OUTFITTER POLICY.

U.S.D.I., NATL. PARK SERVICE AND U.S.D.A., FOREST SERV. 37 PP.

$\begin{array}{ll}\text { QUTFIT MGMT } & \text { IDENT/RECOG CAMP MGMT } \\ \text { CLOSURE } & \text { HARV MGMT }\end{array}$

CLOSURE

YGBE, IMW , , ,

01215

VALKENBURG,P.

1976

A STUDY OF THE BROWN BEAR (URSUS ARCTOS) IN THE PROPOSED NCRTHEAS

TERN ADDITION TO MOUNT MCKINLEY NATIONAL PARK.

M.S. THESIS, UNIV. ALASKA, FAIRBANKS. 86 PP.

$\begin{array}{lll}\text { HARV CATA } & \text { FOOD } & \text { PRED } \\ \text { MAP/TYPE } & \text { PRES DISTR } & \text { MEVE } \\ \text { MARK } & & \text { MEASIQUANT }\end{array}$

AK-I,AK DDEN,

$\mathrm{Cl} 216$

VAN DRIMMELEN, B.

1985

GRIZZLY BEAR MANAGEMENT PLAN FOR SKEENA REGION.

B.C. FISH AND WILDL. BRANCH, CRANBROOK, 20 PP.

\begin{tabular}{|c|}
\hline $\begin{array}{l}\text { POP DENS } \\
\text { HARV DATA }\end{array}$ \\
\hline
\end{tabular}

$B C-C, B C, \quad, \quad, \quad, \quad, \quad, \quad, \quad$ 
01217

VAN HORN, J. AND J. DALLE-MCLLE.

DENALI BEAR-HUMAN CONFLICT MANAGEMENT, 1983.

U.S.D.I.

REACTION

01218

VAN HORN, J. AND J. DALLE-MCLLE.

1984

DENALI BEAR-HUMAN CCNFLICT MANAGEMENT, 1984.

U. A. $_{2 .} 2$. I PP: NATL. PARK SERV. DENALI NATL. PARK AND PRESERVE, ALASK

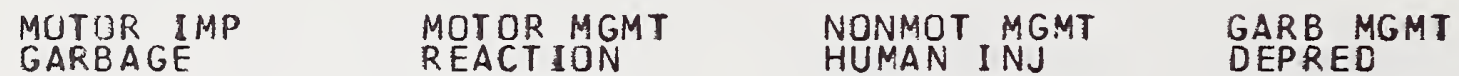

$A K-I, A K$, DENP, ,

01219

VAN KEULEN-KROMHOUT, G.

1978

200 ENCLOSURES FOR BEARS. URSIDAE: THEIR INFLUENCE ON CAPTIVE BEH AVIOUR AND REPRODUCTION.

INT. ZOO YEARB. 18:177-186.

ZOO TECH

GEN,,

01220

VARNEY, J.R., J.J. CRAIGHEAD AND J.S. SUMNER.

1974

AN EVALUATION DF THE USE OF ERTS-1 SATELLITE IMAGERY FOR GRIZZLY BEAR HABITAT ANALYSIS.

PROC. SYMP. 3RD. EARTH RESOUR. TECH. SATELLITE 1:1653-1669.

MAP/TYPE

NCDE,MT, USFS, ,LSWA 
01221

VARNEY, J.R., J.J. CRAIGHEAD AND J.S. SUMNER.

1976

AN EVALUATION OF THE USE OF ERTS-I SATELLITE IMAGERY FOR GRIZZLY BEAR HABITAT ANALYSIS.

INT. CONF. BEAR RES. AND MANAGE. 3:261-273.

HAB ANAL MAP/TYPE

NCDE, MT ,LONF, ,LSWA

01222

VIERECK, L.A., C.T. DYRNESS AND A.R. BATTEN.

1982

REVISION OF PRELIMINARY CLASSIFICATIONS FCR VEGETATION OF ALASKA.

U.S.D.A. FOREST SERV., FAIRBANKS, AK. UNPUBL. RER., INST. NO. FO
RESTRY. 72 PP. HAB ANAL VEG SUCC

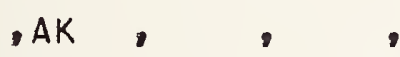

01223

VROOM, G.W., S. HERRERO AND R.T. OGILVIE. 1980 THE ECOLCGY OF WINTER DEN SIIES CF GRIZZLY BEARS IN BANFF NATIONA L PARK, ALBERTA.

INT. CONF. BEAR RES. AND MANAGE • 4:321-330.

DEN DEN CHRON DEN CHAR DEN SITE

CR ,AT ,BANP,

01224

WALKER, E\&P., R.M. NOWAK AND J.L. PARADISC.

1983

WALKER'S MAMMALS OF THE WORLD, VOL. II.

JOHNS HOPKINS UNIV. PRESS, BALTIMORE, MD, 1362 PP.

TAXON/EVOL MORPH/PHYS GEN BIOL DISTR 
01225

WALLACH, J.

1978
URSIDAE. CHAPTER $26 . P P, 628-706$ IN: M.E. FOWLER, ED. ZCO AND WILD ANIMAL
MEDICINE. W. B. SAUNDERS CO. PHILADELPHA, PA.

ZOO TECH

PARASIDIS

DENT

REPRO PHYS

$$
, \text { GEN, , , }
$$

01226

WALLACH, J.D., R. FRUEH AND $M=$ LENTZ.

1967

THE USE UF M.99 AS AN IMMOBILIZING AND ANALGESIC AGENT IN CAPTIVE WILD ANIMALS.

J. AM. VET. MED. ASSOC. 151(7):870-876.

DRUGS 200 TECH

, GEN, , ,

01227

WALSBERG, G.E.

COAT COLOR AND SOLAR HEAT GAIN IN ANIMALS.

BIOSCIENCE 33(2):88-91.

$\begin{array}{lll}\text { PELAGE HAIR TEMP } & \end{array}$

, GEN, , ,

01228

WARNER, $S$.

IN PRESS

VISITOR IMPACT ON BROWN BEARS, ADMIRALTY ISLAND, ALASKA.

INT. CONF. BEAR RES. AND MANAGE. 7 .

NONMOTOR IMP ACT PATT REACTION

AKSE,AK ,AINM, ,PACR 
01229

WASER, P.M. AND h.T. JCNES.

1983

NATAL PHILOPATRY AMONG SOLITARY MAMMALS.

GUART. REV. BIOL. 58:355-390.

INTRASP BEH MATERNAL MCVE

GEN,,$\quad$,

01230

WATSON, G.W.

1955

CARIBOU MUVEMENTS, ABUNCANCE AND DISTRIBUTION.

FED, AID WILDL REST PPROJ. W-3-R-9, JOB NO. 1 , WORK PLAN 8 . ALAS
KA GAME CONMISSION, JUNEAU: 4 PP. PRED

$A K-I, A K \quad, \quad, N E S U$

01231

WATTS, P.D. N.A. ORITSLAND, C. JONKEL AND K. RCNALD.

1981

MAMMALI AN HIBERNATION AND THE OXYGEN CONSUMPTICN OF A DENNING BLA CK BEAR (URSUS AMER ICANUS).

COMP = BIOCHEM. PHYSIOL. 69(1):121-123.

HIB PHYS

,$G E N$

01232

HEA VER, J.

1986

CHARTING THE COURSE, THE FOREST SERVICE GRIZZLY BEAR CONSERVATION PROGRAM.

U.S.D.A. FOREST SERV. 79 PP.

MGMT GEN

MGMT PLAN

,US

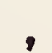


01233

WEAVER, J., R. ESCANG, D. MATTSON, T. PUCHLERZ AND D. DESPAIN. 1985 CUMULATIVE EFFECTS ANALYSIS PROCESS FOR THE YELLOWSTONE ECOSYSTEM - (DRAFT).

U.S.D.A. FGREST SERV
$Y$ GRILLLY AND U.S.D. I B N NATL PAR STUDY TEAM, UNIV. MONT., MISSCULA. 40 PP. CUMEFF MUTOR IMP NCNMOTOR IMP HAB EFFECT HUMAN IMP

YGBE, IMN , ,

01234

WEAVER, J.R. ESCANO, D. MATTSON, T. PUCHLERZ AND D. DESPAIN. 1986 A UMULATIVE EFFECTS MODEL FOR GRIZZLY BEAR MANAGEMENT IN THE YEL LOWSTONE ECOSYSTEM.

PP. 234-246 IN: G.P. CONTRERAS AND K.E. EVANS, EDS. PROCEECINGS-G RIZZLY BEAR HAEITAT SYMPOSIUM.U.S. D. A . FUREST SERV. INTERMOUNTA IN RES. STAT., OGDEN, UTAH. GEN. TECH. REP. INT-207.
CUM EFF
HUMAN IMP
MOTOR IMP
NONMOTOR IMP
HAB EFFECT

YGBE, IMW ,

01235

hECKWORTH, R.P., K. KONCCHE AND J. CROSS.

EIG GAME SURVEY AND INVENTORY.

FED. AID WILOL. REST. PROJ W-130-R-6, JOB NO. I- 1 , JOB COMPLETIO
$N$ REP., JULY 1, $1974-J U N E 30,1975$. MONT. DEP. FISH AND GAME, HEL ENA. 28 PP.
HARV DATA
AGE/SEX
RELOC

NCDE, MT , ,

01236

hEEDEN, R.B.

1971 AND WILOLIFE: A BIOLOGIST'S VIEW.

TRANS NORTH AM. NILDL. AND NAT - RESOUR C CONF. 36:242-251.

ENERGY IMP 
01237

WELSH, C.J. ANU H.D. PICTON.

1984

AN INVESTIGATION OF GRIZZLY AND BLACK BEAR SCAT SEPARATION USING BILE ACIDS.

FINAL REP PREP FOR NATL. PARK SERV \& CRDER NC. PX 1200-3-C423. PREP. BY MONT. STATE UNIV., BOZEMAN. II PP.

SCAT ANAL IDENT/RECOG

$, G E N, \quad$,

01238

WERNER, T., D. GILLESPIE AND C. JONKEL.

1978

GRIZZLY AND BLACK BEAR DENS IN THE BORDER GRIZZLY AREA.

PP. 173-214 IN: C. JONKEL, ED. ANNUAL REPCRT. BCROER GRIZZLY PROJ $\because$ UNIV. MONT., MISSOULA. ANNU. REP. NO. 3.
DEN SITE
DEN CHAR
DEN CHRON

NCDE,MT

01239

WERNER, T. AND C. JONKEL.

1977

GRIZZLY DENS IN THE BORDER GRTZZLY AREA.

PP. 3-1 1 IN: C JONKEL, ED. ANNUAL REPORT . BCRDER GRIZZLY PROJ. UNIV. MONT., MISSCULA. ANNU. REP. NC. 2 .

DEN SITE

NCDE, MT ,

01240

WHITE, T.

1965

THE POSSIBILITY CF GRIZZLY BEARS SIILL EXISTING IN SASKATCHEWAN.

BLUE JAY $23: 136-140$.

HIST DISTR

. SK 
01241

WHITLOCK, B. 1979
SEASONAL USE DF OVABAN AS A MEANS OF CONTRACEPTION IN IHE KODIAK
BEAR.

ANN. PROC. AM. ASSOC. ZOO VET. 1978:179-1980.

REPRO PHYS ZOO TECH

GEN, , , ,

01242

WIELGUS, R.B.

1986

HABITAT ECOLUGY OF THE GRIZZLY BEAR IN THE SOUTHERN ROCKY MCUNTAI NS BF CANADA.

M.S. THESIS, UNIV. IDAHO, MOSCOW. 136 PP.

$\begin{array}{llll}\text { HAB USE } & \text { HAB EFFECT } & \text { FOOD } & \text { HAB ANAL } \\ \text { HOME RNG } & \text { MOVE } & \text { INTRASP BEH } & \text { DEN } \\ \text { PFED } & & \end{array}$

01243

WIMSATT, W.A.

1963

DELAYED IMPLANTATION IN THE URSIDAE, WITH PARTICULAR REFERENCE TO THE BLACK BEAR (URSUS AMER ICANUS PALLAS).

PP.
3 i 9 PP.
P6 IN: DELAYED IMPLANTATION. UNIV. CHICAGO PRESS, CHICAGO. REPRO PHYS $, G E N, \quad$,

01244

WINN, D.S. AND K.R. BARBER.

CARTOGRAPHIC MOLDING: A METHOD OF CUMULATIVE EFFECTS APPRAISAL.

PP. 247-252 IN: G.P. CONTRERAS AND K. E. EVANS, EDS. PROCEECINGS-G IN RES. STAT., OGDEN, UTAH. GEN. TECH. REP. INT-2O7.
MAP/TYPE
CUM EFF

YGBE, IMW , 
01245

WINTER, K.

1969 BIG GAME SURVEY. GRIZZLY BEAR STUDY. FED. AID WILOL. REST. PROJ. W-027-R-23, JCB NO. 4. WYO. GAME AND
FISH COMM., CHEYENNE.

CENSUS METH HARV CATA

YGBE,WY , SHNF, BTNF,

01246

WOLFE, J.R.

1983 ELECTROPHORETIC DIFFERENTIATION BETWEEN ALASKAN BROWN AND BLACK B EARS.

J. WILDL. MANAGE, 47(1):268-271.

IDENT / RECOG

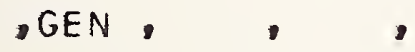

01247

WOLFE, R.R., R.A. NELSEN, T•P. STEIN, L. ROGERS AND M.A. WOLFE. 1982

UREA NITROGEN REUTILIZATION IN HIBERNATING BEARS.

FED. PROC • 41(5):1623.

HIB PHYS

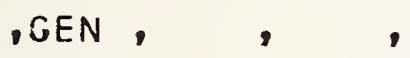

01248

WOOD, K.H.

$1985 \mathrm{~A}$

1985 IMPLEMENTATION PLAN: IMPLEMENTING THE INFORMAT ION AND FACILI

TIES PROGRAM TO MANAGE RECREATION USE IN GR IZZLY HABITAT.

U.S.D.A.' FOREST SERV., ROCKY MOUNTAIN REGION, SHOSHONE NATL. FOR EST, WYO: 39 PP.
MGMT GEN
CAMP MGMT
OUTFIT MGMT

YGBE, WY , SHNF, , 
01249

hOOD, K.H.

$1985 B$

1984 ENVIPONMENTAL ASSESSMENT. MANAGING RECREATION USE IN GRIZZLY HABITAT.

APPFNDIX F IN: K.H. WOOD. 1985 IMPLEMENTATLON PLAN. IMPLEMENTING THE INFORMAT ION AND FACILTIES PROGRAM TO MANAGE RECREATION USE IN GR I ZZLY HAB I TAT. U.S.D.A. FOREST SERV." SHOSHONE NATL. FCREST, WYQ 45 PP. MGMT GEN CAMP MGMT MURT MGMT ZCNING NONMOT MGMT CLOSURE MGMT PLAN YGBE,WY , SHNF,

01250

WOOD. M. AND A. OLSEN.

$1984 \mathrm{~A}$

WILOLIFE IMPACT ASSESSMENT AND SUMMARY OF PREVICUS MITIGATICN REL ATED TO HYCROELECTRIC PROJECTS IN MCNTANA, YOLUME 2A - CLARK FORK PROJECTS: THQNPSON FALLS DAM.

FINAL REP. MONT. DEP. FISH, WILDL. AND PARKS, HELENA.

ENERGY IMP

CYE,MT, , , ,,$\quad L A R$

01251

WOOD, M. AND A. OLSEN.

19848

WILOLIFE IMPACT ASSESSMENT AND SUMMARY OF PREVIOUS MITIGATION REL ATED TO HYDROELECTRIC PROJECTS IN MONTANA, YOLUME $2 B$ - CLARK FORK RIVER PROJECTS: CABINET GORGE AND NOXON RAPIDS DAMS.

FINAL REP. MONT - DEP. FISH, WILDL . AND PARKS, HELENA.

\section{ENERGY IMP}

CYE ,MT, , ,CLAR

01252

HOOD, R.E.

1973

SOU THEASTERN BROWN BEAR STUDIES.

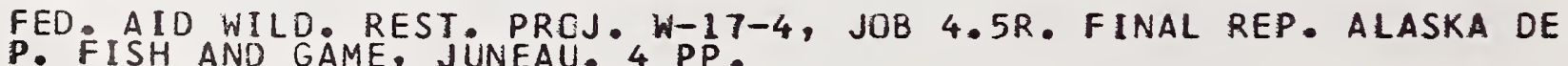
LENGTH WEIGHT
CAPTURE 
01253

hOOD, R.E.

1974

SOUTHEASTERN BROWN BEAR STUDIES.

FED. AID WILD REST. PRQJ. W-17-5, JUE 4.7R. PRCG. REP.. VCL II.
ALASKA DEP. FISH ANC GAME: JUNEAU: 4 PP. LITR SIZE AGE/SEX POP EST

AKSE, AK , , , , $\quad$, IS

01254

hCOD, R.E.

1975

SOU THEASTERN BROWN BEAR STUDIES.

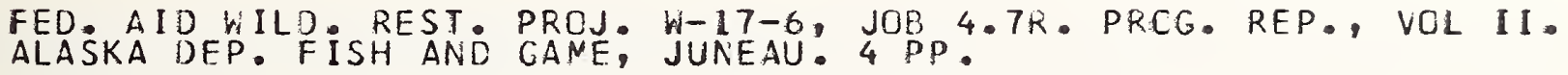

MOVE POP EST AGE/SEX WEIGHT

AKSE,AK, , , ADIS

01255

hOOD, R.E.

1976

MOVEMENT AND POPULATICNS OF BROWN BEARS IN THE HOCD BAY DRAINAGE GF ADMIRALTY ISLAND.

FED AID WILDL, REST, PROJ. W-17-5, W-17-6, AND W-17-7, JOB 4 .7R. MEINAL REP: JUNEAU: 10 PP.

CENSUSTTREND MOVE AGE/SEX WEIGHT

AKSE,AK, , , ADIS

01256

WOODS, R. ANO D. HEBERT.

PRELIMINARY ANALYSIS OF HARVEST DATA FOR COASTAL BEAR POPULATIONS IN REGION V.

B.C. WILDL. BRANCH, VICTORIA. 26 PP.

HARV DATA AGE/SEX POP DENS HARV IMP
HARV MGMT

$B C-C, B C, \quad, \quad$, 
01257

WOOLORI DGE, D.R.

1978

A FIELD AND CAPTIVE STUDY OF REPELLENCY AND INDUCED AVERSION TECH NQIUES ON 3 FAMILIES OF VERTEBRATE PESTS: URSIDAE, CANIDAE AND CE RVIDAE.

M.S. THESIS. SIMCN FRASER UNIV., BURNABY, B.C.

DETER/REPEL

,$G E N$

01258

WCOLDRI DGF, C.R.

1980

CHEMICAL AVERSION CONDITIONING OF PCLAR ANO BLACK BEARS.

INT. CONF - BEAR RES. AND MANAGE - 4:167-173.

AVER COND

, GEN, , ,

01259

WOOLDRIOCE, D.R.

1983

POL AR BEAR ELECTRCNIC DETERRENT AND DETECTICN SYSTEMS.

INT. CONF. BEAR RES. AND MANAGE. 5:264-269.

DETER/REPEL

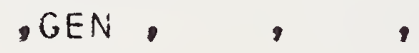

01260

WOOLDRIDGE, D.R.

THE "FERRET" 12 GAUGE SOFT-SLUG AS A BLACK BEAR DETERRENT.

PRES. AT PREDATOR SYMP. 23 MARCH, 1984, MI SSOULA, MONT.

DETER/REPEL

, GEN, , , 
01261

WOOLDRIDGE, D.R. AND P. BELTON.

1980

NATURAL AND SYNTHESIZED AGGRESSIVE SOUNOS AS POLAR BEAR REPELLENT S.

INT. CONF. BEAR RES. AND MANAGE • 4:85-91.

DETER/REPEL

, GEN ,

01262

WOOLEY, D.R.

1976

JERRESTRIAL MAMMAL STUDIES ALONG THE CROSS DELTA PIPELINE ROUTE, 1975 .

CHAPTER 3 IN: R.D. JAKIMCHUK, ED. STUDIES OF MAMMALS ALONG THE PR OPOSED MACKENZIE VALLEY GAS PIPELINE ROUTE, 1975. ARCTIC GAS BIOL - REP. SER., VOL. 36.

PRES DISTR

CARC, NW YK,

01263

WORLEY, D.E., J.C. FOX, J.B. WINTERS, R.H• JACOBSON AND K.R. GREER. 1976

HELMINTH AND ARTHROPOD PARASITES OF GRIZZLY AND BLACK BEARS IN MO NTANA AND ADJACENT AREAS.

INT. CONF. BEAR RES. AND MANAGE. 3:455-464.

PARAS/DIS

, MT .

01264

WORLEY, D.E. K.R. GREER AND D. PALMISCIANO.

1983

POSSIBLE RELATIONSHIPS BETWEEN TRICHINELLOSIS AND ABNORMAL BEHAVI CR IN BEARS.

INT . CONF. BEAR RES. AND MANAGE. 5:280-283.

PARAS/DIS

-MTWY, 
01265

hRAY, D. AND D. HEBERT.

1975 PRELIMINARY INVESTIGATICNS OF THE ECOLOGY OF THE COASTAL GRIZZLY BEAR IN THE AHNUHATI RIVER - KNIGHI INLET.

BRIIISH COLUMBIA, WILDLIFE BRANCH, VICTORIA. 80 PP.

$\begin{array}{cccc}\text { POP EST } & \text { AGON RELOC } & \text { MISC QUANT } \\ B C-C . B C, \quad, \quad \text { AHNU } & \end{array}$

01266

WRIGHT, W.H.

1909

THE GRIZZLY BEAR.

UNIV. NEBRASKA PRESS, LINCOLN. 274 PP.

HIST ACCT GEN BIOL

, GEN, , ,

01267

WYNNK, W.P. AND J.R. GUNSON.

DES IGN AND EFFECTIVENESS OF A PORTABLE ELECTRIC FENCE FOR APIARIE S.

ALBERTA FISH AND WILDL. DIV., EDMONTON. 11 PP.

DETER/REPEL

, AT, , ,

01268

YDE, C.A. AND A. OLSEN.

1984

WILDLIFE IMPACT ASSESSMENT AND SUMMARY OF PREVIOUS MITIGATION REL ATED TO HYDROELECTRIC PROJECTS IN MONTANA, VOLUME 1: LIBBY DAM PR CJECT.

FINAL REP . PREP B BY MONT DEP FISH, WILDL. AND PARKS, HELENA. PR EP. BY BONNEVILLE POWER ADMINISTRATION, PROJ. NC. 83-464.

ENERGY IMP

CYE, MT , , KOOC 
C1269

YOUNG, D.L.

1986

CUMULATIVE EFFECTS ANALYSIS OF GRIZZLY BEAR HABITAT ON THE LEWIS AND CLARK NATIONAL FUREST.

PP. 217-221 IN: G.P. CONTRERAS AND K.E. EVANS EDS PROCEECINGS-G RIZZLY BEAR HABITAT SYMPOSIUM. U.S.D.A. FOREST SERV. INTERMOUNTA IN RES. STAT., OCDEN, UTAH. GEN. TECH. REP. INT-207.

CUM EFF

NCDE,MT ,LCNF, ,

C1270

YOUNG, B.F. AND R.L. RUFF.

1982 POPULATION DYNAMICS AND MOVEMENTS OF BLACK BEARS IN EAST CENTRAL ALBERTA.

J. WILDL. MANAGE. $46(4): 845-860$.

INTRASP EEH AGON PCP REG , GEN, , ,

01271

YUKON DEP. RENEWABLE RESOUR .

YUKON'S ARCTIC BEARS - AVOIDING PROBLEMS WITH POLAR BEARS AND GRI ZZL IES NORTH OF TREEL INE. (DRAFT).

YUKON WILDL. BRANCH, WHITEHORSE. 25 PP.

DETER/REPEL CAMP MGMT

NINT,YK , ,

01272

YUKON DEP. RENEWABLE RESOURCES.

CURRENT MANAGEMENT OF UNGULATES AND THEIR PREDATORS IN THE YUKON TERRITORY.

YUKON RENEWABLE RESCURCES, WHITEHOUSE. 31 PP.

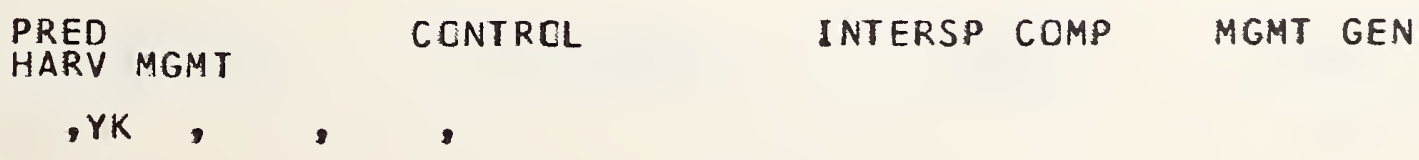


01273

YUKON DEP. RENEWABLE RESOURCES.

1986

YUKON HUNT ING REGULATIONS SYNOPSIS.

YUKON RENEWABLE RES.

HARV MGMT

YK, , ,

01274

ZAGER, $P \cdot E$.

$1980 \mathrm{~A}$

THE INFLUENCE OF LOGGING AND WILDFIRE ON GRIZZLY BEAR HABITAT IN NOR THWESTERN MONTANA.

PH.D. DISS. UNIV. MONT.. MISSCULA. 131 PP.

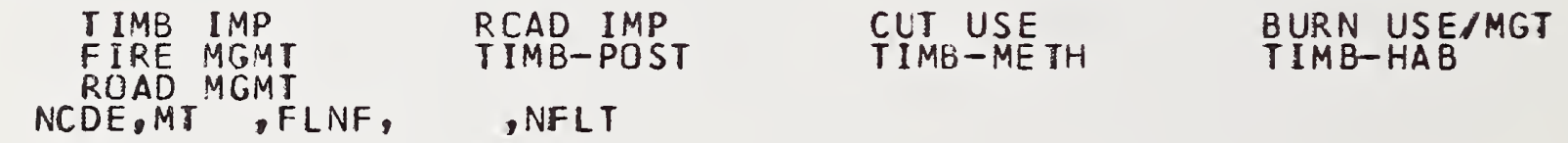

01275

ZAGER, P.E.

$1980 B$

GRIZZLY BEAR HABITAT UTILIZATICN.

PP. 99-132 IN: C. JCNKEL, ED. ANNUAL REPORT. BCRDER GRIZZLY PROJ. , UNIV. MONT., MISSOULA. ANNUAL REP. NO. 5 .

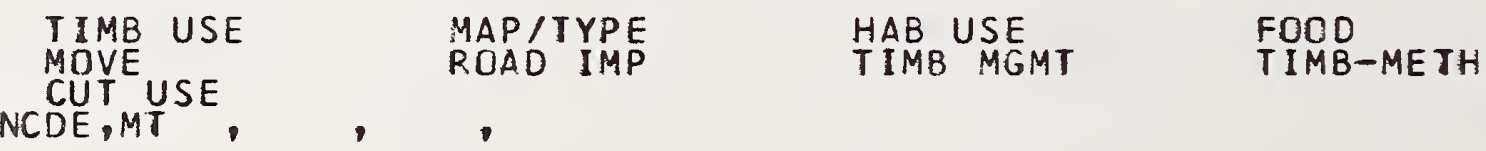

C1276

ZAGER, P.

1981

NORTHERN SELKIRK MCUNTAINS GRIZZLY EEAR HABITAT SURVEY, 1981.

U.S.D.A., FOREST SERV., IDAHO PANHANDLE NATL. FORESTS CONTRACT. 7

$\begin{array}{llll}\text { HAB RECON } & \text { MAPITYPE } & \text { PRES DISTR } & \text { TIMB-METH } \\ \text { ROAD MGMT } & \text { ZONING } & \text { CUT USE } & \text { HAB USE }\end{array}$

SME, IDWA, , 
01277

ZAGER, P.

1983

GRIZZLY BEARS IN IDEAHO'S SELKIRK MCUNTAINS: AN UPDATE.

NOR THWEST SC I. $57(4): 299-309$.

PRES DISTR HCCD HAB RECON HAB USE

SME, ID, , , ,

01278

ZAGER, P. AND C. JONKEL.

1979

GRIZZLY BEAR-WILDFIRE-LOGGING RELATIONSHIPS IN NORTHWESTERA MONTA NA - A PRUGRESS REPORT.

PP. 78-105 IN: C. JCNKEL, ED. ANNUAL REPCRT. BCREER GRIZZLY PROJ. - UNIV. MONT., MISSCULA.
VEG SUCE
BURN USE/MGT
CUT USE
TIMB-METH

NCDE,MT, , ,

01279

ZAGER, P. AND C. JONKEL.

1980

MANAGEMENT GUIDELINES FCR OCCUPIED GRIZZLY BEAR HABITAT IN NORTHW ESTERN MONTANA.

BORDER GRIZZLY PROJ., UNIV. MONT., MISSOULA. SPEC. REP. NC. 51.1 $7 \mathrm{PP}$.
HAB USE
ENERGY MGMT
TIMB MGMT
LIVESTK MGMI
TIMB-POSJ
SUBUIV MGMT
ROAD MGMT

NCDE,MT

01280

ZAGER, P.E. AND C.J. JONKEL.

1983

MANAGING GRIZZLY BEAR HABITAT IN THE NORTHERN ROCKY MOUNTAINS.

J. FORESTRY $81(8): 524-526$.

HAB USE

ENEKGY MGMT

NCDE, MT ,
TIMB MGMT

LIVESTK MGMT
RCAD MGMT

T IMB-ME TH 
01281

ZAGER, P., C. JUNKEL AND J. HABECK.

1983 LCGGING ANO WILDFIRE INFLUENCE ON GRIZZLY BEAR HABITAT IN NORTHWE STERN MONTANA.

INT - CONF - BEAF RES. AND MANAGE • 5:124-132.

$\begin{array}{llll}\text { BURN USE/MGT } & \text { FIRE MGMT } & \text { VEG SUCC } & \text { TIMB-METH } \\ \text { TIMB-PUST } & \text { TIMB IMP } & \text { CUT USE } & \text { ROAD IMP }\end{array}$

NCOE,MT ,FLNF,

01282

ZAGER, P. C. JONKEL ANC R. MACE.

1930

GRI IZLY BEAR HABITAT TERMINOLOGY.

BORDER GRIIZLY PROJ., UNIV. MONT., MISSOULA. SPEC. REP. NO. 41.1
5 PP.

HAB SAMPL MAP/TYPE

, GEN , , , ,

01283

ZARNKE, R.L.

1981

SEROLOGIC SURVEY FOR SELECTED MICROBIAL AGENTS IN MAMMALS FROM AL
EERTA, I976.

J. WILDL. DIS. $17(3): 453-461$.

PARAS/DIS

, AT , , ,

01284

ZARNKE, R.L. 1983
SEROLOGIC SURVEY FOR SELECTED MICRCBIAL PATHCGENS IN ALASKAN WILD
LIFE.

J. WILDL. DIS. $19(4): 324-329$.

PARAS IDIS

, AK , , , 


\section{APENDIX E SUBJECT KEYWORD INDEX}


ACTIVITY PATTERNS

0000900038

0040600452

0003900040000410027600289003510035900404 0094200956

0046700479006380068800721009070091600941 0113101228

AGE DETERMINATION

$\begin{array}{llllllllll}00203 & 00218 & 00219 & 00298 & 00304 & 00366 & 00368 & 00375 & 00678 & 00848\end{array}$ $008530091800920 \quad 009210093100948009670113201285$

AGE/SEX

$0004200057000650006600090 \quad 0012800129001400014100144$ $\begin{array}{lllllllllll}00161 & 00162 & 00163 & 00192 & 00219 & 00226 & 00227 & 00229 & 00246 & 00250\end{array}$ $\begin{array}{llllllllllll}00261 & 00276 & 00278 & 00285 & 00286 & 00287 & 00288 & 00289 & 00337 & 00338\end{array}$ $\begin{array}{llllllllllll}00339 & 00343 & 00347 & 00354 & 00359 & 00360 & 00361 & 00364 & 00378 & 00379\end{array}$ $\begin{array}{llllllllllll}00380 & 00381 & 00382 & 00383 & 00384 & 00385 & 00386 & 00387 & 00389 & 00391\end{array}$ $0039200402 \quad 00403 \quad 00439004550046400507005080050900510$ $\begin{array}{lllllllllll}00518 & 00522 & 00558 & 00587 & 00602 & 00605 & 00606 & 00618 & 00621 & 00623\end{array}$ $\begin{array}{lllllllllll}00627 & 00628 & 00629 & 00630 & 00632 & 00632 & 00640 & 00641 & 00674 & 00675\end{array}$ $\begin{array}{lllllllllll}00676 & 00677 & 00678 & 00681 & 00695 & 00708 & 00711 & 00728 & 00735 & 00740\end{array}$ $\begin{array}{lllllllllll}0 & 0741 & 00743 & 00776 & 00778 & 00779 & 00780 & 00781 & 00782 & 00783 & 00784\end{array}$ $\begin{array}{llllllllll}00788 & 00790 & 00792 & 00794 & 00795 & 00825 & 00829 & 00832 & 00833 & 00834\end{array}$ $\begin{array}{llllllllll}00836 & 00910 & 00917 & 00918 & 00919 & 00920 & 00924 & 00925 & 00935 & 00955\end{array}$ $\begin{array}{llllllllll}00960 & 00963 & 00978 & 00979 & 00980 & 00982 & 00984 & 00987 & 00988 & 00989\end{array}$ $\begin{array}{lllllllllll}00990 & 00991 & 00999 & 01008 & 01009 & 01010 & 01012 & 01014 & 01016 & 01017\end{array}$ $010180102501026 \quad 01028010400104901051 \quad 01052 \quad 0105301055$ $\begin{array}{llllllllllll}01067 & 01079 & 01091 & 01095 & 01106 & 01107 & 01117 & 01118 & 01131 & 01133\end{array}$ $\begin{array}{llllllllll}01139 & 01161 & 01173 & 01174 & 01176 & 01182 & 01183 & 01192 & 01235 & 01252\end{array}$ 01253012540125501256

AGONISTIC

$\begin{array}{llllllllll}00180 & 00181 & 00275 & 00276 & 00297 & 00351 & 00721 & 00806 & 00828 & 00848\end{array}$ $\begin{array}{llllllllll}00856 & 00930 & 00957 & 00978 & 00986 & 01001 & 01014 & 01045 & 01130 & 01131\end{array}$ 0113301138011390126501270

AGR ICULTURAL IMPACTS

00517005180066900771

AIRCRAFT IMPACTS

$00140 \quad 0026100351003720043300446 \quad 0060500606 \quad 0062000688$

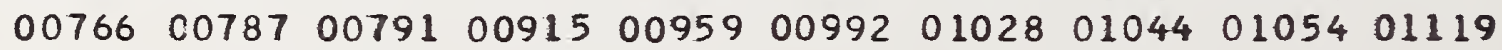

AVERSIVE CONDITIONING

$00020 \quad 00100 \quad 0018400235002640026500321003550040700408$ $\begin{array}{llllllllllll}00471 & 00472 & 00529 & 00530 & 00531 & 00532 & 00559 & 00577 & 00764 & 00777\end{array}$ 0086500977010640110501258

AVOIDANCE \& ATTRACTANTS

$001120011300150 \quad 002330044200450 \quad 00481004870048900494$ $004980057500578 \quad 005790058100608 \quad 0072501214$

BEHAVIOR PATTERNS

$0008500246 \quad 0028900309003510043900452004670051900520$ 
$005210065500688009150092300940 \quad 00941009420095600957$ 0104501121

BIBLIOGRAPHIES

00014001140025200499005290055700599008490108501162 01170

BREEDING AGE

$\begin{array}{llllllllll}00056 & 00089 & 00220 & 00221 & 00298 & 00360 & 00367 & 00484 & 00627 & 00694\end{array}$ $\begin{array}{llllllllll}00788 & 00836 & 00922 & 00940 & 00984 & 00988 & 00991 & 01026 & 01117 & 01118\end{array}$ 01137

BEETLE MANAGEMENT

00554

BURN USE/MGT

$00008 \quad 00426 \quad 00427 \quad 004340060200605 \quad 00637007120073900786$ $0080401274 \quad 0127801281$

CAMPING MANAGEMENT

00006001120011300152001700017100175002150023400236 $\begin{array}{lllllllllll}00442 & 00471 & 00472 & 00481 & 00482 & 00493 & 00494 & 00511 & 00512 & 00533\end{array}$ $\begin{array}{lllllllllll}00577 & 00578 & 00608 & 00684 & 00769 & 00800 & 00802 & 00816 & 00870 & 00874\end{array}$ $0099501036 \quad 010930114401145011570119901207 \quad 0121401248$ 0124901271

CANN I BAL I SM

00251003590049200641009250093000963009840099101001 0105301180

CAPTURE

00015001470022200247003100035900360004360046600625

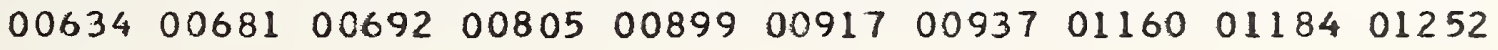
01265

CARCASS

$00052000860017300196 \quad 002810039800423004240042500428$ $\begin{array}{lllllllllll}00430 & 00431 & 00477 & 00525 & 00526 & 00600 & 00632 & 00636 & 00688 & 00721\end{array}$ $\begin{array}{llllllllll}00739 & 00752 & 00797 & 00806 & 00856 & 00902 & 00941 & 00949 & 00959 & 00980\end{array}$ 00981010840109201124

CENSUS METHODS

00048000490006500068000730014500229002460025300257 $\begin{array}{lllllllllll}00274 & 00289 & 00291 & 00299 & 00337 & 00338 & 00339 & 00368 & 00454 & 00458\end{array}$ $00459004750055100580 \quad 006020060500606006090061400615$ 00616006180061900621006250062600628006290063000645 $\begin{array}{lllllllllll}00663 & 00690 & 00827 & 00829 & 00830 & 00832 & 00910 & 00915 & 00916 & 00932\end{array}$ 00934009550096300978009790098001009010100101101015 $010240106101071010990110801150 \quad 01245$

CENSUS/TREND

00019000250004400066000790014600162001630016500186 $\begin{array}{llllllllll}00187 & 00219 & 00229 & 00246 & 00272 & 00285 & 00286 & 00287 & 00293 & 00368\end{array}$ $\begin{array}{lllllllll}0044300498 & 00510 & 00511 & 00522 & 00580 & 00596 & 00597 & 00602 & 00604\end{array}$ 
00605006060061500616006180062100627006300063700640

$\begin{array}{lllllllllll}0 & 0641 & 00643 & 00644 & 00645 & 00676 & 00677 & 00678 & 00681 & 00728 & 00740\end{array}$

$\begin{array}{lllllllllll}00746 & 00810 & 00921 & 00933 & 00952 & 00960 & 00963 & 01008 & 01024 & 01053\end{array}$

$0105701084011280112901150 \quad 0116901174011760117801182$

0118301255

CL IMATE

00037006370094500946009490095001017011390114001141 01143

CLOSURE

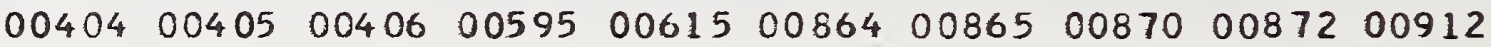
00993011880121401249

CONTROL

$\begin{array}{llllllllll}00006 & 00016 & 00017 & 00022 & 00055 & 00057 & 00091 & 00118 & 00120 & 00131\end{array}$ $\begin{array}{lllllllllll}0 & 0135 & 00161 & 00169 & 00171 & 00172 & 00174 & 00175 & 00176 & 00177 & 00178\end{array}$ $\begin{array}{lllllllllll}00179 & 00188 & 00195 & 00196 & 00203 & 00213 & 00215 & 00226 & 00245 & 00278\end{array}$ $\begin{array}{lllllllllllll}00321 & 00346 & 00375 & 00376 & 00377 & 00378 & 00381 & 00383 & 00384 & 00385\end{array}$ $\begin{array}{llllllllllll}00386 & 00387 & 00388 & 00389 & 00391 & 00392 & 00395 & 00402 & 00403 & 00412\end{array}$ $\begin{array}{lllllllllll}0 & 0493 & 00533 & 00535 & 00550 & 00595 & 00613 & 00624 & 00637 & 00642 & 00677\end{array}$ $\begin{array}{llllllllllll}00681 & 00684 & 00695 & 00705 & 00737 & 00738 & 00740 & 00741 & 00742 & 00743\end{array}$ $\begin{array}{lllllllllll}00744 & 00746 & 00747 & 00771 & 00794 & 00795 & 00796 & 00808 & 00852 & 00864\end{array}$ $\begin{array}{lllllllllll}00868 & 00869 & 00870 & 00873 & 00897 & 00909 & 00912 & 00964 & 01057 & 01093\end{array}$ $01130 \quad 011640116501187011970120201272$

COPULATION

004310049500522008500101401112

COURTSHIP

$\begin{array}{lllllllllll}00056 & 00181 & 00191 & 00197 & 00221 & 00250 & 00275 & 00298 & 00367 & 00424\end{array}$ $\begin{array}{lllllllllll}00425 & 00431 & 00432 & 00433 & 00434 & 00484 & 00495 & 00522 & 00688 & 00836\end{array}$ $00850 \quad 00856 \quad 00861009250094000941010250104501121$

COVER

$\begin{array}{llllllllll}00025 & 00028 & 00086 & 00158 & 00406 & 00423 & 00444 & 00563 & 00750 & 00787\end{array}$ 00791010220104601052010990119501209

CUMULATIVE EFFECTS ANAL

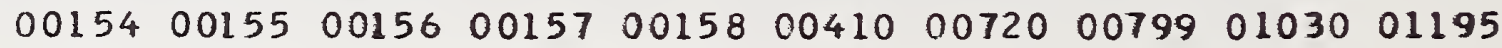
0121201233012340124401269

CUT USE

$\begin{array}{llllllllll}00008 & 00449 & 00691 & 00790 & 00804 & 01099 & 01274 & 01275 & 01276 & 01278\end{array}$ 01281

DAY BED

$\begin{array}{llllllllll}00009 & 00010 & 00028 & 00086 & 00205 & 00207 & 00438 & 00439 & 00631 & 00632\end{array}$ 0068800690006910069201044

DEMOGRAPHIC ANALYSIS

$\begin{array}{llllllllll}00025 & 00042 & 00127 & 00129 & 00144 & 00176 & 00177 & 00178 & 00179 & 00195\end{array}$ $\begin{array}{lllllllllll}00213 & 00223 & 00226 & 00227 & 00262 & 00272 & 00329 & 00388 & 00455 & 00456\end{array}$

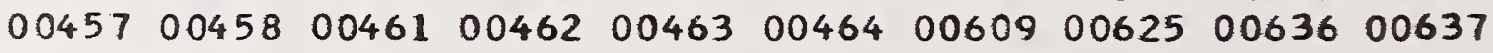


$\begin{array}{llllllllll}00638 & 00643 & 00644 & 00645 & 00776 & 00778 & 00788 & 00827 & 00923 & 01015\end{array}$ $\begin{array}{llllllllll}01079 & 01082 & 01089 & 01127 & 01138 & 01139 & 01140 & 01147 & 01158\end{array}$

DEN

00009000100003500036000370003800039000400004100197 $\begin{array}{lllllllllll}00201 & 00202 & 00204 & 00208 & 00223 & 00232 & 00291 & 00347 & 00357 & 00424\end{array}$ $\begin{array}{llllllllll}00425 & 00430 & 00431 & 00433 & 00434 & 00438 & 00439 & 00556 & 00630 & 00631\end{array}$ $\begin{array}{lllllllllll}00676 & 00677 & 00678 & 00681 & 00736 & 00786 & 00790 & 00825 & 00826 & 00827\end{array}$ $\begin{array}{llllllllll}00835 & 00861 & 00862 & 00921 & 00923 & 00924 & 00927 & 00931 & 00959 & 00980\end{array}$

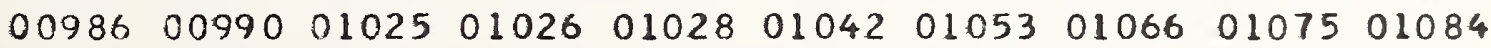
01106011070118301192012150122301242

DEN CHARACTERISTICS

$\begin{array}{llllllllll}00204 & 00205 & 00207 & 00208 & 00356 & 00445 & 00483 & 00591 & 00679 & 00680\end{array}$ $\begin{array}{lllllllll}00716 & 00985 & 01054 & 01073 & 01114 & 01175 & 01179 & 01223 & 01238\end{array}$

DENN ING CHRCNOLOGY

$\begin{array}{llllllllll}00056 & 00065 & 00077 & 00186 & 00198 & 00205 & 00207 & 00208 & 00261 & 00356\end{array}$ $\begin{array}{lllllllllll}00383 & 00445 & 00478 & 00591 & 00592 & 00907 & 00985 & 00989 & 01049 & 01051\end{array}$ $\begin{array}{llllllll}01052 & 01054 & 01055 & 01073 & 01098 & 01223 & 01238\end{array}$

DEN SITE

$\begin{array}{lllllllllll}00065 & 00205 & 00207 & 00210 & 00356 & 00445 & 00483 & 00587 & 00591 & 00592\end{array}$ $\begin{array}{lllllllllll}00679 & 00680 & 00834 & 00925 & 00960 & 00985 & 00999 & 01039 & 01049 & 01051\end{array}$ $\begin{array}{llllllllllll}01052 & 01054 & 01055 & 01073 & 01098 & 01114 & 01175 & 01179 & 01223 & 01238\end{array}$ 01239

DENTITION

$\begin{array}{llllllllll}00093 & 00303 & 00366 & 00371 & 00380 & 00393 & 00415 & 00416 & 00418 & 00673\end{array}$ 0085300965009670108601225

DEPREDATION

00012000220003700118001190012000135001600016100169 $\begin{array}{lllllllllll}00188 & 00213 & 00263 & 00278 & 00321 & 00331 & 00342 & 00377 & 00378 & 00384\end{array}$ $\begin{array}{lllllllllll}00387 & 00388 & 00389 & 00390 & 00392 & 00395 & 00396 & 00397 & 00398 & 00402\end{array}$ $005120053300550 \quad 00582006130062400629006310063800646$ $\begin{array}{lllllllllll}0 & 0675 & 00676 & 00677 & 00678 & 00681 & 00738 & 00742 & 00749 & 00763 & 00816\end{array}$ $\begin{array}{llllllllll}00855 & 00864 & 00869 & 00964 & 01011 & 01012 & 01013 & 01016 & 01057 & 01064\end{array}$ 0116401165011940121701218

DETERRENTS \& REPELLENTS $0002100100 \quad 001120011300166 \quad 0018300235002360025800321$ $\begin{array}{lllllllllll}00346 & 00373 & 00412 & 00442 & 00485 & 00493 & 00529 & 00530 & 00531 & 00532\end{array}$ $\begin{array}{lllllllllll}00569 & 00577 & 00675 & 00749 & 00777 & 00820 & 00821 & 00822 & 00993 & 01003\end{array}$ $\begin{array}{lllllllllll}01078 & 01105 & 01122 & 01123 & 01257 & 01259 & 01260 & 01261 & 01267 & 01271\end{array}$

DIGESTION

00080001260042300539007970080101019

DISTR IBUT ION

$0008200210 \quad 0021300217002310029300295003060041800443$ $\begin{array}{llllllllll}00511 & 00513 & 00588 & 00593 & 00594 & 00715 & 00744 & 01065 & 01071 & 01224\end{array}$

DIURNAL BEHAVIOR 01045 
DIVERSITY

00086001030064701066

CRUGS

$\begin{array}{llllllllll}00102 & 00133 & 00206 & 00218 & 00222 & 00247 & 00350 & 00360 & 00413 & 00414\end{array}$ $\begin{array}{lllllllllll}00466 & 00476 & 00552 & 00582 & 00634 & 00636 & 00665 & 00692 & 00792 & 00805\end{array}$

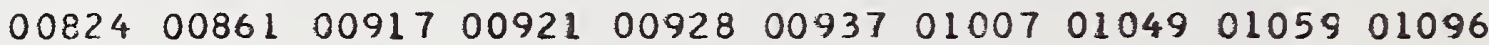
01117011180112501226

EDUCATION

$00006 \quad 000210002700113001300015200156001670016800326$ $\begin{array}{lllllllllll}0 & 0342 & 00442 & 00472 & 00502 & 00514 & 00595 & 00666 & 00682 & 00727 & 00757\end{array}$ $00819008650086600870 \quad 00871009130091400993 \quad 0115101152$ 0115701191011990120001249

ENERGY IMPACTS

00035000360003800039000410010700114001430026600270

$\begin{array}{lllllllllll}00295 & 00296 & 00321 & 00445 & 00446 & 00493 & 00506 & 00517 & 00518 & 00533\end{array}$ $\begin{array}{lllllllllll}00669 & 00687 & 00787 & 00791 & 00825 & 00840 & 00927 & 00986 & 00992 & 01037\end{array}$ $\begin{array}{llllllllll}01054 & 01085 & 01106 & 01107 & 01114 & 01119 & 01189 & 01213 & 01236 & 01250\end{array}$ 0125101268

ENERGY MANAGEMENT

$00038001070011200517005840068700800 \quad 008020084000992$ $\begin{array}{llllllllllll}01054 & 01193 & 01195 & 01197 & 01202 & 01203 & 01205 & 01208 & 01213 & 01279\end{array}$ 01280

FEED ING BEHAVIOR

$\begin{array}{lllllllllll}00086 & 00148 & 00173 & 00225 & 00275 & 00281 & 00346 & 00351 & 00398 & 00401\end{array}$ $\begin{array}{llllllllllll}00430 & 00431 & 00452 & 00479 & 00515 & 00524 & 00550 & 00600 & 00601 & 00603\end{array}$ $\begin{array}{llllllllllll}00697 & 00698 & 00721 & 00751 & 00801 & 00858 & 00941 & 00981 & 01045 & 01131\end{array}$ 01150

FIRE MANAGEMENT

00064002410027700296 00799008000080200803 01202012050120701208

00345004230042700516 00804008980103801195 012100127401281

FOOD

00012000140002400028000340007900085000860008700088 $0012500140 \quad 001480014900162001630016400165$ 00198002010021200214002190022500 0022900230 0018600187 $00248 \quad 00255 \quad 00358 \quad 003640037200374 \quad 00$ 0042000422 $0042700428 \quad 0042900430 \quad 00431004320043300434$ 0023700246 $\begin{array}{llllllllll}0 & 0440 & 00441 & 00443 & 00449 & 00452 & 00477 & 00478 & 00479\end{array}$ 0042300426 $005150051900520 \quad 00521 \quad 005250053400558 \quad 00571$ 0043700438 $\begin{array}{lllllllll}00601 & 00602 & 00603 & 00604 & 00605 & 00606 & 00607 & 00615 \\ 00638 & 00639 & 00640 & 00641 & 00642 & 00647 & 00688 & 00690\end{array}$ 0049100511 0058200600 $\begin{array}{lllllllll}00638 & 00639 & 00640 & 00641 & 00642 & 00647 & 00688 & 00690 \\ 00703 & 00704 & 00706 & 00707 & 00709 & 00711 & 00732 & 00734\end{array}$ 0063000632

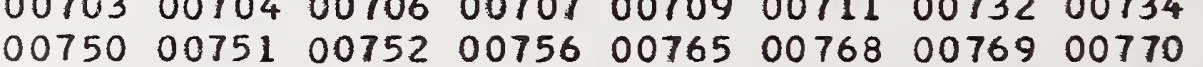
0069100692 $007740079700799008010080300806 \quad 0082500856$ 0073900748 $0089800916 \quad 009170091900920009240092600927$ 0077200773 $00941009420094500950 \quad 00959009600096100972$ 0085700868 0097901000010010100901024010280103901040 0093100940 0097500978 $\begin{array}{lll}01066 & 01067\end{array}$ 
01075010770108401091010920109501099011070111801121 $\begin{array}{lllllllllll}01150 & 01159 & 01160 & 01192 & 01209 & 01215 & 01242 & 01275 & 01277\end{array}$

FORAGING SIATEGIES

$0037200426 \quad 0044100452 \quad 0046700558 \quad 00690 \quad 00752 \quad 00755$

GARBAGE MANAGEMENT

$00006 \quad 000170011200113001520017100172001740017500213$ $\begin{array}{lllllllllll}0 & 0215 & 00248 & 00249 & 00267 & 00442 & 00494 & 00507 & 00553 & 00595 & 00682\end{array}$ $\begin{array}{lllllllllll}0 & 0684 & 00769 & 00796 & 00851 & 00857 & 00864 & 00865 & 00866 & 00870 & 00912\end{array}$ 00993010480115701201012020121701218

GARBAGE

$\begin{array}{llllllllll}00087 & 00171 & 00172 & 00174 & 00176 & 00210 & 00215 & 00266 & 00267 & 00321\end{array}$ $\begin{array}{llllllllllll}0 & 0378 & 00380 & 00381 & 00382 & 00384 & 00385 & 00387 & 00429 & 00467 & 00487\end{array}$ $\begin{array}{llllllllllll}00489 & 00490 & 00493 & 00494 & 00510 & 00511 & 00528 & 00595 & 00636 & 00637\end{array}$ $\begin{array}{lllllllllll}00643 & 00644 & 00737 & 00738 & 00769 & 00796 & 00852 & 00857 & 00897 & 00935\end{array}$ $0094501000 \quad 01005011300113901141011430121701218$

GENERAL BICLOGY

00112001130011500168002230029100442004940055100715 00764007930093901057011340122401266

GENERAL DATA

$00009000100003500037000380003900040 \quad 000410021000211$ $\begin{array}{lllllllllll}00223 & 00262 & 00386 & 00424 & 00425 & 00439 & 00442 & 00467 & 00498 & 00558\end{array}$ $\begin{array}{llllllllllll}00631 & 00636 & 00637 & 00736 & 00737 & 00786 & 00835 & 00848 & 00851 & 00852\end{array}$ $\begin{array}{lllllllllll}00860 & 00861 & 00862 & 00864 & 00915 & 00921 & 00923 & 00925 & 00980 & 00986\end{array}$ $0102501026010420105301106 \quad 0114001183$

GENETICS

$00007 \quad 00023 \quad 0024400330 \quad 00460 \quad 00648 \quad 00654007240099801029$ 01031010430105601071010790108201109

GIRTH

00087003660061800785008590093101252

GROWTH \& DEVELOPMENT

$000750008700126002180036100366 \quad 00368006100061100612$ $006410084800860009580100101140 \quad 01183$

HABITAT ANALYSIS

0018500496012210122201242

HABITAT EFFECTIVENESS

$00010 \quad 00036 \quad 0004100047001850021200225004090044900467$ $\begin{array}{lllllllllll}00587 & 00639 & 00647 & 00703 & 00704 & 00706 & 00750 & 00754 & 00775 & 00798\end{array}$ $\begin{array}{llllllllll}00803 & 00804 & 00999 & 01034 & 01036 & 01100 & 01150 & 01212 & 01233 & 01234\end{array}$ 01242

HAB I TAT RECONNA I SANCE

00009000790008200083001360018500292002930029400295 $\begin{array}{lllllllllll}00296 & 00410 & 00421 & 00443 & 00538 & 00669 & 00671 & 00702 & 00733 & 00768\end{array}$

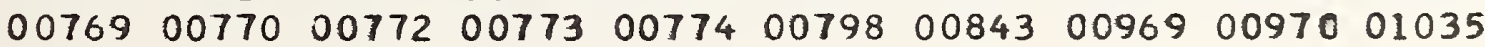


01062010650107401150011600127601277

HABITAT SAMPL ING

$004090051500607006340066800703 \quad 00732007750078900799$ 0096901282

HABITAT USE

$00008 \quad 000100001400034000380003900040000650006600078$ $\begin{array}{llllllllllll}00085 & 00086 & 00103 & 00141 & 00185 & 00211 & 00225 & 00232 & 00237 & 00246\end{array}$ $00255 \quad 002690037200406 \quad 0042000421 \quad 00422 \quad 00423 \quad 0042400425$ $\begin{array}{lllllllllll}00426 & 00427 & 00430 & 00431 & 00432 & 00433 & 00434 & 00437 & 00438 & 00440\end{array}$ $\begin{array}{llllllllllll}00441 & 00443 & 00449 & 00477 & 00478 & 00511 & 00555 & 00558 & 00563 & 00570\end{array}$ $\begin{array}{lllllllllll}00582 & 00587 & 00591 & 00593 & 00594 & 00601 & 00605 & 00606 & 00623 & 00628\end{array}$ $0062900630 \quad 00639006470066900670 \quad 00690006910069200703$ $\begin{array}{llllllllll}00712 & 00714 & 00735 & 00739 & 00750 & 00751 & 00768 & 00769 & 00770 & 00772\end{array}$ $\begin{array}{llllllllll}00773 & 00774 & 00775 & 00790 & 00797 & 00799 & 00801 & 00868 & 00898 & 00901\end{array}$ 00907009170091800920009270093300934009350094000941 $0094200950 \quad 00956009590096100973 \quad 00996 \quad 009990101001022$ $010240103501036 \quad 01039010400104101046 \quad 010510105201055$ $\begin{array}{lllllllllll}01066 & 01067 & 01074 & 01075 & 01084 & 01091 & 01092 & 01098 & 01107 & 01114\end{array}$ $\begin{array}{llllllllll}01121 & 01192 & 01195 & 01209 & 01242 & 01275 & 01276 & 01277 & 01279 & 01280\end{array}$

HAIR

$0084400948 \quad 0111301227$

HARVEST DATA

000790009800099001100011600117 $0018900190 \quad 00192001930019400203$ $\begin{array}{lllllll}00250 & 00262 & 00263 & 00288 & 00289 & 00291\end{array}$ $\begin{array}{lllllll}00328 & 00343 & 00344 & 00362 & 00363 & 00364\end{array}$ $\begin{array}{llllllll}00378 & 00378 & 00379 & 00381 & 00382 & 00383\end{array}$ $\begin{array}{llllllll}00388 & 00389 & 00390 & 00391 & 00392 & 00403\end{array}$ $00500 \quad 0050700508 \quad 0050900510 \quad 00518$ $\begin{array}{llllllll}00617 & 00618 & 00621 & 00661 & 00674 & 00675\end{array}$ $\begin{array}{lllllll}00695 & 00728 & 00729 & 00730 & 00731 & 00771\end{array}$ $\begin{array}{lllllll}00783 & 00784 & 00826 & 00833 & 00834 & 00836\end{array}$ $\begin{array}{lllllll}00894 & 00895 & 00897 & 00904 & 00909 & 00933\end{array}$ 00129001610016300188 00211002260022900230 $\begin{array}{lllll}00294 & 00307 & 00308 & 00327\end{array}$ 00368003750037600377 00384003850038600387 $0043800468 \quad 0046900497$ 00540005410054500594 $0067600677 \quad 00678 \quad 00681$ $0077900780 \quad 0078100782$ $0084100860 \quad 0089200893$ $\begin{array}{lllllll}01008 & 01009 & 01010 & 01021 & 01089 & 01097\end{array}$ 00934009350094700983 011740121501216012350124501256

01102011110112901173

HARVEST IMPACTS

00129001940025600262002630032900343003440045500456 $\begin{array}{lllllllllll}00457 & 00562 & 00694 & 00695 & 00771 & 00776 & 00862 & 00897 & 00913 & 01089\end{array}$ $\begin{array}{llllll}01127 & 01137 & 01166 & 01216 & 01256\end{array}$

HAR VEST MANAGEMENT

$0000200003 \quad 0000400017001110012700144001940021300256$ $\begin{array}{lllllllllll}00262 & 00263 & 00293 & 00324 & 00337 & 00338 & 00339 & 00343 & 00344 & 00354\end{array}$ $\begin{array}{llllllllllll}00375 & 00385 & 00386 & 00387 & 00394 & 00402 & 00455 & 00456 & 00457 & 00458\end{array}$ $\begin{array}{lllllllllllll}00461 & 00463 & 00464 & 00510 & 00517 & 00545 & 00675 & 00678 & 00694 & 00695\end{array}$ $\begin{array}{lllllllllll}00717 & 00718 & 00779 & 00782 & 00783 & 00784 & 00841 & 00842 & 00862 & 00900\end{array}$ $\begin{array}{lllllllllll}00910 & 00926 & 01050 & 01089 & 01098 & 01102 & 01103 & 01111 & 01127 & 01156\end{array}$ $\begin{array}{lllllll}01166 & 01173 & 01214 & 01216 & 01256 & 01272 & 01273\end{array}$ 
HEART

00102003110031400315003160031700319003200082000882 00992

HEMATOLOGY

00001000430005700101001020010400133002030021700300

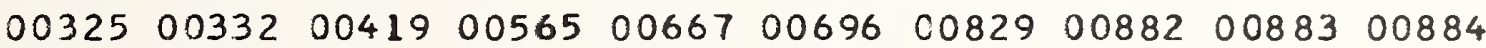
$\begin{array}{llllllllll}00885 & 00886 & 00887 & 00888 & 00889 & 00891 & 00911 & 00929 & 01060 & 01117\end{array}$ 0111801154

HIBERNATION PHYSIOLOGY

$00001000430019700205 \quad 002090022800300003110031200314$ $\begin{array}{llllllllll}00315 & 00316 & 00317 & 00318 & 00319 & 00323 & 00332 & 00419 & 00480 & 00696\end{array}$ $\begin{array}{lllllllllll}00882 & 00883 & 00884 & 00885 & 00886 & 00887 & 00888 & 00889 & 00890 & 00891\end{array}$ 009110123101247

HISTORICAL ACCOUNT

$\begin{array}{lllllllllll}00046 & 00062 & 00084 & 00115 & 00222 & 00352 & 00453 & 00474 & 00527 & 00650\end{array}$ $\begin{array}{llllllllll}00660 & 00671 & 00726 & 00767 & 00771 & 00845 & 00855 & 00896 & 00897 & 01023\end{array}$ $01120 \quad 011340114801266$

HISTORICAL DISTRIBUTION

00012000440004600062000840011500138001390015900195 $\begin{array}{lllllllllll}00283 & 00292 & 00294 & 0 & 0352 & 00400 & 00417 & 00453 & 00500 & 00527 & 00568\end{array}$ $\begin{array}{lllllllllllll}00650 & 00651 & 00652 & 00657 & 00659 & 00661 & 00671 & 00683 & 00717 & 00718\end{array}$ $\begin{array}{lllllllllll}00726 & 00728 & 00771 & 00810 & 00815 & 00845 & 00896 & 00897 & 00905 & 00907\end{array}$ $\begin{array}{llllllllll}00938 & 00951 & 00963 & 00965 & 00974 & 01098 & 01115 & 01116 & 01120 & 01134\end{array}$ $\begin{array}{llllllllll}01148 & 01153 & 01168 & 01171 & 01174 & 01186 & 01240\end{array}$

HOME RANGE

$00008 \quad 000280003600056 \quad 000570006500066 \quad 00078 \quad 0009000129$

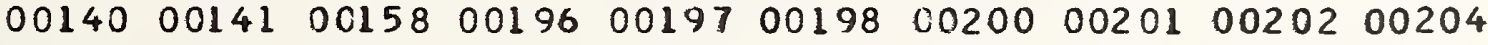
$\begin{array}{llllllllllll}00205 & 00209 & 00232 & 00369 & 00428 & 00433 & 00434 & 00438 & 00441 & 00447\end{array}$ $\begin{array}{llllllllllll}0 & 0448 & 00465 & 00470 & 00473 & 00478 & 00519 & 00520 & 00521 & 00543 & 00563\end{array}$ $\begin{array}{llllllllll}00582 & 00587 & 00589 & 00590 & 00593 & 00594 & 00629 & 00630 & 00632 & 00633\end{array}$ $\begin{array}{lllllllllll}00638 & 00640 & 00647 & 00688 & 00690 & 00708 & 00710 & 00711 & 00790 & 00825\end{array}$ $\begin{array}{llllllllll}00826 & 00827 & 00829 & 00838 & 00907 & 00922 & 00924 & 00926 & 00931 & 00950\end{array}$ $0097900982 \quad 00988 \quad 0098900990 \quad 0099901010010110101201014$ $\begin{array}{llllllllllll}01017 & 01033 & 01039 & 01040 & 01044 & 01051 & 01052 & 01055 & 01066 & 01067\end{array}$ 0107501091010950110701110011260119201242

HUMAN IMPACTS

$0000200266 \quad 0027900353004100054500553005680063500669$ $\begin{array}{lllllllllll}00705 & 00833 & 00845 & 01037 & 01040 & 01041 & 01042 & 01065 & 01071 & 01100\end{array}$ 01161012120123301234

HUMAN INJURY

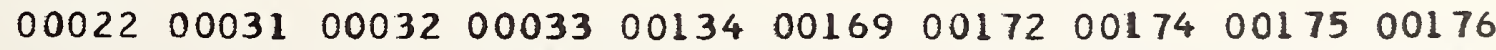
$\begin{array}{lllllllllll}0 & 0177 & 00178 & 00179 & 00213 & 00215 & 00321 & 00402 & 00403 & 00429 & 00442\end{array}$ $\begin{array}{llllllllll}00486 & 00487 & 00489 & 00490 & 00493 & 00494 & 00498 & 00533 & 00575 & 00577\end{array}$ $\begin{array}{lllllllllll}0 & 0579 & 00595 & 00596 & 00608 & 00613 & 00682 & 00735 & 00736 & 00737 & 00738\end{array}$ $\begin{array}{lllllllllll}0 & 0740 & 00742 & 00744 & 00747 & 00763 & 00764 & 00777 & 00794 & 00795 & 00796\end{array}$ $\begin{array}{lllllllllll}00816 & 00851 & 00863 & 00864 & 00867 & 00868 & 00869 & 00873 & 00908 & 01046\end{array}$ 010570109301164011650121701218 
IOENTIFICATION \& RECOG

$0025400370 \quad 00371 \quad 0037900393004350044200502 \quad 0091300914$ 0106801160012140123701246

INT RODUCT ION/REINTRC

0001700082000830018200292005670071400907

INTERSPECIFIC COMPETITION

$00030 \quad 00050 \quad 0005100052000580006000068004910049200561$

$\begin{array}{llllllllllll}00564 & 00574 & 00582 & 00583 & 00601 & 00603 & 00605 & 00606 & 00631 & 00721\end{array}$

$\begin{array}{lllllllllll}0 & 0739 & 00828 & 00851 & 00854 & 00856 & 00858 & 00860 & 01028 & 01084 & 01124\end{array}$

01272

INTRASPECIFIC BEHAVIOR

00068001810019700200002030020400205002070020800217

$\begin{array}{lllllllllll}00275 & 00276 & 00291 & 00297 & 00404 & 00492 & 00494 & 00522 & 00575 & 00697\end{array}$

$\begin{array}{lllllllllll}0 & 0735 & 00736 & 00737 & 00741 & 00743 & 00755 & 00764 & 00806 & 00826 & 00828\end{array}$

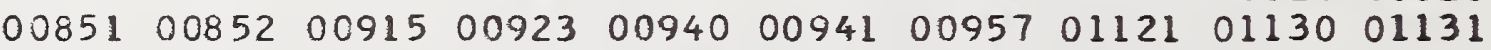

$\begin{array}{llllllllll}01133 & 01137 & 01138 & 01139 & 01140 & 01141 & 01229 & 01242 & 01270\end{array}$

LEGAL

00005000180008100096001090018200249002680032100376

$\begin{array}{lllllllll}0 & 0537 & 00595 & 00717 & 00718 & 00865 & 00964 & 01157 & 01191\end{array}$

LENGTH

00087003660037600377006110061800642007850091700924 0093101252

LITTER FREQUENCY

$\begin{array}{llllllllll}00056 & 00089 & 00220 & 00221 & 00361 & 00367 & 00484 & 00627 & 00640 & 00664\end{array}$ 006940078800984009880099101137

LITTER SIZE

$00056 \quad 0006500066 \quad 00089001620022000221002460025000261$ $\begin{array}{lllllllllll}00285 & 00286 & 00287 & 00359 & 00361 & 00367 & 00484 & 00508 & 00509 & 00602\end{array}$ $\begin{array}{lllllllllll}00605 & 00618 & 00621 & 00623 & 00627 & 00628 & 00640 & 00664 & 00676 & 00677\end{array}$ $\begin{array}{llllllllll}00678 & 00694 & 00740 & 00741 & 00743 & 00788 & 00836 & 00919 & 00922 & 00925\end{array}$ $\begin{array}{llllllllll}00934 & 00935 & 00945 & 00949 & 00963 & 00984 & 00988 & 00991 & 01008 & 01009\end{array}$ $\begin{array}{llllllllllll}01010 & 01014 & 01016 & 01106 & 01117 & 01118 & 01137 & 01138 & 01141 & 01143\end{array}$ 0117401253

LIVESTOCK IMPACTS

$\begin{array}{lllllllllll}00035 & 00039 & 00040 & 00041 & 00118 & 00120 & 00131 & 00132 & 00160 & 00210\end{array}$ $\begin{array}{lllllllllll}0 & 0211 & 00292 & 00331 & 00382 & 00397 & 00571 & 00582 & 00583 & 00646 & 00669\end{array}$ $\begin{array}{lllllllllll}00670 & 00672 & 00705 & 00749 & 00771 & 00809 & 00906 & 01036 & 01041 & 01042\end{array}$ 0114901161

LIVESTOCK MANAGEMENT

$\begin{array}{lllllllllll}00017 & 00038 & 00106 & 00131 & 00331 & 00397 & 00550 & 00558 & 00583 & 00672\end{array}$ $\begin{array}{llllllllll}00749 & 00799 & 00800 & 00802 & 00809 & 00906 & 01149 & 01191 & 01194 & 01195\end{array}$ $\begin{array}{llllllllll}01197 & 01201 & 01202 & 01203 & 01205 & 01207 & 01208 & 01209 & 01210 & 01279\end{array}$ 01280

LONGEVITY

0022600227 
MAPPING

$000290003500036 \quad 00037000470006300137001540015600157$ $00158 \quad 00212002160022500259003570040900410 \quad 0042500432$ $\begin{array}{lllllllllll}0 & 0433 & 00434 & 00477 & 00560 & 00563 & 00587 & 00662 & 00668 & 00703 & 00719\end{array}$ $\begin{array}{lllllllllll}00751 & 00753 & 00799 & 00843 & 00901 & 01121 & 01160 & 01163 & 01167 & 01204\end{array}$ $\begin{array}{lllllllll}01205 & 01212 & 01215 & 01220 & 01221 & 01244 & 01275 & 01276 & 01282\end{array}$

MARKING

$0002800180 \quad 00434004380043900502 \quad 00690 \quad 006920095700971$ 01084010990118501215

MATERNAL BEHAVICR

$00197002750027600290 \quad 002970035100359003670036800369$ $\begin{array}{llllllllll}00478 & 00479 & 00491 & 00522 & 00575 & 00608 & 00615 & 00655 & 00697 & 00828\end{array}$ 00831008560104401131011550118101229

MEASUREMENTS

$\begin{array}{lllllllllll}0 & 0035 & 00037 & 00057 & 00140 & 00217 & 00232 & 00291 & 00347 & 00359 & 00360\end{array}$ $\begin{array}{lllllllllll}00368 & 00378 & 00379 & 00380 & 00381 & 00508 & 00509 & 00587 & 00592 & 00593\end{array}$ $\begin{array}{lllllllllll}00594 & 00634 & 00636 & 00708 & 00711 & 00712 & 00714 & 00780 & 00781 & 00786\end{array}$ $\begin{array}{llllllllll}00790 & 00792 & 00829 & 00835 & 00848 & 00851 & 00860 & 00861 & 00862 & 00918\end{array}$ $\begin{array}{llllllllll}00920 & 00923 & 00978 & 00979 & 00982 & 00986 & 00988 & 00999 & 01025 & 01039\end{array}$ $\begin{array}{llllllllllll}01040 & 01042 & 01066 & 01067 & 01117 & 01118 & 01176 & 01183 & 01215 & 01285\end{array}$

MANAGEMENT, GENERAL

00005000170002500027000360010900132001560016100171 $\begin{array}{lllllllllll}00172 & 00174 & 00175 & 00176 & 00177 & 00178 & 00179 & 00194 & 00195 & 00196\end{array}$ $\begin{array}{llllllllll}00223 & 00225 & 00226 & 00227 & 00241 & 00249 & 00255 & 00263 & 00291 & 00293\end{array}$ $00294002950029600324 \quad 00356 \quad 0038900394 \quad 00422 \quad 0042400425$ $\begin{array}{llllllllllll}00437 & 00467 & 00486 & 00489 & 00490 & 00501 & 00504 & 00517 & 00537 & 00555\end{array}$ $\begin{array}{llllllllllll}00566 & 00570 & 00573 & 00621 & 00659 & 00669 & 00670 & 00682 & 00701 & 00703\end{array}$ $\begin{array}{llllllllll}00717 & 00718 & 00738 & 00774 & 00776 & 00778 & 00793 & 00794 & 00795 & 00796\end{array}$ 00798008190083900857008860091200915009210094600950 $\begin{array}{llllllllllll}00951 & 00969 & 01029 & 01038 & 01041 & 01042 & 01048 & 01057 & 01070 & 01071\end{array}$ $0110001111011300115701160011610118701197 \quad 0119801199$ $\begin{array}{llllllllll}01200 & 01200 & 01203 & 01205 & 01206 & 01207 & 01209 & 01211 & 01232 & 01248\end{array}$ 0124901272

MANAGEMENT PLAN $\begin{array}{lllllllllll}00002 & 00006 & 00013 & 00021 & 00079 & 00109 & 00110 & 00131 & 00262 & 00682\end{array}$ $00800 \quad 00802 \quad 00864 \quad 008650087000871 \quad 0091201066 \quad 0111101157$ $\begin{array}{llllllll}01190 & 01191 & 01201 & 01202 & 01206 & 01208 & 01232 & 01249\end{array}$

MINIMUM POPULATICN

$\begin{array}{lllllllllll}00273 & 00460 & 00658 & 00701 & 01031 & 01032 & 01071 & 01079 & 01080 & 01081\end{array}$ 010820108301147

MISCELLANEOUS QUANTITIES

$\begin{array}{llllllllll}00087 & 00288 & 00289 & 00298 & 00364 & 00366 & 00375 & 00376 & 00393 & 00507\end{array}$ $\begin{array}{llllllllll}00618 & 00621 & 00675 & 00676 & 00677 & 00678 & 00681 & 00779 & 00782 & 00783\end{array}$ 009160091700924010980117401265

MONITOR ING SYSTEMS

00006001420016100178001790050300585006340068200761 
$007620076300795008640086500870 \quad 00912010680109301104$ 01157

MORPHOLDGY \& PHYSIOLOGY

00001000800010100102001260021700218002190024000298

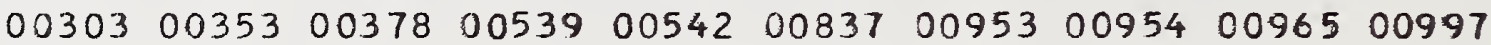
0114001224

MOR TAL I TY DATA

$\begin{array}{llllllllll}00025 & 00035 & 00091 & 00116 & 00132 & 00146 & 00161 & 00176 & 00177 & 00210 \\ 00211 & 00219 & 00263 & 00272 & 00361 & 00375 & 00376 & 00379 & 00380 & 00381 \\ 00382 & 00383 & 00384 & 00385 & 00386 & 00387 & 00388 & 00389 & 00390 & 00391 \\ 00392 & 00403 & 00493 & 00508 & 00509 & 00517 & 00553 & 00563 & 00568 & 00570 \\ 00628 & 00631 & 00635 & 00638 & 00640 & 00641 & 00642 & 00643 & 00653 & 00705 \\ 00736 & 00737 & 00740 & 00741 & 00743 & 00746 & 00755 & 00781 & 00794 & 00833 \\ 00835 & 00861 & 00862 & 00868 & 00909 & 00935 & 00950 & 00982 & 00987 & 00989 \\ 00990 & 01009 & 01010 & 01011 & 01012 & 01013 & 01014 & 01015 & 01016 & 01017 \\ 01018 & 01054 & 01106 & 01107 & 01176 & 01183 & & & \end{array}$

MOR TAL I TY MANAGEMENT

001610038200635011910120501249

MORTALITY RATE

$\begin{array}{llllllllll}00042 & 00065 & 00066 & 00089 & 00128 & 00129 & 00195 & 00226 & 00227 & 00227\end{array}$

$\begin{array}{lllllllllll}00262 & 00367 & 00632 & 00637 & 00644 & 00645 & 00776 & 00788 & 00825 & 00835\end{array}$ $\begin{array}{llllllll}00836 & 00963 & 00980 & 00984 & 00987 & 00991 & 01053 & 01079\end{array}$

MOTORIZED IMPACTS

$00556 \quad 00755 \quad 0079100970 \quad 0101801093 \quad 01094011630116901218$ 0123301234

MOTORIZED MANAGEMENT

$000470010800152007720077400800 \quad 00802008660109401157$ 011630121701218

MOVEMENTS

$\begin{array}{llllllllll}00008 & 00025 & 00034 & 00056 & 00057 & 00065 & 00066 & 00077 & 00078 & 00090\end{array}$

$\begin{array}{llllllllll}00163 & 00196 & 00197 & 00198 & 00200 & 00201 & 00202 & 00203 & 00205 & 00207\end{array}$

$\begin{array}{llllllllll}00215 & 00217 & 00219 & 00237 & 00246 & 00360 & 00362 & 00364 & 00365 & 00369\end{array}$

$\begin{array}{lllllllllll}00410 & 00421 & 00422 & 00423 & 00428 & 00437 & 00438 & 00441 & 00452 & 00478\end{array}$

$\begin{array}{lllllllllll}00519 & 00520 & 00521 & 00587 & 00589 & 00590 & 00592 & 00593 & 00594 & 00629\end{array}$

$\begin{array}{lllllllllll}00630 & 00635 & 00638 & 00641 & 00646 & 00647 & 00688 & 00690 & 00691 & 00692\end{array}$

$\begin{array}{llllllllllll}00708 & 00710 & 00711 & 00714 & 00746 & 00790 & 00826 & 00827 & 00829 & 00831\end{array}$

$\begin{array}{llllllllll}00834 & 00856 & 00907 & 00918 & 00919 & 00920 & 00922 & 00946 & 00950 & 00956\end{array}$

$\begin{array}{lllllllllll}00959 & 00960 & 00961 & 00978 & 00979 & 00982 & 00987 & 00988 & 00989 & 00990\end{array}$

$\begin{array}{lllllllllll}00996 & 01009 & 01010 & 01011 & 01012 & 01024 & 01028 & 01036 & 01039 & 01040\end{array}$

$0104401055 \quad 0106301066 \quad 01067 \quad 01074 \quad 01075 \quad 01095 \quad 0110701114$

$\begin{array}{lllllllllll}0119 & 01161 & 01176 & 01177 & 01215 & 01229 & 01242 & 01254 & 01255 & 01275\end{array}$

NOCTURNAL BEHAVIOR 01045

NONMOTORI ZED MANAGEMENT

$000210004700108 \quad 0013100150 \quad 0015200236 \quad 004210042900471$ 
$\begin{array}{llllllllll}00472 & 00496 & 00575 & 00577 & 00578 & 00579 & 00735 & 00736 & 00737 & 00742\end{array}$ $\begin{array}{llllllllll}00747 & 00769 & 00772 & 00774 & 00800 & 00802 & 00851 & 00866 & 00870 & 00872\end{array}$ $\begin{array}{lllllllllll}00956 & 00993 & 00995 & 01025 & 01026 & 01093 & 01144 & 01145 & 01146 & 01151\end{array}$ 01157011630118701205012170121801249

NONMOTORI ZED IMPACTS

$0013100150 \quad 00151004040040500406 \quad 00406 \quad 004520057500579$ $\begin{array}{lllllllllll}00581 & 00594 & 00608 & 00615 & 00791 & 00956 & 01012 & 01014 & 01016 & 01017\end{array}$ $0101801046 \quad 01093 \quad 01163 \quad 012170122801233 \quad 01234$

NUTR ITIDN

002710094401000010010102701095

NUTRITIONAL ANALYSES

$0012400126 \quad 002250027100372 \quad 00423 \quad 00424 \quad 00426 \quad 0043100432$

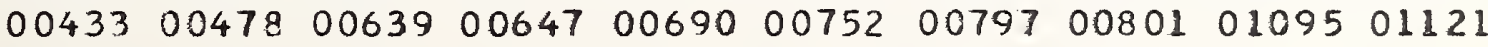

ORPHAN

00011002070052200546005670063100735010120102501026

GUTFITTER MANAGEMENT

0048200511005120069400874012140124801249

PARASITES \& DISEASES

$\begin{array}{llllllllll}00074 & 00092 & 00095 & 00097 & 00122 & 00153 & 00223 & 00239 & 00376 & 00377\end{array}$ $\begin{array}{lllllllllll}00378 & 00379 & 0 & 0380 & 00381 & 00383 & 00385 & 00386 & 00388 & 00390 & 00391\end{array}$ $\begin{array}{lllllllllll}00416 & 00565 & 00758 & 00759 & 00846 & 00848 & 00852 & 00875 & 00876 & 00877\end{array}$ $\begin{array}{llllllllll}00878 & 00879 & 00880 & 00908 & 00920 & 00968 & 01006 & 01027 & 01135 & 01225\end{array}$ 01263012640128301284

PELAGE

$\begin{array}{llllllllll}00261 & 00291 & 00303 & 00393 & 00636 & 00837 & 00860 & 00915 & 00916 & 00960\end{array}$ $0096501000 \quad 01002010260102801227$

PHYSICAL CHEMISTRY

0000100656008890111701118

POACHING \& ILLEGAL MORT.

$00091001100013500188 \quad 002490026300377003790038100383$

$\begin{array}{llllllllll}00384 & 00385 & 00387 & 00388 & 00389 & 00390 & 00391 & 00392 & 00402 & 00403\end{array}$

$\begin{array}{llllllllll}00518 & 00621 & 00622 & 00624 & 00646 & 00676 & 00695 & 00897 & 00909 & 00915\end{array}$ 00963010110101601017010180111101216

POI SONING

000670053500549008180084700906

POLITICAL \& ADMIN. MGMT.

00109001320015600182002480024900517006590105701071 01187

POPULATION AUGMENTATION

000230045100460007220106901071010720120101207

POPULATIDN BIOLOGY

00035000360003800039000400004100197002030021700232 
$\begin{array}{llllllllll}00262 & 00263 & 00291 & 00368 & 00631 & 00715 & 00736 & 00737 & 00786 & 00826\end{array}$ $\begin{array}{lllllllllll}0 & 0851 & 00860 & 00861 & 00862 & 00921 & 00959 & 00986 & 01025 & 01075 & 01114\end{array}$ 011830.1191

POPULATION DENSITY

00089000940011000140

$00140 \quad 00162$

01950019600215002230022900230

$003440034700445006230062800694 \quad 00$

$007370073800740 \quad 007410074300744$

$00830 \quad 0083200834008350085200860 \quad 00$

$009460095900960 \quad 009800098100982$

$00990 \quad 009910102501026$

$011690117401182 \quad 01192$

01036

01052

0017600186

0018700194

$0023200246 \quad 00250 \quad 00253$

00711007150073500736

0078800826

0082700829

0086100862

0092500935

0098300984

0098600988

$01216 \quad 0121701256$

POPULATION ESTIMATE

$0017700178 \quad 0019400195$

$\begin{array}{llll}00347 & 00362 & 00389 & 00402\end{array}$

00089

00110

0021700226

00171

00172

0017500176

00628006940071500735

0049800511

00248

0032400344

$0077600778 \quad 0082900830$

0073600738

0061600627

00984009860099101015

00848008510085200946

0074300744

$01216 \quad 01253 \quad 0125401265$

0098000982

$\begin{array}{llllllll}01050 & 01071 & 01074 & 01106 & 01111 & 01182\end{array}$

POPULATION REGULATION

00042000730012800171 $0049100598 \quad 0064400776$

00176

00195

00220002270027300461 $01137011380113901140 \quad 01141011420114301270$

PREDATION

00028000450005000051

00059000600006100076

00163001650017300200

00280002810033300334

00358003590036000364

00411004230042400425

00479005090052300524

$00778 \quad 00986$

01000

0107901130

00692006970069800739

00052

00053

0005400055

00079000940012100140

0005700058

0023000242

0024300248

0014100149

0033500336

0034600347

0026000275

0036800369

003720040

0034900351

0042800430

0043100432

0040500406

0052600628

0062900676

0046700477

$00828 \quad 008350085400856$

0075200765

0077000797

0068500686

$\begin{array}{lllll}00941 & 00973 & 00981 & 01028\end{array}$

0085800868

0088100902

00801

00827

$\begin{array}{lllll}01121 & 01124 & 01131 & 01177\end{array}$

0109201098

0090300940

01088

01230

01242

01106

01118

PRESENT DISTRIBUTION

$000090003500036 \quad 00069000790008100084000850008800110$

$\begin{array}{llllllllllll}0 & 0115 & 00146 & 00162 & 00194 & 00211 & 00229 & 00230 & 00238 & 00261 & 00269\end{array}$

$\begin{array}{lllllllllll}00294 & 00301 & 00302 & 00382 & 00402 & 00512 & 00519 & 00520 & 00521 & 00563\end{array}$

$\begin{array}{lllllllllll}00568 & 00570 & 00584 & 00586 & 00625 & 00628 & 00629 & 00630 & 00633 & 00639\end{array}$

$\begin{array}{llllllllllll}00640 & 00651 & 00661 & 00671 & 00702 & 00708 & 00710 & 00733 & 00735 & 00794\end{array}$

$008100086800896009260095100952 \quad 00960 \quad 0096100970 \quad 01009$

01010010110101201013010140101601017010180102801035

$\begin{array}{llllllllllll}01036 & 01041 & 01050 & 01051 & 01058 & 01062 & 01074 & 01098 & 01148 & 01163\end{array}$

$\begin{array}{llllllllllll}01171 & 01172 & 01178 & 01189 & 01191 & 01207 & 01215 & 01262 & 01276 & 01277\end{array}$

PUBLIC ATTITUDES

$000850012300150002480032600340 \quad 00342004860049800514$ 


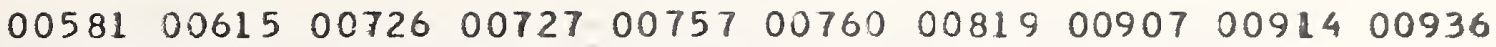
0093900956010160115101152

REACTION

$0000900070 \quad 000850011200150001510020000207 \quad 0024800403$ $\begin{array}{llllllllllll}00404 & 00406 & 00424 & 00425 & 00428 & 00429 & 00430 & 00452 & 00487 & 00489\end{array}$

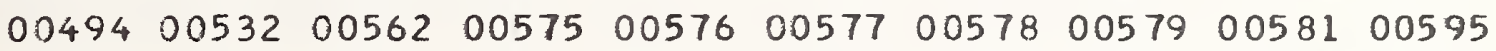
$\begin{array}{lllllllllll}00596 & 00597 & 00608 & 00624 & 00761 & 00762 & 00763 & 00786 & 00787 & 00791\end{array}$ $\begin{array}{llllllllll}00873 & 00915 & 00916 & 00923 & 00956 & 01044 & 01045 & 01046 & 01047 & 01093\end{array}$ 0111901169012170121801228

RECREATIONAL IMPACTS 00070000850010300135002100021100250003050035900390 $\begin{array}{lllllllllll}00399 & 00403 & 00410 & 00498 & 00524 & 00556 & 00633 & 00639 & 0072 C & 00773\end{array}$ $\begin{array}{llllllllll}00775 & 00868 & 00897 & 00969 & 00994 & 01041 & 01042 & 01065 & 01177\end{array}$

RECREATIONAL MANAGEMENT 000060001700021 $00248 \quad 0024900262$ 00022 00031 00032 00033000700017900213 $0049400498 \quad 0051400595$ 0032600422 0043700486 $0076300768 \quad 00773 \quad 00775$ 00604 00720 0074800757 0048700490 $\begin{array}{lllll}01191 & 01195 & 01197 & 01201\end{array}$ 0079600865 00871 008970092101048 01279

RELOCATION

$\begin{array}{llllllllllll}00016 & 00020 & 00037 & 00057 & 00135 & 00171 & 00172 & 00175 & 00196 & 00215\end{array}$

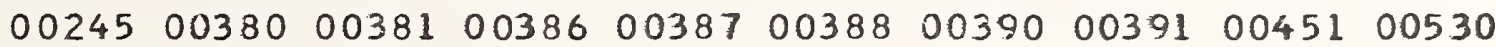
$\begin{array}{llllllllllll}00533 & 00559 & 00567 & 00708 & 00711 & 00713 & 00714 & 00722 & 00744 & 00745\end{array}$ $\begin{array}{llllllllll}00796 & 00831 & 00865 & 00868 & 00870 & 00873 & 00907 & 01004 & 01017 & 01018\end{array}$ $\begin{array}{lllllllll}010630106401119 & 01130 & 0116101187 & 01196 & 01235 & 01265\end{array}$

REPRODUCT IVE RATE $\begin{array}{llllllllll}00042 & 00128 & 00172 & 00177 & 00178 & 00179 & 00195 & 00219 & 00220 & 00226\end{array}$ $\begin{array}{llllllllll}00227 & 00229 & 00287 & 00347 & 00491 & 00632 & 00640 & 00641 & 00644 & 00825\end{array}$ $\begin{array}{lllllllllll}00826 & 00835 & 00848 & 00852 & 00861 & 00862 & 00919 & 00963 & 00978 & 00979\end{array}$ $\begin{array}{lllllllllll}00980 & 00982 & 00987 & 00989 & 00990 & 01052 & 01053 & 01079 & 01101 & 01107\end{array}$ $011380113901140 \quad 0114101142011430115501192$

REPRODUCTION

00244004620049100495006540066400677006810083600875 $00876 \quad 008770115501183$

REPRODUCT IVE PHYSIOLOGY $\begin{array}{llllllllll}00221 & 00284 & 00298 & 00303 & 00325 & 00484 & 00542 & 00664 & 00836 & 00848\end{array}$ $00852009230096201000 \quad 0100101060 \quad 012250124101243$

RESEARCH MORTALITY $003880039100403 \quad 00438005820101101018010490111701187$

RESEARCH TECHNIQUES $\begin{array}{lllllllll}00206 & 00217 & 00219 & 00222 & 0022300224 & 00230 & 00380 & 00565 & 00567\end{array}$ 00625006480092300969

ROAD IMPACTS

00010000280003600039000400004100103002630026600279 
00294002950029600518005550056300594006910069900700 $\begin{array}{lllllllllll}0 & 0746 & 00755 & 00786 & 00787 & 00791 & 00831 & 01022 & 01038 & 01041 & 01042\end{array}$ $01050 \quad 01090 \quad 010940111901169012740127501281$

ROAD MANAGEMENT

$002950029600410005160055500558 \quad 00563006910080400817$ 00951010220103801050011630119701201012030121001213 01274012760127901280

ROAD MORTALITY 00391

SCAT ANALYSIS 00370004350060000634007230080101237

SEASONAL BEHAVIOR $00173001790020200203 \quad 002040022900230002320034600372$ 0042000522007970080100888010670109501114

SEN SORY

00467

SIBLING BEHAVLOR

003510036700432

SIGHT

0020000957

SKULL

00231002880028900298003640036600371003760038000386 $00392004180050700508 \quad 0050900510 \quad 00618006730069300779$ $00780 \quad 007810078200783007840085300920009240096500966$ 009670108601115011160125201285

SMELL

00957

SUBDIVISION MANAGEMENT

001310041000518005470054801279

SUPPLEMENTAL FEEDING

0064200886

TAXONOMY/EVOLUTION

$002230041700418004880049100492 \quad 00575006490069300811$ 0081200813008140082300965009660108601224

TEL EMETRY

00071000720019900200002010020200204002050020600207 00209002280031300322003230034800440005440063400636 0065300805008990092100943010760108701136

TEMPERATURE

00102002280031100315003230053600716008200083700882 
008840094301227

TEMPORARY BAITING

00689

TERRITORIALITY \& SPACING

00034001960019700204002150027500276003030049100615 $00711007440079900806 \quad 008280085600971010010113101133$

THREAT

$00180 \quad 00275 \quad 00276008500095701133$

TIMBER IMPACTS

00025000260002800146001850021000211002790029500517 $\begin{array}{llllllllll}00518 & 00570 & 00572 & 00699 & 00700 & 00710 & 00803 & 00807 & 00934 & 00935\end{array}$ $010220102401050 \quad 01090010990127401281$

TIMBER MANAGEMENT

$\begin{array}{llllllllll}00131 & 00185 & 00225 & 00277 & 00293 & 00295 & 00296 & 00410 & 00554 & 00555\end{array}$ $\begin{array}{lllllllllll}00558 & 00570 & 00572 & 00734 & 00756 & 00799 & 00800 & 00802 & 00847 & 00935\end{array}$ $\begin{array}{llllllllll}01022 & 01090 & 01191 & 01195 & 01197 & 01201 & 01202 & 01203 & 01205 & 01206\end{array}$ 012070120801211012750127901280

TIMBER USE

$0008500086 \quad 001250037200406 \quad 0063800639006470075000756$ $0078901046 \quad 01275$

TIMBER (MGMT BY) ENTRANCE 008170090601050

TIMBER (MGMT BY) HABITAT $001050034500505 \quad 00750 \quad 0080400906 \quad 01024010500105401210$ 01274

TIMBER (HARVEST) METHOD $00086001050018500293 \quad 002940034500505005720058700691$ $\begin{array}{llllllllll}00803 & 00804 & 00817 & 00906 & 00934 & 01022 & 01050 & 01099 & 01209 & 01210\end{array}$ $01274012750127601278 \quad 01280 \quad 01281$

TIMBER (MGMT) POST-HARV. $00105001850034500505 \quad 00516 \quad 00572 \quad 00700 \quad 007340080400817$ $\begin{array}{llllllll}00898 & 00906 & 01022 & 01210 & 01274 & 01278 & 01279 & 01281\end{array}$

TYPE DESCRIPTIONS 00009000100006300136001370025900409004440055800563 $007030070400706 \quad 00750 \quad 0095101040 \quad 01042010740107501195$

UNGULATE COMPETITION 00372

URBAN DEVELOPMENT 00103001310028200572

VEGETATIVE SUCCESSION

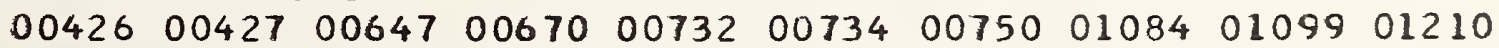


$0122201278 \quad 01281$

VOC AL IZATIONS

002750035100957

WEANING

$000660020400290 \quad 00367003820038300432004340049500546$ 007410074300836008600092501106

WEIGHT

$\begin{array}{llllllllll}00087 & 00090 & 00126 & 00128 & 00203 & 00222 & 00228 & 00232 & 00300 & 00361\end{array}$ $\begin{array}{llllllllllll}00366 & 00376 & 00377 & 00383 & 00385 & 00492 & 00610 & 00611 & 00612 & 00629\end{array}$ $\begin{array}{llllllllll}00631 & 00632 & 00636 & 00637 & 00642 & 00785 & 00825 & 00826 & 00827 & 00829\end{array}$ $\begin{array}{llllllllll}00834 & 00859 & 00917 & 00918 & 00919 & 00924 & 00925 & 00931 & 00987 & 00989\end{array}$ $\begin{array}{lllllllllll}00990 & 00991 & 01001 & 01005 & 01013 & 01016 & 01017 & 01018 & 01026 & 01049\end{array}$ $\begin{array}{lllllllllll}01051 & 01052 & 01053 & 01091 & 01095 & 01142 & 01192 & 01252 & 01254 & 01255\end{array}$

ZONING

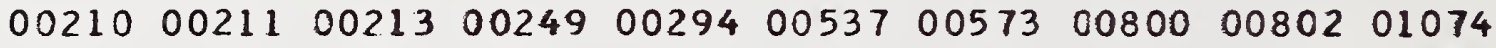
$\begin{array}{lllllllllll}01201 & 01202 & 01205 & 01206 & 01207 & 01208 & 01211 & 01216 & 01249 & 01276\end{array}$

ZOO TECHNIQUES

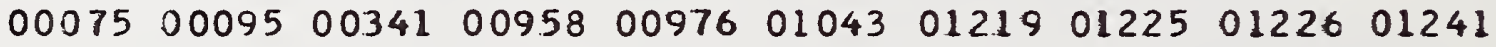




\section{APENDIX F}

GEOGRAPHIC INDEX (SORTED BY INDIVIDUAL GEOGRAPHIC KEYWORD 
$A B C$

006180105201054

$A B M$

00790

AD I S

00545006190067900765009350104901051010530105501252 $0125301254 \quad 01255$

AHNU

00692010240109901265

AINM

0095601228

AK

00002000030001700021000220003400045000500005100052 $00053 \quad 00054 \quad 00055000560005700058 \quad 00059000600006100065$ $0006600070 \quad 0007700078000790009400098000990010100102$ 00104001340013500140001410014900163001640016500166 $\begin{array}{lllllllllll}00169 & 00192 & 00193 & 00229 & 00230 & 00232 & 00234 & 00235 & 00236 & 00237\end{array}$ $\begin{array}{lllllllllll}00242 & 00243 & 00246 & 00247 & 00248 & 00249 & 00250 & 00251 & 00253 & 00260\end{array}$ $\begin{array}{llllllllllll}00266 & 00267 & 00275 & 00276 & 00278 & 00285 & 00286 & 00287 & 00288 & 00289\end{array}$ $\begin{array}{llllllllllll}00290 & 00291 & 00297 & 00299 & 00305 & 00321 & 00333 & 00334 & 00335 & 00336\end{array}$ $\begin{array}{llllllllllll}00346 & 00347 & 00349 & 00351 & 00352 & 00358 & 00359 & 00360 & 00361 & 00362\end{array}$ $\begin{array}{llllllllllll}00363 & 00364 & 00365 & 00366 & 00367 & 00368 & 00369 & 00477 & 00478 & 00479\end{array}$ $\begin{array}{lllllllllll}00483 & 00484 & 00497 & 00506 & 00507 & 00508 & 00509 & 00510 & 00527 & 00536\end{array}$ $\begin{array}{lllllllllll}00545 & 00546 & 00577 & 00578 & 00580 & 00617 & 00618 & 00619 & 00620 & 00621\end{array}$ $\begin{array}{lllllllllll}00655 & 00673 & 00674 & 00675 & 00676 & 00677 & 00678 & 00679 & 00680 & 00681\end{array}$ $\begin{array}{llllllllllll}00685 & 00686 & 00688 & 00697 & 00698 & 00721 & 00758 & 00759 & 00765 & 00766\end{array}$ $\begin{array}{lllllllllll}00779 & 00780 & 00781 & 00782 & 00783 & 00784 & 00807 & 00808 & 00825 & 00826\end{array}$ $\begin{array}{llllllllll}00827 & 00828 & 00829 & 00830 & 00831 & 00832 & 00833 & 00834 & 00836 & 00854\end{array}$ $\begin{array}{lllllllllll}00856 & 00865 & 00869 & 00875 & 00876 & 00877 & 00878 & 00879 & 00880 & 00881\end{array}$ $0089200893 \quad 00894008950090200903 \quad 00904 \quad 009330093400935$ $\begin{array}{llllllllll}00940 & 00941 & 00942 & 00952 & 00956 & 00959 & 00960 & 00963 & 00964 & 00965\end{array}$ $\begin{array}{lllllllllll}00967 & 00968 & 00978 & 00979 & 00980 & 00981 & 00982 & 00983 & 00984 & 00985\end{array}$ $\begin{array}{lllllllllll}00986 & 00987 & 00988 & 00989 & 00990 & 00991 & 00992 & 01047 & 01049 & 01051\end{array}$ $\begin{array}{llllllllll}01052 & 01053 & 01054 & 01055 & 01088 & 01093 & 01094 & 01097 & 01106 & 01107\end{array}$ $\begin{array}{lllllllllll}01114 & 01117 & 01118 & 01121 & 01124 & 01131 & 01133 & 01151 & 01164 & 01165\end{array}$ $\begin{array}{llllllllll}01169 & 01173 & 01174 & 01175 & 01176 & 01177 & 01178 & 01179 & 01180 & 01181\end{array}$ $\begin{array}{llllllllll}01182 & 01183 & 01184 & 01192 & 01215 & 01217 & 01218 & 01222 & 01228 & 01230\end{array}$ $01236 \quad 0125201253012540125501284$

$A K-I$

00094001010010200104001340013500141002300023400235 $\begin{array}{llllllllllll}00236 & 00237 & 00246 & 00247 & 00250 & 00251 & 00253 & 00260 & 00267 & 00349\end{array}$ $\begin{array}{lllllllllll}00546 & 00577 & 00578 & 00620 & 00685 & 00686 & 00697 & 00758 & 00759 & 00856\end{array}$ $\begin{array}{llllllllll}00865 & 00903 & 00904 & 00952 & 00983 & 00988 & 00990 & 01093 & 01094 & 01097\end{array}$ $\begin{array}{lllllllll}01121 & 01124 & 01151 & 01169 & 01215 & 01217 & 01218 & 01230\end{array}$

AKKA

00034000650006600077000780016300164001650016600278 


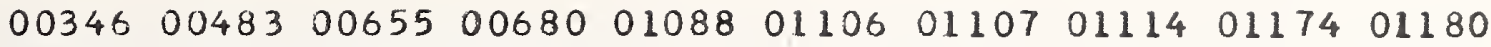
01181011820118301184

AKK I

0078600790

AKPN

$00021000220004500070 \quad 000790014900169002480027500276$ $\begin{array}{llllllllll}00285 & 00286 & 00287 & 00290 & 00297 & 00299 & 00305 & 00333 & 00334 & 00335\end{array}$ $\begin{array}{lllllllllll}0 & 0336 & 00358 & 00359 & 00360 & 00361 & 00362 & 00363 & 00364 & 00365 & 00366\end{array}$ $\begin{array}{llllllllll}00367 & 00369 & 00484 & 00580 & 00673 & 00698 & 00836 & 00869 & 00881 & 00963\end{array}$ 01131011330116401165011730117501176011770117801179

AKRG

009830098800990

AKSC

$00050 \quad 00051 \quad 0005200053 \quad 000540005500056 \quad 000570005800060$ $\begin{array}{lllllllllll}00061 & 00140 & 00825 & 00826 & 00827 & 00828 & 00829 & 00830 & 00831 & 00832\end{array}$ 008340111701118

AKSE

$0054500617006180061900679007650080700902 \quad 0093300934$

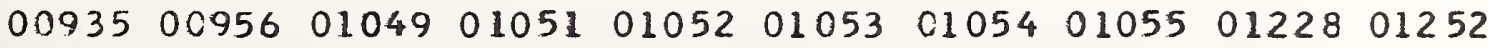
012530125401255

ALSE

009160091700918009190092000923

AMER

00290

ANBU

0055501041

ANWR

00101001020034700940009410094201192

APGR

0060200605006060091501084

$A R C$

$\begin{array}{llllllllll}00059 & 00229 & 00232 & 00242 & 00243 & 00347 & 00351 & 00477 & 00478 & 00479\end{array}$ $\begin{array}{lllllllllll}00506 & 00688 & 00721 & 00766 & 00875 & 00876 & 00877 & 00940 & 00941 & 00942\end{array}$

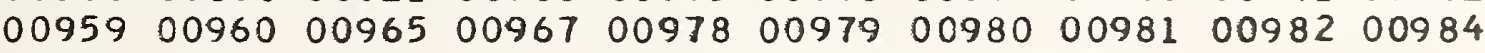
0098500986009870098900991009920104701192

ASHT

$0039500396 \quad 01194$

AT

00004000050000600123001910040200403004230042400425 $\begin{array}{llllllllll}00426 & 00427 & 00428 & 00429 & 00430 & 00431 & 00432 & 00433 & 00434 & 00435\end{array}$ $00436 \quad 00496 \quad 0051500517005180051900520 \quad 005210053300538$ 


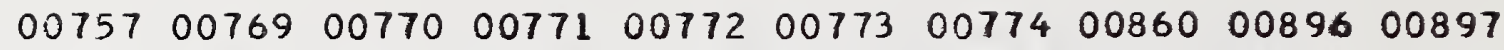
$\begin{array}{llllllllll}00899 & 00901 & 00912 & 00924 & 00931 & 00961 & 00975 & 00993 & 01025 & 01026\end{array}$

0115201167012230126701283

ATBC

005950072701242

ATMT

00454

ATPP

00006

AT SA

00231

AZNM

00046

BACR

01036

BANP

$\begin{array}{llllllllll}00191 & 00423 & 00424 & 00425 & 00426 & 00427 & 00431 & 00432 & 00433 & 00434\end{array}$ $\begin{array}{llllllllllll}00435 & 00436 & 00495 & 00538 & 00727 & 00897 & 00901 & 00975 & 01167 & 01223\end{array}$

BARN

00925

$\mathrm{BC}$

00018000250002600027000280002900063000760010900110 $\begin{array}{lllllllllll}00111 & 00256 & 00274 & 00307 & 00308 & 00324 & 00343 & 00344 & 00421 & 00422\end{array}$ $\begin{array}{lllllllllll}00437 & 00438 & 00439 & 00440 & 00441 & 00476 & 00493 & 00495 & 00690 & 00691\end{array}$ $\begin{array}{llllllllllll}00692 & 00726 & 00760 & 00768 & 00775 & 00786 & 00788 & 00789 & 00806 & 00848\end{array}$ $\begin{array}{llllllllll}00850 & 00851 & 00852 & 01024 & 01091 & 01099 & 01111 & 01166 & 01216 & 01256\end{array}$ 01265

$B C-C$

$\begin{array}{llllllllll}00025 & 00026 & 00027 & 00028 & 00029 & 00063 & 00274 & 00324 & 00438 & 00439\end{array}$ $\begin{array}{lllllllllll}00440 & 00441 & 00476 & 00690 & 00692 & 00806 & 01024 & 01099 & 01216 & 01256\end{array}$ 01265

$B C-I$

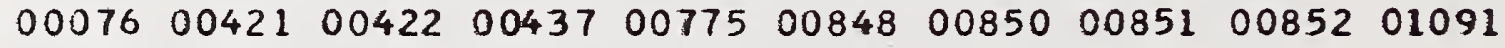

$B C I W$

00661

BCMT

$007870079100898 \quad 01092$

BCWA

01148 
BIM

00714

BINF

01034

BLIR

00032

ELKL

0035900360003610036200363003640036500836

BLM

00035000360003700038000390004000041010380103901040 010420121201213

BMWA

0070400706

BORF

008600092401058

BRKR

$\begin{array}{lllllll}00875 & 00876 & 00877 & 00981 & 00984 & 00992 & 01047\end{array}$

BRON

$00070 \quad 002480096701177$

BTNF

00152001620051100512008550100901010010110101201013

0101401016010170101801199012090121001245

CA

006220113401186

$C A B$

001540015700158005590071901160

CAMA

00995

CAN

0045300611006820071500859009260112701157

CARC

00261004450044600612008610086200925009270102801098 01262

CASC

00191004230042400425004260043300434004360090101167

CAUS

00803 


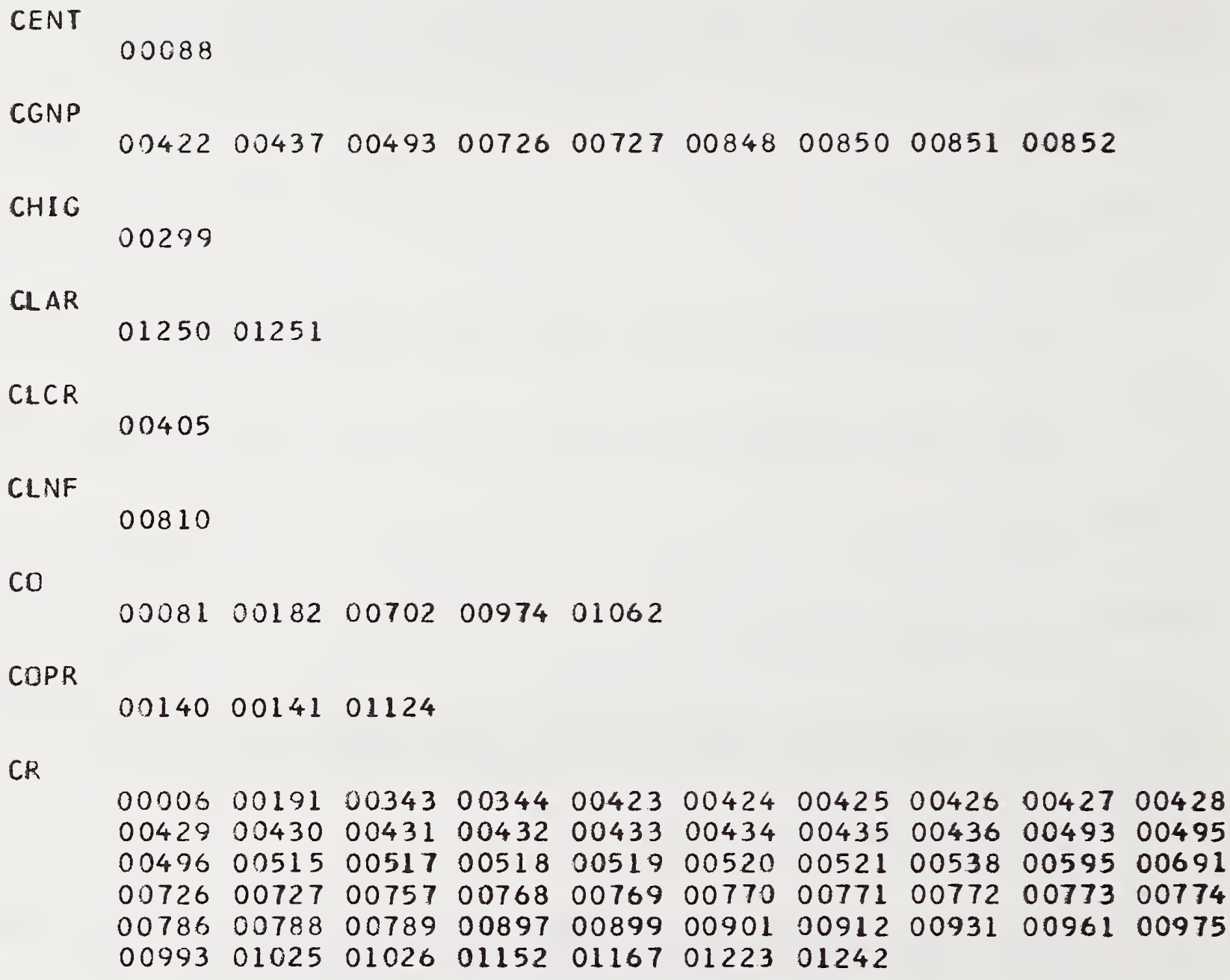

CUW I

0043100432

CYE

00019001050015400157001580029400295002960034500420 $0055900592 \quad 00593 \quad 0059400714007190072000722 \quad 0073300843$ $00907 \quad 0095101072 \quad 0116001196 \quad 01250 \quad 01251 \quad 01268$

CYNC

0015500505012010120701211

CYPR

00231

DENP

$0013400135002340023500236 \quad 00237 \quad 00246 \quad 00250 \quad 0025100253$ $\begin{array}{llllllllll}00267 & 00577 & 00578 & 00856 & 00865 & 01093 & 01094 & 01121 & 01151 & 01169\end{array}$ 012150121701218

EBRK

002320068800721007660095900960009780097900985 
ECAN

00283005740111501116

ELLK

00033

FISH

001080063900868

FLIR

00131001480016000161003420044400614006150106301066 01067010730107401075

FLNF

$0001200020 \quad 0006400124001430014600186001870021200225$ $\begin{array}{lllllllllll}0 & 0409 & 00410 & 00444 & 00449 & 00516 & 00564 & 00572 & 00584 & 00703 & 00704\end{array}$ $\begin{array}{lllllllllll}00706 & 00734 & 00804 & 01067 & 01092 & 01128 & 01129 & 01159 & 01193 & 01203\end{array}$ 012080127401281

GALL

0015000151

GANF

$0008500106 \quad 00107 \quad 00270 \quad 006330068700798 \quad 0084001202$

GEN

00001000070001100014000150002300024000430004400067 $\begin{array}{llllllllll}00071 & 00072 & 00073 & 00074 & 00075 & 00080 & 00092 & 00093 & 00095 & 00096\end{array}$ $0009700100 \quad 0011400122 \quad 00126 \quad 00127 \quad 00128001290013300138$ $00139001440014500147001670016800170 \quad 001800018100183$ $\begin{array}{llllllllll}00184 & 00185 & 00194 & 00216 & 00218 & 00224 & 00228 & 00233 & 00239 & 00240\end{array}$ $\begin{array}{lllllllllll}00244 & 00252 & 00254 & 0 & 0255 & 00257 & 00258 & 00264 & 00265 & 00271 & 00273\end{array}$ $\begin{array}{lllllllllll}00277 & 00279 & 00280 & 00281 & 00282 & 00284 & 00298 & 00300 & 00303 & 00304\end{array}$ $\begin{array}{lllllllllll}00309 & 00310 & 00311 & 00312 & 00313 & 00314 & 00315 & 00316 & 00317 & 00318\end{array}$ $\begin{array}{lllllllllll}00319 & 00320 & 00322 & 0 & 0323 & 00325 & 00329 & 00330 & 00332 & 00337 & 00338\end{array}$ $\begin{array}{lllllllllll}00339 & 00341 & 00348 & 00350 & 00353 & 00354 & 00355 & 00370 & 00371 & 00373\end{array}$ $00400 \quad 00407 \quad 00408 \quad 004110041200413 \quad 00414004150041600417$ $\begin{array}{lllllllllll}00418 & 00419 & 00447 & 00448 & 00455 & 00457 & 00458 & 00459 & 00460 & 00461\end{array}$ $\begin{array}{lllllllllll}00462 & 00463 & 00464 & 00465 & 00466 & 00470 & 00471 & 00472 & 00473 & 00474\end{array}$ $\begin{array}{lllllllllll}00475 & 00480 & 00482 & 00486 & 00487 & 00488 & 00489 & 00490 & 00491 & 00492\end{array}$ $\begin{array}{lllllllllll}00494 & 00500 & 00514 & 00529 & 00530 & 00531 & 00532 & 00535 & 00539 & 00542\end{array}$ $\begin{array}{lllllllllll}00543 & 00544 & 00549 & 00551 & 00554 & 00557 & 00562 & 00565 & 00569 & 00598\end{array}$ 00599006100064900654006560065800663006640066500666 $\begin{array}{llllllllll}00667 & 00689 & 00693 & 00696 & 00699 & 00700 & 00701 & 00716 & 00723 & 00724\end{array}$

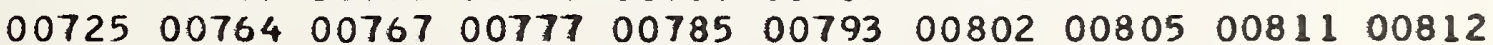
$\begin{array}{llllllllll}00813 & 00814 & 00820 & 00821 & 00822 & 00823 & 00824 & 00837 & 00838 & 00844\end{array}$ $\begin{array}{llllllllll}00846 & 00849 & 00853 & 00858 & 00882 & 00883 & 00884 & 00885 & 00886 & 00887\end{array}$ $\begin{array}{lllllllllll}00888 & 00889 & 00890 & 00891 & 00908 & 00910 & 00911 & 00921 & 00932 & 00937\end{array}$ $\begin{array}{llllllllll}00939 & 00943 & 00944 & 00948 & 00953 & 00954 & 00955 & 00957 & 00958 & 00962\end{array}$ $\begin{array}{lllllllllll}00966 & 00971 & 00972 & 00976 & 00977 & 00994 & 00997 & 00998 & 01000 & 01001\end{array}$ $\begin{array}{llllllllll}01002 & 01003 & 01004 & 01005 & 01006 & 01007 & 01019 & 01020 & 01023 & 01027\end{array}$ $\begin{array}{llllllllll}01029 & 01030 & 01031 & 01032 & 01033 & 01043 & 01050 & 01056 & 01059 & 01060\end{array}$ $\begin{array}{llllllllll}01061 & 01076 & 01077 & 01079 & 01080 & 01082 & 01083 & 01085 & 01087 & 01090\end{array}$ $\begin{array}{llllllllll}01096 & 01100 & 01105 & 01109 & 01110 & 01113 & 01120 & 01122 & 01123 & 01125\end{array}$ 
$\begin{array}{llllllllll}01126 & 01130 & 01132 & 01135 & 01136 & 01137 & 01138 & 01139 & 01140 & 01142\end{array}$ $\begin{array}{llllllllll}01154 & 01155 & 01156 & 01158 & 01162 & 01170 & 01185 & 01219 & 01224 & 01225\end{array}$ $\begin{array}{lllllllllll}01226 & 01227 & 01229 & 01231 & 01237 & 01241 & 01243 & 01246 & 01247 & 01257\end{array}$ $\begin{array}{lllllllll}01258 & 01259 & 01260 & 01261 & 01266 & 01270 & 01282 & 01285\end{array}$

GINF

00292

GIWA

00292

GLNP

$00031000320003300047001370014200340 \quad 00498 \quad 0049900575$ $\begin{array}{lllllllllllll}00576 & 00579 & 00581 & 00596 & 00597 & 00602 & 00604 & 00605 & 00606 & 00607\end{array}$ $\begin{array}{llllllllll}00608 & 00735 & 00736 & 00737 & 00738 & 00739 & 00740 & 00741 & 00742 & 00743\end{array}$ $\begin{array}{lllllllllll}00744 & 00745 & 00746 & 00747 & 00748 & 00761 & 00762 & 00763 & 00816 & 00819\end{array}$

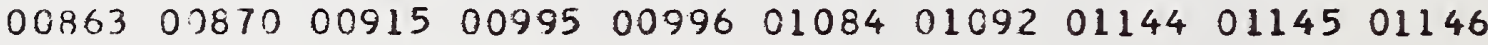

GTNP

00513

HAYD

00372

HUNG

00143

ID

$0000900010 \quad 00241003310039500396 \quad 0039700398 \quad 00550 \quad 00583$ $\begin{array}{llllllllllll}00749 & 00810 & 00817 & 00818 & 00847 & 00951 & 01149 & 01194 & 01197 & 01277\end{array}$

IDMT

$0001900088001360015400156 \quad 00157 \quad 00270 \quad 005920059300594$ $0066200719007220084300845010340119601198 \quad 01204$

10WA

000080066001276

IDWY

005820067200809009060119501206

IMW

$0001600030 \quad 0004200068000690008600087000890009000091$ $\begin{array}{lllllllllll}00103 & 00171 & 00172 & 00173 & 00174 & 00175 & 00176 & 00177 & 00178 & 00179\end{array}$ $0019500196001970019900200 \quad 00202 \quad 00209002100021100213$ $\begin{array}{llllllllll}00214 & 00215 & 00220 & 00223 & 00226 & 00227 & 00259 & 00272 & 00326 & 00388\end{array}$ $\begin{array}{llllllllll}00399 & 00450 & 00452 & 00467 & 00485 & 00525 & 00526 & 00589 & 00590 & 00591\end{array}$ $\begin{array}{llllllllll}00600 & 00603 & 00609 & 00613 & 00623 & 00624 & 00625 & 00626 & 00627 & 00628\end{array}$ $\begin{array}{lllllllllll}0 & 0629 & 00630 & 00631 & 00632 & 00634 & 00635 & 00636 & 00637 & 00638 & 00640\end{array}$ $\begin{array}{lllllllllll}00641 & 00642 & 00643 & 00644 & 00645 & 00646 & 00647 & 00684 & 00750 & 00753\end{array}$ $\begin{array}{llllllllll}00754 & 00755 & 00756 & 00776 & 00778 & 00794 & 00795 & 00796 & 00799 & 00800\end{array}$ $\begin{array}{lllllllllll}00801 & 00864 & 00866 & 00871 & 00872 & 00873 & 00874 & 00945 & 00949 & 00950\end{array}$ $\begin{array}{llllllllllll}00969 & 01015 & 01044 & 01045 & 01046 & 01057 & 01081 & 01086 & 01141 & 01143\end{array}$ $\begin{array}{lllllllll}01147 & 01187 & 01188 & 01214 & 01233 & 01234 & 01244\end{array}$ 
I PNF

0114901197

ISL P

002700033100749

JANP

00899009310102501026

JAR D

001070068700840

JDR

00513

JIML

00685

KANA

$00770 \quad 00771007720077401242$

KANM

00021000220007000169002480058000869011640116501175 01176011770117801179

KANP

004960051500993

KARL

0007700163001660034600655010880117401184

KENA

00079003330033400335003360035800881

KGNP

00775

KGPP

00769

KIMS

0002600027000280006300438004390044000441

KLGS

00916009170091800919009200092200923

KNWR

00034000650006600077000780016400483006800111401173 01174011800118101184

KOIS

000340016400165003460117301180011810118201183

KONF

00008000090001000012001050015400155001570015800294 
$00345004090071900720 \quad 007330084301200 \quad 0120101207$

KOOC

01268

LAKE

005230052400973

LCNF

$001860018700212002250103501036 \quad 01128011290119001193$ 01269

LONF

$00293002940042000505007030070400706 \quad 008040116301211$ 01221

LOU I

00538

LSWA

00212002250122001221

MADR

00085

MANY

00031

MCGS

$00276 \quad 00305 \quad 00367006980113101133$

MCNE

$0027500276 \quad 00297003050036700697006980113101133$

MCPK

0014800615

MEX

00238006510065200671006830117101172

MISS

$0034200374004440061401066 \quad 010670107501159$

MMTN

008.35

MNTB

01153

MT

$000120001300020 \quad 0003100032000330003500036 \quad 0003700038$ $0003900040 \quad 0004100047000640008500105001060010700116$ 00117001180011900120001210012400125001310013700142 $001430014600148001510015500158 \quad 00160001610018600187$ 


$\begin{array}{llllllllll}00188 & 00189 & 00190 & 00212 & 00225 & 00245 & 00262 & 00263 & 00269 & 00293 \\ 00294 & 00295 & 00296 & 00301 & 00302 & 00327 & 00328 & 00340 & 00342 & 00345 \\ 00356 & 00357 & 00374 & 00375 & 00376 & 00377 & 00378 & 00379 & 00380 & 00381 \\ 00382 & 00383 & 00384 & 00385 & 00386 & 00387 & 00389 & 00390 & 00391 & 00392 \\ 00393 & 00394 & 00409 & 00410 & 00420 & 00443 & 00444 & 00449 & 00456 & 00468 \\ 00469 & 00498 & 00499 & 00505 & 00516 & 00528 & 00534 & 00540 & 00541 & 00547 \\ 00548 & 00552 & 00553 & 00555 & 00556 & 00558 & 00559 & 00560 & 00561 & 00563 \\ 00564 & 00566 & 00567 & 00570 & 00571 & 00572 & 00573 & 00575 & 00576 & 00579 \\ 00581 & 00584 & 00585 & 00586 & 00587 & 00588 & 00596 & 00597 & 00602 & 00604 \\ 00605 & 00606 & 00607 & 00608 & 00614 & 00615 & 00616 & 00633 & 00668 & 00669 \\ 00670 & 00687 & 00703 & 00704 & 00705 & 00706 & 00707 & 00708 & 00709 & 00710 \\ 00711 & 00712 & 00713 & 00720 & 00728 & 00729 & 00730 & 00731 & 00732 & 00733 \\ 00734 & 00735 & 00736 & 00737 & 00738 & 00739 & 00740 & 00741 & 00742 & 00743 \\ 00744 & 00745 & 00746 & 00747 & 00748 & 00761 & 00762 & 00763 & 00792 & 00798 \\ 00804 & 00816 & 00819 & 00839 & 00840 & 00841 & 00842 & 00863 & 0087 C & 00905 \\ 00907 & 00909 & 00915 & 00936 & 00946 & 00947 & 00995 & 00996 & 00999 & 01008 \\ 01010 & 01011 & 01021 & 01035 & 01036 & 01037 & 01038 & 01039 & 01040 & 01041 \\ 01042 & 01063 & 01064 & 01065 & 01066 & 01067 & 01072 & 01073 & 01074 & 01075 \\ 01084 & 01095 & 01128 & 01129 & 01144 & 01145 & 01146 & 01150 & 01159 & 01160 \\ 01161 & 01163 & 01190 & 01193 & 01200 & 01201 & 01202 & 01203 & 01207 & 01208 \\ 01211 & 01212 & 01213 & 01220 & 01221 & 01235 & 01238 & 01239 & 01250 & 01251 \\ 01263 & 01266 & 01269 & 01274 & 01275 & 01278 & 01279 & 01280 & 01281 & \end{array}$

MTWY

$006 C 1 \quad 00650 \quad 01264$

NAKR

00806

NCDE

$\begin{array}{llllllllll}00012 & 00020 & 00031 & 00032 & 00033 & 00035 & 00036 & 00037 & 00038 & 00039\end{array}$ $\begin{array}{llllllllllll}00040 & 00041 & 00047 & 00064 & 00116 & 00117 & 00121 & 00124 & 00125 & 00131\end{array}$

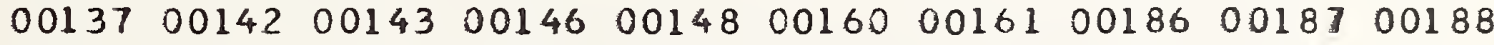
$\begin{array}{lllllllllll}00189 & 00190 & 00212 & 00225 & 00245 & 00262 & 00263 & 00269 & 00293 & 00301\end{array}$ $\begin{array}{lllllllllll}00302 & 00327 & 00340 & 00342 & 00356 & 00357 & 00374 & 00409 & 00410 & 00444\end{array}$ $\begin{array}{llllllllll}00449 & 00454 & 00456 & 00468 & 00469 & 00498 & 00499 & 00516 & 00528 & 00534\end{array}$ $\begin{array}{lllllllllll}00540 & 00541 & 00547 & 00548 & 00552 & 00553 & 00555 & 00556 & 00558 & 00560\end{array}$ $\begin{array}{llllllllllll}00561 & 00563 & 00564 & 00566 & 00567 & 00570 & 00571 & 00572 & 00573 & 00575\end{array}$ $\begin{array}{lllllllllll}00576 & 00579 & 00581 & 00584 & 00585 & 00586 & 00587 & 00588 & 00596 & 00597\end{array}$ $\begin{array}{llllllllllll}00602 & 00604 & 00605 & 00606 & 00607 & 00608 & 00614 & 00615 & 00616 & 00668\end{array}$ $\begin{array}{lllllllllll}00669 & 00670 & 00703 & 00704 & 00705 & 00706 & 00707 & 00708 & 00709 & 00710\end{array}$ $\begin{array}{llllllllll}00711 & 00712 & 00713 & 00728 & 00729 & 00730 & 00731 & 00732 & 00734 & 00735\end{array}$ $\begin{array}{llllllllll}00736 & 00737 & 00738 & 00739 & 00740 & 00741 & 00742 & 00743 & 00744 & 00745\end{array}$ $\begin{array}{llllllllll}00746 & 00747 & 00748 & 00761 & 00762 & 00763 & 00787 & 00790 & 00791 & 00792\end{array}$ $\begin{array}{llllllllll}00804 & 00816 & 00819 & 00863 & 00870 & 00898 & 00905 & 00915 & 00936 & 00947\end{array}$ $\begin{array}{lllllllllll}00995 & 00996 & 00999 & 01016 & 01021 & 01035 & 01036 & 01037 & 01038 & 01039\end{array}$ $\begin{array}{lllllllllll}01040 & 01041 & 01042 & 01063 & 01064 & 01065 & 01066 & 01067 & 01073 & 01074\end{array}$ $0107501084 \quad 01092 \quad 01095 \quad 0112801129011440114501146 \quad 01150$ $\begin{array}{lllllllllll}01159 & 01161 & 01163 & 01190 & 01193 & 01203 & 01208 & 01212 & 01213 & 01220\end{array}$ $\begin{array}{lllllllllll}01221 & 01235 & 01238 & 01239 & 01269 & 01274 & 01275 & 01278 & 01279 & 01280\end{array}$ 01281

NCE

00082000830008401148 
NCNP

000820008300084

NESU

$00050 \quad 000510005200053000540005500056000570005800059$ $00060 \quad 00061 \quad 00260 \quad 00825008260082700828008290083000831$ 0083200834011170111801230

NFLT

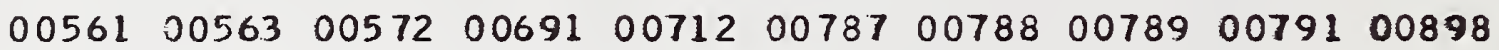
00936009990109201274

NINT

00835009160091700918009190092000922009230092800929 009300111901271

$\Lambda M$

$$
0029200306
$$

NPNF

01034

NPR

004770047800479009800098600992

NPS

0008901104

NSLP

0022900230

NWT

00062001120011300401004450044600717007180083500862 0090000927010580107801098

NWYK

01262

CMIN

0034300344

ONT

001590093801168

PACR

0095601228

PC

00595

PELI

0040400406

PIBU

0066900670 
PRWM

00952

RATT

0106501163

REVL

0042101091

RGNF

00702

RICH

$00445 \quad 00446 \quad 00927 \quad 01098$

RMEF

00035000360003700038000390004000041010380103901040 010420121201213

SBE

0013600241008100084501034

SBWA

0013601034

SCAP

01150

SEEL

00293

SFLT

002690035700449005870070800710007110079201095

SHNF

00048000490065300970010090101001011010120101301014 $\begin{array}{lllllllll}01016 & 01017 & 01018 & 01022 & 01189 & 01245 & 01248 & 01249\end{array}$

SIMP

01058

SJMT

00702

SJNF

00702

SK

01240

SKEE

01216

SKYL

0063300798 


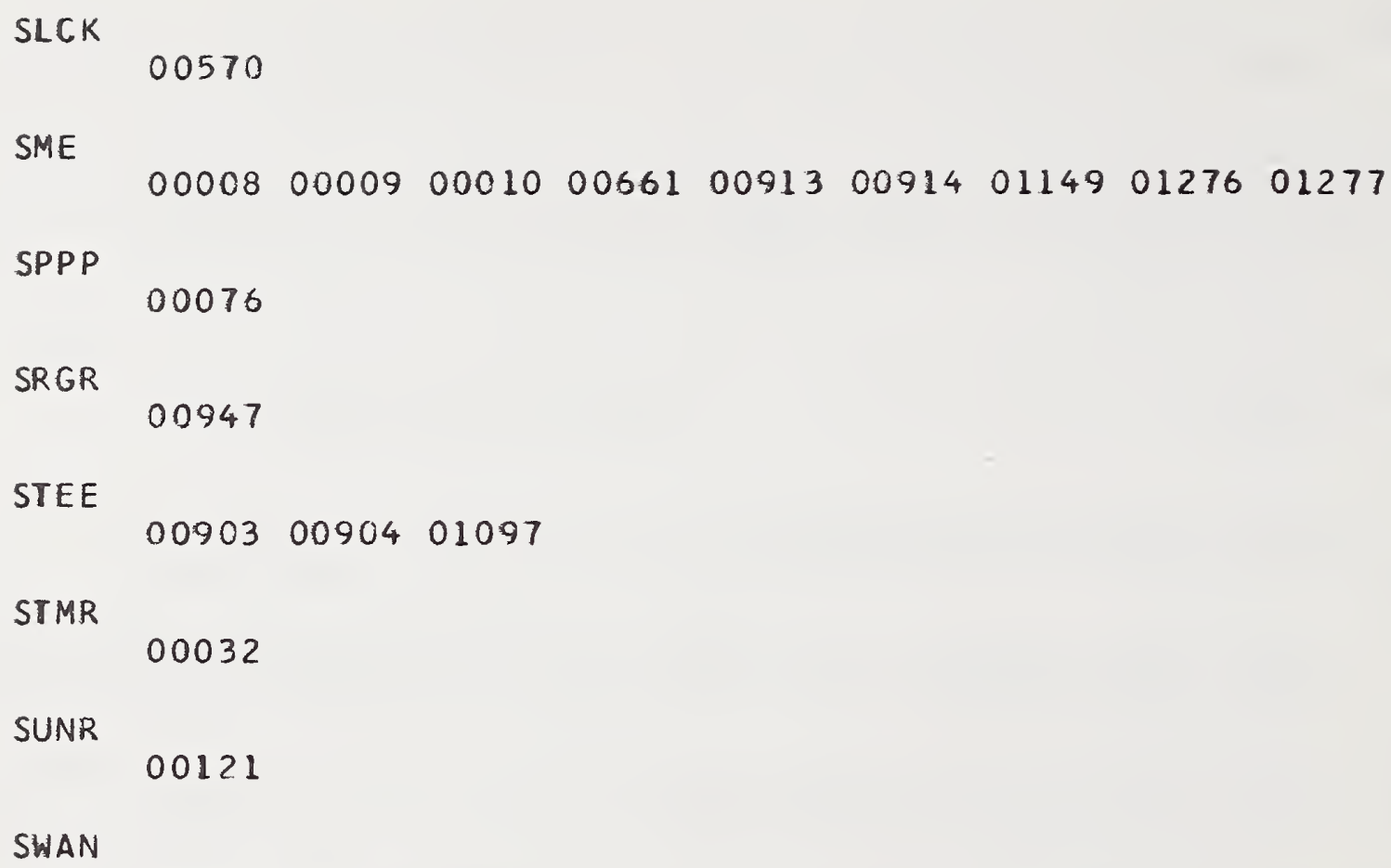

SWHI

$00860 \quad 00924$

$\sin x$

0011500568

TANF

$\begin{array}{llllllllll}00270 & 00331 & 00395 & 00396 & 00397 & 00398 & 00550 & 00582 & 00583 & 00672\end{array}$ $007490080900817008180084700906 \quad 011940119501206$

TERL

00483011060110701114

TEW I

00162

THGS

00401

TONF

009330093400935

TROU

00522

TUKP

0085900862 
TWOM

0004700137

US

$00130 \quad 00132002680045100504 \quad 0053700648008150104801068$ 01069010700107101104011910120501232

USF S

00016000350003600037000380003900040000410006900084 $\begin{array}{lllllllllll}00089 & 00136 & 00176 & 00195 & 00209 & 00211 & 00213 & 00226 & 00296 & 00342\end{array}$ $\begin{array}{llllllllll}00374 & 00450 & 00662 & 00799 & 00800 & 01038 & 01039 & 01040 & 01042 & 01066\end{array}$ $0107301150 \quad 0120401205012120121301220$

VAPP

0076800775

WA

000820008300084005010050200503006590091300914

hANP

00428004290043000518007570091201152

hBRK

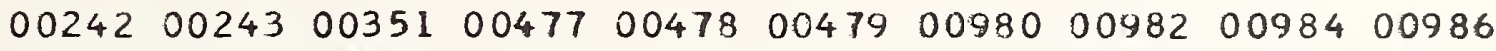
009870098900991

WGLA

00528

WHIL

00867

WHR

001240040900410005520056400804

WY

$000480004900108 \quad 00150 \quad 001520016200198002010020300204$ $\begin{array}{llllllllll}00205 & 00206 & 00207 & 00208 & 00217 & 00219 & 00221 & 00222 & 00372 & 00404\end{array}$ $\begin{array}{lllllllllll}0 & 0405 & 00406 & 00511 & 00512 & 00513 & 00522 & 00523 & 00524 & 00639 & 00653\end{array}$ $\begin{array}{lllllllllll}00657 & 00751 & 00752 & 00797 & 00855 & 00857 & 00867 & 00868 & 00970 & 00973\end{array}$ 01009010120101301014010160101701018010220111201189 011990120901210012450124801249

YAKR

00907

YGBE

$0001600030 \quad 0004200048 \quad 000490006800069000850008600087$ $\begin{array}{lllllllllll}00088 & 00089 & 00090 & 00091 & 00103 & 00106 & 00107 & 00108 & 00150 & 00151\end{array}$ $\begin{array}{llllllllllll}00152 & 00162 & 00171 & 00172 & 00173 & 00174 & 00175 & 00176 & 00177 & 00178\end{array}$ $\begin{array}{lllllllllll}00179 & 00195 & 00196 & 00197 & 00198 & 00199 & 00200 & 00201 & 00202 & 00203\end{array}$ $002040020500206 \quad 00207 \quad 00208 \quad 0020900210002110021300214$ $\begin{array}{llllllllll}00215 & 00217 & 00219 & 00220 & 00221 & 00222 & 00223 & 00226 & 00227 & 00259\end{array}$ $\begin{array}{llllllllll}00270 & 00272 & 00326 & 00331 & 00372 & 00395 & 00396 & 00397 & 00398 & 00399\end{array}$ 


$\begin{array}{llllllllll}00404 & 00405 & 00406 & 00450 & 00452 & 00467 & 00485 & 00511 & 00512 & 00513 \\ 00522 & 00523 & 00524 & 00525 & 00526 & 00550 & 00582 & 00583 & 00589 & 00590 \\ 00591 & 00600 & 00601 & 00603 & 00609 & 00613 & 00623 & 00624 & 00625 & 00626 \\ 00627 & 00628 & 00629 & 00630 & 00631 & 00632 & 00633 & 00634 & 00635 & 00636 \\ 00637 & 00638 & 00639 & 00640 & 00641 & 00642 & 00643 & 00644 & 00645 & 00646 \\ 00647 & 00653 & 00672 & 00684 & 00687 & 00749 & 00750 & 00751 & 00752 & 00753 \\ 00754 & 00755 & 00756 & 00776 & 00778 & 00794 & 00795 & 00796 & 00797 & 00798 \\ 00799 & 00800 & 00801 & 00809 & 00817 & 00818 & 00840 & 00847 & 00855 & 00857 \\ 00864 & 00866 & 00867 & 00868 & 00871 & 00872 & 00873 & 00874 & 00906 & 00945 \\ 00949 & 00950 & 00969 & 00970 & 00973 & 01009 & 01010 & 01011 & 01012 & 01013 \\ 01014 & 01015 & 01017 & 01018 & 01022 & 01044 & 01045 & 01046 & 01057 & 01081 \\ 01086 & 01112 & 01141 & 01143 & 01147 & 01187 & 01188 & 01189 & 01194 & 01195 \\ 01199 & 01202 & 01206 & 01209 & 01210 & 01214 & 01233 & 01234 & 01244 & 01245 \\ 01248 & 01249 & & & & & & & & \end{array}$

YK

$\begin{array}{lllllllllll}00153 & 00261 & 00442 & 00481 & 00612 & 00694 & 00695 & 00861 & 00916 & 00917\end{array}$ $\begin{array}{lllllllllll}00918 & 00919 & 00920 & 00922 & 00923 & 00925 & 00928 & 00929 & 00930 & 01028\end{array}$ 010890110101102011030110801119012710127201273

YNP

00016000300006800069001030010800150001510017100172 $\begin{array}{lllllllllllll}0 & 0173 & 00174 & 00175 & 00176 & 00177 & 00178 & 00179 & 00195 & 00196 & 00197\end{array}$ $0019800199 \quad 00200 \quad 00201 \quad 00202 \quad 00203 \quad 00204 \quad 002050020600207$ $\begin{array}{lllllllllll}0.0208 & 00209 & 00211 & 00213 & 00214 & 00215 & 00217 & 00219 & 00220 & 00221\end{array}$ $\begin{array}{lllllllllll}00222 & 00223 & 00226 & 00227 & 00326 & 00372 & 00399 & 00404 & 00405 & 00406\end{array}$ $\begin{array}{lllllllllll}00450 & 00452 & 00485 & 00522 & 00523 & 00524 & 00525 & 00526 & 00613 & 00639\end{array}$ $\begin{array}{lllllllllll}00645 & 00684 & 00751 & 00752 & 00755 & 00794 & 00795 & 00796 & 00797 & 00799\end{array}$ $\begin{array}{llllllllllllll}00800 & 00801 & 00857 & 00864 & 00866 & 00867 & 00868 & 00871 & 00872 & 00873\end{array}$ 009450097301057011120118701188

YUKR

00481 


\section{APPENDIX G \\ GEOGRAPHIC INDEX (SORTED BY GEOGRAPHIC LOCATION GROUPING}




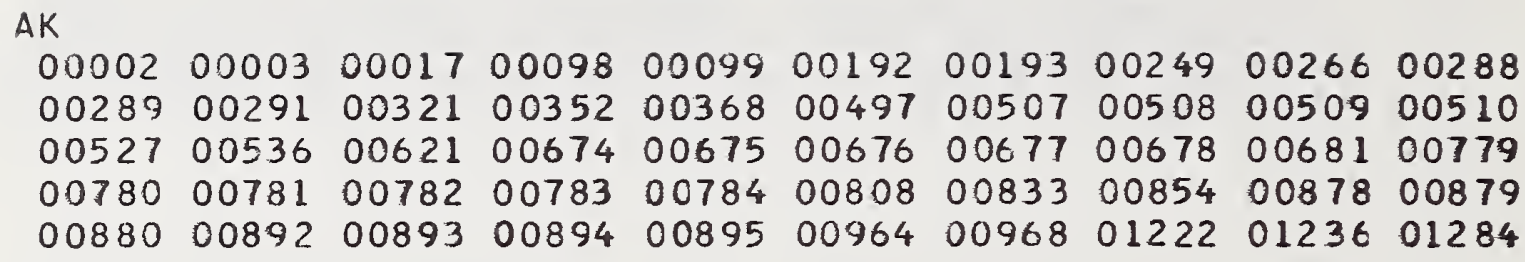

A T

000040000500123004020040300533008960126701283

ATSA

CYPR

00231

AZNM

00046

$B C$

00018001090011000111002560030700308007600111101166

$C A$

006220113401186

CAN

00453006110068200715009260112701157

$C A N$

00859

TUKP

CAUS

00803

$\mathrm{CO}$

00081001820097401062

ECAN

00283005740111501116

GEN

00001000070001100014000150002300024000430004400067 $\begin{array}{lllllllllll}00071 & 00072 & 00073 & 00074 & 00075 & 00080 & 00092 & 00093 & 00095 & 00096\end{array}$ $\begin{array}{lllllllllll}00097 & 00100 & 00114 & 00122 & 00126 & 00127 & 00128 & 00129 & 00133 & 00138\end{array}$ $\begin{array}{llllllllllll}00139 & 00144 & 00145 & 00147 & 00167 & 00168 & 00170 & 00180 & 00181 & 00183\end{array}$ $\begin{array}{lllllllllll}00184 & 00185 & 00194 & 00216 & 00218 & 00224 & 00228 & 00233 & 00239 & 00240\end{array}$ $\begin{array}{llllllllllll}0 & 0244 & 00252 & 00254 & 00255 & 00257 & 00258 & 00264 & 00265 & 00271 & 00273\end{array}$ $\begin{array}{lllllllllll}00277 & 00279 & 00280 & 00281 & 00282 & 00284 & 00298 & 00300 & 00303 & 00304\end{array}$ $\begin{array}{llllllllllll}00309 & 00310 & 00311 & 00312 & 00313 & 00314 & 00315 & 00316 & 00317 & 00318\end{array}$ $\begin{array}{llllllllllll}00319 & 00320 & 00322 & 00323 & 00325 & 00329 & 00330 & 00332 & 00337 & 00338\end{array}$ $\begin{array}{lllllllllll}00339 & 00341 & 00348 & 00350 & 00353 & 00354 & 00355 & 00370 & 00371 & 00373\end{array}$ $00400 \quad 00407 \quad 00408 \quad 00411004120041300414004150041600417$ $\begin{array}{llllllllllll}00418 & 00419 & 00447 & 00448 & 00455 & 00457 & 00458 & 00459 & 00460 & 00461\end{array}$ $\begin{array}{llllllllllll}00462 & 00463 & 00464 & 00465 & 00466 & 00470 & 00471 & 00472 & 00473 & 00474\end{array}$ $\begin{array}{lllllllllll}00475 & 00480 & 00482 & 00486 & 00487 & 00488 & 00489 & 00490 & 00491 & 00492\end{array}$ 


$\begin{array}{llllllllll}00494 & 00500 & 00514 & 00529 & 00530 & 00531 & 00532 & 00535 & 00539 & 00542 \\ 00543 & 00544 & 00549 & 00551 & 00554 & 00557 & 00562 & 00565 & 00569 & 00598 \\ 00599 & 00610 & 00649 & 00654 & 00656 & 00658 & 00663 & 00664 & 00665 & 00666 \\ 00667 & 00689 & 00693 & 00696 & 00699 & 00700 & 00701 & 00716 & 00723 & 00724 \\ 00725 & 00764 & 00767 & 00777 & 00785 & 00793 & 00802 & 00805 & 00811 & 00812 \\ 00813 & 00814 & 00820 & 00821 & 00822 & 00823 & 00824 & 00837 & 00838 & 00844 \\ 00846 & 00849 & 00853 & 00858 & 00882 & 00883 & 00884 & 00885 & 00886 & 00887 \\ 00888 & 00889 & 00890 & 00891 & 00908 & 00910 & 00911 & 00921 & 00932 & 00937 \\ 00939 & 00943 & 00944 & 00948 & 00953 & 00954 & 00955 & 00957 & 00958 & 00962 \\ 00966 & 00971 & 00972 & 00976 & 00977 & 00994 & 00997 & 00998 & 01000 & 01001 \\ 01002 & 01003 & 01004 & 01005 & 01006 & 01007 & 01019 & 01020 & 01023 & 01027 \\ 01029 & 01030 & 01031 & 01032 & 01033 & 01043 & 01050 & 01056 & 01059 & 01060 \\ 01061 & 01076 & 01077 & 01079 & 01080 & 01082 & 01083 & 01085 & 01087 & 01090 \\ 01096 & 01100 & 01105 & 01109 & 01110 & 01113 & 01120 & 01122 & 01123 & 01125 \\ 01126 & 01130 & 01132 & 01135 & 01136 & 01137 & 01138 & 01139 & 01140 & 01142 \\ 01154 & 01155 & 01156 & 01158 & 01162 & 01170 & 01185 & 01219 & 01224 & 01225 \\ 01226 & 01227 & 01229 & 01231 & 01237 & 01241 & 01243 & 01246 & 01247 & 01257 \\ 01258 & 01259 & 01260 & 01261 & 01266 & 01270 & 01282 & 01285 & & \end{array}$

ID IPNF

01197

IDMT

0015601198

IDMT USFS

0066201204

IDWA

00660

I MW

00388

MEX

002380065200671006830117101172

MNTB

01153

MT

00013001180011900120003280037500376003770037800379 $\begin{array}{lllllllllll}00380 & 00381 & 00382 & 00383 & 00384 & 00385 & 00386 & 00387 & 00389 & 00390\end{array}$ $\begin{array}{llllllllll}00391 & 00392 & 00393 & 00394 & 00443 & 00839 & 00841 & 00842 & 00909 & 00946\end{array}$ 0100801263

MT

00469

NCDE

MT KONF

01200

MTWY

$00650 \quad 01264$ 


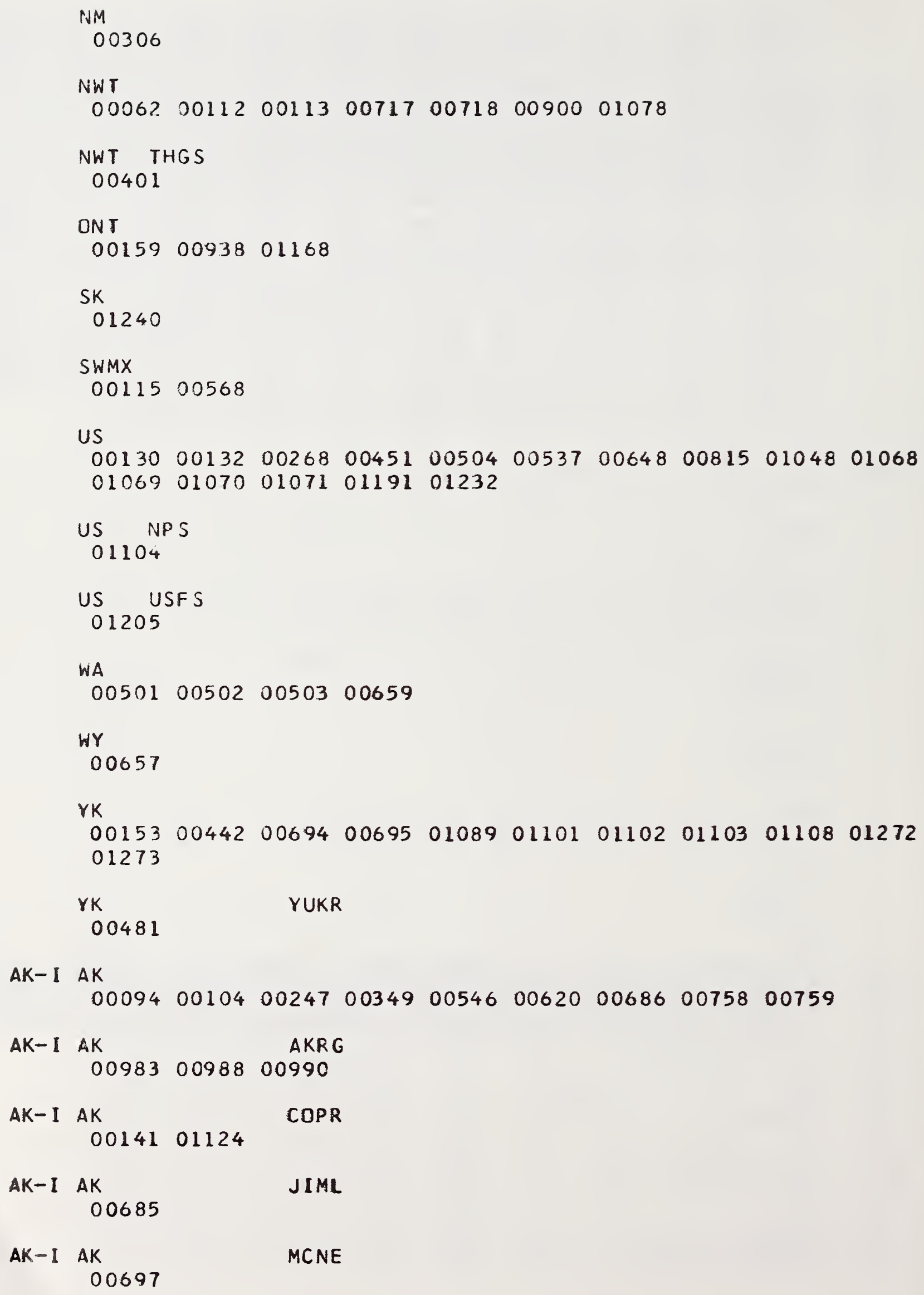




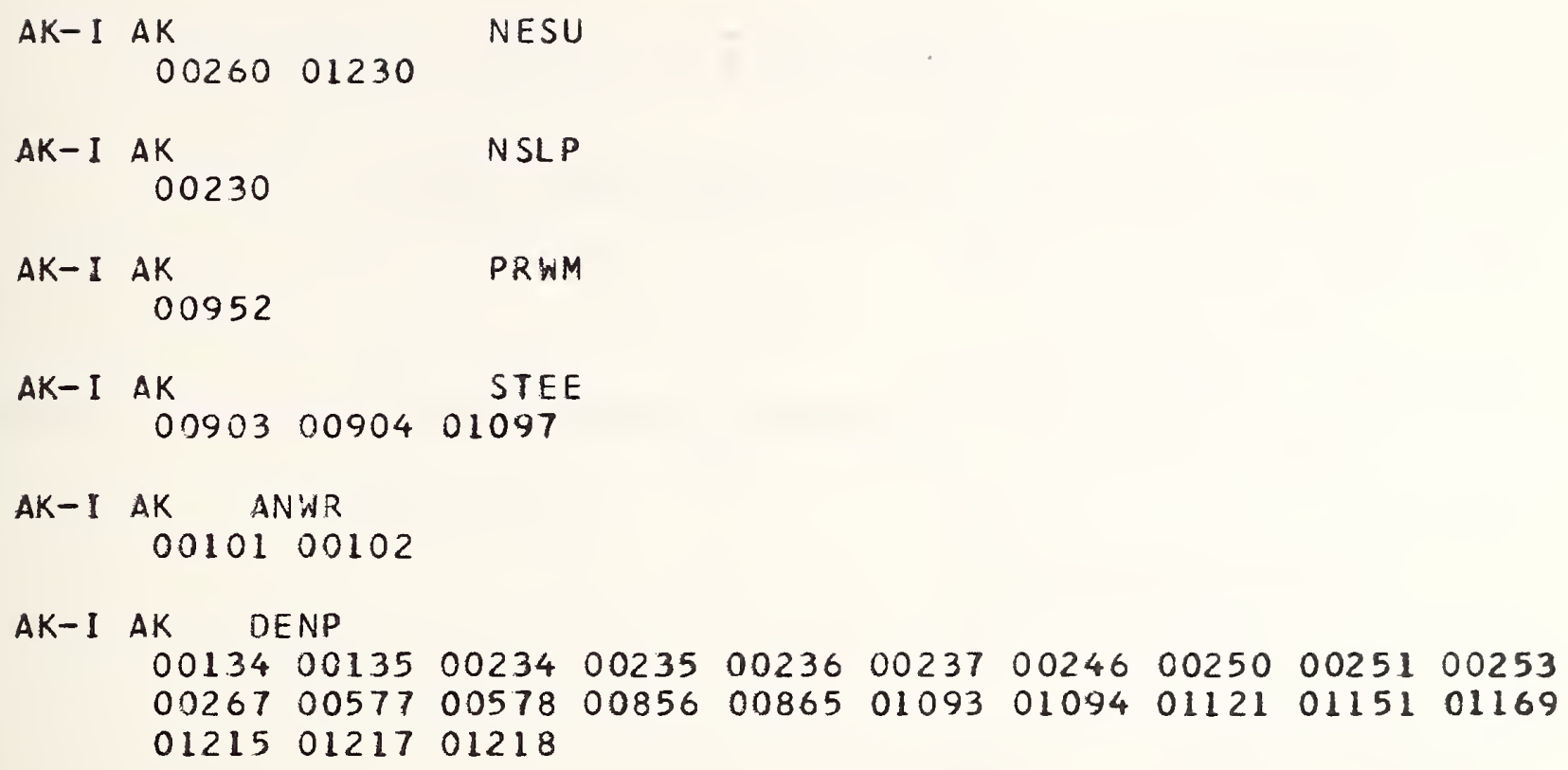

AKKA AK

00278

AKKA AK

KARL

00163001660065501088

AKKA AK KOIS

001650118201183

AKKA AK

TERL

0110601107

AKKA AK KARL KOIS

00346

AKKA AK KNWR

00065000660007800680

AKKA AK KNWR KARL

000770117401184

AKKA AK KNWR KOIS

00034001640118001181

AKKA AK KNWR TERL

0048301114

AKPN AK

00045001490028500286002870036600369004840067300963

AKPN AK

AMER

00290

AKPN AK

BLKL

0035900360003610036200363003640036500836 
$\begin{aligned} \text { AKPN AK } & \text { CHIG } \\ & 00299\end{aligned}$

AKPN AK KENA

$0007900333003340033500336 \quad 00358 \quad 00881$

AKPN AK

MCNE

0027500297

AKPN AK KANM

$00021000220016900580 \quad 008690116401165011750117601178$ 01179

$\triangle K P N$ AK KANM BROC

$00070 \quad 00248 \quad 01177$

AKPN AK KNWR KOIS

01173

AKPN AK MCGS MCNE

002760030500367006980113101133

AKSC AK

00140

COPR

AKSC AK

NESU

$00050 \quad 000510005200053 \quad 000540005500056000570005800060$ $\begin{array}{llllllllll}00061 & 00825 & 00826 & 00827 & 00828 & 00829 & 00830 & 00831 & 00832 & 00834\end{array}$ 0111701118

AKSE AK

006170080700902

AKSE AK ABC

006180105201054

AKSE AK ADIS

00545006190067900765010490105101053010550125201253 0125401255

AKSE AK AINM PACR

$00956 \quad 01228$

AKSE AK TONF

0093300934

AKSE AK TCNF ADIS

00935

ARC AK

$00506 \quad 00965$

ARC AK BRKR

$\begin{array}{llllll}00875 & 00876 & 00877 & 00981 & 01047\end{array}$ 
ARC AK EBRK

$00232006880072100766 \quad 0095900960 \quad 009780097900985$

ARC AK

NESU

00059

ARC AK

NSLP

00229

$A R C \quad A K$

WBRK

00242002430035100982009870098900991

ARC AK WBRK BRKR

00984

ARC AK ANWR

$0034700940 \quad 009410094201192$

ARC AK BROO

00967

ARC AK NPR BRKR

00992

ARC AK NPR WBRK

$\begin{array}{llllll}0 & 0477 & 00478 & 00479 & 00980 & 00986\end{array}$

$\mathrm{BC}-\mathrm{C} \quad \mathrm{BC}$

$0002500029002740032400476 \quad 00690 \quad 01256$

$B C-C \quad B C$

AHNU

00692010240109901265

$\mathrm{BC}-\mathrm{C} \quad \mathrm{BC}$

KIMS

$00026000270002800063004380043900440 \quad 00441$

$B C-C \quad B C$

NAKR

00806

$B C-C \quad B C$

SKEE

01216

$B C-I \quad B C$

01091

REVL

BC-I BC CGNP

$004220043700848 \quad 00850 \quad 0085100852$

$B C-I B C$ KGNP VAPP

00775

$B C-I \quad B C \quad$ REVL

00421 


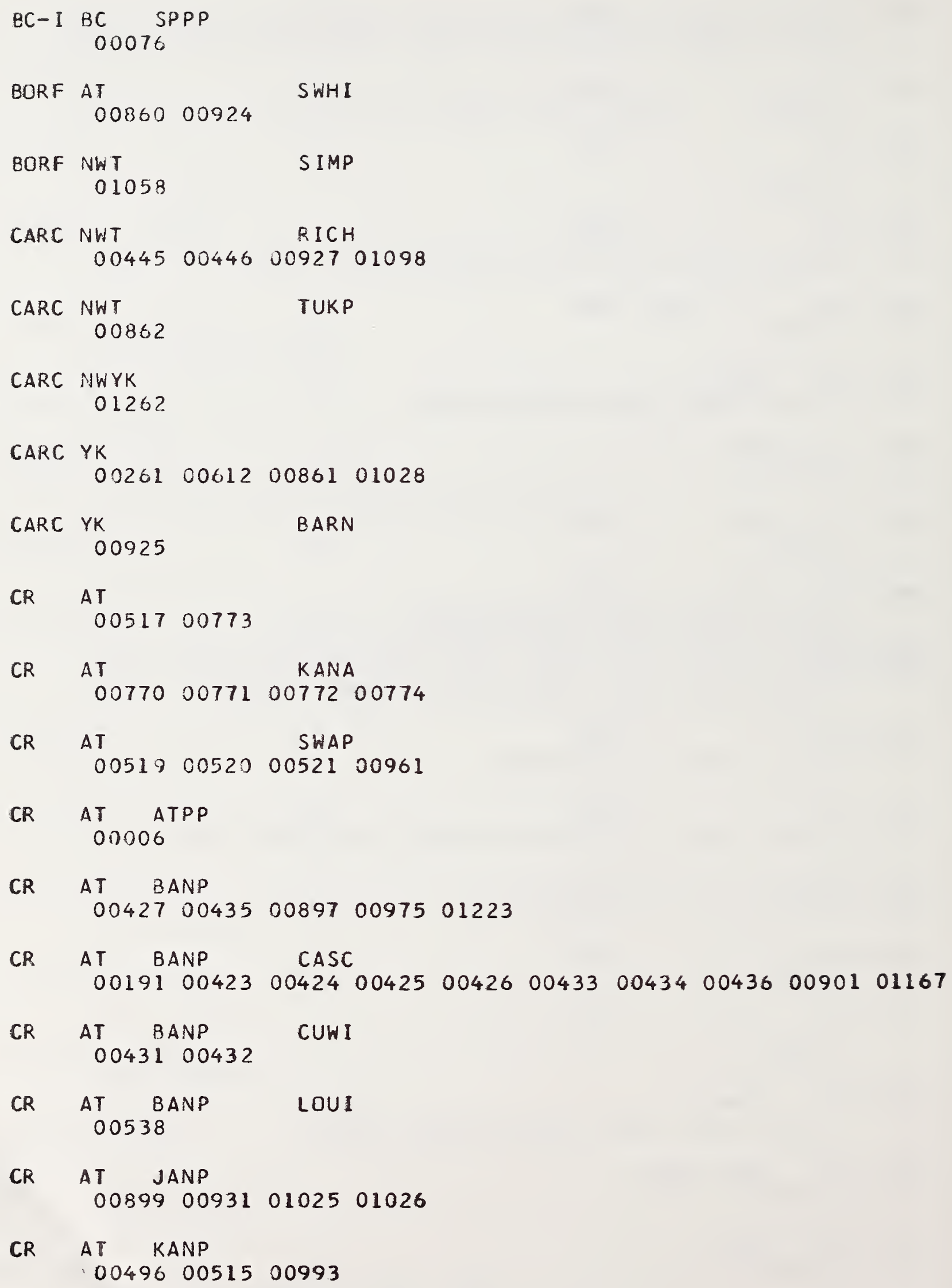


CR AT $\underset{0769}{ }$ KGPP

CR AT WANP

00428004290043000518007570091201152

CR ATBC

01242

KANA

CR ATBC BANP CGNP

00727

CR ATBC PC

00595

$\begin{array}{lll}\text { CR } & B C & \text { AKKI }\end{array}$

CR BC NFLT

006910078800789

CR BC OMIN

0034300344

CR BC BANP

00495

CR BC CGNP

0049300726

CR BC VAPP

00768

CYE BIM

00714

CYE ID

00951

CYE IDMT

000190059200593005940072201196

CYE IDMT KONF

00843

CYE IDMT KONF CAB

001540015700719

CYE MI

0029501072

CYE MT

$C A B$

0055901160 


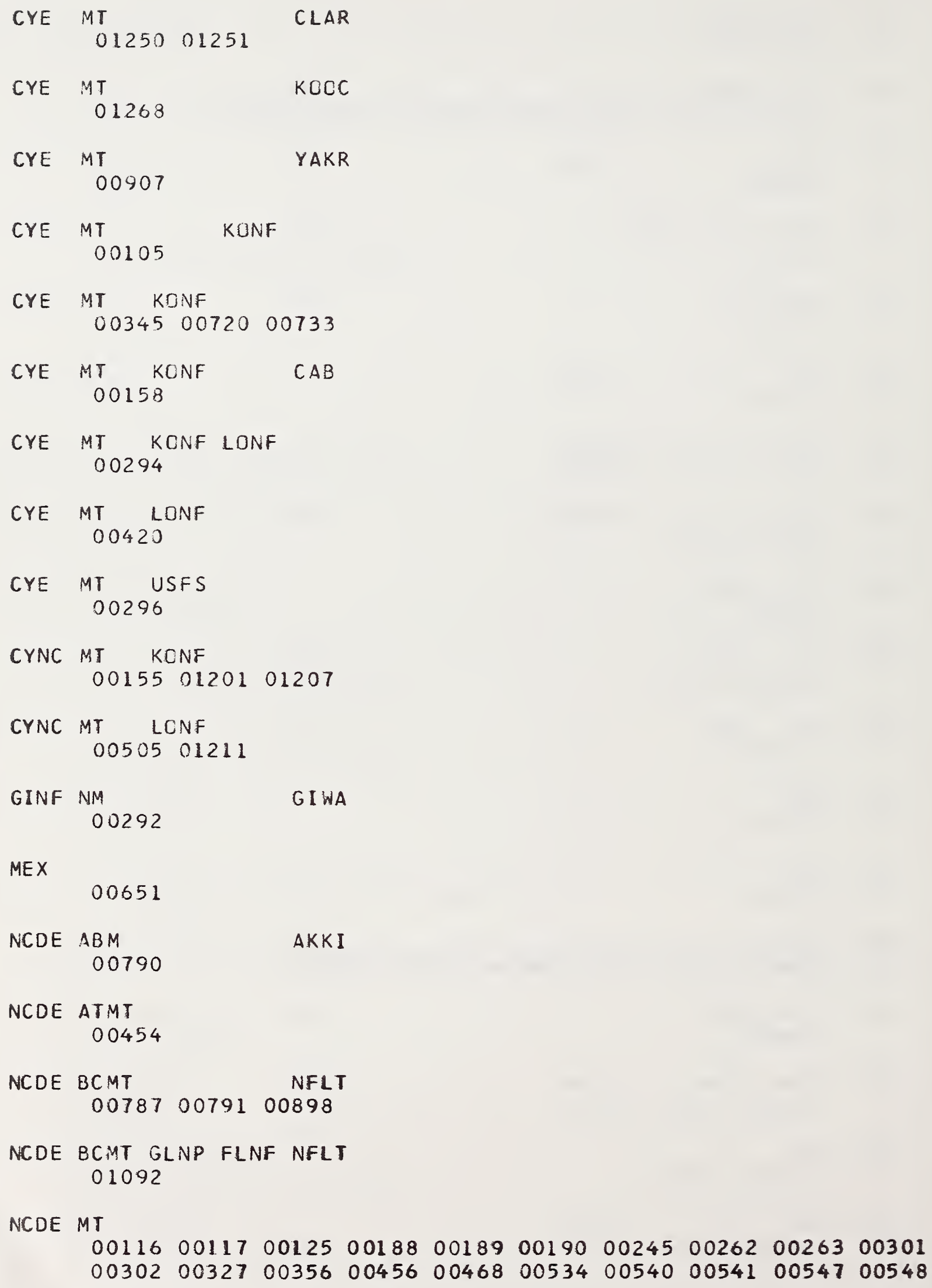


$00553 \quad 00556 \quad 00558 \quad 00560 \quad 00566 \quad 00567 \quad 00571 \quad 00573 \quad 0058500586$ $0058800616 \quad 0066800705007070070900713007280072900730$ 00731007320090501021010370106401161012350123801239 01275012780127901280

NCDE MT ANBU 0055501041

NCDE MT NFL T 0056100563007120093600999

NCDE MT $0066900670 \quad$ PIBU

NCDE MT RATT 01065

NCDE MT SFLT 0026900357005870070800710007110079201095

NCDE MT 00121 SUNR

NCDE MT 00528

WGLA

NCOE MT 00552

WHR

NCDE MT FLIR

0013100160001610106301074

NCDE MT FLIR MCPK 0014800615

NCDE MT FLIR MISS

0061401075

NCDE MT FLIR FLNF MISS 01067

NCDE MT FLIR USFS MISS 0034201066

NCDE MT FLNF 00064005160058400734012030120801281

NCDE MT FLNF HUNG 00143

NCDE MT FLNF MISS 01159

NCDE MT FLNF 0057201274

NFLT 


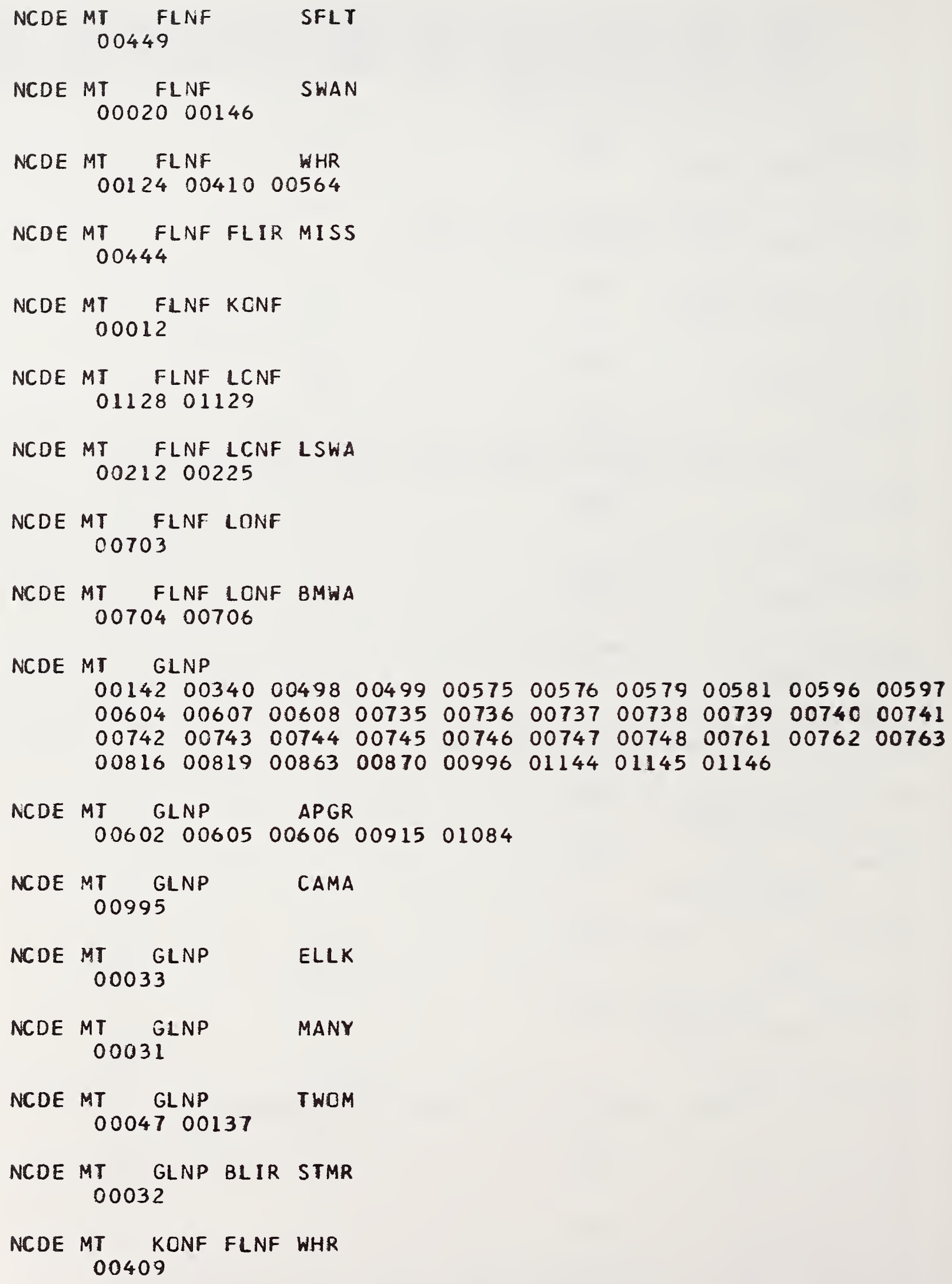




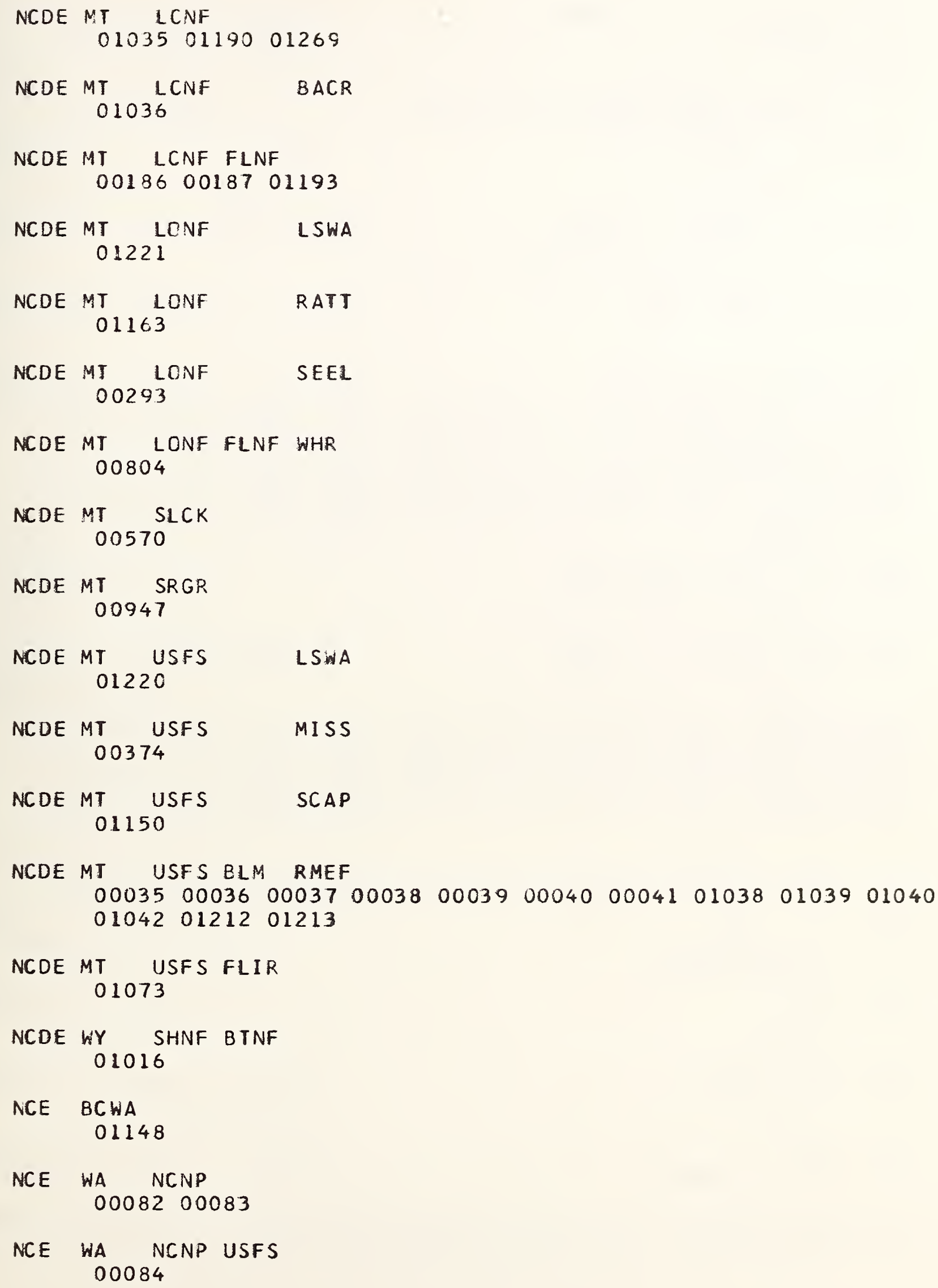




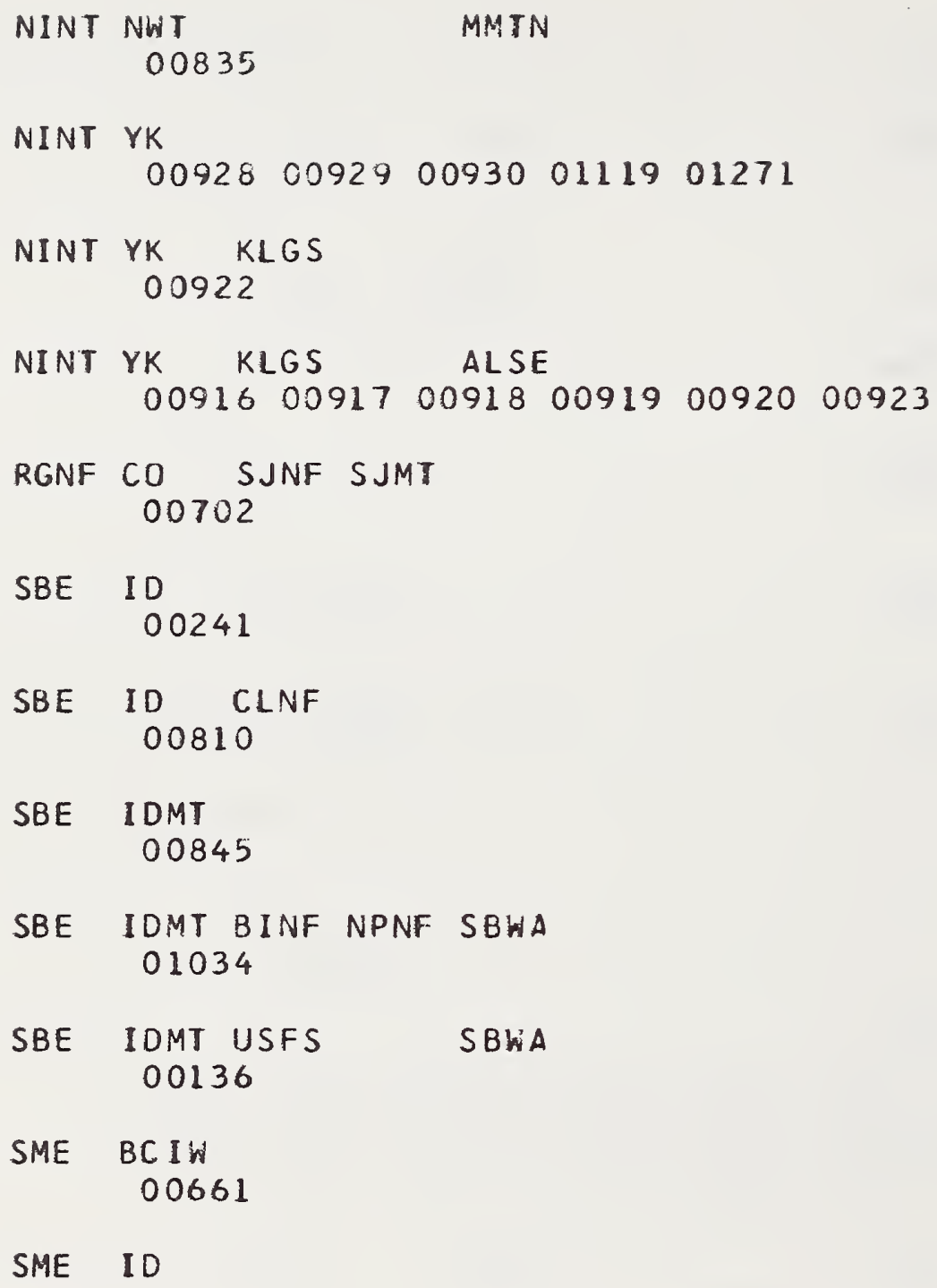


YGBE ID TANF ASHT 003950039601194

YGBE ID TANF ISLP 0033100749

YGBE IDMT 00088

CENT

YGBE IDMT TANF GANF ISLP 00270

YGBE IDWY TANF

005820067200809009060119501206

YGBE IMW

$00042000860008700090 \quad 000910021000255002720046700589$ $\begin{array}{llllllllll}00590 & 00591 & 00600 & 00603 & 00609 & 00623 & 00624 & 00625 & 00626 & 00627\end{array}$ $\begin{array}{lllllllllll}00628 & 00629 & 00630 & 00631 & 00632 & 00634 & 00635 & 00636 & 00637 & 0.0638\end{array}$ $\begin{array}{lllllllllll}0 & 0640 & 00641 & 00642 & 00643 & 00644 & 00646 & 00647 & 00750 & 00753 & 00754\end{array}$ $\begin{array}{lllllllllll}00756 & 00776 & 00778 & 00874 & 00949 & 00950 & 00969 & 01015 & 01044 & 01045\end{array}$ $01046 \quad 0108101086 \quad 01141011430114701214012330123401244$

YGBE IMW NPS USFS 00089

YGBE IMH USFS YNP

000160079900800

YGBE IMW YNP

$\begin{array}{lllllllllll}00030 & 00068 & 00103 & 00171 & 00172 & 00173 & 00174 & 00175 & 00177 & 00178\end{array}$ $\begin{array}{llllllllll}00179 & 00196 & 00197 & 00199 & 00200 & 00202 & 00214 & 00215 & 00220 & 00223\end{array}$ $0022700326 \quad 0039900452 \quad 0 C 4850052500526006130064500684$ $\begin{array}{lllllllllll}00755 & 00794 & 00795 & 00796 & 00801 & 00864 & 00866 & 00871 & 00872 & 00873\end{array}$ 00945010570118701188

YGBE IMW YNP USFS

0006900176001950020900211002130022600450

YGBE MT BTNF SHNF 01010

YGBE MT GANF

0010601202

YGBE MT GANF JARD 001070068700840

YGBE MT GANF MADR 0.0085

YGBE MT GANF SKYL 0063300798 


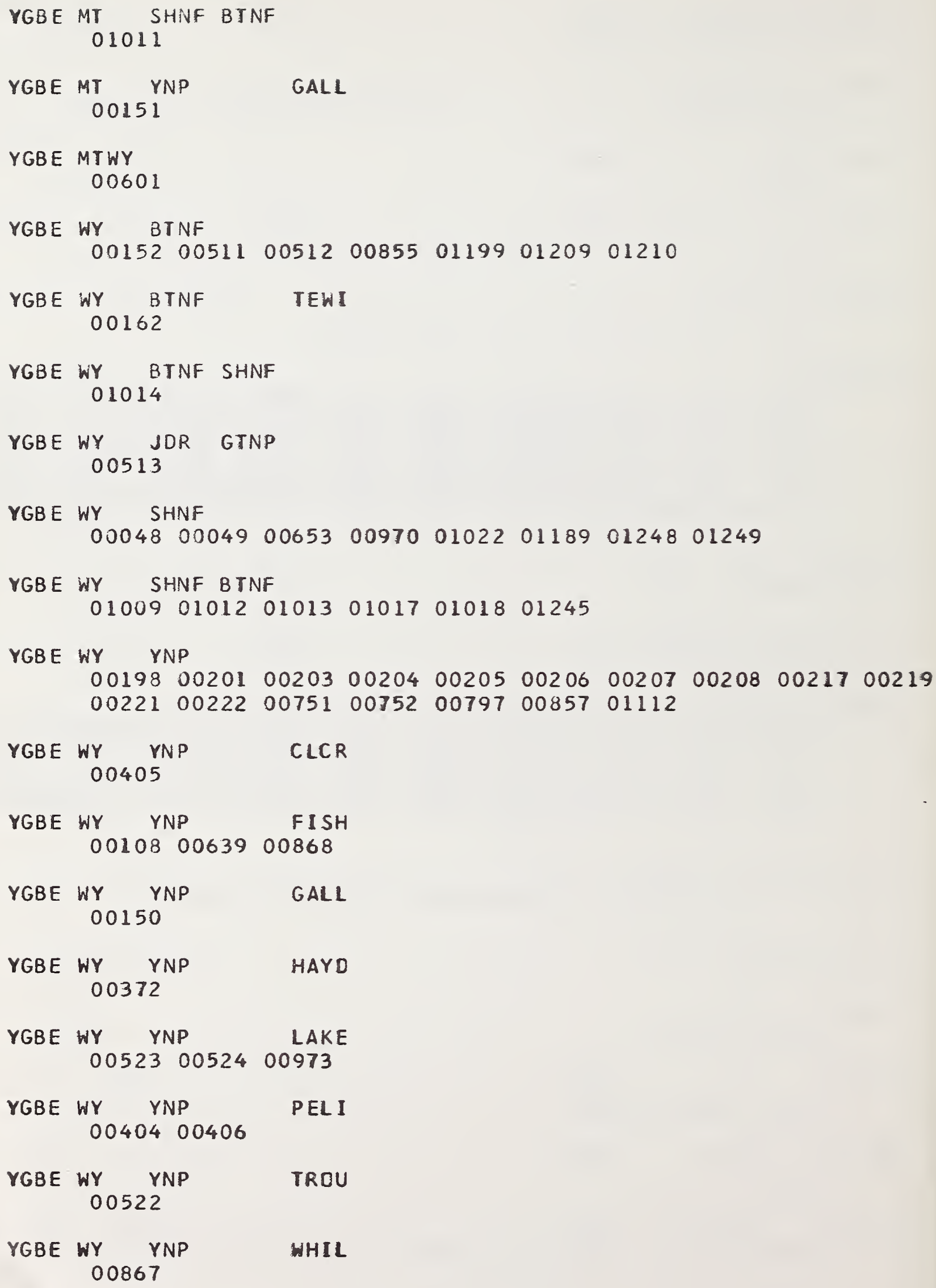



